\title{
A AUDITORIA EXTERNA E AS DEMONSTRAÇÕES CONTÁBEIS NO DIREITO COMERCIAL
}

Trabalho apresentado na Faculdade de Direito da Universidade de São Paulo como requisito parcial para a obtenção do título de doutor em Direito Comercial.

Orientador:

Prof. Haroldo Malheiros Duclerc Verçosa.

Faculdade de Direito da USP

São Paulo

2010 


\section{FICHA CATALOGRÁFICA}

Pereira, Alexandre Demetrius

A auditoria externa e as demonstrações contábeis no Direito Comercial. São Paulo, 2010. $398 \mathrm{p}$.

Tese de Doutorado - Faculdade de Direito da Universidade de São Paulo.

Orientador: Prof. Haroldo Malheiros Duclerc Verçosa.

1. Auditoria externa. 2. Contrato de auditoria. 3. Repercussões jurídicas e contábeis. 4. Responsabilidade civil do auditor. I. Universidade de São Paulo. Faculdade de Direito. Doutorado. II. Título. 


\section{RESUMO}

A auditoria externa de demonstrações contábeis é um dos instrumentos mais importantes para o desenvolvimento do mercado, pelo fato de adicionar credibilidade e segurança às informações financeiras prestadas pelos agentes econômicos que buscam captar recursos junto ao público investidor. A doutrina jurídica pátria, entretanto, ao contrário do que ocorre em outros países, tem relegado o estudo do assunto a um papel secundário, quase não abordado nas obras nacionais, deixando sua pormenorização integralmente sob o domínio da ciência contábil. Esta postura causa um afastamento do jurista da realidade das circunstâncias em que a auditoria se desenvolve, fazendo com que, pela falta de compreensão das peculiaridades da matéria, haja a aplicação inadequada de muitos institutos a uma realidade específica e, muitas vezes, diversa daquela para as quais referidos institutos foram concebidos. Como a matéria abrange tanto o Direito quanto a Contabilidade, tencionamos fazer aqui uma abordagem conjunta, a fim de possibilitar a comunicação das duas ciências e compartilhar os problemas que o tema apresenta. Passamos em revista a natureza dos principais institutos de auditoria; seu relacionamento e importância na economia; as características jurídicas do contrato, suas obrigações, as partes contratantes e os terceiros interessados; o desenvolvimento contábil de sua execução; e seu relacionamento com os sistemas de governança corporativa. Além disso, verificamos as atuais tendências quanto ao sistema de riscos e responsabilidade civil do auditor, matéria amplamente discutida no âmbito internacional. 


\begin{abstract}
The external audit of financial statements is one of the most important instruments in market development, to add credibility and security to the financial information provided by economic agents seeking to attract resources from the investor public. The national legal doctrine, however, contrary to what occurs in other countries, has relegated the study of the subject to a secondary role, almost national works not covered in detail, leaving fully under the domain of accountant science. This attitude causes a hiving-off lawyer of the circumstances in which the audit develops, causing, by lack of understanding of the peculiarities of the subject, inadequate application of many institutes to a specific reality occurs and, often, different from that for which these institutes were designed. As the subject covers Law and Accounting, we intend to do a joint approach to enable the communication of both science and share the problems that the theme displays. Passing across the nature of the main audit institutes, their relationship and importance in the economy, the legal characteristics of the agreement, their obligations, the contracting parties and third parties, your ledger development and relationship with the corporate governance systems. In addition, we verify the current trends regarding the system of auditor's civil liability and risk, widely discussed internationally.
\end{abstract}




\section{RIASSUNTO}

La revisione contabile delle dimostrazioni finanziarie è uno degli strumenti più importanti nello sviluppo del mercato quando aggiunge la credibilità e la sicurezza alle informazioni finanziarie fornite dagli agenti economici quale cercano risorse vicino al pubblico d'investimento. La dottrina legale natale, tuttavia, in opposizione di che cosa accade in altri paesi, ha relegato lo studio della disciplina ad una condizione secondaria, quasi non imbarcato nelle opere nazionali, lasciando integralmente $i$ suoi dettagli sotto il dominio della scienza contabile. Questo causa di una rimozione del jurista della realtà delle circostanze dove la revisione contabile se si sviluppa, facendo con che, per la mancanza di comprensione delle caratteristiche della materia, habbia l'applicazione inadeguata di molti dispositivi legale ad una realtà specifica la e, molte volte, diversi di quell'per cui $i$ dispositivi relativi erano stati concepiti. Poichè la materia acclude la Giurisprudenza in tale maniera quando la Contabilità, cerchiamo fare un studio assieme, per rendere possibile la comunicazione delle due scienze e per comunicare i problemi che l'oggetto presenta. Passiamo in scomparto alla natura dei dispositivi principali della revisione contabile, il suo rapporto ed importanza nell'economia, le caratteristiche legali del contratto, $i$ suoi obblighi, le parte contratanti ed i terzi interessati, lo sviluppo contabile della sua esecuzione ed il rapporto con i sistemi del governança corporativo. Inoltre, verifichiamo la attuale tendenza quanto al sistema dei rischi e della responsabilità civile del revisore dei conti, materia internazionalmente ampiamente discussa. 


\section{SUMÁRIO}

1. O TEMA A SER DESENVOLVIDO E SUAS LIMITAÇÕES, IMPORTÂNCIA E CONTRIBUIÇÃO ORIGINAL À CIÊNCIA JURÍDICA BRASILEIRA

2. JUSTIFICATIVA DA ESCOLHA, OBJETIVOS, METODOLOGIA E PRINCIPAIS QUESTÕES A SEREM ANALISADAS

3. CONCEITUAÇÃO E ESPÉCIES DE AUDITORIA................................................. 24

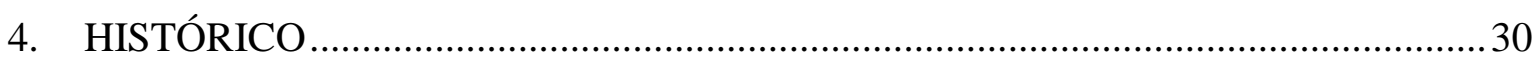

5. IMPLICAÇÕES ECONÔMICAS DA AUDITORIA E SUA AVALIAÇÃO DO PONTO DE VISTA DA ANÁLISE ECONÔMICA DO DIREITO ...................................... 37

5.1 A ATIVIDADE DE AUDITORIA COMO REDUTORA DA ASSIMETRIA DE INFORMAÇÕES 42

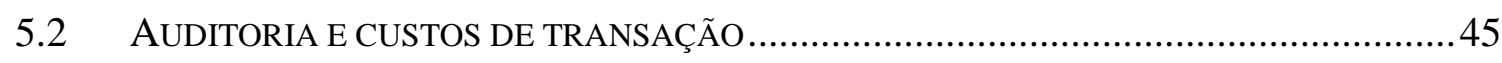

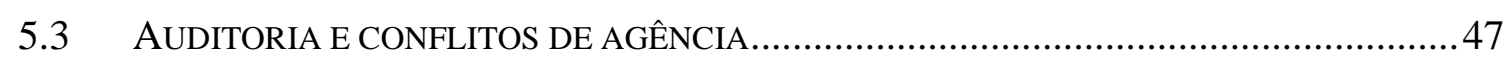

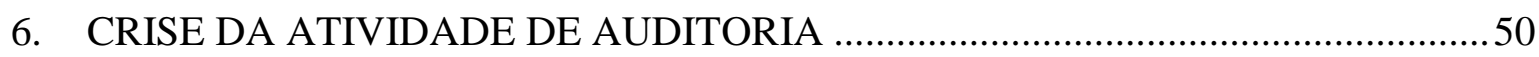

6.1 PRINCIPAIS CASOS QUE ABALARAM A CREDIBILIDADE DA AUDITORIA INDEPENDENTE

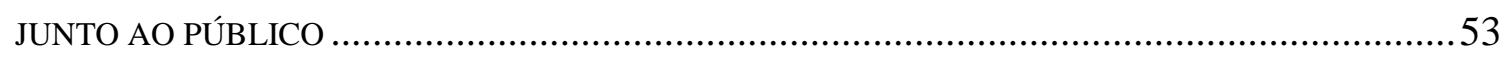

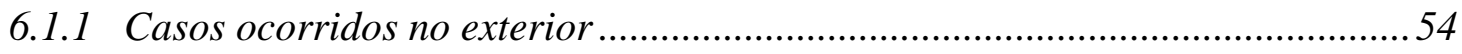

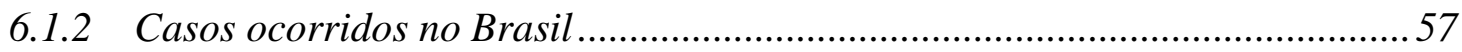

7. RELAÇÕES CONTRATUAIS ENVOLVENDO OS SERVIÇOS DE AUDITORIA

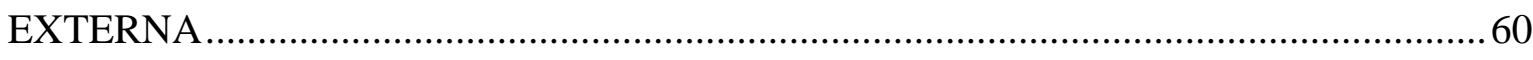

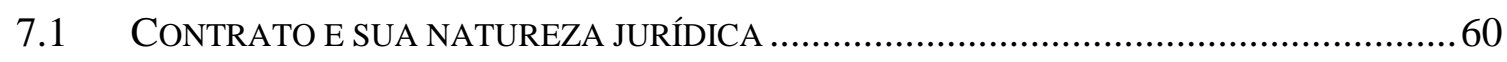

7.1.1 Investigação da natureza contratual nos casos de auditoria externa obrigatória 62

7.1.2 Liberdade de conteúdo de contrato e contratação de adesão em auditoria ..... 67

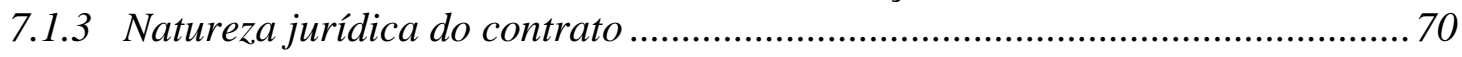

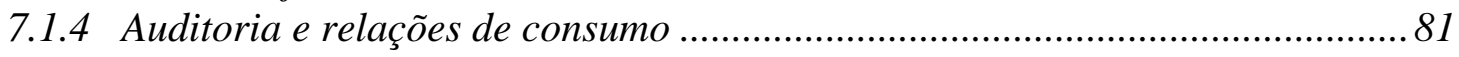

7.2 REGULAÇÃO CONCERNENTE AO CONTRATO DE AUDITORIA EXTERNA .....................87

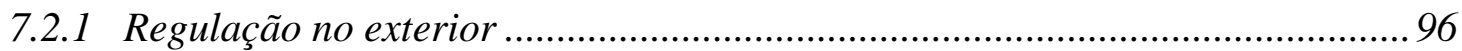

7.2.2 Regulação no Brasil ............................................................................... 101

7.2.3 Campo de responsabilidade do auditor pela observância da regulação ......... 107

7.3 OBRIGAÇÕES DAS PARTES NO CONTRATO DE AUDITORIA ...................................... 109

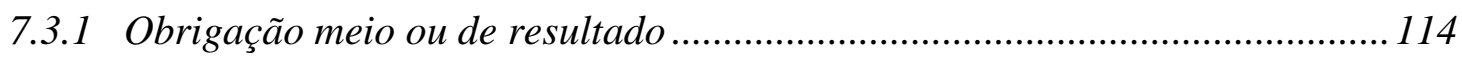

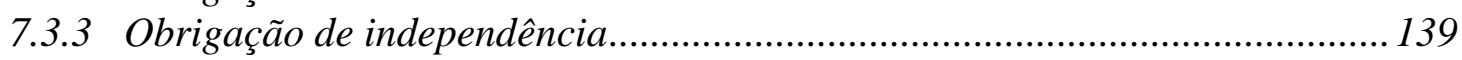

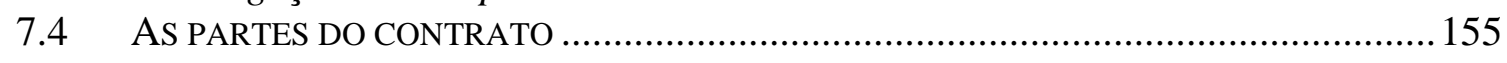

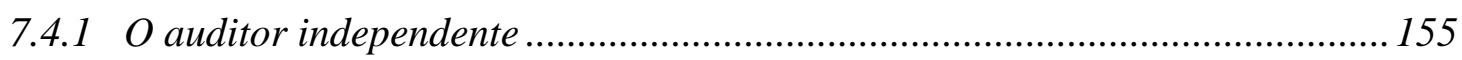

7.4.1.1 Registro profissional e qualificação técnica.......................................... 155 
7.4.1.2 Educação continuada e controle de qualidade 160

7.4.1.3 Análise quanto à natureza empresária ou civil da atividade do auditor ... 166

7.4.1.4 Tipicidade societária das sociedades de auditores .................................. 171

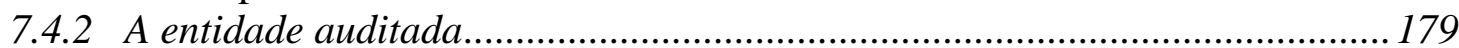

7.4.2.1 Auditoria em sociedades de grande porte .............................................. 180

7.5 PRAZO DO CONTRATO E RODÍZIO DE AUDITORIA.................................................... 191

7.6 FORMALIZAÇÃO DO CONTRATO E DA EXECUÇÃO DOS SERVIÇOS DE AUDITORIA ... 196

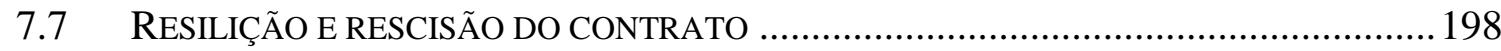

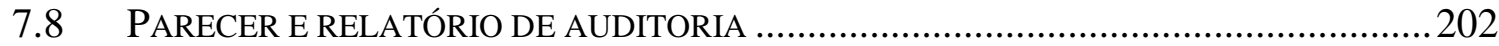

8 LIMITAÇÕES E EXPECTATIVAS EM AUDITORIA EXTERNA.........................208

8.1 LIMITAÇÕES EFETIVAS ENFRENTADAS PELOS AUDITORES …..............................208

8.2 EXPECTATIVAS SOCIAIS EM FACE DOS SERVIÇOS DE AUDITORIA EXTERNA ............211

8.2.1 Expectativas sociais de detecção de fraudes ................................................216

8.2.1.1 Fraude e gerenciamento de resultados (contabilidade criativa) ...............225

8.2.2 Expectativas sociais de garantia de solidez econômico-financeira .................227

9. MÉTODOS E PROCEDIMENTOS NA ATIVIDADE DE AUDITORIA EXTERNA..

9.1 PROVIDÊNCIAS PRELIMINARES E PLANEJAMENTO DE AUDITORIA …....................237

9.2 DETERMINAÇÃO DA RELEVÂNCIA E MATERIALIDADE.........................................2240

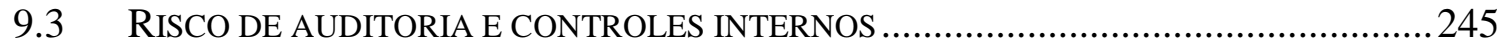

9.4 TESTES DE CONTROLE, REVISÃO ANALÍTICA E TESTES SUBSTANTIVOS .................252

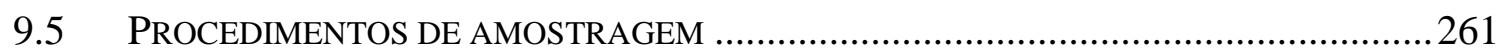

10. O OBJETO DA AUDITORIA EXTERNA: DEMONSTRAÇÕES CONTÁBEIS E A

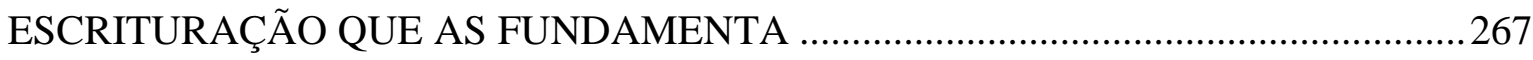

10.1 A ESCRITURAÇÃO QUE FUNDAMENTA AS DEMONSTRAÇÕES ................................269

10.2 NATUREZA JURÍDICA DAS DEMONSTRAÇÕES CONTÁBEIS...................................2275

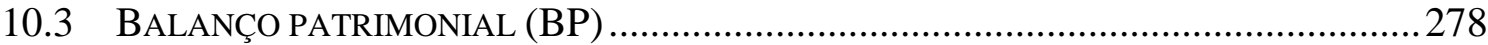

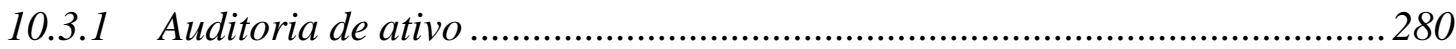

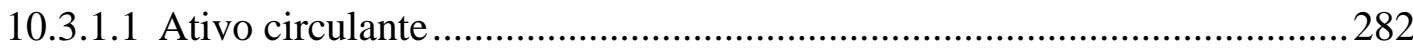

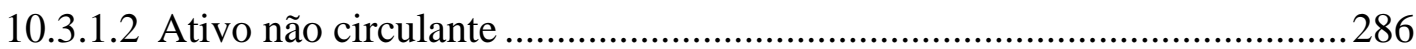

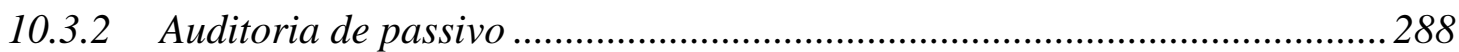

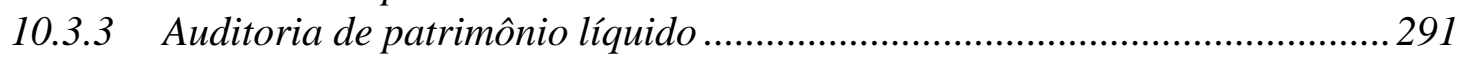

10.4 DEMONSTRAÇÃO DO RESULTADO DO EXERCícIO (DRE) ....................................292

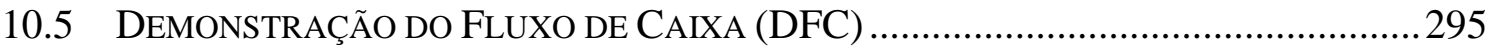

10.6 DEMONSTRAÇÃo DE LuCROS E PREJUÍZOS ACUMULAdOS (DLPA) E

DEMONSTRAÇÃO DE MUTAÇÕES NO PATRIMÔNIO LÍQUIDO (DMPL) ................................301 


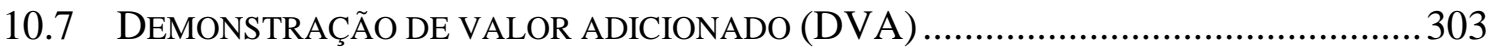

11 AUDITORIA EXTERNA E GOVERNANÇA CORPORATIVA …..........................307

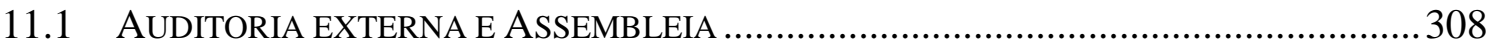

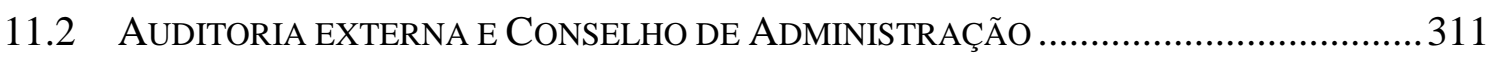

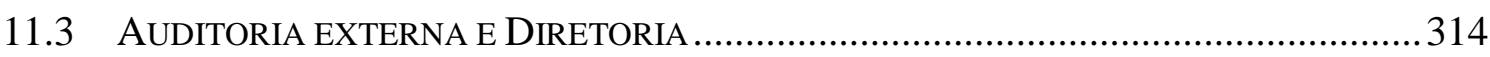

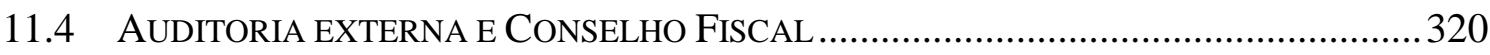

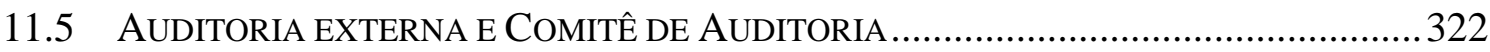

12 RESPONSABILIDADE CIVIL DO AUDITOR INDEPENDENTE ..........................327

12.1 EVOLUÇÃO DO TEMA E PRIMEIROS CASOS SURGIDOS ENVOLVENDO A

RESPONSABILIDADE CIVIL DO AUDITOR. DISTINÇÕES NOS PAÍSES DE TRADIÇÃO ANGLO-

SAXÔNICA E ROMANO-GERMÂNICA

12.2 FONTES NORMATIVAS E SISTEMAS DE RESPONSABILIDADE. NORMAS QUE REGULAM

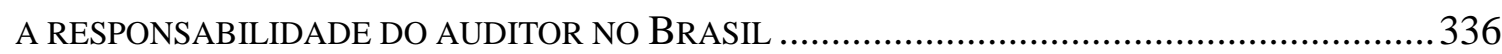

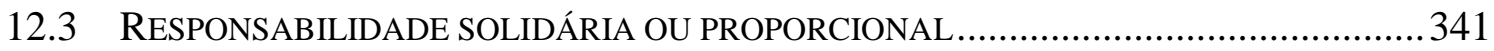

12.4 RESPONSABILIDADE CONTRATUAL E EXTRACONTRATUAL DO AUDITOR .................343

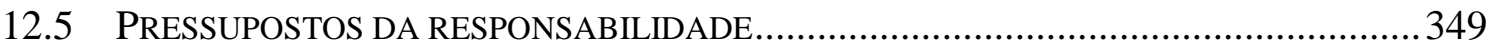

12.5.1 Ação ou omissão. Fatos que ensejam a responsabilização: casuística........350

12.5.2 Culpa (responsabilidade subjetiva) ou risco (responsabilidade objetiva).. 353

12.5.2.1 Análise das vantagens e desvantagens dos regimes de responsabilidade 355

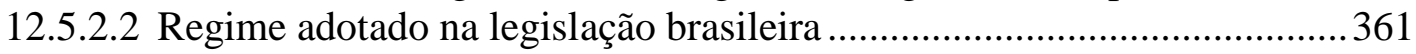

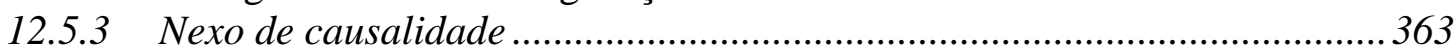

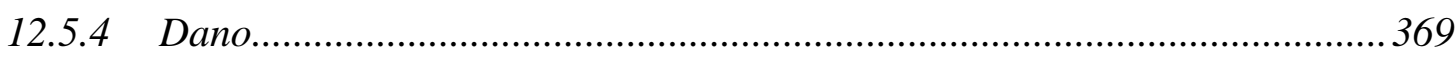

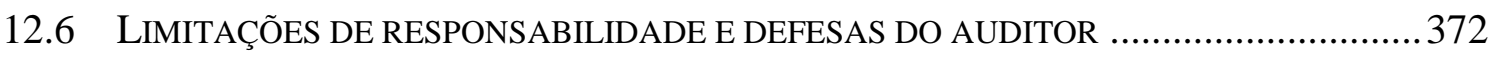

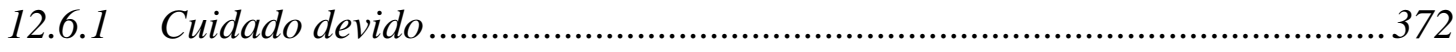

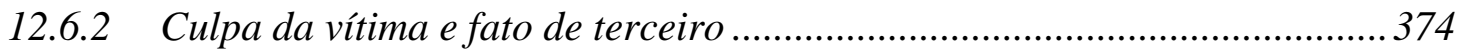

12.6.3 Limitação contratual de responsabilidade .....................................................377

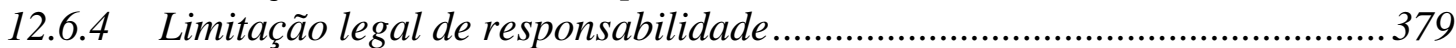

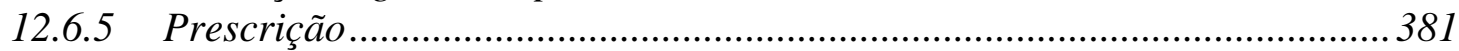

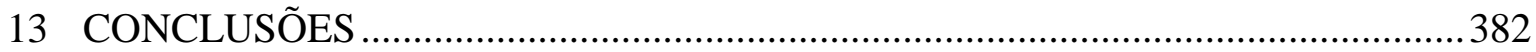

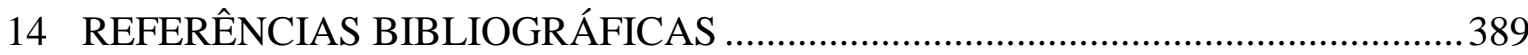




\section{ÍNDICE DE TABELAS}

Tabela 1: Aplicabilidade das disposições do Código Civil aos contratos de auditoria ........76 Tabela 2: Resultados da análise de custos e benefícios da adoção das normas internacionais de auditoria (ISA) na União Europeia (em milhões de Euros $-€)$.......................................99

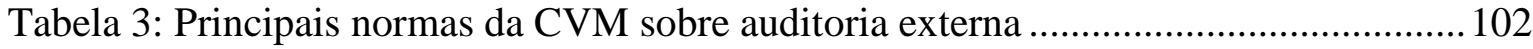

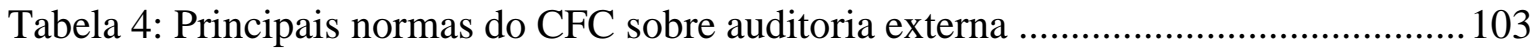

Tabela 5: Principais pronunciamentos do IBRACON sobre auditoria externa ................... 106 Tabela 6: Regime legal dos diversos países da Comunidade Europeia quanto à permissão para o auditor produzir prova confidencial em sua própria defesa em processo judicial.. 137 Tabela 7: Ameaças à independência e respectivas salvaguardas .......................................152 Tabela 8: Regime legal dos diversos países da Comunidade Europeia quanto aos tipos societários permitidos para as sociedades de auditores ................................................... 174 Tabela 9: Distinções entre critérios contábeis aplicáveis às sociedades anônimas e às

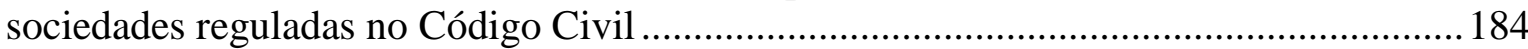

Tabela 10: Distinções entre os órgãos regulatórios a respeito da rotação de auditores ..... 194 Tabela 11: Distinções quanto aos tipos de parecer, conforme as situações apresentadas ao

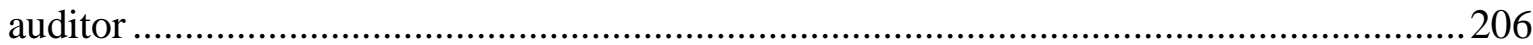

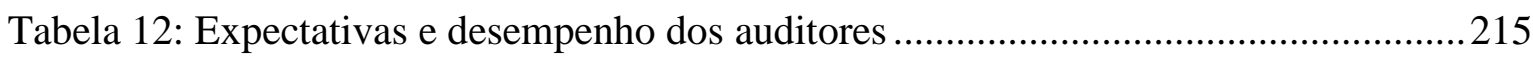

Tabela 13: Alguns tipos de fraude segundo a doutrina especializada ............................2217

Tabela 14: Evolução das normas nacionais em matéria de fraude, acompanhando a

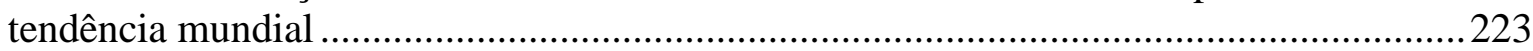
Tabela 15: Eventos ou condições que podem levantar dúvida com relação à continuidade

Tabela 16: Limites típicos para julgamento de materialidade

Tabela 17: Tamanho de amostras estatísticas para testes de controles, para populações com mais de 5.000 unidades (risco de amostragem de 5\%) .....................................................2. Tabela 18: Tamanho de amostras estatísticas para testes de controles, para populações com

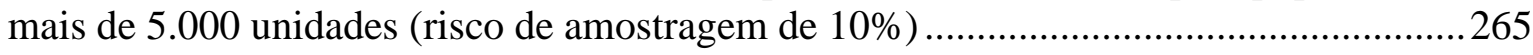

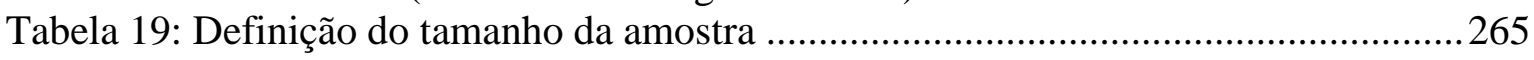

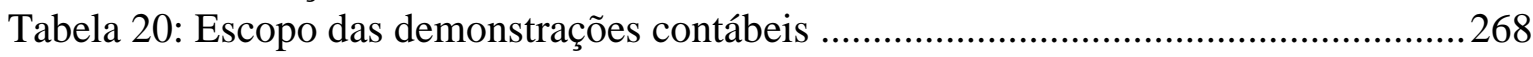

Tabela 21: Formas de aumento e diminuição entre as contas dos diversos grupos............270

Tabela 22: Princípios gerais de contabilidade nos termos da Resolução CFC n. 750/93 .. 272

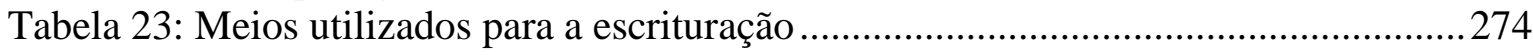

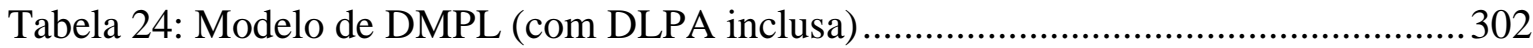

Tabela 25: Resumo das posições assumidas no ordenamento norte-americano em relação à

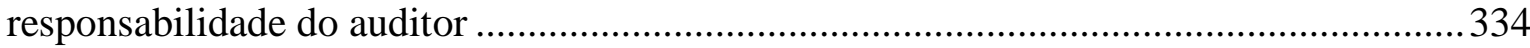

Tabela 26: Sistemas legais de responsabilidade na União Europeia ..................................337

Tabela 27: Alocação de responsabilidade nos Estados-Membros da União Europeia .......342

Tabela 28: Verbas que compõem a indenização nos países da União Europeia .................369

Tabela 29: Opções de limitação de risco aos auditores no âmbito da União Europeia ......380 


\section{ÍNDICE DE FIGURAS}

Figura 1: Fluxo de recursos no mercado de capitais por meio de relacionamento direto entre unidades econômicas deficitárias e superavitárias no mercado de capitais.

Figura 2: Fluxo de recursos no mercado financeiro por meio de relacionamento indireto (intermediado por instituições financeiras) entre unidades econômicas deficitárias e superavitárias no mercado de capitais.

Figura 3: Sucessivas mudanças de critério em prejuízo da comparabilidade da informação contábil.

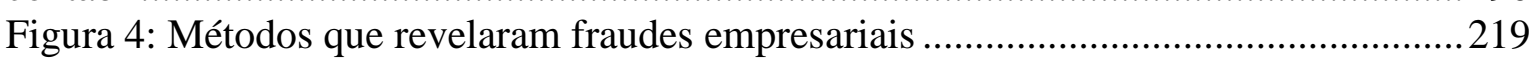

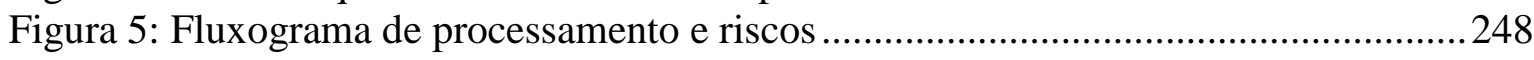

Figura 6: Planejamento da auditoria conforme a ênfase dada pelo auditor .......................2.260

Figura 7: Forma gráfica usual de representação do balanço patrimonial ..........................2279

Figura 8: Critérios de organização interna das contas do balanço patrimonial ..................220

Figura 9: Giro econômico usual e contas utilizadas para registro ....................................283

Figura 10: Composição geral da Demonstração de Resultado do Exercício (DRE) .........293

Figura 11: Expressão gráfica simplificada da conversão dos valores de fluxo de caixa

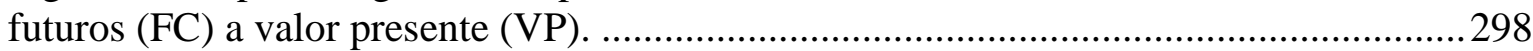

Figura 12: Expressão matemática da conversão dos valores de fluxo de caixa futuros (FC)

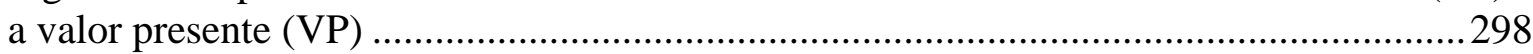

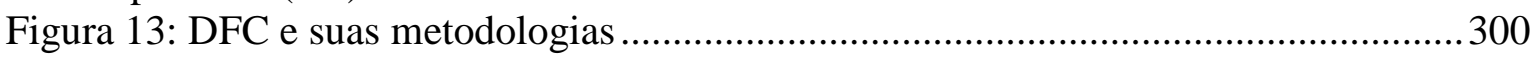

Figura 14: Modelo de DVA apresentado por Neves e Viceconti .....................................305 


\section{LISTA DE ABREVIATURAS E SIGLAS}

AICPA - American Institute of Certified Public Accountants;

$\mathrm{BP}$ - Balanço patrimonial;

CC - Código Civil;

CDC - Código de Defesa do Consumidor;

CF, CR ou CF/88 - Constituição Federal, Constituição da República ou Constituição Federal de 1988, respectivamente;

CLT - Consolidação das Leis do Trabalho;

CONSOB - Commissione Nazionale per le Società e la Borsa;

CP - Código Penal;

CPC - Código de Processo Civil;

CPP - Código de Processo Penal;

CPA - Certified Public Accountant;

CRSFN - Conselho de Recursos do Sistema Financeiro Nacional;

CVM - Comissão de Valores Mobiliários;

DFC - Demonstração de Fluxos de Caixa;

DJ - Diário da Justiça;

DLPA - Demonstração de Lucros e Prejuízos Acumulados;

DMPL - Demonstração de Mutações no Patrimônio Líquido;

DOAR - Demonstração de Origens e Aplicações de Recursos;

DRE - Demonstração do Resultado do Exercício;

DVA - Demonstração de Valor Adicionado;

FASB - Financial Accounting Standards Board;

IASB - International Accounting Standards Board;

IFRS - International Financial Reporting Standards;

ISA - International Standards on Auditing;

PCAOB - Public Company Accounting Oversight Board;

PGCA - Princípios Contábeis Geralmente Aceitos;

Res. - Resolução;

SOX - Lei Sarbanes-Oxley;

STF - Supremo Tribunal Federal; 


STJ - Superior Tribunal de Justiça;
TJ - Tribunal de Justiça;
TRF(s) - Tribunal(is) Regional(is) Federal(is);
TU/TUF - Testo Unico delle disposizioni in materia di intermediazione
Finanziaria;
UE - União Europeia;
US GAAP - United States General Accepted Accounting Principles.




\section{O TEMA A SER DESENVOLVIDO E SUAS LIMITAÇÕES, IMPORTÂNCIA E CONTRIBUIÇÃO ORIGINAL À CIÊNCIA JURÍDICA BRASILEIRA}

No mundo moderno, a atividade empresarial assume importância inegável.

Embora sem prescindir da figura do Estado como regulador do sistema econômico e da intervenção deste em episódios de crises econômicas, verificamos nas últimas décadas que os empreendimentos particulares ingressaram cada vez mais em setores estratégicos da economia, influenciando definitivamente a vida dos indivíduos.

Com o aumento da competição global e a consequente diminuição das barreiras ao livre comércio mundial, é cada vez maior a busca por eficiência, menores custos e vantagens competitivas por parte daqueles que desejam fornecer bens ou serviços a outrem.

Neste ambiente, os sistemas de mercado e a atividade empresarial particular são os únicos aptos a enfrentar os desafios que se apresentam, substituindo com vantagens, em muitos casos, a atuação estatal, usualmente lenta, burocrática, demasiadamente custosa e de gerenciamento ineficiente. ${ }^{1}$

Assim, embora haja resistências de alguns a este novo modelo, é fato inevitável que cada vez mais a atividade empresarial retoma papel preponderante em assuntos antes reservados aos entes públicos, ficando estes restritos a um papel regulatório e não diretamente interveniente.

\footnotetext{
${ }^{1} \mathrm{O}$ esgotamento da ação estatal como mola propulsora do desenvolvimento econômico nacional é fenômeno que data principalmente das últimas décadas. Como historicamente se constata, em meados do século XX, ao contrário do que ocorre hoje, o desenvolvimento industrial brasileiro deu-se num modelo de substituição de importações, mediante proeminente intervenção do Estado, o qual atuou intensamente como agente econômico à frente de empresas estatais (v.g., no setor siderúrgico através da CSN, Usiminas, Cosipa, etc.; no setor de mineração por meio do controle da Companhia Vale do Rio Doce; além do monopólio dos setores de telecomunicações e energia). O fim deste modelo de atuação do Estado deriva principalmente da necessidade deste em manter restrições fiscais e orçamentárias, manutenção de inflação baixa e carga tributária dentro de determinados parâmetros, fatos estes que impossibilitam políticas irresponsáveis de gastos estatais e financiamento de grandes projetos com recursos públicos. Neste contexto é que crescem, nos últimos anos, as privatizações e o desenvolvimento das parcerias público-privadas estabelecidas na Lei n. $11.079 / 2004$.
} 
Ocorre que a atividade empresarial, ao contrário do que sucede na intervenção estatal na economia, está sujeita a eventualidades diversas, em grande parte imprevisíveis ao longo do tempo, submetendo-se a riscos de insucesso em seu resultado. ${ }^{2}$

Risco, aliás, é justamente no que reside toda a potencialidade do empreendimento, pois, se por um lado ele traz consigo a ameaça de encerramento do negócio, aumenta também a expectativa de seu retorno. ${ }^{3}$ A obtenção de resultados econômicos superiores à média, por um lado, ou a falência, por outro, são eventos inerentes a qualquer atividade que se submeta às regras de mercado.

Para que a atividade privada cumpra seu papel no desenvolvimento da economia, porém, é necessário que haja disponibilidade de fontes de financiamento, as quais podem ser obtidas das mais diversas formas junto ao mercado. ${ }^{4}$

Na obtenção do funding necessário aos empreendimentos privados, há uma barreira essencial a ser enfrentada, qual seja, a assimetria de informações entre o investidor (aquele que viabiliza o financiamento necessário ao empreendimento, buscando retorno sobre o capital aplicado) e o gestor do empreendimento (aquele que recebe os recursos do investidor, comprometendo-se a remunerá-lo).

Com efeito, as informações sobre o negócio a ser desenvolvido restam usualmente concentradas de modo quase exclusivo nas mãos de acionistas majoritários e gestores, os quais podem sonegar dados importantes aos investidores ou mesmo ter interesses conflitantes com estes. ${ }^{5}$

\footnotetext{
${ }^{2}$ Em administração financeira, é comum a doutrina classificar os riscos empresariais em duas espécies: 1) risco sistêmico ou sistemático, que é aquele inerente à atividade econômica como um todo, ou seja, o risco de a empresa ser afetada pela situação da economia em geral em que se encontra inserida; e 2) risco não sistemático, que é aquele interno da empresa, ou seja, de que esta não consiga gerar resultados suficientes para se manter em operação, derivado apenas de suas circunstâncias e das decisões internas de seus gestores. A importância da classificação está no fato de que, enquanto para um investidor o risco não sistemático pode ser minimizado pela diversificação de seu portfólio, o risco sistemático não pode ser evitado, pois afeta a totalidade da economia.

${ }^{3}$ Esta é uma circunstância que não é inerente tão só à atividade empresarial, mas a toda conduta humana. Quanto maiores os riscos de perda, maior será a remuneração que se exigirá ao aplicar recursos em uma determinada atividade. Assim, aumentando os riscos, aumenta-se também a expectativa de retorno. Entendase que todo o problema do risco não está em sua eliminação (o que seria impossível), mas em seu gerenciamento; isto é, na ponderação da relação risco-retorno que melhor se adapte ao caso concreto.

${ }^{4}$ Resumidamente, podemos dizer que um empreendimento pode se financiar, grosso modo, por dois tipos de fontes: 1) capital de terceiros; 2) capital próprio. No primeiro caso, temos a constituição de um passivo (obrigações a pagar a credores), pelo qual a entidade se obrigará, usualmente, ao pagamento de juros. No segundo, o financiamento se dará basicamente pelo aporte de recursos dos sócios ou acionistas (capital), remunerados por dividendos ou juros sobre o capital próprio, ou mesmo pelos recursos obtidos do exercício da atividade econômica (lucros).

${ }^{5}$ A situação de conflito de interesses entre os titulares de um empreendimento e seus gestores é costumeiramente conhecida como conflito de agência, e comumente causadora de maiores custos de
} 
O investidor e outros usuários das demonstrações contábeis, por seu turno, embora tenham ciência de possuir diante de si um investimento essencialmente de risco, necessitam ter uma série de informações para que possam avaliar e mensurar, ainda que de modo aproximado, a álea a ser enfrentada e até mesmo precificar a remuneração que exigirão por aplicar seus recursos naquele negócio específico.

Diante disto, faz-se necessária a disponibilização, por parte dos titulares de um empreendimento privado que se financia através de recursos externos, de um conjunto de informações econômicas consubstanciadas nas demonstrações contábeis (balanço patrimonial, demonstração de resultado do exercício, demonstração de lucros e prejuízos acumulados, demonstração de mutações do patrimônio líquido, demonstração de fluxos de caixa e demonstração de valor adicionado).

Como bem ressaltam Stassano et al.:

Ora, é de se notar que um sistema informativo se apresenta como um complexo orgânico dos dados e informações que, pela sua natureza, complementaridade que os liga e a compatibilidade da técnica adotada para obtê-los e elaborá-los, permite a perseguição de um objetivo específico de conhecimento.

No caso do sistema do balanço do exercício (...) o objetivo se identifica, note-se, em fornecer um mínimo comum de informação sobre a gestão do negócio às várias classes de interesses convergentes na empresa: portadores de capital e de trabalho, fornecedores, clientes, administração pública.

Tal "informação mínima” está relacionada à demonstração da capacidade da empresa de se desenvolver em condições do equilíbrio econômico (...), e é fornecida com o objetivo de se dispor de elementos para se julgar a gestão passada e formular previsões para a futura. ${ }^{6}$

transação (agency costs) visando a compatibilizar os interesses dessas categorias. Voltaremos ao tema mais adiante.

${ }^{6}$ STASSANO, Giuseppe; STASSANO, Matteo. Il Falso in bilancio. Milão: Giuffrè, 1996. p. 2. Tradução livre do original: "Ora, è noto che un sistema informativo si presenta come un complesso organico di dati e informzioni che, per la loro natura, la complementarietà che li lega e la compatibilità delle techiniche adotatte per raccolglierli ed elaborarli, consente il perseguimento de uno specifico obiettivo di conoscenza. Nel caso del sistema bilancio d'esercizio (...) l' obiettivo si identifica, per l'appunto, nel fornire un minimo comune di informazioni sulla gestione aziendale alle diverse classi di interessi convergenti nell'impresa: portatori del capitale e del lavoro, fornitori, clienti, pubblica amministrazione. Tale 'minima informazione' è attinente alla dimonstrazione della capacita dell'impresa di svolgersi in condizioni di equilíbrio econômico (...), ed è fornita con lo scopo di disporre di elementi per giudicare la gestione passata e formulare previsioni per quella futura". 
Mas não basta a prestação das informações constantes das demonstrações contábeis para que o investidor e demais usuários tenham plena segurança. De fato, por serem referidas demonstrações verdadeiras declarações unilaterais de vontade, nada impede, em princípio, que sejam alteradas (ainda que dentro dos "limites" legalmente permitidos, por meio dos chamados procedimentos criativos de contabilidade ou de gerenciamento de resultados), ou mesmo falsificadas por seus emissores, interessados no estímulo ou desestímulo de um determinado comportamento.

Diante de tal quadro, surge a necessidade básica da auditoria, aqui considerada apenas a auditoria externa, feita por profissional individual ou sociedade independente, de modo a assegurar a fidedignidade das informações prestadas pelos gestores empresariais aos financiadores do negócio no mercado.

Embora venhamos mais adiante a debater e aprofundar o conceito de auditoria externa (também denominado por alguns auditoria de demonstrações contábeis ou financeiras), podemos adotar provisoriamente a definição de Rittenberg et al. para o fenômeno estudado:

Auditoria de demonstrações financeiras, no seu contexto mais amplo, é o processo que envolve a verificação de afirmações sobre eventos e ações econômicas. Em consequência, frequentemente concerne a um serviço de atestação. A atestação é um processo de três partes: coleta de evidências sobre afirmações, avaliação destas evidências em face de critérios objetivos e comunicação da conclusão às partes interessadas. Nós adotamos essa abordagem ampla para descrever uma auditoria financeira. $^{7}$

Ressaltam Rashad e Khalik a importância da auditoria:

$\mathrm{Na}$ ausência de uma função independente de auditoria, os usuários individuais de demonstrações contábeis teriam muito menos probabilidade de assumir que as demonstrações contábeis publicadas são representações honestas de certos assuntos contábeis das entidades. Por quê? Porque os proprietários da empresa e os executivos não proprietários da empresa têm um incentivo econômico para maquiar suas

\footnotetext{
${ }^{7}$ RITTENBERG, Larry E. et al. Auditing - A business risk approach. Ohio: South-Western Cengage Learning, 2010. p. 7. O texto é tradução livre de: "Financial statement auditing, in its broadest context, is the process of attesting to assertions about economic actions and events. It is therefore frequently referred to as an attestation service. Attestation is a three-part process: gathering evidence about assertions, evaluating that evidence against objective criteria, and communicating the conclusion reached to interested parties. We adopt this broad approach for describing a financial audit”.
} 
demonstrações contábeis, isto é, fazer suas entidades parecerem mais lucrativas e financeiramente estáveis do que elas realmente são. ${ }^{8}$

A auditoria, ao contrário do que se pode pensar, é matéria essencialmente regulada pelo Direito e, como tal, objeto de conhecimento do jurista, não devendo este delegar suas atribuições essenciais aos profissionais de ciências correlatas, mas trabalhar em conjunto para atingir melhores resultados.

Busca-se no presente trabalho, em primeira linha, um aprofundamento doutrinário da matéria, necessariamente interdisciplinar. Procura-se ver a auditoria não somente como um processo burocrático, mas primordialmente como uma efetiva forma de garantir credibilidade e segurança a um sistema de informações empresariais, destinado aos representantes da sociedade empresária (sócios, acionistas, etc.), aos financiadores (bancários ou não) e mesmo a terceiros interessados.

Dada a amplitude do tema, elabora-se desde já sua primeira delimitação, de modo a incluir apenas subsidiariamente no presente trabalho o estudo de aspectos jurídicos referentes à atividade de auditoria interna, cuja finalidade encontra-se meramente vinculada ao controle administrativo interno de um ente empresarial, visando à: 1) proteção de bens e direitos contra fraudes, desvios e desfalques; 2) constatação de irregularidades no uso de ativos; 3) busca de eficiência e eficácia operacionais através da pesquisa de aspectos que impeçam o melhor desempenho empresarial.

Outros serviços correlatos com o de auditoria independente, tais como a prestação de consultorias por auditores, serviços de asseguração (assurance), de observância de aspectos legais (auditoria de compliance), somente serão abordados de maneira secundária, no que apresentarem pontos de conexão com o tema principal ora tratado.

Abordaremos principalmente, portanto, a denominada auditoria externa ou independente de demonstrações contábeis, trazendo a lume seus principais aspectos jurídicos no que tange ao Direito Comercial, restando a auditoria interna e outros serviços paralelos meramente como assuntos complementares.

Não serão abordados, igualmente, assuntos referentes à perícia em escrituração empresarial ou demonstrações contábeis. Com efeito, embora similares, perícia contábil e

\footnotetext{
${ }^{8}$ RASHAD, A.; KHALIK, Abdel. Dicionário enciclopédico de contabilidade. São Paulo: Atlas, 2004. p. 31.
} 
auditoria externa de demonstrações são temas essencialmente distintos, não sendo o primeiro incluído aqui.

Do mesmo modo, não estarão incluídos aprofundamentos sobre matérias referentes à auditoria pública, ou auditoria fiscal, uma vez que não se busca nesta tese analisar a atividade de órgãos públicos de controle ou mesmo a atividade estatal de recolhimento de tributos, que se utilizam da auditoria como um de seus instrumentos.

A matéria, como já salientamos, é interdisciplinar. Assim sendo, o trabalho restaria prejudicado ou incompleto se não abordássemos, em conjunto com a parte jurídica, a disciplina contábil da auditoria externa de demonstrações.

Desta forma, embora sem pretender fazer do trabalho um manual de auditoria, optamos por traçar uma abordagem que inclua os principais aspectos da ciência do Direito e também da ciência da Contabilidade. Dentre estes últimos, estarão necessariamente abrangidos os princípios gerais de contabilidade que regem a matéria (p.ex., competência, entidade, custo como base de valor, entre outros), além das rubricas contábeis objeto de auditoria.

Restará incluído também, como veremos mais adiante, o problema do risco de auditoria, tema pouco abordado pela doutrina e jurisprudência nacionais, mas que influencia significativamente na determinação do limite de responsabilidade do profissional de auditoria pelas omissões ou mesmo erros que venham a prejudicar terceiros. Este tópico, aliás, embora amplamente debatido na doutrina e jurisprudência estrangeiras, não recebeu ainda o devido tratamento em nosso país, havendo raros casos de responsabilização de auditores independentes no Judiciário pátrio.

Dada a globalização econômica, as empresas passaram a atuar em diversos mercados, o que terminou por causar uma recente necessidade de uniformização da normatização internacional sobre auditoria. Diante disto, órgãos internacionais passaram nos últimos anos a regulamentar a matéria; regulamentação esta que, por força de exigências de mercado, vem sendo adotada além do âmbito territorial dos organismos mencionados. Incluiremos mencionado tema no trabalho, inserindo as principais referências no direito comparado no que toca ao assunto.

O presente trabalho presta uma contribuição original à ciência jurídica nacional em vários aspectos. 
A primeira contribuição consiste no próprio assunto escolhido e na maneira de abordá-lo.

Com efeito, verifica-se que no âmbito da ciência jurídica nacional praticamente inexistem trabalhos a respeito das questões jurídicas referentes à auditoria externa. A maior parte dos trabalhos que tangenciam o tema é voltada primordialmente à área da contabilidade, pouco ou nada tratando da matéria jurídica. ${ }^{9}$

Outro aspecto que confere originalidade à contribuição dada pela presente tese à ciência jurídica brasileira encontra-se em sua abordagem interdisciplinar. Como já salientamos, o exame da matéria sob o aspecto de pelo menos duas ciências (Direito e Contabilidade) traz consigo a sinergia derivada da união dos conhecimentos em único trabalho, possibilitando sua transmissão de forma integrada e agregadora do ponto de vista de ramos distintos.

Possibilita-se também o alinhamento da visão jurídica e contábil, proporcionando certa dose de comunicação entre ciências distintas que não podem ficar separadas quando se deseja conhecimento de um todo formado por aspectos de ambas.

Inova-se ainda pela preocupação da análise e da compatibilização entre as normas nacionais e internacionais de auditoria, tão necessárias diante da globalização econômica e consequente internacionalização das atividades de auditoria externa, tema este não abordado em nenhuma publicação jurídica nacional.

Por todos os aspectos ora mencionados e os demais a serem apresentados no correr da elaboração da presente tese, estamos convencidos de que o tema será completamente inovador na ciência jurídica pátria, que muito pouco desenvolveu a este respeito até o momento.

Em linhas gerais, este é o tema a ser desenvolvido na tese que ora se inicia. Maiores especificações poderão ser vistas no tópico seguinte.

\footnotetext{
${ }^{9}$ Uma rápida pesquisa pelo sistema de base de dados da Universidade de São Paulo (DEDALUS-USP, <http://dedalus.usp.br:4500/ALEPH/POR/USP/USP/DEDALUS/SHORT/221430/1/>. Acesso em 21.10.2008) com os argumentos “auditoria and demonstrações”, retornou apenas catorze resultados. Praticamente todos voltados à área de contabilidade e administração financeira, sem nenhum ponto de contato com a ciência jurídica.
} 


\section{JUSTIFICATIVA DA ESCOLHA, OBJETIVOS, METODOLOGIA E PRINCIPAIS QUESTÕES A SEREM ANALISADAS}

A auditoria das demonstrações contábeis, como ressaltam Boynton et al., remonta aos primórdios da atividade econômica:

Auditoria começa em época tão remota quanto à contabilidade. Sempre que o avanço da civilização tinha implicado que a propriedade de um homem fosse confiada, em maior ou menor extensão, a outro, a desejabilidade da necessidade de verificação da fidelidade do último tornou-se clara. ${ }^{10}$

Desde a crise de 1929 na Bolsa de Valores de Nova Iorque, porém, a necessidade da auditoria externa de demonstrações contábeis vem se impondo de modo cada vez mais pujante.

Os acontecimentos econômicos então ocorridos demonstraram que o investidor encontrava-se desprovido de informações econômicas fidedignas para avaliar corretamente o negócio no qual aportava seus recursos e, consequentemente, sobre o risco enfrentado.

A evolução dos mercados e dos instrumentos de negociação nos tempos modernos torna a auditoria de demonstrações cada vez mais essencial para bem atestar a qualidade da informação prestada aos financiadores dos empreendimentos.

Com efeito, a complexidade dos instrumentos financeiros negociados (incluindo derivativos, opções, contratos a termo, futuros e swaps) torna mais fácil a subtração de informações do público investidor. Esta complexidade fez com que, recentemente, importantes companhias norte-americanas conseguissem esconder fraudulentamente imensos passivos de seus acionistas, até que sua situação financeira se tornasse tão grave a ponto de não poder ser mais subtraída do conhecimento destes. ${ }^{11}$

\footnotetext{
${ }^{10}$ BOYNTON, Willian C. et al. Auditoria. São Paulo: Atlas, 2002. p. 34.

${ }^{11}$ São representativos da situação supracitada os casos das empresas americanas Enron e WorldCom, cuja falência também envolveu uma das maiores empresas de auditoria norte-americanas, a Arthur Andersen. Tais acontecimentos originaram a resposta legislativa correspondente, consubstanciada na Lei Sarbanes-Oxley
} 
No âmbito da Comunidade Europeia, a necessidade da auditoria (ou revisão de contas) como atividade primordial para a realização e expansão de um mercado único foi expressamente demonstrada em estudo elaborado por especialistas:

A obrigação imposta a determinadas empresas de sujeitar as suas contas anuais e consolidadas a uma revisão por um profissional qualificado, introduzida para toda a Comunidade pelas diretivas contabilísticas, tem por objetivo a proteção do interesse geral. A garantia oferecida pelas contas certificadas contribui para reforçar a confiança de todas as partes que têm relações econômicas com estas empresas. $\mathrm{O}$ aumento da transparência decorrente da harmonização da informação financeira publicada pelas empresas em conjunto com o aumento da fiabilidade desta informação decorrente da certificação efetuada por um profissional independente e qualificado são consideradas como uma importante contribuição para a realização do mercado único. ${ }^{12}$

A recente crise financeira, ocorrida em 2008, também revela a grande importância da auditoria externa de demonstrações, que tende a passar por sérias reformulações, uma vez que não foi suficientemente hábil para informar os investidores do risco de crédito existente em empréstimos destinados ao financiamento da compra de imóveis, operações que resultaram em importantes emissões de títulos em contratos de securitização não consolidados nas demonstrações financeiras dos bancos. ${ }^{13}$

Mais recentemente, mudança na legislação brasileira do anonimato, operada pela Lei n. 11.638/07, trouxe novas questões sobre auditoria de demonstrações contábeis, obrigando também as sociedades limitadas de grande porte a se submeterem a tal processo, fato que será abordado no presente trabalho.

As repercussões jurídicas modernas da auditoria externa de demonstrações contábeis estendem seus efeitos não somente sobre o Direito Comercial, em matérias como

(SOx). Esta situação, que gerou ponderável desconfiança dos investidores em relação à atividade de auditoria externa, será analisada mais adiante.

${ }^{12}$ EUROPEAN COMMISSION. Green Paper on the role, the position and the liability of the statutory auditor within the European Union. Disponível em <http://europa.eu/documents/comm/green_papers/pdf/com96_338_en.pdf>. Acesso em 7 mar. 2010.

13 Embora ainda haja outros aspectos a serem revelados, duas falhas têm sido atribuídas aos auditores externos independentes, relacionadas à crise econômica de 2008: 1) omissão na verificação do valor de avaliação dos títulos hipotecários de alto risco (subprime) emitidos pelas entidades auditadas, os quais foram negociados e declarados nas demonstrações contábeis por preço que não correspondia a seu valor justo (neste sentido, veja-se interessante reportagem do jornal Valor Econômico: "Fraude em fundos 'subprime' deixa auditorias sem palavras", edição de 19.04.2010, Caderno EU\&Investimentos, p. D7); 2) omissão em revelar aos usuários das demonstrações contábeis os riscos inerentes à continuidade operacional das entidades auditadas emissoras ou portadoras de títulos hipotecários de alto risco. 
governança corporativa, full disclosure e falência, mas também sobre o Direito Civil (que define as hipóteses de responsabilidade civil profissional do contador e do auditor), Direito Tributário (em relação à auditoria de tributos), e Direito Penal (que define crimes correlatos à matéria).

O tema, portanto, é dotado de marcante atualidade e repercussão em áreas correlatas, o que por si só já justifica sua escolha. Além disso, a opção pelo assunto também se baseou na evidente escassez de doutrina jurídica que o abrangesse.

Torna-se, assim, necessário um maior estudo sobre referido objeto, a fim de aprofundar os conhecimentos jurídicos e uni-los aos detalhes contábeis inerentes.

Assim sendo, a presente tese se propõe a suprir a lacuna no que diz respeito à ausência de trabalhos sobre análise da normatização jurídica da atividade de auditoria externa de demonstrações.

Dentro desta perspectiva, vários assuntos devem ser tratados.

Com relação ao contrato de auditoria, objetivamos analisar os diversos aspectos inerentes a este fenômeno, tais como sua natureza jurídica, as partes envolvidas, as obrigações ínsitas à respectiva contratação, bem como seus aspectos acessórios, como a proteção jurídica do sigilo dos documentos e resultados da auditoria, investigando quais sejam seus limites.

Versaremos a respeito do desenvolvimento da atividade de auditoria independente, especialmente no tocante ao principal objeto auditado (demonstrações contábeis), investigando algumas das melhores práticas recomendadas.

Também será tratado aqui o relacionamento da atividade de auditoria independente com os princípios e práticas de governança corporativa, assunto que instiga inúmeras pesquisas de estudiosos. Isto significa cuidar de questões que envolvem as implicações da auditoria externa com os órgãos internos das sociedades, tais como os Conselhos de Administração e Fiscais, tratando também de forma inovadora dos Comitês de Auditoria, criados no exterior por efeito da Lei Sarbanes-Oxley, cuja constituição também é necessária para alguns ramos de negócios no Brasil.

Do mesmo modo, abordaremos o tema referente à responsabilidade do auditor, ainda incipiente em nossa doutrina e jurisprudência. Saliente-se que o trabalho não se limitará a discutir a responsabilidade do auditor somente sob os aspectos clássicos da responsabilidade civil indenizatória ou mesmo do Código do Consumidor (Lei n. 
8.078/90). Serão vistas também as repercussões do tema sob o ponto de vista da Análise Econômica do Direito (Law and Economics), uma vez que os limites da responsabilização do auditor podem influenciar significativamente os estímulos econômicos à prática de mencionada atividade, privando ou não a sociedade de uma função extremamente relevante aos investimentos privados.

Abordaremos ainda, de maneira inovadora, a questão da natureza empresarial ou não da atividade de auditoria diante das novas normas do Código Civil, abarcando a proibição do caráter empresarial e a vedação de qualquer limitação de responsabilidade das sociedades destinadas à auditoria de demonstrações, por força de determinação regulamentar da CVM, além de confrontar os aspectos das normas de auditoria com aqueles referentes às normas contábeis constantes de nossa legislação societária.

Será também abrangida a questão do relacionamento entre a auditoria e a necessidade ou não de se atestar (ou prever) a continuidade do empreendimento por tempo ilimitado (going concern), bem como as consequências de sua não continuidade ou falência em relação à tarefa do auditor, até agora não explorada em nossa doutrina e jurisprudência.

Para a obtenção dos escopos almejados, utilizaremos metodologia ${ }^{14}$ que envolve combinação de pesquisa teórica e histórica das matérias tratadas, sem olvidar da discussão das pesquisas de campo já realizadas por fontes diversas sobre temas específicos. Procuraremos dar ao tema uma abordagem sistêmica, privilegiando o estudo de seu objeto de forma globalizada e interdisciplinar, dando ênfase às interações de seus elementos constitutivos e seus aspectos estruturais.

\footnotetext{
${ }^{14}$ Para um trabalho científico de pós-graduação, bem define metodologia Antônio Joaquim Severino: "Tratase de explicitar aqui se se trata de pesquisa empírica, com trabalho de campo ou de laboratório, de pesquisa teórica ou de pesquisa histórica ou se de um trabalho que combinará, e até que ponto, as várias formas de pesquisa. Diretamente relacionados com o tipo de pesquisa serão os métodos e técnicas a serem adotados. Entende-se por métodos os procedimentos mais amplos de raciocínio, enquanto técnicas são procedimentos
} 


\section{CONCEITUAÇÃO E ESPÉCIES DE AUDITORIA}

A atividade de auditoria não pode ser conceituada de uma única forma.

Isto porque uma ampla gama de serviços está abarcada neste conceito, razão pela qual devemos trazer, além da conceituação inicial, uma série de distinções entre situações análogas, para bem fixarmos o objeto tratado no presente trabalho. Sobre isto bem relatam Araújo et al.:

A tarefa de conceituar auditoria não é das mais fáceis, especialmente em face da possibilidade de aplicação dessa técnica em muitas áreas do conhecimento humano. Etimologicamente, a palavra "auditoria" originase do latim audire (ouvir). Inicialmente, foi utilizada pelos ingleses (auditing) para significar o conjunto de procedimentos técnicos utilizados para a revisão da escrituração e evidenciação dos registros contábeis. ${ }^{15}$

Uma das mais respeitadas definições do tema provém da American Accounting Association, que define genericamente auditoria como:

Um processo sistemático de obtenção objetiva e avaliação de evidências concernentes a afirmações sobre ações econômicas e eventos, para verificar o grau de correspondência entre essas assertivas e os critérios estabelecidos, bem como os aspectos de comunicação dos resultados aos usuários interessados. ${ }^{16}$

mais restritos que operacionalizam os métodos, mediante emprego de instrumentos adequados". (SEVERINO, Antônio Joaquim. Metodologia do trabalho científico. São Paulo: Cortez, 2002. p. 162).

15 ARAÚJO, Inaldo da Paixão Santos; ARRUDA, Daniel Gomes; BARRETO, Pedro Humberto Teixeira. Auditoria Contábil - Enfoque teórico, normativo e prático. São Paulo: Saraiva, 2008. p. 1.

16 AMERICAN ACCOUNTING ASSOCIATION. A statement on basic auditing concepts. Accounting Review, vol. 47, 1972. O texto é tradução livre da seguinte definição: "a systematic process of objectively obtaining and evaluating evidence regarding assertions about economic actions and events to ascertain the degree of correspondence between those assertions and established criteria and communicating the results to interested users". A legislação norte-americana (Lei Sarbanes-Oxley) também contém definição do que considera auditoria independente, nos seguintes termos: “AUDIT.- The term 'audit' means an examination of the financial statements of any issuer by an independent public accounting firm in accordance with the rules of the Board or the Commission (or, for the period preceding the adoption of applicable rules of the Board under section 103, in accordance with then-applicable generally accepted auditing and related standards for such purposes), for the purpose of expressing an opinion on such statements". 
Como faz a doutrina especializada, ${ }^{17}$ podemos dissecar os principais elementos da definição supracitada, para avaliar os pontos prioritários do objeto estudado:

- Um processo sistemático: ressalta que a auditoria não é composta de um ato único, mas de uma sequência de atos que seguem uma lógica, devidamente estruturada e organizada em uma série de etapas ou procedimentos;

- Avaliação e evidenciação objetivas: a atividade de auditoria é caracterizada, na medida do possível, pelo exame objetivo de provas e evidências, sem considerações ou manifestações de caráter pessoal. $O$ auditor deve obter $e$ avaliar as provas e as bases para suas afirmações, além de analisar e avaliar criteriosamente os resultados, sem preconceito ou prejuízo, a favor ou contra o indivíduo (ou entidade) sobre a qual recai seu trabalho;

- Afirmações sobre eventos econômicos: para os efeitos deste trabalho, devemos considerar que a atividade de auditoria recai sobre os eventos economicamente avaliáveis da entidade auditada. Fatos sem repercussão econômica estarão fora do objeto auditado;

- Avaliação da correspondência entre as afirmações economicamente avaliadas e os critérios estabelecidos: a auditoria deve se utilizar de parâmetros (quantitativos e qualitativos) para verificar a correspondência entre o material auditado e os padrões exigidos;

- Estabelecimento de critérios: significa que a auditoria trabalha sobre padrões normativos, ou seja, confronta suas pesquisas com normas estabelecidas, para efetivar juízos de valor. Tais regras podem ser legislativas (no Brasil, p.ex.: Leis ns. 10.406/2002, 6.404/76, etc.), regulamentares (regras de auditoria internacional - ISA, normas internacionais de contabilidade IFRS, Instruções da CVM, Resoluções do CFC, etc.) ou princípios de contabilidade geralmente aceitos (PGCA ou GAAP);

- Comunicação aos destinatários: a auditoria sempre deve terminar pela comunicação das evidências aos usuários da informação contábil. Tal comunicação pode se dar por meio de um parecer ou relatórios escritos, que indicam o grau de correspondência entre os eventos verificados e os critérios estabelecidos e utilizados.

\footnotetext{
${ }^{17} \mathrm{O}$ mesmo processo de exame dissecado dos elementos da definição da American Accounting Association é feito por Boyton et al. (Op. cit. p. 31).
} 
Como ressaltamos, interessa-nos aqui a atividade de auditoria externa (ou auditoria independente). Devemos, portanto, separá-la das demais atividades e serviços correlatos, retratando as particularidades destes serviços em relação à definição geral anteriormente apresentada.

$\mathrm{Na}$ auditoria independente, encontram-se presentes os elementos da definição supracitada relativos ao estabelecimento de um processo sistemático, que recai sobre fatos econômicos da entidade auditada e é avaliado segundo normas estabelecidas, de modo objetivo. No entanto, devemos ressaltar que, na auditoria independente, existem as seguintes particularidades:

- $O$ auditor não pertence aos quadros da entidade auditada: diferentemente dos serviços de auditoria interna, na auditoria externa o auditor não está vinculado, de qualquer forma, à entidade auditada. Não pertence aos quadros de pessoal da auditada, nem mantém vínculo de emprego ou qualquer subordinação hierárquica com esta. Justamente por isto, tem a obrigação de manter postura de independência em relação ao ente auditado;

- Os destinatários dos resultados da auditoria externa são usualmente indeterminados ou de difícil determinação (wide spectrum of users): como os resultados do trabalho de auditoria externa se consubstanciam frequentemente na publicação de um parecer, seus destinatários são indeterminados (abrangendo acionistas, empregados, administradores, investidores, etc.), ao contrário da auditoria interna, que se destina ao auxílio de usuários determinados, quais sejam, os administradores da entidade;

- Os critérios levados em consideração pela auditoria externa devem ser baseados em regras postas por órgãos reguladores, ou padrões contábeis e de auditoria definidos e aceitos pela generalidade da ciência contábil: a auditoria externa não observa meramente critérios estabelecidos pela gestão como parâmetros de comparação a serem seguidos. Não visa a auxiliar a gestão da entidade auditada a melhor administrar o negócio. Ao contrário, considerando-se que um dos objetivos da auditoria independente é justamente fiscalizar a administração, seus padrões de comparação devem ser fixados externamente pelos órgãos próprios ou 
pela ciência contábil (Princípios Contábeis Geralmente Aceitos - PGCA). Isto indica também que os parâmetros e objetivos da auditoria externa são normativos, e não meramente destinados a fins gerenciais;

- Os resultados da auditoria independente são transmitidos, em regra, de forma normatizada e padronizada: o grau de liberdade do auditor externo para emitir suas opiniões é mais restrito do que o existente em uma auditoria interna. Precisamente por se destinar a usuários indeterminados, a auditoria externa deve se manifestar de maneira apta a atingir a generalidade dos destinatários de suas informações. Para tanto, são usualmente estabelecidos padrões de pareceres ou relatórios.

Aditando à definição inicial os aspectos ora mencionados, poderíamos definir auditoria externa (ou auditoria independente) como um processo sistemático de obtenção objetiva e avaliação de evidências concernentes a afirmações sobre ações econômicas $e$ eventos, a cargo de auditor que não mantenha vínculo de subordinação com o ente auditado, para verificar o grau de correspondência entre essas assertivas e critérios normativamente estabelecidos por órgãos competentes ou geralmente aceitos pela ciência contábil, e comunicar publicamente de forma padronizada seus resultados a usuários interessados indeterminados ou de difícil determinação.

Estabelecidos os primeiros contornos da atividade de auditoria externa, faz-se mister passar em revista aos diversos tipos e classificações da atividade de auditoria, para que se apartem da auditoria externa outros serviços semelhantes, melhor delimitando seu conteúdo.

Distingue-se da auditoria externa a auditoria operacional ou de gestão. De fato, este tipo de auditoria visa à verificação da eficácia e eficiência da gestão do ente auditado, buscando seu aprimoramento e a apresentação de soluções administrativas, enquanto o escopo principal da auditoria externa é dar segurança razoável de que as demonstrações contábeis retratam a realidade econômica do auditado e estão de acordo com os PGCA e legislação pertinente.

Não se confunde a auditoria externa com a auditoria de cumprimento (compliance audit), uma vez que esta última busca apenas atestar o cumprimento de determinadas normas ou de procedimentos estabelecidos pela gestão. O escopo da 
auditoria de cumprimento, portanto, é usualmente limitado, e seu objeto pode incidir sobre eventos não passíveis de avaliação econômica. ${ }^{18}$

Diferencia-se a auditoria externa dos serviços de assurance, ou asseguração. Estes objetivam a coleta de informações, melhora de sua confiabilidade e a viabilidade de melhores decisões por parte dos destinatários ${ }^{19}$ (p.ex., a avaliação independente do risco do negócio de um tomador de empréstimo por parte de um profissional de contabilidade contratado por uma instituição financeira, com fim de analisar a concessão de um empréstimo). Não há emissão de parecer formal, não há normas rígidas ou aplicação necessária dos PGCA, podendo os critérios ser estabelecidos pelos interessados, e os usuários da informação normalmente são determinados ou determináveis.

Também não se confunde a auditoria externa com a auditoria fiscal ou tributária. Com efeito, este último tipo visa apenas a verificar a correção da incidência de tributos sobre a atividade da entidade auditada e dos respectivos pagamentos efetuados por esta, podendo ainda ser instrumento para a realização de planejamento tributário. Seu escopo é limitado a estas matérias, não abrangendo a totalidade dos itens das demonstrações contábeis. Não é voltada à satisfação das necessidades de usuários externos. Apesar de poder ser realizada por particulares, na grande maioria das vezes é determinada por órgãos públicos, distinguindo-se também neste caso da auditoria externa, que é realizada somente por particulares.

\footnotetext{
${ }^{18}$ A compliance audit pode ser voluntariamente estabelecida pelas partes interessadas (p.ex., auditoria para certificações de qualidade ou de cumprimento da legislação ambiental), ou determinada em norma. Exemplo são as normas do Banco Central que determinam a realização de auditoria de cumprimento, por exemplo, para verificação dos controles internos de entidades do sistema financeiro na prevenção de crimes de lavagem de dinheiro (p.ex., Carta Circular n. 3.337/08). A própria CVM também estabelece normas sobre referido tema (Instruções n. 301/99 e 461/07). Com base nesta e outras regras, a BMF\&Bovespa criou área própria de supervisão de mercados (Bovespa Supervisão de Mercados - BSM), que realiza auditorias de cumprimento sobre diversos procedimentos dos participantes do mercado de capitais (p.ex.: cadastro, ordens, integridade, home broker, tecnologia de informação, clubes de investimento, risco, recursos humanos, etc.). Ao final do trabalho em campo, é elaborado um relatório com eventuais deficiências identificadas (não cumprimento ou não conformidade), com encaminhamento à CVM para as providências cabíveis. O órgão responsável pela supervisão dos mercados (BSM) também tem atribuição para aplicar penalidades pelo descumprimento de suas normas e administrar o mecanismo de ressarcimento de prejuízos a investidores.

${ }^{19}$ Veja-se, neste sentido, a definição do AICPA: "Assurance services are independent professional services that improve the quality of information, or its context, for decision makers". Disponível em <http://www.aicpa.org>. Acesso em $2 \mathrm{dez}$. 2009. Muitos autores colocam os serviços de assurance como um gênero no qual os serviços de auditoria estão inseridos (vide BOYTON et al. Op.cit. p. 900). Importante ressaltar que são ínsitos ao conceito dos serviços de asseguração: 1) independência do auditor; 2) três partes determinadas envolvidas: o usuário da informação (que pode ser o contratante dos serviços), o auditor e o auditado.
} 
Pelo mesmo motivo mencionado acima, a auditoria externa se diferencia da auditoria governamental ou pública, realizada pelos órgãos públicos de controle interno e externo sobre seus próprios procedimentos e agentes ou sobre os particulares.

Distinta também a auditoria externa dos serviços de compilação ou de consultoria. ${ }^{20}$ Estes não prestam qualquer forma de segurança ou garantia a usuários externos, e desenvolvem-se meramente entre as partes contratantes, sem efeitos diretos a terceiros destinatários. A prestação de serviços de consultoria visa a que o contabilista preste assessoria à entidade contratante em diversos aspectos relacionados com sua profissão. A compilação envolve a contratação de um profissional de contabilidade para que este delineie e compile as demonstrações financeiras para o cliente, com base em dados previamente estabelecidos, sem qualquer certificação de conformidade.

Finalmente, como já ressaltamos neste trabalho, distingue-se a auditoria externa da auditoria interna, já que esta última é realizada por auditores com vínculo de subordinação à entidade auditada (dependência), buscando dar auxílio aos gestores (usuários dos serviços de auditoria interna), e não a produção de parecer sobre as demonstrações de acordo com critérios estabelecidos.

\footnotetext{
${ }^{20}$ Devemos lembrar que os diversos "escândalos" contábeis já mencionados acabaram por ensejar a elaboração de severa regulação no setor de auditoria em diversos países. Um dos pontos principais, adotado por vários Estados, é a vedação da prestação concomitante de serviços de auditoria externa e consultoria a uma mesma entidade, uma vez que isto põe em risco a independência do auditor. Voltaremos ao tema mais adiante.
} 


\section{HISTÓRICO}

Como já citado, a história da atividade de auditoria está ligada intimamente ao surgimento da contabilidade como ciência.

É de se reconhecer, entretanto, que a investigação histórica sobre o surgimento dessas duas áreas do conhecimento é um tanto divergente entre os doutrinadores.

Com relação à atividade de contabilidade ou escrituração, ${ }^{21}$ alguns autores argumentam que referido ramo tenha surgido desde os primórdios da humanidade, vinculado às primeiras formas de apropriação de bens.

Nesse sentido, Iudícibus nos relata:

Alguns historiadores fazem remontar aos primeiros sinais objetivos da existência de contas aproximadamente há 4.000 anos a.C. Entretanto, antes disso o homem primitivo, ao inventariar o número de instrumentos de caça e pesca disponíveis, ao contar seus rebanhos, ao contar suas ânforas de bebidas, já estava praticando uma forma rudimentar de Contabilidade. $^{22}$

Divergindo de Iudícibus, Rubens Requião insere o início da atividade contábil e escritural na Idade Média (embora se refira a achados ainda mais antigos), identificando alguns de seus primórdios na sociedade romana:

\footnotetext{
${ }^{21}$ Inserimos aqui os termos contabilidade e escrituração conjuntamente. No entanto, trata-se de fenômenos essencialmente diversos. Nos termos da lição de Fran Martins: "Por contabilidade deve-se entender a ciência que tem por finalidade a orientação e o controle dos atos e feitos de uma administração econômica. A escrituração é a redução a escrito das operações contábeis, ou seja, a fixação metódica, nos livros apropriados, das operações efetuadas pelo comerciante. Os dois termos são, às vezes, confundidos na prática, mas, como esclarece Waldemar Ferreira, a contabilidade é o gênero e a escrituração é a espécie" (MARTINS, Fran. Curso de Direito Comercial. Rio de Janeiro: Forense, 1990. p. 114-5). Igualmente, a opinião de J. X. Carvalho de Mendonça, para quem os dois conceitos (escrituração e contabilidade) restam bem distintos, não possuindo relações de meio-fim ou gênero-espécie: "A palavra contabilidade costuma ser empregada no mesmo sentido de escrituração, conforme o uso mercantil (Ferreira Borges, Dicc. Jurídico, verb. Contabilidade). Este vocábulo (contabilidade) é genuinamente português e significa: receita e despesa de uma casa comercial; a arte de arrumar os livros comerciais. Consulte-se Aulete, Dicionário Contemporâneo. Certo é, porém, que se não deve confundir a contabilidade com a escrituração mercantil: aquela é uma ciência, tendo por objeto a organização dos livros e o estabelecimento das contas relativas aos produtos do trabalho e às transformações do capital, ou, mais brevemente, à ciência do cálculo aplicada aos negócios; esta, uma arte, tendo por objeto o lançamento ou registro metódico das operações comerciais, de acordo com os princípios da contabilidade ou ciência das contas. Esta distinção é bem explicada por Léautev \& Gilbault, no Traité Théorique et Pratique de Comptabilité (p. 5 a 24), depois de criticar inúmeras definições que de contabilidade (comptabilité) e escrituração (tênue des livres) deram os autores" (MENDONÇA, José Xavier Carvalho de. Dos livros dos comerciantes. São Paulo: Rothschild, 1906. p. 1).

${ }^{22}$ IUDÍ́CIBUS, Sérgio de. Teoria da Contabilidade. São Paulo: Atlas, 2000. p. 30.
} 
Como é impossível à memória humana reter normalmente a profusão de dados e fatos cotidianos, desde a alta idade média se impôs o costume de registrá-los por escrito (...). A arqueologia revelou, nas ruínas de templos da Babilônia, tábuas de escrita, onde os sacerdotes registravam as quantidades de cereais, cujos depósitos públicos estavam sob sua guarda. Em Roma, ao pater familias cabia o dever de registrar em livros próprios os negócios de sua atividade econômica e doméstica, usando dois livros: o adversaria, que recebia diariamente o lançamento sumário das operações efetuadas, e o codex accepti et expensi, os quais, ao fim de cada mês, acolhiam, com o histórico respectivo, os assentos que eram ali diligentemente lavrados. ${ }^{23}$

Estudo do Instituto dos Auditores Independentes do Brasil (IBRACON) traz referências a atividades ainda mais antigas envolvendo rudimentos de contabilidade:

Já no Paleolítico Superior (cerca de 20000 a.C.), essa economia de subsistência pressupunha determinada forma de controle sobre quanto se acumulara, hábito que permitia saber quando não era necessário buscar na natureza bens indispensáveis à vida. Inúmeras provas arqueológicas demonstram a existência dessa Contabilidade primitiva, como as pequenas lascas de ossos de rena com incisões que indicam o controle quantitativo de algum objeto, encontradas na França, na Gruta de D’Aurignac. Há ainda pinturas líticas e registros rupestres que comprovam a capacidade desse homem do Paleolítico para registrar fatos relacionados à própria atividade. ${ }^{24}$

Tal estudo ainda consigna a importância da contabilidade em várias civilizações antigas. Na Mesopotâmia, o incremento nos registros de natureza contábil seria derivado do grande império comercial estabelecido do local por diversos povos. No Egito, os rudimentos de contabilidade se deram primordialmente em virtude da necessidade de controle das rendas e propriedade dos faraós e para a fiscalização da arrecadação. Na Índia, houve evidências de primórdios de atividade contábil, inclusive com a separação do lucro operacional daquele não operacional (extraordinário). Na Grécia, o desenvolvimento filosófico e matemático se deu juntamente com a atividade contábil, que era utilizada para regular a administração financeira das cidades-estados.

\footnotetext{
${ }^{23}$ REQUIÃO, Rubens. Curso de Direito Comercial. São Paulo: Saraiva, 1991. p. 125.

${ }^{24}$ INSTITUTO DOS AUDITORES INDEPENDENTES DO BRASIL. Auditoria: Registros de uma profissão. São Paulo: IBRACON, 2007. p. 13.
} 
É certo, porém, que após o incremento das atividades de troca de mercadorias e o surgimento da moeda, a atividade contábil e a escriturária experimentaram sensível desenvolvimento, que coincidiu em boa parte, sob o aspecto temporal (Idade Média) e espacial (cidades italianas de Veneza, Gênova, Florença Piza e outras), com o desenvolvimento do Direito Comercial como disciplina autônoma.

Atribui-se o crescimento da escrituração empresarial e da ciência da contabilidade, como as conhecemos hoje, à obra pioneira do Frei Luca Pacioli, Tractatus de Computis et Scripturis, inserido na obra maior Summa de Arithmetica, Geometria, Proportioni et Proporcionalità, editada em 1494. Referida obra é conhecida principalmente por revelar o chamado sistema de partidas dobradas, no qual todo e qualquer lançamento envolve simultaneamente débito e crédito de duas ou mais contas.

Além disso, ao sistematizar a ciência contábil e as formas de escrituração, Pacioli inaugura com sua obra a "escola italiana", por alguns denominada "escola europeia". Surge então a oportunidade para o aparecimento de outras obras de autores importantes (Cerboni, Francesco Villa, Amaduzzi, etc.).

O período imediatamente posterior à obra de Pacioli é também denominado período científico da contabilidade, marcado por uma grande evolução científica e pelo aprimoramento durante os séculos posteriores.

Com o surgimento das grandes companhias modernas, principalmente no início do século XX, o desenvolvimento do comércio entre os países e do mercado financeiro e de capitais, passou a predominar a "escola americana" de contabilidade, referência feita à doutrina exportada dos Estados Unidos da América, marcada por um reforço teórico sobre auditoria e agências de regulação do mercado, proteção de investidores menores, entre outros temas. ${ }^{25}$

\footnotetext{
${ }^{25}$ Interessante verificar a lição do filósofo Alain de Botton, que, após ter observado o trabalho dos profissionais de contabilidade e auditoria na Inglaterra, traz opinião interessante tanto a respeito da história quanto do comportamento dos que atuam nesta área: "Os contadores não atendem a necessidades superficiais da vida. Sua atividade só veio a existir tardiamente na história das profissões, apenas depois que milhões de pessoas já haviam se concentrado em cidades e se agrupado em falanges industriais - pois até então a contabilidade não exigia mais do que poucos e esporádicos minutos diante do livro-razão, iluminado por velas na sala dos fundos. O advento de dedicados especialistas financeiros, incapazes de pescar, construir casas ou costurar casacos, mas inteiramente empenhados em responder a questões sobre amortização, receita padrão de contratos e impostos de transferência, parece ser o resultado de um longo processo de divisão do trabalho que começou há três milênios no Egito antigo e que, pelo menos em casos como este, gerou recompensas espetaculares, assim como alguns efeitos colaterais peculiares sobre nossa psicologia" (BOTTON, Alain. Os prazeres e desprazeres do trabalho. Rio de Janeiro: Rocco, 2009. p. 228).
} 
No Brasil, houve grande influência das escolas italiana e europeia, muito embora tenhamos sofrido ingerência mais recente da escola americana. ${ }^{26}$

Em relação aos serviços de auditoria, há também inúmeras divergências no tocante ao seu início histórico, reconhecendo alguns autores a dificuldade na fixação de um momento inicial de referida atividade.

Nesses termos, Araújo et al. ressaltam:

Sobre a origem da atividade auditorial, menciona-se, apenas, que existem relatos de ações dessa natureza praticadas pelos sumérios. Mesmo em manuais e publicações de auditoria de outros países mais desenvolvidos, encontram-se apenas referências esparsas sobre o tema. Alguns afirmam que a auditoria é uma técnica contábil e, como tal, surgiu a partir do momento em que terceiros começaram a analisar e emitir opinião independente sobre os demonstrativos elaborados pela contabilidade. ${ }^{27}$

Vários autores identificam os primórdios da atividade de auditoria na ação de órgãos estatais que, visando à arrecadação de tributos, faziam verificações nos papéis e registros contábeis dos cidadãos, ou mesmo em atividades de prestação de contas por terceiros que administravam recursos públicos ou particulares. Nessa linha, lecionam Boynton et al:

No Egito antigo, autoridades providenciavam verificações independentes nos registros de arrecadação de impostos; na Grécia eram realizadas inspeções nas contas de funcionários públicos; os romanos comparavam gastos com autorizações de pagamento; e os nobres de castelos medievais ingleses indicavam auditores que revisavam os registros contábeis e relatórios preparados pelos criados. ${ }^{28}$

Importante citar novamente o estudo do Instituto dos Auditores Independentes do Brasil (IBRACON), que relata o seguinte sobre o surgimento da atividade de auditoria:

A atividade do auditor é quase tão antiga quanto a Contabilidade. Podemos remontar ao Império Persa, por exemplo, no qual Dario I, ao realizar a reforma político-administrativa, criou a função de "olhos e

\footnotetext{
${ }^{26}$ Apontam-se como exemplos de influências da escola americana os diversos institutos destinados a proporcionar informação e proteção ao pequeno investidor, tais como a ingerência de órgãos governamentais (CVM) nas normas referentes às demonstrações contábeis e a necessidade de auditoria externa (art. 177, § 3을 da Lei n. 6.404/76).

${ }^{27}$ Op. cit. p. 9.

${ }^{28}$ Op. cit. p. 34.
} 
ouvidos do rei”, funcionários encarregados de vigiar a ação dos sátrapas (governadores das províncias persas) garantir o cumprimento das ordens imperiais e fiscalizar a cobrança de impostos. ${ }^{29}$

Este último estudo ainda menciona atividades típicas de auditoria no século XII, na França, onde os barões realizavam leituras públicas de suas contas na presença de funcionários da Coroa e na instituição dos missi dominici pelo imperador Carlos Magno (768-814) para auditar províncias sob seu domínio.

Embora não se tenha como pacificado na doutrina o momento do surgimento da atividade auditorial, ou mesmo um nome responsável por seu início, ${ }^{30}$ há certo consenso entre os autores que a auditoria tem seus moldes, na forma como é conhecida hoje, no período de expansão ultramarina (séculos XV e XVI) e durante a Revolução Industrial na Inglaterra.

É fato que as expedições marítimas exigiram o emprego de grandes capitais e criação de verdadeiras joint ventures, com emprego intensivo de capital público e privado. Isso tudo gerou a necessidade de prestação de contas das receitas e dos gastos aos governos e demais investidores, criando a necessidade de revisão ou verificação de contas.

Do mesmo modo, a Revolução Industrial (século XVIII, na Inglaterra) causou a expansão do capitalismo e a criação de fábricas fora do alcance territorial e vigilância dos proprietários, fazendo surgir a necessidade de delegação de atribuições para auditar os resultados empresariais.

Nesses dois fenômenos percebe-se que o impulso marcante para o começo da auditoria externa foi a separação entre propriedade e gestão do empreendimento, fato este que causou a necessidade de prestação de contas e sua verificação por especialistas. ${ }^{31}$

\footnotetext{
${ }^{29}$ Op. cit. p. 43.

${ }^{30}$ Como relata Sérgio Jund: “Ao contrário da contabilidade, que tem no Frade Luca Paccioli o seu ícone, a história da auditoria se perdeu no tempo, e o nome do primeiro auditor talvez permaneça para sempre ignorado" (JUND, Sérgio. Auditoria - Conceitos, normas, técnicas e procedimentos. Rio de Janeiro: Elsevier, 2007. p. 5).

${ }^{31} \mathrm{O}$ fenômeno está intimamente ligado ao tema tratado no clássico trabalho de Berle e Means, relativo à separação entre propriedade e controle nas sociedades anônimas. Nas demais espécies societárias, segundo estes autores, a propriedade de parcela do patrimônio social implica necessariamente o controle dos mecanismos de gestão e administração societárias, ou pelo menos participação nas decisões societárias. Na sociedade anônima, porém, separam-se tais atributos, e o detentor da propriedade das ações usualmente não é quem controla os destinos da sociedade. Como ressaltam: "Criou-se uma grande massa de acionistas que não exercem virtualmente nenhum controle sobre a riqueza com que eles ou seus predecessores contribuíram para a empresa". Tal fenômeno acarreta a clara necessidade de um sistema de prestação de contas, por parte dos diretores ou administradores detentores do controle societário, que seja auditado por terceiros que não tenham ligação com a sociedade anônima respectiva, para propiciar confiabilidade à correta administração
} 
A expansão e influência britânicas fizeram que a atividade auditorial se alastrasse para outros países e continentes, principalmente por meio de empreendimentos estabelecidos em territórios estrangeiros, para os quais os investidores enviavam seus auditores a fim de constatar o andamento dos negócios por eles financiados. Nessa linha, é importante frisar a criação, em 1880, da Associação dos Contadores Públicos Certificados (Institute of Chartered Accontants in England and Wales - ICAEW).

O surgimento e incremento do mercado de capitais e das grandes sociedades anônimas que nele buscavam financiamento de suas atividades fizeram que a demanda por serviços de auditoria crescesse de modo impressionante, dada a necessidade de proteção do público investidor. Como já citado, após a quebra da Bolsa de Valores em 1929, a necessidade de auditoria mostrou-se premente. Diante disto, em 1932 a Bolsa de Valores de Nova York passou a exigir das sociedades nela registradas um parecer de auditores independentes. A demanda ainda foi incrementada pela edição do Securities Act, em 1933, do Securities Exchange Act, em 1934, e pela criação da Securities Exchange Comission (SEC) nos Estados Unidos da América. Nessa década (1930), também foi criado o AICPA (American Institute of Certified Public Accountants).

No Brasil, a atividade de auditoria se desenvolveu, em princípio, também por influência inglesa, ao receber filiais de empreendimentos daquele país (bem como de outros países estrangeiros) e com elas seus respectivos auditores. Entretanto, o início exato dos serviços de auditoria independente é rodeado por incertezas doutrinárias.

Sobre o desenvolvimento da atividade de auditoria no Brasil, interessante a lição de Sérgio Jund:

Não existem divulgações de pesquisas sobre os primórdios da auditoria no Brasil, sendo certo somente que teve origem inglesa. Sabe-se também que a recém-extinta firma de auditoria Arthur Andersen S/C e a atualmente denominada Price Waterhouse Coopers já mantinham estabelecimentos no Rio de Janeiro, com outras denominações, desde 1909 e 1915, respectivamente. Apesar de formalmente organizada em 26 de março de 1957, quando formado o Instituto de Contadores Públicos no Brasil, em São Paulo, a auditoria foi oficialmente reconhecida apenas em 1968, por ato do Banco Central do Brasil. O fortalecimento da atividade, todavia, ocorreu em 1972, por regulamentações do Banco Central do

dos recursos investidos. (BERLE, Adolf Augustus; MEANS, Gardiner C. A moderna sociedade anônima e a 
Brasil, Conselho Federal de Contabilidade e pela formação de um órgão nacional para congregação dos profissionais, o Instituto dos Auditores Independentes do Brasil. ${ }^{32}$

Foram igualmente importantes para o fortalecimento da atividade de auditoria no Brasil, além dos aspectos supracitados, a promulgação da Lei n. 6.385, de 7 de dezembro de 1976, que dispôs sobre o mercado de valores mobiliários e criou a Comissão de Valores Mobiliários (CVM), bem como a Lei n. 6.404/76 (Lei das Sociedades por ações), ambas regulamentando o serviço do auditor independente. A partir de então, diversas normas profissionais do Conselho Federal de Contabilidade e da CVM (recentemente com o auxílio do Comitê de Pronunciamentos Contábeis - CPC) têm incrementado os deveres e direitos da profissão de auditor no Brasil.

Deve-se mencionar que durante todo seu tempo de evolução, os serviços de auditoria passaram por diversas transformações, dentre as quais duas podem ser citadas como as mais relevantes: 1) o aumento progressivo do volume e da velocidade dos negócios empresariais, fato que acarretou a impossibilidade da auditoria da totalidade das transações de muitas das entidades; 2) o surgimento gradual de mecanismos de controles internos e sistemas informatizados, que passaram a constituir boa parte das preocupações da atividade de auditoria. ${ }^{33}$

propriedade privada. São Paulo: Nova Cultural, 1988. p. 35).

${ }^{32}$ Op. cit, p. 6. Estudo do IBRACON (Op. cit. p. 65) revela que: "O primeiro trabalho de auditoria registrado no Brasil de que se tem conhecimento ocorreu há pouco mais de um século, quando o balanço da São Paulo Tramway, Light and Power Company, relativo ao período compreendido entre junho de 1899 e dezembro de 1902, foi analisado pela empresa de auditoria Clarkson \& Cross - atualmente Ernst \& Young”.

${ }^{33}$ A dimensão moderna da atividade empresarial impossibilitou, em muitos casos, a verificação de todas as transações das entidades para fim de emissão do parecer de auditoria. Se no início destes serviços era possível realizar o exame de $100 \%$ dos negócios da entidade auditada, isto, na maioria das vezes, não mais se repete nos dias de hoje, uma vez que a relação custo-benefício de uma auditoria tão abrangente resultaria inviável financeiramente. Diante disso, atualmente é amplo o emprego de técnicas de amostragem no processo de verificação das transações. Grosso modo, podemos dizer que a auditoria, em seus primórdios, era baseada prioritariamente na verificação física de documentos (document based auditing), passando posteriormente a ter ênfase nos processos de controle interno (quanto maior a confiabilidade dos controles, menos testes de transações eram necessários ao auditor), para, nos últimos tempos, priorizar a avaliação dos riscos do negócio (risk based auditing). 


\section{IMPLICAÇÕES ECONÔMICAS DA AUDITORIA E SUA AVALIAÇÃo DO PONTO DE VISTA DA ANÁlISE ECONÔMICA DO DIREITO}

Os serviços de auditoria exercem amplo e relevante papel na economia de um país como um todo e na administração das unidades microeconômicas. Autores apontam diversos benefícios da realização de auditoria externa, dentre os quais a existência de melhor controle e eficiência das operações empresariais, melhor domínio sobre o risco empresarial, desestímulo a fraudes e maior segurança aos usuários da informação contábil.

O maior benefício da atividade de auditoria, porém, está no suprimento de uma deficiência de mercado, consistente na carência de informações dos agentes econômicos.

Como se sabe, a ciência econômica clássica tem como suposição básica que os agentes econômicos atuem como maximizadores racionais, ou seja, que sejam capazes de, diante da escassez de recursos, realizar suas escolhas de forma lógica, consistente e de forma a maximizar os benefícios de suas decisões em face dos custos nos quais incorrem ao selecioná-las, ordenando as diversas alternativas que se apresentam no mercado em função da melhor utilidade que proporcionem à satisfação de seus interesses.

No entanto, a suposição de maximização racional dos agentes econômicos somente é possível se admitirmos implicitamente que a informação destes agentes é suficiente e correta, ou seja, não está sujeita a distorções relevantes. Nesse sentido, a lição de Heilbroner e Thurow:

Todo o sistema de mercado, como vimos no Capítulo 4, está construído sobre a suposição de que os indivíduos são maximizadores racionais. Mas enterrada nessa suposição, encontra-se a expectativa implícita de que compradores e vendedores têm uma informação pelo menos aproximadamente exata sobre o mercado (...). Sem informações corretas ou suficientes, é óbvio que os participantes do mercado não podem tomar decisões corretas. ${ }^{34}$

\footnotetext{
${ }^{34}$ HEILBRONER, Robert L.; THUROW, Lester C. Introdução à microeconomia. Rio de Janeiro: Guanabara, 1988. p. 129.
} 
Ligada a este objetivo de melhoria da qualidade da informação para os agentes, uma das mais proeminentes funções econômicas da auditoria está relacionada aos mercados de capitais e financeiro. ${ }^{35}$

De fato, o surgimento de referidos mercados proporciona o encontro de unidades econômicas deficitárias (tomadores de recursos) com unidades econômicas superavitárias (poupadores de recursos), implicando a melhor alocação de haveres na economia e possibilitando a realização de projetos e empreendimentos econômicos através da captação de financiamentos necessários para tanto.

Os mercados de capitais e financeiros, portanto, são uma necessidade de qualquer Estado que deseje minimamente prosperar no campo econômico. Não se trata, portanto, meramente do interesse particular dos agentes econômicos que atuam em tais mercados, mas do interesse público de toda sociedade em seu desenvolvimento.

\section{Como ressaltam Lima et al.:}

Por meio do mercado financeiro, é possível apresentar alternativas de aplicação de recursos para as unidades econômicas superavitárias e de captação de recursos para as unidades econômicas deficitárias, transferindo recursos daquelas para estas (...). A partir da transferência de recursos financeiros entre tomadores e poupadores, o mercado pode exercer importante função de otimizar a utilização de recursos financeiros, por meio da transferência desses recursos dos poupadores para os tomadores, bem como da criação de condições de liquidez e administração de riscos. Para que exista transferência de recursos financeiros, é necessário que ocorra prévia ou simultaneamente poupança e que existam instituições e mecanismos capazes de transformar poupança em investimento. O mercado financeiro deve possibilitar que os agentes econômicos sejam colocados em contato, direto ou indireto, a um custo mínimo e com as menores dificuldades possíveis. Ao fazer isso, o mercado possibilita um aproveitamento das oportunidades em toda a

\footnotetext{
${ }^{35}$ Interessante mencionar aqui a citação feita no Parecer CVM RJ n. 2001/8045, invocando o teor de nota explicativa à Instrução CVM n. 308/99 que menciona, dentre outros, os seguintes fundamentos: "1) a importância de um sistema de auditoria independente como suporte indispensável ao órgão regulador; 2) a figura do auditor independente como elemento imprescindível para a credibilidade do mercado e como instrumento de inestimável valor na proteção dos investidores, na medida que a sua função é zelar pela fidedignidade e confiabilidade das demonstrações contábeis da entidade auditada; 3) a exatidão e a clareza das demonstrações contábeis, inclusive a divulgação em notas explicativas de informações indispensáveis à visualização da situação patrimonial e financeira e dos resultados da entidade auditada, dependem de um sistema de auditoria eficaz".
} 
economia, resultando em um aumento geral da produtividade, da eficiência e do bem-estar da sociedade. ${ }^{36}$

Graficamente, teríamos a seguinte composição do mercado de capitais e financeiro:

Figura 1: Fluxo de recursos no mercado de capitais por meio de relacionamento direto entre unidades econômicas deficitárias e superavitárias no mercado de capitais.

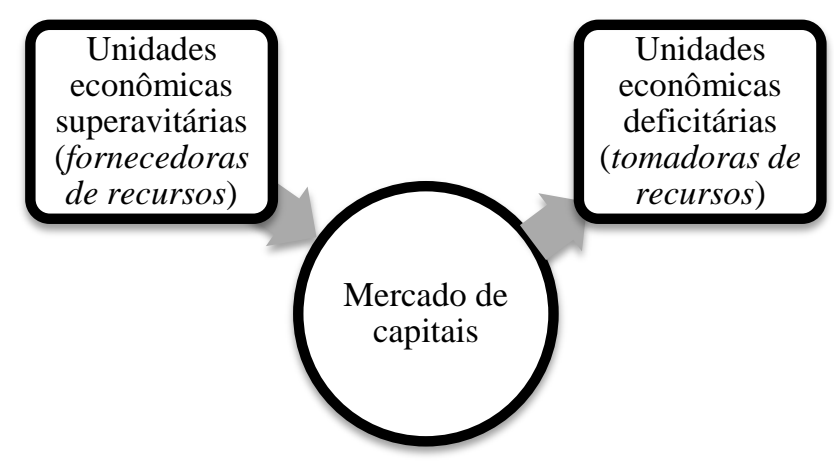

Figura 2: Fluxo de recursos no mercado financeiro por meio de relacionamento indireto (intermediado por instituições financeiras) entre unidades econômicas deficitárias e superavitárias no mercado de capitais.

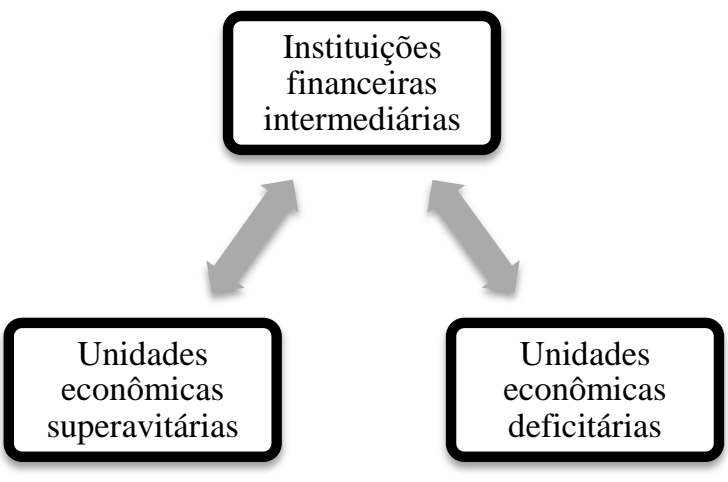

\footnotetext{
${ }^{36}$ LIMA, Iran Siqueira; LIMA, Gerlando Augusto Sampaio Franco de; PIMENTEL, Renê Coppe. Curso de mercado financeiro. São Paulo: Atlas, 2006. p. 8.
} 
Como se sabe, as transações no mercado de capitais ou financeiro, consubstanciadas nas transferências de recursos de unidades econômicas superavitárias às unidades econômicas deficitárias, são realizadas na expectativa de que, pela correta e lucrativa aplicação dos recursos destinados a projetos financeiramente mensuráveis, possa haver retorno positivo do montante aplicado ao investidor respectivo.

No entanto, a unidade superavitária que investe numa sociedade ou a financia (constitua-se como um investidor externo ao negócio, um credor, ou um acionista minoritário que faça parte do quadro societário), em regra, encontra-se desprovida de informação suficiente para realizar suas alocações de recursos no mercado, por não conhecer detalhes do negócio sobre o qual seu investimento recai.

Outrossim, não é economicamente viável que, para realizar uma transação no mercado financeiro ou de capitais, o investidor tenha de constantemente analisar, constatar, avaliar e acompanhar o investimento realizado. Tal medida, obviamente, imporia custos de transação extremados a qualquer aporte de recursos, inviabilizando seu retorno lucrativo.

Desta forma, resta aos investidores, credores ou outros financiadores (unidades superavitárias) realizar aplicações de recursos com base em informações dadas pelos próprios tomadores (unidades deficitárias), através de um conjunto de relatórios financeiros (demonstrações contábeis).

A comunicação dessas informações sobre os projetos de investimento dos recursos aportados, porém, nem sempre é isenta. Como já mencionamos, os administradores de recursos podem ter interesses divergentes dos financiadores, o que pode resultar em estímulo para a distorção ou manipulação das informações prestadas.

Doutrinam Berle e Means:

Os administradores dispõem de outra arma poderosa que pode ser combinada com qualquer uma das precedentes ou com todas elas. Têm um alto grau de controle sobre a contabilidade dos rendimentos da companhia. Enquanto os padrões contábeis ainda não se estabilizaram e a lei ainda não impôs regras específicas, os diretores e seus contadores podem, dentro de certos limites, acomodar suas cifras como quiserem (...). São muitos os métodos contábeis para se conseguir tal coisa. Entre os mais simples estão o de considerar ou não a depreciação, o de deduzir do capital despesas que deveriam realmente ser cobradas da conta de 
receita, o de considerar os lucros aperiódicos como renda, embora devessem constar do excedente de criação de reservas latentes. ${ }^{37}$

Para investir, portanto, é necessário que os agentes econômicos sejam providos de informações consubstanciadas em relatórios transparentes, e não tendenciosos (unbiased reporting).

Os investidores, credores e demais financiadores estão distantes da gestão das unidades econômicas tomadoras de seus recursos (remoteness of users), não podendo avaliar a qualidade da administração, além de não possuírem, em regra, formação suficiente para realizar esta tarefa, dada a complexidade envolvida. A distância e a complexidade mencionadas tornam proibitiva a atuação pessoal daqueles na obtenção das informações necessárias, uma vez que os custos para fazê-lo seriam demasiados (v. g.: custos de formação profissional, dispêndio de tempo e outros custos de oportunidade para cada interessado em realizar pessoalmente esta missão). Isto acarreta a necessidade de confiar nos relatórios produzidos pela administração e delegar a tarefa de fiscalizá-los a um determinado agente com competência para tanto.

Desta forma, podemos claramente constatar que:

1. Os investidores, credores, acionistas minoritários e outros financiadores (unidades superavitárias) não possuem, em regra, o mesmo grau de informações que os tomadores (unidades deficitárias) sobre os projetos de aplicação dos recursos fornecidos (situação de assimetria de informações), necessitando de relatórios isentos ou não tendenciosos;

2. Não é viável economicamente que o investidor ou financiador busque pessoalmente o nível de informações aceitável para possibilitar o investimento, uma vez que o custo de transação envolvido usualmente tornaria o aporte proibitivo em termos financeiros;

3. Os tomadores de recursos que, em regra, os administram, frequentemente podem ter interesses conflitantes com os investidores e demais interessados, podendo ser estimulados a distorcer ou manipular as informações econômico-financeiras prestadas (conflito de agência).

Os três tópicos objeto de constatação, ordinariamente estudados pela disciplina de Análise Econômica do Direito (Law and Economics) são especificamente o ponto em

${ }^{37}$ Op. cit. p. 175. 
que a atividade de auditoria se encontra inserida. A auditoria externa, minimizando assimetrias, custos de transação e aqueles derivados do conflito de agência, fornece ao investidor um poderoso instrumento de gestão do risco (risk management) ao adicionar credibilidade aos relatórios financeiros emitidos pelas entidades auditadas tomadoras de recursos no mercado.

Sua análise pormenorizada será feita nos subtítulos seguintes.

\subsection{A atividade de auditoria como redutora da assimetria de informações}

$\mathrm{Na}$ teoria econômica tradicional, tem-se como pressuposto que os agentes econômicos possuem à sua disposição todas as informações disponíveis, de forma a realizar a alocação de recursos otimizada para a consecução de seus resultados. Admite-se que a obtenção da informação é totalmente livre, distribuída de forma razoavelmente homogênea entre os agentes e isenta de custos.

No entanto, os estudos mais modernos envolvendo economia das organizações, nova economia institucional e análise econômica do direito abandonam referido pressuposto da teoria tradicional, defendendo postura mais consentânea com a realidade, segundo a qual os agentes econômicos não possuem usualmente o mesmo nível de informações (assimetria), que existem custos no processo de obtenção destas informações e que há estímulos à sonegação ou manipulação de informação entre os agentes.

Transportando essas lições para o campo da auditoria externa, devemos frisar inicialmente que a escrituração contábil de uma entidade empresarial, resumida em relatórios com fins específicos (demonstrações contábeis), é a principal fonte de informações financeiras disponível ao investidor e demais interessados para fundamentar suas decisões de aplicação de recursos. ${ }^{38}$

\footnotetext{
${ }^{38}$ Não se ignora, porém, que as demonstrações financeiras não são as únicas fontes de informação disponíveis ao investidor. Além de ser acompanhadas de relatórios da administração, o investidor pode basear suas decisões em pareceres de terceiros (consultorias, corretoras, etc.) para avaliar seu investimento. Note-se igualmente que, nos últimos tempos, tem-se dado maior ênfase a processos de avaliação empresarial que não se resumam aos aspectos financeiros da entidade, mas a outros igualmente importantes; é o caso da metodologia do balanced scorecard, desenvolvida por Kaplan e Norton, que, infelizmente, ainda não é de realização e divulgação obrigatória pelas entidades que captam recursos junto ao público investidor.
} 
Muito embora trabalhe com cifras já ocorridas (passadas ou históricas), a contabilidade resumida nas demonstrações tem inegável valor preditivo ao investidores, credores e outros financiadores, que podem projetar para o futuro as tendências de ganho ou perda do investimento, lastreando com maior fidedignidade as possibilidades de retorno de sua alocação de recursos. ${ }^{39}$

Assim, a contabilidade, por si só, é inegavelmente responsável pela redução da assimetria de informações entre os administradores e os potenciais investidores. A auditoria externa, por seu turno, funciona como um intermediário informacional entre as duas categorias supracitadas de agentes econômicos, tendo um papel garantidor da veracidade, ou, ao menos, da segurança razoável da informação contábil.

Nesse sentido, argumentam Alexsandro Broedel Lopes e Eliseu Martins:

Investidores e administradores possuem informações assimétricas. Os auditores são mecânicos informacionais na tentativa de fornecer "atestados" de fidedignidade das demonstrações da empresa para os investidores que não têm o mesmo acesso à informação que os administradores. Os intermediários informacionais, como auditores, agências de rating, analistas de mercado, etc. procuram reduzir a assimetria entre administradores e acionistas. ${ }^{40}$

A redução das assimetrias informacionais, objetivo que a atividade de auditoria tenta obter intermediando a informação entre administradores e investidores, é essencial para a alocação ótima de recursos no mercado de capitais e financeiro. Isto ocorre porque, de posse de razoável segurança quanto à informação prestada, o investidor pode assumir riscos dentro de uma perspectiva planejada e adaptada à sua realidade econômica, o que é fundamental para o crescimento do mercado e de um país.

Ressalte-se que o problema da assimetria de informações não atinge somente as relações entre os gestores e os investidores, podendo ser inserido em outras relações, tais como as existentes entre acionista(s) controlador(es) e minoritário(s), entre gestor(es) e

\footnotetext{
${ }^{39}$ Uma das maiores críticas feitas por analistas às demonstrações contábeis é a de que elas apresentam valores do passado da entidade empresarial, quando o importante seria a predição de eventos ou fluxos futuros. A afirmação, entretanto, não procede na maior parte das vezes. Com efeito, além de as alternativas futuras da entidade empresarial serem limitadas pelas suas escolhas passadas - o que pode delimitar e sinalizar ao investidor o âmbito e o limite nos quais ocorrerão as escolhas e decisões administrativas -, as demonstrações contábeis permitem ampla projeção de tendências futuras. Este, aliás, é o motivo principal da publicação das demonstrações de mais de um exercício, possibilitando a formulação de inclinações vindouras.
} 
credores, ou mesmo entre gestor(es) e acionista(s) minoritário(s). Também nestes casos, as categorias referidas possuem graus relevantes de disparidade de informações sobre o negócio em que atuam, exercendo a auditoria externa, igualmente nestas hipóteses, papel extremamente relevante na redução das assimetrias.

Outro problema derivado da assimetria informacional, também evitado pela correta atividade de auditoria, é o relativo ao que se costuma chamar por seleção adversa.

O fenômeno da seleção adversa remete necessariamente ao exemplo tratado por George Akerlof, em seu clássico artigo "The market for lemons". ${ }^{41}$ Este autor faz uma análise do que ocorre no mercado de carros usados (chamado de mercado de limões, ou lemons), quando uma das partes contratantes (vendedor de automóveis usados) não consegue demonstrar ou convencer a contraparte (comprador) da veracidade das informações prestadas.

No texto, Akerlof trabalha a questão da assimetria informacional entre as partes e verifica que o comprador não possui o conhecimento necessário para distinguir os carros usados em bom estado daqueles que não estejam em boas condições de uso. Da mesma forma, a informação do vendedor não é suficiente para tanto, uma vez que há a constante suspeita por parte do comprador de que aquele aja de modo oportunista, ou seja, unicamente com o intuito de vender. Este fenômeno acaba provocando que a preferência do consumidor se dê apenas por intermédio do sistema de preços, favorecendo os veículos de menor valor, usualmente os que se encontram em pior condição de uso, o que acaba por selecionar justamente os piores empresários, ou seja, aqueles que oferecem menores preços e que frequentemente vendem os piores automóveis, em detrimento dos que cobrem preços mais altos e vendam carros de qualidade. Em outras palavras, o veículo usado de boa qualidade tenderia a desaparecer do mercado. Para evitar tal problema é que se criam, muitas vezes, as certificações de qualidade dos produtos.

Transportando as lições de Akerlof para os serviços de auditoria em mercado de capitais ou financeiros, verifica-se que, na ausência de uma garantia de credibilidade da informação por uma terceira parte independente, a possibilidade de ação oportunista dos controladores, diretores ou administradores de sociedades por ações poderia fazer que fossem omitidos ou manipulados dados relevantes cuja veracidade o investidor, acionista

${ }^{40}$ LOPES, Alexsandro Broedel; MARTINS, Eliseu. Teoria da contabilidade - Uma nova abordagem. São Paulo: Atlas, 2005. p. 31. 
minoritário ou credor não teriam condições de aferir. Isto poderia levar, eventualmente, a que estes baseassem suas decisões unicamente por informações de rentabilidade ou retorno do valor alocado, ainda que não verdadeiras, o que acabaria por selecionar adversamente as entidades que prestassem informações de pior qualidade em detrimento daquelas que o fizessem de modo consentâneo à realidade.

A atividade de auditoria, portanto, funciona como um certificado de qualidade da informação contábil prestada pelas entidades que buscam captação de recursos junto aos investidores, credores, acionistas minoritários e quaisquer outras desprovidas de níveis aceitáveis de informação, reduzindo a assimetria entre as partes e o fenômeno da seleção adversa.

\subsection{Auditoria e custos de transação}

Assentado que os investidores, credores e outros financiadores possuem frequentemente grau de informação menor que os administradores ou controladores das entidades investidas, deve-se verificar agora a questão dos custos envolvidos na obtenção das informações necessárias ao investimento (custos de transação).

O fenômeno dos custos de transação é reconhecido prioritariamente nos estudos de Análise Econômica do Direito (Law and Economics) e Economia das Organizações, tendo como grande nome e defensor o economista Ronald Coase. Entendese por custos de transação todos aqueles que os agentes econômicos (p.ex., as partes num contrato) incorrem pelas atividades necessárias a viabilizar a concretização de uma transação ou alienação de propriedade, dentre elas as atividades de busca pela informação e de negociação, a realização e formalização dos contratos, e o monitoramento dos parceiros. Podem ser divididos em custos de transação ex ante (em negociação, obtenção de informações, salvaguardas e fechamento de acordos) e ex post (em resolução de disputas, cumprimento de contratos, etc.).

Embora haja alguma sorte de divergências na doutrina quanto ao conceito exato de custo de transação, há certa unanimidade em que o principal componente desta

${ }^{41}$ AKERLOF, George. "The Market for 'Lemons': Quality Uncertainty and the Market Mechanism 
espécie de custo deriva da tarefa da obtenção de informações necessárias à concretização e manutenção de transações na economia.

Como leciona Anthony Saunders:

Um dos problemas enfrentados por um poupador típico, ao aplicar diretamente nos instrumentos financeiros emitidos por uma empresa, é o alto custo de coleta de informação. Os poupadores individuais são obrigados a monitorar as atividades das empresas de maneira oportuna e completa, após adquirir seus títulos. ${ }^{42}$

Este problema não passou despercebido por Heilbroner e Thurow:

A falta de informação pode ser corrigida, pelo menos até certo ponto; mas essa correção custa dinheiro ou seu equivalente - tempo. Poucos de nós dispõem de recursos ou paciência para realizar todo um trabalho de pesquisa sobre cada item que adquirimos. ${ }^{43}$

De fato, para a realização de negociações, as partes inicialmente buscam informações suficientes sobre o objeto da transação que efetivam, sobre a parte contrária, ou mesmo a respeito de condições especiais que envolvam o negócio. Da mesma forma, negócios de execução continuada ou diferida requerem frequente coleta de informações (monitoramento) entre as partes quanto à subsistência das condições vantajosas iniciais ou mesmo para evitar eventual comportamento oportunista. Referida atividade, obviamente, acarreta gastos de recursos, os quais podem, eventualmente, impedir o retorno efetivo do investimento realizado.

Quando a informação não está disponível, nem seja de fácil acesso, as negociações podem ser mais difíceis, ou mesmo restarem impossíveis. Além disso, a tarefa de busca de informações pelas partes torna as transações na economia mais custosas, uma vez que será necessário todo um dispendioso esforço de aquisição. Na ausência de obtenção ou insuficiência informacional, as partes podem ainda ser estimuladas a só contratar mediante exigência de garantias específicas ou cobrança de maior preço (ou juro) para a assunção dos riscos daí derivados. ${ }^{44}$

Quarterly", Journal of Economics, 84: 488- 500. 1970.

${ }^{42}$ SAUNDERS, Anthony. Administração de instituições financeiras. São Paulo: Atlas, 2007. p. 82.

${ }^{43}$ Op. cit. p. 129.

${ }^{44}$ Uma breve explicação tornará mais claro o conceito. Os juros cobrados têm seu valor determinado por uma série de fatores. Dentre eles, encontram-se a taxa básica de juros livre de risco (normalmente determinada pelo valor pago pelos títulos do governo federal - ente cujo risco de inadimplência é assumido como inexistente -, constituindo-se como o nível mínimo exigido por qualquer credor para emprestar); o tempo do empréstimo (quanto maior o tempo, maiores os juros cobrados, pois maiores as incertezas envolvidas); $o$ 
Assim sendo, podemos concluir que a ausência ou insuficiência de informações acarreta: 1) inviabilidade ou dificuldade nas transações econômicas; 2) custos de obtenção da informação e monitoramento (custos de transação) que podem tornar a negociação inviável economicamente; 3) aumento na quantidade de garantias ou remuneração pelo risco assumido diante da situação de informação deficitária.

Ao proporcionar segurança a uma das partes contratantes quanto às informações dadas por sua contraparte, a atividade de auditoria viabiliza a realização de negociações entre estas, além de reduzir os custos de transação nos mercados financeiros e de capitais, tornando desnecessárias buscas diretas dos contratantes pela informação desejada e os gastos daí advindos. ${ }^{45}$

\subsection{Auditoria e conflitos de agência}

Estabelece-se uma relação de agência ou de agente/principal toda vez que uma das partes em determinado negócio (agente) seja admitida pela outra (principal) para, mediante delegação, tomar determinadas decisões que afetem a rentabilidade ou o retorno do investimento feito pelo último. ${ }^{46}$

Nos mercados financeiros e de capitais, o investimento nos diversos títulos de companhias abertas usualmente traz consigo uma relação de agência em que o investidor,

lucro desejado pelo credor (quanto maior o lucro desejado pelo credor, maiores serão os juros cobrados); $a$ inflação do período (uma vez que os juros deverão superar a inflação e ainda resultar num retorno positivo ao credor); e, finalmente, o risco de inadimplência (quanto maior o risco de o empréstimo não ser pago pelo devedor, seja simplesmente desonrando seu compromisso ou lançando mão de quaisquer recursos legais, maior será o juro a ser cobrado). Se as partes tiverem informações insuficientes sobre a probabilidade de recebimento do crédito, ou mesmo sobre seu provável retorno, maior será a taxa de juros exigida para aplicação de recursos.

${ }^{45}$ Saliente-se que a atividade de auditoria é apenas um dos meios pelos quais os custos de transação envolvendo a coleta de informações podem ser minimizados. Anthony Saunders (Op. cit. p. 82), por exemplo, cita outra solução, qual seja, a intermediação de uma instituição financeira entre os investidores e as entidades tomadoras de recursos, fato que usualmente sucede nos mercados financeiros. Referida intermediação teria como consequência a transferência do encargo de coleta de informação dos investidores para a instituição financeira, que agiria como uma espécie de fiscal delegado dos investidores.

${ }^{46}$ Em clássico estudo, Jensen e Meckling, tendo como base o trabalho de Berle e Means, definem a relação de agência consubstanciada num ajuste ou contrato, formal ou informal, entre uma ou mais partes principais e agentes, no qual os principais atribuem aos agentes uma tarefa de executar uma atividade em seu nome, incluindo delegação de autoridade e possibilidade de tomada de decisões pelos agentes (MECKLING, William H.; JENSEN, Michael C., Theory of the Firm: Managerial Behavior, Agency Costs and Ownership Structure. Julho, 1976). Parte da doutrina amplia ainda o conceito de conflito de agência para abarcar neste conceito não somente as relações dissonantes entre acionistas e gestores, mas também os conflitos entre credores e acionistas (estes agindo por intermédio dos gestores). Nesse sentido, BRIGHAM, Eugene F. et al. Administração financeira: teoria e prática. São Paulo: Atlas, 2001. 
credor, acionista minoritário ou outro financiador (principal), proprietário dos títulos adquiridos, delega a administração do resultado do negócio em que aloca seus recursos a terceiros administradores (agentes).

Ocorre que frequentemente o agente não possui os mesmos interesses do principal e, não raras vezes, os interesses de ambos são contrapostos. Nesta situação, pode haver um alto nível de estímulos para que o agente atue na defesa de seus interesses próprios em detrimento daquilo que busca o principal. Referido caso é tratado pela doutrina como problema ou conflito de agência, e está na base de inúmeras contendas de mercado.

O conflito de agência não é uma figura nova nos estudos de economia. Já o clássico trabalho de Berle e Means, separando a propriedade da ação do controle exercido pelos administradores, faz menção à referida hipótese:

$\mathrm{O}$ acionista tem certos interesses bem definidos no funcionamento da companhia, na distribuição da renda e nos mercados públicos de ações. Em geral, é de seu interesse, em primeiro lugar, que a companhia proporcione o lucro máximo compatível com um grau razoável de risco; em segundo lugar, que seja distribuída uma proporção tão grande desses lucros quanto permitam os interesses superiores do negócio, e que não aconteça nada que prejudique o direito de receber a parte que lhe cabe dos lucros distribuídos; e, finalmente, que suas ações continuem livremente negociáveis a um preço justo (...). Se admitirmos que o desejo de lucro pessoal é a força motriz do controle, devemos concluir que os interesses do controle são diferentes e que muitas vezes se opõem radicalmente aos da propriedade; devemos concluir também que, muito significativamente, os proprietários não serão bem servidos por um grupo de controle que vise o lucro. Na operação de uma sociedade anônima, o grupo de controle, mesmo possuindo um grande volume de ações, pode servir melhor a si mesmo lucrando às expensas da companhia do que produzindo lucros para ela. ${ }^{47}$

Desta forma, resta claro que o agente, de posse de condições e informações particulares, pode agir de forma oportunista, contrariando os interesses do principal, delegante de suas atribuições, seja ocultando informações do principal (hidden information), obtendo ganhos à custa deste, ou mesmo utilizando-se da estrutura e das informações privilegiadas que possui para auferir lucros pessoais.

${ }^{47}$ Op. cit. p. $124-5$. 
Para evitar ou minimizar referida situação, preconiza-se doutrinariamente a realização de contratos entre as partes (principal e agente) que promovam o alinhamento de seus interesses, acompanhados de mecanismos de motivação ou incentivos de cumprimento das avenças. Nesse sentido, podem ser úteis a previsão contratual de remuneração variável do agente, proporcional aos lucros empresariais, incentivos vinculados à produtividade, ameaça de intervenção direta dos acionistas nas operações societárias ou demissão dos administradores, entre outras medidas. ${ }^{48}$

Embora não atue diretamente no alinhamento de interesses entre as partes supracitadas, a informação contábil, desde que devidamente auditada por terceiros não vinculados ou subordinados aos agentes, ${ }^{49}$ proporciona mecanismo crível para a fiscalização da gestão, viabilizando dados necessários à intervenção direta do principal na defesa de seus interesses. ${ }^{50}$

A informação contábil auditada, outrossim, pode servir de mecanismo complementar à fiscalização do agente por parte do principal, quando a tentativa de alinhamento de interesses com base em remuneração vinculada aos resultados empresariais não seja suficiente. Com efeito, a mera vinculação de remuneração aos lucros pode não ser medida acurada da gestão; exemplo disto, recentemente ocorrido durante a crise econômica mundial de 2008, é o fato de gestores, buscando a obtenção de ganhos oriundos de bônus vinculados aos lucros contábeis, embrenharem-se em negócios de extremo risco buscando excessiva lucratividade, causando exposição de companhias a riscos inadmissíveis à maioria dos acionistas. 5152

\footnotetext{
${ }^{48}$ Embora não seja o objetivo deste trabalho examinar com profundidade o conflito de agência, suas consequências e a forma de minimizá-lo, é de se consignar que nem sempre o alinhamento de interesses é tão simples de ser realizado. Besanko et al. ressaltam que há casos de extrema dificuldade no alinhamento, dentre os quais: 1) quando a remuneração variável sujeitar o agente a um nível excessivo de risco ou flutuações, caso em que a aversão ao risco pode ser contraproducente; 2) quando as medidas de alinhamento de interesses sejam "ruidosas", ou seja, acabem por não conseguir separar os fatores que alinham os interesses daqueles que não os alinham (ruído); 3) quando as medidas de alinhamento não refletem as ações desejadas do agente (BESANKO, David, et al. A economia da estratégia. Porto Alegre: Bookman, 2006).

${ }^{49}$ Podemos citar como exemplo normativo que busca evitar o conflito de agência o art. 142, IX, da Lei n. 6.404/76, que atribui ao Conselho de Administração a competência para escolher e destituir os auditores independentes. Isto impede que a diretoria, cujo trabalho é fiscalizado, eleja pessoas vinculadas ao exclusivo interesse dos administradores, retirando a independência dos auditores e possibilitando-lhes agir contra o interesse dos acionistas.

${ }^{50}$ BRIGHAM et al. (Op. cit. p. 40) incluem os custos de auditoria como gastos para monitorar gestores, evitando os conflitos de agência. Ao lado dos demais gastos para estruturar a organização e custos de oportunidade, os custos de auditoria estariam enquadrados na categoria principal de custos de agência.

${ }^{51}$ Corroborando o que se disse no texto, mais uma vez interessante citar a lição de Alexsandro Broedel Lopes e Eliseu Martins (Op. cit. p. 34): "Um exemplo dos papéis da contabilidade está na remuneração dos administradores. Para reduzir os aspectos do conflito de agência tem sido apregoada a chamada remuneração variável. A ideia é que os administradores da empresa possuem parte de sua remuneração atrelada ao sucesso
} 


\section{CRISE DA ATIVIDADE DE AUDITORIA}

A atividade de auditoria externa vige sob a base da credibilidade das informações prestadas. Sob esta ótica, poder-se-ia argumentar que o objeto principal ou substancial dos serviços de auditoria externa não é consubstanciado em parecer sobre as demonstrações contábeis, mas sim na atribuição de credibilidade às informações econômico-financeiras prestadas pela administração de uma entidade.

Esta, aliás, é a linha de argumentação de Philip Kotler, sob a ótica do marketing da atividade, identificando que o objeto central do produto, serviço ou ideia adquirida de uma determinada empresa é o benefício trazido, e não o componente que serve de meio para tanto:

da empresa. Dessa forma, eles se tornam um pouco 'acionistas' e passam a agir como donos do negócio. Em tese, a ideia parece ótima. Então, temos o problema de implementação. Para que a remuneração variável possa ser efetivamente praticada, é necessário que se tenha uma métrica do esforço do administrador para que ele possa ser remunerado adequadamente. Ocorre que o esforço de um gestor não é observável na prática. Como saber que o executivo está realmente dando tudo de si e não somente perdendo tempo e dinheiro da empresa? Simples: basta remunerá-lo com base no lucro. Administradores incompetentes não conseguirão gerar empresas lucrativas, não é mesmo? Não, nem sempre. O resultado de uma empresa é função de diversas variáveis, como o cenário econômico e sua posição estratégica, por exemplo. O lucro da empresa é influenciado por todos esses fatores e não somente pelo esforço do administrador. Quando um administrador recebe seu bônus somente com base no lucro, sua remuneração está contaminada por vários fatores externos à sua vontade. Dessa forma, a contabilidade tem um papel fundamental na definição de medidas de performance e remuneração".

${ }^{52}$ Richard Posner, com o brilhantismo que caracteriza suas observações, assevera que um dos fatores que contribuiu com a crise econômica de 2008 foi o problema do conflito de agência, não resolvido (mas antes agravado) pelo "alinhamento" de interesses de principais e agentes consistente no recebimento pelos administradores de bônus com base na lucratividade das companhias. Segundo leciona, a distribuição de bônus em dinheiro incentiva os executivos a realizarem operações de risco para maximizarem o lucro no curto prazo (maximize short-run profits), uma vez que, em grande parte das vezes, não serão afetados pelas consequências de longo prazo de suas ações e, se forem, usualmente restarão cobertos por altos valores de rescisão contratual (severage packages). $\mathrm{O}$ autor defende que parte da remuneração variável dos executivos seja paga em ações da companhia, para melhor alinhar os interesses dos administradores com os interesses dos acionistas no longo prazo (POSNER, Richard A. A failure of capitalism. Cambridge, Massachussetts: Harvard University Press, 2009). Contrariando o recomendado por Posner, reportagem do Jornal O Estado de S. Paulo, de 25.11.2009, ressalta que os executivos de bancos norte-americanos afetados pela crise econômica de 2008 continuam mantendo patrimônio pessoal elevado, apesar da perda do valor das ações conferidas como bônus por suas atividades. Referido tipo de remuneração, segundo a reportagem (baseada em estudo da Universidade de Harvard) pode estimular os executivos a se concentrarem no ganho que terão com a alta do preço das ações derivada da lucratividade de curto prazo, embora assumam riscos excessivos em longo prazo, que terão de ser suportados pela entidade: “A distribuição de riquezas se deu sob a forma de bonificações em dinheiro, além de milhares de ações vendidas pelos executivos quando o preço delas estava nas alturas. A maioria dos executivos vendeu durante este período um número muito maior de ações do que aquele que mantiveram em seu poder quando as empresas chegaram ao fundo do poço". ("Empresas quebram, mas executivos continuam ricos". O Estado de S. Paulo. 26.11.2009, Caderno de negócios, p. B19). 
A importância dos produtos físicos não está muito em possuí-los, mas na obtenção dos serviços que proporcionam. Compramos um carro porque ele fornece um serviço de transporte, um forno de micro-ondas porque ele fornece serviço de cozimento. Portanto, os produtos físicos são, realmente, veículos que nos prestam serviços (...). Frequentemente, os fabricantes cometem o erro de prestar mais atenção a seus produtos físicos do que aos serviços produzidos pelos mesmos. Veem-se vendendo um produto em vez de fornecendo uma solução ou atendendo a uma necessidade. Um carpinteiro não compra uma furadeira; compra um furo. Um objeto físico é um meio de embalar um serviço. O trabalho de uma empresa é vender os benefícios ou serviços "embutidos" nos produtos físicos, em vez de apenas descrever suas características físicas. Diz-se que os vendedores que concentram seu pensamento no produto físico em vez de nas necessidades dos consumidores sofrem de miopia de marketing. ${ }^{53}$

Nesta linha de raciocínio, podemos focar o princípio segundo o qual os serviços de auditoria, na verdade, têm como principal benefício oferecido aos seus clientes a atribuição de credibilidade à informação contábil prestada pela entidade auditada, e não meramente a emissão de um parecer, que serve apenas de meio para veicular o serviço prestado. Para atestar a credibilidade de uma informação, como não poderia deixar de ser, é preciso que o auditor, por si só, tenha credibilidade suficiente para tanto, ou pelo menos não possua fator algum que a retire ou denegue. Interessante, neste sentido, a observação de Robert Henry Srour:

Ora, de que vive uma empresa de auditoria independente? Essencialmente de sua reputação, um conceito que abarca e transcende, a um só tempo, a própria competência técnica (...). A reputação está intimamente associada à confiança coletiva, ou melhor, à legitimidade que se conquista pelas políticas praticadas ou pelas ações cometidas. ${ }^{54}$

Desta forma, em nada cumpre um contrato de prestação de serviços de auditoria independente a oferta de um parecer que não seja dotado de credibilidade (p.ex.: o parecer oferecido por auditor externo sem condições devidas de independência). Ao contrário, em caso como tal, teríamos um mero cumprimento formal do contrato aludido em contrapartida de um inadimplemento material.

\footnotetext{
${ }^{53}$ KOTLER, Philip. Administração de marketing. São Paulo: Atlas, 1998. p. 28.

${ }^{54}$ SROUR, Robert Henry. Ética empresarial - A gestão da reputação. Rio de Janeiro: Campus, 2003. p. 341.
} 
Além disso, como os serviços de auditoria externa destinam-se não apenas à entidade auditada, mas também usualmente ao público investidor em geral, referidos serviços devem gozar de boa aceitação junto aos terceiros destinatários, para que seja possível, com base nos resultados apresentados pela auditoria, tomar decisões de investimento.

Ocorre que os serviços de auditoria externa têm passado por ampla crise de valores junto à sociedade, dadas as revelações de inúmeros casos em que fraudes foram cometidas por administradores com a conivência ou contando com a inoperância de auditores.

É bem verdade que referida falta de credibilidade já é percebida há certo tempo, não se tratando propriamente de uma novidade. Nesse sentido, há décadas se manifestava Waldemar Ferreira:

Inúmeras companhias contratam com empresas de contabilidade a sua assistência técnica, permanente ou periodicamente, senão apenas uma vez por ano, de molde que as contas do exercício se apresentem ao conselho fiscal com o seu parecer. Essa prática não substitui, nem prejudica, a ação permanente dos fiscais, que são, ainda assim, obrigados a cumprir os deveres que a lei lhes impôs. A circunstância de apresentarem-se as contas com parecer de peritos nomeados pela diretoria não exclui o direito da assembleia de mandar proceder a novo exame. O que a prática revela é que os escritórios de contabilistas ou de revisores fiscalizam mui superficialmente. Limitam-se, na generalidade dos casos, a verificar se os lançamentos dos livros se acham comprovados por documentos hábeis ou, mesmo, por papeluchos, a que apõem seus carimbos. Contentam-se com isso. Não entram a fundo no exame das contas e, principalmente, do desenvolvimento patrimonial da companhia. Os relatórios, assim elaborados, são inexpressivos. ${ }^{55}$

Recentemente, porém, os denominados "escândalos contábeis" envolveram uma proporção muito maior de auditores, resultando, inclusive, na falência de uma das grandes empresas de auditoria internacionais. Pode-se verificar menção a referido fenômeno em publicação da Comunidade Europeia:

${ }^{55}$ FERREIRA, Waldemar Martins. Instituições de direito comercial. São Paulo: Max Limonad, 1954. v. 1. p. 523. 
O papel do revisor oficial de contas foi objeto nos últimos tempos de numerosos debates no mundo inteiro. Foram levantadas questões relativas à função da revisão legal de contas e à independência do revisor oficial após, nomeadamente, um certo número de falências importantes no setor financeiro. Foi difícil responder a estas questões em nível da União Europeia, porque o quadro regulamentar no qual se inscreve a revisão legal de contas é incompleto. Não existe, em nível da União Europeia, uma posição comum sobre o papel, o estatuto e a responsabilidade do revisor oficial de contas, o que tem um impacto negativo na qualidade da revisão e na liberdade de estabelecimento e liberdade de prestação de serviços em matéria de auditoria. ${ }^{56}$

Para melhor análise desta circunstância, traremos no tópico seguinte os principais casos que abalaram a credibilidade dos auditores externos perante o público.

\subsection{Principais casos que abalaram a credibilidade da auditoria independente junto ao público}

Na última década, casos de conivência ou inoperância de auditores geraram forte desconfiança social a respeito dos serviços de auditoria. A descoberta de hipóteses em que sociedades de auditores estavam em conluio com administradores para omitir ou manipular informações, ou em que a negligência dos auditores não permitiu que o público investidor soubesse de detalhes gravíssimos a respeito da situação econômico-financeira de entidades auditadas, gerou imenso descrédito na sociedade.

Considerando que a atividade de auditoria, como dito no tópico anterior, vive da credibilidade atribuída por seus destinatários, não era de se esperar que o abalo na confiança dos profissionais e das sociedades de auditoria fosse diferente diante das falhas evidenciadas.

Podemos dividir didaticamente os casos envolvendo escândalos contábeis, com maior ou menor repercussão em atividades de auditoria, entre os casos ocorridos no Brasil e aqueles ocorridos no exterior, conforme veremos a seguir.

\footnotetext{
${ }^{56}$ EUROPEAN COMMISSION. Green Paper on the role, the position and the liability of the statutory auditor within the European Union. Disponível em <http://europa.eu/documents/comm/green_papers/pdf/com96_338_en.pdf>. Acesso em 7 mar. 2010.
} 


\subsubsection{Casos ocorridos no exterior}

O principal caso de fraude contábil ocorrido no exterior nos últimos tempos envolveu a gigante norte-americana do setor energético Enron Corporation, no ano de 2001. Referida companhia atuava no setor de energia, gás natural e petróleo, tendo participações em várias entidades empresariais por todo o globo. O caso abalou seriamente a credibilidade do público investidor nas informações contábeis prestadas pelas companhias e no desempenho dos auditores independentes. ${ }^{57}$

As práticas desleais de contabilidade envolvendo a Enron, segundo estudiosos do caso, envolveram os seguintes aspectos:

- Lucros artificialmente inflados: os executivos da Enron usualmente escondiam despesas da demonstração de resultados e avaliavam ativos a preços artificiais para aumentar os lucros;

- Utilização de Sociedades de Propósito Específico (SPE) para alterar valores contábeis: os diretores da Enron criaram um complexo sistema de transferência de ativos e passivos para SPEs, de forma a esconder do público investidor créditos de alto risco e passivos que levantariam suspeitas sobre sua solvabilidade, organizando-se de forma a tornar a consolidação de balanços desnecessária.

Outro caso importante de fraude contábil, com repercussão nos serviços de auditoria, ocorreu na também norte-americana WorldCom (2002), que atuava no setor de telecomunicações, ocupando posição de destaque.

\footnotetext{
${ }^{57}$ Análise feita pela União Europeia sobre o caso da Enron ressalta em nota oficial que: "Uma investigação intensa das medidas tomadas pelo auditor da Enron nos Estados Unidos desencadeou observações muito críticas e conduziu a uma certa perda de confiança do público na função de revisão oficial de contas, embora não tenha até ao presente afetado em grande medida a confiança geral nos mercados de capitais da UE. O caso da Enron pôs em evidência as deficiências e limitações da revisão oficial de contas dos Estados Unidos, conduziu nomeadamente a críticas, às revisões pelos pares entre empresas de auditoria (garantia de qualidade externa), à ineficácia do atual organismo público de supervisão financiado pelo próprio setor e ao funcionamento deficiente dos conselhos de auditoria, tendo ainda suscitado preocupações face à aparente falta de independência dos auditores". (Nota dirigida ao conselho informal - ECOFIN, realizado em Oviedo em 12 e 13 de abril. Assunto: Uma primeira resposta da UE às questóes relacionadas com a Enron. Disponível em <http://ec.europa.eu/internal_market/company/docs/enron/ecofin_2004_04_enron_pt.pdf>. Acesso em 17 dez. 2009.)
} 
Ao contrário do que ocorreu com a Enron, a WorldCom não realizou um esquema contábil complexo, mas efetivou simples manobras contábeis de ativação de despesas, ou seja, contabilizou despesas que deveriam reduzir o lucro do período como verdadeiro investimento. Os valores, inseridos no balanço patrimonial, tiveram o efeito de inflar artificialmente o lucro da companhia apresentado em sua demonstração de resultado do exercício, iludindo os usuários externos das demonstrações contábeis.

Como já referido, tais casos abalaram a credibilidade da sociedade de auditoria que até então prestava serviços para ambas as companhias supracitadas, a Arthur Andersen, arrastando-a para situação falimentar. ${ }^{58}$ Consta que os auditores da Andersen incidiram nos seguintes problemas:

- Prestação de serviços de consultoria às entidades auditadas: os auditores teriam participado de modo relevante da estruturação das operações da Enron, revelando falta de independência suficiente para auditar o serviço por eles prestado;

- Destruição de provas: os auditores foram acusados de destruir documentação comprobatória do caso Enron, impedindo as investigações;

- Negligência na descoberta de fraudes e processos “criativos” de contabilidade: os auditores da Andersen, principalmente no tocante ao caso da WorldCom, teriam sido omissos em apontar fraudes (violações da lei) e processos "criativos" de contabilidade (burla indireta dos princípios legais e contábeis, omitindo ou manipulando informação do usuário da contabilidade).

No ano de 2002, caso emblemático de fraude contábil ocorreu com a empresa americana Xerox, que passou a contabilizar integralmente suas receitas de longo prazo nos exercícios em que eram pactuadas (vendas financiadas de copiadoras, cuja receita era antecipada e indevidamente reconhecida), independentemente da prestação efetiva, violando o princípio contábil da competência. Isto, obviamente, resultou no aumento

\footnotetext{
${ }^{58}$ Não só as sociedades de auditoria tiveram sua credibilidade abalada. Analistas de mercado, bancos e outros agentes que atuam como intermediários entre a informação contábil e o público investidor também restaram com sua imagem desgastada, principalmente devido às frequentes recomendações de compra dos papéis da Enron. Houve, igualmente, acusações de que bancos e seus analistas, embora cientes da fraude contábil praticada, continuaram a recomendar compra de papéis da Enron, por possuírem ações desta empresa em carteiras de fundos de investimento.
} 
artificial de receitas e dos lucros, iludindo o usuário externo em relação à informação contábil, acarretando igualmente desconfiança da sociedade responsável pela auditoria. ${ }^{59}$

Outro caso simbólico envolveu a multinacional italiana Parmalat, cuja concordata foi pedida em dezembro de 2003, que teria ocultado sua real situação financeira e patrimonial por meio do reconhecimento de falsos créditos a receber, vindo a fraude a ser descoberta com a ausência de confirmação de um dos bancos (Bank of America) em relação a crédito afirmado pela Parmalat.

Este último acontecimento envolveu também amplo descrédito das sociedades de auditoria, que recentemente entabularam acordo judicial para pagamento de indenizações aos investidores em valores que chegam à cifra de quinze milhões de dólares. $^{60}$

\footnotetext{
${ }^{59}$ Reportagem do jornal Valor Econômico divulgou algumas das consequências desses fatos para a sociedade de auditoria KPMG: "A Securities and Exchange Commission anunciou hoje que vai processar a KPMG e quatro sócios da firma de auditoria por conta das fraudes contábeis praticadas pela empresa americana entre 1997 e 2000. A SEC - órgão que regula o mercado de capitais nos Estados Unidos - abriu processo em um tribunal federal de Nova York para pedir a devolução dos honorários pagos aos auditores e a aplicação de penalidades civis. O argumento da SEC é de que a KPMG foi conivente com a maquiagem nos balanços da Xerox, que engordou em US\$ 3 bilhões o resultado operacional da companhia. Durante os quatro anos, os auditores atestaram que as demonstrações financeiras da empresa estavam de acordo com as normas contábeis. De acordo com a SEC, os escritórios da KPMG na Europa, Brasil, Canadá e Japão e auditores da principal unidade da Xerox nos Estados Unidos, em Rochester, reiteradamente alertaram os colegas que eram responsáveis pelos balanços sobre a manipulação dos números. São alvo da ação movida pela SEC Michael Conway, 59, presidente do comitê de auditoria e finanças da KPMG; Joseph Boyle, 59; Anthony Dolanksi, atual diretor financeiro da Internet Capital Group; Ronald Safran, 49. Embora tenham algumas vezes manifestado à Xerox que discordavam das práticas adotadas pela empresa, pouco ou nada fizeram após terem seus alertas ignorados" ("SEC abre processo contra KPMG por fraudes na Xerox". Valor Online. 29.01.2003. Disponível em <http://www.valoronline.com.br>. Acesso em 26 jan. 2009).

${ }^{60}$ Neste sentido, a informação da reportagem do jornal Valor Econômico, de 23.11.2009: "As empresas de auditoria e consultoria Grant Thornton e Deloitte \& Touche vão pagar um total de US\$15 milhões para resolver um processo no qual investidores da Parmalat Finanziaria, da Itália, acusam as firmas de contabilidade de ajudar a fraudá-los, segundo consta em documentos que deram entrada na Justiça na sextafeira. A Deloitte, com sede em Nova York, vai pagar US\$ 8,5 milhões, e a Grant Thornton, de Chicago, US\$ 6,5 milhões, segundo os documentos que pedem ao juiz distrital de Nova York, Lewis Kaplan, que aprove o acordo preliminar firmado entre as partes. 'O acordo encerra o litígio com a Parmalat', diz James Sabella, um advogado dos investidores que processaram as duas firmas de contabilidade. $\mathrm{O}$ advogado, que trabalha para a Grant \& Eisenhofer, de Nova York, chamou o acordo de um bom resultado. Decisões recentes de Kaplan 'reduziriam dramaticamente os danos máximos recuperáveis' se o caso fosse a julgamento, disse ele anteriormente. Os investidores recuperaram cerca de US\$ 91 milhões no caso, disse Sabella. Antes disso, o Credit Suisse First Boston e o Banca Nazionale del Lavoro já haviam pago um total de US\$ 50 milhões, e a Parmalat (após a reorganização realizada pela companhia), US\$ 26 milhões. As reivindicações dos investidores contra o Citigroup e o Bank of America (BofA) foram negadas. Sabella disse que o acordo é notável porque quem está pagando são 'as organizações guarda-chuva, ou de coordenação internacional', das duas firmas de contabilidade, e não as entidades que fizeram o trabalho de auditoria. Essas organizações guarda-chuva tentaram escapar da responsabilidade legal. A Parmalat Finanziaria pediu concordata em dezembro de 2003, depois que investidores alegaram uma enorme fraude. A companhia sucessora abreviou seu nome para Parmalat SpA e voltou a ser negociada no mercado de ações em 2005. Os investidores processaram a Parmalat, seus bancos e auditores por causa da implosão da companhia. Os investidores da ação coletiva alegaram que os auditores da Parmalat deveriam ser responsabilizados pela fraude supostamente contábil. O problema na Parmalat aconteceu logo depois dos escândalos contábeis das
} 
Outros casos também podem ser mencionados, embora de menor repercussão, tais como os que aconteceram com as companhias norte-americanas Bristol-Myers (2002), Merk (2001), Tyco (2002) e ImClone Systems (2002).

\subsubsection{Casos ocorridos no Brasil}

Embora menos divulgados, no Brasil também tivemos exemplos clássicos de fraudes contábeis que repercutiram negativamente na credibilidade da atividade de auditoria. Exemplos marcantes envolveram os Bancos Nacional e Econômico, e recentemente a Bombril S/A.

No caso do Banco Nacional, restou evidenciado que, por vários exercícios, referida instituição financeira lançou créditos em sua contabilidade de maneira fraudulenta. O procedimento foi consubstanciado com a escrituração de centenas de contas-correntes negativas (denominadas “contas 917”, pertencentes a clientes inadimplentes que não tinham mais relação negocial com o banco), que totalizaram bilhões em lançamentos de inocorrentes operações de crédito, gerando receitas e lucros artificiais, e escondendo prejuízos de monta. ${ }^{61}$

Consta que, por estes fatos, a sociedade de auditoria à época responsável pela revisão contábil das demonstrações do Banco Nacional foi condenada pelo Banco Central ao pagamento de multa, além da suspensão do registro profissional e processo criminal (este último na esfera judicial) do sócio responsável pela auditoria.

empresas Enron e WorldCom, que levaram a uma profunda mudança de regulação no mercado de capitais americano. Com o colapso dessas companhias, foi criada, em 2002, a Lei Sarbanes-Oxley (SOX). A nova legislação tornou a rotina das auditorias mais rigorosa, exigiu que a administração das empresas atestasse a veracidade dos demonstrativos financeiros e impôs que determinados comitês dos conselhos de administração tivessem uma maioria de membros independentes". ("Auditorias indenizam investidor da Parmalat”. Valor Econômico. 23.11.2009, Caderno EU\&S.A., p. D4).

61 Síntese interessante do que ocorreu pode ser retirada do voto da apelação criminal no feito 2002.02.01.012109-6, proveniente do Tribunal Regional Federal da $2^{\text {a }}$ Região, que ora transcrevemos em parte: "Consistia a fraude em contabilizar perdas como se fossem receitas, mediante alterações nas datas de vencimentos e saldos de contas de clientes inadimplentes que, em vez de serem lançadas como prejuízos nos demonstrativos financeiros, eram mantidas como contas ativas, geradoras de lucro. Com tal procedimento, o BANCO NACIONAL S/A apresentava falsa situação de prosperidade, resultando, dentre outras consequências, na captação de recursos através da emissão de ações, distribuição de dividendos aos acionistas e incidência de carga tributária sobre o lucro supostamente apurado. As rendas fictícias geradas pelas referidas contas, agrupadas sob o código 'natureza 917', alcançaram a cifra de US\$ 16.904.148.224,09 (dezesseis bilhões, novecentos e quatro milhões, cento e quarenta e oito mil, duzentos e vinte e quatro dólares e nove centavos), que, uma vez expurgadas, revelou um prejuízo de US\$ 10.181.442.000,00 (dez bilhões, 
Em relação ao Banco Econômico, uma das principais fraudes contábeis teria ocorrido pela ação dos administradores, que teriam obtido crédito no exterior com o fim de financiar exportações nacionais mediante o oferecimento de garantia consistente em contratos de câmbio de exportação. Tais recursos, entretanto, eram em boa parte desviados em benefício dos administradores e do próprio banco, sem que tal manobra fosse percebida pela auditoria independente.

No caso da Bombril, as suspeitas foram inerentes à aquisição simulada de títulos do Tesouro americano, para encobrir o envio irregular de quantias ao exterior. Referidos valores teriam transitado irregularmente pela contabilidade, sem que fossem sequer descobertos pela auditoria independente. Houve ainda acusações de empréstimos irregulares a controlador, sem que igualmente fossem descobertos pelos auditores.

Outro acontecimento relevante ocorrido no Brasil, envolvendo problemas de credibilidade na área contábil e de auditoria, marcou um dos poucos casos em que litígios entre supostos prejudicados e auditores foram levados ao Poder Judiciário nacional. Tratase da antiga viação aérea Panair do Brasil S/A, falida na década de sessenta. Tal ocorrência, embora em data não recente, levou um grupo de acionistas a demandar judicialmente a empresa antecessora de uma das grandes entidades de auditoria internacionais, sob a fundamentação de falha nos trabalhos, principalmente na verificação das disponibilidades e do caixa da auditada, sendo o resultado do processo favorável aos auditores. $^{62}$

Deve-se mencionar ainda o caso ocorrido com o Banco Noroeste, na década de noventa, particularmente entre os anos de 1995 e 1998, que, juntamente com o anterior, é representativo das poucas hipóteses em que questões concernentes à auditoria externa foram levadas à apreciação do Judiciário. Neste caso, tanto no âmbito civil quanto penal, a acusação contra os auditores se fundamentou na imputação de negligência destes na

cento e oitenta e um milhões, quatrocentos e quarenta e dois mil dólares), conforme laudo de exame técnico contábil (pág. 50, Apenso VI, v. Item 6.5.3 - Composição dos Resultados Ajustados)".

${ }^{62}$ Reportagem da revista Exame sumariza bem o caso: "A legislação brasileira também prevê a possibilidade de os auditores serem levados à Justiça caso se constatem problemas de correção nas empresas que inspecionam, mas essa nunca foi a norma. Há um - isso mesmo, apenas um - caso conhecido de ação do gênero. Um grupo de acionistas da companhia de aviação Panair, falida há mais de trinta anos, moveu um processo no qual pedia uma indenização vultosa de sua auditora, a firma antecessora da atual Deloitte Touche Tohmatsu. A Deloitte foi absolvida. Mais recentemente, alguns associados da Cooperativa Agrícola Cotia, também na lona, pensaram em abrir um processo semelhante contra a KPMG, a última auditora da empresa. Desistiram ao constatar que os pareceres da firma, ainda que na linguagem incompreensível dos auditores, previam as dificuldades para a Cotia continuar de pé" ("Afinal, para que servem as auditorias?". Portal Exame. 27.03.1996. Disponível em <http://portalexame.abril.com.br/revista/exame/edicoes/0606/afinalservem-auditorias-50905.html>. Acesso em 19 ago. 2010). 
detecção de desvios cometidos pela gestão e por funcionários do banco, diante da remessa ilegal de importâncias ao exterior (aproximadamente US\$ 242 milhões). ${ }^{63}$

${ }^{63}$ No âmbito cível, houve julgamento favorável à sociedade de auditoria em primeira instância (11 ${ }^{\text {a }}$ Vara Cível de São Paulo, processo 99.042.264-0) e pelo extinto Primeiro Tribunal de Alçada Civil de São Paulo (autos de apelação n. 1218741-6). Conforme pesquisas, o feito estaria ainda sub judice. Os detalhes deste julgamento, entretanto, serão analisados no capítulo próprio referente à responsabilidade do auditor. No âmbito criminal, o Superior Tribunal de Justiça excluiu os auditores do polo passivo da ação penal, sob o argumento da inexistência de dolo por parte destes quanto à acusação de gestão temerária de instituição financeira, além de reconhecer a ausência de descrição do vínculo subjetivo com a gestão do banco por parte dos auditores, necessário à coautoria em tal tipo de crime. A ementa do acórdão é transcrita a seguir: Superior Tribunal de Justiça: Processo HC 125853 / SP. HABEAS CORPUS 2009/0004088-6. Relator(a) Ministro NAPOLEÃO NUNES MAIA FILHO (1133) Órgão Julgador T5 - QUINTA TURMA Data do Julgamento 02/02/2010. Data da Publicação/Fonte: DJe 01/03/2010. Ementa. PENAL. HABEAS CORPUS PREVENTIVO. GESTÃO TEMERÁRIA. DESVIO DE RECURSOS EFETUADOS POR FUNCIONÁRIOS DA ÁREA INTERNACIONAL DO BANCO. COAUTORIA ADMISSÍVEL. NECESSIDADE, TODAVIA, DE INDICAÇÃO DE VÍNCULO SUBJETIVO ENTRE OS AUDITORES INDEPENDENTES EXTERNOS (RÉUS) E OS GERENTES/ADMINISTRADORES. AUDITORIA CONTRATADA POR AMOSTRAGEM. ELEMENTO VOLITIVO DO TIPO. DOLO EVENTUAL NÃO DEMONSTRADO. NECESSIDADE DE ANTEVISÃO E ASSUNÇÃO DE RESULTADO LESIVO. INCOMPATIBILIDADE, NO CASO, COM A CONDUTA DOS ACUSADOS, QUE, CIENTES DA POSSIBILIDADE DE IRREGULARIDADES EM CONTAS EXTERNAS, COMUNICARAM A INSTITUIÇÃO BANCÁRIA SOBRE A NECESSIDADE DA REVISÃO DE ROTINAS DE CONCILIAÇÃO BANCÁRIA. INVIABILIDADE DA INCRIMINAÇÃO DOS AUDITORES INDEPENDENTES EXTERNOS PELA NÃO ESCRITURAÇÃO DAS OPERAÇÕES. FATO ANTERIORMENTE APURADO EM JUÍZO CÍVEL. CONCLUSÃO PELA IRRESPONSABILIDADE DA SOCIEDADE AUDITORA EXTERNA. INDEPENDÊNCIA DOS ORBES CÍVEL E PENAL QUE NÃO SE PRESTA A PETRIFICAR VERDADES INCONGRUENTES. NECESSIDADE DE A ACUSAÇÃO APRESENTAR AO MENOS RASTROS DE DESACERTO NA VERSÃO CORPORIFICADA NA AÇÃO DE REPARAÇÃO DE DANOS EM QUE SE INVESTIGAVA O MESMO FATO PARA JUSTIFICAR SEU PROCEDER NO JUÍZO PENAL. PARECER MINISTERIAL PELA DENEGAÇÃO DA ORDEM. ORDEM CONCEDIDA, NO ENTANTO, PARA TRANCAR A AÇÃO PENAL. 1. A gestão temerária, como crime próprio, apenas poderá ser imputada a sujeito que não detém as qualidades exigidas pelo tipo (gerência, administração, direção) se em associação com outrem que as detenha. Sobre o auditor independente externo só podem recair as penas do delito em questão se proceder em conluio com gestor da instituição financeira, fato não apresentado, sequer em tese, pela acusação. 2. Para que se verifique o elemento volitivo do tipo - o dolo eventual próprio da gestão temerária - é necessária a demonstração de que os acusados anteviram e aceitaram o risco lesivo, o que não ocorreu na espécie, uma vez que os pacientes, no curso da auditoria externa a que procediam, contratados para realizá-la por amostragem, identificaram possíveis irregularidade na gestão bancária da área internacional e comunicaram os gestores do Banco sobre a necessidade de revisão dos procedimentos de conciliação bancária em agências externas, como consignado na sentença cível. 4. Se não eram penalmente responsáveis pela fraude, alegadamente perpetrada por funcionários da própria Instituição Financeira, com muito mais razão aos auditores externos independentes não se pode imputar sua escrituração ou documentação. Não é plausível, portanto, sua incriminação pelo tipo correspondente ao art. 10 da Lei 7.492/85, que prevê apenação para omissão de elemento exigido pela legislação em demonstrativos contábeis. 5. A finalidade precípua da autonomia entre o juízo cível e o penal é permitir a este perscrutar a verdade real além dos limites dentro dos quais se satisfaria aquele. Não se presta à petrificação de versões colidentes sobre o mesmo fato. 6. A acusação, para pretender demonstrar a verossimilhança da versão que defende, precisa, ao menos em tese, apresentar rastros de desacerto na tese que terminou vencedora no Juízo Cível em que o mesmo fato foi esquadrinhado, com a conclusão pela ausência total de qualquer responsabilidade dos auditores independentes externos pelo rombo financeiro encontrado na área internacional, circunstância aqui não verificada. 7. Parecer ministerial pela denegação da ordem. 8. Ordem concedida, no entanto, para trancar a ação penal em relação aos ora pacientes". 


\section{RELAÇÕES CONTRATUAIS ENVOLVENDO OS SERVIÇOS DE AUDITORIA EXTERNA}

Bem delimitado o tema de estudo, faz-se necessário analisar as relações contratuais que se estabelecem na atividade de auditoria externa.

Buscaremos neste tópico verificar, em suma:

1. O tipo e natureza jurídica das relações negociais que se estabelecem entre as partes interessadas no serviço de auditoria externa (auditor, auditado e usuários da informação);

2. Quais os requisitos e as características das partes contratantes ou beneficiárias;

3. Quais as principais obrigações envolvendo as relações estabelecidas entre contratantes e beneficiários;

4. Qual espécie de regulação incide sobre a matéria, no ordenamento nacional e no direito comparado.

Para melhor divisão do trabalho, dividiremos a matéria nos subitens seguintes.

\subsection{Contrato e sua natureza jurídica}

Não há na doutrina nacional maiores discussões sobre a natureza jurídica do contrato envolvendo a prestação de serviços de auditoria independente.

No entanto, um breve apanhado a respeito dos diversos problemas que referida contratação envolve e das lições da doutrina estrangeira nos dá noção de que a matéria não é pacífica.

A primeira indagação que pode surgir é a de se saber se a prestação de serviços de auditoria tem efetivamente natureza contratual em todos os casos. Como se sabe, a auditoria externa pode resultar de uma imposição legal ou de um ajuste de vontades entre os interessados. Em outras palavras, tal tipo de auditoria pode ser obrigatória ou voluntária. 
Enquanto a auditoria obrigatória constitui-se verdadeiramente numa obrigação de as partes firmarem um contrato, sob pena de incorrerem em sanções, dado o interesse público envolvido na contratação, nos casos de auditoria voluntária há somente um ônus, ${ }^{64}$ cujo descumprimento pode apenas determinar a não fruição de determinados benefícios, financiamentos ou autorizações específicas.

Veja-se a lição de Maria Vittoria Cozzi, citando os ensinamentos de doutrinadores italianos:

De acordo com R. CALDARONE-G. Tucci, La responsabilità nell'esercizio dell'attività di revisione e certificazione dei bilancio: prime pronunce della giurisprudenza e tendenze evolutive, in Giur. comm., 1995, I, p. 294, a atividade de auditoria configura-se diversamente em relação à natureza obrigatória ou voluntária da instituição deste encargo (a auditoria voluntária seria, portanto, sujeita a um regime parcialmente diverso daquele a que se submete a revisão obrigatória). A subordinação à revisão voluntária pode depender da persecução de objetos subjetivos como, por exemplo, a intenção de atribuir maior força às propostas de investimento no confronto de determinado assunto, ou a fim de dar maior confiabilidade à imagem societária, ou de obter um benefício, uma autorização, um financiamento, e assim por diante. Nesses casos, a doutrina (M. Bussoletti, La società di revisione, Milano, 1985, p. 462 e 464) usa o conceito de ônus para qualificar a subordinação da auditoria voluntária, uma vez que a única consequência do inadimplemento é a perda de um benefício ou a revogação de uma autorização. ${ }^{65}$

\footnotetext{
${ }^{64}$ A diferença entre obrigação e ônus jurídico é bem salientada por Orlando Gomes: "O conceito de obrigação deve ser depurado da intromissão de outras noções jurídicas tecnicamente distintas, tais como as de dever jurídico, sujeição e ônus. A obrigação é, numa relação jurídica, o lado passivo do direito subjetivo, consistindo no dever jurídico de observar certo comportamento exigível pelo titular deste (...). O ônus jurídico, a necessidade de agir de certo modo para tutela do interesse próprio (...). A obrigação comporta com sacrifício do interesse próprio em favor de um interesse alheio; no ônus, o sacrifício do interesse próprio visa outro interesse próprio que o sujeito considere preponderante sobre o primeiro" (GOMES, Orlando. Obrigações. Rio de Janeiro: Forense, 2001. p. 8).

${ }^{65}$ COZZI, Maria Vitória. Tutela dei mercati finanziari e responsabilità della società di revisione. Napoli: Edizione Scientifiche Italiane, 2001. p. 9. O texto é tradução livre de: "Secondo R. CALDARONE-G. Tucci, La responsabilità nell'esercizio dell'attività di revisione e certificazione dei bilancio: prime pronunce della giurisprudenza e tendenze evolutive, in Giur. comm., 1995, I, p. 294, l'attività di revisione si configura diversamente in relazione alla natura obbligatoria o volontaria dell'atto di conferimento dell'incarico (la revisione volontaria sarebbe per tanto soggetta a un regime parzialmente diverso da quello cui è sottoposta la revisione obbligatoria). La sottoposizione a revisione volontaria può dipendere dal perseguimento di obiettivi soggettivi quali, ad esempio, 1'intenzione di attribuire maggior forza a proposte di investimento nei confronti di un determinato soggetto oppure per conferire maggiore affidabilità all'immagine societária o per ottenere un beneficio, un'autorizzazione, un finanziamento, e cosi via. In tali casi la dottrina (M. Bussoletti, La società di revisione, Milano, 1985, pp. 462 e 464) utilizza il conceto di onere per qualificare la sottoposizione
} 
Nos casos de auditoria externa obrigatória, devemos discutir se há efetivamente contrato entre as partes, dada a obrigação legal impositiva da prestação dos serviços, que poderia ferir a liberdade do consentimento das partes e a autonomia da vontade inerente às relações contratuais.

Se concluirmos pela existência de uma relação contratual nos casos de auditoria externa obrigatória, deveremos investigar, com mais pormenores, nessas hipóteses e naquelas envolvendo a auditoria voluntária, qual a natureza jurídica e a espécie contratual que se forma entre as partes e os terceiros beneficiados.

\subsubsection{Investigação da natureza contratual nos casos de auditoria externa obrigatória}

Como dissemos, a atividade de auditoria é essencial à economia, por suprir uma deficiência de mercado e oferecer um aumento da credibilidade e qualidade da informação aos agentes econômicos, proporcionando-lhes melhores condições de negociação, em virtude de diminuição dos custos de transação e redução de riscos.

Ocorre que, em grande parte dos casos, não é do interesse privado de uma das partes firmar contrato destinado à prestação de serviços de auditoria. Com efeito, o agente econômico que usualmente deve disponibilizar a informação aos interessados em financiar determinada atividade empresarial não tem interesse em fazê-lo, uma vez que somente incorrerá em custos para a veiculação da informação de qualidade superior. Assim, dado o interesse público inerente ao desenvolvimento econômico por meio das relações de mercado entre os agentes econômicos, é necessária a intervenção do Estado para obrigar as partes recalcitrantes a contratar, o que se dá frequentemente através da atividade regulatória.

No entanto, a obrigatoriedade ou imposição da contratação dos serviços de auditoria por meio normativo ${ }^{66}$ traz consigo o questionamento inerente à manutenção ou não da natureza contratual da relação estabelecida entre as partes.

a revisione contabile, posto che l'unica conseguenza dell'inadempimento è la perdita di un beneficio o la revoca di un'autorizzazione".

${ }^{66}$ Dentre outros casos, a auditoria externa é obrigatória no Brasil: 1) para as sociedades anônimas abertas (art. 177, § $3^{\circ}$, da Lei n. 6.404/76); 2) para as sociedades de grande porte, independente do tipo societário (art. $3^{\text {}}$ da Lei n. 11.638/07); 3) para as instituições financeiras, demais instituições autorizadas a funcionar 
Efetivamente, à entidade auditada não é dada a opção de não contratar os serviços de auditoria, sob pena de incorrer em sanções legais, o que limita efetivamente a autonomia da vontade no que concerne à liberdade de concluir ou não um contrato.

Além disso, também é afetada a autonomia da vontade no tocante à liberdade de conteúdo do contrato e de escolha do contratante, uma vez que muitas de suas cláusulas são obrigatórias e somente com determinadas partes (auditores qualificados) é possível a contratação de serviços de auditoria. Além disso, várias normas internacionais e nacionais sobre o tema impõem a troca periódica de auditores ou das sociedades de auditoria, limitando ainda mais a capacidade de escolha da contraparte.

Na doutrina italiana, Daniela Casadei destaca alguns aspectos da relação contratual estabelecida quando normas imperativas impõem a contratação de auditoria externa:

\begin{abstract}
Uma autonomia limitada é reconhecida somente em relação à escolha do contratante entre um elenco de sociedades de revisão contábil (de pessoas ou de capitais) que, possuindo determinados requisitos indicados pelo art.
\end{abstract}

pelo Banco Central do Brasil, câmaras e prestadores de serviços de compensação e de liquidação (Resolução 3.198/04 do Banco Central); 4) para sociedades seguradoras, de capitalização e entidades abertas de previdência complementar (Resolução n. 118/04 do Conselho Nacional de Seguros Privados); 5) para os fundos de investimento financeiro, fundos de aplicação em quotas de fundos de investimento financeiro e fundos de investimento no exterior (Instrução n. 386/03 da CVM); 6) no caso de incorporação, fusão e cisão envolvendo companhia aberta, em que as demonstrações financeiras que servirem de base para operações deverão ser auditadas por auditor independente registrado na CVM (Instrução n. 319/99 da CVM). Na Itália, refere-se Daniela Casadei aos seguintes casos de obrigatoriedade da contratação de auditoria (contratto di revisione): "Il contratto di revisione e stato imposto inizialmente alle societa con azioni quotate in borsa dall'art. 1 del d.p.r. n. 136/1975. Successive disposizioni hanno esteso l'obbligo di certificazione alle imprese controllate da enti di gestione delle partecipazioni statali o da essi finanziate (art. 14 legge 12 agosto 1977, n. 675), alle imprese assicurative contro i danni e del ramo vita (art. 68 legge 10 giugno 1978, n. 295, art. 66 legge 22 ottobre 1986, n. 742, d.lgs. 26 maggio 1997, n. 173), ad alcune societa di quotidiani e di periodici (artt. 7 e 18 legge 5 agosto 1981, n. 416, e successive modifiche, da ultimo art. 3 legge 7 agosto 1990, n. 250), alle societa di gestione ed ai fondi comune d'investimento (art. 6 legge 23 marzo 1983, n. 77), alla Montetitoli S.p.. (art. 11 legge 19 giugno 1986, n. 289), alle societa di intermediazione mobiliare (art. 10 legge 2 gennaio 1991, n. 1), a cooperative eccedenti determinati limiti dimensionali e/o di fatturato (art. 12 legge 31 gennaio 1992, n. 59), agli organismi di investimento collettivo in valori mobiliari, operanti nella forrna di società di investimento a capitale variabile (Sicav) (art. 10 d.lgs. 25 gennaio 1992, n. 84). Come sopra si e detto, il t.u. ha esteso l'obbligo alle società italiane con azioni quotate in mercati regolamentati italiani (attualmente, in borsa e al mercato ristretto) o di altre paesi dell'U.E. (art. 119). Inoltre, il contratto di revisione e stato imposto alle società di gestione del risparmio (art. 9), alle societa di gestione accentrata (art. 80) e alle società controllate da società con azioni quotate, fatti salvi i casi di esenzione (per le societa che non nvestono significativa rilevanza ai fini del consolidamento) stabiliti con regolamento Consob (art. 165); per il caso di societa appartenenti a gruppi facenti capo a Sim e Sicav, l'obbligo sussiste solo se espressamente richiamato dalla Banca d'Italia (art. 12 t.u.). Per il resto, rimane fermo il previgente arnbito applicativo: quanto alle Sim alle societa di gestione del risparmio ed alle Sicav, in virtù dell'art. 9 t.u.; quanto alle altre ipotesi citate, in virtù del generale nnvio operato dall'art. 214 t.u. Peraltro, pur non ponendosi particolari questioni circa l'individuazione dei soggeffi obbligati a stipulare il contratto di revisione, il t.u. prospetta problemi specifici di disciplina applicabile" (CASADEI, Daniela. La responsabilità della società di revisione. Milão: Giuffrè, 2000. p. 21). 
161 t.u., tenham já obtido anteriormente a aprovação da Consob por meio do registro em rol específico, valoração prévia de sua capacidade técnica. ${ }^{67}$

Em suma, na relação estabelecida entre as partes no que diz respeito aos serviços de auditoria externa imposto por disposições normativas: 1) não há liberdade de concluir ou não o contrato; 2) há limitada liberdade de escolha de conteúdo contratual; 3) há limitada liberdade de escolha do auditor com quem se contrata a prestação dos serviços.

Cabe agora enfrentar a questão de se saber se as limitações impostas ao consentimento ou à autonomia da vontade das partes (no tocante à capacidade de voluntariamente concluir ou não o contrato, estabelecer livremente seu conteúdo ou escolher livremente a contraparte) chegam ao ponto de excluir dessa relação negocial estabelecida o caráter contratual.

Sobre referido tema, ressalta Pontes de Miranda que a liberdade contratual é uma prerrogativa do próprio exercício da personalidade, pois, se o ser humano não possuísse certo campo para o exercício livre de sua vontade, não se poderia falar em personalidade. No entanto, essa liberdade deve ser restrita pelas limitações de ordem pública e os interesses de outrem. Segundo preceitua este autor:

O autorregramento da vontade, a chamada autonomia da vontade, é que permite que a pessoa, conhecendo o que se produzirá com o seu ato, negocie ou não, tenha ou não o gestum, que a vincule (...). Não há autonomia absoluta ou ilimitada de vontade; a vontade tem sempre limites, e a alusão à autonomia é alusão ao que se pode querer dentro desses limites. ${ }^{68}$

Pontes de Miranda, com a perspicácia que lhe era peculiar, aponta três classes de limitações à liberdade de conclusão do contrato, derivadas das seguintes circunstâncias: 1) contratação com empresas prestadoras de serviços públicos, na qual estas não podem se recusar a contratar com o usuário do serviço; 2) no caso de serviços de interesse coletivo cuja recusa acarrete dano a outrem, como os casos de prestação de serviço médico ou de

\footnotetext{
${ }^{67}$ Op. cit. p. 21. O texto citado é tradução livre de: "Una limitata autonomia è riconosciuta solo in relazione alla scelta del contraente tra una rosa di società di revisione (di persone o di capitali) che, essendo in possesso di determinati requisiti indicati all'art. 161 t.u., hanno gia ottenuto in via preventiva l'approvazione della Consob mediante l'iscrizione nell'albo speciale, previa valutazione dell'idoneità tecnica delle stesse".

${ }^{68}$ MIRANDA, Pontes de. Tratado de Direito Privado. São Paulo: Revista dos Tribunais, 1983. t. XXXVIII. p. 39.
} 
abastecimento de gêneros essenciais; 3) nos casos em que determinado setor da economia seja objeto de ingerência ou controle estatal.

A atividade de auditoria parece estar compreendida na última alternativa mencionada, qual seja, a relativa à ingerência estatal na economia. Com efeito, considerando a necessidade de proteção do investidor contra a precariedade ou falsidade da informação econômico-financeira prestada pelas entidades empresariais, bem como a exigência de estimular o investimento público no mercado de capitais, proporcionando a alocação otimizada de recursos, o Estado passa a exigir de determinadas categorias de agentes econômicos a contratação de serviços de revisão contábil independente.

No entanto, embora a imposição normativa acarrete um verdadeiro dever de contratar para quem esteja obrigado, não chega a impor a desnecessidade da manifestação de vontade ou do consentimento da parte obrigada para a conclusão do contrato.

De fato, embora as entidades obrigadas a contratar serviços de auditoria externa tenham o dever de fazê-lo, a avença entre o ente auditado e o auditor independente só se consubstancia quando haja a manifestação externa da vontade de ambos. Em não havendo esta manifestação (consentimento) da entidade auditada, o dever jurídico de contratar se resolve na imposição de penalidade ou de responsabilização daquele(s) que $\operatorname{estava}(\mathrm{m})$ obrigado(s).

Não há, desta forma, como se impor, manu militari, a contratação de auditoria externa, nem mesmo como suprir, administrativa ${ }^{69}$ ou judicialmente, ${ }^{70}$ a vontade daquele

\footnotetext{
${ }^{69}$ No ordenamento nacional, a CVM não está autorizada a suprir a omissão do Conselho de Administração pela ausência de contratação de auditoria, podendo meramente penalizar seus membros pela inércia. Confirma isto o parecer lançado no Inquérito Administrativo CVM n. RJ 2001/8045, em que foi proposta a aplicação de multa aos conselheiros responsáveis. A ementa está assim redigida: "O parecer dos auditores independentes é parte integrante das demonstrações financeiras das companhias abertas e não pode ser suprimido pela companhia ou dispensado pela CVM. Responsabilidade do Conselho de Administração". Na Itália, porém, é previsto expressamente o suprimento administrativo da omissão da assembleia na contratação dos serviços de auditoria externa (revisione contabile) pela Consob, nos seguintes termos do art. 159 do Decreto Legislativo de 24 de fevereiro de 1998, n. 58 (com grifos nossos): “Art. 159. (Conferimento e revoca dell'incarico) 1. L'assemblea, in occasione dell'approvazione del bilancio o della convocazione annuale prevista dall'articolo 2364-bis, secondo comma, del codice civile, su proposta motivata dell'organo di controllo conferisce l'incarico di revisione del bilancio di esercizio e del bilancio consolidato ad una società di revisione iscritta nell'albo speciale previsto dall'articolo 161 approvandone il compenso. La Consob provvede d'ufficio al conferimento dell'incarico, quando esso non sai deliberato, determinandone anche il corrispettivo". Regulamentando o artigo mencionado, o art. 148 da deliberação Consob n. 11.971, de 14.05.1999, dispõe: “Conferimento dell'incarico da parte della Consob 1. La Consob conferisce d'ufficio l'incarico di revisione e ne determina il corrispettivo, qualora la società obbligata non vi abbia provveduto, trascorsi sessanta giorni dal sorgere dell'obbligo o dalla scadenza di un precedente incarico".

${ }^{70}$ Entendemos inaplicável ao caso a lição de Pontes de Miranda, segundo a qual havendo dever de concluir o contrato, o interessado pode ingressar judicialmente para obtê-lo (Op. cit. p. 43): "Sempre que há um dever de conclusão, o interessado, alegada e provada sua legitimação, tem a ação declaratória, a ação do art. 1.006
} 
sobre quem recai o dever de contratar os serviços supracitados, razão pela qual o consentimento resta imprescindível para a conclusão efetiva do negócio, tornando inafastável a conclusão da natureza contratual do acordo de vontades entre auditado e auditor em relação à avença envolvendo os serviços de auditoria externa obrigatórios. ${ }^{71}$

Este aspecto, aliás, não passou despercebido da doutrina italiana, que assevera a natureza contratual nos casos de auditoria obrigatória, mesmo que tais serviços atendam a necessidades de interesse público e parte do conteúdo contratual possa ser estabelecido pelo legislador. Interessante a lição de Maria Vittoria Cozzi a respeito do tema:

A atividade da auditoria, ainda que efetivada para realizar um interesse publicístico, tem natureza privada. Isto significa que as sociedades sujeitas à revisão contábil têm de deliberar em assembleia a atribuição do encargo à sociedade de auditoria, e tal atribuição vem formalizada com a estipulação de um contrato que constitui exatamente a fonte da disciplina de tal relacionamento, mesmo se o conteúdo do contrato for parcialmente imposto pelo legislador. ${ }^{72}$

Entendemos, portanto, que estaremos, em tais casos, diante daquilo que Orlando Gomes chamou de contrato coativo:

O contrato coativo, considerado por alguns uma relação paracontratual, é aquele em que a lei obriga as partes a estipulá-lo sem alternativa ou a conservá-lo mesmo contra a vontade de uma das partes. Enquadram-se na

do Código de Processo Civil, a ação de preceito cominatório e ação de condenação pelos danos". A inaplicabilidade do lecionado por este ilustre autor decorre, a nosso ver, do fato de que os interessados na contratação (que podem ser, diretamente, um auditor ou sociedade de auditoria e, indiretamente, a CVM ou terceiro beneficiário do serviço de auditoria) não têm como exigir judicialmente a particularização do objeto da obrigação. Não há como o juiz, sem nenhuma regra orientadora ou manifestação anterior de vontade das partes, determinar quais serão as condições gerais e especiais dos serviços de auditoria a serem prestados (p.ex.: o preço, a contraparte, a extensão dos serviços, etc.), nem mesmo como fixar multa cominatória para que as partes venham a contratar.

${ }^{71}$ Uma das consequências importantes da afirmação da natureza contratual dos serviços de auditoria externa obrigatória é a de que, admitindo-se uma relação contratual entre as partes, a responsabilidade pelo descumprimento derivado desta relação também é contratual, o que implica inversão de ônus de prova da responsabilidade pelo inadimplemento. Esta questão foi examinada em julgado do Tribunal de Milão no caso Parmalat (TRIBUNALE DI MILANO, sez. VIII, 4 novembre 2008 - Pres. Ciampi - Rel. Fiecconi - V.C. avv. Panarese, F.G. avv. Lozupone e altri c. Italaudit s.p.a. in liquidazione avv. Taglioretti): "Tuttavia, anche nel caso di revisione obbligatoria, è difficile negare che sussista un rapporto contrattuale fra le parti, nascente proprio dal conferimento dell'incarico e che trova la propria espressione in uno scambio di prestazioni (espletamento dell'incarico verso il pagamento di un corrispettivo)". O texto é encontrado no trabalho de Valerio Sangiovanni, in Corriere giuridico, 4/2009, p. 531-542.

${ }^{72}$ Op. cit. p. 29. O texto é tradução livre de: "L'attività di revisione pur essendo finalizzata a realizzare um interesse publicistico, ha comunque natura privatistica. Cio significa che le società soggette a revisione sono tenute a deliberara in assemblea il conferimento dell'incarico alla società di revisione e tale incarico viene formalizzato con la stipula di un contratto che appunto costituisce la fonte della disciplina di tale rapporto, anche se i contenuli dei contratto sono in parte imposli dal legislalore". 
categoria o seguro obrigatório e a locação prorrogada por determinação legal. $^{73} 74$

Do mesmo modo, as restrições à liberdade contratual inerentes à escolha do outro contratante e à liberdade de conteúdo do contrato não retiram a natureza contratual da relação estabelecida entre as partes.

A restrição à liberdade da escolha do outro contratante é circunstância frequentemente existente nas relações contratuais modernas. Encontra-se presente no caso de contratos envolvendo profissões regulamentadas, nos chamados pactos de preferência ou direitos legais de preferência, entre outros casos. Em nenhuma dessas hipóteses, porém, está ausente a natureza contratual nas relações estabelecidas.

Por seu turno, a liberdade de conteúdo do contrato é usualmente restringida pelo legislador para atingir diversos propósitos, dentre os quais, evitar o abuso das partes, equilibrar o poderio econômico dos contratantes, assegurar o controle de atividades econômicas estratégicas, promover padronização de contratos, entre outros fins. Do mesmo modo, não está ausente, em tais casos, a natureza contratual na avença.

Esta última restrição à liberdade contratual (liberdade de conteúdo do contrato), entretanto, faz surgir importante questão, qual seja, a de se saber se o contrato envolvendo serviços de auditoria externa, voluntária ou obrigatória, consubstancia-se em contrato de adesão. Para melhor analisá-la, abriremos a seguir tópico específico.

\subsubsection{Liberdade de conteúdo de contrato e contratação de adesão em auditoria}

Devemos estabelecer aqui se a contratação de serviços de auditoria externa se conceitua como contrato de adesão. Para tanto, primeiramente precisamos bem conceituar o fenômeno do contrato de adesão, embora sem a pretensão de nos aprofundarmos no

\footnotetext{
${ }^{73}$ GOMES, Orlando. Contratos. Rio de Janeiro: Forense, 2008. p. 33.

${ }^{74}$ Não devemos deixar de consignar a opinião (à qual não nos filiamos) daqueles que não consideram como contratual a relação estabelecida entre as partes tornada obrigatória por efeito de norma. Sílvio de Salvo Venosa, por exemplo, assevera com relação aos contratos coativos: "Existe no fenômeno aparência de contrato e não contrato propriamente dito. Trata-se de negócio jurídico guarnecido de normas de Direito Público" (VENOSA, Sílvio de Salvo. Direito Civil - Teoria geral das obrigações e teoria geral dos contratos. São Paulo: Atlas, 2003, 2 v. p. 386).
} 
estudo desta espécie contratual, ${ }^{75}$ para nela enquadrar ou não a situação existente em relação aos contratos de auditoria.

\section{Leciona Antunes Varela:}

Na sua formação teórica tradicional, o contrato é normalmente precedido de uma livre discussão entre os pactuantes sobre o teor de cada cláusula. Pressuposto do debate prévio entre os contraentes e a igualdade jurídica das partes, uma das premissas em que o liberalismo individualista assentava a força soberana do contrato. À medida, porém, que o poder econômico dos grupos se foi fortalecendo com o desenvolvimento do capitalismo, a atividade das empresas se foi diversificando e a oferta dos produtos em massa se foi alargando, começaram a surgir a multiplicar-se no comércio jurídico os casos em que a lex contractus é praticamente elaborada por um só dos contraentes, sem nenhum debate prévio acerca de seu conteúdo (...) Ao tipo de contratos assim forjados, bem próprios das sociedades de consumo e bem distanciados do modelo clássico da época liberal, é que na doutrina e na prática dos países latinos se tem dado o nome sugestivo de contratos de adesão. Diz-se, por conseguinte, contrato de adesão aquele em que um dos contraentes - o cliente, o consumidor - como sucede, por exemplo, na generalidade dos contratos de seguro e de transporte por via aérea, férrea, ou marítima ou dos contratos bancários, não tendo a menor participação na preparação e redação das respectivas cláusulas, se limita a aceitar o texto que o outro contraente oferece, em massa, ao público interessado. ${ }^{76}$

O fenômeno dos contratos de adesão, como ensina o autor supracitado, decorre fundamentalmente da disparidade de forças entre as partes contratantes, situação da qual se origina o poder de uma delas de estabelecer integralmente o conteúdo do contrato, predeterminando suas cláusulas unilateralmente e sem negociação prévia com a parte contrária.

Bem ressalta Orlando Gomes que os contratos de adesão se configuram por três características básicas: 1) uniformidade de cláusulas; 2) predeterminação de conteúdo por

\footnotetext{
${ }^{75}$ Em virtude disto, e por não se enquadrar no propósito deste trabalho, não entraremos aqui nas discussões sobre a natureza jurídica do contrato de adesão, na diferenciação entre este fenômeno e as chamadas cláusulas gerais dos contratos, em sua interpretação e nas normas que regulam algumas espécies contratuais subsumidas a esta espécie contratual.

${ }^{76}$ VARELA, João de Matos Antunes. Das obrigações em geral. Coimbra: Almedina, 1994. p. 261.
} 
uma das partes ou mesmo por autoridades regulatórias competentes; 3) rigidez do modelo contratual, não sujeito à negociação. ${ }^{77}$

Além dessas características, o contrato de adesão configura-se pela abstração de suas cláusulas, que se destinam não apenas a uma contratação única ou específica, mas sim a ser aplicadas em inúmeras relações contratuais da mesma espécie (contratação de massa). Pressupõe esta espécie contratual uma oferta genérica ao público de idêntico conteúdo contratual, com aceitação unitária e em bloco das cláusulas contratuais constantes da oferta por cada contratante.

$\mathrm{Na}$ relação existente entre auditor e entidade auditada, as características supracitadas não se encontram presentes.

Primeiramente, é comum que em tais contratos as partes estejam em posição de igualdade jurídica e econômica, ou mesmo que a entidade auditada tenha porte econômico superior ao do auditor.

Ademais, devemos verificar que as cláusulas do contrato envolvendo os serviços de auditoria não são padronizadas, nem mesmo fixadas unilateralmente por uma das partes.

É bem verdade que as autoridades regulatórias fixam algumas cláusulas específicas que envolvem o conteúdo do contrato, dentre elas, o prazo máximo de contratação e recontratação, a proibição da prática concomitante de outros serviços, e as incompatibilidades de determinados contratantes em face do objeto contratual. No mais, porém, as partes são livres para negociar as cláusulas que regerão sua relação, não existindo características de contrato de adesão, como rigidez de modelos contratuais, abstração de cláusulas mediante oferta de serviços ao público ou contratação em massa.

Ausente também a abstração de cláusulas contratuais para servir a vários contratos em série (contratação de massa). Usualmente, o contrato de auditoria é estipulado pelas partes para cada caso concreto, e não para contratações sucessivas com o público em geral.

Por outro lado, não se deve confundir a regulamentação de cláusulas contratuais com a regulamentação existente na profissão de uma das partes do contrato. Com efeito, nos contratos envolvendo profissões regulamentadas, uma das partes está sujeita a agir dentro do determinado por um ordenamento técnico de normas que regem sua

${ }^{77}$ Contratos,_cit., p. 139. 
atividade, sob pena de falta profissional. Isto, porém, além de não se configurar predeterminação de cláusulas contratuais (mas em meras regras de boa conduta profissional), não elimina a necessidade de julgamento técnico do profissional contratado, nem mesmo faz com que uma das partes possa estabelecer unilateralmente as condições em que os serviços serão prestados. ${ }^{78}$

Desta forma, entendemos que o contrato envolvendo os serviços de auditoria externa não se configura como contrato de adesão nos moldes estabelecidos pela doutrina.

\subsubsection{Natureza jurídica do contrato}

A questão envolvendo a natureza jurídica do contrato cujo objeto recai sobre os serviços de auditoria externa tem levado os doutrinadores estrangeiros a inúmeras discussões.

$\mathrm{Na}$ Itália, divergem os autores sobre a natureza jurídica de tais contratos. Basicamente, as seguintes posições são defendidas: 1) são contratos de prestação de obra intelectual (prestazione di opera intellettuale), previstos nos arts. 2.230 e seguintes do Código Civil italiano; ${ }^{79}$ 2) são contratos de empreitada ou prestação de serviços (appalto di servizi), disciplinados nos arts. 1.655 e seguintes do referido diploma legal; ${ }^{80}$ 3) cuida-se de contrato de mandato; 4) trata-se de contrato autônomo e atípico, não se subsumindo a outras categorias contratuais.

A divergência da doutrina italiana entre estas categorias não é meramente acadêmica.

\footnotetext{
${ }^{78}$ Pensar contrariamente levaria a considerar que todo contrato envolvendo profissões regulamentadas seria caracterizado como contrato de adesão, o que não se afigura correto a nosso ver. Cabe novamente a lição de Orlando Gomes (Contratos,_cit. p. 354): “A parte que presta o serviço estipulado não o executa sob a direção de quem se obriga a remunerá-lo e utiliza os métodos e processos que julga convenientes, traçando, ela própria, a orientação técnica a seguir, e assim exercendo sua atividade profissional com liberdade. Na realização do trabalho, não está subordinada a critérios estabelecidos pela outra parte. Enfim, é juiz do modo por que o serviço deve ser prestado. O cirurgião, por exemplo, opera como lhe parece mais adequado, quando e onde reputa oportuna e apropriada a intervenção. Não é o paciente quem dita o orientação técnica a ser observada ou o momento em que deve ser feita".

79 "Art. 2.230 Prestazione d'opera intellettuale. Il contratto che ha per oggetto una prestazione di opera intellettuale è regolato dalle norme seguenti (att. 202) e, in quanto compatibili con queste e con la natura del rapporto, dalle disposizioni del Capo precedente. Sono salve le disposizioni delle leggi speciali."

80 "Art. 1.655 Nozione: L'appalto (2.222 e seguenti) è il contratto col quale una parte assume, con organizzazione dei mezzi necessari e con gestione a proprio rischio, il compimento di un'opera o di un servizio verso un corrispettivo in danaro."
} 
Isto porque, se conceituado o contrato como prestação de obra intelectual, incide sobre tal relação o art. 2.237 do Código Civil italiano, ${ }^{81}$ que permite a resilição imotivada do contrato pelo contratante da obra, desde que venha a ressarcir o prestador das despesas e demais compensações devidas. Do mesmo modo, em termos de responsabilidade civil do auditor, incidiria o art. 2.236 de referido diploma legal, que limita a responsabilidade, nos casos de prestação de especial dificuldade, às hipóteses em que o prestador tenha obrado com dolo ou culpa grave. ${ }^{82}$ Outrossim, argumenta-se que a pessoalidade do prestador de serviço, exigida pelo art. 2.232 do Código Civil italiano, ${ }^{83}$ aplicável aos contratos de prestação de obra intelectual, seria incompatível com a realização empresarial (e não pessoal) dos serviços por sociedades de auditoria.

Por estes motivos, embora reconheçam os serviços de auditoria como produção de uma obra intelectual, grande parte da doutrina italiana conceitua a contratação de tais serviços como integrada na disciplina da empreitada ou prestação de serviços (appalto di servizi). ${ }^{84}$ Algumas das normas do Código Civil italiano que regulam esta espécie contratual, porém, não são aplicáveis aos contratos envolvendo auditoria, tais como as que regulam empreitadas de materiais (appalto di opera).

Os doutrinadores que defendem a existência de contrato de mandato asseveram que o auditor atuaria como mandatário dos terceiros (mandantes) interessados em fazer uso da informação contábil e que, portanto, incumbiriam o auditor da tarefa de fiscalizar as demonstrações contábeis da entidade auditada mediante representação.

Por fim, os autores que defendem que o contrato de auditoria tem natureza jurídica autônoma e atípica em relação às demais categorias de contratos nominados

\footnotetext{
81 “Art. 2.237 Recesso . Il cliente può recedere dal contratto, rimborsando al prestatore d'opera le spese sostenute e pagando il compenso per l'opera svolta. Il prestatore d'opera può recedere dal contratto per giusta causa. In tal caso egli ha diritto al rimborso delle spese fatte e al compenso per l'opera svolta, da determinarsi con riguardo al risultato utile che ne sia derivato al cliente. Il recesso del prestatore d'opera deve essere esercitato in modo da evitare pregiudizio al cliente."

82 "Art. 2.236 Responsabilità del prestatore d'opera. Se la prestazione implica la soluzione di problemi tecnici di speciale difficoltà, il prestatore d'opera non risponde dei danni, se non in caso di dolo o di colpa grave (1.176)."

83 "Art. 2.232 Esecuzione dell'opera. Il prestatore d'opera deve (1.176) eseguire personalmente l'incarico assunto. Può tuttavia valersi, sotto la propria direzione e responsabilità, di sostituti e ausiliari, se la collaborazione di altri è consentita dal contratto o dagli usi e non è incompatibile con l'oggetto della prestazione."

${ }^{84}$ Também Daniela Casadei, ilustre doutrinadora italiana, opina no sentido de que o contrato envolvendo os serviços de auditoria não possa ser qualificado como prestação de obra intelectual. Esta autora cita, porém, as lições de M. Bussoletti, para quem os problemas supracitados, mormente a pessoalidade do serviço, não afetam a natureza do contrato, que é, na sua opinião, de prestação de obra intelectual. A autora cita ainda posições intermediárias, como as de Galgano e Messineo, que distinguem a natureza jurídica do contrato de
} 
argumentam que a relação contratual estabelecida entre as partes deriva de uma causa autônoma, com estrutura e funcionalidades próprias, diversas e complexas, sem que se precise recorrer, para sua definição, a qualquer integração normativa decorrente da aplicação das normas de outras espécies contratuais. Do mesmo modo, o apelo para a atipicidade contratual permitiria compatibilizar a aplicação de normas próprias ao contrato envolvendo serviços de auditoria, sem ter de adaptar outras normas destinadas a contratos distintos.

Interessante a lição de Maria Vittoria Cozzi:

A riqueza do conteúdo do contrato de auditoria induz, entretanto, a dúvida no reconhecimento, em sua complexidade, de um único esquema contratual típico. As diversas prestações necessárias a realizar a finalidade da auditoria, segundo a previsão negocial das partes e o complexo de normas legislativas, regulamentares e deontológicas que regulam a matéria parecem reciprocamente conexas a excluir que entre essas possa se pôr uma relação de principal ao acessório que consinta pensar nas prestações ulteriores como absorvidas nas principais e consequentemente reentrantes na elasticidade de um tipo contratual assim caracterizado. O resultado complexo que as partes querem realizar através do contrato é diverso daquele que caracteriza a causa típica dos contratos nominados a que se tentou fazer referência, constituindo isso uma síntese original de prestações incindíveis que em sua totalidade realizam a função própria do contrato considerado. A análise das cláusulas contratuais que caracterizam os modelos comumente usados geralmente evidencia, de fato, a presença simultânea de obrigações do resultado, como, por exemplo, a verificação da contabilização exata dos fatos da administração ou do controle da correspondência entre escritas da contabilidade e as contas anuais; as obrigações de diligência, como a verificação da correspondência entre o balanço e as normas que lhe regulam a redação, o controle de congruência de sobrepreço acionário, da adequação e da correção dos critérios contábeis adotados pelos administradores e da razoabilidade das estimativas efetuadas. Em conclusão, o contrato de revisão é caracterizado pela execução de prestações heterogêneas típicas de vários modelos contratuais, mas não subsumíveis na causa típica de nenhum deles. Nem, a meu aviso, pode-se 
pensar que a presença no TUF de uma disciplina específica das qualidades exigidas para o desenvolvimento da atividade da auditoria e de algumas das obrigações oriundas do contrato sejam suficientes a considerar que a lei especial com isso tenha configurado um tipo contratual novo. A disciplina considerada parece, de fato, considerar a atividade da sociedade de auditoria um contrato por esta não estipulado. Qual seja a solução sobre tal ponto, remanesce o fato de que, em todo caso, a disciplina existente apresenta lacunas que não são completáveis com o recurso à disciplina de um tipo contratual disciplinado no código ou outras leis especiais. ${ }^{85}$

Transpondo as lições da doutrina italiana para a realidade existente no ordenamento jurídico nacional, podemos observar inicialmente que não se encontra normatizada no Código Civil de 2002 a figura do contrato de produção de obra intelectual, de forma a restar impossível o enquadramento dos contratos envolvendo serviços de auditoria nesta modalidade.

Outrossim, não é possível subsumir os contratos de auditoria entre os contratos de empreitada, uma vez que, nos termos dos arts. 610 e seguintes do Código Civil pátrio, a empreitada (de trabalho ou de materiais) visa à elaboração ou construção de obra física

intelectual), ou de capital (caso em que se configuraria empreitada ou prestação de serviços).

${ }^{85}$ Op. cit. p. 39-40. O texto é tradução livre de: "La ricchezza dei contenuto dei contratto di revisione induce tuttavia il dubbio sulla riconducibilità, nella sua complessità, ad un único schema contrattuale típico. Le diverse prestazioni necessarie per realizzare la finalità della revisione secondo la previsione negoziale delle parti e il complesso di norme legislative, regolamentari e deontologiche che regolano la matéria sembrano infatti cosi reciprocamente connesse da escludere che tra esse possa porsi una relazione da principale ad accessorio che consenta di ritenere le prestazioni ulteriori assorbite in quelle principali e dunque rientranti nell'elasticità dei tipo contrattuale da queste caratterizzato. Il risultato complessivo che le parti vogliono realizzare attraverso il contratto è diverso da quello che caratterizza la causa típica dei contratti nominati ai quali si è tentato di far riferimento, costituendo esso una sintesi originale di prestazioni inscindibili che nel loro insieme realizzano Ia funzione própria dei contratto considerato. L'analisi delle clausole contrattuali che caratterizzano i modelli più comunemente utilizzati evidenzia infatti la compresenza di obbligazioni di risultato, come ad esempio la verifica dell'esatta contabilizzazione dei fatti di gestione o il controllo della corrispondenza fra scritture contabili e conti annuali; obbligazioni di pura diligenza come la verifica della corrispondenza dei bilancio alle norme che ne regolano la redazione, il controllo della congruità dei sovrapprezzo azionario, dell'adeguatezza e correttezza dei criteri contabili adottati dagli amministratori e della ragionevolezza delle stime da quelli effet-tuate. In conclusione il contratto di revisione si caratterizza per l'esecuzione di prestazioni eterogenee tipiche di piú modelli contrattuali, ma non sussumibili nella causa típica di nessuno di essi. Ne, a mio avviso, può ritenersi che la presenza nel TUF di una disciplina specifica delle qualità richieste per lo svolgimento dell'attività di revisione e di alcune delle obbligazioni nascenti dal contratto sia sufficiente a far ritenere che la legge speciale abbia con cio configurato un nuovo tipo contrattuale. La disciplina considerata sembra infatti riguardare l'attività della società di revisione, non il contratto da questa stipulato. Quale che sia la soluzione su tale punto, resta peraltro il fatto che in ogni caso la disciplina esistente presenta lacune che non sono colmabili con il ricorso alla disciplina di un tipo contrattuale già disciplinato dal codice o da altre leggi speciali”. 
tangível, ${ }^{86}$ fato este que não está presente na atividade de auditoria. Ademais, a aplicação das normas da empreitada, presentes na legislação pátria, ao contrato de auditoria teria um grande número de restrições ou inaplicabilidades, o que torna impraticável referido enquadramento.

Definitivamente, entendemos que a identificação da atividade de auditoria com o objeto do contrato de mandato é inaceitável, vez que o auditor não representa os terceiros, os quais não entabulam qualquer contrato com ele, inexistindo manifestação de vontade de quaisquer das supostas partes envolvidas num imaginado contrato de mandato. Ademais, a indeterminação que existe dos terceiros beneficiários inviabilizaria o reconhecimento das partes eventualmente envolvidas na contratação.

Se mais não fosse, é de se dizer que o auditor não está sujeito às ordens e diretivas dos terceiros usuários da informação contábil auditada, diversamente do que ocorre no mandato. Outrossim, a relação entre terceiros beneficiários da informação prestada pela auditoria e o auditor é extracontratual, não existindo qualquer liame ou avença que os vincule, sendo incabível cogitar-se de contrato de mandato.

Tudo isto, sem dizer que a conceituação do contrato de auditoria como mandato só retrataria a natureza das relações entre terceiros e auditor, omitindo a relação principal entre o auditor e a entidade auditada, esta sim de natureza contratual.

Poder-se-ia conceituar o contrato de auditoria como simples prestação de serviços, nos termos dos arts. 593 e seguintes do Código Civil. No entanto, há algumas particularidades que especializam os serviços de auditoria da prestação de serviços comum, dentre as quais podemos citar:

- Os serviços são prestados, em regra, no interesse de terceiros, ${ }^{87}$ e não no das partes contratantes: com efeito, as informações prestadas pelos

\footnotetext{
${ }^{86}$ Veja-se o conceito de Silvio Rodrigues: "Através do contrato de empreitada, uma das partes - o empreiteiro - se compromete a executar determinada obra, pessoalmente ou por meio de terceiros, em troca de certa remuneração fixa a ser paga pelo outro contraente - dono da obra -, de acordo com instruções deste e sem relação de subordinação" (RODRIGUES, Silvio. Direito Civil - Dos contratos e das declarações unilaterais de vontade. São Paulo: Saraiva, 2003. 3. v. p. 245). Igualmente importante a lição de Washington de Barros Monteiro, fazendo a distinção entre empreitada e prestação de serviços: "Outra diferença: na empreitada, visa-se à produção de uma obra, a caracterização dela está na sua finalidade. Na locação de serviços, o objeto do contrato é o próprio trabalho, material ou imaterial, que alguém põe a serviço de outrem, por certo tempo e mediante determinada remuneração. Naquela, o objetivo dos contratantes é a obtenção de um opus, nesta, a própria força orgânica do trabalho, a ser recompensada pelo salário" (MONTEIRO, Washington de Barros. Curso de Direito Civil - Direito das obrigações, 2ª parte. São Paulo: Saraiva, 1994. 5. v. p. 196).

${ }^{87}$ Obviamente, não fica excluída a contratação de auditoria externa para a prestação de informações de interesse da própria entidade auditada, de seus sócios/acionistas ou de seus gestores. Aliás, é comum que a
} 
auditores independentes interessam usualmente a terceiros estranhos à relação contratual estabelecida entre auditor e entidade auditada, ao contrário da prestação de serviços comum, em que o serviço é prestado no interesse de uma das partes contratantes. Tem-se, portanto, nos serviços de auditoria uma espécie de "relação triangular" envolvendo auditor, auditado e usuários da informação de auditoria que não ocorre nas prestações de serviço comuns;

- No contrato envolvendo auditoria externa, uma das partes assume um caráter de fiscalização do comportamento da outra como objeto do contrato: o auditor deve fiscalizar o comportamento histórico da entidade auditada sob o ponto de vista contábil e contrariar, se for o caso, os interesses desta última, quando não estiverem de acordo com os padrões estabelecidos. Nas prestações de serviço comuns, as partes agem de modo a favorecer a realização recíproca de seus interesses, e não no intuito de fiscalizar condutas ou contrariar interesses;

- A exigência de independência entre as partes é elemento essencial ${ }^{88}$ do contrato de auditoria externa: muito embora em todas as prestações de serviços o prestador guarde certa independência técnica do outro contratante, no sentido de decidir autonomamente como executar os serviços contratados, a atuação do prestador se dá de modo vinculado ao interesse do outro contratante, não havendo qualquer dever de independência. Já no contrato de auditoria externa, a independência é elemento essencial do negócio jurídico, consubstanciando-se em dever a ser observado pelo auditor e pela parte que o contrata, podendo sua falta

gestão se utilize dos relatórios de auditoria para finalidades internas. Veja-se, por exemplo, a contratação de auditoria externa por acionistas de companhia fechada para fiscalização das contas dos administradores em seu exclusivo interesse. Ou ainda um caso de frequente ocorrência, no qual uma gestão que assume determinado empreendimento vem a contratar auditores independentes externos para analisar, sob o ponto de vista contábil, os atos praticados pela gestão passada. Esta última hipótese, porém, não é da essência dos serviços de auditoria externa, nem mesmo se constituiria em situação na qual tais serviços se mostrassem essenciais; neste último caso, para os mesmos fins, a gestão poderia ter se servido de serviços de auditoria interna.

${ }^{88}$ É sabida a distinção, entre nós defendida por Pontes de Miranda, entre elementos nucleares, completantes e complementares do ato jurídico. No entanto, não entraremos nesta discussão neste momento, para voltar a ela posteriormente. 
tornar ineficaz a auditoria prestada, além de poder gerar penalidades às partes que não observarem este requisito no contrato. ${ }^{89}$

Não bastassem as diferenças antes mencionadas, verifica-se que ocorrem diversos problemas na aplicabilidade dos dispositivos do Código Civil aos contratos de auditoria externa.

Neste sentido, para melhor verificarmos a compatibilidade entre as normas do Código Civil e o contrato de auditoria, trazemos a tabela seguinte.

\section{Tabela 1: Aplicabilidade das disposições do Código Civil aos contratos de auditoria}

\section{Dispositivo do Código Civil}

Art. 593. A prestação de serviço, que não estiver sujeita às leis trabalhistas ou a lei especial, reger-se-á pelas disposições deste Capítulo.

Art. 594. Toda a espécie de serviço ou trabalho lícito, material ou imaterial, pode ser contratada mediante retribuição.

Art. 595. No contrato de prestação de serviço, quando qualquer das partes não souber ler, nem escrever, o instrumento poderá ser assinado a rogo e subscrito por duas testemunhas.

Art. 596. Não se tendo estipulado, nem chegado a acordo as partes, fixar-se-á por arbitramento a retribuição, segundo o costume do lugar, o tempo de serviço e sua qualidade.

Art. 597. A retribuição pagar-se-á depois de prestado o serviço, se, por convenção, ou costume, não houver de ser adiantada, ou paga em prestações.

\section{Aplicabilidade aos contratos envolvendo serviços de auditoria}

Inaplicável em grande parte: as disposições dos contratos de auditoria de companhias abertas, instituições financeiras, seguradoras, etc., estão regidas por leis e normas especiais, como as Leis ns. 6.404/76 e 6.385/76, normas da CVM, BACEN, CNSP, CFC, etc.

Teoricamente aplicável a qualquer prestação de serviços

\section{Nenhuma aplicação prática aos contratos de} auditoria

\section{Teoricamente aplicável a qualquer prestação de serviços}

Teoricamente aplicável como norma subsidiária

(continua)

\footnotetext{
${ }^{89}$ Várias espécies de prestações de serviços permitem maior grau de independência do prestador em relação à parte contrária. Veja-se, por exemplo, o advogado contratado para elaborar parecer jurídico, o médico ou engenheiro contratados como assistentes técnicos de uma parte para proferir parecer a respeito de determinada matéria. Todos esses profissionais têm liberdade para opinar, podendo inclusive fazê-lo de modo a contrariar os interesses de seus constituintes. Em nenhum desses casos, entretanto, impõe-se como elemento essencial do contrato a independência total do prestador de serviços, sob pena de afetar a eficácia do negócio ou mesmo gerar penalidades às partes contratantes. $\mathrm{O}$ advogado, o médico e o engenheiro pareceristas terão na sua independência tão somente um fundamento da credibilidade de seus atos; poderão manter relações outras com a parte contrária (p.ex.: prestação de outros serviços, relações familiares ou de amizade, etc.) sem que isto afete o contrato. Já no contrato envolvendo serviços de auditoria externa, o auditor e a parte que o contrata têm o dever de somente estabelecerem um acordo de vontades quando puder ser mantida a independência completa entre os contratantes.
} 
Art. 598. A prestação de serviço não se poderá convencionar por mais de quatro anos, embora o contrato tenha por causa o pagamento de dívida de quem o presta, ou se destine à execução de certa e determinada obra. Neste caso, decorridos quatro anos, dar-se-á por findo o contrato, ainda que não concluída a obra.

Art. 599. Não havendo prazo estipulado, nem se podendo inferir da natureza do contrato, ou do costume do lugar, qualquer das partes, a seu arbitrio, mediante prévio aviso, pode resolver o contrato. Parágrafo único. Dar-se-á o aviso: I com antecedência de oito dias, se o salário se houver fixado por tempo de um mês, ou mais; II com antecipação de quatro dias, se o salário se tiver ajustado por semana, ou quinzena; III - de véspera, quando se tenha contratado por menos de sete dias.

Art. 600. Não se conta no prazo do contrato o tempo em que o prestador de serviço, por culpa sua, deixou de servir.

Art. 601. Não sendo o prestador de serviço contratado para certo e determinado trabalho, entender-se-á que se obrigou a todo e qualquer serviço compativel com as suas forças e condições.

Art. 602. O prestador de serviço contratado por tempo certo, ou por obra determinada, não se pode ausentar, ou despedir, sem justa causa, antes de preenchido o tempo, ou concluída a obra.

Parágrafo único. Se se despedir sem justa causa, terá direito à retribuição vencida, mas responderá por perdas e danos. $O$ mesmo dar-seá, se despedido por justa causa.

Art. 603. Se o prestador de serviço for despedido sem justa causa, a outra parte será obrigada a pagar-lhe por inteiro a retribuição vencida, e por metade a que lhe tocaria de então ao termo legal do contrato.

Art. 604. Findo o contrato, o prestador de serviço tem direito a exigir da outra parte a declaração de que o contrato está findo. Igual direito lhe cabe, se for despedido sem justa causa, ou se tiver havido motivo justo para deixar o serviço.
Inaplicável em grande parte: as disposições de normas especiais que regem os serviços de auditoria estabelecem a necessidade de rodízio de auditores em prazo de cinco anos, com intervalo de três anos para recontratação, como veremos mais adiante.

Inaplicável em grande parte: várias das disposições de normas especiais que regem os serviços de auditoria estabelecem a necessidade de prazo máximo de cinco anos para o serviço, com intervalo de três anos para recontratação, como veremos mais adiante. Assim, inviável o contrato por prazo indeterminado em muitos casos.

Inaplicável em grande parte: as disposições de normas especiais que regem os serviços de auditoria não estabelecem a faculdade de prorrogar o prazo máximo do contrato pela ausência de prestação do serviço. A aplicação do dispositivo violaria a necessidade de rodízio de auditores.

Inaplicável em grande parte: as disposições de normas especiais que regem os serviços de auditoria vedam, na maioria dos casos, a prestação concomitante de serviços de auditoria e consultoria para a mesma entidade, ainda que compatível com a formação profissional do auditor.

\section{Teoricamente aplicável}

Inaplicável em grande parte: normas especiais de auditoria exigem a comunicação da substituição de auditores, acompanhada da respectiva justificativa, ao órgão regulador competente. Assim, inviável a resilição sem justa causa em grande parte dos contratos.

\section{Inaplicável em grande parte: idem.}

Teoricamente aplicável, salvo em relação aos casos em que se proíbe a dispensa sem justa causa. (continua) 
Art. 605. Nem aquele a quem os serviços são prestados, poderá transferir a outrem o direito aos serviços ajustados, nem o prestador de serviços, sem aprazimento da outra parte, dar substituto que os preste.

Art. 606. Se o serviço for prestado por quem não possua título de habilitação, ou não satisfaça requisitos outros estabelecidos em lei, não poderá quem os prestou cobrar a retribuição normalmente correspondente ao trabalho executado. Mas se deste resultar benefício para a outra parte, o juiz atribuirá a quem o prestou uma compensação razoável, desde que tenha agido com boa-fé.

Parágrafo único. Não se aplica a segunda parte deste artigo, quando a proibição da prestação de serviço resultar de lei de ordem pública.

Art. 607. O contrato de prestação de serviço acaba com a morte de qualquer das partes. Termina, ainda, pelo escoamento do prazo, pela conclusão da obra, pela rescisão do contrato mediante aviso prévio, por inadimplemento de qualquer das partes ou pela impossibilidade da continuação do contrato, motivada por força maior.

Art. 608. Aquele que aliciar pessoas obrigadas em contrato escrito a prestar serviço a outrem pagará a este a importância que ao prestador de serviço, pelo ajuste desfeito, houvesse de caber durante dois anos.

Art. 609. A alienação do prédio agrícola, onde a prestação dos serviços se opera, não importa a rescisão do contrato, salvo ao prestador opção entre continuá-lo com o adquirente da propriedade ou com o primitivo contratante.
Inaplicável em grande parte: o dispositivo prevê a prestação do serviço em caráter intuitu personae. No entanto, os serviços de auditoria são prestados, na maioria das vezes, em caráter impessoal, com relacionamento entre pessoas jurídicas, podendo a sociedade de auditoria substituir livremente seus prepostos, sem anuência da parte contrária.

Aplicável subsidiariamente: a proibição da prática dos serviços por quem não possua habilitação (diploma de bacharel em ciências contábeis, registro em órgão profissional ou na CVM) resulta de lei de ordem pública, uma vez que visa a proteger o público investidor e a sociedade em geral. Razoável, portanto, que não possa obter remuneração derivada de serviço irregularmente prestado.

Inaplicável em grande parte: o dispositivo prevê a prestação do serviço em caráter intuitu personae. No entanto, os serviços de auditoria são prestados, na maioria das vezes, em caráter impessoal, com relacionamento entre pessoas jurídicas, não havendo término do contrato por morte.

Diante deste quadro, verifica-se que o contrato envolvendo a atividade de auditoria tem uma série de particularidades que o separam do contrato usual de prestação de serviços, sem, entretanto, constituir-se em contrato inteiramente atípico, como quer certa parte da doutrina italiana.

Nesta linha leciona Pontes de Miranda que, para ser considerado atípico, um determinado negócio jurídico não deve ter o potencial de se enquadrar na moldura de um contrato típico ou em uniões de contratos típicos. Definitivamente, não é o caso do contrato 
de auditoria, que, embora peculiar, continua podendo ser enquadrado na relação típica contratual de prestação de serviços. ${ }^{90}$

No contrato de auditoria, não se pode negar completamente seu enquadramento no tipo contratual concernente à prestação de serviço, uma vez que tecnicamente ainda contém a mesma função econômica deste. Assume-se a existência de especificidades, mas não se afigura correto dizer que os serviços de auditoria se afastam, em sua essência, do tipo contratual básico disposto em lei.

Interessante notar, como ressalta a Raquel Sztajn, que se admite em contratos típicos a inserção (até mesmo por iniciativa das partes) de nuances que os afastem da regulamentação prevista em lei, sem que os transformem em contratos inteiramente atípicos:

A disciplina dos contratos típicos pode ser modificada pelas partes mediante a introdução de cláusulas que não são próprias do tipo (atípicas), o que é admitido, sem muitas indagações, desde que tais cláusulas sejam subordinadas à função econômica típica do contrato, de forma que este não perca sua individualidade..$^{91}$

$\mathrm{Na}$ esteira do argumento desta autora, há de se entender que, se podem as partes inserir elementos atípicos em contratos, os quais lhes confiram particularidades, sem lhes subtrair a causa econômica final ou lhes retirar a natureza própria, também pode fazêlo a regulação estatal peculiar de um determinado contrato (como é o caso do de auditoria) sobre o qual incidam normas especiais que afastem a submissão da avença às regras básicas do contrato do qual é derivado.

A conceituação do contrato de auditoria como prestação de serviços, do mesmo modo, parece-nos mais adaptada ao tratamento dispensado pela regulamentação nacional da matéria, que constantemente se refere ao contrato em análise como "prestação de serviços de auditoria", ou faz referência a "serviços de auditoria" (cf. Instrução CVM n. 308/09).

Parece-nos, portanto, mais consentâneo com a realidade negocial entender a natureza jurídica do contrato de auditoria externa como contrato especial de prestação de serviços, ou contrato de prestação de serviços sui generis, dadas suas peculiaridades em confronto com o contrato usual de prestação de serviços regulado no Código Civil e a

\footnotetext{
${ }^{90}$ Op. cit. p. 369: "Os negócios jurídicos atípicos, bilaterais ou plurilaterais, são aqueles que não podem ser insertos em contrato típico, ou em uniões de contratos típicos. Sirva de exemplo o negócio jurídico, bilateral ou plurilateral, pelo qual alguém se vincula a dar fiança, ou a título cambiário ou cambiarifome”.
} 
inaplicabilidade de algumas das normas deste diploma legal àquela espécie contratual em análise.

Definida a natureza jurídica do contrato de auditoria, cabe ainda indagar, dentro deste tema, se a relação triangular estabelecida entre auditor, auditado e terceiros beneficiários da atividade de auditoria acaba por consubstanciar verdadeira estipulação em favor de terceiros. Em outras palavras, é de se saber se a entidade auditada, ao contratar com o auditor, estaria pactuando com este a entrega de um direito ou benefício a terceiros, usuários da informação contábil.

Como se sabe, a estipulação em favor de terceiros ou contrato em favor de terceiros consubstancia-se no pacto em que um determinado contratante (estipulante ou promitente) atribui, por conta e ordem da parte contrária (estipulado ou promissário), uma vantagem a um terceiro não participante da relação contratual originária (beneficiário). ${ }^{92} \mathrm{E}$ o que sucede, por exemplo, na contratação de um seguro de vida para terceiro beneficiário, nas aquisições de bens para entrega a outrem, etc.

No contrato de auditoria, entretanto, entendemos inexistente qualquer estipulação em favor de terceiros.

Isto porque, como ensina Antunes Varela, em referida espécie negocial é necessário que as partes contratantes ajam no sentido de atribuir, através do contrato, um direito (pessoal ou real) a terceiro, ou que da avença resulte, ao menos, uma atribuição patrimonial imediata ao beneficiário. Esta é a pedra de toque, segundo citado autor, para a distinção do contrato em favor de terceiro daqueles contratos obrigacionais em que a prestação se destina a terceiro, sem que este adquira qualquer direito à prestação. ${ }^{93}$

Uma breve análise da relação econômico-jurídica presente no contrato de auditoria revela que nenhum dos requisitos supracitados está presente na hipótese.

De fato, ao terceiro que se utiliza da informação prestada pelo auditor contábil não é atribuído nenhum direito subjetivo patrimonial, de natureza pessoal ou real. Não possui crédito ou direito subjetivo a uma prestação determinada. A simples consulta ou mesmo o uso da informação auditada não lhe altera o patrimônio nem lhe confere qualquer prerrogativa.

\footnotetext{
${ }^{91}$ SZTAJN, Raquel. Contrato de sociedade e formas societárias. São Paulo: Saraiva, 1989. p. 14.

92 Conceito interessante é trazido por Silvio Rodrigues: "Dá-se estipulação em favor de terceiro quando num contrato entre duas pessoas, pactua-se que a vantagem resultante do ajuste reverterá em benefício de terceiro, estranho à convenção e nela não representado" (Op. cit. p. 94).
} 
Não assiste ao terceiro o direito de exigir a prestação do serviço de auditoria oriunda do contrato estabelecido entre auditor e auditado. É apenas reflexamente beneficiado com a informação provinda da relação estabelecida entre essas partes.

Ademais, analisando sob perspectiva razoável, é difícil identificar que a entidade auditada, ao contratar serviços de auditoria, venha a fazê-lo com o fim precípuo de beneficiar terceiros ou conferir-lhes direitos e prerrogativas, principalmente em se considerando os custos ordinariamente atribuídos a este tipo de contratação. $O$ interesse da entidade auditada, desta forma, não é sequer similar ao de um estipulante em benefício de terceiros. $^{94}$

Entendemos, pois, ainda na esteira do que ensina Antunes Varela, que o contrato de auditoria se enquadra na categoria de contrato com efeito reflexo sobre terceiros, e não como contrato ou estipulação em favor de terceiros. ${ }^{95}$

\subsubsection{Auditoria e relações de consumo}

Cumpre analisar agora se nos contratos de auditoria - e na relação entre partes contratantes e terceiros - estabelece-se um vínculo jurídico que se possa conceituar como relação de consumo.

A investigação desta matéria envolve complexidade razoável para o intérprete, já que o contrato de auditoria pode se estabelecer envolvendo pessoas físicas e jurídicas, de forma voluntária ou obrigatória. Outrossim, a relação de consumo, nos termos do ordenamento nacional, não se resume aos limites do contrato estabelecido entre o suposto fornecedor e o consumidor, abarcando outras partes que venham a ser afetadas, sendo necessário, portanto, uma conclusão que envolva todas as hipóteses elencadas.

\footnotetext{
${ }^{93}$ Op.cit. p. 410.

94 Também Daniela Casadei (Op.cit. p. 84) entende não haver no contrato de auditoria uma estipulação em favor de terceiro, justamente por não se identificar o interesse da sociedade auditada (società revisionata) com o do estipulante. Para a autora, a entidade auditada apenas quita uma obrigação própria, tutelando (indiretamente) uma vantagem a terceiros.

95 Este autor, citando a doutrina alemã, ressalta que a importância dos contratos com efeitos reflexos sobre terceiros é que, ao contrário do que ocorre nos contratos em favor de terceiro, naqueles considera-se "os terceiros reflexamente beneficiados como titulares, não de qualquer direito referente às prestações principais ou secundárias emergentes do contrato, mas dos direitos correspondentes a alguns dos deveres acessórios de conduta que integram a relação contratual" (Op.cit. p. 412).
} 
Deve-se salientar também que a definição da existência de uma relação de consumo é repleta de repercussões práticas e implica a incidência de todo um conjunto de normas, que afetam substancialmente a forma de prestação dos serviços e o vínculo jurídico existente entre as partes. No caso dos serviços de auditoria, por exemplo, a definição de uma relação de consumo entre as partes contratantes ou entre estas e os terceiros afetados pode gerar consequências na aplicação do tipo de responsabilidade pelo inadimplemento de obrigações (objetiva ou subjetiva), na possibilidade de se excluir ou restringir tal responsabilidade contratualmente (cláusula de exclusão de responsabilidade), na viabilidade de tutela coletiva de relações de consumo, na inversão de ônus probatório, ou mesmo na incidência de tipos penais respectivos. ${ }^{96}$

Para definirmos a presença de relação de consumo entre as partes de contrato de auditoria, duas questões são de suma importância: 1) saber se o consumidor dos serviços de auditoria os utiliza como destinatário final; 2) pesquisar se existe, na prestação desses serviços, vulnerabilidade ou hipossuficiência do suposto consumidor em confronto com a parte contrária.

A utilização dos serviços como destinatário final, de forma não profissional, ou estranha aos fins da atividade empresarial, é um dos requisitos básicos para a definição da relação de consumo, nos termos do art. $2^{\frac{0}{}}$ do Código de Defesa do Consumidor (Lei n. 8.078/90), bem como na legislação comparada. ${ }^{97}$ É necessário, portanto, para que se tenha uma relação de consumo, como ensinam José Geraldo Brito Filomeno et al., que o seguinte tipo de vínculo esteja presente:

O conceito de consumidor adotado pelo Código foi exclusivamente o de caráter econômico, ou seja, levando-se em consideração tão somente o personagem que no mercado de consumo adquire bens ou então contrata a prestação de serviços, como destinatário final, pressupondo-se que

\footnotetext{
${ }^{96}$ Voltaremos mais adiante a discutir questões de responsabilidade civil do auditor com maiores detalhes.

${ }^{97}$ Art. $2^{\circ}$ da Lei n. 8.078/90: "Consumidor é toda pessoa física ou jurídica que adquire ou utiliza produto ou serviço como destinatário final". Na legislação portuguesa, a definição de consumidor está presente no art. $2^{\underline{0}}$ da Lei n. 24/03, aludindo ao uso não profissional dos bens ou serviços: "Considera-se consumidor todo aquele a quem sejam fornecidos bens, prestados serviços ou transmitidos quaisquer direitos, destinados a uso não profissional, por pessoa que exerça com carácter profissional uma actividade económica que vise a obtenção de benefícios". Na Itália, o art. 3ำ "a" do Decreto Legislativo de 6 de setembro de 2005, n. 206, refere-se ao uso com objetivo estranho à atividade empresarial: "Ai fini del presente codice, ove non diversamente previsto, si intende per: a) consumatore o utente: la persona fisica che agisce per scopi estranei all'attivita' imprenditoriale, commerciale, artigianale o professionale eventualmente svolta".
} 
assim age com vistas ao atendimento de uma necessidade própria e não para o desenvolvimento de uma outra atividade negocial. ${ }^{98}$

É necessário, portanto, que o consumidor esteja ocupando posição inerente à última fase da cadeia de consumo, ou seja, de destinatário final do produto ou serviço, nos termos definidos por Cláudia Lima Marques:

O destinatário final é o Endverbraucher, o consumidor final, o que retira o bem do mercado ao adquirir ou simplesmente utilizá-lo (destinatário final fático), aquele que coloca um fim na cadeia de produção (destinatário final econômico) e não aquele que utiliza o bem para continuar a produzir, pois ele não é o consumidor final, ele está transformando o bem, utilizando o bem para oferecê-lo por sua vez ao seu cliente, ao seu consumidor. Portanto, em princípio, estão submetidos às regras do Código os contratos firmados entre o fornecedor e o consumidor não profissional, e entre o fornecedor e o consumidor, o qual pode ser um profissional, mas que, no contrato em questão, não visa lucro, pois o contrato não se relaciona com sua atividade profissional, seja este consumidor pessoa física ou jurídica. ${ }^{99}$

Confrontando os requisitos ora tratados com a relação estabelecida entre as partes num contrato de auditoria, não é difícil verificar que a entidade auditada, recebedora dos serviços fornecidos pelo auditor, não os utiliza, em regra, como destinatária final.

Salvo raríssimas exceções, ${ }^{100}$ quando da contratação de um serviço de auditoria externa, a entidade auditada não busca atingir objetivos internos próprios ou utilizá-los sem caráter profissional. Igualmente, ao contratar auditoria externa de suas demonstrações, não ocupa referida entidade posição concernente à última etapa na cadeia de consumo. Ao contrário, os serviços de auditoria são usados com fins puramente empresariais, dentre os quais podem se destacar: 1) ingresso no mercado financeiro e de capitais; 2) financiamento através da emissão de títulos de dívida (debêntures, commercial papers, etc.); 3) obtenção

${ }^{98}$ FILOMENO, José Geraldo Brito. Código brasileiro de defesa do consumidor. Rio de Janeiro: Forense, 1993. p. 24.

${ }^{99}$ MARQUES, Claudia Lima. Contratos no Código de Defesa do Consumidor. São Paulo: RT, 2002. p. 279.

${ }^{100}$ Podemos vislumbrar a hipótese de utilização de serviços de auditoria como destinatário final no exemplo mencionado em nota anterior: uma gestão que assume determinado empreendimento vem a contratar auditores independentes externos para analisar, sob o ponto de vista contábil, os atos praticados pela gestão passada. No entanto, sequer poderemos conceituar propriamente tal situação como uma exceção, pois, como aludimos previamente, esta hipótese não é da essência dos serviços de auditoria externa, nem mesmo se constituiria em situação na qual tais serviços se mostrassem essenciais; no caso ora mencionado, para os mesmos fins, a gestão poderia ter se servido de serviços de auditoria interna. 
de empréstimos junto a instituições financeiras; 4) capitalização através de emissão de ações; 5) acesso a mercados externos; etc. ${ }^{101}$

Desta forma, entendemos que, em regra, não estarão preenchidos os requisitos insertos no art. $2^{\circ}$ do Código de Defesa do Consumidor no contrato de auditoria, de forma a não poder conceituá-lo como uma relação de consumo.

Devemos ainda verificar se está presente o requisito de vulnerabilidade de uma das partes contratantes, para o fim de justificar a aplicação da legislação consumerista às partes do contrato em análise.

A vulnerabilidade, segundo o que preconiza a melhor doutrina, ${ }^{102}$ pode ser: 1 ) técnica: quando o consumidor não possui conhecimento suficiente sobre o objeto do contrato, inexistindo equilíbrio de informação entre as partes; 2) jurídica: quando haja disparidades de conhecimentos jurídicos entre as partes; 3) fática ou socioeconômica: quando a disparidade econômica entre as partes seja pronunciada, podendo uma delas impor seu poder econômico sobre a outra.

No contrato de auditoria, não há disparidade técnica entre o consumidor (auditado) e o fornecedor do serviço (auditor). Isto porque os serviços de auditoria contábil pressupõem que a entidade auditada tenha um corpo específico de pessoas capacitadas para elaborar as demonstrações financeiras objeto de auditoria. Assim, não é possível admitir que aquele que elabora as demonstrações tenha menos conhecimento do que quem verifica as informações contábeis ali inseridas. Não é incomum, aliás, que o contrário ocorra, ou seja, o auditado possua muito mais informações sobre o negócio e suas particularidades que o auditor contratado.

Pelos mesmos motivos, não se vislumbra qualquer disparidade de conhecimentos jurídicos entre as partes contratantes capaz de configurar vulnerabilidade e justificar a aplicação do Código de Defesa do Consumidor.

Por fim, a disparidade socioeconômica não nos parece relevante a ponto de viabilizar que uma das partes imponha suas condições sobre a outra. Usualmente, as entidades auditadas não são hipossuficientes do ponto de vista econômico, de modo que

\footnotetext{
${ }^{101}$ Este aspecto não passou despercebido por Daniela Casadei (Op. cit. p. 84), que ressalta que a relação estabelecida entre entidade auditada e auditor não serve unicamente à primeira, como usuária final: "La relazione in sè non serve alla società revisionata, ma è uno strumento imposto per legge che (serve per presentarsi sul mercato in situazione di transparenza così) crea le condizioni perchè il pubblico investa avendo fiducia nella stabilità e solidità dell'impresa".

${ }^{102}$ Claudia Lima Marques, op. cit. p. 274.
} 
eventual desigualdade entre as partes neste campo não costuma ser pronunciada nem vem a repercutir na relação contratual subjacente. Também neste aspecto é comum a postura inversa, ou seja, que o poderio econômico esteja do lado da entidade auditada, e não do auditor. $^{103}$

Diante do exposto, entendemos que a relação estabelecida entre as partes no contrato de auditoria não se estabelece como relação de consumo nem se rege pela legislação consumerista, uma vez que o consumidor (auditado) não se utiliza, em regra, dos serviços de auditoria como usuário final, bem como não está presente o requisito de vulnerabilidade ou hipossuficiência do consumidor para ensejar a incidência das normas protetivas constantes da legislação de consumo.

Resta agora definir se a relação estabelecida entre as partes contratuais e os terceiros beneficiários do serviço de auditoria podem se reger pelas disposições do Código de Defesa do Consumidor.

Uma primeira objeção para tal incidência normativa, ainda que sem maior fundamento, seria o princípio da relatividade dos contratos, ${ }^{104}$ segundo o qual o contrato só opera seus efeitos entre as partes. Como o terceiro beneficiário da informação auditada não é parte no contrato de auditoria, não estaria abrangido pela legislação mencionada.

No entanto, tal objeção não deve prevalecer.

\footnotetext{
${ }^{103}$ Devemos lembrar que o contrato de auditoria usualmente é firmado entre pessoas jurídicas, ou mesmo entre pessoa jurídica (auditada) e pessoa física (auditor), não se vislumbrando hipóteses, no ordenamento nacional, de auditoria externa de pessoas físicas (salvo, talvez, uma cerebrina contratação voluntária envolvendo empresário individual e sociedade de auditoria, o que seria de restrito interesse ou repercussão econômica). Para os contratos envolvendo pessoas jurídicas na posição de consumidor, o Superior Tribunal de Justiça tem assumido postura restritiva, exigindo para a aplicação da legislação consumerista a demonstração da efetiva vulnerabilidade. Neste sentido: "Processo REsp 684613 / SP. RECURSO ESPECIAL 2004/0120460-3. Relator(a) Ministra NANCY ANDRIGHI (1118). Órgão Julgador T3 TERCEIRA TURMA. Data do Julgamento: 21.06.2005. Data da Publicação/Fonte: DJ 01.07.2005, p. 530 $R D D P$ vol. 30, p. 135. Ementa: DIREITO DO CONSUMIDOR. RECURSO ESPECIAL. CONCEITO DE CONSUMIDOR. PESSOA JURÍDICA. EXCEPCIONALIDADE. NÃO CONSTATAÇÃO NA HIPÓTESE DOS AUTOS. FORO DE ELEIÇÃO. EXCEÇÃO DE INCOMPETÊNCIA. REJEIÇÃO. - A jurisprudência do STJ tem evoluído no sentido de somente admitir a aplicação do CDC à pessoa jurídica empresária excepcionalmente, quando evidenciada a sua vulnerabilidade no caso concreto; ou por equiparação, nas situações previstas pelos arts. 17 e 29 do CDC. - Mesmo nas hipóteses de aplicação imediata do CDC, a jurisprudência do STJ entende que deve prevalecer o foro de eleição quando verificado o expressivo porte financeiro ou econômico da pessoa tida por consumidora ou do contrato celebrado entre as partes. - É lícita a cláusula de eleição de foro, seja pela ausência de vulnerabilidade, seja porque o contrato cumpre sua função social e não ofende à boa-fé objetiva das partes, nem tampouco dele resulte inviabilidade ou especial dificuldade de acesso à Justiça. Recurso especial não conhecido”.

${ }^{104}$ Sobre o conteúdo de referido princípio, manifesta-se Silvio Rodrigues (Op.cit. p. 17): "Os efeitos dos contratos só se manifestam entre as partes, não aproveitando nem prejudicando terceiros. O que, aliás, é lógico. Como o vínculo contratual emana da vontade das partes é natural que terceiros não possam ficar atados a uma relação jurídica que não lhes foi imposta pela lei nem derivou de seu querer”.
} 
Para afastá-la, devemos reafirmar que o contrato de auditoria de qualquer forma produz efeitos reflexos sobre terceiros, possuindo potencial de influenciar o comportamento destes. Não se pode, portanto, afirmar que referidos terceiros, embora não sejam partes, não sofrerão qualquer repercussão da contratação dos serviços de auditoria, razão pela qual a aplicação do princípio da relatividade deve ser mitigada nesta espécie contratual.

Ademais, é necessário que se verifique que o Código de Defesa do Consumidor superou o princípio da relatividade do contrato, ao estabelecer o que a doutrina costumou denominar conceito extensivo de consumidor, ou conceito de consumidor por equiparação.

Citada superação da relatividade contratual veio estabelecida nos arts. 17 e 29 do $\mathrm{CDC},{ }^{105}$ quando determinaram a equiparação aos consumidores daqueles que sofreram acidente de consumo ou daqueles que estão sujeitos aos efeitos das práticas comerciais ou de veiculação de informações. Isto tudo sem que haja necessidade de contratação entre tais pessoas indeterminadas e o fornecedor dos produtos ou serviços.

É inegável que o terceiro usuário das informações auditadas pode sofrer dano pela inadequação da prestação dos serviços de auditoria (vícios de quantidade ou qualidade por inadequação), o que se conceituaria como acidente de consumo para os efeitos legais, atraindo as normas relativas à responsabilidade por fato do serviço.

Também não se pode esquecer que os terceiros usuários das informações auditadas estão sujeitos à influência de práticas comerciais abusivas por parte do fornecedor dos serviços (auditor) ou mesmo provenientes da entidade auditada. ${ }^{106}$

Ressalte-se, igualmente, que, embora não se trate aqui do conceito clássico de consumidor (art. $2^{\underline{0}}$ do CDC), mas do conceito por equiparação (arts. 17 e 29 do CDC), o terceiro se utiliza das informações auditadas como destinatário final, e se encontrará presente na grande maioria dos casos, de modo bastante claro, a vulnerabilidade ou hipossuficiência técnica, jurídica e econômica.

\footnotetext{
${ }^{105}$ Verbis: "Art. 17. Para os efeitos desta Seção, equiparam-se aos consumidores todas as vítimas do evento (...)" "Art. 29. Para os fins deste Capítulo e do seguinte, equiparam-se aos consumidores todas as pessoas determináveis ou não, expostas às práticas nele previstas".

${ }^{106}$ Uma das práticas previstas no CDC que mais poderá se coadunar com a realidade dos contratos de auditoria está inserida, a nosso ver, no art. 56, VIII, deste diploma, que se refere a colocar, no mercado de consumo, qualquer produto ou serviço em desacordo com as normas expedidas pelos órgãos oficiais competentes. Assim, a prestação de serviços de auditoria (ou sua oferta a consumo) sem respeitar as normas inerentes à atividade expedidas pelos órgãos reguladores configurará conduta abusiva, com as consequentes repercussões legais.
} 
Diante disto, entendemos que o terceiro destinatário das informações contábeis auditadas possui relação extracontratual com as partes do contrato de auditoria (entidade auditada e auditor), e não se insere no vínculo mantido por estes. Nesta relação, entretanto, por força da superação da relatividade dos contratos trazida pelo CDC, equipara-se o terceiro a consumidor para todos os efeitos legais, fazendo que a legislação consumerista incida na espécie. ${ }^{107}$

\subsection{Regulação concernente ao contrato de auditoria externa}

Dada a importância da atividade de auditoria externa para o funcionamento da economia, bem como diante dos recentes casos que abalaram a credibilidade desses serviços, formou-se extensa regulação desta espécie contratual, no Brasil e no exterior. ${ }^{108}$

É importante dizer que, de certo modo, a regulação da atividade de auditoria tem caminhado conjuntamente com a criação de padrões normativos para a elaboração das demonstrações contábeis. Desta forma, pode-se dizer que nos dias de hoje a regulamentação de uma atividade repercute - ou mesmo se imiscui - na outra.

Em termos gerais, a regulação da atividade de auditoria tem buscado, dentre outros, atender aos seguintes objetivos:

- Obter uniformidade nos critérios e mecanismos de auditoria: nos últimos anos tem-se buscado a convergência das normas de auditoria entre os diversos países, visando a atender às necessidades da economia cada vez mais globalizada e integrada;

\footnotetext{
${ }^{107}$ Interessante, neste sentido, o acórdão da Terceira Turma do STJ (REsp 181.580/SP, Rel. Ministro Castro Filho), ressaltando que se equiparam ao consumidor "todas as pessoas que, embora não tendo participado diretamente da relação de consumo, venham sofrer as consequências do evento danoso, dada a potencial gravidade que pode atingir o fato do produto ou do serviço, na modalidade vício de qualidade por insegurança".

${ }^{108}$ Veja-se que a regulação é apenas uma das formas de se lidar com o problema de se garantir a qualidade e confiabilidade da informação contábil. Outras maneiras seriam a tributação (p.ex.: a instituição de um tributo sobre a entidade que não fornecesse ao mercado informações auditadas segundo determinados padrões) ou o subsídio (p.ex.: o estabelecimento de incentivos governamentais para as entidades que apresentassem informações contábeis devidamente auditadas). No caso da auditoria, a regulação estatal tem-se apresentado como melhor opção, uma vez que a tributação pode beneficiar companhias de maior porte (que terão mais condições de pagar tributos e não fornecer as informações auditadas), e o subsídio pode mascarar os custos empresariais totais de uma atividade econômica específica.
} 
- Melhoria da qualidade da informação contábil: com a melhora dos serviços de auditoria, aumenta a transparência do sistema de informações fornecido pela contabilidade das entidades, possibilitando maior transparência ao investidor;

- Coibir processos “criativos" de contabilidade e fraudes contábeis: embora ainda haja alguma divergência sobre o papel do auditor na pesquisa e descoberta de fraudes, é clara a opção da regulação da matéria em aumentar o comprometimento do auditor externo com referida tarefa;

- Aumentar o envolvimento da administração com as práticas contábeis e de auditoria: tem-se entendido que a administração da entidade auditada não pode mais ficar alheia aos processos contábeis e de auditoria concernentes ao empreendimento, nem se admite que os gestores se escusem alegando ignorância desses processos;

- Incrementar a credibilidade da auditoria: a regulação mais recente da matéria procurou aumentar a credibilidade dos serviços prestados, criando uma série de restrições e proibições visando a tornar mais sério e isento o trabalho do auditor.

Em regra, especialistas aprovam a busca desses objetivos mencionados, uma vez que há certo consenso de que tais providências trazem benefícios aos usuários da informação contábil. ${ }^{109}$ Entretanto, dois tipos de objeções têm sido feitas: a primeira relativa à efetiva melhora da informação ao usuário, comparativamente à situação de mercado sem regulamentação; a segunda, concernente à relação custo-benefício da regulação. $^{110}$

\footnotetext{
${ }^{109}$ Bem reflete referida posição reportagem veiculada pelo jornal $O$ Estado de S. Paulo, de 14.12.2009, na qual especialistas recomendam maior regulamentação e controle de aplicações em derivativos financeiros, dentre os quais se encontram a divulgação clara aos usuários de suas demonstrações, fato este objeto de auditoria: "O tombo sofrido por empresas como Sadia e Aracruz no ano passado, por causa do uso indevido de instrumentos de proteção contra variações da taxa de câmbio, deveria levar o governo a aprofundar a regulamentação do uso desses mecanismos por parte das empresas. A avaliação é de dois economistas da PUC do Rio de Janeiro (...). Segundo os economistas, as medidas já determinadas pela Comissão de Valores Mobiliários (CVM), como a obrigatoriedade de as empresas divulgarem de maneira clara e precisa os instrumentos utilizados, já representam uma mudança para garantir mais transparência" ("Economistas querem mais regulação". O Estado de S. Paulo. São Paulo, 14.12.2009. p. B9).

${ }^{110}$ A regulação da atividade de auditoria pode ser inserida no que alguma doutrina chama de normas de direito-custo. Neste sentido, Fábio Ulhoa Coelho leciona: "Da crítica que a análise econômica do direito faz à economia do bem-estar, no tocante ao mecanismo de internalização de externalidades, como apresentado sinteticamente acima, resulta um dado de extrema importância, que a tecnologia do direito não pode ignorar, isto é, a afirmação de que algumas normas jurídicas repercutem diretamente no custo da atividade econômica (...). Há normas jurídicas que importam aumento de custo da atividade produtiva. Quando a lei cria um novo direito trabalhista, por exemplo, os empresários alcançados refazem seus cálculos para redefinir o aumento
} 
Com relação ao questionamento inerente à melhora da informação contábil, interessante o argumento de Alexsandro Broedel Lopes:

Os argumentos favorecendo a regulamentação da contabilidade são, em sua maior parte, baseados no argumento de que agências governamentais e outros órgãos similares têm vantagens comparativas em relação ao mercado na exigência do fornecimento de informações. Esses argumentos fundamentam-se na hipótese de que o mercado livremente não seria capaz de impor uma disciplina adequada para a evidenciação pública de informações; nesse cenário, investidores minoritários e outros agentes menos favorecidos, como sindicatos, seriam penalizados (...). Mas não há evidências empíricas claras a esse respeito. Casos como o do mercado financeiro e da contabilidade no Reino Unido, que permaneceram, durante grande parte do século XX, absolutamente livres da influência governamental, são exemplos contrários à hipótese apresentada anteriormente (...). ${ }^{111}$

No que tange à relação custo-benefício da regulação, trazemos a seguir trechos da reportagem do jornal Valor Econômico, de 27.05.2005, citando matéria do jornal The Economist, sob o título "Lei tem custo alto e benefícios duvidosos", que questiona os custos proibitivos da regulação da matéria de auditoria instituída com a Lei SarbanesOxley nos Estados Unidos, citando especialistas na matéria:

O estatuto Sarbanes-Oxley, que os Estados Unidos fizeram vigorar em uma atmosfera de extraordinária agitação em 2002, é uma das mais influentes e controversas peças da legislação societária que já existiram e que conseguiram atingir o status de lei. Seu objetivo inicial aparente era bastante modesto: melhorar a prestação de contas aos acionistas por parte dos administradores e, consequentemente, abrandar a violenta crise de confiança no sistema capitalista americano provocada pelos escândalos da Enron, WorldCom e outras empresas. Entretanto, os métodos legais eram bem pouco modestos e suas implicações estão, bem ou mal, longe de serem atingidas. É cedo para emitir uma opinião definitiva, considerando que os novos princípios contábeis e infraestrutura regulamentadora que os acompanham ainda estão em formação. Mesmo

dos custos de seu negócio. Esse aumento de custos implica, quase sempre, aumento dos preços dos produtos ou serviços que o empresário oferece ao mercado consumidor. Conceitua-se como 'direito-custo' as normas dessa categoria” (COELHO, Fábio Ulhoa. Curso de direito comercial. São Paulo: Saraiva, 2003. v. 1. p. 37). 
assim, aqueles que se aventuraram tendem a acreditar que os custos excederão aos benefícios. Enquanto isso, muitos executivos americanos estão profundamente infelizes, e com razão: os custos iniciais da nova lei têm sido superiores ao esperado. Pode-se argumentar que, quando se trata de restaurar a governança empresarial, a lei vai sempre apontar os sintomas mais do que as causas. Não há dúvida de que a relação custobenefício da legislação tende a melhorar significativamente com o passar do tempo, já que alguns custos incidem uma única vez. Mas no momento a relação parece bem desfavorável (...). O custo disso tudo é muito elevado. Segundo um estudo que chamou muito a atenção, o custo líquido das empresas totaliza US\$ 1,4 trilhão. Esse número surpreendente surgiu em um estudo feito por Ivy Xiying Zhang, da faculdade William E. Simon, da Universidade de Rochester. É uma estimativa econométrica da "perda de valor total de mercado sobre os eventos legais mais significativos", ou seja, o custo menos os benefícios segundo a visão do mercado de ações no momento em que as novas regras passaram a vigorar. Em princípio, essa estimativa deverá refletir todos os custos e benefícios antecipados, diretos e indiretos, que incidem sobre os valores das empresas. Se este número estiver correto, a SOX teria que evitar uma quantidade imensa de fraudes antes que pudesse ser considerada um bom investimento. $^{112}$

Não concordamos com nenhuma das linhas de objeção supracitadas em relação à regulação da matéria de auditoria.

A desregulamentação da matéria não nos parece factível. Nenhuma das economias mundiais, igualmente, parece seguir este rumo.

Embora especialistas questionem os benefícios da regulação em comparação com o mercado completamente livre de regras, baseados na inexistência de estudos empíricos que mostram com segurança a melhoria da regulação para os usuários, as recentes situações práticas de crises econômicas parecem confirmar que a regulação é medida absolutamente necessária para evitar prejuízos de monta para investidores. A

${ }^{111}$ LOPES, Alexsandro Broedel. A informação contábil e o mercado de capitais. São Paulo: Thomson, 2002. p. 48.

${ }_{112}$ Disponível em <www.valoronline.com.br>. Acesso em 12 dez. 2009. O mesmo periódico publicou matéria em 11.05.2005, revelando que as empresas brasileiras poderiam chegar a ter gastos de US\$ 120 milhões (cento e vinte milhões de dólares norte-americanos) para implantar as medidas exigidas pela Lei Sarbanes-Oxley. 
hipótese econômica de existência de mercados eficientes e autônomos, aptos a resolver por suas forças todos os problemas, parece não ter sido amplamente confirmada pela prática.

Ademais, a regulação atende ao anseio de segurança jurídica necessária para possibilitar o funcionamento dos mercados e o investimento por parte de seus agentes.

Por outro lado, embora não se possa retirar totalmente a credibilidade dos que argumentam quanto à existência dos custos da regulação, parece-nos que o problema está em se dimensionar razoável e proporcionalmente os benefícios gerados pela regulamentação em confronto com os custos daí advindos.

Deve-se verificar ainda que, ao contrário do preconizado por alguns, estudos específicos têm afirmado, no que concerne à matéria de auditoria independente, que a relação entre benefícios e custos derivados da adoção das normas internacionais de auditoria (ISA) é positiva e deve ser incentivada.

Neste sentido, pesquisa encomendada pela Comissão Europeia à University of Duisburg-Essen revelou os montantes dos benefícios em números específicos, em contraposição aos custos de implementação da regulação internacional de auditoria. ${ }^{113} \mathrm{O}$ estudo foi baseado na aplicação desta regulação pelos clientes de sociedades de auditores que participam do denominado Forum of the Firms (FoF), componentes de órgão da IFAC (International Federation of Accountants).

O estudo citado analisou basicamente três efeitos sobre os custos e benefícios da adoção das normas internacionais de auditoria: 1) efeito de redesenho de auditoria (audit redesign effect): os efeitos de custos e benefícios de mudança das atuais práticas de auditoria para normas internacionais - ISA; 2) efeito de harmonização de auditoria (audit harmonisation effect): os efeitos de custos e benefícios do uso dos mesmos padrões de auditoria de maneira idêntica em toda a União Europeia; 3) efeito de regulação de auditoria (audit regulation effect): custos e benefícios por efeito da introdução de normas de auditoria apoiadas em sanção jurídica direta, adotadas pela União Europeia por meio de instrumento jurídico. Numericamente, o estudo trouxe os seguintes dados:

\footnotetext{
${ }^{113}$ UNIVERSITY OF DUISBURG-ESSEN. Evaluation of the Possible Adoption of International Standards on Auditing (ISAs) in the EU. Disponível em <http://ec.europa.eu/internal_market/auditing/docs/ias/study2009/summary_en.pdf>. Acesso em 16 dez. 2009.
} 
Tabela 2: Resultados da análise de custos e benefícios da adoção das normas internacionais de auditoria (ISA) na União Europeia (em milhões de Euros - €)

\begin{tabular}{|c|c|c|c|c|c|}
\hline Participantes afetados & $\begin{array}{c}\text { Efeitos } \\
\text { recorrentes } \\
\text { de curto e } \\
\text { médio prazos }\end{array}$ & $\begin{array}{c}\text { Custos } \\
\text { recorrentes }\end{array}$ & $\begin{array}{l}\text { Benefícios } \\
\text { recorrentes }\end{array}$ & $\begin{array}{l}\text { Benefícios } \\
\text { líquidos } \\
\text { recorrentes }\end{array}$ & $\begin{array}{c}\text { Razão } \\
\text { benefício / } \\
\text { custo }\end{array}$ \\
\hline $\begin{array}{l}\text { Participantes no mercado } \\
\text { de auditoria cobertos } \\
\text { pelas entidades } \\
\text { componentes do FoF }\end{array}$ & $\begin{array}{l}\text { Efeito de } \\
\text { regulação }\end{array}$ & 137 & 1.900 & 1763 & $14: 1$ \\
\hline $\begin{array}{l}\text { Participantes no mercado } \\
\text { de auditoria cobertos } \\
\text { pelas entidades } \\
\text { nãocomponentes do FoF, } \\
\text { em jurisdições em que } \\
\text { são aplicáveis as ISA } \\
\text { compliant auditing } \\
\text { standards }\end{array}$ & $\begin{array}{l}\text { Efeito de } \\
\text { regulação; } \\
\text { ausência de } \\
\text { harmonização, } \\
\text { uma vez que } \\
\text { se assume } \\
\text { auditoria não- } \\
\text { transnacional }\end{array}$ & 5 & 101 & 96 & $20: 1$ \\
\hline $\begin{array}{l}\text { Participantes no mercado } \\
\text { de auditoria cobertos } \\
\text { pelas entidades } \\
\text { nãocomponentes do FoF, } \\
\text { em jurisdições em que } \\
\text { não são aplicáveis as ISA } \\
\text { compliant auditing } \\
\text { standards }\end{array}$ & $\begin{array}{c}\text { Efeito de } \\
\text { regulação; } \\
\text { efeito de } \\
\text { redesenho; } \\
\text { ausência de } \\
\text { harmonização, } \\
\text { uma vez que } \\
\text { se assume } \\
\text { auditoria não- } \\
\text { transnacional }\end{array}$ & 104 & 247 & 143 & $2,4: 1$ \\
\hline TOTAL & & 246 & 2.248 & 2.002 & 9:1 \\
\hline
\end{tabular}

Fonte: UNIVERSITY OF DUISBURG-ESSEN. Evaluation of the Possible Adoption of International Standards on Auditing (ISAs) in the EU

Constata-se claramente dos dados da tabela que os benefícios econômicofinanceiros da adoção de uma regulação em tema de auditoria externa superam os custos inerentes a este processo.

Em suma, entendemos que a regulação é indispensável no que concerne à auditoria, tornando inviável a opção pela ausência de regulação. Além disso, embora contestada por alguns, resta razoavelmente demonstrado que a regulação da atividade de auditoria traz vantagens econômicas aos mercados que a adotam.

Sem prejuízo do antes exposto, entendemos que alguns parâmetros devem basear a atividade regulatória de auditoria. Assim, dentro da razoabilidade que a regulação da matéria deve obedecer, acreditamos aplicável a lição de Alan Greenspan, que propõe alguns pontos de equilíbrio para que a regulação seja o menos interferente possível na atividade econômica: 
Com o passar dos anos, aprendi muito sobre o tipo de regulamentação que gera menos interferência. Aqui estão três regras práticas: 1. As regulamentações aprovadas durante crises sempre devem passar, posteriormente, pelo processo de sintonia fina. A Lei Sarbanes-Oxley, aprovada às pressas pelo Congresso na sequência das falências da Enron e da WorldCom, que impõe às empresas maiores exigências de divulgação de informações, é hoje forte candidata à revisão. 2. Às vezes, vários reguladores são melhores que um. O regulador solitário torna-se avesso ao risco, tentando proteger-se de todos os resultados negativos imagináveis, tornando difícil e onerosa a observância de suas normas. Nos setores financeiros, nos quais o Fed compartilha jurisdição regulatória com o Comptroller of the Currency e com a Securities and Exchange Commission, e outras autoridades, tendemos a controlar-nos mutuamente. 3. Os regulamentos sobrevivem à própria razão de ser e devem ser renovados periodicamente. Aprendi essa lição com Virgil Mattingly, chefe havia muito tempo do departamento jurídico do Federal Reserve Board. Ele levava muito a sério a determinação estatutária de rever cada norma de cinco em cinco anos; as que fossem consideradas obsoletas eram revogadas sem cerimônia. ${ }^{114}$

Entendemos que as observações de Greenspan são muito razoáveis e se aplicam, com algumas poucas ressalvas, à regulação em auditoria externa.

Primeiramente, é fato que a regulação da atividade de auditoria infelizmente tem surgido ex post factum, isto é, tem sido elaborada após a ocorrência de eventos emergenciais de crise que, muitas vezes, causam um montante incalculável de prejuízos aos investidores, bem como tem procurado agir, em vários casos, pela punição de condutas (dissuasão pela ameaça de imposição de sanções), e não por sua prevenção, o que muitas vezes não é eficaz sob o ponto de vista econômico.

Como bem ensina Richard Posner, a regulação no setor financeiro deve se dar ex ante, no sentido de prevenir a ocorrência de situações não desejadas ou prejudiciais:

Por regulação "ex ante" entende-se a regulamentação de comportamentos antes de algo prejudicial acontecer. Limites de velocidade são uma forma de regulamentação ex ante; responsabilidade por ferir alguém num acidente de automóvel é uma forma de regulação ex post. A última forma

\footnotetext{
${ }^{114}$ GREENSPAN, Alan. A era da turbulência - Aventuras em um novo mundo. Rio de Janeiro: Elsevier,
} 2008. p. 361. 
de regulamentação é mais barata porque entra em jogo apenas nos casos relativamente raros em que ocorre um infortúnio. Mas ela opera no princípio da dissuasão - supõe-se que a ameaça de responsabilização torne as pessoas mais cuidadosas - e a dissuasão é raramente perfeita. Assim, quando as consequências de um único acidente podem ser catastróficas, a ênfase deve se deslocar da dissuasão para a prevenção. É o caso relativo aos incidentes no setor financeiro. Tal como conhecemos, tais incidentes podem provocar um desastre econômico. ${ }^{115}$

A regulação ex post traz ainda consigo o problema citado por Greenspan, de que as normas de regência se tornem parte de uma regulação de tempos de crise, usualmente refletindo as vicissitudes e os apelos emocionais que referidas situações apresentam.

Além disso, os motivos presentes em situações de crise muitas vezes deixam de existir no futuro, tornando a norma regulatória sem razão de existir.

A regulação antecipada às situações de crise, baseadas no princípio da prevenção, e não no da dissuasão (principle of deterrence), além da revisão periódica das normas regulatórias, na forma defendida por Greenspan e Posner, parece-nos altamente recomendável.

Pondere-se igualmente que o custo da regulação nem sempre é plenamente conhecido quando da edição das normas respectivas. Muitas vezes, além de estudos prévios, é necessária a implementação prática dos ditames normativos para que se possa calcular o custo efetivo da observância das regras pelos destinatários. Neste ponto a revisão periódica é essencial, para que os custos da atividade regulada não tornem proibitiva sua prática.

Embora não cheguemos propriamente a discordar da observação de Alan Greenspan quanto à pluralidade de órgãos reguladores, temos dúvida, entretanto, quanto aos benefícios totais de tal situação. De fato, a regulação de uma mesma matéria por vários órgãos, embora agregue alguns benefícios, também tende a gerar disparidades e

\footnotetext{
${ }^{115}$ Op. cit. p. 31. O texto é tradução livre de: "By 'ex ante' regulation I mean regulating behavior before anything bad happens. Speed limits are a form of ex ante regulation; liability for injuring someone in an automobile accident is a form of ex post regulation. The latter form of regulation is cheaper because it comes into play only in the relatively rare instances in which a mishap occurs. But it operates on the principle of deterrence - the threat of liability is assumed to make people more careful - and deterrence is rarely perfect. So when the consequences of a single accident can be catastrophic, the emphasis shifts from deterrence to prevention. That is the case concerning mishaps in the finance industry. As we are experiencing, such mishaps can cause economic disaster. Ex ante regulation failed in this instance".
} 
contradições nas normas estabelecidas, além de conflitos de autoridade, o que acarreta uma grave confusão aos destinatários, além de toda sorte de custos ao cumprimento das normas, dificultando que se atinja o objetivo de uniformidade de regulação antes referido.

Mais uma vez, é essencial citar a lição de Richard Posner, que, contrariando Greenspan, critica a regulação da mesma matéria por diversos órgãos estatais no sistema financeiro dos Estados Unidos:

A existência de vários organismos reguladores financeiros federais incluindo o Federal Reserve, o Federal Deposit Insurance Corporation, a Securities Investor Protection Corporation, a Securities and Exchange Commission, a Commodity Futures Trading Commission, o Federal Housing Administration, o Federal Housing and Finance Administration, o Office of Housing Enterprise Oversight, o National Credit Union Administration, o Treasury Department e suas agências, tais como a Comptroller of the Currency and the Office of Thrift Supervision, e cinquenta comissários de bancos e seguros de Estado - levou a uma fragmentação da autoridade regulatória, falta de coordenação, disputas, lacunas normativas concernentes aos fundos de hedge, substitutos de bancos e novos instrumentos financeiros, além de incapacidade para agregar e analisar informações sobre problemas emergentes nos mercados financeiros. $^{116}$

No Brasil, como veremos mais adiante, possuímos, por vezes, quatro a cinco órgãos de regulação da matéria de auditoria externa, o que acarreta contradições nas diretrizes regulatórias do setor, tornando muitas vezes difícil a situação do destinatário. ${ }^{117}$

Parece-nos, portanto, que a multiplicidade de órgãos regulando determinada matéria, se existente, deve ser precedida de mecanismos de alinhamento e unidade de

\footnotetext{
${ }^{116}$ Op. cit. p. 289. O texto é tradução livre de "The existence of multiple federal financial regulatory bodies - including the Federal Reserve, the Federal Deposit Insurance Corporation, the Securities Investor Protection Corporation, the Securities and Exchange Commission, the Commodity Futures Trading Commission, the Federal Housing Administration, the Federal Housing and Finance Administration, the Office of Housing Enterprise Oversight, the National Credit Union Administration, the Treasury Department and its agencies, such as the Comptroller of the Currency and the Office of Thrift Supervision - and fifty state banking and insurance commissioners - has led to a fragmentation of regulatory authority, a lack of coordination, turf wars, yawning regulatory gaps with respect to hedge funds, bank substitutes, and novel financial instruments, and an inability to aggregate and analyze information about emerging problems in the financial markets".

${ }^{117}$ Exemplo disto, que veremos mais adiante, é a regulação da rotação obrigatória de auditores, objeto de divergência nas normas nacionais de auditoria.
} 
atuação dos reguladores, ou mesmo divisão e definição clara do campo de atribuições de cada qual.

Em conclusão, temos que a regulação da matéria: 1) deve ocorrer ex ante e basear-se no princípio da prevenção, e não no da dissuasão, para a aplicação de sanções; 2) deve ser permanentemente revisada, principalmente quando editada em momentos de crise econômica; 3) não deve ignorar os custos regulatórios; 4) deve ser proveniente de único órgão, ou precedida de mecanismos de alinhamento e unidade de atuação dos órgãos reguladores, ou, ainda, incidir sobre campos específicos e claramente delimitados.

Passaremos em revista, a seguir, as principais normas que compõem o arcabouço regulatório da matéria no ordenamento pátrio e estrangeiro.

\subsubsection{Regulação no exterior}

A regulação da matéria inerente à auditoria externa no exterior é bastante extensa.

Em grande parte, o arcabouço regulatório é composto de normas fixadas para o exercício profissional, estabelecidas por autoridades competentes, não integrantes do Poder Legislativo.

No entanto, a recente busca por uniformidade e a relevância internacional dos casos envolvendo falhas de auditoria fizeram que a matéria fosse guindada à regulação em documentos hierarquicamente superiores, como diretivas aplicáveis a vários Estados e legislação aprovada pelos respectivos Poderes Legislativos. Sobre este tema, é importante lembrar que os casos anteriormente citados, que abalaram a credibilidade da atividade de auditoria, acabaram por repercutir na regulação da matéria, fazendo com que esta saísse, pelo menos em grande parte, das mãos dos órgãos regulamentadores da profissão de auditoria e contabilidade e passassem para organismos externos, como se deu com a edição da Lei Sarbanes Oxley e com a criação do PCAOB. ${ }^{118}$

Perante a Comunidade Europeia, a matéria vem disciplinada na Diretiva $\mathrm{n}$. 2006/43/CE do Parlamento Europeu e do Conselho, de 17 de maio de 2006, relativa à

\footnotetext{
${ }^{118}$ Tal fenômeno, é bem verdade, ainda não aconteceu de forma pronunciada no Brasil, país cujas normas de auditoria ainda são predominantemente elaboradas por órgãos de classe da profissão contábil e de auditoria, como o CFC e o IBRACON.
} 
revisão legal das contas anuais e consolidadas. Referida norma altera as Diretivas ns. 78/660/CEE e 83/349/CEE, e revoga a Diretiva n. 84/253/CEE.

Esta norma trata, dentre outros temas, dos seguintes aspectos: objeto e definições, aprovação, formação contínua e reconhecimento mútuo, registro, deontologia profissional, independência, objetividade, confidencialidade e sigilo profissional, normas e relatórios de auditoria, controle de qualidade, inspeção e sanções, supervisão pública e acordos regulamentares entre Estados-Membros, disposições especiais relativas à revisão legal das contas de entidades de interesse público, designação e destituição, aspectos internacionais.

Segundo os elaboradores da aludida norma, os objetivos buscados foram: 1) combater fraudes e as práticas ilícitas; 2) permitir que sejam apresentadas rapidamente respostas regulamentares europeias em face de novas evoluções e situações de crise, com base na criação de um comitê regulamentar de auditoria composto por representantes dos Estados-Membros; 3) contribuir para que os auditores resistam a eventuais pressões indevidas dos gestores, dentre elas a criação de comissões de auditoria com atribuições de comunicação direta com o auditor (sem passar pelos órgãos de gestão) e exigência de destituição motivada dos auditores, quando houver; 4) fixação de hierarquia clara no caso de auditoria de grupos empresariais; 5) harmonização, aumento da qualidade e da transparência da auditoria, com a obrigatoriedade de obediência a normas internacionais de auditoria e qualificação contínua dos auditores; 6) fiscalização do trabalho de auditoria com criação de comitês específicos.

Além das normas elaboradas por autoridades competentes, no âmbito internacional vêm ganhando força as diretrizes estabelecidas por órgãos independentes, como a IFAC (International Federation of Accountants) e o IAASB (International Auditing and Assurance Standards Board), que elaboram as chamadas normas internacionais de auditoria (ISA — International Standards on Auditing), as quais vêm sendo progressivamente incorporadas às normas postas pelos diversos países.

$\mathrm{Na}$ Itália, mais especificamente, além da diretiva antes referida, o assunto é regulado pelo Decreto Legislativo de 24 de fevereiro de 1998, n. 58, que aprova o Testo unico delle disposizioni in materia di intermediazione finanziaria, ai sensi degli articoli $8 e$ 21 della legge 6 febbraio 1996, n. 52. A matéria relativa à auditoria (revisione contabile) vem disciplinada nos arts. 155 a 165, abrangendo o seguinte: 1) atividade de auditoria; 2) relações da revisão; 3) efeitos dos relatórios e pareceres sobre as demonstrações; 4) 
propostas do aumento de capital, fusões, cisões e distribuição de dividendos; 5) assunção e revogação da atribuição; 6) incompatibilidade; 7) registro especial das sociedades de revisão contábil; 8) vigilância das sociedades de revisão; 9) provisões da Consob; 10) responsabilidades; 11) revisões contábeis dos grupos; 12) sociedades que controlam outras sociedades com ações quotadas.

$\mathrm{Na}$ França, várias disposições normativas regulam a matéria, dentre as quais se destaca a Loi $n^{-}$2.003-706, de $1^{o}$ de agosto de 2003, de sécurité financière, que, no Título III, trata da modernização do controle legal das contas e transparência (Modernisation du contrôle légal des comptes et transparence), disciplinando os fundamentos da atividade de auditoria nesse país.

Na Alemanha, a supervisão técnica dos auditores externos independentes é realizada pelo Abschlussprüferaufsichtskommission (APAK), sem prejuízo da atuação de câmaras técnicas subordinadas ao Ministério da Economia.

Em Portugal, foi criado o Conselho Nacional de Supervisão de Auditoria (CNSA), pelo Decreto-Lei n. 225/2008. Citado órgão tem, dentre outras, a atribuição de fiscalização profissional sobre os auditores independentes (revisores oficiais de contas). ${ }^{119}$

Nos Estados Unidos da América, a matéria hoje é regulada em vários diplomas legais e normas técnicas, dentre os quais se destaca a Lei Sarbanes-Oxley (Sox), editada em 2002.

Esta última legislação, surgida em razão dos escândalos contábeis envolvendo as companhias Enron e WorldCom, influenciou não só as companhias norte-americanas, mas todas as demais companhias que negociavam ações ou títulos neste mercado.

Dentre as principais medidas tomadas pela Lei Sarbanes-Oxley referentes ao tema em estudo, podem ser mencionadas as seguintes:

- Obrigatoriedade de o diretor presidente (CEO - Chief Excecutive Officer) $e$ de o diretor financeiro (CFO - Chief Financial Officer) firmarem declaração de ciência e conformidade no tocante às demonstrações

\footnotetext{
${ }^{119}$ Dispõe o art. $5^{\circ}$ do Decreto sobre a fiscalização dos revisores oficiais de contas, nos seguintes termos: "1 O CNSA dispõe de poderes de fiscalização, nomeadamente, através: a) Da verificação da conformidade legal e técnica dos processos de inscrição, dos registros, da formação contínua e das inspecções regulares realizadas a revisores oficiais de contas e sociedades de revisores oficiais de contas; b) Da realização de inspecções às entidades sujeitas à sua supervisão, sempre que existam indícios da prática de irregularidades; c) Da realização de inquéritos para averiguação de infracções de natureza contra-ordenacional cometidas no exercício da actividade de auditoria."
} 
contábeis, assumindo responsabilidade por seu conteúdo e impossibilitando eventual alegação de ignorância, tornando tais profissionais expressamente responsáveis pelos controles internos e pela divulgação aos auditores e ao respectivo comitê das deficiências e fraudes eventualmente existentes;

- Obrigatoriedade da criação de comitê de auditoria para todas as companhias abertas que negociem valores mobiliários em bolsa de valores, devendo referido comitê incluir dentre seus membros um especialista financeiro (financial expert); ${ }^{120}$

- Vedação à prestação de serviços que importem em conflitos de interesse por parte do auditor (Services outside the scope of practice of auditors), tais como: escrituração, elaboração de demonstrações contábeis, elaboração de sistemas, gestão, serviços de consultoria empresarial concomitante com os serviços de auditoria, etc. $;^{121}$

- Obrigatoriedade da criação e divulgação de um Código de Ética, obrigatório para todos os níveis de colaboradores da companhia, devendo seu cumprimento ser buscado pela administração;

- Rodízio de auditores (audit partner rotation) a cada cinco exercícios de prestação de serviços de auditoria; ${ }^{122}$

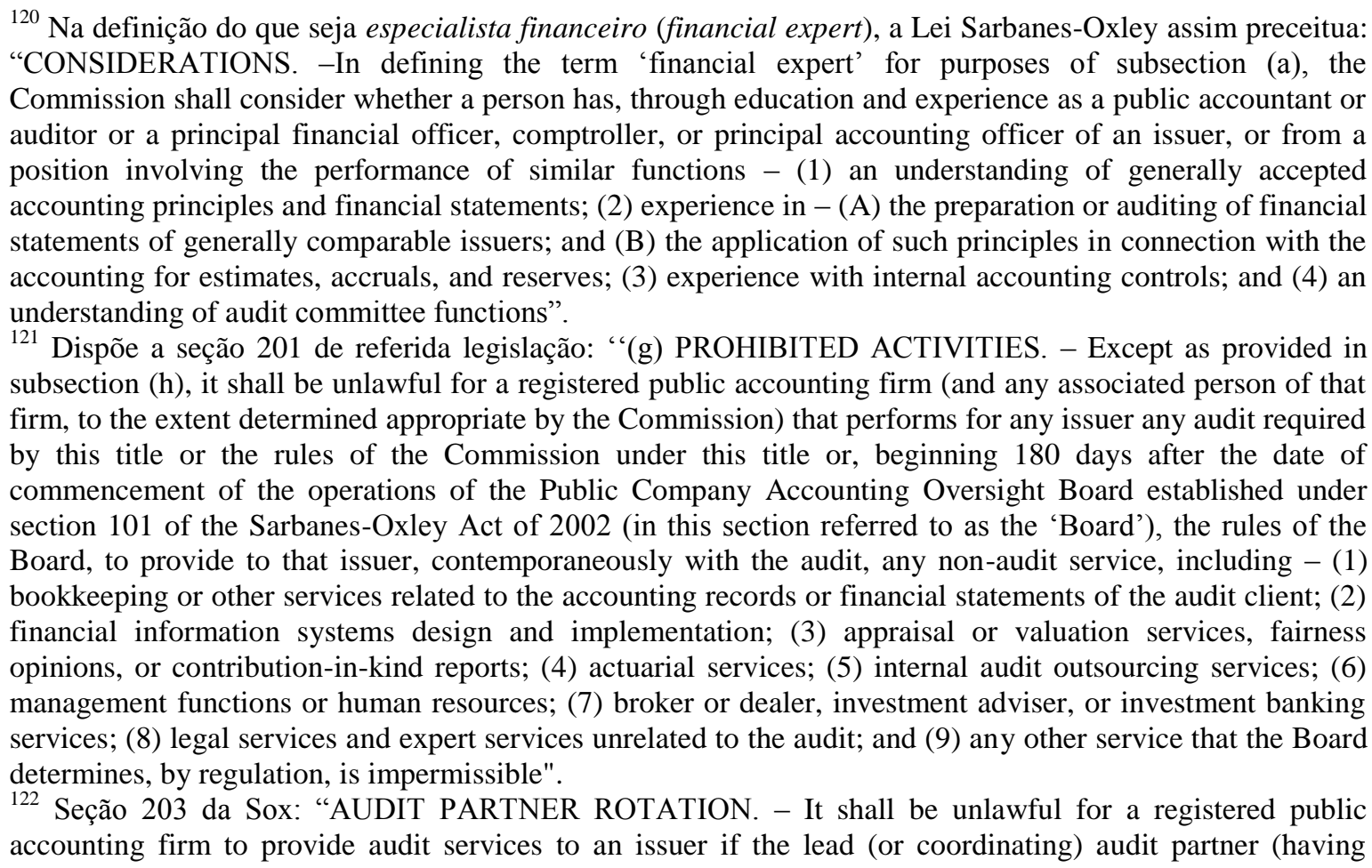


- Regras de atuação para advogados e procuradores (rules of professional responsibility for attorneys), determinando que eventuais irregularidades detectadas por advogados da companhia devam ser reportadas por estes profissionais à diretoria ou ao comitê de auditoria; ${ }^{123}$

- Criação do Public Company Accounting Oversight Board (PCAOB), ou Conselho de Supervisão de Contabilidade de Companhias Abertas, organismo privado destinado a normatizar e supervisionar a atividade de auditoria das companhias, visando a proteger os interesses dos investidores e promover o interesse público na elaboração dos relatórios de auditoria independente. ${ }^{124} 125$

primary responsibility for the audit), or the audit partner responsible for reviewing the audit, has performed audit services for that issuer in each of the 5 previous fiscal years of that issuer".

${ }^{123}$ Seção 307 da Sox: "Not later than 180 days after the date of enactment of this Act, the Commission shall issue rules, in the public interest and for the protection of investors, setting forth minimum standards of professional conduct for attorneys appearing and practicing before the Commission in any way in the representation of issuers, including a rule - (1) requiring an attorney to report evidence of a material violation of securities law or breach of fiduciary duty or similar violation by the company or any agent thereof, to the chief legal counsel or the chief executive officer of the company (or the equivalent thereof); and (2) if the counsel or officer does not appropriately respond to the evidence (adopting, as necessary, appropriate remedial measures or sanctions with respect to the violation), requiring the attorney to report the evidence to the audit committee of the board of directors of the issuer or to another committee of the board of directors comprised solely of directors not employed directly or indirectly by the issuer, or to the board of directors".

124 Seção 101 da Sox: "ESTABLISHMENT OF BOARD. - There is established the Public Company Accounting Oversight Board, to oversee the audit of public companies that are subject to the securities laws, and related matters, in order to protect the interests of investors and further the public interest in the preparation of informative, accurate, and independent audit reports for companies the securities of which are sold to, and held by and for, public investors. The Board shall be a body corporate, operate as a nonprofit corporation, and have succession until dissolved by an Act of Congress".

${ }^{125}$ Interessante estudo da União Europeia enfatiza as semelhanças e diferenças entre a regulação vigente na Europa (International Standards on Auditing - ISA) e a estabelecida pelo PCAOB nos Estados Unidos. A conclusão do estudo, resumidamente, é a de que o conteúdo de ambas as regulamentações são muito semelhantes, havendo áreas limitadas em que há diferentes regulamentações, dentre as quais as seguintes (tradução livre com modificações necessárias): “1) Avaliação de relatórios sobre o controle interno de emissão de relatórios financeiros: perante as regras do PCAOB, o auditor deve emitir um parecer sobre a qualidade do controle interno do cliente sobre a emissão de relatórios financeiros. As ISA não têm uma exigência comparável, nem exigem um auditoria integrada (ou seja, que inclua uma auditoria da eficácia do controle interno como parte da auditoria das demonstrações financeiras). É importante observar que as normas PCAOB no controle interno e auditoria integrada são uma consequência da SOX 302 e 404 . 2) Utilização do trabalho de outro auditor de parte de um grupo de auditoria: Em contraste com as normas do PCAOB, as ISA não permitem que o principal auditor faça qualquer referência ao trabalho de outro auditor. 3) Documentação: a documentação requerida ao abrigo de normas PCAOB e ISA segue uma diferente abordagem. Enquanto as normas do PCAOB são vistas como mais prescritivas, as ISA são percebidas como mais baseadas no julgamento profissional (por exemplo, em contraste à ISA 230, AS 3 requer preparação e manutenção de uma conclusão de memorando de contrato). 4) Avaliação de risco e respostas aos riscos avaliados: a abordagem para avaliar e responder ao risco dentro das ISA difere das normas do PCAOB. As ISA exigem que o auditor obtenha uma compreensão ampla de uma entidade e seu ambiente, por meio de procedimentos de avaliação de risco específicos, a fim de identificar onde pode haver riscos materiais de declarações inexatas. Esta perspectiva inclui que um auditor compreenda os riscos do negócio da entidade (por exemplo, risco estratégico e os de funcionamento) e como a entidade responde a eles no curso do planejamento e realização da auditoria, a fim de avaliar o risco material de declarações inexatas tanto no demonstrativo financeiro e níveis de afirmação. O PCAOB está atualmente trabalhando em 
Destacam-se ainda na regulação norte-americana as normas expedidas pela Security Exchange Comission (SEC) e pelo AICPA (American Institute of Certified Public Accountants), que edita as normas denominadas Statement on Auditing Standards (SAS).

\subsubsection{Regulação no Brasil}

A regulação da matéria no Brasil vem passando por inúmeras reformulações, principalmente visando a atingir um elevado grau de uniformidade com as normas internacionais de auditoria.

Além da legislação ordinária, que faz referência sobre a matéria de auditoria externa (Leis ns. 6.404/76, 6.385/76, 11.638/07, entre outras), o tema é regulado por diversos órgãos, dentre os quais podemos citar a Comissão de Valores Mobiliários (CVM), o Banco Central do Brasil (BACEN), o Conselho Federal de Contabilidade (CFC), o Conselho Nacional de Seguros Privados (CNSP) e o Instituto dos Auditores Independentes do Brasil (IBRACON).

A Lei n. 6.404/76 se refere à matéria de auditoria em vários artigos, dentre os quais: 133, II (parecer dos auditores como documentação disponibilizada pela administração antes da assembleia geral ordinária); 134, $\S 1^{\circ}$ e $2^{\underline{o}}$ (presença do auditor em assembleia e seu adiamento); 142, IX, e $\S 2^{-}$(competência do Conselho de Administração para a escolha e destituição dos auditores independentes e veto); $163, \S \S 4^{\underline{0}}$ e $5^{\underline{o}}$ (possibilidade de esclarecimentos do auditor ao Conselho Fiscal e contratação na ausência de auditor); 177, $\S 3^{\circ}$ (obrigatoriedade de a companhia aberta ter suas demonstrações auditadas, observadas as normas da $\mathrm{CVM}$ ); 275, $\S 4^{\mathrm{o}^{\circ}}$ (auditoria de demonstrações consolidadas de grupos societários).

A Lei n. 6.385/76 dedica seu capítulo VII (arts. 26 e 27) à disciplina dos auditores independentes, consultores e analistas de valores mobiliários, regulando aspectos referentes à responsabilidade e ao registro dos auditores e sociedades de auditores.

uma grande revisão de suas normas de avaliação de risco. No momento deste relatório não há nenhuma exigência comparável às ISA para avaliar e responder ao risco. 5) Continuidade: As normas do PCAOB limitam o futuro previsível de continuidade, a ser analisada pelo auditor, para 12 meses, enquanto sob as ISA é de, pelo menos, mas não se limitando a 12 meses" (EU Project n. MARKT/2007/15/F LOT 2. Evaluation of the differences between International Standards on Auditing (ISA) and the standards of the US Public Company Accounting Oversight Board (PCAOB). Maastricht Accounting, Auditing and Information Management Research Center (MARC) - Executive Summary. 20 July 2009). 
A Lei n. 11.638/07 inovou a matéria ao estabelecer em seu art. $3^{\mathrm{o}}$ a necessidade de auditoria em sociedades de grande porte, independente do tipo societário.

A CVM, por seu turno, editou várias normas referentes à auditoria no mercado de capitais, incluindo as seguintes:

Tabela 3: Principais normas da CVM sobre auditoria externa

\begin{tabular}{cc}
\hline Norma & Tema tratado \\
\hline INSTRUÇÃO n. 308 de 14.05.1999 & $\begin{array}{c}\text { Dispõe sobre o registro e o exercício da atividade de } \\
\text { auditoria independente no âmbito do mercado de valores } \\
\text { mobiliários, define os deveres e as responsabilidades dos } \\
\text { administradores das entidades auditadas no relacionamento } \\
\text { com os auditores independentes. }\end{array}$ \\
\hline
\end{tabular}

INSTRUÇÃO n. 381 de 14.01.2003

Dispõe sobre a divulgação, pelas entidades auditadas, de informações sobre a prestação, pelo auditor independente, de outros serviços que não sejam de auditoria externa

DELIBERAÇÃO n. 570 de 30.03.2009

Programa de Educação Continuada dos Auditores Independentes

OFÍCIO-CIRCULAR/CVM/SNC/N. 001/04
Rotatividade dos Auditores Independentes
OFÍCIO-CIRCULAR/CVM/SNC/N. Envio de Informações Periódicas Anuais e Atualização 006/08
Cadastral
OFÍCIO-CIRCULAR/CVM/SNC/N. $007 / 08$
Deveres e Obrigações dos Auditores Independentes com relação aos Fundos de Investimentos OFICIO-CIRCULAR/CVM/SNC/N. Demonstrações Contábeis encerradas em 31 de dezembro
012/09 de 2009 - Atuação dos Auditores Independentes 
O Banco Central do Brasil (BACEN) obrigou as instituições financeiras e equiparadas a manterem auditoria externa de suas demonstrações financeiras por meio da Resolução n. 3.198/04, que altera e consolida a regulamentação relativa à prestação de serviços de auditoria independente para as instituições financeiras, demais instituições autorizadas a funcionar pelo Banco Central do Brasil e para as câmaras e prestadores de serviços de compensação e de liquidação, além de regulamentar a obrigatoriedade de instituição de comitês de auditoria.

Por sua vez, o Conselho Nacional de Seguros Privados (CNSP) editou a Resolução CNSP n. 118, de 2004, que dispõe sobre a prestação de serviços de auditoria independente para as sociedades seguradoras, de capitalização e entidades abertas de previdência complementar e sobre a criação de comitê de auditoria.

O Conselho Federal de Contabilidade (CFC), órgão regulador da profissão de auditoria, tem editado extensa regulamentação sobre a matéria, a qual recentemente vem passando por ampliação e revisão para se adequar aos ditames das normas internacionais de auditoria. ${ }^{126}$ Dentre as principais normas sobre o assunto, podem ser citadas as seguintes:

\section{Tabela 4: Principais normas do CFC sobre auditoria externa}

\begin{tabular}{lc}
\hline \multicolumn{1}{c}{ NORMA DO CFC e tema tratado } & $\begin{array}{c}\text { Resolução CFC n. e } \\
\text { alterações }\end{array}$ \\
\hline $\begin{array}{l}\text { NBC PA 01 - Controle de Qualidade para Firmas (Pessoas } \\
\text { Jurídicas e Físicas) de Auditores Independentes }\end{array}$ & $1.201 / 09$ \\
\hline NBC PA 02 - Independência & $1.267 / 09$ \\
NBC PA 03 - Revisão Externa de Qualidade pelos Pares & $1.158 / 09$ \\
NBC P 1 - Normas Profissionais de Auditor Independente & $821 / 97$ \\
\hline NBC P 1.6 - Sigilo & $1.100 / 07$ (continua) \\
\hline
\end{tabular}

\footnotetext{
${ }^{126}$ As normas mais recentes emitidas pelo CFC, aliás, consubstanciam tradução das equivalentes normas ISA emitidas pela IFAC. O próprio CFC ressalta, nas considerações inicias dessas normas, que se constitui como membro associado da IFAC e que suas últimas regulamentações sobre a matéria de auditoria seguem a política de tradução e reprodução de normas, emitida pela IFAC em dezembro de 2008. Consta também que a IFAC autorizou, no Brasil, como tradutores das suas normas e publicações, o Conselho Federal de Contabilidade e o IBRACON.
} 
NBC P 1.8 - Utilização de Trabalho de Especialistas

$1.023 / 05$

(alt. 1.042/05)

NBC P 1 - IT 1 - Regulamentação do item 1.9 da NBC P 1

$851 / 99$

NBC P - IT - 3 - Regulamentação do item 1.4 - Honorários

$976 / 03$

NBC P 4 - Educação Profissional Continuada

NBC P 5 - Normas sobre o Exame de Qualificação Técnica

$1.109 / 07$

(alt. 1.147/08)

Cadastro Nacional de Auditores Independentes (CNAI)

$1.019 / 05$

(alt. 1.147/08)

NBC TA 01 - Estrutura Conceitual para Trabalho de Asseguração

$1.202 / 09$

NBC TA 200 - Objetivos Gerais do Auditor Independente e a

Condução da Auditoria em Conformidade com Normas de Auditoria

$1.204 / 09$

Auditoria

$1.205 / 09$

Demonstrações Contábeis

$1.206 / 09$

NBC TA 230 - Documentação de Auditoria

$1.207 / 09$

NBC TA 240 - Responsabilidade do Auditor em Relação à Fraude, no Contexto da Auditoria de Demonstrações Contábeis

$1.208 / 09$

de Demonstrações Contábeis

$1.209 / 09$

NBC TA 260 - Comunicação com os Responsáveis pela Governança

$1.210 / 09$

NBC TA 265 - Comunicação de Deficiências do Controle Interno

$1.211 / 09$

Contábeis

NBC TA 315 - Identificação e Avaliação dos Riscos de Distorção

Relevante por meio do Entendimento da Entidade e de seu Ambiente

$1.212 / 09$

NBC TA 320 - Materialidade no Planejamento e na Execução da Auditoria

NBC TA 330 - Resposta do Auditor aos Riscos Avaliados

$1.214 / 09$

NBC TA 402 - Considerações de Auditoria para a Entidade que

Utiliza Organização Prestadora de Serviços

$1.215 / 09$

NBC TA 450 - Avaliação das Distorções Identificadas durante a Auditoria

$1.216 / 09$

NBC TA 500 - Evidência de Auditoria 
NBC TA 501 - Evidência de Auditoria - Considerações Específicas para Itens Selecionados

NBC TA 505 - Confirmações Externas

NBC TA 540 - Auditoria de Estimativas Contábeis, Inclusive do

Valor Justo, e Divulgações Relacionadas

NBC TA 600 - Considerações Especiais - Auditorias de Demonstrações Contábeis de Grupos, Incluindo o Trabalho dos Auditores dos Componentes

NBC TA 610 - Utilização do Trabalho de Auditoria Interna

NBC TA 700 - Formação da Opinião e Emissão do Relatório do Auditor Independente sobre as Demonstrações Contábeis

NBC TA 706 - Parágrafos de Ênfase e Parágrafos de Outros Assuntos no Relatório do Auditor Independente

NBC TA 710 - Informações Comparativas - Valores Correspondentes e Demonstrações Contábeis Comparativas

NBC TA 720 - Responsabilidade do Auditor em Relação a Outras Informações Incluídas em Documentos que Contenham 
Finalmente, o Instituto dos Auditores Independentes do Brasil (IBRACON), ao contrário dos demais órgãos reguladores citados, é instituição privada de caráter técnico, não editando, em princípio, normas com caráter obrigatório e vinculante a particulares, mas meros pronunciamentos com cunho de recomendação técnica. No entanto, vários de seus pronunciamentos têm sido encampados por órgãos reguladores, passando a fazer parte de normas de observância obrigatória. ${ }^{127}$

Sobre o tema de auditoria, o IBRACON elaborou uma série de NPAs (Normas e Procedimentos de Auditoria), cujas principais são transcritas a seguir:

\section{Tabela 5: Principais pronunciamentos do IBRACON sobre auditoria externa}

\begin{tabular}{cl}
\hline NPA n. & \multicolumn{1}{c}{ Tema tratado } \\
\hline $\mathbf{0 1}$ & Parecer dos Auditores Independentes sobre Demonstrações Contábeis \\
$\mathbf{0 2}$ & $\begin{array}{l}\text { Procedimentos de Auditoria Independente de Instituições Financeiras e Entidades } \\
\text { Equiparadas }\end{array}$ \\
$\mathbf{0 3}$ & Procedimentos de Auditoria Independente de Administradoras de Consórcios \\
$\mathbf{0 4}$ & Revisão Limitada de Demonstrações Contábeis \\
$\mathbf{0 5}$ & Requisitos de Auditoria Independente sobre as Informações Complementares e sobre a \\
$\mathbf{0 6}$ & Observância das Normas Legais e Regulamentares pelas Entidades Estatais \\
$\mathbf{0 7}$ & Revisão Limitada das Informações Trimestrais das Companhias Abertas \\
\hline $\mathbf{0 8}$ & Serviços de Auditoria dos Processos de Privatização \\
$\mathbf{0 9}$ & Incertezas \\
\hline $\mathbf{1 0}$ & Diretrizes Básicas sobre Controle Interno de Qualidade para Auditores Independentes \\
$\mathbf{1 1}$ & Balanço e Ecologia \\
$\mathbf{1 2}$ & Emissão da Carta de Conforto (revoga a NPA n. 12 de 3/4/97) \\
\hline $\mathbf{1 3}$ & Procedimentos Mínimos de Auditoria para uma Entidade Fechada de Previdência \\
\hline $\mathbf{1 4}$ & Complementar \\
\hline
\end{tabular}

${ }^{127}$ O art. 20 da Instrução n. 308/99 da CVM ressalta (com grifos nossos) que: "O auditor independente pessoa física e o auditor independente - pessoa jurídica, todos os seus sócios e integrantes do quadro técnico deverão observar, ainda, as normas emanadas do Conselho Federal de Contabilidade - CFC e os pronunciamentos técnicos do Instituto Brasileiro de Contadores - IBRACON, no que se refere à conduta profissional, ao exercício da atividade e à emissão de pareceres e relatórios de auditoria". 


\subsubsection{Campo de responsabilidade do auditor pela observância da regulação}

Como visto, a atividade de auditoria externa se desenvolve sobre um arcabouço regulatório.

Não se pode pretender, entretanto, que o auditor independente de demonstrações contábeis seja responsável pela verificação do cumprimento de todas as normas que incidem sobre a atividade da entidade auditada, mesmo que com influência remota sobre o resultado da auditoria. O auditor não é um consultor jurídico, nem mesmo necessita possuir formação jurídica para sua tarefa, devendo haver certa limitação quanto às normas cuja incidência o auditor deve observar em seu trabalho.

Para iniciar esta delimitação, pode-se separar as normas aplicáveis ao trabalho de auditoria entre aquelas que podem influir diretamente sobre o trabalho do auditor e as que tem mera repercussão indireta na tarefa de auditoria.

Assim, exemplificativamente, as normas de contabilidade que definem critérios para a valoração de ativos ou o reconhecimento de passivos, ou mesmo a forma de escrituração de determinados fatos econômicos, possuem repercussão imediata na auditoria externa, influenciando o resultado do trabalho a ser apresentado. De fato, a falta de observância desta categoria de normas pode repercutir de maneira substancial no conteúdo das demonstrações contábeis, determinando, conforme o caso, distorções materialmente relevantes, as quais devem ser pesquisadas e reveladas pelo auditor.

Outras normas, porém, podem influenciar apenas de um modo indireto a atividade do auditor, por não possuírem influência imediata no conteúdo das demonstrações contábeis, repercutindo nestas apenas obliquamente. Esta categoria de normas, nos termos da Res. CFC n. 1.208/09 (norma baseada na correspondente ISA n. 250), pode ser essencial para a conclusão de continuidade do negócio, ou para evitar penalidades relevantes (por exemplo, a conformidade com os termos de uma licença de operação, a conformidade com as exigências regulamentares de solvência ou a conformidade com os regulamentos ambientais); a não conformidade com tais leis $e$ regulamentos, portanto, pode ter efeito relevante sobre as demonstrações contábeis.

Considerando as duas espécies de regulamentação aqui tratadas e o reconhecimento de que o auditor não pode ser responsável pela verificação do cumprimento de todas as normas aplicáveis à atividade empresarial objeto de auditoria 
(responsabilidade esta que cabe primariamente à administração da entidade auditada), a obrigação do auditor pelo reconhecimento e revisão das normas aplicáveis ao seu trabalho resta composta por duas formas de atuação básicas:

1. Normas com repercussão direta nas demonstrações contábeis: o auditor deve obter evidência de auditoria suficiente em relação à conformidade da atuação da administração da entidade auditada na aplicação dessas regras, uma vez que podem implicar modificação dos valores e conteúdo das demonstrações, de forma a causar distorções relevantes;

2. Normas com repercussão indireta sobre as demonstrações contábeis: a responsabilidade do auditor fica restrita, na forma da Res. $n .1 .208 / 99,{ }^{128}$ a executar procedimentos de auditoria específicos para ajudar a identificar casos de não conformidade com outras leis e regulamentos que possam ter efeito relevante sobre as demonstrações contábeis.

Boyton et al. bem indicam a distinção na responsabilidade do auditor em face das duas categorias de normas aludidas:

A responsabilidade do auditor por distorções resultantes de atos ilegais
que tenham efeito direto e relevante sobre as demonstrações contábeis é a
mesma que ele tem pela detecção de erros ou fraudes. Em outras
palavras, o auditor deve incluir a detecção de tais atos ilegais no
planejamento da auditoria e então deve executar o plano com cuidado
profissional devido. Para esses atos, o auditor deve aplicar procedimentos
de auditoria que busquem verificar se algum ato ilegal foi praticado. Para
todos os outros atos ilegais, a responsabilidade do auditor restringe-se a
informações que cheguem a sua atenção. Dadas as características de atos
ilegais, uma auditoria realizada de acordo com PGCA não fornece
nenhuma segurança de que todos os atos ilegais sejam detectados. ${ }^{129}$

Em sendo constatada alguma irregularidade no cumprimento de alguma das categorias normativas supracitadas, o auditor deve comunicar o fato à administração e aos responsáveis pela governança da entidade. Não sendo tomadas providências, referido profissional deve avaliar a resilição do contrato de auditoria ou a relevância do

\footnotetext{
${ }^{128}$ Esta norma determina que os procedimentos do auditor para ajudar a identificar a regulamentação supracitada envolvem: “(a) indagações junto à administração e, quando apropriado, aos responsáveis pela governança, para determinar se a entidade tem cumprido com tais leis e regulamentos; e (b) inspeção de correspondência, se houver, com as autoridades responsáveis por licenciamento e regulamentação".

${ }^{129}$ Op. cit. p. 80 .
} 
descumprimento da norma nas demonstrações contábeis auditadas, podendo isto repercutir na opinião final veiculada em seu parecer.

\subsection{Obrigações das partes no contrato de auditoria}

O contrato de prestação de serviços de auditoria externa enfeixa uma série de obrigações às partes, sendo algumas comuns às demais prestações de serviços e outras específicas deste tipo contratual.

Cuidando-se de contrato bilateral, a contratação da auditoria externa acarreta obrigações para ambas as partes. ${ }^{130}$

Para a entidade auditada, as principais obrigações consistem em: 1) conferir as qualificações do auditor (capacitação profissional conferida pelos registros competentes nos órgãos de controle profissional, educação profissional continuada, etc.) e sua independência previamente à contratação; 2) pagar o preço dos serviços prestados (honorários do auditor ${ }^{131}$ e demais quantias pactuadas); 3) fornecer livre acesso ao auditor

\footnotetext{
${ }^{130}$ Em se tratando de contrato bilateral, havendo simultaneidade das prestações, entendemos plenamente cabível a invocação da exceptio non adimpleti contractus entre as partes do contrato de prestação de serviços de auditoria. No entanto, se alegado pela entidade auditada descumprimento contratual, deverá especificar qual o serviço ou cláusula descumpridos, pois insuficiente mera alegação genérica de descumprimento. Neste sentido decidiu o Tribunal de Justiça do Rio de Janeiro: “0040255-27.2002.8.19.0001 (2005.001.13359) APELAÇÃO - $1^{\underline{a}}$ Ementa DES. CÁSSIA MEDEIROS - Julgamento: 30.08.2005 - DÉCIMA OITAVA CÂMARA CÍVEL. ADMINISTRATIVO E PROCESSUAL - CONTRATO DE PRESTAÇÃO DE SERVIÇOS DE AUDITORIA EXTERNA - AÇÃO DE COBRANÇA - PAGAMENTO DO PRINCIPAL ANTES DA CITAÇÃO - JUROS E CORREÇÃ̃O MONETÁRIA - SUCUMBÊNCIA Ação proposta pela apelada em face do apelante para cobrança da quantia de RS 64.900,00, com juros e correção monetária, relativos a honorários do Contrato de Prestação de Serviços de Auditoria Externa. Pagamento efetuado pelo réu, através de depósito em conta corrente, antes da citação. Sentença que julgou parcialmente procedente o pedido, para condenar o réu ao pagamento de juros e correção monetária, a serem apurados em liquidação de sentença. Considerando que o pedido inicial foi de pagamento do valor contratado acrescido de juros e correção monetária, o pagamento do principal não importa na extinção do processo sem julgamento do mérito, por falta de interesse processual, com fundamento no artigo 267, inciso VI, do Código de Processo Civil. A simples alegação de que a autora descumpriu a cláusula décima segunda do contrato não autoriza o acolhimento de exceção de contrato, não cumprido, prevista no artigo 476 Código Civil, posto que o apelante não indicou quais os documentos faltantes nem a data em que os mesmos the foram apresentados. Desprovimento do recurso".

${ }^{131}$ Para preservar a independência do auditor externo, as normas nacionais e internacionais de auditoria não têm permitido a cobrança de honorários contingenciais (contingent fees) por parte do auditor, assim considerados como aqueles calculados em uma base predeterminada com relação ao desfecho ou ao resultado de uma transação ou trabalho executado (Resolução n. 976/03 do CFC). Perante a União Europeia, o art. 25 da Diretiva n. 2006/43/CE, determina que "Os Estados-Membros devem assegurar a existência de regras adequadas que disponham que os honorários relativos às revisões legais das contas: a) não sejam influenciados ou determinados pela prestação de serviços adicionais à entidade examinada; b) não se possam basear em qualquer forma de contingência”.
} 
ou seus representantes às instalações e aos documentos necessários ao trabalho; ${ }^{132} 4$ ) prestar as informações necessárias ao correto desempenho da prestação de serviços, abstendo-se de sonegar informações relevantes; 5) divulgar, se companhia aberta ou emissora de valores mobiliários, ressalvadas as exceções normativas, a prestação de qualquer serviço que não seja de auditoria externa pelo auditor independente ou por partes relacionadas com o auditor independente (Instrução CVM n. 381/03).

O inadimplemento das obrigações supracitadas por parte da entidade auditada terá diferentes consequências práticas, conforme o aspecto descumprido.

A contratação de auditor sem as qualificações profissionais necessárias (p.ex.: sem registro profissional adequado) ou sem independência poderá ensejar a ineficácia do serviço e a punição administrativa (multa) por parte dos órgãos reguladores (CVM e CFC).

O não pagamento do preço ajustado pelos serviços contratados poderá ensejar a cobrança cabível na espécie, além da paralisação dos serviços ou rescisão contratual por justa causa.

A ausência de prestação de informações ou de faculdade de acesso do auditor aos locais e documentos necessários por parte da entidade auditada (Management-Imposed Limitation) deverá ensejar providências diversas, tomadas sucessivamente: 1) em princípio, o auditor deve comunicar o fato à administração da entidade auditada; 2) caso não sejam tomadas providências, deverá comunicar o fato ao Conselho de Administração, Comitê de Auditoria, ou outro órgão de representação dos acionistas; 3) poderá, se isto for possível, resilir o contrato com justa causa (audit withdraw) ou, não havendo esta última possibilidade, apresentar parecer com ressalva ou abstenção de opinião. ${ }^{133}$

\footnotetext{
${ }^{132}$ Veja-se, na Itália, o disposto no art. 155, 2, do Decreto Legislativo de 24 de fevereiro de 1998, n. 58:"La società di revisione ha diritto di ottenere dagli amministratori della società documenti e notizie utili alla revisione e può procedere ad accertamenti, ispezioni e controlli; essa informa senza indugio la Consob e il collegio sindacale dei fatti ritenuti censurabili”.

${ }^{133}$ Essas possibilidades são mencionadas na norma ISA n. 750, nos seguintes termos: "Consequence of an Inability to Obtain Sufficient Appropriate Audit Evidence Due to a Management-Imposed Limitation after the Auditor Has Accepted the Engagement 11. If, after accepting the engagement, the auditor becomes aware that management has imposed a limitation on the scope of the audit that the auditor considers likely to result in the need to express a qualified opinion or to disclaim an opinion on the financial statements, the auditor shall request that management remove the limitation. 12. If management refuses to remove the limitation referred to in paragraph 11 , the auditor shall communicate the matter to those charged with governance, unless all of those charged with governance are involved in managing the entity, 2 and determine whether it is possible to perform alternative procedures to obtain sufficient appropriate audit evidence. 13. If the auditor is unable to obtain sufficient appropriate audit evidence, the auditor shall determine the implications as follows: (a) If the auditor concludes that the possible effects on the financial statements of undetected misstatements, if any, could be material but not pervasive, the auditor shall qualify the opinion; or (b) If the auditor concludes that the possible effects on the financial statements of undetected misstatements, if any,
} 
Por fim, caso não venha a entidade auditada a divulgar eventuais serviços prestados pelo auditor, poderá haver a imposição de multa pelos órgãos reguladores (CFC, CVM, BACEN, SUSEP).

O auditor, por seu turno, tem as seguintes obrigações no contrato: 1) prestar os serviços contratados nos termos das normas técnicas que regem a profissão; 2) elaborar parecer ou relatório final sobre as demonstrações contábeis; 3) documentar os serviços e evidências de auditoria em papéis de trabalho ou outro meio similar; ${ }^{134}$ 4) manter confidencialidade (sigilo) sobre o objeto do contrato; 5) manter-se em condições de independência em relação ao contratante, declarando à administração da entidade auditada as razões por que, em seu entendimento, a prestação de outros serviços não afeta a independência e a objetividade necessárias ao desempenho dos serviços de auditoria externa (art. $3^{\text {o }}$ da Instrução CVM n. 381/03).

O descumprimento dos dois primeiros itens supracitados envolve o inadimplemento contratual e suas consequências legais. A ausência de documentação prejudica a prova do cumprimento das obrigações contratuais assumidas pelo auditor, podendo resultar, conforme o caso, na impossibilidade de evidenciar referido cumprimento ou mesmo na imposição de sanções regulatórias. A violação do sigilo profissional poderá acarretar a extinção do contrato e/ou a obrigatoriedade de indenização pelas perdas e danos

could be both material and pervasive so that a qualification of the opinion would be inadequate to communicate the gravity of the situation, the auditor shall: (i) Withdraw from the audit, where practicable and possible under applicable law or regulation; or (Ref: Para. A13-A14) (ii) If withdrawal from the audit before issuing the auditor's report is not practicable or possible, disclaim an opinion on the financial statements".

${ }^{134}$ É pacífico dentre os doutrinadores que se dedicaram ao estudo da matéria que os papéis de trabalho e demais evidências de auditoria documentadas são de propriedade do auditor, e não da entidade auditada. Não há, perante o ordenamento brasileiro, a necessidade de que o auditor consigne em ata ou em livro do auditado fatos e detalhes sobre a atividade de auditoria desenvolvida ou suas intercorrências (nem existe, aliás, previsão legal de livro destinado a tanto). Restará apenas consignado em livro ou ata a deliberação sobre a escolha e destituição dos auditores (art. 142, IX, da Lei n. 6.404/76). Na Itália, porém, o art. 155, item 3, do Decreto Legislativo de 24 de fevereiro de 1998, n. 58, determina que a sociedade de auditoria consigne em livro da entidade que lhe conferiu esta atribuição os procedimentos de auditoria, nos seguintes termos: "La società di revisione riporta in apposito libro tenuto presso la sede della società che ha conferito l'incarico. Le informazioni concernenti l'attività di revisione svolta, secondi i criteri e le modalità stabiliti dalla Consob con regolamento. Si applica l'articolo 2421, terzo comma, del codice civile". Regulamentando referido dispositivo, o art. 145 da deliberação Consob n. 11.971 de 14.05.1999 dispõe sobre o conteúdo do livro mencionado, nos seguintes termos: "Contenuto del libro della revisione contabile. 1. La società incaricata dell'attività di revisione contabile riporta, per ciascun esercizio, nel libro previsto dall'articolo 155, comma 3 del Testo unico: a) il risultato degli accertamenti, delle ispezioni e dei controlli effettuati ai fini dell'articolo 155, comma 1 del Testo unico. Il risultato delle attività indicate nella lettera a) del predetto articolo è riportato non appena eseguite le verifiche; b) la natura e l'estensione delle procedure di revisione svolte tenuto conto del sistema di controllo interno e dei principali fattori che hanno influenzato la gestione societaria; le considerazioni formulate ai fini dell'espressione del giudizio sui bilanci; c) le informazioni più significative acquisite dagli organi sociali nonché quelle scambiate con l'organo di controllo; d) i fatti 
correspondentes. Por derradeiro, a ausência de independência, como já ressaltado, poderá acarretar a ineficácia do serviço prestado, além de sanções regulatórias.

Devemos consignar que a prestação dos serviços de auditoria é, em princípio, de caráter pessoal (intuitu personae), ou seja, assenta-se a contratação nas qualidades pessoais do auditor, não podendo este fazer-se substituir na execução do serviço a que se obrigou.

Tal obrigação resta clara no caso de auditor pessoa física. No entanto, especial atenção deve ser dada a esta característica, quando se verifica que grande parte dos serviços de auditoria externa é prestada por pessoas jurídicas, as quais poderão, teoricamente, modificar seus representantes encarregados da execução do serviço contratado. Deve-se, portanto, questionar se o requisito da pessoalidade também se encontra presente no caso da contratação de pessoas jurídicas para a atividade de auditoria.

Para solucionar referida questão, devemos invocar o entendimento de parte da doutrina italiana, segundo o qual o conceito de pessoalidade da prestação existente nos contratos celebrados intuitu personae deve ser revisto diante das necessidades práticas impostas por determinados serviços, cuja dimensão não permite a execução pessoal, exigindo a formação de equipes regidas por meio de pessoas jurídicas, em que a individualidade do prestador ou executor do serviço não mais é relevante para a parte contrária. Assim, a pessoalidade da prestação há de ser entendida como uma relação de confiança entre as partes (entidade auditada e auditor pessoa jurídica) no que concerne a requisitos de qualidade do serviço prestado, e não como individualização imutável dos componentes da equipe encarregada do serviço. ${ }^{135}$

Não viola igualmente a característica de pessoalidade do contrato de prestação de serviços de auditoria a delegação pelo auditor de parte de sua tarefa a terceiros, na forma permitida na Res. CFC n. 1.230/09. Com efeito, por vezes é necessária ao auditor a subcontratação (ou "terceirização") de parcela de sua atividade a especialistas ${ }^{136}$ na área

censurabili non appena riscontrati; e) le informazioni rese e la documentazione trasmessa alle Autorità di controllo; f) le attività svolte nei confronti della società conferente non rientranti nell'incarico".

${ }^{135}$ Neste sentido, Daniela Casadei. Op.cit. p. 30.

${ }^{136}$ O item 6 da Res. n. 1.230/09 do CFC assim define tais profissionais: "Especialista do auditor é uma pessoa ou organização com especialização em área que não contabilidade ou auditoria, contratado pelo auditor, cujo trabalho nessa área é utilizado pelo auditor para ajudá-lo a obter evidência de auditoria suficiente e apropriada. $\mathrm{O}$ especialista do auditor pode ser interno (um sócio, ou equivalente no setor público quando relevante, ou uma pessoa que faz parte da equipe, incluindo equipe temporária, da firma do auditor ou de firma da rede), ou externo". 
contábil ou em disciplinas não pertinentes à contabilidade (p.ex., profissionais de tecnologia da informação, juristas, engenheiros, etc.).

O motivo pelo qual entendemos que a subcontratação de terceiros especialistas para parte das tarefas atribuídas ao auditor não viola a característica de pessoalidade do contrato repousa nas seguintes circunstâncias: 1) a delegação não pode ser total, mas somente de parcelas demarcadas no objeto contratual e por tempo delimitado; 2) o auditor continua no comando e na coordenação da atividade, devendo controlar a qualidade do serviço do terceiro; 3) mesmo fiando-se parcialmente no trabalho de terceiros, o auditor continua o único responsável pela entrega dos serviços contratados, consubstanciados na emissão de opinião sob a forma de parecer ou relatório de auditoria. ${ }^{137}$

Dado o caráter pessoal do contrato entre auditor e entidade auditada, não é possível a contratação de auditoria externa por meio de pessoa jurídica ou pessoa física que, não sendo habilitada como prestadora(s) do serviço em questão, sirva(m) apenas como mero(s) intermediário(s) para subcontratar o auditor, ainda que o profissional ao fim contratado seja representante do intermediário. ${ }^{138}$

Dadas as peculiaridades de algumas das obrigações das partes no contrato de auditoria, abriremos a seguir tópicos específicos para tratar dos assuntos referentes às obrigações de confidencialidade ou sigilo e de independência das partes no contrato. Antes, porém, é necessário determinar se a obrigação do auditor na prestação do serviço de auditoria externa é de meio ou de resultado.

\footnotetext{
${ }^{137}$ Veja-se o item 3 da Res. n. 1.230/09 do CFC: “O auditor é o único responsável por expressar opinião de auditoria e essa responsabilidade não é reduzida pela utilização do trabalho de especialista contratado pelo auditor (doravante especialista do auditor ou especialista). No entanto, se o auditor, tendo utilizado o trabalho desse especialista e seguido esta norma, concluir que o trabalho desse especialista é adequado para fins da auditoria, o auditor pode aceitar que as constatações ou conclusões desse especialista em sua área de especialização constituem evidência de auditoria apropriada".

${ }^{138}$ Assim decidiu o CRSFN no ACÓRDÃO/CRSFN 5232/04. Recurso 5265. Processo CVM RJ2001/8739: "EMENTA: RECURSOS VOLUNTÁRIOS - Mercado de Valores Mobiliários - Auditoria independente Contratação da pessoa jurídica e serviços efetuados pelo representante da empresa - Irregularidade caracterizada - Defesa do profissional acolhida em parte - Improvimento ao apelo formulado pela sociedade". Do inteiro teor da decisão, importante destacar o seguinte excerto: "Reafirme-se que o objetivo das instruções expedidas na espécie pela autoridade supervisora recorrida é o de obrigar prévio registro, no órgão, do nome do auditor responsável pela auditoria de demonstrações contábeis de companhias emissoras de valores mobiliários, não se podendo aceitar conduta atípica, em que a contratada apresenta-se como mera intermediária entre a firma a ser auditada e aquele que vai efetivamente realizar o serviço de auditoria".
} 


\subsubsection{Obrigação meio ou de resultado}

Embora a discussão sobre a natureza da obrigação do auditor no contrato de auditoria externa mantenha relação próxima com a natureza da responsabilidade civil deste profissional (do que cuidaremos mais adiante nesta obra), entendemos por bem tratá-la nesta oportunidade, uma vez que se vincula em maior grau à natureza da prestação objeto de referido contrato.

Segundo a lição de esmerada doutrina, ocorre obrigação de meio quando a prestação assumida por determinado profissional perante a parte contrária cinja-se ao emprego de um determinado grau de diligência na execução de uma dada tarefa, sem que se vincule à obtenção de um resultado final, que usualmente é aleatório. Em outros termos: realizada a conduta de acordo com o padrão esperado, considera-se cumprida a obrigação, ainda que não sobrevenha o resultado esperado da ação tomada. Por sua vez, entende-se existir obrigação de resultado quando a prestação do sujeito passivo somente se considere adimplida com a superveniência do resultado pactuado entre as partes, independente do grau de diligência daquele que estava obrigado a consegui-lo.

Nas palavras de Rui Stoco, temos que:

Na obrigação de meios o que se exige do devedor é pura e simplesmente o emprego de determinados meios sem ter em vista o resultado. É a própria atividade do devedor que está sendo objeto do contrato. Esse tipo de obrigação é o que aparece em todos os contratos de prestação de serviços, como o de advogados, médicos, publicitários, etc. (...). $\mathrm{Na}$ obrigação de resultado o devedor, ao contrário, obriga-se a chegar a determinado fim sem o qual não terá cumprido sua obrigação. Ou consegue o resultado avençado ou deverá arcar com as consequências. É o que se dá, por exemplo, no contrato de empreitada, transporte e no de cirurgia estritamente estética ou cosmetológica. Em outras palavras, na obrigação de meios a finalidade é a própria atividade do devedor e na obrigação de resultado, o resultado dessa atividade. ${ }^{139}$

Do conceito ora referido extraem-se importantes consequências práticas quanto ao inadimplemento contratual por parte do auditor e do respectivo ônus da prova.

${ }^{139}$ STOCO, Rui. Tratado de Responsabilidade Civil. São Paulo: RT, 2004. p. 533. 
De fato, em conceituando uma determinada relação obrigacional como obrigação de meio, o devedor terá cumprido sua prestação meramente empregando comportamento idôneo e satisfatório em relação a determinado padrão de comparação. Além disso, alegando inadimplemento contratual, caberá ao credor comprovar que o devedor não se comportou da forma devida ou não empregou meios idôneos no cumprimento de sua prestação. Por outro lado, em havendo obrigação de resultado, o adimplemento somente ocorrerá se o fim avençado for alcançado e o credor, invocando descumprimento contratual, simplesmente terá de demonstrar que o resultado não foi atingido, cabendo ao devedor o ônus da prova em relação aos motivos pelos quais este não sobreveio.

Para avaliar o tipo de obrigação do auditor independente, devemos considerar primeiramente que nem sempre é simples classificar um determinado tipo de obrigação como de meio ou de resultado simplesmente pela análise geral da espécie de atividade profissional realizada. Com efeito, embora muitas das profissões liberais que envolvem prestação de serviços (advocacia, medicina, etc.) estejam submetidas a regime de responsabilidade que envolvem obrigações de meio, há prestações específicas dessas atividades que merecem ser classificadas como obrigações de resultado. ${ }^{140}$

Desta forma, a complexidade das relações profissionais estabelecidas entre as partes pode ensejar distintas repercussões práticas no tipo de obrigação assumido em cada caso concreto. Diante disto, aqui será somente analisada a espécie de obrigação assumida pelo auditor independente quando realiza estritamente a atividade de revisão das demonstrações contábeis de uma entidade auditada, visando à emissão de um parecer ou relatório. $^{141}$

\footnotetext{
${ }^{140}$ Imaginemos, por exemplo, a obrigação de um advogado em elaborar um contrato escrito a um cliente ou um médico que se obriga a um resultado estético em cirurgia plástica. Em ambos os casos estaremos diante de obrigações de resultado, embora tais profissionais estejam submetidos ordinariamente a regime de responsabilidade inerente às obrigações de meio.

${ }^{141}$ É importante que isto seja corretamente informado, uma vez que a assunção de outros serviços por parte de auditor externo, por exemplo, de assessoria contábil (nas hipóteses em que isto não seja vedado) pode ensejar configuração de regime próprio quanto às obrigações do auditor. Neste sentido, acórdão do Tribunal de Justiça do Rio de Janeiro (0009738-47.1999.8.19.0000 - 1999.001.02847) entendeu que a prestação de serviços de consultoria por sociedade de auditoria configura obrigação de resultado: "APELAÇÃO - 1" Ementa. DES. MURILO ANDRADE DE CARVALHO - Julgamento: 30.09.1999 - TERCEIRA CÂMARA CÍVEL. CIVIL E PROCESSUAL CIVIL. OBRIGAÇÃO DE RESULTADO. PRETENSÃO DE CUMPRIMENTO PARCIAL POR MERA MINUTA PROVISÓRIA E INCOMPLETA QUANTO A TOTALIDADE DO DEVER JURÍDICO. RESULTADO NÃO ALCANÇADO. INADIMPLEMENTO. PERDAS E DANOS. EXIGÊNCIA DE PROVA DE FATO NOVO. LIQUIDAÇÃO POR ARTIGOS. EMPRESA INDEPENDENTE DE AUDITORIA CONTRATADA PARA ESTUDOS E APRESENTAÇÃO DE RELATÓRIO FINAL DE RECONFIGURAÇÃO ADMINISTRATIVA DE EMPRESA COMERCIAL E ALTERNATIVAS DE MELHOR POSICIONAMENTO FISCO-TRIBUTÁRIO, VISANDO
} 
Em relação à atividade do auditor independente, a doutrina pátria é silente em relação ao tipo de obrigação configurada. Na Itália, porém, embora haja grandes divergências doutrinárias, há um forte movimento dos estudiosos no sentido de aumentar progressivamente os casos em que a obrigação do auditor seja considerada como de resultado, e não somente de meio.

Daniela Casadei, por exemplo, após afirmar que nem sempre a responsabilidade do profissional liberal deva ser considerada como de meio, principalmente quando o resultado da prestação assumida por referidos agentes não seja de particular dificuldade, admite que a obrigação do auditor externo seja de resultado na grande maioria das hipóteses de atuação deste profissional, exemplificando com as seguintes condutas: omissão na verificação de criações irregulares de reservas contábeis, ausência de constatação de operações contábeis fictícias, não evidenciação de passivos existentes ou garantias hipotecárias firmadas, entre outras. Excepcionalmente, admite que a obrigação seja de meio quando o auditor for chamado a dar parecer sobre operações de emissão de ações por aumento de capital e sobre a adequação patrimonial em operações de fusão e cisão.

A mesma autora afirma ainda não ser convincente, para o fim de concluir tratar-se de uma obrigação de meio, o argumento segundo o qual o auditor não expressa em seu parecer uma declaração de certeza sobre as demonstrações contábeis. Isto seria, segundo pondera, reconhecer contraditoriamente que, de uma parte, o auditor certifica a veracidade do conteúdo das demonstrações contábeis e, de outra, não conferir efeitos de certeza a essa mesma certificação. ${ }^{142}$

Para bem concluirmos qual o tipo de obrigação do auditor independente, ou seja, se na atividade deste profissional há uma obrigação de meio ou de resultado, precisamos analisar três pontos específicos: 1) o que se conceitua como o resultado

ENXUGAMENTO DOS CUSTOS, SEM PRAZO DETERMINADO. INCURSÃO EM MORA POR NOTIFICAÇÃO (CC, ART. 960, $2^{\underline{a}}$ PARTE) SEGUIDA DE APRESENTAÇÃO DE MINUTA PROVISÓRIA E INCOMPLETA NO QUE RESPEITA AO DEVER JURÍDICO, OMISSA NA ANÁLISE DA APRESENTAÇÃO DE ALTERNATIVAS À POSTURA DA EMPRESA FRENTE AO MERCADO COMUM DO CONE SUL MERCOSUL. OBRIGAÇÃO DE RESULTADO INADIMPLIDA. RESPONSABILIZAÇÃO POR PERDAS E DANOS CONSISTENTE NA REPETIÇÃO DA PARCELA RECEBIDA COMO PARTE DA CONTRAPRESTAÇÃO E NOS LUCROS CESSANTES. FATO NOVO A SER DEMONSTRADO. QUANTUM DEBEATUR DOS LUCROS CESSANTES A SEREM APURADOS EM PROCESSO DE LIQUIDAÇÃO POR ARTIGOS. PROVIMENTO DO RECURSO PARA PROCEDÊNCIA INTEGRAL DO PEDIDO, COM INVERSÃO DA SUCUMBÊNCIA. UNÂNIME". Entendemos que este acórdão não serve para fundamentar qualquer conclusão sobre o tipo de obrigação existente em atividade própria de auditoria externa, pois tratou de atividade atípica (consultoria) prestada por auditor. 
buscado pelo auditor; 2) se o resultado visado pelo auditor é passível de ser atingido com razoável facilidade ou se está fora de seu controle; 3) quais as consequências da atribuição de uma obrigação de meio ou de resultado a este profissional.

Comecemos, portanto, com a conceituação do resultado esperado do auditor independente no exercício de sua atividade.

Primeiramente, é necessário desvincularmos a expectativa social que recai sobre o auditor da obrigação normativamente estabelecida para este profissional.

Se bem verificarmos, a sociedade espera, em grande parte das vezes de maneira desarrazoada, que o resultado supostamente vinculado à atividade do auditor independente seja a afirmação ou certificação da veracidade de todas as informações contábeis contidas nas demonstrações da entidade auditada.

Fosse este o resultado exigido pelas normas que regulam a profissão, teríamos de, obviamente, conceituar a obrigação do auditor como uma obrigação de meio, pois o resultado mencionado não é passível de ser atingido pela atividade do auditor independente.

Isto porque, como veremos com mais detalhes posteriormente, há uma série de limitações à atividade do auditor que não permitem que este chegue a um resultado absolutamente concludente sobre a veracidade de todas as informações prestadas pela entidade auditada. $\mathrm{O}$ auditor trabalha diante de tempo e custos limitados, o que não permite que venha a verificar a totalidade das transações econômicas constantes das demonstrações; trabalha ainda com estimativas e contingências inseridas nas demonstrações (p.ex.: inadimplência, grau de depreciação de ativos, passivos futuros, etc.) cuja existência e dimensão não pode garantir. Tudo isto sem dizer das próprias limitações da ciência contábil, que lhe serve de instrumento.

Entretanto, ao contrário do esperado por grande parte do corpo social, a obrigação do auditor independente não é atestar certeza a respeito do conteúdo das operações econômicas retratadas nas demonstrações contábeis, mas sim garantir segurança razoável de que as transações constantes destas demonstrações não contenham distorções relevantes no tocante a sua existência, classificação e correta avaliação.

${ }^{142}$ Op. cit. p. 85. 
Veja-se, por exemplo, a conceituação presente no item 5 da Resolução CFC n. 1.203/09 que aprova a NBC TA n. 200 (objetivos gerais do auditor independente e a condução da auditoria em conformidade com normas de auditoria), cuja transcrição ora se faz necessária, com grifos nossos:

Como base para a opinião do auditor, as NBC TAs exigem que ele obtenha segurança razoável de que as demonstrações contábeis como um todo estão livres de distorção relevante, independentemente se causadas por fraude ou erro. Asseguração razoável é um nível elevado de segurança. Esse nível é conseguido quando o auditor obtém evidência de auditoria apropriada e suficiente para reduzir a um nível aceitavelmente baixo o risco de auditoria (isto é, o risco de que o auditor expresse uma opinião inadequada quando as demonstrações contábeis contiverem distorção relevante). Contudo, asseguração razoável não é um nível absoluto de segurança porque há limitações inerentes em uma auditoria, as quais resultam do fato de que a maioria das evidências de auditoria em que o auditor baseia suas conclusões e sua opinião, é persuasiva e não conclusiva

\section{Como retratam Boyton et al.:}

$\mathrm{O}$ auditor deve planejar e realizar a auditoria de forma tal que obtenha segurança razoável de que as demonstrações não contenham distorções relevantes. O conceito de segurança razoável, contudo, não assegura exatidão das demonstrações contábeis. O conceito de segurança razoável relaciona-se com o fato de que auditorias envolvem aplicação de testes. Auditores raramente examinam 100\% dos itens de uma classe de contas ou transações. Em vez disso, selecionam parte desses itens e aplicam procedimentos para formar opinião sobre as demonstrações contábeis. O auditor aplica competência e julgamento para decidir quais evidências buscar, quando buscá-las e com qual profundidade analisá-las, quem deverá coletar e avaliar determinada evidência e quem deverá interpretar e avaliar os resultados. Se os testes não indicarem evidência de distorções relevantes, o auditor conclui que as demonstrações estão apresentadas adequadamente, de acordo com os PGCA. O conceito de segurança razoável também se relaciona com o fato de que as demonstrações preparadas pela administração da entidade contêm estimativas contábeis

- não são exatas. Embora o auditor dedique muita atenção ao 
entendimento do negócio e do setor de atividades do cliente, a velocidade com que as condições econômicas se alteram impõe limitações importantes à auditoria. Consequentemente, uma auditoria não pode garantir exatidão de demonstrações contábeis. ${ }^{143}$

Fica claro, portanto, que o resultado exigido do auditor não é a obtenção de segurança absoluta ou certificação da veracidade da totalidade dos lançamentos contábeis contidos ou representados nas demonstrações, mas meramente a emissão de um juízo que confira que as demonstrações examinadas estão livres de distorções materialmente relevantes.

Assim conceituado o resultado, podemos passar a responder ao segundo item antes mencionado, qual seja, o de se saber se o resultado pretendido do trabalho do auditor está razoavelmente dentro de seu alcance ou se foge ao seu controle.

Esta questão é de extrema relevância, pois se concluirmos que o resultado pretendido está dentro daquilo que o auditor, com seu comportamento profissional diligente, pode alcançar, deveremos conceituar sua obrigação como de resultado. Caso contrário, concluindo que o resultado foge ao controle do auditor ou está na dependência de fatores aleatórios (como ocorre com o médico em face da cura da doença, ou com o advogado em face do ganho da causa), será imperioso conceituar a obrigação do auditor como obrigação de meio.

$\mathrm{Na}$ esteira do aqui já salientado, considerando que o resultado normativamente esperado do trabalho do auditor é inerente à obtenção de segurança razoável quanto à inexistência de distorções relevantes nas demonstrações contábeis - e não de certificação de veracidade absoluta -, resta evidente que o fim último pretendido com a atividade de auditoria externa é passível de plena realização pela atuação diligente deste profissional, não fugindo de seu controle nem dependendo de eventos outros determinados por fatores aleatórios.

Resta responder ao terceiro item antes mencionado, referente às consequências práticas da definição da obrigação do auditor como de meio ou de resultado.

\footnotetext{
${ }^{143}$ Op. cit. p. 78. Na mesma linha, a Resolução n. 1.203/09 do CFC ressalta que: "Em geral, as distorções, inclusive as omissões, são consideradas relevantes se for razoável esperar que, individual ou conjuntamente, elas influenciem as decisões econômicas dos usuários tomadas com base nas demonstrações contábeis. Julgamentos sobre a materialidade são estabelecidos levando-se em consideração as circunstâncias envolvidas e são afetadas pela percepção que o auditor tem das necessidades dos usuários das demonstrações contábeis e pelo tamanho ou natureza de uma distorção, ou por uma combinação de ambos. A opinião do
} 
A principal repercussão prática da definição supracitada se dá em relação ao ônus da prova. Na obrigação de meio, o credor deve provar em juízo, além do inadimplemento da obrigação, também que o devedor não agiu com a diligência necessária que dele se esperava (culpa). Na obrigação de resultado, inversamente, ao credor cabe provar apenas que o resultado esperado não foi atingido (inadimplemento), ficando a cargo do devedor provar que foi, por qualquer modo, impossível conseguir a obtenção do resultado esperado (ausência de culpa).

Não é difícil verificar, porém, que em muitos casos a prova da culpa do auditor por parte do credor (entidade auditada ou terceiro) tornar-se-á praticamente impossível, tornando mais adequada a imposição de uma obrigação de resultado ao auditor, de forma a onerar-lhe com o encargo de provar a exclusão de sua conduta negligente, com inversão do ônus da prova, toda vez que o resultado razoavelmente esperado desse profissional não tiver sido atingido.

Com efeito, a culpa do auditor, na grande maioria dos casos concretos na modalidade de negligência, é apurada pelo cotejamento entre a conduta deste profissional e o que lhe é determinado pelas normas que regem a atividade de auditoria.

No entanto, exigir que o prejudicado pela conduta prove a negligência do auditor é imputar àquele a tarefa hercúlea de conhecer todas as normas técnicas mencionadas, sua aplicabilidade em cada caso concreto, o momento e a responsabilidade individual do profissional que as violou. Em se tratando de entidades auditadas de grande porte e sociedades de auditoria que prestam o serviço em caráter institucional e mediante o uso de grandes equipes, esta tarefa pode ser absolutamente inviável ao credor prejudicado (principalmente quando este seja um terceiro, pessoa física, usuário das demonstrações auditadas), ocasionando a impunidade do auditor negligente.

É muito mais justo e consentâneo com a realidade que a prova dos fatos extintivos, modificativos ou impeditivos da obrigação do auditor, com o fim de excluir sua conduta negligente, fiquem a cargo deste, operando-se a inversão do ônus da prova.

Como ensina Daniela Casadei:

auditor considera as demonstrações contábeis como um todo e, portanto, o auditor não é responsável pela detecção de distorções que não sejam relevantes para as demonstrações contábeis como um todo". 
Não fica a cargo do autor indicar a regra técnica violada no caso concreto, nem individualizar o momento em que a sociedade de auditoria errou. $^{144}$

Seguindo esta mesma linha, Maria Vittoria Cozzi, salienta:

Em uma realidade em que é fortemente percebida a exigência de proteção ao prejudicado no confronto com uma contraparte profissional e organizada, é delineado, assim, um uso da noção de obrigações de meio e resultado, de maneira evolucionária, como o instrumento para realizar, em tutela do prejudicado, uma inversão do ônus da prova. ${ }^{145}$

Deste modo, verificamos que: 1) o resultado exigido do auditor não é a certeza absoluta quanto à veracidade de todos os lançamentos contábeis representados nas demonstrações auditadas, mas sim a obtenção de segurança razoável quanto à inexistência de distorções relevantes; 2) o resultado exigido pode ser facilmente alcançado pelo auditor, não estando fora de seu controle ou a depender de fatores aleatórios; 3) a conceituação da obrigação do auditor como de resultado acarreta a inversão do ônus da prova, o que apresenta situação muito mais consentânea com a defesa do prejudicado, dentro de uma perspectiva razoável.

A resposta favorável aos três tópicos supracitados faz que consideremos a obrigação do auditor, no que tange estritamente ao exame do conteúdo das demonstrações contábeis, como uma obrigação de resultado.

\subsubsection{Obrigação de confidencialidade ou sigilo}

O dever de confidencialidade ou sigilo é essencial à atividade de auditoria externa, na medida em que o auditor, ao exercer sua tarefa, acaba por ter acesso a documentos e informações estratégicas da entidade auditada, cuja divulgação poderia causar a esta danos de monta.

\footnotetext{
${ }^{144} O$ p. cit. p. 179. O texto é tradução livre de: "Non é a carico dell'attore indicare la regola dell'arte violada nel caso concreto, nè individuare il momento in cui la società di revisione ha sbagliato".

${ }^{145} \mathrm{Op}$. cit. p. 62. O texto é tradução livre de: "In una realtà in cui è fortemente avvertita l'esigenza di proteggere il danneggiato nei confronti di una controparte professionale e organizzata, si delinea cosi un uso della nozione di obbligazioni di mezzi e di risultato, in chiave evolutiva, come strumento per realizzare, a tutela dei danneggiato, un'inversione dell'onere della prova".
} 
Por outro lado, na ausência de qualquer obrigação de sigilo por parte do auditor perante terceiros, a entidade auditada teria todo incentivo a sonegar informações essenciais sobre sua gestão, fato este que causaria prejuízos sociais relevantes, uma vez que a auditoria ficaria impossibilitada de revelar aos destinatários da informação contábil todos os aspectos do negócio objeto de verificação. O sigilo, portanto, atende a um relevante aspecto de interesse público, uma vez que acaba por incentivar o livre fluxo de informações entre auditores e auditados, repercutindo na qualidade do serviço prestado aos interessados.

A regra geral sobre a confidencialidade das informações obtidas na atividade de auditoria externa é corolário do sigilo da escrituração empresarial, regra que está insculpida no art. 1.190 do Código Civil. ${ }^{146}$

Por meio da proteção do sigilo das informações inerentes à auditoria, garantese indiretamente a inviolabilidade da escrituração, cuja necessidade vem demonstrada magistralmente por J. X. Carvalho de Mendonça:

Nos livros e correspondência do comerciante acham-se gravados os traços de suas operações, a história da sua vida mercantil, já dissemos; deles constam as transações com os fornecedores e os clientes, os lucros e os prejuízos, as obrigações contraídas, as despesas domésticas e mais minuciosidades do exercício da profissão. O comerciante esforça-se por manter na maior reserva os livros e a correspondência de sua casa, acentuando-se, todos os dias, a necessidade dessa precaução, em virtude do aumento da livre concorrência, da complexidade da vida comercial, do desenvolvimento do crédito, e ainda por exigência implícita de terceiros que com ele mantêm transações. Aos banqueiros, por exemplo, muitas operações são confiadas, especialmente as de comissão e depósito, a título implicitamente confidencial. O segredo é a alma do comércio, proclamava o Alvará de 16 de dezembro de 1756, cap. 17; ele é para o comerciante, disse também Bédarride, a alma de suas operações, o elemento essencial e indispensável ao êxito dos negócios (...) A lei garante a inviolabilidade desses livros, chegando a declarar, por cautela aliás indispensável, que a nenhuma autoridade, juiz ou tribunal, debaixo de pretexto algum, por mais especioso que seja, é lícito praticar ou

146 “Art. 1.190. Ressalvados os casos previstos em lei, nenhuma autoridade, juiz ou tribunal, sob qualquer pretexto, poderá fazer ou ordenar diligência para verificar se o empresário ou a sociedade empresária observam, ou não, em seus livros e fichas, as formalidades prescritas em lei." 
ordenar qualquer diligência para examinar se o comerciante arruma ou não devidamente seus livros ou se neles tem cometido algum vício. ${ }^{147}$

\section{No mesmo sentido Haroldo Malheiros Duclerc Verçosa:}

Os livros guardam informações extremamente importantes para o empresário, que poderiam ser utilizadas por terceiros - concorrentes ou não - para delas tirarem proveito econômico. Os antigos já diziam que "o segredo é a alma do negócio”. Mesmo nas companhias abertas, que, por princípio, devem adotar o princípio de ampla transparência não só perante seus acionistas, mas também junto aos investidores em potencial (o mercado), o acesso às informações que podem ser tiradas a partir do exame de seus livros não é completamente livre, mas se encontra subordinado a uma determina disciplina. ${ }^{148}$

O dever de sigilo dos dados de auditoria acaba também por proteger o uso da informação contábil por aqueles que têm acesso privilegiado a seu conteúdo (insider information) em seu próprio benefício.

Em diversos países, a obrigação de sigilo das informações coletadas em auditoria externa tem recebido proteção.

Perante a União Europeia, ressalta-se o dever de sigilo do auditor independente no art. 23 da Diretiva n. 2006/43/CE. ${ }^{149}$ Nos Estados Unidos, o código de ética da IFAC impõe a todos os auditores e demais contabilistas (Certified Public Accountants Professional accountants) a observância do princípio de confidencialidade em sua atuação profissional. ${ }^{150}$ No Brasil, os itens 1.6.2.1 e 1.6.2.2 da Resolução n. 1.100/07 do Conselho

\footnotetext{
${ }^{147}$ MENDONÇA, José Xavier Carvalho de. Dos livros dos comerciantes. São Paulo: Rothschild, 1906. p. 109.

${ }^{148}$ VERÇOSA, Haroldo Malheiros Duclerc. Curso de Direito Comercial. São Paulo: Malheiros, 2004. p.199.

149 "Art. 23. Confidencialidade e sigilo profissional. 1. Os Estados-Membros devem assegurar que todas as informações e documentos a que tem acesso o revisor oficial de contas ou a sociedade de revisores oficiais de contas, quando da realização de uma revisão legal das contas, se encontram protegidos com base em regras adequadas em matéria de confidencialidade e de sigilo profissional. 2. As regras em matéria de confidencialidade e de sigilo profissional relacionadas com os revisores oficiais de contas ou as sociedades de revisores oficiais de contas não prejudicam a aplicação das disposições da presente diretiva. 3. Sempre que um revisor oficial de contas ou uma sociedade de revisores oficiais de contas for substituído por outro revisor oficial de contas ou sociedade de revisores oficiais de contas, o primeiro revisor oficial de contas ou sociedade de revisores oficiais de contas deve facultar o acesso a todas as informações pertinentes relativamente à entidade examinada ao novo revisor oficial de contas ou sociedade de revisores oficiais de contas. 4. Qualquer revisor oficial de contas ou sociedade de revisores oficiais de contas que cesse de tomar parte num determinado trabalho de revisão ou auditoria e qualquer anterior revisor oficial de contas ou sociedade de revisores oficiais de contas permanece sujeito às disposições dos ns. 1 e 2 relativamente a esse trabalho."

150 "The principle of confidentiality imposes an obligation on all professional accountants to refrain from: (a) Disclosing outside the firm or employing organization confidential information acquired as a result of
} 
Federal de Contabilidade impõem como regra geral o dever de sigilo do auditor perante a entidade auditada, terceiros, outros auditores e órgãos de fiscalização. ${ }^{151}$ Do mesmo modo, para o registro do auditor independente nos quadros da CVM, a Instrução n. 308/99 deste órgão exige, em seus arts. $3^{\circ}$, III, e $4^{\stackrel{0}{ }}$, VII, que o auditor pessoa física ou jurídica disponha de condições que garantam a guarda, a segurança e o sigilo dos documentos e informações decorrentes desta atividade.

A regra geral, portanto, é que o auditor independente mantenha estrita confidencialidade dos documentos e dados obtidos em sua atividade, não os revelando se não autorizado expressamente pela entidade auditada. A obrigação de sigilo é tão relevante, aliás, que perdura ainda após a cessação do contrato de auditoria. ${ }^{152}$

Considerando que a proteção dos dados de auditoria é meio para o resguardo dos dados contábeis, devemos entender que, como exceção que é, a publicidade da escrituração empresarial e, por consequente, das informações de auditoria, deve ser interpretada restritivamente. Com efeito, a norma que exclui o sigilo sobre tais matérias, determinando, portanto, exceção à regra geral de confidencialidade, acaba por restringir prerrogativas e só abrange os casos que especifica (exceptiones sunt strictissimae interpretationis).

Bem explica Carlos Maximiliano o motivo deste tipo de interpretação:

As disposições excepcionais são estabelecidas por motivos ou considerações particulares, contra outras normas jurídicas, ou contra o Direito comum; por isso não se estendem além dos casos e tempos que

professional and business relationships without proper and specific authority or unless there is a legal or professional right or duty to disclose; and (b) Using confidential information acquired as a result of professional and business relationships to their personal advantage or the advantage of third parties" (INTERNATIONAL FEDERATION OF ACCOUNTANTS. Code of ethics for professional accountants. Disponível em: <http//www.ifac.org >. Acesso em 3 jan. 2010).

151 "1.6.2.1 O sigilo profissional do auditor independente deve ser observado nas seguintes circunstâncias: a) na relação entre o auditor independente e a entidade auditada; b) na relação entre os auditores independentes; c) na relação entre o auditor independente e os organismos reguladores e fiscalizadores; e d) na relação entre o auditor independente e demais terceiros. 1.6.2.2. O auditor independente deve respeitar e assegurar o sigilo relativamente às informações obtidas durante o seu trabalho na entidade auditada, não as divulgando, sob nenhuma circunstância, salvo as contempladas na legislação vigente, bem como nas Normas Brasileiras de Contabilidade."

${ }^{152}$ Item 1.6.2.6, “a”, da Resolução n. 1.100 do CFC: “O dever de manter o sigilo prevalece: a) para os auditores independentes, mesmo após terminados os compromissos contratuais”. Em havendo sucessão de auditores, esta mesma norma dispõe, em seu item 1.6.2.3 que "o auditor independente, quando previamente autorizado por escrito, pela entidade auditada, deve fornecer as informações que por aquela foram julgadas necessárias ao trabalho do auditor independente que o suceder, as quais serviram de base para emissão do último parecer de auditoria por ele emitido". Portanto, os termos em que o sigilo deve ser aberto, em caso de sucessão, dependem do nível de autorização da entidade auditada. Neste mesmo sentido a Instrução n. 308/99 da CVM em seu art. 25, VI. 
designam expressamente (...). Restrições ao uso ou posse de qualquer direito não se presumem: é isto que o preceito estabelece. Devem ressaltar dos termos da lei, ato jurídico ou frase de expositor. ${ }^{153}$

Várias situações, entretanto, põem em conflito a confidencialidade a ser preservada pelo auditor externo com outros bens jurídicos de igual ou superior importância, tornando duvidosa a prevalência do sigilo profissional. Passaremos a seguir ao estudo específico de algumas dessas hipóteses.

O primeiro ponto a ser analisado quanto à obrigação de sigilo do auditor externo é referente à concessão de informação aos próprios membros da entidade auditada, particularmente a seus sócios e acionistas.

Em relação às sociedades de pessoas ou sociedades limitadas regulamentadas no Código Civil usualmente o problema não se põe, uma vez que a todos os sócios, exerçam estes ou não a administração, é amplamente facultado, como forma de fiscalização das operações societárias, o acesso aos documentos contábeis e, consequentemente, aos dados contidos na documentação de auditoria.

Com relação às sociedades anônimas, entretanto, o problema é mais complexo, uma vez que a separação entre a propriedade das ações e a administração social, além da dispersão acionária em companhias abertas, pode fazer com que terceiros venham adquirir quantidades pequenas de ações para que, ostentando a qualidade de acionistas, tenham acesso a dados confidenciais da companhia indevidamente.

Diante desta possibilidade de acesso indevido aos livros e sistemas contábeis, dispôs o art. 105 da Lei n. 6.404/76 que a exibição por inteiro dos livros da companhia pode ser ordenada judicialmente sempre que, a requerimento de acionistas que representem, pelo menos, $5 \%$ (cinco por cento) do capital social, sejam apontados atos violadores da lei ou do estatuto, ou haja fundada suspeita de graves irregularidades praticadas por qualquer dos órgãos da companhia.

Se bem observarmos, o legislador restringiu o acesso aos livros contábeis de sociedades anônimas, resultando em que a publicidade determinada pela legislação do anonimato se aplique tão somente às demonstrações contábeis e não à escrituração. $O$ acesso às demonstrações, se e quando obrigatória sua publicação, deve ser amplo e

${ }^{153}$ MAXIMILIANO, Carlos. Hermenêutica e aplicação do direito. Rio de Janeiro: Forense, 2001. p. 198. 
irrestrito, o que não implica o acesso aos livros ou sistemas contábeis de escrituração, o que é vedado, em certas circunstâncias, até mesmo aos acionistas.

Bem explica o fenômeno a lição de Modesto Carvalhosa, ressaltando que a possibilidade de exame irrestrito dos livros contábeis pelo sócio não se aplica às sociedades anônimas, pois: A possibilidade legal de qualquer acionista, a qualquer tempo, ter completo acesso aos livros da companhia poderia causar-lhe graves danos. Tal regra, nos dizeres do autor, se justifica, uma vez que: Tem por finalidade evitar que tais livros fiquem à mercê de pessoas que adquiriram ações com a única finalidade de aproveitar-se delas para conhecimentos de negócios sigilosos. ${ }^{154}$

Na mesma linha, Haroldo Malheiros Duclerc Verçosa ressalta que, ainda nas sociedades anônimas abertas, nas quais a publicidade de alguns de seus dados é imposta por lei como defesa do investidor, verifica-se que o sigilo da escrituração ainda está presente. $^{155}$

Deste modo, entendemos que facultar ao acionista de modo irrestrito o acesso aos dados da documentação de auditoria é, por via oblíqua, permitir o acesso aos dados contábeis, tornando letra morta o disposto no art. 105 da Lei n. 6.404/76. O acesso aos documentos do auditor, portanto, há de ser limitado às hipóteses do dispositivo legal ora mencionado, sob pena de sua completa ineficácia em garantir o sigilo aos dados contábeis.

Igualmente não nos convence a concordar com a permissão irrestrita de acesso de qualquer acionista à documentação de auditoria o argumento de que o auditor independente tem o dever de estar presente e prestar esclarecimentos em assembleia aos acionistas sobre as demonstrações contábeis (art. 134, § $1^{\frac{0}{}}$, da Lei n. 6.404/76). De fato, prestar esclarecimentos sobre pontos específicos requisitados por acionista é muito diferente de facultar acesso irrestrito a praticamente todas as informações contábeis da companhia, ou mesmo a dados específicos, contidos nos papéis de trabalho do auditor, que devam ser mantidos em sigilo.

Diante disto, discordamos de acórdão prolatado pelo Tribunal de Justiça do Rio de Janeiro, que permitiu a livre ciência do acionista aos papéis de trabalho de auditor independente, ainda que referentes a contas específicas da companhia, sob o argumento de que em face do acionista minoritário não seria aplicável o sigilo de informações, uma vez

${ }^{154}$ CARVALHOSA, Modesto; LATORRACA, Nilton. Comentários à lei de sociedades anônimas. São Paulo: Saraiva, 1998, v. 2. p. 220.

${ }^{155}$ Op.cit. p. 199. 
que este não seria terceiro não pertencente ao quadro societário, e ainda sob a alegação de que, se o auditor possui a obrigação de fornecer informações aos acionistas em assembleia, deveria este igualmente facultar acesso às demais informações obtidas em sua atividade. ${ }^{156}$

Obviamente, o sigilo do auditor independente ora referido não se aplica ao membro de Conselho Fiscal, que pode, nos termos do art. 163 e incisos da Lei n. 6.404/76, ter amplo acesso aos documentos escriturados para realizar seu mister fiscalizatório, podendo, inclusive, ingressar em juízo para pleitear a exibição de livros contábeis.

Também entendemos que a obrigação de confidencialidade não se aplica a membro(s) do Conselho de Administração. Isto porque tal órgão tem a atribuição de escolher e destituir os auditores independentes (art. 142, IX, da Lei n. 6.404/76). Ora, não seria possível que os conselheiros fundamentassem a escolha do auditor (incluindo eventual recondução deste) e a destituição respectiva (que deve ser, em regra, motivada) se não pudessem ter acesso ao trabalho de auditoria.

Outro ponto a ser analisado é a invocação de sigilo profissional do auditor independente em face de órgãos públicos, dentre os quais: 1) órgãos de fiscalização da profissão do auditor; 2) órgãos de fiscalização tributária; e 3) demais órgãos estatais.

Em relação aos órgãos de fiscalização profissional do auditor, além da supervisão do Conselho Federal de Contabilidade (CFC) e dos respectivos Conselhos Regionais (CRCs), os auditores externos independentes que venham a auditar demonstrações de companhias abertas, instituições financeiras e equiparadas e seguradoras deverão se submeter à fiscalização da Comissão de Valores Mobiliários (CVM), Banco Central do Brasil (BACEN) e Superintendência de Seguros Privados (SUSEP).

\footnotetext{
156 “Tribunal de Justiça do Rio de Janeiro: 0037100-45.2004.8.19.0001 (2005.001.18215) - APELAÇÃO - 1 ${ }^{\text {a }}$ Ementa DES. FERNANDO CABRAL - Julgamento: 28.09.2005 - QUARTA CÂMARA CÍVEL. SOCIEDADE EMPRESARIAL. AUDITORIA. DIREITO A INFORMAÇÃO. DIREITO DE ACIONISTA. VIOLAÇÃO DO SIGILO. INOCORRÊNCIA. Direito Empresarial. Acionista minoritária. Direito de acesso às informações provenientes do trabalho de auditoria independente realizado pela ré. Existência de relação jurídica entre as partes. Alegação de violação de sigilo profissional. Inocorrência. Art. 134, par. 1., da L.S.A. É direito da sociedade autora ter acesso às informações relativas às contas e demonstrações financeiras da empresa da qual é acionista, porquanto existe relação jurídica a ensejar o pedido. Estando a empresa de auditoria independente, por força de lei, obrigada a se fazer representar perante a assembleia dos acionistas, com a finalidade de prestar esclarecimentos a estes, a respeito do trabalho de auditagem, permitindo-lhes a exata compreensão sobre as demonstrações financeiras, sua adequação e veracidade, a recusa injustificada de fazê-lo, na ocasião oportuna, faz nascer o direito de o acionista exigir, posteriormente, dos auditores independentes, diretamente, que sejam condenados a prestar as informações recusadas, na assembleia seguinte. Obrigação legal que une as partes, legitimando-as para o processo. Não configura a quebra do dever de sigilo a prestação de informações relacionadas ao trabalho de auditagem ao acionista, conforme determina a lei, que não pode ser considerado, neste caso, como terceiro. Interesse processual evidenciado para lide, sendo irrelevante que a obrigação perseguida tenha sido cumprida por força da decisão que antecipou a tutela de mérito, a qual deve ser confirmada ou não, em decisão final. Recurso desprovido.”
} 
Em relação a todos os órgãos mencionados no parágrafo anterior, é inoponível por parte do auditor a prerrogativa de sigilo profissional, uma vez que o acesso à documentação de auditoria, em tais casos, é elemento essencial à correta fiscalização da profissão, inerente ao poder de polícia da Administração Pública, cujo interesse público deve preponderar sobre a necessidade de manutenção do sigilo. ${ }^{157}$ Obviamente, a quebra de sigilo profissional pelos órgãos de fiscalização deve ser devidamente fundamentada, sob pena de se configurar eventual abuso da autoridade respectiva.

No que toca aos órgãos de fiscalização tributária, deve-se considerar inicialmente que o próprio art. 1.193 do Código Civil excepciona a inviolabilidade da escrituração empresarial com relação a esta atividade estatal, ao estabelecer que restrições ao exame da escrituração, em parte ou por inteiro, não se aplicam às autoridades fazendárias, no exercício da fiscalização do pagamento de impostos, nos termos estritos das respectivas leis especiais.

Assim, a possibilidade de acesso direto à escrituração empresarial pelas autoridades fazendárias inviabilizaria a alegação de sigilo das informações obtidas em auditoria, como forma indireta de proteção do sigilo contábil, uma vez que a contabilidade da entidade auditada não é sigilosa para tais autoridades.

Devemos considerar, igualmente, que, em alguns países, por muito tempo não havia qualquer obrigação de confidencialidade entre o contabilista (incluindo o auditor) e o cliente. Neste sentido, Beaty e Samuelson advertem que perante a legislação federal norteamericana inexistia, até pouco tempo, obrigação de sigilo entre cliente e contabilista (accountant-client privilege), comentando interessante caso em que o órgão tributário federal daquele país (Internal Revenue Service - IRS) persuadiu e se utilizou (licitamente) das informações dadas por um contador para formular acusações de sonegação fiscal inclusive de natureza criminal - contra um cliente, gerando a remodelação do sistema, por

\footnotetext{
${ }^{157} \mathrm{O}$ acesso da CVM à documentação de auditoria está regulado no art. 9º, I, da Lei n. 6.385/76, que ressalta que "A Comissão de Valores Mobiliários, observado o disposto no $\S 2^{2}$ " do art. 15, poderá: I - examinar e extrair cópias de registros contábeis, livros ou documentos, inclusive programas eletrônicos e arquivos magnéticos, ópticos ou de qualquer outra natureza, bem como papéis de trabalho de auditores independentes, devendo tais documentos ser mantidos em perfeita ordem e estado de conservação pelo prazo mínimo de cinco anos: (...) e) dos auditores independentes". Em relação ao CFC e CRCs, o item 1.6.2.4 da Resolução n. 1.100/07 do CFC determina: "O auditor independente, quando solicitado, por escrito e fundamentadamente, pelo Conselho Federal de Contabilidade e Conselhos Regionais de Contabilidade, deve exibir as informações obtidas durante o seu trabalho, incluindo a fase de pré-contratação dos serviços, a documentação, papéis de trabalho, relatórios e pareceres, de modo a demonstrar que o trabalho foi realizado de acordo com as Normas de Auditoria Independente das Demonstrações Contábeis, da presente norma e das demais normas legais aplicáveis".
} 
parte do Congresso norte-americano, para limitar a atuação do IRS e manter, dentro de certos limites, o sigilo profissional.

Tradicionalmente, um privilégio de confidencialidade na relação contabilista-cliente não existia perante a legislação federal. Contabilistas não possuíam nenhuma obrigação de manter confidenciais todas as informações que receberam de seus clientes. Em um caso famoso, o IRS suspeitou que o proprietário de uma cadeia de pizzaria estava sonegando seu rendimento. A Agência persuadiu o contador do proprietário, James Checksfield, a espioná-lo por oito anos (O IRS concordou em retirar as acusações contra Checksfield, que não tinha quitado seus próprios impostos por um período de três anos). Graças às informações que Checksfield passou ao IRS, seu cliente foi indiciado criminalmente por acusações de sonegação de impostos (...). O Congresso americano aprovou o Internal Revenue Service Restructuring and Reform Act para reduzir abuso dos contribuintes por parte do IRS. Este estatuto fornece proteção limitada para comunicações confidenciais entre clientes e contabilistas. Esta é a boa notícia. A má notícia é a palavra "limitada". Este novo privilégio aplica-se apenas em casos cíveis, envolvendo o IRS ou o Governo dos Estados Unidos. Ela não se aplica aos casos criminais, casos cíveis não envolvendo o Governo dos Estados Unidos ou casos com outras agências federais, como a SEC (...). Cerca de 30 Estados reconhecem um privilégio de confidencialidade na relação contabilistacliente, mas um privilégio estadual aplica-se apenas às questões da lei estadual e não oferece nenhuma proteção contra acusações envolvendo leis federais. ${ }^{158}$

No entanto, com o devido respeito aos argumentos contrários à obrigação de confidencialidade do auditor para com o fisco, parece-nos que, por motivos outros, o sigilo

${ }^{158}$ BEATTY, Jeffrey F.; SAMUELSON, Susan S. Business Law and the legal environment. Ohio: SouthWestern Cengage Learning, 2010. p. 936. O texto é tradução livre de: "Traditionally, an accountant-client privilege did not exist under federal law. Accountants were under no obligation to keep confidential any information they received from their clients. In one notorious case, the IRS suspected that the owner of a chain of pizza parlors was underreporting his income. The agency persuaded the owner's CPA, James Checksfield, to spy on him for eight years. (The IRS agreed to drop charges against Checksfield, who had not paid his own taxes for three years.). Thanks to the information that Checksfield passed to the IRS, his client was indicted on criminal charges of evading taxes (...). Congress passed the Internal Revenue Service Restructuring and Reform Act to reduce IRS abuse of taxpayers. This statute provides limited protection for confidential communications between accountants and clients. That is the good news. The bad news is the "limited." This new privilege applies only in civil cases involving the IRS or the U.S. Government. It does not apply to criminal cases, civil cases not involving the U.S. government or cases with other federal 
das informações obtidas em auditoria ainda deve prevalecer com respeito aos órgãos estatais fiscalizatórios de tributos.

Primeiramente, porque o auditor independente não mantém qualquer relação com o fisco no tocante aos tributos devidos pela entidade auditada; não é sujeito passivo nem responsável pelos tributos devidos pelo auditado, não podendo ser atingido por uma obrigação acessória de caráter fiscal consistente em fornecer dados de seus clientes à administração tributária, aptos a ensejar o competente lançamento.

Assim fosse, aliás, estaria o auditor externo equiparado a um verdadeiro delator de tributos devidos, o que estimularia a sonegação de informações tributárias por parte da entidade auditada ao profissional de auditoria. Obviamente, soubesse a entidade auditada que poderia ser denunciada às autoridades fiscalizatórias de tributos, teria todo o incentivo para não informar ao auditor quaisquer irregularidades, o que acarretaria sério prejuízo ao trabalho de auditoria, que se baseia, em grande parte, na confiabilidade das informações prestadas pelo auditado.

Ao depois, deve-se salientar que a exigência do fisco ao auditor para que este informe dados inerentes ao seu trabalho não encontra qualquer respaldo no ordenamento jurídico tributário nacional e, em regra, não se encontra naquelas hipóteses em que o auditor está obrigado a delatar fatos aos órgãos regulatórios do mercado de capitais ou financeiro, como veremos mais adiante. ${ }^{159}$

agencies such as the SEC (...). Around 30 states do recognize an accountant-client privilege, but a state privilege applies only to issues of state law and provides no protection against federal charges".

${ }^{159}$ Ressalvada a hipótese rara de a sonegação tributária estar enquadra nas disposições da Resolução n. 3.198/04 do BACEN e da Resolução CNSP n. 118/04 que obrigam a delação aos órgãos regulatórios (basicamente consubstanciadas na existência de risco à continuidade da entidade, existência de fraudes ou erros materialmente relevantes). Embora não tratando do sigilo do auditor, mas sim do contabilista em geral, já se decidiu no sentido exposto no texto. A decisão, a nosso ver, é plenamente aplicável ao caso. "Tribunal Regional Federal da Quinta Região: Ementa. TRIBUTÁRIO. OBRIGAÇÃO DE PRESTAR INFORMAÇÕES AO FISCO. ESCRITÓRIOS DE CONTABILIDADE. SIGILO PROFISSIONAL. AUSÊNCIA DE PREVISÃO LEGAL. 1. A prestação de informações, assim como a apreensão de documentos e equipamentos, constituem instrumentos indispensáveis à atividade fiscalizatória do Estado, nos termos do art. 197 do CTN e dos arts. 34 a 36 da Lei n. 9.430. O poder de investigação do Poder Público é dirigido a coibir atividades violadoras à ordem jurídica, e a garantia de privacidade e o sigilo não se estendem às atividades ilícitas. Todavia, a própria lei ressalva o sigilo profissional, eximindo aqueles que estejam legalmente obrigados a observar segredo em razão de cargo, ofício, função, ministério, atividade ou profissão de prestar informações quanto aos respectivos fatos. A violação do segredo profissional está inclusive capitulada como crime (art. 154 do CP), pois o profissional ostenta a condição de depositário de informações confidenciais resultantes de sua relação com o cliente (art. 229, I, do CC, art. 406, II, do CPC, e art. 207 do CPP). Com efeito, a possibilidade de quebra do sigilo deve estar prevista em lei específica. 2. A relação profissional estabelecida entre cliente e contador está assentada na confiança gerada por expectativas legítimas e recíprocas. Com efeito, impor ao profissional a obrigação de identificar o cliente que se encontra em situação irregular perante o Fisco e comunicar o fato à autoridade administrativa implica dele exigir que quebre essa confiança para denunciar fato por ele conhecido em razão do exercício profissional (art. $2^{\circ}$, II, da 
Em relação aos demais órgãos estatais (não fiscalizadores da profissão ou de arrecadação tributária), aos quais está vedado o acesso à contabilidade empresarial, ${ }^{160}$ entendemos que a confidencialidade das informações obtidas em auditoria deve sempre prevalecer, obrigando o auditor externo a invocar a prerrogativa de sigilo para não atender eventuais solicitações ilegais. ${ }^{161}$

Resolução CFC n. 290/70, editada com base no art. 10 do Decreto-lei 1.040/69). 'O interesse público do sigilo profissional decorre do fato de se constituir em um elemento essencial à existência e à dignidade de certas categorias, e à necessidade de se tutelar a confiança nelas depositada, sem o que seria inviável o desempenho de suas funções, bem como por se revelar em uma exigência da vida e da paz social.' (STJ, $4^{\text {a }}$ Turma, RMS 9.612/SP, rel. Min César Asfor, DJ 09.11.1998, p. 103). 3. E ainda que se entenda não ter, a exigência, imbricações com o segredo profissional, a conduta da autoridade fiscal carece de respaldo legal, ante a inexistência de lei que designe o contador como pessoa obrigada a prestar informações obtidas no desempenho de sua profissão (art. $5^{\circ}$, II, da CF)".

${ }^{160}$ Como lembramos anteriormente no texto, o sigilo da contabilidade (fundamento sobre o qual se funda a proteção dos dados de auditoria), como regra, só comporta as exceções legalmente previstas em seus estritos termos, dentre as quais não se encontram as prerrogativas de quaisquer órgãos que não os de fiscalização tributária, do Poder Judiciário ou que possuam poderes investigatórios das autoridades judiciais. Haroldo Malheiros Duclerc Verçosa (Op.cit. p. 199) explica com brilhantismo as hipóteses de quebra de dever de sigilo: "Em circunstâncias normais da atividade mercantil, somente os agentes fiscais podem ter acesso aos livros e documentos dos empresários, no estrito exercício de suas funções (NCC, art. 1.193). Além disso, exercendo suas funções constitucionais, as Comissões Parlamentares de Inquérito podem requerer informações e examinar livros e documentos dos empresários, que digam respeito ao objeto preciso da investigação (CF, art. 58, § $\left.3^{\circ}\right)$. Esta situação, como se verifica, é excepcional (...) No regime do Código Comercial Brasileiro, esta regra era quebrada em duas hipóteses, as quais foram apropriadas no mesmo sentido pelo Código Civil/2002. Trata-se da exibição parcial e da exibição integral dos livros e documentos mercantis".

${ }^{161}$ Exemplo disto é o ocorrido com a fiscalização do trabalho. Entendemos que, não possuindo autorização legal de acesso à escrituração contábil, também não poderá ter acesso às informações e documentos de auditoria. Veja-se, neste sentido, interessante decisão indeferindo o acesso de tais autoridades às informações contábeis: "Tribunal Regional Federal da Primeira Região: Classe: REO - REMESSA EX-OFFICIO 01121668 Processo: 199601121668 UF: PA Órgão Julgador: TERCEIRA TURMA Data da decisão: 16.12.1997 Documento: TRF100058895 Fonte DJ DATA: 06.02.1998 PÁGINA: 193 Relator(a) JUIZ TOURINHO NETO Decisão Por unanimidade, negar provimento à remessa. Ementa. ADMINISTRATIVO. FISCALIZAÇÃO DO TRABALHO. EXIGÊNCIA DE APRESENTAÇÃO DE LIVROS CONTÁBEIS. ATO ABUSIVO. Afigura-se abusivo o ato do Fiscal do Trabalho, que após examinar os documentos necessários para o exame do recolhimento do FGTS e do pagamento das férias dos empregados da empresa, exige a apresentação dos livros contábeis, estranhos à matéria trabalhista". E no inteiro teor da decisão acima citada, destaca o relator, referindo-se ao parecer da Procuradoria-Geral da República, que "a exigência levada a termo pelo delegado do trabalho não encontra amparo legal. Em seu artigo 630, $\S \S 3^{\circ}$ e $4^{\circ}$, prevê a CLT a apresentação de 'quaisquer documentos que digam respeito ao fiel cumprimento das normas de proteção ao trabalho'. Ora, da leitura do trecho do artigo transcrito, depreende-se que a abrangência da competência do fiscal do trabalho restringe-se à fiscalização dos documentos relativos às relações laborais, não abrangendo a fiscalização tributária, que deve ser feita pelo órgão competente. Assim, uma vez apresentados os documentos comprobatórios do recebimento das guias do FGTS relativo às férias, bem como do lançamento no caixa do mês do numerário destinado ao pagamento de férias por parte da impetrante, abusiva e especulativa se tornou a requisição do fiscal do trabalho, no tocante à análise dos livros fiscais. Destarte, a infringência de multa por parte do referido fiscal foi praticada com abuso de poder, haja vista a falta de competência deste para fazer análise nos livros contábeis da empresa, sob o pálio de fiscalização de direitos trabalhistas. Os atos administrativos dos agentes públicos têm que observar, como condição de sua validade, a competência. No magistério de Hely Lopes Meirelles, esta é entendida como 'o poder atribuído ao agente da Administração para desempenho específico de suas funções' (MEIRELLES, Hely Lopes. Direito Administrativo Brasileiro, Editora Malheiros, 18 $8^{\mathrm{a}}$ edição, 1993). Vê-se, assim, não ser pertinente às funções do fiscal do trabalho o manuseio dos livros contábeis da empresa". Outro exemplo que indeferiu o acesso a documentos de auditoria externa envolveu o Ministério Público Federal, cuja decisão transcrevemos a seguir. "Tribunal Regional Federal da $3^{\text {a }}$ Região: Órgão julgador TERCEIRA TURMA Fonte DJU 
Questão que também envolve discussão quanto à prevalência da obrigação de confidencialidade do auditor independente é a relativa à determinação judicial de prestação de informações ou exibição dos papéis de trabalho de auditoria. Em outras palavras, a dúvida diz respeito à possibilidade de o juiz determinar, em ação criminal ou cível, usualmente envolvendo a entidade auditada ou seus representantes (e na qual o auditor, em regra, não é parte), a revelação de informações em detrimento do dever de sigilo do auditor.

Sobre o tema, a jurisprudência tem sido amplamente divergente, ora autorizando a divulgação das informações, ora decidindo a favor da prevalência do sigilo profissional. As decisões que determinam a abertura dos dados de auditoria se baseiam na inoponibilidade do dever de sigilo a uma ordem judicial, a qual consistiria, por si, justa causa para sua quebra, argumentando ainda que o sigilo não é prerrogativa absoluta do auditor. ${ }^{162}$ Por sua vez, a corrente jurisprudencial que entende deva prevalecer o dever de confidencialidade encontra-se lastreada nas razões de interesse público que fundamentam a

DATA:14.04.2004 PÁGINA: 208 Decisão Prosseguindo o julgamento, a Turma, por unanimidade, negou provimento ao agravo regimental, nos termos do voto do Relator. Ementa. AGRAVO REGIMENTAL NO AGRAVO DE INSTRUMENTO. MINISTÉRIO PÚBLICO. ACESSO A DOCUMENTO INTERNO DE EMPRESA PRIVADA. RECURSOS E INTERESSES DA PRÓPRIA INSTITUIÇÃO FINANCEIRA. DIREITO À INTIMIDADE E AO SIGILO. SATISFATIVIDADE DA DECISÃO. 1. O documento pretendido pelo Ministério Público - relatório de auditoria relativo a licitações no setor de engenharia do Banco do Brasil - não veicula qualquer notícia sobre aplicação de dinheiro público, mas de recursos e interesses da própria instituição financeira. 2. Afastada a aplicação da jurisprudência do STF (mandado de segurança n. 21.729-4/DF), a qual reconheceu aquele direito ao MPF em hipótese do documento particular referir-se a dinheiro público. 3. As empresas, tal como os indivíduos, também têm direito à intimidade e ao sigilo de correspondência. 4. Natureza satisfativa da decisão de primeiro grau, gerando o esgotamento do mérito do mandado de segurança, bem como do agravo de instrumento. 5. Agravo Regimental improvido".

${ }^{162}$ Tribunal de Justiça de São Paulo: "AÇÃO DE ANULAÇÃO - Assembleia que deliberou a autoliquidação de cooperativa - Exigência, por perito judicial, à sociedade civil de prestação de serviços de auditoria externa, de documentos indispensáveis para completa análise da situação - Admissibilidade Inexistência de afronta ao sigilo profissional - Inteligência dos arts. 339, 341 e 429 do CPC (TJSP) RT 748/236”. Tribunal de Justiça de São Paulo: "MANDADO DE SEGURANÇA - Empresa de auditoria externa - Decisão que determinou a apresentação de documentos e papéis de trabalho da empresa para verificação de contas, em ação movida por banco credor que objetiva deliberação assemblear relacionada à autoliquidação de cooperativa - Invocação de sigilo profissional - Direito que não é absoluto - Dever de colaborar com o Poder Judiciário para o descobrimento da verdade - Segurança denegada. (Mandado de Segurança n. 53.392-4 - São Paulo - 10ª Câmara de Direito Privado - Relator: Ruy Camilo - 14.10.97 V.U.)". Tribunal de Justiça de São Paulo: "MANDADO DE SEGURANÇA - Ato judicial - Decisão que determinou a revelação de informações decorrentes de auditoria em empresa - Impetrante que se recusou a fornecê-las, invocando o direito de sigilo profissional - Inadmissibilidade - Direito que não é absoluto e não pode ser invocado diante de requisição judicial - Existência do dever de colaboração com o Poder Judiciário para o descobrimento da verdade - Possibilidade de violação, por determinação legal, quando houver uma "justa causa" respaldando a atitude - "Justa causa" que é elemento normativo do tipo e exclui a tipicidade, ou seja, o crime - Ordem denegada. (Mandado de Segurança n. 405.245-4/5-00 - São Paulo - 3 $3^{\text {a }}$ Câmara de Direito Privado - Relator: Beretta da Silveira - 13.05.08 - V.U. - Voto n. 14.420)". 
imposição do sigilo ao auditor e na inexistência de lei específica a determinar o rompimento desta regra. ${ }^{163}$

Filiamo-nos à corrente que entende ser possível ao juiz determinar a prestação de informações pelo auditor independente, em detrimento do dever de confidencialidade, ainda que este não seja parte em processo civil ou criminal. Isto porque, uma melhor análise dos argumentos daqueles que não admitem a quebra do sigilo profissional do auditor faz com que vejamos sua insubsistência.

163 Superior Tribunal de Justiça: “ACÓRDÃO: ROMS 9612/SP (199800228268). RECURSO ORDINÁRIO EM MANDADO DE SEGURANÇA. DECISÃO: Por unanimidade, dar provimento ao recurso. DATA DA DECISÃO: 03.09.1998 ÓRGÃ̉O JULGADOR: - QUARTA TURMA. E M E N T A. PROCESSUAL CIVIL. SIGILO PROFISSIONAL RESGUARDADO. O sigilo profissional é exigência fundamental da vida social que deve ser respeitado como princípio de ordem pública, por isso mesmo que o Poder Judiciário não dispõe de força cogente para impor a sua revelação, salvo na hipótese de existir específica norma de lei formal autorizando a possibilidade de sua quebra, o que não se verifica na espécie. $O$ interesse público do sigilo profissional decorre do fato de se constituir em um elemento essencial à existência e à dignidade de certas categorias, e à necessidade de se tutelar a confiança nelas depositada, sem o que seria inviável o desempenho de suas funções, bem como por se revelar em uma exigência da vida e da paz social. Hipótese em que se exigiu da recorrente ela que tem notória especialização em serviços contábeis e de auditoria e não é parte na causa - a revelação de segredos profissionais obtidos quando anteriormente prestou serviços à ré da ação. Recurso provido, com a concessão da segurança. RELATOR: MINISTRO CESAR ASFOR ROCHA". Tribunal de Justiça de São Paulo: "PROVA - Criminal - Pericial - Exibição de auditoria efetuada em empresa pública municipal - Quebra de sigilo profissional da empresa auditora Inadmissibilidade - Empresa que não está obrigada a apresentar seus trabalhos - Inaplicabilidade do artigo 37, da Constituição da República - Perícia privada, ademais, que não é considerada de valor probante ante a oficial - Embargos rejeitados. (Embargos de Declaração em Mandado de Segurança n. 173.633-3 - Campinas - 1aㅡ Câma Criminal - Relator: Fortes Barbosa - 11.09.95 - M.V.). Tribunal de Justiça de São Paulo: "MANDADO DE SEGURANÇA - Sigilo profissional - Determinação pelo Juízo da falência para que empresa, especializada na área contábil, apresentasse documentos e papéis resultantes de auditoria externa independente realizada na empresa falida - Ilegalidade da determinação judicial - Recusa que se mostra legítima - Concessão de mandado de segurança nesse sentido". (Mandado de Segurança n. 264.541-4 - São Paulo - 6 ${ }^{\mathbf{a}}$ Câmara de Direito Privado - Relator: Octavio Helene - 17.10.02 - V.U.). Tribunal de Justiça de São Paulo: "MANDADO DE SEGURANÇA - Ato judicial - Requisição de documentos relativos à auditoria externa realizada em empresa falida - Inadmissibilidade - Violação ao sigilo profissional - Ilegalidade da determinação judicial - Recusa legítima - Ordem concedida - JTJ 261/441”. Tribunal de Justiça de São Paulo: "MANDADO DE SEGURANÇA - Matéria criminal - Crime falimentar - Empresa de auditoria Determinação de envio de documentos - Impossibilidade - Manutenção do sigilo profissional - Segurança concedida - JTJ 275/586". Tribunal de Justiça do Rio de Janeiro: "0100661-77.2003.8.19.0001 (2004.001.15884) - APELAÇÃO - 1 ${ }^{\underline{a}}$ Ementa. DES. NAGIB SLAIBI - Julgamento: 17.08.2004 - SEXTA CÂMARA CÍVEL. Direito Civil. Ação cautelar de exibição de documentos posta em face de empresa de auditoria. Defesa fundada no sigilo profissional. Caráter vinculante das resoluções do Conselho Federal de Contabilidade que dispõem sobre o exercício profissional, que, no entanto, não excluem a cognição judicial exigida pelo disposto no art. $5^{\circ}, \mathrm{XXXV}$, da Constituição como garantia mínima do Estado Democrático de Direito. Ação cautelar em que se exigiu da recorrente - que tem notória especialização em serviços contábeis e de auditoria e que não ostenta legitimidade ad causam para a futura demanda principal de indenização - a revelação de segredos profissionais obtidos quando anteriormente prestou serviços a condomínio edilício. $\mathrm{O}$ sigilo profissional é exigência fundamental da vida social que deve ser respeitado como princípio de ordem pública. O interesse público do sigilo profissional decorre do fato de se constituir em um elemento essencial à existência e à dignidade de certas categorias, e à necessidade de se tutelar a confiança nelas depositada, sem o que seria inviável o desempenho de suas funções, bem como por se revelar em uma exigência da vida e da paz social (precedentes do Superior Tribunal de Justiça). O auditor deve respeitar e assegurar o sigilo, relativamente às informações obtidas durante seu trabalho na entidade auditada, a circunstância, sem autorização expressa da entidade, salvo quando houver obrigação legal de fazê-lo, inclusive em decorrência 
A alegação de que não há lei específica a determinar a quebra do dever de confidencialidade por parte do auditor não chega a convencer. De fato, se é possível ao juiz determinar a exibição dos livros contábeis, total ou parcialmente, nos termos dos arts. 381 e 382 do Código de Processo Civil (CPC), não é razoável que seja proibido ao magistrado determinar a exibição da documentação de auditoria e das informações dela constantes. Ora, se é possível ao juiz ordenar a abertura dos livros comerciais em juízo, os quais possuem a base de toda escrituração da entidade auditada, seria verdadeiro contrassenso vedar a exibição de documentos que se baseiam justamente na escrituração mencionada. Tal linha de argumentação equivale a afirmar, contraditoriamente, que aquele que pode o mais (ordenar a exibição da escrituração) não possa o menos (determinar a exibição dos documentos de auditoria).

A autorização legal para que o auditor exiba a documentação de seu trabalho em juízo, portanto, deve ser considerada implícita na faculdade de exibição da escrituração contábil em juízo, nos termos dos arts. 381 e 382 do CPC.

O fato de o auditor não ser parte na lide penal ou civil também não deve prevalecer. Como entendemos que o fundamento da possibilidade de quebra do sigilo profissional se encontra implícito na faculdade judicial de exibição da contabilidade em juízo, é de se entender que a exibição cabe tanto em face da parte no litígio quanto de terceiros que não sejam partes (arts. 355 e 360 do CPC). A única diferença entre essas duas hipóteses (exibição determinada em face da parte ou de terceiro) será a natureza final do provimento jurisdicional em caso de recusa injustificada: se contra a parte, presumir-se-ão verdadeiros os fatos que, por meio do documento ou da coisa, a parte contrária pretendia provar (art. 359 do CPC); se contra terceiros, determinará o juiz a busca e apreensão do documento ou coisa (art. 362 do CPC).

Também não vemos suficiente argumento na alegação de que a proteção da confidencialidade do sigilo atende a razões de interesse público. Referida afirmação, obviamente, não pode ser levada a extremos, nem interpretada em caráter absoluto. Haverá casos, efetivamente, em que o interesse público na quebra do sigilo profissional do auditor suplantará o interesse protegido pela manutenção deste mesmo sigilo. Justamente por isso, entendemos que o magistrado deve ponderar em cada caso concreto quanto à conveniência da manutenção ou não da confidencialidade do auditor.

de decisão cautelar ou definitiva proferida em processo judicial. Provimento do apelo com a cassação da sentença, julgando-se extinto o processo pela ilegitimidade passiva, com a inversão dos ônus sucumbenciais". 
Leve-se em consideração ainda que seria extremamente contraditório que autoridades administrativas fiscalizadoras do mercado de capitais e da profissão de auditoria externa (CVM, CFC, CRCs, etc.) tenham amplo acesso aos documentos do auditor, como vimos anteriormente, e este mesmo acesso seja vedado ao Poder Judiciário em processo regular.

Devemos ainda analisar a situação do auditor independente em face do chamamento judicial para funcionar como testemunha em processo judicial (de natureza cível ou criminal) envolvendo matéria inerente ao objeto da auditoria, ocasião em que restará em conflito o dever de sigilo e a obrigação de colaborar com o Poder Judiciário na descoberta da verdade.

Como se sabe, é comum que, no exercício de sua atividade, o auditor externo se depare com fraudes e irregularidades que deem origem a processos cíveis ou criminais contra os responsáveis, vindo o auditor a ser chamado em juízo como testemunha dos fatos. Nesses casos, a questão é saber se o auditor, não autorizado a revelar o mérito de seu trabalho pela entidade auditada, poderá escusar-se do dever de depor como testemunha diante de sua obrigação de confidencialidade (art. 207 do CPP e art. 406, II, do CPC).

Muito embora haja decisões que isentem o contabilista (categoria profissional à qual o auditor externo pertence) do dever de testemunhar em juízo, ${ }^{164}$ entendemos que a questão deva ser analisada em cada caso concreto, ponderando-se os bens jurídicos colocados em jogo. Em havendo possibilidade de o auditor esclarecer os fatos em juízo

${ }^{164}$ Tribunal Regional Federal da $4^{\underline{a}}$ Região: "Processo HC 9504213910 HC - HABEAS CORPUS. Relator(a) TÂNIA TEREZINHA CARDOSO ESCOBAR. Sigla do órgão: TRF4. Órgão julgador: SEGUNDA TURMA. Fonte DJ 13.09.1995 PÁGINA: 61114. Decisão POR MAIORIA. VENCIDO O JUIZ DORIA FURQUIM, ENTENDENDO QUE O CONTABILISTA TEM O DEVER DE DEPOR, AINDA QUE O CÓDIGO DE ÉTICA DE SUA CORPORAÇÃO O EXIMA DESSE DEVER; ENTENDENDO AINDA QUE SOMENTE A POSTERIORI, PODE SER APRECIADA A DISPENSA AO DEPOIMENTO. Descrição: JURISPRUDÊNCIA: STF, RE 86.402-RS, DJ 02.06.78, P. 3932. Ementa. PROCESSO PENAL. "HABEAS CORPUS". CONTABILISTA. SIGILO PROFISSIONAL. DEPOIMENTO TESTEMUNHAL. PROIBIÇÃO LEGAL. 1. O DEVER JURÍDICO DE DEPOR CONTIDO NO PRECEITO DO ART-206 DO CPP-41 NÃO É ABSOLUTO. HÁ CASOS EM QUE AS TESTEMUNHAS PODEM RECUSAR-SE A DEPOR, ESTANDO, EM OUTROS, EXPRESSAMENTE PROIBIDAS DE FAZÊ-LO, SE NÃO DISPENSADAS PELA PARTE INTERESSADA. 2. O CONTABILISTA QUE TEM O DEVER DE SIGILO PROFISSIONAL, ARROLADO COMO TESTEMUNHA DA ACUSAÇÃO EM AÇÃO PENAL MOVIDA CONTRA O SEU EMPREGADOR POR FALTA DE RECOLHIMENTO DE CONTRIBUIÇÕES PREVIDENCIÁRIAS, NÃO ESTANDO POR ESTE DESOBRIGADO, ESTÁ PROIBIDO DE DEPOR POR IMPOSIÇÃO DO ART.-207 DO CÓDIGO DE PROCESSO PENAL. 3. O DEVER DE SIGILO PROFISSIONAL, INSTITUIIDO PARA ASSEGURAR A CONFIANÇA DA SOCIEDADE EM DETERMINADAS PROFISSÕES, MERECEU DUPLA ATENÇÃO DO LEGISLADOR. ALÉM DAQUELA PROIBIÇÃO, A VIOLAÇÃO DO SEGREDO CONFIGURA O CRIME PREVISTO NO ART-154 DO CP-40.” 
sem revelar questões internas da entidade auditada, não deverá prevalecer a recusa ao dever de testemunhar. ${ }^{165}$

Também causa polêmica referente à violação de sigilo a hipótese de o auditor ser demandado em juízo por terceiro usuário das informações contábeis auditadas, que alega ter sofrido prejuízo derivado da conduta inidônea deste profissional. A questão aqui é saber se o auditor, em sua defesa, pode produzir prova (documental, testemunhal, etc.) ou mesmo apresentar documentos nos autos que envolvam matéria sigilosa objeto da auditoria realizada.

Sobre o tema, estudo específico na Comunidade Europeia revelou que os diversos países dão distintas respostas ao problema. ${ }^{166} \mathrm{~A}$ tabela a seguir transcrita demonstra a solução dada por cada um:

\footnotetext{
${ }^{165}$ Caso interessante envolvendo situação em que o auditor deu causa, por seu trabalho, a processo penal contra pessoa envolvida em crime de estelionato, teve decisão do STJ reconhecendo a importância do testemunho do profissional de auditoria, determinando a obrigação de depor, devendo ser separadas as explicações a serem dadas em juízo dos fatos que pudessem revelar questões interna corporis da entidade auditada, mantendo o sigilo quanto a estes últimos. A ementa veio assim redigida: "Processo ROMS 200400061297 ROMS - RECURSO ORDINÁRIO EM MANDADO DE SEGURANÇA - 17783. Relator(a) FELIX FISCHER. Sigla do órgão: STJ. Órgão julgador QUINTA TURMA. Fonte: DJ DATA:31.05.2004 PG:00331 RJADCOAS VOL.:00057 PG:00545 Decisão. Vistos, relatados e discutidos os autos em que são partes as acima indicadas, acordam os Ministros da QUINTA TURMA do Superior Tribunal de Justiça, por unanimidade, dar parcial provimento ao recurso, nos termos do voto do Sr. Ministro Relator. Os Srs. Ministros Gilson Dipp, Laurita Vaz e José Arnaldo da Fonseca votaram com o Sr. Ministro Relator. Ausente, justificadamente, o Sr. Ministro Jorge Scartezzini. Ementa PROCESSUAL PENAL. TESTEMUNHA. ESCUSA. ART. 207 DO CPP. CONTADOR. REALIZAÇÃO DE AUDITORIA. QUESTÕES INTERNAS DA EMPRESA. DEVER DE SIGILO. I - É possível a um contador prestar esclarecimentos sobre o método de realização de uma auditoria específica e o porquê das conclusões a que chegou, sem que adentre a questões interna corporis da empresa auditada. II - Relevância do depoimento do experto, porquanto os fatos por ele relatados, em razão da feitura da auditoria, é que levaram à instauração da persecutio criminis contra o recorrido, diante da suposta prática de estelionato contra a empresa. III - Hipótese em que o acórdão recorrido resguardou o sigilo profissional em relação às questões internas da empresa, contudo, afastou a sua aplicação no tocante aos termos da perícia realizada. Conclusões que levam, na verdade, a uma concessão parcial da segurança, e não à sua denegação. Recurso parcialmente provido”.

${ }^{166}$ EUROPEAN COMISSION. A study on systems of civil liability of statutory auditors in the context of a single Market for auditing services in the European Union. Disponível em <http://ec.europa.eu/internal_market/auditing/liability/index_en.htm\#study>. Acesso em 27 dez. 2009.
} 
Tabela 6: Regime legal dos diversos países da Comunidade Europeia quanto à permissão para o auditor produzir prova confidencial em sua própria defesa em processo judicial

\begin{tabular}{|cc}
\hline País & $\begin{array}{c}\text { O auditor independente pode produzir documentos } \\
\text { confidenciais em sua própria defesa? }\end{array}$ \\
\hline Áustria & Sim \\
\hline Bélgica & Sim \\
\hline Dinamarca & Não \\
\hline Finlândia & Sim* \\
\hline França & Sim \\
\hline Alemanha & Sim** \\
\hline Grécia & Não \\
\hline Irlanda & Sim \\
\hline Itália & Sim \\
\hline Luxemburgo & Sim \\
\hline Holanda & Sim \\
\hline Portugal & Sim*** \\
\hline Espanha & Sim*** \\
\hline Suíça & Sim \\
\hline Reino Unido & Sim \\
\hline $\begin{array}{l}\text { * No entanto, em alguns casos tais informações poderiam ser declaradas confidenciais pelo } \\
\text { produzir documentos confidenciais em sua defesa em uma ação de responsabilidade, ele iria } \\
\text { provavelmente ser autorizado a violar o seu dever de confidencialidade para proteger seu } \\
\text { *** Com a permissão do tribunal. }\end{array}$ \\
\hline
\end{tabular}

Fonte: EUROPEAN COMISSION. A study on systems of civil liability of statutory auditors in the context of a single Market for auditing services in the European Union

Verifica-se claramente que a solução dada pela maioria dos países é a de se permitir a produção de documentos confidenciais pelo auditor em sua própria defesa, solução esta que efetivamente nos parece a melhor, por fazer preponderar o primado da ampla defesa de quem é demandado em processo judicial sobre o interesse na manutenção do sigilo profissional. A manutenção da confidencialidade dos dados trazidos aos autos do processo, como ocorre em alguns dos países supracitados, parece igualmente desejável, por evitar que, através da publicidade do processo em juízo, informações confidenciais venham a ser conhecidas por terceiros. 
Por fim, ainda referente à obrigação de confidencialidade do auditor, vem tomando corpo, principalmente após os diversos casos de fraudes contábeis internacionais, a tese de que o auditor independente, ao tomar conhecimento de fatos violadores da lei e potencialmente prejudiciais a terceiros por parte da administração da entidade auditada, deve denunciá-los aos órgãos sociais responsáveis pela tomada de providências (Conselho de Administração, Comitê de auditoria, etc.) ou mesmo aos órgãos estatais responsáveis pela investigação e punição de referidas práticas. Cumpre neste momento, portanto, analisar este dever de delação do auditor externo em face de sua obrigação de sigilo.

A obrigatoriedade de delação do auditor independente diretamente à Consob foi acolhida na Itália, no art. 155, 2, do Decreto Legislativo de 24 de fevereiro de 1998, n. 58. ${ }^{167}$ No Brasil, dentre outras normas, a obrigação consta do art. 23 da Resolução n. 3.198/04 do BACEN ${ }^{168}$ e do art. 29 da Resolução CNSP n. 118/04. ${ }^{169}$

Aqui não parece haver qualquer problema com relação à divulgação do sigilo. Por dois motivos: 1) o sigilo profissional do contabilista, bem como o do auditor, abrange o exercício profissional lícito por parte da entidade auditada, não acobertando práticas ilícitas ou até mesmo criminosas; ${ }^{170}$ 2) não sendo absoluto, o dever de sigilo pode ser excepcionado por norma específica que permita sua divulgação (Resolução n. 1.100/07 do CFC).

\footnotetext{
167 "La società di revisione ha diritto di ottenere dagli amministratori della società documenti e notizie utili alla revisione e può procedere ad accertamenti, ispezioni e controlli; essa informa senza indugio la Consob e il collegio sindacale dei fatti ritenuti censurabili" (grifos nossos).

168 "Art. 23. O auditor independente e o comitê de auditoria,quando instalado, devem, individualmente ou em conjunto, comunicar formalmente ao Banco Central do Brasil, no prazo máximo de três dias úteis da identificação, a existência ou as evidências de erro ou fraude representadas por: I - inobservância de normas legais e regulamentares, que coloquem em risco a continuidade da entidade auditada; II - fraudes de qualquer valor perpetradas pela administração da instituição; III - fraudes relevantes perpetradas por funcionários da entidade ou terceiros; IV - erros que resultem em incorreções relevantes nas demonstrações contábeis da entidade."

169 "Art. 29. O auditor independente e comitê de auditoria, quando existente, e o diretor responsável, devem, individualmente ou em conjunto, comunicar formalmente à SUSEP, no prazo máximo de três dias úteis da identificação, a existência ou as evidências de erros ou fraudes representadas por: I - inobservância de normas legais e regulamentares, que coloquem em risco a continuidade da sociedade supervisionada; II fraudes de qualquer valor perpetradas pela administração da sociedade supervisionada; III - fraudes relevantes perpetradas por funcionários da sociedade supervisionada ou terceiros; e IV - erros que resultem em incorreções relevantes nas demonstrações contábeis da sociedade supervisionada."

${ }^{170}$ Neste sentido, interessante a decisão do Tribunal Regional Federal da $3^{\underline{a}}$ Região: Classe: ACR APELAÇÃO CRIMINAL - 16013. Processo: 200161810067449 UF: SP Órgão Julgador: PRIMEIRA TURMA. Data da decisão: 03.10.2006. Documento: TRF300106844. Não está obrigado ao dever de sigilo profissional o contabilista empregado de uma firma que toma conhecimento de fraudes perpetradas através da escrituração mercantil, realizada por outros contadores a mando do patrão (Código de Ética Profissional do Contabilista, Capítulo II, artigo $2^{\underline{o}}$, inciso II). Ora, se o regulamento que disciplina a profissão de contabilista exige do profissional a guarda de sigilo sobre "exercício profissional lícito", resta evidente que a salvaguarda não abrange a falsificação de balancetes da empresa.
} 


\subsubsection{Obrigação de independência}

A independência entre as partes é elemento necessário ao contrato envolvendo a atividade de auditoria externa. Embora comumente se refira à independência do auditor, cuida-se de obrigação recíproca das partes contratantes de serviços de auditoria externa, por cuja ausência tanto o auditor quanto a entidade auditada poderão ser demandados, e até mesmo punidos. Também são atingidos pelo dever de imparcialidade os componentes da equipe de auditoria, em caso de prestação coletiva coordenada por sociedade de auditoria.

A isenção entre as partes, estado em que se não haja qualquer conflito aparente de interesses a determinar potenciais vieses ou distorções no trabalho de auditoria, compõe-se, segundo a IFAC, de dois aspectos: a) independência mental ou "de espírito" (independence of mind): que se refere ao estado mental em que é possível ao auditor a emissão de uma opinião em parecer sem ser afetado por influências que comprometam seu julgamento profissional, permitindo ao profissional agir com integridade e exercer sua função com objetividade e ceticismo profissional; b) aparência de independência (independence in appearance): que se resume no procedimento destinado a evitar fatos e circunstâncias significativos razoáveis de modo a que um terceiro informado, possuindo conhecimento de todas as informações relevantes, incluindo quaisquer salvaguardas aplicadas, concluiria razoavelmente que a empresa, ou um membro da equipe, tiveram sua integridade, objetividade ou ceticismo profissional comprometidos. ${ }^{171}$

Entendemos que a independência constitui-se elemento complementar ao núcleo do negócio jurídico (contrato de prestação de serviços especial) estabelecido entre auditor e auditado, na esteira dos ensinamentos de Pontes de Miranda, que divide os elementos do negócio jurídico em nucleares, completantes e complementares:

Se o elemento de vontade é multíplice, alguma declaração de vontade, ou alguma manifestação de vontade exerce papel de núcleo, isto é, elemento

\footnotetext{
${ }^{171}$ No texto original da IFAC, os termos são definidos na seguinte forma: "Independence comprises: (a) Independence of mind - the state of mind that permits the provision of an opinion without being affected by influences that compromise professional judgment, allowing an individual to act with integrity, and exercise objectivity and professional skepticism. (b) Independence in appearance - the avoidance of facts and circumstances that are so significant a reasonable and informed third party, having knowledge of all relevant information, including any safeguards applied, would reasonably conclude a firm's, or a member of the assurance team's, integrity, objectivity or professional skepticism had been compromised".
} 
definidor do conteúdo específico do negócio jurídico. Noutros termos: sem esse elemento, ou o negócio jurídico não seria, ou seria outro negócio jurídico. Em torno do núcleo, estão outros elementos volitivos, inclusive os que as regras jurídicas dispositivas revelam; sem que sejam necessários à determinação do conteúdo específico do negócio jurídico. Sem eles, o negócio jurídico, tal qual é, em sua especificidade, seria; e a diferença entre o negócio jurídico sem eles ou o negócio jurídico com eles não the afetaria a natureza (...). O elemento do suporte fático em contato com o núcleo ou a) o completa (elemento completante do núcleo) ou b) o complementa (elemento complementar). ${ }^{172}$

$\mathrm{Na}$ forma supracitada, os elementos nucleares e completantes influenciariam a própria natureza e existência do ato jurídico, enquanto os complementares repercutiriam em sua validade ou eficácia, sem atingi-lo em seu âmago.

Verifica-se que no contrato de prestação de serviços envolvendo a atividade de auditoria externa, a independência das partes é elemento que complementa o núcleo da manifestação volitiva do contrato efetivado. Em outros contratos, a independência das partes poderia ser inserida como mero elemento acidental (accidentalia negotii) por não fazer parte de sua substância. Em se tratando de auditoria externa, entretanto, esta é da essência do negócio jurídico (essentialia negotii).

A independência, aliás, é a razão de ser da auditoria externa. Como visa, em regra, ao interesse de terceiros indeterminados, a situação de liberdade ou autonomia do auditor em face do auditado é condição sine qua non para que haja algum interesse econômico ou jurídico na prestação desses serviços. Sem independência entre os contratantes, portanto, não haveria razão para contratar tal modalidade de revisão de contas, uma vez que sua ratio essendi está na credibilidade das informações prestadas pelo auditor, que não pode subsistir se houver qualquer vínculo que ligue o interesse das partes além daquele necessário para o estabelecimento do contrato. ${ }^{173}$

(INTERNATIONAL FEDERATION OF ACCOUNTANTS. Handbook of international standards on auditing and quality control. Disponível em: <http//www.ifac.org>. Acesso em 03 jan. 2010).

${ }_{172}$ MIRANDA, Pontes de. Tratado de Direito Privado. São Paulo: Revista dos Tribunais, 1983. t. III. p. 11.

${ }^{173}$ A Resolução n. 1.267/09 do CFC igualmente retrata este ponto de vista em seu item 9: "A condição de independência é fundamental e óbvia para o exercício da atividade de auditoria independente. Entende-se como independência o estado no qual as obrigações ou os interesses da entidade de auditoria são, suficientemente, isentos dos interesses das entidades auditadas para permitir que os serviços sejam prestados com objetividade. Em suma, é a capacidade que a entidade de auditoria tem de julgar e atuar com integridade e objetividade, permitindo a emissão de relatórios imparciais em relação à entidade auditada, aos acionistas, 
A auditoria não independente falha em informar corretamente aos terceiros destinatários sobre as condições econômicas da entidade auditada, não facilita a melhor alocação de recursos econômicos ao reduzir o risco do investimento no mercado financeiro e de capitais, nem minimiza o potencial conflito de agência existente entre administradores e acionistas. Havendo dependência entre as partes, resta prejudicada a defesa do interesse público pelo qual é determinada a atividade de auditoria. Em suma, não se atingem quaisquer dos objetivos a que a atividade tratada originalmente se propõe.

Tamanha é a importância da desvinculação dos contratantes que, na ausência de independência, não deverá haver entre as partes contratação com escopo de verificação isenta de demonstrações contábeis, devendo ocorrer recusa à contratação ou cessação da prestação dos serviços anteriormente contratados, diante de vedação expressa em norma. ${ }^{174}$ Em termos técnicos, entendemos que a relação de dependência entre as partes conduz à falta de legitimação ${ }^{175}$ destas para realizar o negócio jurídico em questão, diante da especial posição da(s) parte(s) em face do objeto contratado.

Se, mesmo diante da ausência de independência, suceder citada contratação entre as partes, entendemos que, por falta de um elemento complementar do núcleo do

aos sócios, aos quotistas, aos cooperados e a todas as demais partes que possam estar relacionadas com o seu trabalho".

${ }^{174}$ As normas de diversos países proíbem a contratação de auditoria externa e obrigam a cessação do contrato e a prestação do serviço na ausência de independência entre as partes. Perante a União Europeia, a Diretiva n. 2006/43/CE ressalta em sua introdução: "Os revisores oficiais de contas e as sociedades de revisores oficiais de contas deverão ser independentes quando realizarem revisões legais das contas. Poderão informar a entidade examinada das questões suscitadas pela revisão ou auditoria, mas deverão abster-se dos processos de decisão internos da entidade examinada. Caso estejam numa situação em que a importância das ameaças à sua independência seja elevada, mesmo após a aplicação de salvaguardas para atenuar estas ameaças, deverão renunciar ou abster-se do trabalho de revisão ou auditoria”. Na Itália, o art. 160 do Decreto Legislativo de 24 de fevereiro de 1998, n. 58, assevera: "Al fine di assicurare l'indipendenza della società e del responsabile della revisione, l'incarico non può essere conferito a società di revisione che si trovino in una delle situazioni di incompatibilità stabilite con regolamento dalla Consob”. No Brasil, igualmente, o art. 22 da Instrução n. 308/99 da CVM estabelece: “Art. 22. Não poderão realizar auditoria independente o auditor independente pessoa física, os sócios e os demais integrantes do quadro técnico de auditor independente - pessoa jurídica quando ficar configurada, em sua atuação na entidade auditada, suas controladas, controladoras ou integrantes de um mesmo grupo econômico, a infringência às normas do Conselho Federal de Contabilidade CFC relativas à independência”. E em seu art. 24, dispõe: "O auditor independente deverá renunciar à função na ocorrência das situações previstas no art. 22".

${ }^{175}$ A doutrina civilista costuma fazer distinção entre incapacidade e falta de legitimação. Enquanto a primeira é condição inata à pessoa física sujeito de direitos, operando inabilitação deste (ou necessidade de representação) para todo ato jurídico (ou uma categoria deles), a falta de legitimação resulta de situação exterior ao sujeito de direitos, pois deriva de sua posição especial em face do objeto do negócio realizado, que o impede de praticá-lo (p.ex., por falta de titularidade do direito ou poder de disposição deste). No caso da prestação de serviços de auditoria externa, em havendo vinculação do auditor ao objeto de sua atividade, a lei retira legitimação das partes para contratarem o serviço. A insistência destas é punida com a ineficácia do ato praticado. 
negócio jurídico estabelecido, levar-se-á a cabo, na verdade, ato jurídico ineficaz, ${ }^{176}$ podendo haver apenas a produção de efeitos residuais e internos entre os contratantes comuns a outras espécies contratuais (consultoria, auditoria interna, operacional, compliance, etc.), mas não ínsitos ao contrato de auditoria externa.

Daí por que a prestação de serviços de auditoria externa sem independência entre as partes é considerada por disposição expressa de norma como sem efeito para o fim de cumprir as obrigações legais a que se destinava, além de sujeitar os contratantes a penalidades ${ }^{177}$ e obrigação de substituir o auditor ou sociedade de auditoria. ${ }^{178}$

\footnotetext{
${ }^{176}$ No sentido da ineficácia do ato, doutrina Marcos Bernardes de Mello, distinguindo as situações de incapacidade e falta de legitimação quanto às consequências: "As consequências da incapacidade e da falta de legitimação também são diferentes. Enquanto a incapacidade leva, sempre, à invalidade, a falta de legitimação pode acarretar (a) somente a ineficácia do negócio jurídico em relação ao titular do bem ou direito a que se dispôs, ou, em algumas espécies, (b) a nulidade, como ocorre na transmissão, pela efetiva tradição de bem móvel" (MELLO, Marcos Bernardes de. Teoria do fato jurídico: plano de validade. São Paulo: Saraiva, 1995. p. 32.).

${ }^{177}$ Neste sentido o art. 27 da Instrução CVM n. 308/99: "Os administradores das entidades auditadas serão responsabilizados pela contratação de auditores independentes que não atenderem às condições previstas nesta Instrução, especialmente quanto à sua independência e à regularidade de seu registro na Comissão de Valores Mobiliários. Parágrafo único. Sem prejuízo das sanções legais cabíveis, constatada a falta de independência do auditor ou a ausência de registro nesta CVM, o trabalho de auditoria será considerado sem efeito para o atendimento da lei e das normas da Comissão". Também o art. 5ํㅡㄹ da Resolução CNSP n._118 de 2004: "Os administradores das sociedades supervisionadas serão responsabilizados pela contratação de auditor independente que não atenda aos requisitos previstos nesta Resolução. Parágrafo único. Constatada a inobservância dos requisitos estabelecidos nesta Resolução, os serviços de auditoria independente serão considerados sem efeito para o atendimento às normas emanadas do Conselho Nacional de Seguros Privados - CNSP e da SUSEP". E finalmente o art. 4º da Resolução n. 3.198/04 do BACEN: "Os administradores das instituições, câmaras e prestadores de serviços referidos no art. $1^{\circ}$ serão responsabilizados pela contratação de auditor independente que não atenda aos requisitos previstos neste regulamento. Parágrafo único. Constatada a inobservância dos requisitos estabelecidos neste regulamento, os serviços de auditoria serão considerados sem efeito para o atendimento às normas emanadas do Conselho Monetário Nacional e do Banco Central do Brasil".

${ }^{178}$ Instrução CVM n. 308/99, art. 24, parágrafo único: "Constatada a não observância do disposto neste artigo, a Comissão de Valores Mobiliários poderá determinar a substituição do auditor independente". Como se verifica, a CVM pode determinar a substituição, sob pena da aplicação de sanções aos destinatários. Sua atuação, entretanto, não incide diretamente sobre o contrato estabelecido entre as partes, nem sobre a deliberação do Conselho de Administração que instituiu os auditores: não há rescisão contratual, nem anulação da deliberação colegiada. Na Itália, porém, a Consob, verificando qualquer incompatibilidade do auditor por ameaça de perda de independência, pode revogar diretamente o encargo conferido ao auditor, determinando a realização de nova deliberação societária para escolha de outros auditores, sob pena de atribuição da tarefa, de ofício, a outros auditores, por decisão da própria Consob. Há, portanto, intervenção direta no contrato e na manifestação colegiada da entidade auditada. Neste sentido, o Decreto Legislativo de 24 de fevereiro de 1998, n. 58, art. 159, 6: "La Consob dispone d'ufficio la revoca dell'incarico di revisione contabile qualora rilevi una causa di incompatibilità ovvero qualora siano state accertate gravi irregolarità nello svolgimento dell'attività di revisione, anche in relazione ai principi e criteri di revisione stabiliti ai sensi dell'articolo 162, comma 2, lettera a). Il provvedimento di revoca è notificato alla società di revisione e comunicato immediatamente alla società interessata, con l'invito alla società medesima a deliberare il conferimento dell'incarico ad altra società di revisione, secondo le disposizioni del comma 1, entro trenta giorni dalla data di ricevimento della comunicazione. Qualora la deliberazione non sia adottata entro tale termine, la Consob provvede d'ufficio al conferimento dellincarico entro trenta giorni. Le funzioni di controllo contabile continuano ad essere esercitate dalla società revocata fino a quando la deliberazione di conferimento dell'incarico non sia divenuta efficace ovvero fino al provvedimento della Consob".
} 
A ineficácia contratual ora mencionada, porém, terá lugar de forma residual, ou seja, quando não houver outros motivos que levem à anulação do ato jurídico. Dentre algumas das hipóteses que devem ser analisadas, estão: 1) a omissão intencional de uma das partes em informar a outra sobre sua falta de independência; 2) a omissão intencional de ambas as partes em informar a contraparte nos mesmos termos anteriores; 3) o conluio de ambas as partes que, sabedoras da ausência de isenção e com o fim de prejudicar terceiros, executam o serviço pessoalmente ou por intermédio de interposta pessoa.

No primeiro caso supracitado, estaremos diante de dolo (omissão dolosa) de uma das partes em relação à outra. O dolo deve ser considerado como principal, e não meramente acidental, uma vez que, se a parte contrária, de boa-fé, estivesse ciente da ausência de independência, o contrato em questão não se realizaria. $O$ contrato deverá ser considerado anulável nos termos do art. 147 do Código Civil.

Na segunda hipótese aventada, tratar-se-á de dolo bilateral, situação em que, nos termos do art. 150 do Código Civil, nenhuma das partes poderá alegá-lo para anular o negócio, ou reclamar indenização. A anulação poderá ser obtida por terceiro interessado, subsistindo, em todos os casos, a ineficácia derivada da falta de independência.

Na terceira hipótese, entendemos estar diante de caso de fraude à lei. Citado defeito do negócio jurídico abrange a situação em que as partes burlam indiretamente o comando legal, colocando-se propositadamente em situação em que não sejam atingidas por determinada disposição normativa, usualmente para prejudicar terceiros. Cuida-se de caso de nulidade absoluta (e não mera anulabilidade), nos termos do art. 166, VI, do Código Civil.

Nos casos em que o contrato seja anulável, tanto as partes (salvo na existência de dolo bilateral) quanto os terceiros interessados poderão obter a respectiva anulação em juízo. Os efeitos da anulação pleiteada por um ou por alguns dos interessados deverão aproveitar aos demais, por tratar-se de obrigação indivisível (art. 177 do Código Civil).

Entendemos que ainda nos casos nos quais o contrato de auditoria seja meramente anulável, não poderá ser convalidado ou confirmado pelas partes contratantes, uma vez que isto feriria certamente direito de terceiros, nos termos do art. 172 do Código Civil. Ora, a auditoria externa é realizada, na grande maioria dos casos, no interesse de terceiros, de modo que a conservação do contrato contrariaria em qualquer hipótese o direito dos beneficiários, fazendo com que restasse juridicamente validado contrato de 
auditoria sem independência das partes e bloqueando a ação dos eventuais prejudicados em obter a anulação do contrato pelas vias judiciais.

Apesar do mencionado até este ponto, cabe salientar que vários são os autores que, diante da forma de contratação, não acreditam na existência de independência do auditor em face da entidade auditada, asseverando a impropriedade de tal termo para designar profissional que é remunerado pela parte contrária, condição em que, segundo creem, causa elevado grau de subordinação, tornando impossível uma atuação desvinculada. Muitos defendem, inclusive, a criação de fundos administrados por órgãos públicos para a remuneração de auditores, visando a dar maior liberdade e autonomia ao trabalho destes. ${ }^{179}$

Citadas críticas, entretanto, não nos parecem procedentes.

A condição de ser o auditor remunerado pela parte contrária não the retira necessariamente a independência, dado que a relação comercial estabelecida com o cliente não necessariamente será apta a influenciar o julgamento do auditor. Obviamente, porém, a independência deste profissional poderá ser tão mais comprometida quanto maior for a essencialidade da manutenção do cliente para a saúde econômico-financeira do auditor. Tais situações, usualmente existentes em face de clientela única ou de singular importância, devem merecer maior atenção dos órgãos públicos de fiscalização. ${ }^{180}$

\footnotetext{
${ }^{179}$ Argumenta Edson Cordeiro da Silva: "Somente a título de sugestão, talvez o melhor seria criar um Fundo de Recursos pagos pelas empresas abertas para remuneração dos auditores independentes, ao invés da contratação direta pelas empresas. Esse fundo seria regulado pela CVM com regras rígidas de controle, administração e responsabilidade, que poderia indicar um 'grupo gestor' para administração dos recursos junto às empresas de auditoria independente. O grupo gestor poderia ser composto pela CVM, Bovespa, CFC, Ibracon e outros órgãos ligados ao Mercado de Capitais. A finalidade é aumentar a indiferença dos auditores junto às empresas, com relação ao aspecto formal de contratação" (SILVA, Edson Cordeiro da. Governança corporativa nas empresas. São Paulo: Atlas, 2006. p. 26.).

${ }^{180}$ Também com o intuito de preservação de independência do auditor (neste caso independência financeira da entidade auditada), a Res. CFC n. 1.267/09, com base nas normas internacionais de auditoria, impõe uma série de procedimentos em relação aos honorários, conforme a seguir transcrevemos: "106. Quando os honorários de auditoria forem de valor, substancialmente, inferior ao estabelecido para os outros serviços que a entidade de auditoria realize para a entidade auditada, pode se estabelecer o conflito de interesses, por razões de dependência financeira e, por conseguinte, a perda de independência. 107. Para que se caracterize a dependência financeira, é necessário que o conjunto dos honorários de serviços prestados à entidade auditada, ou seja, os de auditoria e os demais, seja relevante dentro do total de honorários da entidade de auditoria. 108. Considera-se como conjunto de honorários relevante aquele que represente $25 \%$ (vinte e cinco por cento), ou mais, do total de honorários da entidade de auditoria. 109. Uma ameaça de interesse próprio também pode ser gerada quando os honorários gerados pela entidade auditada representam grande proporção da receita do sócio encarregado do trabalho de auditoria. A importância da ameaça deve ser avaliada e, se a ameaça não for claramente insignificante, devem ser consideradas e aplicadas salvaguardas conforme necessário para reduzir a ameaça a um nível aceitável. Essas salvaguardas podem incluir: - políticas e procedimentos para monitorar e implementar controle de qualidade do trabalho de auditoria; e envolvimento de outro sócio que não faça parte da equipe de auditoria e nem seja o revisor do controle de qualidade do respectivo trabalho de auditoria, para revisar o trabalho feito ou de outra forma dar assessoria
} 
Por outro lado, a substituição da contratação particular de auditores por uma atividade estatal direta de auditoria ou mediante remuneração pública de auditores por meio da administração de fundos específicos também não parece razoável.

A atuação direta estatal nesta matéria seria inviável, por extremamente cara e ineficiente, uma vez que necessitaria da contratação e treinamento de um número exacerbado de servidores. Isto sem contar com a notória inabilidade administrativa estatal, em contraposição às necessidades prementes do mercado.

A remuneração através de fundos públicos igualmente seria impossível. Duas seriam as dificuldades em tal tipo de sistema remuneratório: 1) se o fundo remunerasse livremente o auditor, de acordo com o que fora pactuado pelas partes, haveria sérios problemas de manutenção da solvência de mencionado fundo, sempre que este não fosse suficiente para suportar o incremento dos honorários avençados no mercado. Outrossim, muito difícil seria o cálculo do necessário à arrecadação para manutenção da solvência do fundo, dada a variabilidade de honorários dos diversos profissionais; 2) a remuneração por meio de fundos públicos em montantes fixos preestabelecidos por seu órgão gestor (sem interveniência das partes) retiraria a capacidade dos agentes econômicos que atuam no mercado de auditoria de estabelecer livremente seus honorários conforme critérios fixados com base em informações peculiares de cada contratação (especificidades das partes, custos, lucratividade, utilidade e necessidade do serviço, etc.). Esta hipótese, diante da falta de informação dos critérios utilizados pelas partes para fixarem seus honorários ao contratar, poderia acabar por remunerar insuficientemente os serviços de auditoria, afastando bons profissionais deste mercado.

Assim, a contratação privada dos serviços de auditoria, mediante sistema de mercado, é o único meio que apresenta razoabilidade para a manutenção desta atividade em patamares aceitáveis.

conforme necessário. 110. Uma ameaça de interesse próprio pode ser gerada se os honorários devidos pela entidade auditada por serviços profissionais prestados continuarem sendo devidos por período de tempo prolongado, especialmente se parte significativa não for paga antes da emissão do relatório de auditoria do exercício seguinte. Geralmente, o pagamento desses honorários deve ser exigido antes da emissão do relatório. As seguintes salvaguardas podem ser aplicadas: - discussão do nível dos honorários pendentes com o comitê de auditoria ou outros responsáveis pela governança; - envolvimento de mais um profissional que não foi membro da equipe de auditoria para prestar assessoria ou revisar o trabalho feito. 111. A entidade de auditoria também deve analisar se os honorários vencidos podem ser considerados como equivalentes a um empréstimo à entidade auditada e se, por causa da importância dos honorários vencidos, é adequado que a entidade de auditoria seja recontratada". 
Nos termos das normas contábeis nacionais e internacionais, podemos resumir as potenciais ameaças à independência entre as partes em algumas espécies:

- Risco de interesse próprio do auditor na entidade auditada: que ocorre quando o auditor seja proprietário de relevante investimento ou valores mobiliários de emissão da sociedade auditada, suas controladas, controladoras ou integrantes de um mesmo grupo econômico, ou tenha realizado operações de crédito (empréstimos, financiamentos, etc.) ou prestado garantia à entidade auditada;

- Risco de familiaridade ou relações de parentesco: existente quando o auditor possa, diante do vínculo familiar com pessoas ligadas à entidade auditada (diretores, administradores, empregados, etc.), vir a se identificar com os interesses da entidade auditada;

- Risco de autorrevisão (self review risk): ocorre quando o auditor possa vir a exercer, sem imparcialidade, verificação sobre seu próprio trabalho, como, por exemplo, na hipótese de este profissional ter prestado serviços de assessoria, gestão, elaboração de demonstrações, etc.;

- Risco de defesa de interesses da entidade auditada: usualmente presente quando haja subordinação entre o auditor ou membros da equipe de auditoria e a entidade auditada, de modo que aquele(s) possa(m) estar vinculado(s) ao interesse desta última;

- Risco de existência de ameaças ou intimidação: quando, visando a determinado resultado, são impostos óbices à atuação do auditor ou equipe, ou mesmo realizadas ameaças de imposição de mal injusto e grave.

Ao contrário do que se costuma entender a respeito das causas de suspeição e impedimento dos magistrados e demais órgãos essenciais à justiça, os motivos que ameaçam a independência do auditor não são exaustivos (Res. CFC n. 1.267/09, item 112). Deste modo, toda e qualquer situação relevante de conflito de interesses poderá ensejar perda de independência.

A primeira das causas supracitadas pode comprometer a independência do auditor, uma vez que este possa ter interesse em não divulgar informações relevantes aos usuários externos de seu trabalho para não prejudicar seus investimentos na entidade auditada, ou mesmo divulgar informações indevidas para delas tomar proveito. 
De acordo com a Res. n. 1.267/09 do CFC, os interesses financeiros podem ser: 1) diretos: aqueles sobre os quais o detentor tem controle, seja em ações, debêntures ou em outros títulos e valores mobiliários; e 2) indiretos: aqueles sobre os quais o detentor não tem controle algum, ou seja, são interesses em empresas ou outras entidades, mantidas por titular beneficiário mediante plano de investimento global, sucessão, fideicomisso, fundo comum de investimento ou entidade financeira sobre os quais a pessoa não detém o controle nem exerce influência significativa. A relevância de interesse financeiro indireto deve ser considerada no contexto da entidade auditada, do trabalho e do patrimônio líquido do indivíduo em questão. Um interesse financeiro indireto é considerado relevante se seu valor for superior a 5\% do patrimônio líquido da pessoa. Para este fim, deve ser adicionado ao patrimônio líquido dos membros imediatos da família.

Para a perda da independência em face da propriedade de investimentos, é necessário que o auditor ou membro de sua equipe possa influenciar o resultado do trabalho de auditoria. Não haverá falta de independência, portanto, quando a parcela do trabalho pessoal do possuidor do investimento não tiver qualquer relevância no resultado final.

Obviamente, nem todos os investimentos e operações financeiras devem ensejar comprometimento da independência, principalmente quando forem de menor monta e realizados sob regras objetivas de mercado. Além do investimento irrelevante, na forma antes mencionada, são permitidas as seguintes operações (item 31 da Res. n. 1.267/09 do CFC): (a) operações de créditos para aquisição de veículo; (b) arrendamento de veículo; (c) saldos em cartão de crédito que não superem 20 salários-mínimos; $e(d)$ operações de créditos para aquisição de imóveis, com garantia.

No que concerne à familiaridade ou relações de parentesco, a perda da independência deriva da situação em que familiar do auditor exerça cargo de relevância na entidade auditada, cujo trabalho possa ser objeto de verificação. A Res. n. 1.267/09 do CFC estabelece que se consideram como membros imediatos da família o cônjuge e todos os dependentes, financeiramente, dos membros da equipe de auditoria.

Não basta, evidentemente, a mera relação de parentesco. Nos termos da norma de regência, neste caso, a perda de independência está sujeita a uma série de fatores, entre eles a responsabilidade do membro da equipe de auditoria no trabalho, a proximidade do relacionamento e o papel do membro da família ou de relacionamento pessoal na entidade auditada. 
A perda de independência ainda está condicionada à função que o familiar exerce na entidade auditada. Mera relação com parente empregado da entidade auditada não será ameaça à independência do auditor, desde que a função daquele não seja objeto de auditoria. Para a Res. n. 1.267/09 do CFC, as funções ocupadas por pessoas próximas ou familiares, que prejudicam a independência do auditor ou da equipe, são aquelas que: $(a)$ exercem influência significativa sobre as políticas operacionais, financeiras ou contábeis. Em geral, diz respeito a uma pessoa que tem funções como presidente, diretor, administrador, gerente geral da entidade auditada; (b) exercem influência nas demonstrações contábeis da entidade auditada. Em geral, diz respeito a funções consideradas críticas no ambiente contábil, como controller, gerente de contabilidade, contador; e (c) são consideradas sensíveis sob o ponto de vista da auditoria. Em geral, inclui cargos com atribuições de monitoramento dos controles internos da entidade auditada, como, por exemplo, tesoureiro, auditor interno, gerente de compras/vendas, entre outras.

$\mathrm{O}$ risco de autorrevisão decorre praticamente da prestação concomitante à entidade auditada de serviços outros que não os de auditoria externa, o que poderá retirar do revisor o incentivo para denunciar erros em seu próprio trabalho.

A proibição da prestação de outros serviços por parte do auditor independente sempre esteve rodeada de polêmicas; argumenta-se contrariamente à vedação que: a) não há evidência empírica a demonstrar a perda da independência; b) a prestação de outros serviços aprimora o conhecimento do auditor em relação aos procedimentos de gestão da entidade auditada, o que vem em benefício de seu trabalho de auditoria; c) a prestação de serviços de auditoria conjuntamente com outros serviços traz consigo o benefício de redução de custos diante do que se denomina economicamente economia de escopo, tornando-se mais barata a prestação dos diversos serviços conjuntamente do que realizá-los de modo separado, uma vez que serão utilizadas bases conceituais, técnicas, pessoal e matérias-primas comuns na efetivação concomitante de dois ou mais serviços, evitando-se custos repetitivos; d) evitam-se custos de transação em transações no mercado, na forma preconizada por Ronald Coase, ${ }^{181}$ quando os serviços se encontram internalizados na entidade auditada.

\footnotetext{
${ }^{181}$ Sem querer aprofundar o tema aqui, cabe a referência à proposição de Coase (que conta com grande aceitação no meio econômico), segundo a qual a própria existência das entidades empresariais ("firmas", no jargão econômico) é justificada pelo fato de que, ao internalizar os contratos dentro de uma entidade, ocorre a diminuição dos custos de transação anteriormente existentes em relações contratuais de mercado. Daí a
} 
Os escândalos financeiros ocorridos na última década, porém, fizeram com que a maior parte dos países adotasse regulação restritiva em relação à concomitância de serviços de auditoria com outros que pudessem retirar independência do auditor. Argumenta-se contrariamente às razões antes expostas que: a) embora não se possa medir a independência do auditor, existem estudos que apresentam evidências de falta de isenção dos auditores que prestam outros serviços concomitantes; b) a prestação de outros serviços não traz contribuição significativa ao aprimoramento do conhecimento do auditor sobre a realidade da entidade auditada, os quais não possam ser obtidos por outros meios; c) os custos derivados da perda de independência podem superar em muito as economias de escopo e aquelas inerentes à ausência ou diminuição de custos de transação.

Seguindo esta linha, a União Europeia recomenda aos Estados-Membros que estes:

Devem assegurar que os revisores oficiais de contas ou as sociedades de revisores oficiais de contas não realizem revisões legais de contas, caso exista qualquer relação financeira, empresarial, de trabalho ou de qualquer outro tipo - incluindo a prestação de serviços complementares que não sejam de revisão ou auditoria -, direta ou indireta, entre o revisor oficial de contas, a sociedade de revisores oficiais de contas ou a rede e a entidade examinada, em virtude da qual um terceiro objetivo, racional e informado, concluiria que a independência do revisor oficial de contas ou da sociedade de revisores oficiais de contas estava comprometida (Diretiva n. 2006/43/CE de 17 de maio de 2006).

Nos Estados Unidos, a Lei Sarbanes-Oxley (2002) proibiu expressamente, em sua seção 201, a prática pelo auditor independente de serviços que estejam fora de seu escopo (services outside the scope of practice of auditors), dentre os quais se incluem a escrituração contábil ou outros serviços relacionados com a contabilidade ou demonstrações financeiras da entidade auditada, o desenho de sistemas de informação financeira e sua implementação, a estimação ou serviços de avaliação, os pareceres de equidade ou relatórios de contribuição em espécie, os serviços atuariais, os serviços de terceirização de auditoria interna, o gerenciamento de funções ou recursos humanos, corretagem ou revenda, a consultoria de investimentos ou serviços de banco de investimento, os serviços legais e serviços de especialistas não relacionados à auditoria, além de qualquer outro serviço que o PCAOB entender, por regulamento, indevido.

consideração de que a empresa (ou "firma") seja concebida como um feixe de contratos (COASE, Ronald. 
No Brasil, esta tendência foi seguida pelos órgãos regulatórios.

Dentre os serviços cuja prestação concomitante é vedada ao auditor independente, a Instrução n. 308/99 da CVM arrola os de: I - assessoria à reestruturação organizacional; II - avaliação de empresas; III - reavaliação de ativos; IV - determinação de valores para efeito de constituição de provisões ou reservas técnicas e de provisões para contingências; V - planejamento tributário; VI - remodelamento dos sistemas contábil, de informações e de controle interno; ou VII - qualquer outro produto ou serviço que influencie ou que possa vir a influenciar as decisões tomadas pela administração da instituição auditada. Na mesma linha, a Resolução n. 1.267/09 do CFC arrola os seguintes serviços, que poderão retirar a independência do auditor, conforme o caso: (a) de avaliação de empresas e reavaliação de ativos; (b) de assistência tributária, fiscal e parafiscal; (c) de auditoria interna à entidade auditada ${ }^{182}(d)$ de consultoria de sistema de informação computadorizado; (e) de apoio em litígios, perícia judicial ou extrajudicial; (f) de finanças corporativas e assemelhados; ( $g$ ) de seleção de executivos; (h) registro (escrituração) contábil; (i) serviços legais. ${ }^{183}$

The nature of the firm, In The Firm, the Market, and the Law. University of Chicago Press, 1988).

${ }^{182}$ Recente polêmica no exterior surgiu com a assunção concomitante, na Inglaterra, pela KPMG, da atividade de auditoria interna de entidade auditada (Rentokil Initial) à qual também prestava serviço de auditoria externa. Citada concomitância é vedada no Brasil se retirar a independência do auditor (Res. n. 1.267/09 do CFC), e nos EUA (Seção 201 da SOX). Reportagem do jornal Valor Econômico bem retrata a questão: "A Rentokil Initial negociou com a KPMG uma forma de auditoria mais enxuta e mais barata que poderá ser adotada por outras companhias, mas que causou estranheza no mundo da governança empresarial. A Rentokil reduziu em 1 milhão de libras, ou quase um terço, seus pagamentos anuais aos auditores externos e internos. O acordo prevê que a KPMG, nova auditoria externa, assumirá trabalho de auditoria interna ao lado da própria equipe da Rentokil. Anteriormente, a PwC fazia o trabalho externo, enquanto a Deloitte cuidava de grande parte interna. O esquema é controvertido, uma vez que os escândalos contábeis na Enron e WorldCom resultaram em novas regras em grande parte destinadas a desmembrar os papéis de auditorias externa e interna para evitar que os auditores fiquem excessivamente vinculados a seus clientes. As questões cruciais estão relacionados com não permitir que auditores auditem seu próprio trabalho interno ou assumam qualquer função administrativa. A KPMG disse não haver conflitos em seu acordo com a Rentokil e que está consciente da regra. 'Conceitualmente, realizar auditoria interna não caracteriza conflito [de interesses, o que ocorreria] apenas se houvesse maior envolvimento em aspectos mais amplos - como de administração -, algo que não estamos fazendo', disse Oliver Tant, diretor de auditoria da KPMG no Reino Unido. Entretanto, especialistas em governança têm questionado a prática de "misturar" auditorias interna e externa. Essa separação baseia-se no princípio de que auditores internos trabalham para a administração, ao passo que externos, ou "independentes", atendem aos interesses de investidores. "As duas funções apresentam uma superposição parcial, mas fazem trabalhos bastante distintos, por mais que algum executivo chefe possa achar que são idênticas', disse um auditor sênior. A PwC também fez propostas para assumir a auditoria nesses termos na Rentokil. 'Nossa independência é absolutamente vital para que conservemos a confiança do público. Sempre procuramos, onde apropriado, nos basearmos em trabalho de auditoria interna. Tem uma boa relação custo-benefício, mas permite que mantenhamos nossa independência', disse Richard Sexton, diretor de auditoria na PwC". ("KPMG assume auditorias externa e interna da Rentokil e causa polêmica". Valor Online. 5.08.2009. Disponível em <http://www.valoronline.com.br>. Acesso em 2 jan. 2010).

${ }^{183} \mathrm{Na}$ Itália, o art. 149-decies, 1, da deliberação Consob n. 11.971 de 14.05.1999, proíbe os serviços que consistam em atribuições de poder de representação da entidade auditada pelo auditor, além dos serviços de assistência legais em controvérsias: "Rientrano tra gli altri servizi di cui all'articolo 160, comma 1-ter, lettera 
A Resolução CNSP n. 118 de 2004 proíbe, sem ressalvas, em seu âmbito de aplicação, a prestação concomitante de serviços de auditoria independente e de consultoria, planejamento tributário e auditoria interna.

Para dar ciência aos terceiros, a Instrução CVM n. 381/03 exige que as entidades auditadas divulguem informações relacionadas à prestação, pelo auditor independente ou por partes relacionadas com o auditor independente, de qualquer serviço que não seja de auditoria externa, ressalvado quando a remuneração desses serviços representar menos de 5\% (cinco por cento) daquela pactuada pelos serviços de auditoria externa.

O risco de defesa dos interesses da entidade auditada surge quando haja vínculo de trabalho, subordinado ou não, em que o auditor (ou membro da equipe de auditoria) exerça ou tenha exercido cargo de gestão ou que possa influenciar o objeto da auditoria. A perda da independência, neste caso, dependerá da análise de vários fatores, dentre eles o cargo ocupado, a influência no trabalho de auditoria, etc.

A Res. n. 1.267/09 do CFC, adotando os ditames das normas internacionais de auditoria, considera haver conflito de interesse e possível perda de independência da do auditor quando sócio ou membro da equipe de auditoria possa estar em processo de negociação para ingressar na entidade auditada.

Deve haver um trabalho preventivo para evitar que um auditor não isento venha a efetuar qualquer serviço de auditoria externa. Para tanto, em todos os casos em que possa haver ameaça à independência, o auditor deve, permanentemente, avaliar se alguns dos casos de risco supracitados ocorrem. Na constatação de tal situação, devem ser aplicadas salvaguardas correspondentes (ações corretivas destinadas a remover o risco respectivo), para que não se caracterize perda de independência. As principais salvaguardas recomendadas pela Res. n. 1.267/09 do CFC são trazidas na tabela seguinte:

i), del Texto unico, i servizi di consulenza che comportano l'attribuzione di poteri di rappresentanza del cliente nonchè i servizi di assistenza legale nell'ambito di controversie". 
Tabela 7: Ameaças à independência e respectivas salvaguardas

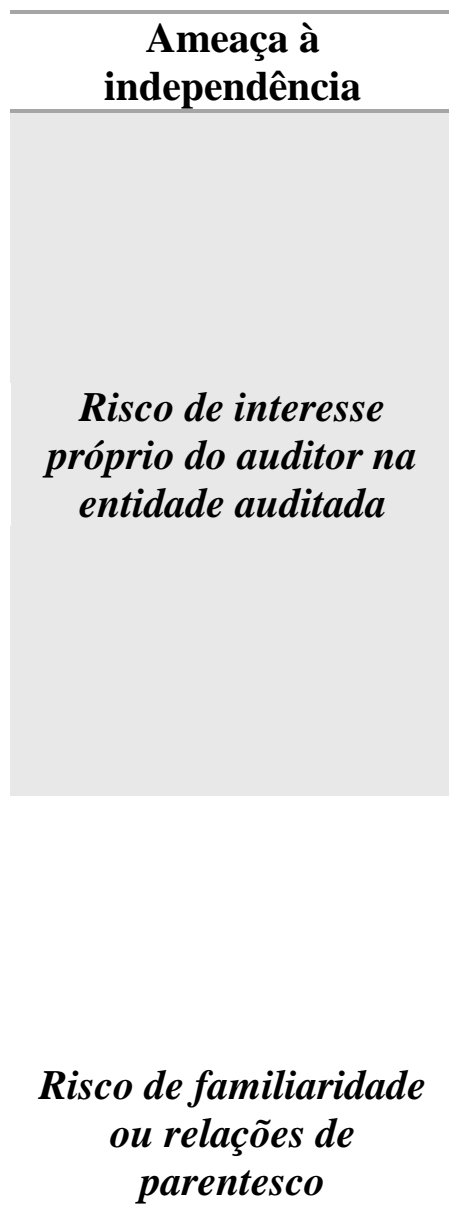

(a) obtenção da participação de auditor adicional que não tenha feito parte do trabalho de auditoria para revisar o trabalho feito pelo membro da equipe de auditoria; ou

(b) exclusão da pessoa da tomada de decisões importantes referentes ao trabalho de auditoria;

(c) liquidação total do empréstimo pela entidade de auditoria;

(d) liquidação total do empréstimo pelo sócio ou membro da equipe da entidade de auditoria; ou

(e) afastamento do sócio ou membro da equipe de trabalho de auditoria.

(a) obter a participação de auditor adicional que não tenha sido membro da equipe de auditoria para revisar o trabalho feito ou opinar conforme necessário;

(b) confirmar com a entidade auditada o entendimento desta sobre as premissas de avaliação e a metodologia a serem usadas, e obter aprovação para seu uso;

(c) obter da entidade auditada declaração de aceitação de responsabilidade pelos resultados do trabalho realizado pela entidade de auditoria;

(d) tomar providências para que o pessoal que prestar tais serviços não participe do trabalho de auditoria. 
(a) obter a participação de auditor adicional que não tenha sido membro da equipe de auditoria para revisar o trabalho feito ou opinar conforme necessário;

(b) confirmar com a entidade auditada o entendimento desta sobre as premissas de avaliação e a metodologia a serem usadas, e obter aprovação para seu uso;

(c) obter da entidade auditada declaração de aceitação de responsabilidade pelos resultados do trabalho realizado pela entidade de auditoria;

(d) tomar providências para que o pessoal que prestar tais serviços não participe do trabalho de auditoria;

(e) assegurar que o pessoal da entidade de auditoria não atue nem pareça atuar em condição equivalente à de membro da administração da entidade auditada;

Risco de autorrevisão (f) assegurar que a entidade auditada reconheça sua responsabilidade por instituir, manter e monitorar o sistema de controle interno;

(g) assegurar que a entidade auditada designe empregado competente, preferivelmente da alta administração, para ser o responsável pelas atividades de auditoria interna;

(h) assegurar que a entidade auditada seja responsável por avaliar e determinar quais as recomendações da entidade de auditoria que devam ser implementadas;

(i) assegurar que a entidade auditada avalie a adequação dos procedimentos de auditoria interna executados e as conclusões resultantes mediante a obtenção de relatórios da entidade de auditoria e a tomada de decisões com base nesses relatórios; e

(j) assegurar que as conclusões e as recomendações decorrentes da atividade de auditoria interna sejam devidamente informadas aos responsáveis pela entidade auditada.

(a) modificar o plano de auditoria, se necessário;

(b) designar equipe de auditoria que inclua membros com

Risco de defesa de interesses da entidade auditada

\section{Risco de existência de ameaças ou intimidação}

experiência superior àquela do profissional que se transferiu para a entidade auditada;

(c) envolver outro profissional que não seja membro da equipe de auditoria para revisar o trabalho realizado; ou

(d) ampliar o nível de controle de qualidade do trabalho.

Não há previsão de salvaguardas específicas. A análise deve se dar a cada caso concreto.

Haverá casos, porém, em que mesmo a aplicação das salvaguardas 
casos, o auditor (por dever profissional) e a entidade auditada devem optar por terminar o relacionamento comercial anteriormente iniciado ou recusar a contratação inicial dos serviços de auditoria.

Duas últimas questões devem ser abordadas, ainda que perfunctoriamente, em relação à independência nos serviços de auditoria externa.

A primeira diz respeito ao recebimento de presentes, brindes ou outros benefícios da entidade auditada. Tal procedimento, vedado pelas normas internacionais e nacionais de auditoria (Res. n. 1.267/09 do CFC), é extremamente grave, além de ser de difícil constatação, uma vez que em regra é praticado de maneira privada. Isto, entretanto, pode criar ameaça à objetividade do auditor pela familiaridade ou mesmo ameaça de intimidação ao trabalho deste profissional se houver qualquer perda de independência pela comunicação do fato publicamente. $\mathrm{O}$ auditor deve, portanto, a cada caso, avaliar as potenciais ameaças ao seu trabalho derivadas dessas condutas, para não incidir em perda da independência. ${ }^{184}$

A segunda é o caso da existência de litígio atual ou iminente entre auditor e entidade auditada. Quando referida situação venha a ocorrer, podem existir ameaças à independência derivadas de conflitos de interesse ou intimidação, o que dificulta ou inviabiliza a transparência do trânsito da informação entre as partes. Neste caso, as normas nacionais e internacionais de auditoria determinam que, conforme a natureza, relevância e tempo em que decorrer o litígio (p.ex., antes ou depois da conclusão dos trabalhos) a independência possa estar comprometida.

\footnotetext{
${ }^{184}$ Critério não mencionado nas normas nacionais é referido no Código de Ética da IFAC, que determina que o profissional de contabilidade somente aceite presentes ou hospitalidade se forem razoáveis, de valor insignificante e passíveis de ser comunicados a terceiros em toda sua extensão. Transcrevemos a seguir o texto mencionado: "SECTION 260. Gifts and Hospitality. 260.1 A professional accountant in public practice, or an immediate or close family member, may be offered gifts and hospitality from a client. Such an offer may create threats to compliance with the fundamental principles. For example, a self-interest or familiarity threat to objectivity may be created if a gift from a client is accepted; an intimidation threat to objectivity may result from the possibility of such offers being made public. 260.2 The existence and significance of any threat will depend on the nature, value, and intent of the offer. Where gifts or hospitality are offered that a reasonable and informed third party, weighing all the specific facts and circumstances, would consider trivial and inconsequential, a professional accountant in public practice may conclude that the offer is made in the normal course of business without the specific intent to influence decision making or to obtain information. In such cases, the professional accountant in public practice may generally conclude that any threat to compliance with the fundamental principles is at an acceptable level. 260.3 A professional accountant in public practice shall evaluate the significance of any threats and apply safeguards when necessary to eliminate the threats or reduce them to an acceptable level. When the threats cannot be eliminated or reduced to an acceptable level through the application of safeguards, a professional accountant in public practice shall not accept such an offer". (INTERNATIONAL FEDERATION OF ACCOUNTANTS. Code of ethics for professional accountants. Disponível em: <http//www.ifac.org>. Acesso em 3 jan. 2010).
} 


\subsection{As partes do contrato}

O estudo das partes no contrato de prestação de serviços de auditoria externa permite enfrentar várias questões intrincadas, dentre as quais podemos citar: aquelas referentes aos requisitos que cada parte deve possuir para contratar (registro, controle de qualidade, educação continuada, etc.); a natureza (empresária ou não) sob a qual deve se constituir o auditor ou sociedade de auditoria; os tipos societários permitidos para as sociedades de auditoria; as questões inerentes à auditoria de sociedades de grande porte, independente do tipo societário adotado; entre outras.

Deste modo, organizaremos a seguir tópicos específicos para tratar de cada um dos assuntos inerentes às partes contratantes.

\subsubsection{O auditor independente}

\subsubsection{Registro profissional e qualificação técnica}

Dado o interesse público que envolve a atividade de auditoria externa, a regulação da matéria nos diversos países normalmente impõe um controle estatal sobre o exercício da profissão.

No âmbito da União Europeia, a Diretiva n. 2006/43/CE, de 17 de maio de 2006, trata da aprovação dos auditores externos independentes, estabelecendo que as revisões legais das contas são realizadas apenas por revisores oficiais de contas ou por sociedades de revisores oficiais de contas aprovados pelo Estado-Membro que exige a revisão legal das contas. Referida diretiva permite aos Estados-Membros que deleguem a aprovação a órgãos de físcalização de profissão, desde que estes se encontrem sujeitos a um sistema de supervisão pública. 
Na Itália, as sociedades de auditoria estão sujeitas à inscrição no registro da Commissione Nazionale per le Società e la Borsa (Consob). ${ }^{185}$

Uma primeira questão doutrinária que surge a respeito do registro do auditor é se esta inscrição tem natureza de oferta pública de contrato (cuja aceitação se daria com a deliberação do órgão societário competente da sociedade auditada ao escolher o auditor), ou se resta configurada como mera condição para o exercício da profissão.

Sobre o tema, opina Maria Vittoria Cozzi, citando entendimentos de doutrinadores italianos:

Não aceitável é a tese de R. Clarizia, o.c, p. 49, segundo a qual a inscrição em registro de sociedade de auditoria constituiria uma proposta contratual na modalidade de oferta ao público, enquanto a deliberação de escolha e atribuição do encargo valeriam como aceitação da proposta. Como, de fato, asseverou M. Cera, Revisione contabile e certificazione del bilancio, cit., p. 765, o registro, longe ser dirigido à conclusão de um contrato, representa somente uma condição legal para poder exercitar a atividade de auditoria. ${ }^{186}$

Realmente, parece-nos que esta autora tem toda razão em seu argumento.

Para se configurar em sua essência, a proposta de contrato deve ser inequívoca, precisa e completa, contendo tal grau de determinação da relação contratual pretendida que, pela mera aceitação de seus termos pela contraparte, possa-se ter o contrato como firmado. ${ }^{187}$ Não é isto o que ocorre com o registro do auditor nos órgãos próprios. Não há ali qualquer proposição concreta de contrato, nem mesmo se particularizam suas condições e cláusulas essenciais. Cuida-se, pois, de mera condição para o exercício profissional.

No Brasil, o controle estatal sobre a profissão do auditor independente ocorre de duas formas: 1) controle único (único órgão), em casos de exercício de auditoria não referente a entidades que se constituam como sociedades anônimas abertas, sociedades de

${ }^{185}$ Decreto Legislativo de 24 de fevereiro de 1998, n. 58: “Art. 161 (Albo speciale delle società di revisione) 1. La Consob provvede alla tenuta di un albo speciale delle società di revisione abilitate all'esercizio delle attività previste dagli articoli 155 e 158. 2. La Consob iscrive le società di revisione nell'albo speciale previo accertamento dei requisiti previsti dall'articolo 6, comma 1, del decreto legislativo 27 gennaio 1992, n. 88, e del requisito di idoneità".

${ }^{186} \mathrm{Op}$. cit., p. 29. O texto é tradução livre de: "Non condivisibile è la tesi di R. Clarizia, o.c, p. 49, secondo il quale l'iscrizione all'albo delia società di revisione costituirebbe una proposta contratuale nel modo dell'offerta al pubblico, mentre la delibera di conferimento dell'incarico varrebbe come accettazione della proposta. Come ha, infatti, rilevato M. Cera, Revisione contabile e certificazione del bilancio, cit., p. 765, l'iscrizione all'albo, lungi dall'essere diretta alla conclusione di un contratto, rappresenta soltanto una condizione posta dalla legge per poter esercilare l'attività di revisione". 
grande porte, instituições financeiras, seguradoras ou equiparadas, bastando o registro profissional do auditor pessoa física ou sociedade de auditoria perante os órgãos de fiscalização da profissão contábil (CFC e CRCs); 2) controle duplo (duplicidade de órgãos), para a prática de auditoria de entidades que se constituam como sociedades anônimas abertas, sociedades de grande porte, instituições financeiras, seguradoras ou equiparadas, hipótese em que o auditor pessoa física ou sociedade de auditores deverá, além de possuir registro em seu órgão profissional, ser ainda registrado perante a Comissão de Valores Mobiliários (CVM).

É importante salientar, porém, que, apesar da necessidade do duplo registro, na forma anteriormente mencionada, a própria CVM, em nota explicativa à Instrução n. 308/99, assevera que o registro em seus quadros não estabelece uma nova categoria profissional, não havendo, portanto, conflito entre os registros mencionados. Com efeito, o registro nesta autarquia destina-se precipuamente à fiscalização dos participantes do mercado de capitais - dentre eles o auditor independente -, e não diretamente ao controle estatal sobre a profissão. ${ }^{188}$

Para a obtenção do registro nos órgãos profissionais, até pouco tempo não havia no ordenamento nacional a exigência de exame de qualificação técnica ou suficiência, o que passou a existir com o advento da Lei 12.249/2010. ${ }^{189}$

\footnotetext{
${ }^{187}$ Neste sentido, Orlando Gomes, Contratos, cit., p. 73.

${ }^{188}$ Interessante divergência quanto à existência de duplo registro profissional surgiu quando a CVM instituiu a cobrança de taxa de fiscalização de mercado tendo como sujeitos passivos, entre outros, os auditores independentes (arts. $2^{\text {o }}$ e $3^{\circ}$ da Lei n. 7.940/89). Argumentava-se que os auditores externos já estariam sujeitos à fiscalização profissional por parte dos Conselhos de Contabilidade, para os quais já recolhiam as respectivas anuidades, as quais legalmente já seriam consideradas como taxas devidas pelo exercício do poder de polícia estatal. Desta forma, a fiscalização profissional por parte da CVM, com instituição de outra taxa para tanto, seria espécie de bitributação, pois incidiria sobre o mesmo fato gerador. Ademais, arguia-se violação do princípio da isonomia, por discriminar entre os auditores registrados somente nos CRCs e aqueles que deviam obrigatoriamente também se inscrever na CVM. Na maior parte dos casos, o Poder Judiciário rejeitou os argumentos apresentados, sob a fundamentação de que se tratava de registros distintos, não havendo conflito de atribuições entre os órgãos, nem discriminação injustificada. A constitucionalidade da exação mencionada foi consagrada na Súmula n. 665 do STF.

189 Antes da sobrevinda da Lei 12.249/2010, muito embora o Conselho Federal de Contabilidade tivesse tentado inserir a necessidade de exame de suficiência profissional para a concessão do registro por intermédio de normas internas, o Poder Judiciário vinha entendendo a exigência como ilegal, por não contar com qualquer previsão em lei. Neste sentido: Superior Tribunal de Justiça: "Processo: RESP 200201688412. RESP - RECURSO ESPECIAL - 503918. Relator(a) FRANCIULLI NETTO. Sigla do órgão STJ. Órgão julgador: SEGUNDA TURMA. Fonte DJ DATA:08.09.2003 PG:00311 Decisão. Vistos, relatados e discutidos os autos em que são partes as acima indicadas, acordam os Ministros da SEGUNDA TURMA do Superior Tribunal de Justiça, por unanimidade, em não conhecer do recurso, nos termos do voto do Sr. Ministro Relator. Os Srs. Ministros João Otávio de Noronha, Castro Meira, Francisco Peçanha Martins e Eliana Calmon votaram com o Sr. Ministro Relator. Sustentou oralmente o Dr. Pedro Miranda, pelo recorrente. Ementa: RECURSO ESPECIAL. CONSELHO REGIONAL DE CONTABILIDADE. NATUREZA JURÍDICA. AUTARQUIA FEDERAL. COMPETÊNCIA DA JUSTIÇA FEDERAL. RESOLUÇÃO DO CONSELHO FEDERAL DE CONTABILIDADE. APROVAÇÃO EM EXAME DE
} 
Ressalte-se, porém, que, para o exercício da atividade de auditoria externa, não bastará o registro como profissional de nível médio (técnico em contabilidade), ${ }^{190}$ pois a realização de trabalhos de auditoria é prerrogativa de bacharel em ciências contábeis, profissional com formação superior.

Nas hipóteses em que é necessário o duplo registro, a inscrição perante os conselhos profissionais constitui-se pressuposto para o posterior registro junto à CVM. Justamente por isso a cassação do registro profissional junto aos órgãos de fiscalização da profissão contábil determina necessariamente o cancelamento do registro junto à CVM (art. 15, III, da Instrução n. 308/99).

Para a obtenção do registro junto à CVM, além do prévio registro profissional, é necessário que o auditor (pessoa física) ou a sociedade de auditoria atendam a outros requisitos constantes da Instrução n. 308/99 da CVM, os quais poderiam ser classificados na forma seguinte:

- Suficiência técnica: para a inscrição nos quadros da CVM, o auditor deve passar por exame de qualificação técnica, organizado pelo próprio $C F C$, em conjunto com o IBRACON. Os auditores que lograram êxito na aprovação em referido exame têm direito a ser inscritos em cadastro

SUFICIÊNCIA PROFISSIONAL PARA REGISTRO NOS CONSELHOS REGIONAIS DE CONTABILIDADE. EXIGÊNCIA NÃO PREVISTA EM LEI. NÃO CABIMENTO. "O Superior Tribunal de Justiça entende que os Conselhos Regionais de fiscalização do exercício profissional têm natureza jurídica de autarquia federal e, como tal, atraem a competência da Justiça Federal nos feitos de que participem (CF/88, Art. 109, IV)" (AGREsp n. 314.237/DF, Rel. Min. Humberto Gomes de Barros, DJ de 09.06.2003). O Conselho Federal de Contabilidade extrapolou a previsão legal ao estabelecer, por Resolução, a aprovação em exame de suficiência profissional como requisito para o registro nos Conselhos Regionais. Com efeito, tal exigência não está prevista no Decreto-lei n. 9.295/46, que apenas dispõe, em seu artigo 10, que cabe aos referidos órgãos fiscalizar o exercício da profissão e organizar o registro dos profissionais. A atividade de fiscalizar é completamente distinta do poder de dizer quem está ou não apto ao exercício de determinada atividade profissional. Trata-se, pois, de entidades distintas, não se subsumindo uma no conceito de outra, nem mesmo quanto à possibilidade de atividades concêntricas. De qualquer forma, impende frisar que somente a lei poderá atribuir a outras entidades, que não escolas e faculdades, capacidade e legitimidade para dizer sobre a aptidão para o exercício dessa ou daquela profissão. $\mathrm{O}$ legislador, quando entende ser indispensável a realização dos aludidos exames para inscrição no respectivo órgão de fiscalização da categoria profissional, determina-o de forma expressa. Nesse sentido, cite-se o artigo $8^{o}$, IV, da Lei $n$. 8.906/94 (Estatuto da Advocacia), que exige a aprovação em Exame de Ordem para inscrição como advogado na Ordem dos Advogados do Brasil. Recurso especial não conhecido".

${ }^{190}$ Saliente-se que a Lei 12.249/2010 também alterou a situação dos técnicos em contabilidade, passando a exigir diploma de nível superior para o exercício da contabilidade e, em consequência, extinguindo esta categoria profissional. Admitiu, porém, em caráter de norma transitória, que os técnicos em contabilidade já registrados em Conselho Regional de Contabilidade e os que venham a fazê-lo até $1^{\circ}$ de junho de 2015 tenham assegurado o seu direito ao exercício da profissão. 
nacional de auditores independentes (CNAI), mantido pelo próprio CFC; ${ }^{191}$

- Experiência profissional: é necessário que o profissional individual ou responsável técnico de sociedade de auditores tenha exercido previamente atividade de auditoria de demonstrações contábeis, dentro do território nacional, por período não inferior a cinco anos, consecutivos ou não, contados a partir da data do registro em Conselho Regional de Contabilidade, na categoria de contador;

- Estrutura compatível com o exercício da profissão: o auditor ou sociedade de auditoria deve contar com instalações compatíveis com o exercício da atividade, em condições que garantam a guarda, a segurança e o sigilo dos documentos e informações decorrentes desta atividade, bem como a privacidade no relacionamento com seus clientes;

- Indicação clara de responsáveis técnicos: para o auditor pessoa jurídica, é necessário que todos os sócios sejam contadores, e que pelo menos a metade desses seja cadastrada como responsável técnico;

- Inscrição em Registro Civil de Pessoas Jurídicas: é necessário que a sociedade de auditores esteja registrada sob a forma de sociedade civil, constituída exclusivamente para prestação de serviços profissionais de auditoria e demais serviços inerentes à profissão de contador.

\footnotetext{
${ }^{191}$ A exigência de exame de qualificação técnica está em consonância com o exigido no âmbito da União Europeia, na Diretiva n. 2006/43/CE: “Artigo 6º․ Qualificações acadêmicas. Sem prejuízo do artigo 11, uma pessoa singular só pode ser aprovada para efeitos da realização de revisão legal das contas após ter obtido um nível acadêmico correspondente ao que permite o acesso à universidade ou um nível equivalente, ter completado subsequentemente um curso de formação teórica, ter obtido formação prática e ter obtido aprovação num exame de aptidão profissional de nível correspondente ao exame de fim de estudos universitários ou equivalente, organizado ou reconhecido pelo Estado-Membro em questão. Artigo $7^{\underline{0}}$ Exame da aptidão profissional. $O$ exame da aptidão profissional referido no artigo $6^{0}$ deve assegurar o nível necessário de conhecimentos teóricos das matérias relevantes para a revisão legal das contas e a capacidade para aplicar na prática esses conhecimentos. Pelo menos, uma parte desse exame deve ser escrita. Artigo $8^{\circ}$ Prova de conhecimentos teóricos 1 . A prova de conhecimentos teóricos incluída no exame deve abranger, em especial, as seguintes matérias: a) Teoria e princípios da contabilidade geral; b) Requisitos e normas legais relativos à elaboração das contas anuais e consolidadas; c) Normas internacionais de contabilidade; d) Análise financeira; e) Contabilidade de custos e de gestão; f) Gestão de risco e controle interno; g) Auditoria e qualificações profissionais; h) Requisitos legais e normas profissionais relativos à revisão legal das contas e aos revisores oficiais de contas; i) Normas internacionais de auditoria; j) Deontologia profissional e independência. 2. Deve abranger igualmente, no mínimo, as seguintes matérias, na medida em que sejam relevantes para auditoria: a) Direito das sociedades e governança das sociedades; b) Direito da insolvência e procedimentos análogos; c) Direito fiscal; d) Direito civil e comercial; e) Direito de segurança social e direito do trabalho; f) Tecnologias da informação e sistemas informáticos; g) Economia empresarial, geral e financeira; h) Matemática e estatística; i) Princípios básicos da gestão financeira das empresas. 3. A Comissão pode, nos termos do n. 2 do artigo 48, proceder à adaptação da lista de matérias a incluir na prova
} 
Não existe no ordenamento nacional, como condição de registro, a necessidade de capitalização mínima de sociedade de auditoria ou mesmo de apresentação de garantias ou seguro obrigatório para assegurar indenizações em face de eventual responsabilidade civil de auditor ou sociedade de auditoria. ${ }^{192}$

Concedido o registro na CVM ao auditor ou sociedade de auditoria, este poderá ser suspenso ou cancelado, sem prejuízo de outras sanções legais cabíveis, nos casos elencados no art. 15 da Instrução n. 308/99 da CVM. ${ }^{193}$

\subsubsection{Educação continuada e controle de qualidade}

Além da exigência inicial de qualificação técnica para a obtenção do registro, é necessário que o profissional que exerce a atividade de auditoria externa (individualmente,

de conhecimentos teóricos referida no n. 1. Quando adotar essas medidas de execução, a Comissão deve ter em conta a evolução no domínio da auditoria e do exercício profissional da auditoria”.

${ }^{192} \mathrm{Na}$ Itália, entretanto, tais condições (seguro, garantias bancárias, etc.) são requisitos para a inscrição das sociedades de auditoria externa no registro da Consob. Neste sentido, o Decreto Legislativo de 24 de fevereiro de 1998, n. 58, art. 161: “(Albo speciale delle società di revisione) 4. Per l'iscrizione nell'albo le società di revisione devono essere munite di idonea garanzia prestata da banche, assicurazioni o intermediari iscritti nell'elenco speciale previsto dall'articolo 107 del decreto legislativo $1^{\circ}$ settembre 1993, n. 385, o avere stipulato una polizza di assicurazione della responsabilità civile per negligenze o errori professionali, comprensiva della garanzia per infedeltà dei dipendenti, per la copertura dei rischi derivanti dall'esercizio dell'attività di revisione contabile. L'ammontare della garanzia o della copertura assicurativa è stabilito annualmente dalla Consob per classi di volume d'affari e in base agli ulteriori parametri da essa eventualmente individuati con regolamento".

${ }^{193}$ Dentre eles: "I - seja comprovada a falsidade dos documentos ou declarações apresentados para a obtenção do registro na Comissão de Valores Mobiliários; II - sejam descumpridas quaisquer das condições necessárias à sua concessão ou à sua manutenção ou se for verificada a superveniência de situação impeditiva; III - tenham sofrido pena de suspensão ou cancelamento do registro profissional, transitada em julgado, aplicada pelo órgão fiscalizador da profissão; ou IV - forem, por sentença judicial transitada em julgado: a) declarados insolventes; b) condenados em processo crime de natureza infamante, ou por crime ou contravenção de conteúdo econômico; c) impedidos para exercer cargo público; ou d) declarados incapazes de exercerem os seus direitos civis". Perante a União Europeia, a revogação da aprovação pode ser realizada nos seguintes casos apontados na Diretiva n. 2006/43/CE: “Artigo 5ํ Revogação da aprovação. 1. A aprovação de um revisor oficial de contas ou de uma sociedade de revisores oficiais de contas deve ser revogada se a idoneidade dessa pessoa ou sociedade for gravemente comprometida. No entanto, os EstadosMembros podem fixar um prazo razoável para assegurar o respeito dos requisitos de idoneidade. 2. A aprovação de uma sociedade de revisores oficiais de contas deve ser revogada se alguma das condições previstas nas alíneas b) e c) do n. 4 do artigo $3^{-0}$ deixar de ser satisfeita. No entanto, os Estados-Membros podem fixar um prazo razoável para assegurar o cumprimento dessas condições. 3. Quando a aprovação de um revisor oficial de contas ou de uma sociedade de revisores oficiais de contas for revogada por qualquer motivo, a autoridade competente do Estado-Membro onde a aprovação for revogada deve comunicar esse fato e os motivos da revogação às autoridades competentes pertinentes dos Estados-Membros onde o revisor oficial de contas ou a sociedade de revisores oficiais de contas também estiverem aprovados e cujos dados constam do registro do primeiro Estado-Membro, nos termos da alínea c) do artigo 16". Interessante verificar que, em consulta ao site da Comissão de Valores Mobiliários, disponível em 〈http://www.cvm.gov.br〉, acesso em 6 jan. 2010, encontramos a notícia de que, na data de acesso, não havia auditores com registro suspenso ou cancelado por decisão administrativa de referida autarquia. 
ou como responsável técnico de sociedade de auditores) se mantenha permanentemente atualizado e voltado ao aprimoramento de seus conhecimentos.

Desta forma, o auditor pessoa física ou os responsáveis técnicos de uma sociedade de auditoria necessitam, para manter ativo seu registro profissional, cumprir os requisitos impostos referentes a programa de formação, aperfeiçoamento ou educação continuada.

A exigência de formação ou educação continuada é uma exigência na União Europeia, que, no art. 13 da Diretiva n. 2006/43/CE de 17 de maio de 2006, determina que:

Os Estados-Membros devem assegurar que seja exigida aos revisores oficiais de contas a participação em programas adequados de formação contínua, a fim de manterem um nível suficientemente elevado de conhecimentos teóricos, de qualificação profissional e de valores deontológicos, e que o incumprimento dos requisitos em matéria de formação contínua se encontra sujeito a sanções adequadas, de acordo com o previsto no artigo 30.

No Brasil, a educação continuada do auditor é exigida para a manutenção do registro profissional no Cadastro de Auditores Independentes (CNAI), mantido pelo Conselho Federal de Contabilidade, requisito necessário para o registro do auditor junto à CVM e, portanto, para o exercício da profissão de auditoria perante entidades auditadas que se constituam como companhia aberta, instituições financeiras, seguradoras e de previdência. Para o exercício da profissão em outras entidades auditadas que não se enquadrem nas categorias supracitadas, não há exigência de educação continuada do auditor independente.

A regulação da matéria é atualmente feita pelo Conselho Federal de Contabilidade, que editou a Res. n. 1.146/08, exigindo que os auditores externos independentes, inscritos no Cadastro Nacional de Auditores Independentes (CNAI), aqueles com cadastro na Comissão de Valores Mobiliários (CVM), e aqueles que exercem atividades de auditoria nas instituições financeiras, nas sociedades seguradoras e de capitalização e em entidades abertas de previdência complementar devam cumprir 96 (noventa e seis) pontos de educação profissional continuada por triênio-calendário, 
conforme o tipo de atividade educacional e tabelas de pontuação descritas em referida norma. $^{194}$

Além da educação continuada, o auditor ou sociedade de auditores deve manter sistema de controle de qualidade de suas atividades.

Os sistemas de controle obrigatórios aos auditores podem se classificar em externos e internos.

Os internos são aqueles estabelecidos no âmago da sociedade de auditoria ou equipe de auditores para a conformação de sua atividade a requisitos previamente estabelecidos.

A Instrução n. 308/99 da CVM ressalta em seu art. 32 que o auditor independente deverá implementar um programa interno de controle de qualidade, segundo as diretrizes emanadas do Conselho Federal de Contabilidade - CFC e do Instituto Brasileiro de Contadores - IBRACON, que vise a garantir o pleno atendimento das normas que regem a atividade de auditoria de demonstrações contábeis e das normas emanadas desta Comissão de Valores Mobiliários.

Por seu turno, o CFC regulou a matéria nas Resoluções ns. 1.201/09 e 1205/09, vindo a primeira delas a estabelecer que o sistema de controle de qualidade deve incluir políticas e procedimentos que tratem dos seguintes elementos: (a) responsabilidades da liderança pela qualidade na firma; (b) exigências éticas relevantes; (c) aceitação e continuidade do relacionamento com clientes e de trabalhos específicos; (d) recursos humanos; (e) execução do trabalho; (f) monitoramento.

Trata-se, portanto, de uma mera política interna de qualidade, passível de supervisão pelos órgãos de fiscalização da profissão de auditoria e dos órgãos reguladores do mercado financeiro e de capitais, uma vez que se trata de obrigação ex lege.

Já o controle de qualidade externo é mais conhecido como revisão pelos pares (peer review), ou revisão de qualidade pelos pares, uma vez que tal sistema se baseia fundamentalmente na revisão da qualidade dos procedimentos do auditor ou sociedade de auditoria (auditor revisado) por outros auditores (auditor revisor).

\footnotetext{
${ }^{194}$ Tal Resolução define educação profissional continuada como "a atividade programada, formal e reconhecida pelo CFC, visando manter, atualizar e expandir os conhecimentos técnicos, indispensáveis à qualidade e ao pleno atendimento das normas que regem o exercício da atividade de auditoria de demonstrações contábeis".
} 
No âmbito da União Europeia, o sistema de controle externo dos auditores independentes tem como princípio fundamental que os revisores oficiais de contas e as sociedades de revisores oficiais de contas deverão estar sujeitos a um sistema de controle de qualidade organizado de modo que seja independente dos revisores oficiais de contas e das sociedades de revisores oficiais de contas submetidos a supervisão (Diretiva $\mathrm{n}$. 2006/43/CE, de 17 de maio de 2006).

No controle externo de qualidade, há, na verdade, a imposição de um contrato coativo de prestação de serviços de auditoria de cumprimento (compliance audit), em que o auditor revisado deve contratar um auditor revisor ${ }^{195}$ para realizar verificação do cumprimento dos requisitos de qualidade por parte daquele. ${ }^{196}$

Verifique-se que não há na revisão pelos pares prestação de serviços de auditoria de demonstrações, uma vez que o auditor revisor não verifica a adequação dos lançamentos contábeis do auditor revisado, apenas constata se este cumpre determinados requisitos de qualidade necessários ao exercício da profissão. ${ }^{197}$

Tratando-se de um contrato coativo, a inobservância de sua realização ou dos termos em que deve ser desenvolvido pode gerar punições para as partes, seja pelos órgãos

\footnotetext{
${ }^{195}$ Bem ressalta a natureza contratual do controle externo de qualidade o item 26 da Res. n. 1.158 do CFC, que assim dispõe: "A seleção do auditor revisor cabe ao auditor a ser revisado, tanto no caso de auditor pessoa física quanto de firma de auditoria". Cabe, portanto, ao auditor revisado, contratar o auditor revisor de sua preferência, dentre aqueles habilitados a realizar a tarefa de controle de qualidade.

${ }^{196} \mathrm{O}$ auditor revisor, nos termos da Res. n. 1.158/09 do CFC, para exercer suas funções deve observar: "(a) a equipe revisora deve possuir estrutura de recursos humanos e técnicos compatível com a revisão a ser realizada. A compatibilidade refere-se, principalmente, à experiência dos revisores em trabalhos de auditoria de similar complexidade; (b) o auditor revisor pessoa física e os membros da equipe revisora pessoa jurídica devem atender as condições fixadas no Programa de Educação Profissional Continuada estabelecido pela NBC P 4, aprovada pelo CFC; (c) o auditor independente pessoa física e os profissionais responsáveis técnicos da firma de auditoria independente, encarregados da revisão, devem estar devidamente registrados no Cadastro Nacional de Auditores Independentes (CNAI); (d) estar devidamente registrados no Cadastro de Auditores Independentes da Comissão de Valores Mobiliários (CVM); (e) caso o auditor revisado tenha sua lista de clientes, entidades regulamentadas pelo Banco Central do Brasil (BCB) e pela Superintendência de Seguros Privados (SUSEP), os membros da equipe revisora devem estar registrados no CNAI, com habilitação para auditar as respectivas entidades".

${ }^{197}$ Tal circunstância fica particularmente clara ao observarmos os objetivos da revisão pelos pares, traçados no item 29 da Res. n. 1.158 do CFC, que assim preconiza: "A revisão deve ser organizada para permitir que o auditor revisor emita opinião sobre se durante o período coberto pela revisão: (a) o sistema de controle de qualidade, incluindo a estrutura organizacional e a metodologia de auditoria, estabelecido pelo auditor revisado para os trabalhos de auditoria atende às normas profissionais estabelecidas, independentemente de $o$ auditor revisado ter realizado trabalho com emissão de parecer de auditoria no período sob revisão; e (b) os procedimentos de controle de qualidade definidos foram, efetivamente, adotados na realização dos trabalhos pelo auditor revisado". Também a regulamentação da matéria perante a União Europeia (Diretiva n. 2.006/43/CE, art. 29. 1, "f") segue a mesma linha: "O âmbito das verificações do controle de qualidade, apoiado por um teste adequado dos dossiês de revisão ou auditoria selecionados, deve incluir uma apreciação do cumprimento das normas de auditoria aplicáveis e dos requisitos de independência, da quantidade e qualidade dos recursos utilizados e dos honorários de auditoria faturados, assim como uma avaliação do sistema interno de controle de qualidade da sociedade de revisores oficiais de contas".
} 
de fiscalização da profissão de auditoria seja pelos órgãos reguladores do mercado financeiro e de capitais. ${ }^{198}$

No entanto, na revisão pelos pares foi instituída uma forma de supervisão pública mais próxima do que a mera fiscalização dos órgãos ora referidos, impondo-se a intervenção direta de órgãos públicos no contrato de revisão pelos pares estabelecido entre auditor revisado e auditor revisor, além da administração do programa de controle externo de qualidade dos auditores independentes, pelo denominado Comitê Administrador do Programa de Revisão Externa de Qualidade (CRE). ${ }^{199}$

Referido comitê, nos termos da Resolução n. 1.158/09 do CFC, é integrado por 4 (quatro) representantes do Conselho Federal de Contabilidade (CFC) e por 4 (quatro) representantes do IBRACON - Instituto dos Auditores Independentes do Brasil, indicados pelas respectivas entidades, segundo suas disposições estatutárias. ${ }^{200}$ Suas principais atribuições incluem identificar os auditores a serem revisados a cada ano; emitir e atualizar, anualmente, guias de orientação, instruções e questionários detalhados que servirão de roteiro mínimo para orientação na tarefa de revisão pelos pares; revisar os relatórios de revisão recebidos do auditor revisor e os planos de ação corretivos recebidos do auditor revisado; aprovar, em forma final, os relatórios e os planos de ação e comunicar ao Conselho Federal de Contabilidade (CFC) e à Comissão de Valores Mobiliários (CVM) situações que sugerem necessidade de diligências sobre os revisados e revisores. ${ }^{201}$

Por outras palavras, podemos dizer que o CRE determina quem deve contratar a revisão pelos pares, qual a metodologia para a execução do contrato, além de

\footnotetext{
${ }^{198}$ Exemplo disto está contido na decisão do CRSFN, ACÓRDÃO 2884/00. Recurso 2984. Processo origem CVM 98/4845, em que o relatório de revisão emitido pelo auditor revisor não foi assinado pelo responsável técnico da sociedade de auditoria: "EMENTA: RECURSO VOLUNTÁRIO - Mercado de valores mobiliários - Auditoria independente - Relatório de revisão - Assinatura por profissional não integrante do quadro de responsáveis técnicos da sociedade - Irregularidade caracterizada - Recurso a que se nega provimento. PENALIDADE: Advertência. BASE LEGAL: Lei 6.385/76, art. 11, inciso I".

${ }^{199}$ A supervisão pública do controle de qualidade é uma exigência também no âmbito da União Europeia, constante da Diretiva n. 2006/43/CE, que preceitua em seu art. 29, 1, "a": "Cada Estado-Membro deve assegurar que todos os revisores oficiais de contas e sociedades de revisores oficiais de contas se encontram sujeitos a um sistema de controle de qualidade, que respeite, pelo menos, os seguintes critérios: a) O sistema de controle de qualidade deve ser organizado de modo que seja independente dos revisores oficiais de contas e sociedades de revisores oficiais de contas objeto de controlo e que esteja sujeito a supervisão pública descrita no capítulo VIII".

${ }^{200}$ Nos termos da Res. n. 1158/09 do CFC, os representantes devem ser, em todos os casos, contadores no exercício da auditoria independente devidamente registrados no Cadastro Nacional de Auditores Independentes (CNAI) e na Comissão de Valores Mobiliários (CVM). O prazo de nomeação é de 3 (três) anos, sendo permitida a recondução.

${ }^{201}$ O rol completo das atribuições do CRE encontra-se no item 9 da Res. n. 1.158/09 do CFC.
} 
supervisionar o resultado final do serviço prestado pelo auditor revisor sobre a qualidade apresentada pelo auditor revisado. ${ }^{202}$

No Brasil, a contratação do controle externo de qualidade (revisão pelos pares) é necessária aos auditores revisados a cada ciclo de quatro anos. No ano posterior à obtenção do registro junto à CVM, porém, deve haver, obrigatoriamente, a revisão, podendo ainda ser determinado pelo CRE períodos menores de revisão. ${ }^{203}$

A revisão pelos pares deve resultar em relatório formal emitido pelo auditor revisor, denominado relatório de revisão pelos pares ou "carta de revisão por pares", a ser objeto de supervisão do CRE.

Nos termos da Res. n. 1.158/09 do CFC, o relatório de revisão pode apresentar uma das seguintes conclusões: 1) sem ressalvas: quando o auditor revisor não veja qualquer distorção ou problema relevante no sistema de qualidade do auditor revisado; 2) com ressalvas: quando encontrar desconformidades relevantes sobre pontos específicos que não sejam de monta a determinar a emissão de conclusão adversa; 3) com conclusão adversa: quando as desconformidades encontradas sejam tais que resultem na inadequação do sistema de qualidade em face das normas reguladoras; 4) com abstenção de conclusão: quando não houver elementos para que o auditor revisor possa concluir a respeito do sistema de qualidade do auditor revisado, dadas as limitações impostas a seu trabalho.

Considerando que o auditor revisor deve atuar no interesse dos terceiros usuários dos serviços de auditoria externa, interessados em obter garantias de qualidade na realização desta atividade, aplica-se ao contrato de revisão pelos pares a exigência de independência entre as partes.

Do mesmo modo, há de se ter em vista que o auditor revisor, ao realizar seu trabalho, acaba usualmente por ter acesso a dados estratégicos do auditor revisado, razão pela qual também fica obrigado a manter sigilo das informações obtidas nesta atividade (obrigação de confidencialidade).

\footnotetext{
${ }^{202}$ No site do CFC encontra-se o relatório do realizado pelo órgão, constando o seguinte: "Auditores indicados para 2009: Pessoa física 47, Pessoa jurídica 106, Total 153. Processos de diligência: 31 referentes ao Programa 2008 - calendário 2007, 25 referentes ao Programa 2008 - calendário 2007. Processos de autuação: 27 referentes ao Programa de 2009 - calendário 2008". Disponível em <http://www.cfc.org.br/conteudo.aspx?codMenu=67\&codConteudo=4335>. Acesso em 06 jan. 2010.

${ }^{203}$ Perante a União Europeia, a Diretiva 2006/43/CE determina o prazo de seis anos (art. 29, 1, "h"): "As verificações do controlo de qualidade devem decorrer, pelo menos, com uma periodicidade de seis anos".
} 


\subsubsection{Análise quanto à natureza empresária ou civil da atividade do}

\section{auditor}

Para enquadrarmos ou não a atividade de auditoria na categoria de atividade empresária, é necessário que passemos em revista os principais elementos desta espécie jurídica.

Historicamente, várias foram as teorias que procuraram definir o objeto do Direito Comercial, desde sua concepção inicial, como um regulamento de classes (corporações), passando pela teoria dos atos de comércio, até a adoção moderna do conceito de empresa. ${ }^{204}$

Nosso Código Civil, com base no Código Civil italiano de $1942,{ }^{205}$ adotou em seu art. 966 a teoria da empresa, definindo como empresário quem exerce profissionalmente atividade econômica organizada para a produção ou a circulação de bens ou de serviços.

Como ressalta Raquel Sztajn:

O Código Civil brasileiro de 2002, seguindo a concepção do italiano de 1942, abandona a noção de comerciante para adotar a de empresário, mas, diversamente deste, ao invés de considerar a atividade do empresário como uma das possíveis manifestações da atividade econômica, razão pela qual no codice civile o empresário vem tratado no

\footnotetext{
${ }^{204}$ Embora não seja o objetivo deste trabalho, entendemos que cabe aqui um breve esclarecimento sobre as teorias que definem a matéria sobre a qual recai o Direito Comercial. Como se sabe, historicamente o Direito Comercial surgiu na Idade Média, como um direito protetor das relações dos componentes das corporações de ofício. A matéria abrangida por tal ramo jurídico era definida pelo sujeito ao qual se aplicava (critério subjetivo). Posteriormente, sob a inspiração do Código Comercial francês de 1807, tomou corpo a teoria dos atos de comércio, que definia um número determinado de atos supostamente "inerentes ao comércio" que, se praticados com habitualidade, independente da pessoa que o fizesse (critério objetivo), caracterizariam a matéria sobre a qual incidia o Direito Comercial. Esta teoria, que nunca conseguiu ter um sucesso absoluto no exaurimento ou na definição precisa do objeto do Direito Comercial, foi substituída com vantagens pela teoria da empresa, que conceituou o objeto do Direito Comercial como recaindo sobre a atividade organizada visando à produção e troca de bens e serviços no mercado, praticadas por empresário (conceito subjetivo moderno). No Brasil, a teoria inicialmente adotada pelo Código Comercial foi a dos atos de comércio, que vinham definidos no Regulamento n. 737 de 1850, tendo o novo Código Civil (2002) adotado finalmente a teoria da empresa.

205 "Art. 2082 Imprenditore. È imprenditore chi esercita professionalmente un'attività economica organizzata $(2555,2565)$ al fine della produzione o dello scambio di beni o di servizi $(2135,2195)$."
} 
Livro V - Do Trabalho -, escolheu dedicar uma parte ao denominado Direito de Empresa. ${ }^{206}$

Também com base na legislação italiana, ${ }^{207}$ nosso ordenamento excluiu da definição de empresa as atividades intelectuais (de natureza científica, literária ou artística), próprias dos profissionais liberais, ainda que realizadas com o concurso de auxiliares ou colaboradores, salvo se o exercício da profissão se constituir em elemento de empresa, segundo o Código Civil (art. 966, parágrafo único).

As razões que levaram o legislador a excluir as atividades intelectuais do conceito de empresa são objeto de controvérsia na doutrina. As posições defendidas podem ser assim resumidas: 1) falta a este tipo de atividade o requisito da organização dos fatores de produção; 2) a exclusão é motivada pelo fato de que a atividade intelectual não se constitui em produção de bens e serviços no sentido técnico-jurídico; 3) a razão da exclusão se baseia no fato de que na atividade intelectual o profissional não assume o risco do seu trabalho, que caracteriza a atividade empresarial; 4) trata-se de opção política do legislador, uma vez que estão presentes todas as características da atividade empresarial no exercício de profissão intelectual, justificando-se a exclusão apenas pela escolha do legislador em separar os regimes jurídicos respectivos. ${ }^{208}$

Também controverso é o que se considera por elemento de empresa na definição do parágrafo único do art. 966 do Código Civil. Enfrentando a controvérsia, Haroldo Malheiros Duclerc Verçosa doutrina:

Nota-se que a expressão "elemento de empresa", encontrada no art. 966, parágrafo único do NCC, não apresenta sentido jurídico claro. $\mathrm{Na}$ verdade, caberia perguntar - caso o intérprete já não tivesse uma informação nesse sentido, à luz do ordenamento jurídico italiano, no qual o nosso Direito de Empresa está declaradamente calcado - se a intenção do legislador teria sido incluir no rol dos empresários aqueles que exercessem atividade intelectual organizada (de natureza científica, literária ou artística), desde que ela correspondesse ao objeto de empresa,

\footnotetext{
206 SZTAJN, Raquel. Teoria jurídica da empresa - Atividade empresária e mercados. São Paulo: Atlas, 2004. p.109.

207 “Art. 2238 Rinvio. Se l'esercizio della professione costituisce elemento di un'attività organizzata in forma d'impresa, si applicano anche le disposizioni del Titolo II (2082 e seguenti). In ogni caso, se l'esercente una professione intellettuale impiega sostituti o ausiliari, si applicano le disposizioni delle Sezioni II, III e IV del Capo I del Titolo II (2094 e seguenti)".

${ }^{208}$ Na doutrina italiana, Aldo Fiale resume bem as posições doutrinárias que tentam justificar a exclusão das atividades intelectuais do conceito de empresa (FIALE, Aldo. Diritto Commerciale. Napoli: Simone, 2008). Na doutrina nacional, Stajn (Teoria jurídica...cit., p. 109 e ss.).
} 
e qual seria ele, como finalidade econômico-lucrativa. A pergunta que se coloca em seguida é relativa a ser esse objeto da empresa simples (e, portanto, único) ou complexo, coexistindo diversos deles. Se a interpretação em causa pudesse levar a entender que a expressão "elemento de empresa" corresponderia a uma parte do objeto da empresa, então o sujeito dessa atividade poderia ser considerado empresário quanto ao restante do mesmo objeto, subsumindo-se nele a atividade intelectual (...). De outro lado, o exercício de atividade intelectual pura como único objeto da atividade organizada poderia levar à conclusão no sentido de que seu titular seria um empresário para os efeitos do Código Civil de 2002, já que esse objetivo seria elemento de empresa, ou seja, faria parte da atividade organizada (...). O ponto fraco desta interpretação está na constatação de que, assim sendo, bastaria alguém organizar qualquer atividade para que pudesse ser considerado empresário, nos campos da Advocacia, Medicina, Odontologia, Engenharia, Arquitetura, etc. E certamente essa não teria sido a intenção do legislador, historicamente avesso a estender às organizações destinadas ao exercício das chamadas "profissões liberais" o caráter de empresa mercantil (...). A única solução para o problema está em adotar como adequada a primeira interpretação acima enunciada: a atividade intelectual leva seu titular a ser considerado empresário se ela estiver integrada em um objeto mais complexo, próprio da atividade empresarial. ${ }^{209}$

Levando em consideração os conceitos legais e doutrinários ora estudados, a primeira interpretação que se pode ter ao examinar o texto da legislação pátria leva seguramente a enquadrar a atividade de auditoria como intelectual, e não empresária.

De fato, os serviços de auditoria fazem parte de um todo maior contido na profissão contábil, enquadrada dentre as profissões liberais, de natureza intelectual. ${ }^{210}$

A aparente segurança desse primeiro enquadramento, porém, cede certo espaço quando passamos a verificar a caracterização da atividade de auditoria como elemento de empresa e os ensinamentos da doutrina italiana, baseada na legislação fonte de nosso ordenamento.

\footnotetext{
${ }^{209}$ Op. cit. p. 141.

${ }^{210}$ Veja-se que o Dec.-Lei n. 9.295/1946 estabelece em seu art. 25: "São considerados trabalhos técnicos de contabilidade: (...) c) perícias judiciais ou extrajudiciais, revisão de balanços e de contas em geral, verificação de haveres, revisão permanente ou periódica de escritas, regulações judiciais ou extrajudiciais de
} 
Assumindo como possíveis as duas interpretações citadas anteriormente a respeito do significado da expressão elemento de empresa, verificamos que em ambas as hipóteses a atividade de auditoria poderá assim se enquadrar.

Adotando a interpretação segundo a qual a expressão supracitada se refere à organização complexa dos fatores de produção, que substitui a pessoalidade da prestação dos serviços em caráter intelectual, é forçoso admitir que a atividade de auditoria pode ser (e o é na realidade $)^{211}$ explorada de forma empresária. Aliás, a extensão e complexidade da matéria auditada nos dias de hoje (envolvendo companhias de grande porte, instituições financeiras, de previdência, etc.) obrigam que a atividade de auditoria seja cada vez mais prestada de forma organizada, impessoal e de maneira institucionalizada.

Se, por outro lado, adotarmos a interpretação antes mencionada, que entende que a atividade intelectual será elemento de empresa quando for parte de um objeto empresarial maior, também será imperioso concluir que a atividade de auditoria pode ser efetivada em caráter empresarial.

Com efeito, ao contrário do que ocorre com algumas profissões liberais, a contabilidade (na qual se enquadra a matéria de auditoria) é atividade que não demanda exercício separado de outras profissões. Como veremos mais adiante, é possível no ordenamento pátrio, $v . g$., que uma única sociedade, devidamente registrada nos órgãos de fiscalização de profisssão, seja formada por contadores (e, por conseguinte, auditores), prestando este serviço a seus clientes, juntamente com outros sócios não contadores, os quais se dediquem a outro objeto social, mais amplo e complexo, dentro do qual esteja inserida a contabilidade ou a auditoria.

Analisando este último aspecto no ordenamento italiano, que neste ponto apresenta identidade com a legislação nacional, Gastone Cotino entende que a sociedade de auditoria (società di revisione contabile) não se enquadra como sociedade estabelecida unicamente entre profissionais, mas como sociedade empresária. Entende o autor que as sociedades de auditoria se configuram como atividades empresariais auxiliares, sujeitas ao registro empresarial:

Isso significa que as sociedades de auditoria devem, prevalentemente, ser constituídas de profissionais (de extração e de preparação variadas); atribuições de natureza técnica conferidas por lei aos profissionais de contabilidade” (grifos nossos). 
podem, além disso, ser constituídas de indivíduos estranhos à profissão. A sociedade de auditoria (...) não é, portanto, necessariamente uma sociedade entre (somente) profissionais (...). Não é nem mesmo - não o era à luz da disciplina preexistente, não parece sê-lo à luz da atual - uma forma coletiva de exercício da profissão de consultores ou contadores, ou assemelhados. É antes o instrumento (obrigatório) para o desempenho dos serviços de natureza contábil e empresarial. Através dela se oferecem prestações específicas de revisão e certificação, substancialmente recondutíveis à matriz profissional do consultor ou contador, mas não identificáveis com esta (...). Parece consequentemente mais persuasiva a tese que reconhece na sociedade de auditoria o exercício na forma social de uma atividade distributiva de serviços, recondutível ao esquema de atividade empresarial auxiliar, de acordo com o art. 2195, n. 5, Cod. Civ. (A. Rossi; Castelano). O profissional atua nas sociedades de auditoria na forma prevista no parágrafo primeiro do art. 2238 Cod. Civ. A execução da sua parte nas prestações inerentes a sua profissão constitui elemento de uma atividade organizada na forma da empresa. ${ }^{212}$

A possibilidade de exploração da atividade de auditoria de forma empresária também ganha corpo no ordenamento comparado quando, em muitos países, se permite a constituição de sociedades de auditoria na forma de sociedades por ações, como veremos com mais detalhes posteriormente.

Desta forma, podemos concluir que a atividade de auditoria é exercida predominantemente em caráter intelectual, uma vez que está inserida no exercício da profissão contábil. Não obstante, qualquer que seja a interpretação dada à expressão elemento de empresa, contida no parágrafo único do art. 966 do Código Civil pátrio, há

\footnotetext{
${ }^{211}$ Basta constatar a estrutura altamente organizada das grandes sociedades de auditoria que prestam serviços em diversos continentes, hoje também denominadas Big Four (ou quatro grandes).

${ }^{212}$ COTTINO, Gastone. Diritto Commerciale. Padova: Cedam, 1994. p. 72.. O texto é tradução livre do seguinte excerto: "Ciò significache le società di revisione debbono essere costituite prevalentemente da professionisti (di varia estrazione e preparazione); possono inoltre esserlo insieme a sogetti estranei alla professione. La società di revisione (...) non è adunque necessariamente una società tra (soli) professionisti (...). Non è neppure - non lo era alla luce della disciplina preesistente, no pare esserlo alla luce di quella atuale - una forma colletiva di esercizio della professione di dottore commercialista o di ragionere, od assimilati. È piuttosto lo strumento (obbligato) per la prestazione di servizi di natura contabile ed aziendale. Attraverso essa si offrono prestazioni specifiche di revisione e certificazione, sostancialmente reconducibili alla matrice professionale del dottore commercialista o del ragionere ma non identificabile con essa (...). Sembra pertanto più persuasiva la tesi chi ha ravvisato nella società di revisione l'esercizio in forma societaria di un'atività erogatrice di servizi, riconducibile entro lo schema dell'impresa ausiliaria ai sensi dell'art. 2195, n. 5 cod. civ. (A Rossi; Castelano). Il professionista agisce nelle società di revisione nella veste ipotizzata dal primo comma dell'art. 2238 cod. civ. L'esecuzione da parte sua di prestazioni inerenti alla sua professione costituisce elemento de una atività organizata in forma di impresa".
} 
possibilidade de que referida prestação de serviços seja explorada na forma de atividade empresária. Reforça esta viabilidade o fato de que o volume exacerbado da matéria auditada nos dias de hoje venha a exigir a atuação de grandes organizações e a circunstância de que, no ordenamento nacional e alienígena, a sociedade de auditores não é obrigatoriamente composta de modo único por contadores (auditores), podendo esta atividade ser oferecida como parte de um objeto social maior.

\subsubsection{Tipicidade societária das sociedades de auditores}

Tema ligado ao tratado no tópico anterior diz respeito ao tipo societário permitido às sociedades de auditores. Devem-se definir aqui os tipos de sociedades permitidos aos profissionais de auditoria, sua responsabilidade subsidiária e os tipos de sócios que poderão fazer parte do contrato.

O primeiro problema, ligado à tipicidade societária ora tratado, diz respeito à natureza da atividade de auditoria, vista anteriormente.

Em sendo a atividade de auditoria definida como de natureza intelectual (não empresária), a conclusão aparente que daí se extrai é a de que as sociedades que tivessem a prestação de serviços de auditoria como objeto social somente poderiam se constituir sob a forma de sociedades simples (equivalentes às antigas sociedades civis). Este tipo societário, restrito às atividades de natureza não empresarial, traz como consequência imediata a possibilidade de responsabilização subsidiária pelas dívidas sociais (art. 1.023 do CC) de forma solidária ou proporcional.

Este tipo societário é determinado obrigatoriamente para as sociedades de auditoria que pretendam obter o respectivo registro junto à CVM, nos termos do art. $4^{\circ}, \mathrm{I}$, da Instrução CVM n. 308/99, com o agravante de que tais sociedades de auditores não poderão exercer outra atividade, além da auditoria, que não seja própria da profissão de contador. $^{213}$

\footnotetext{
213 “Art. 4ํㅜㄹ Para fins de registro na categoria de Auditor Independente - Pessoa Jurídica, deverá a interessada atender às seguintes condições: I - estar inscrita no Registro Civil das Pessoas Jurídicas, sob a forma de sociedade civil, constituída exclusivamente para prestação de serviços profissionais de auditoria e demais serviços inerentes à profissão de contador". É de se recordar que mesmo alguns serviços inerentes à profissão contábil estarão vedados, conforme o caso, por ameaça à independência do auditor (p.ex.: a concomitância entre prestação de serviços de auditoria, consultoria, planejamento tributário, etc.).
} 
A responsabilidade subsidiária dos sócios, cuja previsão se encontra no citado art. 1.023 do CC, é ainda mais reforçada no caso das sociedades de auditores registradas na CVM, diante da redação do art. 4ํㅡ, III, da Instrução CVM n. 308/99, que obriga a existência de cláusula no contrato social que preveja a responsabilidade ilimitada $e$ solidária dos sócios pelos danos causados a terceiros por culpa ou dolo. ${ }^{214}$ Vedada, portanto, a responsabilidade subsidiária proporcional dos sócios, nos termos do art. 1.023 do $\mathrm{CC}$, representando um incremento na severidade da responsabilidade pessoal dos sócios em relação ao tipo básico de sociedade simples.

Considerando que a responsabilidade solidária dos sócios nas sociedades de auditores com registro na CVM diz respeito tão somente aos danos causados a terceiros (responsabilidade contratual e extracontratual) pelo exercício da atividade de auditoria, entendemos que a cláusula supracitada não abrange a responsabilidade contratual dos sócios por outras dívidas contratuais da sociedade em questão não derivadas diretamente do exercício da profissão de auditor, responsabilidade esta que poderá ser determinada no contrato social como proporcional, nos termos do art. 1.023 do CC. ${ }^{215}$

No entanto, entendemos ser vedado à sociedade de auditores com registro na CVM valer-se da faculdade do art. 983 do Código Civil e constituir-se como sociedade simples sob forma societária que traga como consequência natural a limitação de responsabilidade dos sócios (p.ex., a constituição de uma sociedade simples limitada). Isto porque a cláusula obrigatória de responsabilidade subsidiária e solidária dos sócios pelos danos a terceiros seria incompatível com o contrato social de uma sociedade simples limitada.

Além das restrições mencionadas anteriormente, a sociedade de auditores com registro na CVM só pode ter como sócios pessoas físicas que exerçam a profissão contábil,

\footnotetext{
214 "III - constar do contrato social, ou ato constitutivo equivalente, cláusula dispondo que a sociedade responsabilizar-se-á pela reparação de dano que causar a terceiros, por culpa ou dolo, no exercício da atividade profissional e que os sócios responderão solidaria e ilimitadamente pelas obrigações sociais, depois de esgotados os bens da sociedade."

${ }^{215}$ Também chegamos a esta mesma interpretação se entendermos que a regra geral estabelecida pelo art. 1.023 do CC é a proporcionalidade, e a exceção (a depender de cláusula contratual expressa), a solidariedade. Isto porque, no dizer deste dispositivo, respondem os sócios subsidiariamente pelo saldo, na proporção em que participem das perdas sociais, salvo cláusula de responsabilidade solidária. Nesses termos, considerando que a situação excepcional somente abrange os casos que ela mesma ressalva (exceptiones sunt strictissimae interpretationis) a responsabilidade solidária não atingiria dívidas sociais provenientes de transações econômicas que não envolvessem a prática de serviços de auditoria.
} 
registrados em seu órgão profissional (art. $4^{\text {o }}$, II, da Instrução n. 308/99 da CVM). ${ }^{216}$ Não há possibilidade de holdings ou outras pessoas jurídicas comporem o quadro societário. ${ }^{217}$

A forma de constituição das sociedades de auditoria com registro na CVM, entretanto, difere frontalmente daquelas que exerçam a profissão em âmbito em que seja desnecessário referido registro.

Com efeito, para as sociedades de auditoria não registradas na CVM, a constituição societária segue as mesmas normas das demais sociedades que tenham por objeto a prestação de serviços inerentes à contabilidade. Tais disposições, constantes da Res. n. 1.166/09 do CFC, permitem que as sociedades de contadores sejam registradas como sociedades de profissionais (sociedades simples), adotando ou não a forma de outras sociedades empresariais (p.ex., sociedade simples limitada) nos termos do art. 983 do CC, ou ainda na forma original de sociedades empresárias (sociedade em nome coletivo, limitada, etc.), com registro na junta comercial respectiva. ${ }^{218}$

Permite-se ainda às sociedades de auditoria não registradas na CVM que possuam em seu quadro societário pessoas jurídicas (art. $3^{\circ}$, $§ 3^{\circ}$, da Res. n. 1.166/09 do CFC) e que sejam integradas por sócios oriundos de outras profissões liberais devidamente registrados nos respectivos órgãos (art. 3ㅜㅜ, caput, da Res. n. 1.166/09 do CFC).

Essa disparidade de tratamento entre as sociedades de auditores registradas na CVM e as que não ostentem mencionado registro poderia aparentemente se justificar.

Isto porque a razão que visivelmente orientou a elaboração das restrições regulatórias ao tipo societário inerente às sociedades de auditores com registro na CVM foi a necessidade de se garantir o ressarcimento por parte dessas pessoas jurídicas de eventuais prejuízos causados aos investidores do mercado de capitais ou financeiro. Assim sendo, estaria justificada a adoção de institutos como a responsabilidade subsidiária, ilimitada e solidária entre os sócios, e a restrição a outras pessoas jurídicas compondo o quadro

\footnotetext{
216 "II - que todos os sócios sejam contadores e que, pelo menos a metade desses, sejam cadastrados como responsáveis técnicos, conforme disposto nos $\S \S 1^{\underline{0}}$ e $2^{\underline{o}}$ do art. $2^{\circ}$."

${ }^{217}$ Verifique-se que a atividade de auditoria não é o único tipo de profissão intelectual ou liberal que sofre tal sorte de restrições ao seu exercício. O Estatuto da Advocacia (Lei n. 8.906/94) veda que as sociedades de advogados tomem forma mercantil e também determina que estas somente possam ter como sócios pessoas físicas (advogados) inscritas na $\mathrm{OAB}$, prevendo ainda a responsabilidade subsidiária dos sócios, de forma ilimitada, pelos danos causados a terceiros.

${ }^{218}$ Em linha com a orientação dada pela Res. n. 1.166/09 do CFC, o CRC-SP ressalta em seu portal: "Não cabem à Junta Comercial, Registro Civil de Pessoas Jurídicas, ou ao próprio CRC SP, definir o tipo da sociedade, devendo ela mesma avaliar o que for de interesse, com o conhecimento pleno dos conceitos de 'Sociedade Simples' e 'Sociedade Empresária”'. Informação disponível em <http://www.crcsp.org.br>. Acesso em 8 jan. 2010.
} 
societário, medidas que visam a tornar mais fácil a eventual credor atingir o patrimônio dos sócios pessoas físicas em caso de inadimplência da pessoa jurídica.

Poder-se-ia argumentar também que referidas medidas ainda estimulariam que o auditor responsável pela condução do trabalho em nome da pessoa jurídica adotasse em seu trabalho um padrão de qualidade minimamente aceitável, já que estaria ameaçando seu patrimônio pessoal no exercício de sua atividade. Haveria, portanto, um incentivo ao correto exercício da profissão por parte do auditor representante de sociedade de auditoria na forma de regulação ora em análise.

No entanto, a regulação do tipo societário na forma realizada pela CVM parece estar em dissonância com a grande parte dos países componentes da União Europeia.

De fato, a maioria das nações componentes da União Europeia permite como opção ao tipo societário de pessoas jurídicas, cujo objeto seja a exploração da atividade de auditoria, pelo menos uma espécie de sociedade que adote limitações de responsabilidade subsidiária de seus sócios. Ademais, vários dos países permitem igualmente a constituição de sociedades de auditoria na forma empresarial, incluindo o tipo de sociedades por ações.

A tabela seguinte traz o resultado de estudo feito junto aos países da União Europeia, mostrando os tipos societários permitidos perante cada um. ${ }^{219}$

Tabela 8: Regime legal dos diversos países da Comunidade Europeia quanto aos tipos societários permitidos para as sociedades de auditores

\begin{tabular}{|c|c|c|}
\hline País & $\begin{array}{l}\text { Tipo societário permitido } \\
\text { (Form of business organisation performing statutory audits) }\end{array}$ & $\begin{array}{c}\text { Responsabilidade } \\
\text { dos sócios } \\
\text { (Partners' liability) }\end{array}$ \\
\hline \multirow{6}{*}{ Áustria } & Aktiengesellsschaft (public limited liability company) & Limitada (I) \\
\hline & $\begin{array}{c}\text { Gesellschaft mit beschränkter Haftung (limited } \\
\text { liabilitycompany) }\end{array}$ & Limitada (I) \\
\hline & Kommanditgesellschaft (limited partnership) (II) & $\begin{array}{l}\text { Limitada/ Ilimitada } \\
\text { (IV) }\end{array}$ \\
\hline & $\begin{array}{c}\text { Kommanditerwerbsgesellschaft (non-commercial } \\
\text { limitedpartnership) }\end{array}$ & $\begin{array}{l}\text { Limitada/ Ilimitada } \\
\text { (IV) }\end{array}$ \\
\hline & $\begin{array}{c}\text { Offene Erwerbsgesellschaft (non-commercial } \\
\text { partnership) }\end{array}$ & Ilimitada \\
\hline & Offene Handelsgesellschaft (general partnership) (II) & Ilimitada (continua) \\
\hline
\end{tabular}

${ }^{219}$ EUROPEAN COMISSION. A study on systems of civil liability of statutory auditors in the context of a single Market for auditing services in the European Union. Disponível em <http://ec.europa.eu/internal_market/auditing/liability/index_en.htm\#study>. Acesso em 27 dez. 2009. 


\begin{tabular}{|c|c|c|}
\hline \multirow{3}{*}{ Bélgica } & Société en nom collectif (general partnership) & Ilimitada \\
\hline & $\begin{array}{c}\text { Société privée à responsabilité limitée (limited liability } \\
\text { company) }\end{array}$ & Limitada \\
\hline & Société coopérative (cooperative company) & Limitada/ Ilimitada \\
\hline \multirow{3}{*}{ Dinamarca } & Interessentskab (general partnership) & Ilimitada \\
\hline & Aktieselskab (public limited liability company) & Limitada \\
\hline & Anpartsselskab (private limited company) & Limitada \\
\hline \multirow{3}{*}{ Finlândia (V) } & Avoin yhtio (general partnership) & Ilimitada \\
\hline & Kommandiittiyhtiö (limited partnership) & $\begin{array}{l}\text { Limitada/ Ilimitada } \\
\text { (IV) }\end{array}$ \\
\hline & Osakeyhtio (limited liability company) & Limitada \\
\hline \multirow{2}{*}{ França (VI) } & $\begin{array}{c}\text { Société civile professionnelle or société d'exercice } \\
\text { liberal (professional corporation) }\end{array}$ & Ilimitada \\
\hline & $\begin{array}{l}\text { Société anonyme", "société à responsabilité limitée" } \\
\text { (limited liability company, limited liability company) }\end{array}$ & Limitada \\
\hline \multirow{6}{*}{ Alemanha } & Aktiengesellschaft (public limited liability company) & Limitada \\
\hline & $\begin{array}{c}\text { Kommanditgesellschaft auf Aktien (incorporated } \\
\text { partnership) }\end{array}$ & $\begin{array}{l}\text { Limitada/ Ilimitada } \\
\text { (IV) }\end{array}$ \\
\hline & $\begin{array}{l}\text { Gesellsschaft mit beschränkter Haftung (limited liability } \\
\text { company) }\end{array}$ & Limitada \\
\hline & Offene Handelsgesellschaft (general partnership) & Ilimitada \\
\hline & Kommanditgesellschaft (limited partnership) & Ilimitada \\
\hline & Partnerschaftsgesellschaft (partnership companies) & Ilimitada \\
\hline \multirow{4}{*}{ Grécia } & Omorrythmos Etairia (general partnership) & Ilimitada \\
\hline & Eterorrythmos Etairia (limited partnership) & $\begin{array}{l}\text { Limitada/ Ilimitada } \\
\text { (IV) }\end{array}$ \\
\hline & $\begin{array}{l}\text { Etaireia Periorismenis Euthinis (limited liability } \\
\text { company) }\end{array}$ & Limitada \\
\hline & Anonymi Etairia (public limited liability company) & Limitada \\
\hline Irlanda & Partnership & Ilimitada \\
\hline \multirow{6}{*}{ Itália (VII) } & Societa Semplice (non-commercial partnership) & Ilimitada \\
\hline & Societa in Nome Collectivo (general partnership) & Ilimitada \\
\hline & Societa in Accomandita Semplice (limited partnership) & $\begin{array}{l}\text { Limitada/ Ilimitada } \\
\text { (IV) }\end{array}$ \\
\hline & Societa per Azioni (société par actions) & Limitada \\
\hline & $\begin{array}{c}\text { Societa in Accomandita per Azioni (incorporated } \\
\text { partnership) }\end{array}$ & $\begin{array}{l}\text { Limitada/ Ilimitada } \\
\text { (IV) }\end{array}$ \\
\hline & $\begin{array}{l}\text { Societa a Responsabilita Limitata (limited liability } \\
\text { company) }\end{array}$ & Limitada \\
\hline \multirow{3}{*}{$\begin{array}{l}\text { Luxemburgo } \\
\text { (VIII) }\end{array}$} & Société anonyme (public limited liability company) & Limitada \\
\hline & $\begin{array}{c}\text { Société à responsabilité limitée (private limited liability } \\
\text { company) }\end{array}$ & Limitada \\
\hline & Société civile (non-commercial company) & Ilimitada \\
\hline Holanda & Maatschap (IX) (general partnership) & Ilimitada (continua) \\
\hline
\end{tabular}




\begin{tabular}{|c|c|c|}
\hline & $\begin{array}{c}\text { Besloten Vennootschap met beperkte aansprakelijkheid } \\
\text { (private limited liability company) }\end{array}$ & Limitada \\
\hline & $\begin{array}{c}\text { Naamloze Vennootschap (public limited liability } \\
\text { company) }\end{array}$ & Limitada \\
\hline \multirow{4}{*}{ Portugal $(\mathrm{X})$} & $\begin{array}{c}\text { Sociedades Civis Profissionais (professional } \\
\text { corporation) }\end{array}$ & Limitada \\
\hline & Sociedades Anonimas (public limited liability company) & Limitada \\
\hline & Sociedades em Nome Colectivo (general partnership) & Ilimitada \\
\hline & Sociedades em Comandita (limited partnership) & $\begin{array}{l}\text { Limitada/ Ilimitada } \\
\text { (IV) }\end{array}$ \\
\hline \multirow{7}{*}{ Espanha } & Sociedad civil (non-commercial company) & Ilimitada \\
\hline & Sociedad colectiva (general partnership) & Ilimitada \\
\hline & Sociedad comanditaria (limited partnership) & $\begin{array}{l}\text { Limitada/ Ilimitada } \\
\text { (IV) }\end{array}$ \\
\hline & $\begin{array}{l}\text { Sociedad comanditaria por acciones (incorporated } \\
\text { partnership) }\end{array}$ & $\begin{array}{l}\text { Limitada/ Ilimitada } \\
\text { (IV) }\end{array}$ \\
\hline & $\begin{array}{l}\text { Sociedad de responsabilidad limitada (limited liability } \\
\text { company) }\end{array}$ & Limitada \\
\hline & Sociedad anonima (limited liability company) & Limitada \\
\hline & Sociedad cooperativa (cooperative company) & Limitada \\
\hline \multirow{3}{*}{ Suíça } & Kommanditbolag (limited partnership) & $\begin{array}{l}\text { Limitada/ Ilimitada } \\
\text { (IV) }\end{array}$ \\
\hline & Handelsbolag (partnership) & Ilimitada \\
\hline & Aktiebolag (limited liability company) & Limitada \\
\hline \multirow{4}{*}{ Reino Unido } & Partnership & Ilimitada \\
\hline & Limited Partnership & $\begin{array}{l}\text { Limitada/ Ilimitada } \\
\text { (IV) }\end{array}$ \\
\hline & Public Limited Liability Company & Limitada \\
\hline & Private Limited Liability Company & Limitada \\
\hline
\end{tabular}

I - No entanto, se o sócio for também um representante legal da empresa, sua responsabilidade é ilimitada.

II - A partir de 7 de julho de 1999, empresas de auditoria já não podem se constituir sob esta forma legal. Às sociedades existentes sob a forma de "general partnership" e "limited partnership" foi concedido um periodo de transição até 31 de dezembro de 2005.

III - Na Bélgica, não há nenhuma sociedade de auditoria que opere na forma de "partnership". Existem 258 sociedades de auditoria que adotaram a forma de SPRL. A responsabilidade das cooperativas depende se a entidade é uma cooperativa de responsabilidade limitada (société coopérative à responsabilité limitée) ou uma cooperativa de responsabilidade ilimitada (société coopérative à responsabilité illimitée). Na esmagadora maioria dos casos, a primeira é adotada. Existem atualmente 46 de tais entidades empreendendo atividade de auditoria independente na Bélgica.

IV - Os sócios administradores ou ostensivos têm responsabilidade ilimitada, o sócio oculto (silencioso) ou "de investimento" tem responsabilidade limitada.

$V$ - As companhias ou sociedades que são capazes de atuar como uma sociedade de auditoria independente podem ser aprovadas como uma sociedade de auditores KHT ou como uma sociedade de auditores HTM. Há 21 sociedades de auditores KHT (todas elas sociedades de responsabilidade limitada) e 26 sociedades de auditores HTM (20 sociedades de responsabilidade limitada e 6 "limited partnership " ou "general partnership").

VI - A questão se uma "incorporated partnership" (société en commandite par actions), uma "limited partnership" (société en commandite simples) e uma "general partnership" (société en nom collectif) poderão realizar auditoria independente foi considerada, mas, na prática, este tipo de estrutura nunca é adotada uma vez que a responsabilidade dos sócios é ilimitada.

VII - Isto só é relevante para a sociedade de auditoria.

(continua) 
VIII - A lei não fornece uma lista de organizações de negócios que têm o privilégio de auditor independente. Por conseguinte, todas as formas de organizações empresariais podem, em teoria, se tornar um membro do IRE. Atualmente, todos os membros do IRE são um dos três tipos de entidades listadas acima.

IX - Até recentemente, praticamente todos os revisores oficiais de contas foram organizados como "maatschap".

$X-O$ Decreto-lei. $n \circ 487 / 99$, que foi aprovado em novembro de 1999, prevê novas formas de organizações de negócios que podem ser usadas por auditores independentes e está mais de acordo com o resto da União Europeia. Cada uma destas novas formas deve manter sua natureza civil (ou seja, não podem praticar atos comerciais).

Fonte: EUROPEAN COMISSION. A study on systems of civil liability of statutory auditors in the context of a single Market for auditing services in the European Union

Verifica-se da tabela que somente um dos países da União Europeia (Irlanda) não permite limitações de responsabilidade dos sócios em sociedades destinadas à exploração de serviços de auditoria.

O estudo também relata que catorze dos países da União Europeia permitem a constituição de sociedades sob a forma de limited liability company, o que permite que sócios que não participem da atividade de auditoria possam resguardar seus ativos pessoais em face do risco da atividade.

A postura da maioria dos países da União Europeia, diferente daquela adotada pela CVM no Brasil, ${ }^{220}$ parece estar mais consentânea com a necessidade de ponderar e, de certa forma, limitar os riscos da atividade de auditoria, proporcionando algum incentivo para que os serviços de auditoria permaneçam economicamente viáveis em face dos rigores da responsabilidade civil por danos causados à entidade auditada e a terceiros.

Como veremos mais adiante, a União Europeia vem assumindo postura clara no sentido de que a ausência de limitação de responsabilidade civil do auditor em todos os casos pode tornar a atividade de auditoria não atrativa economicamente, privando a sociedade de um importante serviço ou desestimulando que os auditores aceitem prestar seus serviços às entidades de maior risco. Uma das formas claras de limitação de risco,

\footnotetext{
${ }^{220} \mathrm{O}$ estudo também demonstra que o modelo brasileiro também é praticado em Portugal, onde, apesar da disponibilidade de tipos societários de responsabilidade limitada, resta estabelecido em lei que as sociedades de auditoria que prestem seus serviços no mercado de capitais estão sujeitas à ilimitação da responsabilidade dos sócios. Além disso, poderá haver responsabilidade dos sócios se, por sua intenção ou negligência, o ativo social restar insuficiente para garantir suas obrigações com os credores. Ressalta-se que: "in Portugal, unless its Articles of Incorporation provide otherwise, the managers of the statutory auditors' firm are liable towards its creditors only where, due to their intentional or negligent conduct, disregard of the legal or contractual provisions aiming to protect creditors, the firm's assets have become insufficient. Moreover, the Comissario de Mercado de Valores Mobiliarios ruled that whenever auditors' firms listed at the Comisario de Valores Mobiliarios intentionally or negligently cause damages to entities that issue shares to investors and to third parties, the auditing firm and its partners are jointly, severally and unlimitedly liable for the damages" (EUROPEAN COMISSION. A study on systems of civil liability of statutory auditors in the context of a single Market for auditing services in the European Union". Disponível em <http://ec.europa.eu/internal_market/auditing/liability/index_en.htm\#study>. Acesso em 27 dez. 2009).
} 
além da fixação por lei de patamares máximos de indenização, é a contenção das perdas ao montante investido pelos praticantes da atividade, o que se realiza mediante a adoção de tipos societários em que a responsabilidade dos sócios seja limitada ao que contribuíram com o patrimônio social.

Há ainda outros motivos para que se modifique a estrutura e a tipicidade societária das sociedades de auditoria, possibilitando a adoção de modelos que limitem os riscos ou que permitam que investidores externos possam ingressar nos quadros societários provendo capital à sociedade. Outro estudo encomendado perante a União Europeia revela várias razões para tanto: ${ }^{221}$

- Maior concorrência de mercado: a prática revela que o mercado de auditoria é dominado, em grande parte, por poucas sociedades de grande porte e atuação internacional (hoje, as chamadas big four). Assim, há grande dificuldade de novos competidores ingressarem nesse mercado de modo a oferecerem concorrência efetiva, principalmente se considerarmos a dificuldade de financiamento por meio de capital próprio. A possibilidade de que investidores externos (não auditores) aportem capital nas sociedades de menor porte (com a necessária limitação de risco para atrair o investimento) pode ser necessária para o ingresso de novos competidores no mercado ou para a expansão internacional dos serviços das pequenas e médias sociedades de auditoria;

- Impacto dos riscos de responsabilidade civil (liability risk) no financiamento de capital: obviamente, a ilimitação da responsabilidade, para atingir a pessoa dos sócios, pode gerar grande dificuldade no financiamento sob a forma de aporte de capital. Isto porque os riscos excessivos podem desestimular o investimento ou torná-lo tão caro de modo a ser economicamente proibitivo;

- Proteção da independência do auditor: embora não se trate de um fator decisivo, com o financiamento de investidores externos, as sociedades de auditoria de pequeno porte podem ficar menos dependentes dos clientes, tornando sua atuação mais isenta e independente.

${ }^{221}$ OXERA CONSULTING LTD. Ownership rules of audit firms and their consequences for audit market concentration. 


\subsubsection{A entidade auditada}

Em princípio, não há limitações para que qualquer pessoa física ou jurídica seja objeto de auditoria externa (obrigatória ou voluntária), bastando que exerça atividade econômica, com ou sem fins lucrativos.

No entanto, as situações mais comuns em que são realizados serviços de auditoria externa envolvem hipóteses em que as entidades auditadas realizem atividades econômicas de grande porte, dependam de aportes de investidores dispersos no meio social, ou se trate de entidades que influenciam parcela relevante de um determinado mercado. Em casos como estes, as normas regulatórias usualmente determinam a obrigatoriedade da contratação de serviços de auditoria externa.

No Brasil, como vimos, os serviços de auditoria externa são obrigatórios: 1) para as sociedades anônimas abertas (art. 177, § $3^{\text {o }}$, da Lei n. 6.404/76); 2) para as sociedades de grande porte, independente do tipo societário (art. $3^{\circ}$ da Lei n. 11.638/07); 3 ) para as instituições financeiras, demais instituições autorizadas a funcionar pelo Banco Central do Brasil, câmaras e prestadores de serviços de compensação e de liquidação (Resolução n. 3.198/04 do Banco Central); 4) para sociedades seguradoras, de capitalização e entidades abertas de previdência complementar (Resolução n. 118/04 do Conselho Nacional de Seguros Privados); 5) para fundos de investimento financeiro, fundos de aplicação em quotas de fundos de investimento financeiro e fundos de investimento no exterior (Instrução n. 386/03 da CVM); 6) no caso de incorporação, fusão e cisão envolvendo companhia aberta, em que as demonstrações financeiras que servirem de base para operações deverão ser auditadas por auditor independente registrado na CVM (Instrução n. 319/99 da CVM), 7) para entidades filantrópicas com faturamento superior ao limite fixado pela Lei Complementar n. 123/06, as quais deverão apresentar demonstrações contábeis e financeiras devidamente auditadas por auditor independente legalmente habilitado nos Conselhos Regionais de Contabilidade (art. 29, III, da Lei n. 12.101/09).

Cada uma das sociedades supracitadas, obviamente, apresenta peculiaridades em sua atividade econômica, o que exige que o auditor possua grande afinidade e conhecimento do negócio auditado. 
Não é objetivo deste trabalho analisar pormenorizadamente as especificidades de cada entidade auditada. Porém, entendemos relevante cuidar a seguir, em tópico próprio, da recente imposição (instituída pela Lei n. 11.638/07) de auditoria obrigatória em sociedades de grande porte, independente do tipo societário adotado.

\subsubsection{Auditoria em sociedades de grande porte}

Recente inovação do ordenamento pátrio sobreveio com a Lei n. 11.638/07, que em seu art. $3^{-}$determinou que se aplicam às sociedades de grande porte, ainda que não constituídas sob a forma de sociedades por ações, as disposições da Lei n. 6.404, de 15 de dezembro de 1976, sobre escrituração e elaboração de demonstrações financeiras e a obrigatoriedade de auditoria independente por auditor registrado na Comissão de Valores Mobiliários.

Como sociedade de grande porte, referida lei definiu em seu art. $3^{\circ}$, parágrafo único, a sociedade ou conjunto de sociedades sob controle comum que tiver, no exercício social anterior, ativo total superior a $R \$ 240.000 .000,00$ (duzentos e quarenta milhões de reais) ou receita bruta anual superior a $R \$ 300.000 .000,00$ (trezentos milhões de reais).

Alvo de grande polêmica, a legislação supracitada verdadeiramente revolucionou o ordenamento nacional ao determinar a obrigatoriedade da observância das normas inerentes ao processo de escrituração e elaboração de demonstrações financeiras constantes da Lei n. 6.404/76, bem como de necessariamente sujeitarem-se à auditoria externa.

Parte da doutrina considerou a inovação legislativa como um avanço, apresentando como sua fonte inspiradora as normas europeias sobre a matéria. Neste sentido, a lição abalizada de Erasmo Valladão Azevedo e Novaes França:

Esta disciplina - esclareça-se, por oportuno - não é fruto da inventividade do legislador pátrio. Ao contrário, tem origem bem marcada em importantes experiências de Direito Comparado, em especial nas Diretivas 78/660/CEE, de 25.7.1978, 83/348/CEE, de 13.06.1983, e 84/253/CEE, de 10.4.1984, do Conselho da Comunidade Econômica Europeia: a primeira delas, na essência, institui distintas regras sobre escrituração, elaboração e publicidade de demonstrações financeiras a 
serem observadas por sociedades de pequeno, médio e grande porte, assim classificadas em função de limites quantitativos vinculados aos valores de balanço e de receita (volume de negócios), bem como ao número de empregados (arts. 11, 27 e 47); a segunda, por sua vez, tratou das contas consolidadas dos grupos; e a terceira, e última, regrou as hipóteses de vinculação de auditores independentes, suas qualificações, deveres e responsabilidades. ${ }^{222}$

Argumenta-se também, a favor da legislação em análise, que muitas das sociedades de grande porte (incluindo filiais brasileiras de companhias internacionais) passaram a se constituir como sociedades limitadas - e não como companhias abertas para não terem de enfrentar o maior rigor contábil a que estas últimas estariam sujeitas, o que acarreta uma grande repercussão social. Ademais, aduz-se que o maior grau de exigências contábeis às sociedades de grande porte acaba por proteger a sociedade do risco sistêmico envolvido em falências de grande repercussão.

Entretanto, esta legislação não foi poupada de fortes críticas. Os principais pontos atacados por especialistas foram: 1) aumento demasiado de custos pela necessidade de auditoria; 2) ausência de qualquer razão para a imposição desses custos, uma vez que as sociedades de grande porte que não se constituam como companhias abertas não estão autorizadas a captar recursos junto ao público investidor nem obrigadas a publicar suas demonstrações contábeis; ${ }^{223}$ 3) pequeno espectro de aplicação da norma, uma vez que as sociedades de grande porte constituem reduzida parcela das empresas nacionais.

${ }^{222}$ FRANÇA, Erasmo Valladão Azevedo e Novaes. Direito societário, falimentar e teoria da empresa. São Paulo: Malheiros, 2009. p. 120.

${ }^{223}$ Saliente-se que este foi um dos aspectos mais controversos da legislação ora em análise. A questão principal foi a de se saber se haveria sido instituída com a Lei n. 11.638/07 uma obrigação implícita de publicação de demonstrações contábeis para as sociedades de grande porte, já que esta exigência não consta na lei formalmente. Parte da doutrina, encabeçada por Modesto Carvalhosa, respondeu positivamente à questão, dado que, além dos motivos históricos sobre os quais a Lei n. 11.638/07 foi criada (evitar a prática de algumas companhias se constituírem artificialmente sob a forma de limitadas), há de se considerar que, sendo obrigatória a auditoria independente, não haveria sentido na realização de tal serviço se não fosse necessária a publicação das demonstrações (CARVALHOSA, Modesto. "A nova legislação contábil e as limitadas". Disponível em <http://www.valoronline.com.br>. Acesso em 9 jan. 2010). Outros doutrinadores, entretanto, opuseram-se flagrantemente a tal obrigatoriedade de publicação, argumentando com a ausência de disposição expressa neste sentido, além da geração desnecessária de custos para as sociedades. A CVM, em comunicado ao mercado datado de 14.01.2008, parece ter acolhido a tese da não obrigatoriedade de publicação, ao ressaltar: "Assim, embora não haja menção expressa à obrigatoriedade de publicação dessas demonstrações financeiras, qualquer divulgação voluntária ou mesmo para atendimento de solicitações específicas (credores, fornecedores, clientes, empregados, etc.), as referidas demonstrações deverão ter o devido grau de transparência e estar totalmente em linha com a nova lei (art. $3^{-}$)". Recentemente, a polêmica ressurgiu com a normatização da matéria pelo Departamento Nacional de Registro do Comércio (DNRC), que no Ofício Circular n. 009/2008 ressaltou: "As sociedades de grande porte, para o fim de atender o disposto no art. 40 da Lei 8.934/96, poderão facultativamente publicar suas demonstrações financeiras nos 
O primeiro ponto a se observar na análise do dispositivo legal é que o art. $3^{\circ}$ da Lei n. 11.638/07 aplica-se não apenas às sociedades isoladas, mas também ao conjunto de sociedades sob controle comum cujo ativo total ou receita bruta se enquadrarem nos parâmetros legais. A exata conceituação do que seriam sociedades sob controle comum e de qual ou quais das sociedades consideradas seriam exigidas demonstrações nos termos da Lei n. 6.404/76 e auditoria externa gerou polêmica na doutrina.

Erasmo Valladão Azevedo e Novaes França entende que esta conceituação deve ser abrangente, incluindo não apenas a situação de controle formal de uma sociedade por outra (qualquer que seja o tipo societário envolvido), mas também a situação de diversas sociedades sob controle conjunto, comum, ou acordo de votos. Referido autor entende ainda que a obrigatoriedade se aplica individualmente a cada uma das sociedades sob controle comum, e não ao grupo por elas formado, ressalvados os casos em que a legislação do anonimato determine a obrigatoriedade de elaboração de demonstrações consolidadas. $^{224}$

Outros doutrinadores, entretanto, entendem não fazer sentido que todas as sociedades sob controle comum sejam obrigadas a, por si, publicarem suas demonstrações na forma da Lei n. 6.404/76 e sofrer auditoria, principalmente quando tenham importância econômica diminuta em face do tamanho do ativo ou da receita das sociedades sob controle comum. $^{225}$

jornais oficiais ou outros meios de divulgação, para o efeito de ser deferido o seu arquivamento nas Juntas Comerciais". A respeito desta última norma, já há notícias de decisões de primeiro grau (processo 2008.61.00.030305-7, 25 a Vara da Justiça Federal - SP) determinando a publicação obrigatória das demonstrações, contrariando a facultatividade estabelecida.

${ }^{224}$ Op. cit. p.127-8.

${ }^{225}$ Neste sentido o artigo de Henrique Vargas Beloch e Rafael de Carvalho Ramos Alves publicado no jornal Valor Econômico: "A nosso ver, todavia, é necessário adotar uma interpretação mais racional e teleológica da Lei n. 11.638, a começar por perquirir os propósitos da norma quando, para fins de elaboração e auditoria de demonstrações financeiras, aplicou os atributos da sociedade de grande porte à entidade considerada isoladamente ou ao conjunto de sociedades sob o mesmo controle. Quer nos parecer que a razão fundamental foi apreender a relevância do grupo econômico de um modo geral, evitando inclusive que, justamente por ser um grupo sob um comando único, pudesse partilhar seus ativos ou receitas para fugir à norma. Não é razoável supor que a lei tenha pretendido que toda e qualquer sociedade de um grupo que se qualifique como de grande porte seja compulsoriamente auditada, ainda que irrelevante para tal caracterização, como, por exemplo, uma sociedade de patrimônio diminuto, em descontinuidade de operações ou meramente uma holding de sociedades já auditadas. Se uma ou mais sociedades, conjuntamente, já se enquadram nos parâmetros da lei, não haveria razão para estender o mesmo tratamento, a reboque, às demais sociedades do grupo que sejam insignificantes frente ao todo. Senão em atenção aos princípios da personalidade jurídica e da entidade contábil, ao menos para evitar mais custos para a atividade empresarial. Observa-se cada vez mais na elaboração e aplicação das leis, para além da desconsideração da personalidade jurídica, louvável como medida excepcional, uma certa tendência - cuja banalização deve ser evitada - de a norma ou provimento judicial, mesmo na ausência de abusos ou desvios, dirigir-se indistintamente aos grupos econômicos, com pouca atenção à existência das diferentes sociedades que o compõem como sujeitos autônomos de direitos e obrigações, cada uma com suas particularidades". (BELOCH, Henrique Vargas; 
Além dos pontos polêmicos citados até aqui, o art. $3^{0}$ da Lei n. 11.638/07 ainda se ressente de outros problemas usualmente não abordados na doutrina, quais sejam: 1) definir qual o critério e a metodologia a serem utilizados para se definir o que é uma sociedade de grande porte; 2) saber como ficará a qualidade da informação contábil diante da possibilidade de sucessivos enquadramentos e desenquadramentos de uma determinada sociedade no conceito de entidade de grande porte; 3) como serão efetivadas sanções pelo descumprimento da norma.

Analisaremos as seguir estes três tópicos.

Em relação ao critério ou metodologia, devemos salientar que as companhias abertas, sujeitas às normas das Leis ns. 6.404/76 e 11.638/07, bem como à regulação da matéria contábil pela CVM, possuem, em regra, ${ }^{226}$ critérios substancialmente diversos de outros tipos societários (como as sociedades limitadas) para realizar a escrituração de suas operações econômicas.

Essa diferença de critérios e metodologia entre os tipos societários se reflete de modo importante na avaliação de seu ativo ou mesmo no montante de sua receita. Para que tenhamos uma noção das diferenças mencionadas, trazemos a seguir uma tabela com alguns dos pontos divergentes entre a regulação das chamadas sociedades de pessoas no Código Civil $^{227}$ e os critérios estabelecidos pela Lei n. 6.404/76, modificada pela Lei n.11.638/07.

ALVES, Rafael de Carvalho Ramos. "A auditoria das sociedades de grande porte." Disponível em <http://www.valoronline.com.br >. Acesso em 9 jan. 2010).

${ }^{226} \mathrm{O}$ problema da diversidade de critérios entre as sociedades reguladas no Código Civil e as sociedades anônimas não se põe de forma tão acentuada nos casos em que aquelas optem por serem tributadas pelo regime de lucro real. Neste caso, por força do Dec. Lei 1.598/77 (art. 67, XI), o lucro líquido do exercício deverá ser apurado, a partir do primeiro exercício social iniciado após 31 de dezembro de 1977, com observância das disposições da Lei $n^{\circ}$ 6.404, de 15 de dezembro de 1976, o que faz com que, nesta hipótese, os tipos societários definidos no Código Civil e as sociedades anônimas se aproximem no que toca aos critérios contábeis.

${ }^{227}$ Não entraremos, por não ser o objetivo deste trabalho, na discussão a respeito da propriedade da classificação dada pela doutrina jurídica tradicional, que subdivide as sociedades em de pessoas ou de capitais. As primeiras representadas por aqueles tipos regulados no Código Civil, em que o contrato societário é firmado tendo por consideração principal a pessoa dos sócios, e as segundas, representadas pelas sociedades por ações, em que a pessoa do sócio é irrelevante para o negócio. Consignamos que a doutrina é repleta de divergências quanto à inserção das sociedades limitadas em um desses dois grupos. 
Tabela 9: Distinções entre critérios contábeis aplicáveis às sociedades anônimas e às sociedades reguladas no Código Civil

\begin{tabular}{|c|c|c|}
\hline Critérios & $\begin{array}{c}\text { Sociedades reguladas no } \\
\text { Código Civil }\end{array}$ & Sociedades anônimas \\
\hline Ativo diferido & $\begin{array}{c}\text { Permitida contabilização de gastos } \\
\text { de instalação da sociedade até } \\
\text { 10\% do capital social (art. } 1.187, \\
\text { parágrafo único, I, do CC) }\end{array}$ & $\begin{array}{l}\text { Vedada a contabilização de ativo } \\
\text { diferido, diante da revogação } \\
\text { operada pela Lei n. } 11.941 / 09\end{array}$ \\
\hline Ativo intangível & $\begin{array}{c}\text { Não há previsão de contabilização } \\
\text { como categoria separada }\end{array}$ & Contabilização obrigatória \\
\hline $\begin{array}{c}\text { Avaliação de } \\
\text { participações em } \\
\text { outras sociedades }\end{array}$ & Não há critério estabelecido & $\begin{array}{c}\text { Método de custo ou equivalência } \\
\text { patrimonial }\end{array}$ \\
\hline $\begin{array}{c}\text { Regime de } \\
\text { competência/caixa }\end{array}$ & $\begin{array}{c}\text { Não é obrigatória a adoção de um } \\
\text { dos regimes }\end{array}$ & $\begin{array}{c}\text { É obrigatório o regime de } \\
\text { competência (art. 177, caput, da } \\
\text { Lei } n .6 .404 / 76 \text { ) }\end{array}$ \\
\hline $\begin{array}{l}\text { Títulos disponíveis } \\
\text { para venda e } \\
\text { instrumentos } \\
\text { financeiros }\end{array}$ & $\begin{array}{l}\text { Ações e títulos de renda fixa com } \\
\text { cotação em Bolsa: valor de } \\
\text { cotação. Não cotados e outros } \\
\text { valores mobiliários: valor de custo } \\
\text { ou mercado; dos dois, o menor } \\
\text { (art. 1187, I e II, do CC) }\end{array}$ & $\begin{array}{l}\text { Valor justo (o valor que se pode } \\
\text { obter em um mercado ativo, } \\
\text { decorrente de transação não } \\
\text { compulsória realizada entre partes } \\
\text { independentes; o valor que se pode } \\
\text { obter em um mercado ativo com a } \\
\text { negociação de outro instrumento } \\
\text { financeiro de natureza, prazo e } \\
\text { risco similares; o valor presente } \\
\text { líquido dos fluxos de caixa futuros } \\
\text { para instrumentos financeiros de } \\
\text { natureza, prazo e risco similares; } \\
\text { ou o valor obtido por meio de } \\
\text { modelos matemático-estatísticos } \\
\text { de precificação de instrumentos } \\
\text { financeiros }\end{array}$ \\
\hline $\begin{array}{c}\text { Ajuste a valor } \\
\text { presente do ativo e } \\
\text { passivo de longo } \\
\text { prazo }\end{array}$ & $\begin{array}{c}\text { Não é obrigatório, nem está } \\
\text { autorizado }\end{array}$ & $\begin{array}{c}\text { É obrigatório } \\
\text { (arts. 183, “b”, VI, e 184, III, da } \\
\text { Lei n. 6.404/76) }\end{array}$ \\
\hline Reavaliação & Não há proibição & Proibida (continua) \\
\hline
\end{tabular}




\begin{tabular}{ccc}
\hline $\begin{array}{c}\text { Lucros e Prejuízos } \\
\text { acumulados }\end{array}$ & $\begin{array}{c}\text { Pode conter valores positivos } \\
\text { (lucros retidos) ou negativos } \\
\text { (prejuízos) }\end{array}$ & $\begin{array}{c}\text { Não pode conter valores positivos } \\
\text { Reservas } \\
\text { obrigatórias }\end{array}$ \\
$\begin{array}{c}\text { Não há obrigatoriedade de } \\
\text { constituir reservas }\end{array}$ & $\begin{array}{c}\text { Há obrigatoriedade de } \\
\text { constituição de reservas }\end{array}$ \\
$\begin{array}{c}\text { normas } \\
\text { internacionais } \\
\text { (IFRS) }\end{array}$ & $\begin{array}{c}\text { Aplicabilidade objeto de } \\
\text { divergências }\end{array}$ & Aplicáveis \\
\hline
\end{tabular}

A distinção dos critérios na forma mencionada na tabela chama a atenção para as dificuldades que o operador da norma em estudo pode enfrentar, uma vez que esta não definiu qual seria a metodologia contábil aplicável para avaliar o ativo ou a receita (que são, em última análise, os critérios utilizados pelo legislador para definir o enquadramento como sociedade de grande porte).

Em outras palavras, poderíamos perguntar: a sociedade de grande porte constituída como uma das espécies de sociedades de pessoas ou como sociedade limitada, para sofrer a incidência do art. $3^{\circ}$ da Lei n. 11.638/07, deve avaliar seu ativo e contabilizar sua receita de acordo com as regras do Código Civil ou da Lei n. 6.404/76?

Vejamos alguns exemplos, que tornarão mais concreta a questão.

Imaginemos duas sociedades com os mesmos fatos econômicos a seguir descritos: títulos disponíveis para venda sem cotação em bolsa, com custo de aquisição de $\mathrm{R} \$ 50.000,00$, cujo valor justo seria de $\mathrm{R} \$ 100.000,00$ (valor presente dos fluxos de caixa futuros), gastos pré-operacionais de $\mathrm{R} \$ 50.000,00$, participações societárias em controladas com valor de custo de $\mathrm{R} \$ 100.000,00$, cuja equivalência patrimonial seja avaliada em $\mathrm{R} \$$ 200.000,00, e ativos imobilizados de R\$300.000,00. As sociedades contrataram empréstimos de curto prazo no mesmo valor de $\mathrm{R} \$ 50.000,00$, possuindo capital social de

\footnotetext{
${ }^{228}$ A questão da aplicabilidade das normas internacionais (IFRS) para as sociedades de pequeno, médio e grande porte é atualmente muito discutida e tenderia a levar a adoção de critérios uniformes para as sociedades de pessoas e as anônimas. O tema tem levado especialistas a severas discussões jurídicas, uma vez que a suposta obrigatoriedade de aplicação das normas IFRS aos tipos societários menores consta meramente de normas administrativas do CFC do Comitê de Pronunciamentos Contábeis (CPC). Sobre o assunto, embora alguns postulem a imediata aplicabilidade dessas regras, há defensores da tese de que tais normas não seriam obrigatórias por não constarem de lei formal e pelo fato de que os órgãos mencionados não possuem poder fiscalizatório sobre as empresas (mas meramente sobre os profissionais da área contábil e de auditoria), não podendo sancioná-las com penalidades.
} 
$\mathrm{R} \$ 500.000,00$. Ambas apresentaram receita bruta de $\mathrm{R} \$ 130.000,00$ e despesas de $\mathrm{R} \$$ 450.000,00. Ignoraremos outros dados para facilitar o entendimento.

Uma das sociedades (“A”) apresentará os fatos econômicos supracitados em suas demonstrações contábeis (balanço patrimonial e demonstração do resultado do exercício) de acordo com os critérios da Lei n. 6.404/76. A outra (“B”) o fará de acordo com a metodologia contábil preconizada no Código Civil.

As demonstrações contábeis de ambas as sociedades são apresentadas a seguir, lado a lado:

\begin{tabular}{|c|c|c|c|c|c|}
\hline \multicolumn{6}{|l|}{ BALANÇO (Em R\$ mil) } \\
\hline ATIVO & SOC. A & SOC. B & PASSIVO & SOC. A & SOC. B \\
\hline Ativo Circulante & & & Passivo Circulante & & \\
\hline $\begin{array}{l}\text { Títulos disponíveis para } \\
\text { venda }\end{array}$ & 100.000 & 50.000 & $\begin{array}{l}\text { Empréstimo de curto } \\
\text { prazo }\end{array}$ & 50.000 & 50.000 \\
\hline Ativo não circulante & & & $\begin{array}{l}\text { Passivo não } \\
\text { circulante }\end{array}$ & & \\
\hline Realizável no longo prazo & - & - & $\begin{array}{l}\text { Exigível de longo } \\
\text { prazo }\end{array}$ & - & - \\
\hline Investimentos & 200.000 & 100.000 & Patrimônio líquido & & \\
\hline Diferido & - & 50.000 & Capital & 500.000 & 500.000 \\
\hline Intangível & - & - & Reservas & - & - \\
\hline Imobilizado (liq.) & 30.000 & 30.000 & Prejuízos acumulados & $(220.000)$ & $(320.000)$ \\
\hline Total & 330.000 & 230.000 & & 330.000 & 230.000 \\
\hline
\end{tabular}

\begin{tabular}{lrc}
\hline DEMONSTRAÇÃO DO RESULTADO (Em R\$ mil) & Soc. A & Soc. B \\
\hline Receita Bruta & 130.000 & 130.000 \\
\hline (+) Ganho de mercado com títulos & 50.000 & - \\
(-) Despesas pré-operacionais & $(50.000)$ & - \\
(+/-) Resultado da equivalência patrimonial & 100.000 & - \\
\hline (-) Outras despesas & $(450.000)$ & $(450.000)$ \\
\hline (=) Lucro/Prejuízo líquido & $\mathbf{( 2 2 0 . 0 0 0 )}$ & $\mathbf{( 3 2 0 . 0 0 0 )}$ \\
\hline
\end{tabular}

Verifica-se claramente que, com os mesmos fatos econômicos, a sociedade "A" estaria enquadrada como sociedade de grande porte se utilizasse os critérios determinados na legislação do anonimato, o que não ocorreu com a sociedade "B", que se utilizou das regras do Código Civil. Isto porque, como se verifica nas demonstrações supracitadas, a sociedade "A": 1) teve de avaliar seus títulos disponíveis para venda pelo valor justo, e não pelo custo de aquisição, como fez a sociedade "B"; 2) contabilizou sua participação em controladas pelo método de equivalência patrimonial, totalizando $\mathrm{R} \$ 200.000,00$, em 
contrapartida ao realizado pela sociedade "B", que o fez pelo valor de $\mathrm{R} \$ 100.000,00 ; 3$ ) não pode inserir no ativo os gastos pré-operacionais de $\mathrm{R} \$ 50.000,00$, tendo de contabilizálos como despesas pré-operacionais em sua demonstração de resultado, o que foi feito pela sociedade "B".

Vejamos mais um exemplo com as mesmas sociedades mencionadas, que possuirão em comum, desta feita, os seguintes fatos econômicos: disponibilidades (caixa e aplicações financeiras) no valor de $\mathrm{R} \$ 150.000,00$, ativo realizável de longo prazo de $\mathrm{R} \$$ $50.000,00$, ativo permanente ${ }^{229}$ de $\mathrm{R} \$ 50.000,00$ e passivo realizável de longo prazo de $\mathrm{R} \$$ 150.000,00. Apenas para efeito didático, já incluiremos no resultado (que se refletirá no patrimônio líquido) o ajuste a valor presente, considerando os ativos de longo prazo realizáveis e vencíveis em parcela única, no final de cinco anos posteriores, com taxa anual de $8,5 \%$ ao ano.

Verificando apenas o balanço patrimonial das sociedades "A" e "B", teremos:

\begin{tabular}{|c|c|c|c|c|c|}
\hline \multicolumn{6}{|l|}{ BALANÇO (Em R\$ mil) } \\
\hline ATIVO & Soc. A & Soc. B & PASSIVO & Soc. A & Soc. B \\
\hline Ativo Circulante & & & Passivo Circulante & & \\
\hline Disponibilidades & 150.000 & 150.000 & $\begin{array}{l}\text { Passivo não } \\
\text { circulante }\end{array}$ & & \\
\hline Ativo não circulante & & & $\begin{array}{l}\text { Exigível de longo } \\
\text { prazo }\end{array}$ & 150.000 & 150.000 \\
\hline $\begin{array}{l}\text { Realizável no longo } \\
\text { prazo }\end{array}$ & 50.000 & 50.000 & Ajuste a valor presente & $(50.243)$ & \\
\hline Ajuste a valor presente & $(16.748)$ & & & & \\
\hline Permanente & 50.000 & 50.000 & Patrimônio líquido & 133.495 & 100.000 \\
\hline Total & 233.252 & 250.000 & & 233.252 & 250.000 \\
\hline
\end{tabular}

Constatamos agora que o resultado se inverte: a sociedade "A" não estaria enquadrada no conceito de sociedade de grande porte, enquanto a " $\mathrm{B}$ " estaria sujeita a tal enquadramento.

\footnotetext{
${ }^{229}$ É importante mencionar que, nos termos das últimas modificações na Lei 6.404/76, foram suprimidas as referências ao termo ativo permanente (substituído pelas contas de imobilizado, investimentos e intangível). Também foi suprimido o vocábulo passivo exigivel a longo prazo, fazendo-se agora apenas a menção a passivo não circulante. Considerando, porém, que: 1) trata-se de uma mera mudança de nomenclatura (e não de essência); 2) as expressões anteriores continuam a ser usadas em demonstrações contábeis publicadas; e 3) este trabalho não inclui somente as sociedades anônimas; mantivemos no texto as referências aludidas indistintamente, com a presente ressalva.
} 
Desta forma, a indefinição quanto ao critério a ser utilizado para a definição do que se considerará sociedade de grande porte pode causar inúmeras dúvidas, ou até mesmo a utilização oportunista de brechas legais para se fugir à subsunção ao dispositivo em comento.

Isto tudo, advirta-se, sem considerarmos aqui o aspecto da utilização de expedientes fraudulentos, do chamado "gerenciamento de resultados" (earnings management) ou "contabilidade criativa". Com efeito, muito simples será à sociedade que não deseje se enquadrar nos limites da lei lançar mão de contas que representam estimativas (p.ex.: provisões para créditos de liquidação duvidosa, depreciação, amortização e exaustão, etc.) para, com base nelas, diminuir o valor de seu ativo.

Outro aspecto em que pode haver dificuldades é relativo à comparabilidade das demonstrações contábeis no tempo, considerando-se novamente a possibilidade de critérios diversos entre a Lei n. 6.404/76 e o Código Civil.

Para bem definirmos isto, é necessário saber a partir de que momento após o enquadramento de uma determinada sociedade no conceito de sociedade grande porte esta necessitará da adoção dos critérios da Lei n. 6.404/76 e da contratação de auditoria independente.

Erasmo Valladão Azevedo e Novaes França entende, com nossos aplausos, que, constatando-se em determinado exercício que a sociedade se subsume ao conceito de sociedade de grande porte, ela estará sujeita à observância dos requisitos do art. $3^{\underline{0}}$ da Lei n. 11.638/07 em relação às demonstrações contábeis do exercício seguinte em que surgiu o enquadramento. Assim, segundo este autor, se no exercício de 2007 o ativo ou a receita da sociedade ultrapassarem os limites legais, esta deverá apresentar suas demonstrações nos termos do art. $3^{\mathrm{o}}$ da Lei n. 11.638/07 para o exercício de $2008 .{ }^{230}$ Este entendimento está baseado fundamentalmente na necessidade de uniformidade e da utilização de um único regime contábil para o exercício, bem como para dar condições de contratação tempestiva dos serviços de auditoria externa, que não seriam viáveis apenas no final do exercício.

Outra questão problemática será a possibilidade de desenquadramento, ou seja, que a sociedade, por fatores inerentes à sua atividade empresarial, venha a não mais se subsumir ao conceito de sociedade de grande porte instituído pelo art. $3^{\underline{0}}$ da Lei $\mathrm{n}$. 11.638/07. Muito embora a lei não preveja esta possibilidade, ela é dotada de grande

${ }^{230}$ Op. cit. p. 124. 
razoabilidade, uma vez que não parece correto que uma determinada sociedade fique permanentemente enquadrada como de grande porte mesmo que não mais ostente os requisitos para tanto. Nesta hipótese, portanto, deveremos indagar quando a sociedade voltará ao regime anterior.

Para manter coerência com o entendimento anterior, entendemos que a sociedade deve se considerar não mais enquadrada no dispositivo do art. $3^{0}$ da Lei $n$. 11.638/07 no exercício seguinte ao que seu ativo ou sua receita não atinjam os limites legais. Assim, na forma anteriormente citada, se uma determinada sociedade verifica no exercício de 2007 que seu ativo ou sua receita foram inferiores aos patamares estabelecidos no art. $3^{\circ}$ da Lei n. 11.638/07, poderá deixar de cumprir os requisitos deste dispositivo a partir do exercício de 2008.

O grande problema dos sucessivos enquadramentos e desenquadramentos é que poderá haver um sério prejuízo para a informação contábil no que tange à sua comparabilidade evolutiva.

Com efeito, uma das principais informações dadas pelas demonstrações contábeis é derivada da observação das tendências de determinados fatos econômicos ao longo dos exercícios a que se referem (p.ex.: evolução da receita, dos custos, da liquidez, etc.). Não é por outro motivo que a Lei n. 6.404/76 determina a publicação mínima dos dados de dois exercícios sociais (art. 176, $\S 1^{\circ}$ ), e a legislação falimentar obriga o devedor em recuperação a apresentar as demonstrações dos três exercícios anteriores ao pedido, além daquelas especialmente levantadas para instruir o pedido (art. 51, II, da Lei n. $11.101 / 05)$.

No entanto, já vimos que os critérios da Lei n. 6.404/76 e do Código Civil são substancialmente distintos. Diante disto, pode ocorrer que, em determinado período, as demonstrações de anos sucessivos sejam feitas com critérios absolutamente díspares, prejudicando a comparabilidade ou evolução dos resultados entre os diversos exercícios.

Vejamos um pequeno exemplo na figura seguinte: 
Figura 3: Sucessivas mudanças de critério em prejuízo da comparabilidade da informação contábil.
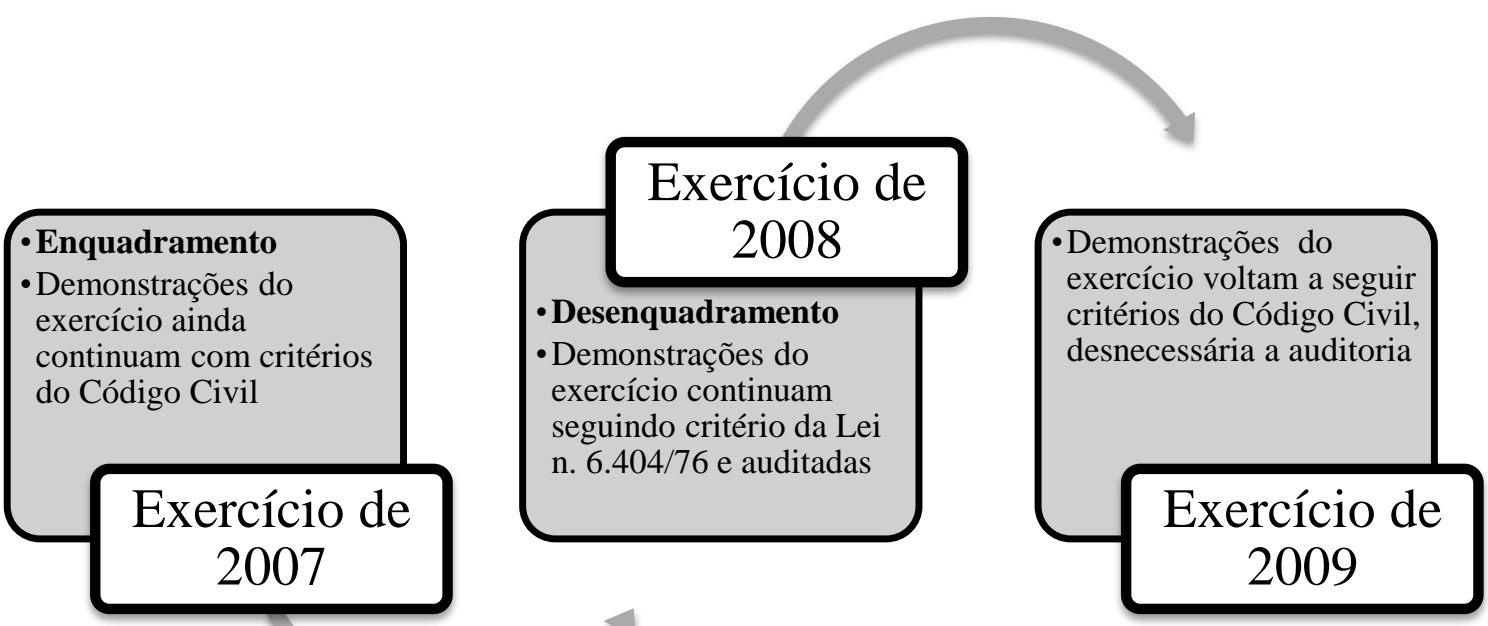

Fica claro, pelo exemplo acima, que, para o usuário externo da informação contábil, pode haver um sério prejuízo na comparabilidade do conteúdo das demonstrações. Afinal, os exercícios de 2007 e 2009 estarão de acordo com os critérios do Código Civil, e o de 2008 com os critérios da legislação do anonimato.

Finalmente, é necessário discutir a aplicabilidade de sanções aos destinatários pelo descumprimento do disposto no art. $3^{0}$ da Lei n. 11.638/07.

Mais uma vez, é importante citar os ensinamentos de Erasmo Valladão Azevedo e Novaes França, que entende impossível a aplicação de penalidades por parte da CVM às sociedades de grande porte que não se constituam em companhias abertas, dado que referidas autarquias não têm ingerência sobre tais tipos societários, podendo haver sanções eventualmente aplicáveis ao auditor independente. Segundo o autor, existem ainda outros tipos de sanções a serem aplicadas às sociedades de grande porte que não obedecerem ao disposto no art. $3^{\underline{0}}$ da Lei n. 11.638/07, todas derivadas da irregularidade da escrituração contábil, tais como a impossibilidade de participar de licitações públicas, vedação ao requerimento de recuperação judicial ou extrajudicial, impossibilidade de operações de crédito, câmbio e seguros, possibilidade de incorrer em crime falimentar, entre outras. ${ }^{231}$

${ }^{231}$ Op. cit. p. 138. 
Muito embora concordemos com este autor quanto à possibilidade teórica da aplicação das sanções mencionadas, é forçoso concluir que sua aplicação prática é de possibilidade muito reduzida.

Primeiramente, devemos constatar que a auditoria independente das demonstrações contábeis das sociedades de grande porte, num primeiro momento, só começa a atuar posteriormente à conclusão sobre o enquadramento da sociedade nesta categoria. Até então, a informação contábil é formulada unicamente pela pessoa jurídica destinatária da norma, que poderá ter todo incentivo para furtar-se à incidência legal sem verificação prévia por profissional independente. A atuação da auditoria, portanto, dependerá muitas vezes da própria manifestação de vontade positiva da entidade auditada em enquadrar-se na disposição normativa em estudo.

Além disso, precisamos reconhecer que, para a aplicação das sanções, o destinatário das demonstrações contábeis (seja ele o Poder Judiciário, os credores em processo de recuperação, uma instituição financeira, ou outros) há de concluir ou inferir que tais relatórios se encontram irregulares em face do porte econômico da sociedade elaboradora. Isto, no entanto, pressupõe seu confronto com os fatos econômicos que originaram os lançamentos contábeis e seu lastro respectivo (documentação das operações que originaram a contabilização). Ora, como isto pressupõe conhecimento específico, interesse, altos custos, dispêndio de tempo para levantamento e confronto de dados, além da possibilidade legal de acesso à informação (em regra, sigilosa), a aplicação das sanções supracitadas fica deveras esvaziada na prática.

\subsection{Prazo do contrato e rodízio de auditoria}

Deve-se investigar aqui a questão do prazo para a contratação da auditoria externa.

Em princípio, os contratos de prestação de serviço podem ser firmados por prazo determinado (limitado a um período de quatro anos, nos termos do art. 598 do CC) ou indeterminado (art. 599 do CC). 
No entanto, no caso de auditoria externa que atue sobre companhias abertas, instituições financeiras ou sociedades de seguro e previdência (casos de auditoria obrigatória), há algumas regras específicas sobre a matéria. ${ }^{232}$

Os problemas em relação ao prolongamento do contrato de auditoria externa por prazo indeterminado derivam da possível perda de independência do auditor, dada a familiaridade decorrente do contato prolongado com a entidade auditada. ${ }^{233}$

Assim, é uma tendência mundial a limitação do tempo de contrato de auditoria ou, ainda, a limitação do período em que é permitido à equipe de trabalho atuar em auditoria externa de uma única entidade. Nos Estados Unidos, como já mencionamos, a Lei Sarbanes-Oxley determina a rotação de auditores ao máximo de cinco exercícios. ${ }^{234}$ No âmbito da União Europeia, a Diretiva n. 2006/43/CE ${ }^{235}$ recomenda aos Estados-Membros a adoção de rodízio das pessoas que compõem a equipe de auditoria ou, alternativamente, da própria sociedade de auditoria prestadora de serviços, consignando prazo de sete anos para a substituição, vedada a recontratação ou nova prestação de serviços pelos mesmos auditores no biênio seguinte. ${ }^{236} \mathrm{Na}$ Itália, o Decreto Legislativo de 24 de fevereiro de 1998 ,

232 O problema não se põe com tanta força nos casos de auditoria voluntária, que usualmente é feita no próprio interesse da entidade auditada ou de sua administração. Mesmo assim, a norma do CFC a respeito da rotação de profissionais deve ser observada pelo auditor, por se aplicar também a esses contratos.

${ }^{233}$ Saliente-se que a matéria é rodeada de polêmicas. Não são poucos os que, contrariamente ao rodízio de auditores, argumentam que a substituição periódica é prejudicial à entidade auditada e ao próprio auditor, pois impede que este profissional aprimore seus conhecimentos a respeito dos processos administrativos e de gestão da entidade auditada por limitar seu tempo de atuação. Há estudos, porém, que demonstram os benefícios da rotatividade de auditores, dentre os quais a maior severidade e maior número de ressalvas aos demonstrativos contábeis, principalmente no último ano do contrato, em que há a possibilidade de observação do trabalho por outro auditor no exercício seguinte. Segundo alguns autores, o rodízio acaba por se constituir em um mecanismo eficiente de monitoramento dos auditores (Neste sentido: ASSUNÇÃO, Juliano; CARRASCO, Vinicius. Avaliação da Rotatividade dos Auditores Independentes. Rio de Janeiro: Pontifícia Universidade Católica, 2008).

${ }^{234}$ Seção 203 da Sox: “AUDIT PARTNER ROTATION.- It shall be unlawful for a registered public accounting firm to provide audit services to an issuer if the lead (or coordinating) audit partner (having primary responsibility for the audit), or the audit partner responsible for reviewing the audit, has performed audit services for that issuer in each of the 5 previous fiscal years of that issuer'.

${ }^{235}$ Assim preceitua referida norma: "A fim de reforçar a independência dos revisores oficiais de contas das entidades de interesse público, os sócios principais responsáveis pelas funções de revisão legal das contas de tais entidades deverão ser sujeitos a rotação. Para organizar esta última, os Estados-Membros deverão exigir a substituição dos sócios principais responsáveis pelas funções de revisão ou auditoria que trabalhem com a entidade examinada, permitindo entretanto que a sociedade de revisores oficiais de contas a que aqueles estão associados continue a proceder à revisão legal de contas das referidas entidades. Caso um Estado-Membro o considere necessário para a realização dos objetivos perseguidos, poderá, alternativamente, exigir a mudança de sociedade de revisores oficiais de contas, sem prejuízo do n. 2 do artigo 42”.

236 “Art. 42, 2. Os Estados-Membros devem assegurar que o(s) sócio(s) principal(is) responsável(is) pela realização da revisão legal das contas seja(m) substituído(s) no seu trabalho de revisão ou auditoria no prazo máximo de sete anos a contar da data de designação e seja(m) autorizado(s) a participar novamente na revisão ou auditoria da entidade examinada após um período mínimo de dois anos." 
n. 58, limita a prestação dos serviços a um período de nove exercícios sociais, ${ }^{237}$ não podendo ser exercitado pela mesma pessoa além do prazo de seis exercícios sociais, vedando a reassunção dos serviços no triênio seguinte. ${ }^{238}$

Percebe-se, portanto, do exame da legislação comparada, que há duas linhas de regras que restringem a prestação de serviços de auditoria: 1) a limitação do prestador de serviços em si, seja este pessoa física ou jurídica (rotação de auditor); 2) a limitação das pessoas que participam da prestação de serviços de auditoria (rotação de componentes da equipe de auditoria).

O primeiro sistema acaba por influenciar o próprio contrato de auditoria, que deve ser encerrado ao final do prazo regulamentar, com a contratação de outro prestador de serviços. O segundo sistema não influencia a vigência do contrato de auditoria em si, determinando apenas a mudança daqueles que prestam o serviço.

Há intenso debate entre os doutrinadores e profissionais atuantes na área quanto aos benefícios e prejuízos de adoção de cada um dos sistemas supracitados.

Os que preferem o sistema de rotação de componentes da equipe de auditoria, argumentam no sentido de que tal modelo permite menores custos ${ }^{239}$ e maiores incentivos na formação de pessoal, além de não prejudicar as pequenas sociedades de auditoria em readquirir novos clientes em prazos regulares.

Os que defendem o sistema de rodízio de auditor, dentre outros argumentos, sustentam que a vontade do auditor em ser reconduzido às suas funções ao término do prazo legal, da forma como pode ocorrer com o mero rodízio da equipe de auditoria, pode

237 "Art. 159, 4. L'incarico ha durata di nove esercizi e non può essere rinnovato o nuovamente conferito se non siano decorsi almeno tre anni dalla data di cessazione del precedente."

238 "Art. 160,1-quater. L'incarico di responsabile della revisione dei bilanci di una stessa società non può essere esercitato dalla medesima persona per un periodo eccedente sei esercizi sociali, né questa persona può assumere nuovamente tale incarico, neppure per conto di una diversa società di revisione, se non siano decorsi almeno tre anni dalla cessazione del precedente. La persona medesima, al termine di tale incarico svolto per sei esercizi, non potrà assumere né continuare ad esercitare incarichi relativi alla revisione dei bilanci di società controllate dalla suddetta società, di società ad essa collegate, che la controllano o sono sottoposte a comune controllo, se non siano decorsi almeno tre anni."

${ }^{239}$ Interessante observar que uma das mais candentes ponderações em relação ao sistema de rodízio do auditor (ou da sociedade de auditoria) em comparação com o rodízio de membros da equipe que realiza referidos trabalhos é inerente às diferenças de custo. No estudo feito por Assunção e Carrasco (Op. cit. p. 356), observa-se que o rodízio de auditor é uma alternativa bem mais custosa que a rotação dos membros da equipe. Os custos daquela modalidade incluiriam: 1) a necessidade de novos treinamentos dos auditores que assumem a função, considerando que a limitação de tempo não possibilitaria a recuperação deste investimento; 2) os custos de contratação de um novo auditor, o que pode ser particularmente difícil quando se trata de grandes entidades auditadas, uma vez que nem todas as sociedades de auditoria possuem capacidade para atender grandes companhias; 3) custos de coordenação, quando, por efeito do rodízio do 
tornar o auditor demasiado permissivo com irregularidades contábeis. Neste sentido é o entendimento de Maria Vittoria Cozzi:

Já G.E. Colombo, o.c., p. 9, tinha enfatizado a exigência de não renovar a atribuição por mais de duas vezes consecutivas a fim de afastar "o perigo de um excesso de permissividade dos auditores com o intuito de obter a recondução às funções e contra o perigo de se formar uma excessiva familiaridade entre controlados e controladores". 240

As normas nacionais sobre a matéria divergem entre a aplicação das duas soluções supracitadas. Um resumo do estabelecido na regulação pátria pode ser visto na tabela seguinte.

Tabela 10: Distinções entre os órgãos regulatórios a respeito da rotação de auditores

\begin{tabular}{|c|c|c|c|c|}
\hline Órgão regulatório & CVM & BACEN & CNSP & CFC \\
\hline Sistema adotado & $\begin{array}{l}\text { Rotação do } \\
\text { auditor }\end{array}$ & $\begin{array}{l}\text { Rotação do } \\
\text { auditor }\end{array}$ & $\begin{array}{l}\text { Rotação do } \\
\text { auditor }\end{array}$ & $\begin{array}{l}\text { Rotação da } \\
\text { equipe de } \\
\text { auditoria }\end{array}$ \\
\hline $\begin{array}{l}\text { Prazo de exercício } \\
\text { consecutivo }\end{array}$ & 5 anos* & 5 anos & 5 anos & $\begin{array}{c}\text { Intervalos } \\
\text { menores ou } \\
\text { iguais a } 5 \\
\text { anos }\end{array}$ \\
\hline $\begin{array}{l}\text { Recontratação ou } \\
\text { recondução do profissional à } \\
\text { equipe }\end{array}$ & $\begin{array}{l}\text { Mínimo de } 3 \\
\text { anos }\end{array}$ & $\begin{array}{l}\text { Mínimo de } 3 \\
\text { anos }\end{array}$ & $\begin{array}{l}\text { Mínimo de } 3 \\
\text { anos }\end{array}$ & $\begin{array}{l}\text { Mínimo de } 3 \\
\text { anos }\end{array}$ \\
\hline $\begin{array}{c}\text { Norma que regulamenta o } \\
\text { tema na atualidade }\end{array}$ & $\begin{array}{c}\text { Instrução } \\
\text { CVM n. } \\
\text { 308/99, art. } \\
31\end{array}$ & $\begin{array}{c}\text { Res. } n . \\
\text { 3198/04 } \\
\text { BACEN, art. } \\
9^{\circ}\end{array}$ & $\begin{array}{l}\text { Res. CNSP n. } \\
\text { 118/04, art. } \\
11\end{array}$ & $\begin{array}{c}\text { Res. } n . \\
\text { 1267/09 CFC, } \\
\text { itens } 51 e \\
\text { seguintes }\end{array}$ \\
\hline
\end{tabular}

* A CVM relativizou a data de início da regra constante do art. 31 da Instrução n. 308/99, por meio da Deliberação n. 549/08, aprovando os seguintes pontos: I - facultar que as companhias abertas não substituam seus atuais auditores independentes até a data de emissão do parecer de auditoria para as demonstrações financeiras relativas ao exercício social a se encerrar em 2011; II - esclarecer que essa faculdade visa a permitir que aquelas que

auditor, uma entidade auditada que atua em diversos países acaba por ser obrigada a contratar auditores distintos para prestar serviços no Brasil e no exterior.

${ }^{240}$ Op. cit. p. 46. O texto é tradução livre de: “Già G.E. Colombo, o.c., p. 9, aveva sottolineato l'esigenza di non rinnovare l'incarico per piú di due volte consecutive ai fine di scongiurare 'il pericolo di un eccesso di remissività dei revisori per ottenere in remcarico e contro il pericolo del formarsi di un'eccessiva familiarità tra controllati e controllori'." 


\footnotetext{
completariam o ciclo de cinco anos nos próximos exercícios sociais possam fazer a substituição do auditor somente após o encerramento das demonstrações financeiras do exercício de 2011; III - esclarecer, ainda, que as companhias abertas que não se utilizarem da faculdade ou que substituírem voluntariamente seus auditores independentes em data anterior àquela prevista no inciso I desta Deliberação, deverão contar normalmente o prazo de cinco anos previsto no art. 31 da Instrução CVM n. 308, de 1999, a partir da data em que contratarem seus auditores independentes.
}

Não havendo conformidade de tratamento da matéria nas normas de regência, cabe ao jurista tentar compatibilizá-las, antes de concluir que não possam coexistir ou entender que tenha havido revogação.

Desta forma, tentando compatibilizar as normas antes mencionadas, podemos constatar que o sistema que determina a rotação do auditor é um plus em relação ao que obriga a rotação dos membros da equipe de auditoria. Cumprindo os objetivos do primeiro (rotação do auditor), em princípio, estar-se-á cumprindo o escopo do segundo, dado que a substituição do auditor contratado deve envolver também a mudança da equipe de auditoria que presta os serviços. Não há, portanto, incompatibilidade entre as disposições.

Não é difícil constatar, igualmente, que há campos próprios para a aplicação das normas antes aludidas: instituições financeiras, seguradoras e companhias abertas devem obedecer, em princípio, às normas do órgão regulador do respectivo ramo. As demais disposições do órgão regulador da profissão de auditoria (CFC) devem servir como normas residuais, ou seja, que somente se aplicam no caso de outras normas especiais mais rigorosas não incidirem no caso concreto, uma vez que lex specialis derogat generalis.

Assim, entendemos que no atual estágio da regulação nacional, o contrato de prestação de serviços de auditoria estará limitado temporalmente por cinco exercícios (sistema de rodízio de auditor) no caso de entidades auditadas que se constituam como instituições financeiras, seguradoras, companhias abertas ou suas assemelhadas em que incidam as normas regulatórias específicas da CVM, BACEN ou CNSP. Para os demais casos de auditoria, caberá apenas o rodízio da equipe de auditores, não havendo limitação de contrato por prazo indeterminado. 


\subsection{Formalização do contrato e da execução dos serviços de auditoria}

Diante do interesse público que usualmente envolve a contratação de auditoria externa, surge a necessidade de formalização do contrato e da execução dos serviços por parte do auditor.

A primeira formalização necessária é a do próprio contrato. Nos termos do art. $1^{\circ}$ da Res. n. 987/03 do CFC, o contabilista ou a organização contábil deverá manter contrato por escrito de prestação de serviços. Assim, qualquer prestação de serviço de natureza contábil, incluindo os serviços de auditoria, deve ser formalizada por escrito. ${ }^{241}$ Disto não discrepa o determinado na Res. n. 1.204/09 deste órgão, a qual, baseada na correspondente norma ISA n. 210, determina que o auditor deve formalizar os termos de seu trabalho em carta de contratação escrita. ${ }^{242} 243$

Cabe indagar se a forma escrita do contrato de auditoria se constitui como ad substantiam ou ad solemnitatem, ou seja, consubstancia uma forma interna, intrínseca ao ato jurídico respectivo, ou se veicula mera formalidade ad probationem ou externa. As

\footnotetext{
${ }^{241}$ A regulação específica no âmbito do CNSP e do BACEN, já citada no texto, igualmente alude a contrato escrito e cláusulas contratuais específicas, obrigando, assim, a realização de contrato escrito.

${ }^{242} \mathrm{O}$ item 10 desta norma ressalta: "Observado o item 11, os termos do trabalho de auditoria estabelecidos devem ser formalizados na carta de contratação de auditoria ou outra forma adequada de acordo por escrito que devem incluir (ver itens A22 a A25): (a) o objetivo e o alcance da auditoria das demonstrações contábeis; (b) as responsabilidades do auditor; (c) as responsabilidades da administração; (d) a identificação da estrutura de relatório financeiro aplicável para a elaboração das demonstrações contábeis; e (e) referência à forma e ao conteúdo esperados de quaisquer relatórios a serem emitidos pelo auditor e uma declaração de que existem circunstâncias em que um relatório pode ter forma e conteúdo diferente do esperado". Saliente-se que nos casos em que haja alguma regulamentação que normatize a maior parte dos temas de interesse das partes do contrato de auditoria, a carta de contratação pode se resumir a simplesmente citar a aplicabilidade e a concordância das partes com os termos da norma. Esta permissão consta do item 11 da Res. n. 1.204/09 do CFC, nos seguintes termos: "Se uma lei ou um regulamento prevê com detalhes suficientes os termos do trabalho de auditoria mencionados no item 10, o auditor não precisa formalizá-los em uma carta de contratação, exceto o fato de que essa lei ou regulamento se aplica e que a administração reconhece e entende suas responsabilidades conforme especificadas no item 6(b) (ver itens A22, A26 e A27)".

${ }^{243}$ Qualquer proposta de trabalho do auditor, ainda que através de pessoa jurídica (sociedade de auditoria), deve contar com o número de registro do auditor ou responsáveis técnicos perante o órgão de fiscalização de profissão (CFC), sob pena de infração administrativa. Neste sentido decidiu o CRSFN no Recurso 4184. Processo CVM RJ2001/7661: "EMENTA: RECURSO VOLUNTÁRIO - Mercado de valores mobiliários Auditoria independente - Emissão de documentos sem constar indicação da categoria profissional e do número de registro no Conselho Regional de Contabilidade - CRC - Cartas-proposta expedidas sem a qualificação dos profissionais integrantes das equipes técnicas de realização dos trabalhados - Falta de avaliação dos controles internos determinada pelas normas regulamentares - Papéis de trabalho insubsistentes - Apelos a que se nega provimento. PENALIDADE: Inabilitação Temporária. BASE LEGAL:Lei n. 6.385/76, art. 11, inciso IV”.
} 
primeiras espécies de forma serviriam à perfeição e ao acabamento dos atos jurídicos, e as segundas à sua prova. ${ }^{244}$

Entendemos que a forma escrita do contrato de auditoria é meramente ad probationem ou externa. De fato, a não utilização da forma escrita somente repercutirá na limitação da prova do contrato por outros meios que não a documental ${ }^{245}$ e na possibilidade de imposição de penalidades às partes contratantes, não afetando a existência, validade ou eficácia da contratação.

Além da formalização do contrato, é necessário que o auditor documente a execução da prestação de serviços a que está obrigado.

Neste sentido, o item 5 da Res. n. 1.206/09 obriga que o auditor produza extensa documentação das atividades realizadas durante a prestação de seus serviços, com o objetivo principal de: 1) fornecer subsídios e embasamentos apropriados do relatório do auditor; e 2) proporcionar evidências suficientes de que a auditoria foi planejada e executada em conformidade com as normas e as exigências legais e regulamentares aplicáveis. ${ }^{246}$ Saliente-se que a inobservância do dever de documentação da auditoria ou a documentação deficiente, além de dificultar sobremaneira a prova em eventual litígio entre

\footnotetext{
${ }^{244}$ A distinção é referida por GOMES, Orlando. Introdução ao Direito Civil. Rio de Janeiro: Forense, 1990. Este autor e boa parte da doutrina não veem mais razão para a distinção entre as duas espécies de forma, preferindo meramente classificar os atos jurídicos, quanto à forma, simplesmente em solenes e não solenes. Mantivemos a distinção referida no texto para que se viabilizasse a discussão ampla da matéria. Por outro lado, como bem explicita Pontes de Miranda (Op. cit. p. 347): "A forma pode ser pressuposto de existência do ato jurídico, de eficácia ou de validade. A doação verbal de bem imóvel não é nula; é inexistente. A doação verbal de bem móvel sem lhe seguir, desde logo, a tradição, também o é. A doação de bem imóvel por instrumento particular é nula, porque não se observou o art. 134, II. A forma pode ser elemento necessário ao suporte fático para que entre no mundo jurídico, ou para que o ato jurídico valha, ou para que o ato jurídico tenha certo efeito, ou certos efeitos".

${ }^{245}$ Considerando que os contratos de prestação de serviço envolvem usualmente investimentos consideráveis e altos valores, será aplicável a restrição constante do art. 227 do CC, que limita a prova testemunhal de contratos, estipulando que, "salvo os casos expressos, a prova exclusivamente testemunhal só se admite nos negócios jurídicos cujo valor não ultrapasse o décuplo do maior salário-mínimo vigente no País ao tempo em que foram celebrados".

${ }^{246}$ Além desses objetivos, a Res. n. 1.206/09 ainda elenca outras finalidades adicionais da documentação de auditoria, como as seguintes: "assistir a equipe de trabalho no planejamento e execução da auditoria; assistir aos membros da equipe de trabalho responsáveis pela direção e supervisão do trabalho de auditoria e no cumprimento de suas responsabilidades de revisão em conformidade com a NBC TA 220 - Controle de Qualidade da Auditoria de Demonstrações Contábeis; permitir que a equipe de trabalho possa ser responsabilizada por seu trabalho; manter um registro de assuntos de importância recorrente para auditorias futuras; permitir a condução de revisões e inspeções de controle de qualidade em conformidade com a NBC PA 01 - Controle de Qualidade para Firmas (Pessoas Jurídicas e Físicas) de Auditores Independentes que executam exames de auditoria e revisões de informação financeira histórica, e outros trabalhos de asseguração e de serviços correlatos (NBC TA 220, item 2); permitir a condução de inspeções externas em conformidade com as exigências legais, regulamentares e outras exigências aplicáveis".
} 
as partes contratantes ou em face de terceiros, caracteriza-se como descumprimento de norma regulatória da atividade de auditoria e, portanto, sujeita o auditor a penalidades. ${ }^{247}$

A forma de armazenamento da documentação é livre ao auditor, sendo permitidos diversos meios de exteriorização, tais como arquivos eletrônicos, documentos em papel, cartas e correspondências, etc. ${ }^{248}$

Qualquer que seja a forma de armazenamento escolhida, o auditor deve organizá-la em arquivo final de auditoria, o que deve ser realizado tempestivamente após a apresentação do relatório ou parecer final.

A documentação de auditoria é de propriedade e responsabilidade do auditor, e não da entidade auditada, sujeita à obrigação de confidencialidade, nos termos já examinados anteriormente. De acordo com o art. 25, III, da Instrução CVM n. 308/99, a conservação e guarda de toda a documentação, correspondência, papéis de trabalho, relatórios e pareceres relacionados com o exercício das funções do auditor deve ser efetivada pelo prazo mínimo de cinco anos (ou por prazo superior por determinação expressa da CVM em caso de Inquérito Administrativo).

\subsection{Resilição e rescisão do contrato}

O encerramento do contrato de prestação de serviços de auditoria externa pode ocorrer de várias formas.

O modo ordinário de término do contrato se dá com o cumprimento das obrigações das partes, nos termos em que foram pactuadas, o que na espécie contratual em análise usualmente ocorre com a apresentação do parecer ou relatório final de auditoria por parte do auditor, com o consequente recebimento da contraprestação pecuniária devida

${ }^{247}$ Veja-se o Recurso 4657 do CRSFN, processo CVM 01/01: "EMENTA: RECURSO VOLUNTÁRIO Mercado de valores mobiliários - Auditoria independente - Execução dos trabalhos em desacordo com as normas profissionais relativamente a demonstrações contábeis de companhias incentivadas - Papéis de trabalho sem anotações e insuficientes para aceitação como comprobatórios de execução dos serviços Irregularidades de natureza grave caracterizadas - Apelo a que se nega provimento. PENALIDADE: Suspensão Temporária. BASE LEGAL: Lei n 6385/76, art. 11, inciso V".

${ }^{248}$ A Res. 1.206/09 traz os seguintes exemplos de possíveis meios em que a documentação de auditoria pode ser armazenada: "(a) programas de auditoria; (b) análises; (c) memorandos de assuntos do trabalho; (d) resumos de assuntos significativos; (e) cartas de confirmação e representação; (f) listas de verificação; (g) correspondências (inclusive correio eletrônico) referentes a assuntos significativos". 
pela entidade auditada. Do mesmo modo, pode haver encerramento do contrato pelo término de seu prazo, como vimos em tópico antecedente.

O contrato em estudo pode ainda ser resolvido pelo inadimplemento das obrigações de uma ou ambas as partes. Por se tratar de contrato bilateral, tem implícita em seus termos a cláusula resolutiva tácita (arts. 474 e 475 do CC), nada impedindo que as partes estipulem expressamente referida cláusula ante o inadimplemento de qualquer dos contratantes.

Nada obsta, igualmente, que as partes venham a distratar (resilição bilateral do contrato).

A questão principal que se põe neste tópico é a de se saber se o contrato de prestação de serviços de auditoria externa pode ser encerrado por resilição unilateral e imotivada (denúncia) de uma das partes.

Dois pontos devem ser abordados para o enfrentamento da questão posta: 1) a contratação por prazo determinado ou indeterminado; 2) a influência da possibilidade de resilição imotivada na independência do auditor.

Como vimos, boa parte dos contratos de prestação de auditoria externa não admite contratação por prazo indeterminado, dada a obrigatoriedade de rotação quinquenal do auditor ou sociedade de auditoria. Assim, tendo a contratação de ser efetivada por prazo determinado, em princípio não caberia em tais hipóteses a denúncia imotivada por uma das partes. ${ }^{249}$ Nos casos em que a contratação puder ser feita por prazo indeterminado, porém, este óbice para a contratação não existirá.

No entanto, não fosse a questão do prazo contratual, é necessário verificar que a possibilidade de resilição imotivada do contrato de auditoria pode ter sérias influências na independência do auditor.

Com efeito, na execução dos trabalhos de auditoria, o auditor pode ter de contrariar interesses da entidade auditada, tornando públicas, por meio de seu parecer, algumas circunstâncias que possam desagradar a parte contrária. Desta forma, a possibilidade de resilição unilateral imotivada do contrato poderia servir como instrumento de punição potencial ao auditor pelo justo exercício de sua prerrogativa de independência, funcionando como mecanismo de controle e pressão sobre este profissional.

\footnotetext{
${ }^{249}$ Neste sentido opina Orlando Gomes (Contratos, cit. p. 227): "Nos contratos por tempo determinado não cabe, em princípio, a resilição unilateral".
} 
Assim, a tendência mundial da regulação da matéria é a de não admitir a resilição imotivada do contrato de auditoria por iniciativa da entidade auditada. ${ }^{250}$ No âmbito da União Europeia, a Diretiva n. 2006/43/CE ${ }^{251}$ recomenda aos Estados-Membros que a destituição do auditor seja precedida da devida justificação e comunicação às autoridades regulatórias, não se admitindo a denúncia imotivada do contrato. Na Itália, o Decreto Legislativo de 24 de fevereiro de 1998, n. 58, também exige justa causa (não permitindo que se entenda como tal a mera divergência de opinião entre as partes), além da comunicação à Consob dos termos da deliberação da assembleia que vier a revogar o encargo atribuído ao auditor. ${ }^{252}$

No Brasil, segue-se a linha do ordenamento estrangeiro, na forma antes aludida, no que tange à necessidade de justa causa para a resilição, além do dever de comunicação dos motivos à autoridade regulatória. A Instrução CVM n. 308/99 determina em seu art. 28 que a administração da entidade auditada deverá, no prazo de vinte dias, comunicar à CVM a mudança de auditor, havendo ou não rescisão do contrato de prestação dos serviços de auditoria, com justificativa da mudança, na qual deverá constar a anuência do auditor substituído.

\footnotetext{
${ }^{250}$ Interessante notar que a principal preocupação da regulação nacional e internacional da matéria é evitar a resilição unilateral imotivada do contrato de prestação de serviços de auditoria por parte da entidade auditada. Em regra, não se cuida da hipótese em que o auditor venha a resilir imotivadamente o contrato. Entretanto, estudo da União Europeia traz interessante informação sobre este assunto, afirmando que a resilição imotivada do contrato por parte do auditor é permitida em alguns Estados-Membros e vedada em outros, inclusive sob pena de responsabilidade civil. Assim se manifesta o estudo: "In nine Member States (Aus, Bel, Ger, Gre, Ita (auditing firms), Lux, Ned, Spa and Swe), the auditor must show cause to resign from his mission. In the remaining cases (Den, Fin, Fra, Ire, Ita (Board of Auditors' members), Por, UK) no showing of cause is necessary. Nevertheless, in these countries any resignation which is untimely or in bad faith could also provide the audited company or a third party with a cause of action for damages. It should be noted that though no duty of showing good cause weighs upon the auditor, he would logically not be allowed to resign for the purpose of avoiding his contractual or statutory obligations. This rule diminishes the importance of the dichotomy that exists among the Member States with respect to this question" (EUROPEAN COMISSION. A study on systems of civil liability of statutory auditors in the context of a single Market for auditing services in the European Union. Disponível em <http://ec.europa.eu/internal_market/auditing/liability/index_en.htm\#study>. Acesso em 27 dez. 2009).

${ }^{251}$ Assim determina esta norma: "O revisor oficial de contas ou a sociedade de revisores oficiais de contas deverão ser nomeados pela assembleia geral de acionistas ou membros da entidade examinada. A fim de proteger a independência do revisor oficial de contas, é relevante que a destituição seja apenas possível quando houver justificação válida para tal e se esta for comunicada à autoridade ou autoridades responsáveis pela supervisão pública".

252 “Art. 159. 2. L'assemblea revoca l'incarico, su proposta motivata dell'organo di controllo, quando ricorra una giusta causa, provvedendo contestualmente a conferire l'incarico ad altra società di revisione secondo le modalità di cui al comma 1 . Non costituisce giusta causa di revoca la divergenza di opinioni rispetto a valutazioni contabili o a procedure di revisione. Le funzioni di controllo contabile continuano ad essere esercitate dalla società revocata fino a quando la deliberazione di conferimento dell'incarico non sia divenuta efficace ovvero fino al conferimento d'ufficio da parte della Consob (...) 5. Le deliberazioni previste dai commi 1 e 2 sono trasmesse alla Consob entro il termine fissato ai sensi del comma 7, lettera b). Entro venti giorni dalla data di ricevimento della deliberazione di revoca, la Consob può vietarne l'esecuzione qualora
} 
A obrigação da comunicação, entretanto, não recai somente sobre a entidade auditada. Caso esta não cumpra com este dever, a obrigação caberá ao auditor independente, que deverá comunicar à CVM a substituição, no prazo de dez dias, contados a partir da data do encerramento do prazo conferido à administração da entidade. Se o auditor não concordar com a justificativa apresentada para sua substituição, deverá encaminhar à CVM as razões de sua discordância no prazo de trinta dias, contados a partir da data da substituição.

Caso a CVM verifique a resilição desmotivada do contrato, ou a ausência da comunicação devida, poderá impor sanções às partes, inclusive multa cominatória diária.

A necessidade de justificação e comunicação também é imposta na regulação da matéria por parte do CNSP (art. 11, $\S 3^{\mathrm{o}}$ e $4^{\mathrm{o}}$, da Res. n. 118/04). ${ }^{253}$

Diante disto, podemos concluir, na esteira de doutrinadores como Orlando Gomes, ${ }^{254}$ que o contrato de prestação de serviços de auditoria externa se situa entre aqueles que, excepcionalmente, não admitem a denúncia imotivada pela entidade auditada, ${ }^{255}$ devendo ser apresentada justa causa para sua resilição, além das devidas comunicações às autoridades competentes, dado o interesse público na manutenção da independência do auditor.

rilevi la mancanza di una giusta causa. La deliberazione di revoca dell'incarico ha effetto dalla scadenza del termine di cui al periodo precedente, qualora la Consob non ne abbia vietata l'esecuzione."

253 “ $\$ 3^{\circ}$ Sempre que houver substituição do auditor independente antes do prazo determinado no caput deste artigo, o fato deverá ser comunicado à SUSEP, em até 15 (quinze) dias, através de exposição formalmente elaborada pela sociedade supervisionada, justificando as razões para tal mudança, dela constando a anuência do auditor independente substituído. $\S 4^{\underline{o}}$ Caso não haja concordância do auditor independente com os motivos expostos pela sociedade supervisionada para sua substituição, este deverá encaminhar à SUSEP as justificativas de sua discordância, no prazo máximo de 15 (quinze) dias, contados da data de ciência da mesma."

${ }^{254}$ Contratos, cit., p. 225: "Em princípio, a denúncia não precisa ser justificada. Meio lícito de pôr termo ao contrato por tempo indeterminado, sabem as partes que, em qualquer momento, pode ser desfeito mediante simples declaração unilateral de vontade, mas em certos contratos exige-se que obedeça à justa causa" (grifos nossos). Excepcionalmente, poderíamos admitir a denúncia imotivada nos contratos de auditoria que não estivessem sob a regulação da CVM ou das outras autoridades competentes cujas normas incidem sobre a matéria. O principal caso seria o da contratação da auditoria voluntária por prazo indeterminado. Nesta hipótese, entendemos que deva ser aplicado subsidiariamente o art. 599 do Código Civil.

${ }^{255}$ Podemos constatar que o contrato de auditoria difere, neste ponto, dos demais contratos de prestação de serviços contábeis em geral. Nestes últimos, a possibilidade de denúncia imotivada é admitida em geral. Inclusive a previsão desta ocorrência faz parte daquelas cláusulas tidas como obrigatórias nesta espécie contratual, nos termos da Res. CFC n. 987/03. Em seu art. 2º, esta norma determina que: "O Contrato de Prestação de Serviços deverá conter, no mínimo, os seguintes dados: a) a identificação das partes contratantes; b) a relação dos serviços a serem prestados; c) duração do contrato; d) cláusula rescisória com a fixação de prazo para a assistência, após a denúncia do contrato; e) honorários profissionais; f) prazo para seu pagamento; g) responsabilidade das partes; h) foro para dirimir os conflitos" (grifos nossos). 


\subsection{Parecer e relatório de auditoria}

O parecer ou relatório do auditor independente é o ato conclusivo do contrato de prestação de serviços respectivo efetivado após a realização da complexa tarefa de verificação de conformidade dos lançamentos contábeis operados pela entidade auditada.

Consubstancia a conclusão opinativa do auditor sobre o conteúdo das demonstrações contábeis investigadas, bem como a comunicação deste profissional com os terceiros interessados na informação contábil. ${ }^{256}$

Podemos dividir as manifestações de opinião do auditor em dois tipos básicos: 1) parecer de auditoria; 2) relatório de auditoria. Muitos autores conceituam o parecer de auditoria como subespécie do gênero relatório de auditoria.

Doutrinam Araújo et al. a respeito:

O relatório é o instrumento técnico pelo qual o auditor comunica ou apresenta os resultados dos trabalhos realizados. Seus comentários, suas observações, conclusões, opiniões e recomendações, e as providências necessárias que devem ser tomadas pela administração (...). Os resultados dos trabalhos de auditoria podem ser apresentados sob a forma de parecer de auditoria, quando da realização de auditorias sobre as demonstrações contábeis, ou sob a forma de relatório amplo, que é mais adequado para a auditoria operacional (...). Logo, tem-se relatório de auditoria, como gênero e parecer de auditoria e relatório amplo de auditoria como espécies. $^{257}$

Em que pese a diferenciação doutrinária supracitada, as normas mais recentes têm preferido o emprego genérico da locução relatório de auditoria em substituição à

\footnotetext{
${ }^{256}$ Interessante verificar que o parecer dos auditores independentes, no caso em que seja obrigatório, é um dos documentos cuja disponibilidade deve ser efetivada pela administração aos acionistas (art. 133, III, da Lei n. 6.404/76). Ressalta Erasmo Valladão e Novaes França a posição assumida no ordenamento jurídico alemão (HGB §316(1)), segundo a qual "se não se efetua a auditoria obrigatória, as contas anuais não podem ser aprovadas e os lucros também não podem ser repartidos" (Op. cit. p. 122). No original, a norma citada encontra-se na forma a seguir transcrita: "§ 316 Pflicht zur Prüfung (1) Der Jahresabschluß und der Lagebericht von Kapitalgesellschaften, die nicht kleine im Sinne des $§ 267$ Abs. 1 sind, sind durch einen Abschlußprüfer zu prüfen. Hat keine Prüfung stattgefunden, so kann der Jahresabschluß nicht festgestellt warden".

${ }^{257}$ Op. cit. p. 292.
} 
expressão parecer de auditoria. Como se trata apenas de uma modificação de terminologia, continuaremos a utilizar as duas expressões indistintamente.

$\mathrm{Na}$ esteira da doutrina citada, o parecer de auditoria (audit report) pode ser conceituado, de modo simplificado, como o relatório conclusivo da prestação de serviços de auditoria externa, por meio do qual o auditor comunica formalmente à entidade auditada e ao público interessado as opiniões obtidas pelo exercício de seu trabalho de revisão contábil. $^{258}$

No que tange às entidades auditadas cujas demonstrações contábeis devem ser publicadas, usualmente consistentes em companhias abertas, instituições financeiras ou sociedades seguradoras, o parecer do auditor deve conter uma série de requisitos. ${ }^{259}$

Nesses casos, o juízo valorativo do auditor independente deve obedecer a condições mais rigorosas, principalmente quanto à forma, sob pena de se mostrar inidôneo para seus propósitos. Dentre outros, deve atender aos requisitos de comparabilidade, padronização, indicação de objeto, finalidade e responsabilidades, além de preservar a confidencialidade dos dados auditados, como explicitado a seguir.

A primeira característica que o parecer de auditoria deve observar é a comparabilidade. Como visa a informar terceiros indeterminados, o parecer de uma determinada entidade auditada deve conter forma e requisitos tais que possam ser comparados com outros da mesma espécie emitidos pela análise das demonstrações contábeis de entidade diversa.

Visando a obter comparabilidade, o parecer de auditoria deve obedecer a uma padronização, que usualmente é estabelecida pelas autoridades regulatórias, buscando que referido ato se enquadre dentro de modelos preestabelecidos.

\footnotetext{
${ }^{258}$ A norma NPA01 do Ibracon, item 5, define parecer de auditoria nos seguintes termos: “O parecer dos auditores independentes é o documento mediante o qual o auditor expressa sua opinião, de forma clara e objetiva, sobre as demonstrações contábeis quanto ao adequado atendimento, ou não, a todos os aspectos relevantes dos assuntos tratados no item 4". Os assuntos tratados neste item são os seguintes: "a. se as demonstrações contábeis foram preparadas de acordo com práticas contábeis adequadas e condizentes com os princípios fundamentais de contabilidade. b. se as demonstrações contábeis atendem aos principais requisitos legais, regulamentares e societários. c. se o conjunto das informações apresentadas pelas demonstrações contábeis é condizente com o conhecimento do auditor sobre os negócios e as práticas operacionais da entidade. d. se há apropriada divulgação de todos os assuntos relevantes para uma adequada apresentação das demonstrações contábeis".

${ }^{259}$ Para as entidades auditadas que não estejam obrigadas a publicar suas demonstrações, os requisitos mencionados no texto podem ser mitigados. É frequente, por exemplo, em auditoria voluntária, que as partes estabeleçam limitações de escopo ou mesmo escolham os padrões comparativos que serão usados. Além disso, como em auditorias voluntárias não há abertura do parecer para terceiros além das partes contratantes, é comum a elaboração de extensos relatórios e recomendações, muito diferentes dos pareceres de auditoria externa apresentados pelas companhias abertas juntamente com suas demonstrações contábeis.
} 
Outrossim, deve o parecer esclarecer ao destinatário o objeto examinado pelo auditor, explicitando o que foi e o que não foi verificado.

Deve o parecer indicar sua finalidade e a responsabilidade do auditor sobre o ato que pratica, relatando que seu ato visa a dar segurança razoável que as demonstrações contábeis, de responsabilidade da administração da entidade auditada, não contenham distorções relevantes.

O parecer deve ainda preservar a confidencialidade das informações auditadas, não podendo o auditor revelar ao público destinatário de seu trabalho dados contábeis obtidos em sua atividade, tirante o que obrigatoriamente tenha que revelar, comedidamente, como ressalva ou ênfase em seu parecer.

De modo a preservar a confidencialidade, o parecer necessita atender ao requisito de concisão e objetividade, não podendo ser demasiado extenso, nem adotar linguajar técnico inacessível aos interessados na informação prestada.

As espécies de parecer de auditoria se classificam conforme o tipo de opinião valorativa emitida pelo auditor a respeito das demonstrações contábeis.

Inicialmente, o parecer de auditoria pode asseverar que, nos termos das evidências de auditoria colhidas, não houve distorções relevantes percebidas nas demonstrações contábeis objeto de revisão em confronto com a legislação de regência e os princípios contábeis geralmente aceitos (PGCA). Trata-se do denominado parecer sem ressalvas, unmodified opinion (ISA n. 700, item 5) ${ }^{260}$ ou giudizio senza rilievi. ${ }^{261}$

Caso a observação e as evidências do auditor o levem a crer que haja risco de distorção materialmente relevante nas demonstrações contábeis analisadas, ele pode seguir um dos vários tipos de parecer seguintes, classificados pela norma ISA n. 750 como three types of modified opinions.

O primeiro tipo de parecer que pode vir a ser adotado pelo auditor é o que se chama de parecer com ressalvas, qualified opinion $^{262}$ ou giudizio con rilievi. Isto deve

\footnotetext{
260 Item 5 da norma ISA n. 700: "The auditor shall express an unmodified opinion when the auditor concludes that the financial statements are prepared, in all material respects, in accordance with the applicable financial reporting framework".

${ }^{261}$ Art. 156, 2, do Decreto Legislativo de 24 de fevereiro de 1998, n. 58: "La società di revisione esprime un giudizio senza rilievi se il bilancio di esercizio e il bilancio consolidato sono conformi alle norme che ne disciplinano i criteri di redazione e se rappresentano in modo veritiero e corretto la situazione patrimoniale e finanziaria e il risultato economico dell'esercizio".

${ }^{262}$ Item 7 da norma ISA n. 705: "The auditor shall express a qualified opinion when: (a) The auditor, having obtained sufficient appropriate audit evidence, concludes that misstatements, individually or in the aggregate,
} 
ocorrer quando o auditor venha a perceber que há relevantes distorções nas demonstrações contábeis, mas que se apresentam isoladas ou estanques, não havendo comprometimento como um todo, ou ainda quando conclua que, apesar de não haver suficientes evidências, os possíveis efeitos das distorções não detectadas possam ser materialmente relevantes, embora isolados. $^{263}$

Entretanto, caso as distorções materialmente relevantes não estejam em pontos isolados, mas se estendam à totalidade ou quase totalidade das demonstrações contábeis, comprometendo sua integralidade geral, ${ }^{264}$ deverá o auditor externar um parecer adverso, adverse opinion, ${ }^{265}$ ou giudizio negativo.

Obviamente, a distinção entre o parecer adverso e aquele com ressalvas decorre muitas vezes do julgamento profissional do auditor e, portanto, depende de certo subjetivismo. Em várias hipóteses, o auditor deverá avaliar se o número de ressalvas pode ser grande o suficiente para determinar a expedição de um parecer adverso, estimando suas consequências sobre a totalidade das demonstrações objeto de revisão. ${ }^{266}$

Nos casos de ressalva ou parecer adverso, porém, o auditor deve sempre, nos termos do art. 25, IV, da Instrução n. 308/99 da CVM, indicar com clareza, e em quanto, as contas ou subgrupos de contas do ativo, passivo, resultado e patrimônio líquido que

are material, but not pervasive, to the financial statements; or (b) The auditor is unable to obtain sufficient appropriate audit evidence on which to base the opinion, but the auditor concludes that the possible effects on the financial statements of undetected misstatements, if any, could be material but not pervasive".

${ }^{263}$ Como ocorre com outras hipóteses de prestação de serviços inadequados de auditoria, a ausência de ressalvas em parecer em que tal menção deveria constar, uma vez que presentes distorções relevantes, além de caracterizar descumprimento contratual, pode sujeitar o auditor a penalidades administrativas. Neste sentido o julgado do CRSFN no processo BCB 0001062236: "EMENTA: RECURSO VOLUNTÁRIO Auditoria independente - Emissão de pareceres sem ressalvas sobre as demonstrações financeiras Elaboração de relatórios de controles internos sem correspondência com a real situação contábil-financeira da instituição e das coligadas - Irregularidades caracterizadas - Apelo a que se nega provimento. PENALIDADE: Multa Pecuniária. BASE LEGAL: Lei n. 6.385/76, art. 11, inciso II”.

${ }^{264} \mathrm{O}$ conceito de comprometimento do todo corresponde ao que se define na norma ISA n. 750 como "pervasive efects", assim definido: "Pervasive effects on the financial statements are those that, in the auditor's judgment: (i) are not confined to specific elements, accounts or items of the financial statements; (ii) if so confined, represent or could represent a substantial proportion of the financial statements; or (iii) in relation to disclosures, are fundamental to users' understanding of the financial statements".

${ }^{265}$ Item 8 da norma ISA n. 705: " 8 . The auditor shall express an adverse opinion when the auditor, having obtained sufficient appropriate audit evidence, concludes that misstatements, individually or in the aggregate, are both material and pervasive to the financial statements".

${ }^{266}$ A CVM, no ofício circular CVM/SNC/N. 12/2009, de 2.09.2009, bem ressalta a subjetividade de julgamento, que em determinados casos pode levar o auditor a emitir parecer com ressalvas, quando deveria emitir parecer adverso. Neste sentido, assevera a autarquia: "Emissão de parecer com ressalva apesar da existência de múltiplas ressalvas que conduziriam à emissão de parecer adverso: foram identificados casos em que os auditores independentes incluíram várias ressalvas no parecer sobre determinadas demonstrações contábeis que, em seu conjunto, dada a relevância dos desvios apontados, poder-se-ia dizer que as demonstrações contábeis auditadas não representavam a posição patrimonial e financeira daquela companhia para 31/12/2008". (grifo nosso) 
estão afetados pela adoção de procedimentos contábeis conflitantes com os Princípios Fundamentais de Contabilidade, bem como os efeitos no dividendo obrigatório e no lucro ou prejuízo por ação, conforme o caso.

Pode ainda o auditor não possuir elementos suficientes para expressar sua opinião com segurança suficiente a atestar a ausência de distorções relevantes nas demonstrações contábeis (p.ex., por algum tipo de limitação imposta), concluindo que se referidas distorções existirem, poderão contaminar as demonstrações como um todo. Neste caso, deverá externar sua tarefa através de um parecer com abstenção de opinião, disclaimer of opinion, ${ }^{267}$ ou dichiarazione di impossibilità di esprimere un giudizio.

A tabela seguinte, retirada da norma ISA n. 750, bem ilustra as diferenças das hipóteses de parecer com reservas, parecer adverso ou parecer com abstenção de opinião.

Tabela 11: Distinções quanto aos tipos de parecer, conforme as situações apresentadas ao auditor

\begin{tabular}{|c|c|c|}
\hline \multirow{2}{*}{$\begin{array}{l}\text { Natureza da matéria } \\
\text { que dá causa à } \\
\text { modificação de opinião }\end{array}$} & \multicolumn{2}{|c|}{$\begin{array}{l}\text { Julgamento do auditor sobre os possíveis efeitos ou } \\
\text { comprometimento das demonstrações contábeis como um } \\
\text { todo }\end{array}$} \\
\hline & $\begin{array}{l}\text { Distorções não comprometem as } \\
\text { demonstrações como um todo } \\
\text { (material but not pervasive) }\end{array}$ & $\begin{array}{l}\text { Distorções comprometem as } \\
\text { demonstrações como um todo } \\
\text { (material and pervasive) }\end{array}$ \\
\hline $\begin{array}{c}\text { Demonstrações contêm } \\
\text { distorções } \\
\text { materialmente } \\
\text { relevantes }\end{array}$ & $\begin{array}{l}\text { Parecer com ressalva } \\
\text { (qualified opinion) }\end{array}$ & $\begin{array}{l}\text { Parecer adverso } \\
\text { (adverse opinion) }\end{array}$ \\
\hline $\begin{array}{c}\text { Impossibilidade de } \\
\text { obter evidência de } \\
\text { auditoria } \\
\text { suficientemente } \\
\text { apropriada }\end{array}$ & $\begin{array}{l}\text { Parecer com ressalva } \\
\text { (qualified opinion) }\end{array}$ & $\begin{array}{l}\text { Parecer com abstenção de } \\
\text { opinião } \\
\text { (Disclaimer of opinion) }\end{array}$ \\
\hline
\end{tabular}

Fonte: ISA n. 750.

É importante ressaltar que pode haver variações na emissão do parecer, qualquer que seja a opinião ou abstenção de opinião emitida. Com efeito, o auditor pode 
desejar ou se ver obrigado a revelar determinados fatos para os quais deseja chamar a atenção dos destinatários de seu parecer. Isto normalmente é feito pela adição de um parágrafo de ênfase (explanatory paragraph) ao parecer original.

Entenda-se que a inserção de um parágrafo de ênfase no parecer de auditoria não traz qualquer modificação de opinião do auditor, ressalva ou abstenção. Trata-se apenas de uma observação explicativa que visa a destacar algum elemento importante observado. Algumas das principais circunstâncias que determinam a colocação de um parágrafo de ênfase no parecer podem assim ser elencadas: 1) afastamento justificado pela entidade de auditoria, em determinada matéria, dos princípios contábeis geralmente aceitos; 2) aplicações inconsistentes dos princípios de contabilidade, como mudança de critérios entre exercícios; 3) dúvida sobre a continuidade empresarial (going concern doubt); 4) ênfase em determinadas transações relevantes com partes relacionadas, decisões e incertezas relevantes e riscos empresariais; 5) referência ao trabalho de outros auditores. $^{268}$

No ordenamento nacional não se prevê a necessidade de comunicação direta e imediata do auditor à CVM em caso de parecer adverso ou com abstenção de opinião. $\mathrm{Na}$ Itália, porém, referida comunicação ao órgão regulador (Consob) é obrigatória nesses casos. $^{269}$

Também no ordenamento italiano prevê-se a possibilidade, inexistente no Brasil, de intervenção do Poder Judiciário, em exercício de jurisdição voluntária e mediante proposta de acionistas que representem pelo menos cinco por cento do capital social, sobre as demonstrações contábeis aprovadas pela assembleia, acompanhadas de parecer com ou sem ressalvas; impossibilitada esta atuação quando o parecer seja adverso ou com abstenção. ${ }^{270}$

\footnotetext{
${ }^{267}$ Item 9 da norma ISA n. 705: "The auditor shall disclaim an opinion when the auditor is unable to obtain sufficient appropriate audit evidence on which to base the opinion, and the auditor concludes that the possible effects on the financial statements of undetected misstatements, if any, could be both material and pervasive". 268 A CVM, no ofício circular CVM/SNC/N. 12/2009, de 02/09/2009, assevera que a inserção de parágrafo de ênfase não deve ser usada quando o auditor discorde de quaisquer fatos materialmente relevantes praticados pela administração da companhia. Nestes casos, deve ele utilizar, conforme o caso, de ressalva no parecer.

${ }^{269}$ Art. 156, 4, do Decreto Legislativo de 24 de fevereiro de 1998, n. 58: "In caso di giudizio negativo o di dichiarazione di impossibilità di esprimere un giudizio la società di revisione informa immediatamente la Consob".

${ }^{270}$ Art. 157, 1 e 2, do Decreto Legislativo de 24 de fevereiro de 1998, n. 58: "1. Salvi i casi previsti dall'articolo 156, comma 4, la deliberazione dell'assemblea o del consiglio di sorveglianza che approva il bilancio d'esercizio può essere impugnata, per mancata conformità del bilancio alle norme che ne disciplinano i criteri di redazione, da tanti soci che rappresentano almeno il cinque per cento del capitale
} 


\section{LIMITAÇÕES E EXPECTATIVAS EM AUDITORIA EXTERNA}

Vistas as principais questões envolvendo o contrato de auditoria externa, faz-se necessário analisar agora as limitações desta atividade.

Dentre os pontos que se deve examinar neste tópico enquadram-se: 1) as limitações efetivas enfrentadas pelos auditores; 2) as expectativas sociais em face dos serviços de auditoria externa; 3) as expectativas sociais da descoberta de fraudes pela atividade de auditoria; 4) as expectativas sociais da atividade de auditoria no exame da continuidade empresarial.

\subsection{Limitações efetivas enfrentadas pelos auditores}

Dentre as limitações de que sofre a atividade, as primeiras são ligadas às restrições da própria ciência contábil e dos documentos produzidos pela contabilidade financeira.

A contabilidade, como ciência que busca a evidenciação de informações econômicas empresariais, ou seja, construir uma metodologia ou sistema estruturado de informações sobre os eventos econômicos realizados por uma entidade a usuários internos e externos a esta, possui limitações ínsitas ao seu próprio método.

Com efeito, a metodologia contábil, por necessidade da própria ciência, procura padrões objetivos de evidenciação e, portanto, registra prioritariamente eventos que possuam mensuração objetiva e quantificável em moeda, sem prejuízo de algumas mensurações que contenham certo subjetivismo, como veremos adiante (v.g., as estimativas contábeis).

sociale. Tanti soci che rappresentano la medesima quota di capitale della società con azioni quotate possono richiedere al tribunale di accertare la conformità del bilancio consolidato alle norme che ne disciplinano $\mathrm{i}$ criteri di redazione. 2. La Consob può esercitare in ogni caso le azioni previste dal comma 1 entro sei mesi dalla data di deposito del bilancio d'esercizio e del bilancio consolidato presso l'ufficio del registro delle imprese". 
Além disso, também para atender a requisitos de objetividade de informação, a contabilidade adota alguns critérios conservadores em determinadas oportunidades (p.ex., a avaliação de bens pelo custo histórico).

Várias das informações empresariais de natureza qualitativa não são apresentadas em seus demonstrativos contábeis. Nos demonstrativos não há menção a prazos, qualidade dos colaboradores, participação ou aceitação de mercado, riscos empresariais, etc.

Como consequência das mencionadas limitações, os demonstrativos contábeis, em regra, não fornecem um valor preciso da entidade empresarial para o usuário da informação neles contida.

Todas as limitações supracitadas que envolvem a ciência contábil e os demonstrativos elaborados com base em seus postulados se constituem também em limitações da atividade de auditoria externa, pois esta trabalha sobre o substrato das demonstrações financeiras e lançamentos contábeis que lhe serviram de base.

Assim, não é de se esperar do auditor que forneça dados que os demonstrativos contábeis, baseados nos postulados da ciência contábil, não estão aptos a revelar, tais como os mencionados anteriormente.

Não bastassem as limitações inerentes à metodologia contábil, a atividade de auditoria externa possui ainda outras restrições próprias.

A primeira delas é a limitação de custo (reasonable cost).

O auditor deve realizar um trabalho de verificação de contas que seja economicamente viável, o que naturalmente impõe restrições a seu trabalho, uma vez que há entidades em que o volume de transações econômicas a serem auditadas é demasiado grande, tornando sua revisão altamente custosa e economicamente proibitiva. Assim, diante da impossibilidade prática (usualmente existente) da verificação da totalidade das transações de uma determinada entidade auditada, os auditores devem lançar mão de instrumentos de amostragem e outros mecanismos seletivos, o que constitui efetivamente uma limitação ao trabalho.

A segunda é a limitação de tempo (reasonable length of time).

Como é cediço, a auditoria externa é atividade que se desenvolve em período delimitado de tempo, normalmente por um exercício social ou, ainda, por prazos inferiores. 
Diante deste quadro, o auditor tem pouco espaço de tempo para a coleta de muitas das evidências sobre a qual desenvolve sua tarefa, bem como para resolver as incertezas que os dados coletados usualmente contêm.

Também limita a atividade de auditoria externa a existência de estimativas contábeis (accounting estimates).

Muitos dos valores que são inseridos nas demonstrações contábeis são incertos quanto a seu montante e ocorrência futura, portanto, definidos apenas por meio de estimativas, ou seja, de prognósticos. Isto ocorre com muitas das contas frequentemente presentes nas demonstrações, como o montante de depreciação (estimativa da perda de valor de um determinado bem pelo uso ou obsolescência), as provisões para inadimplência (provisão para créditos de liquidação duvidosa) e naquelas destinadas ao reconhecimento de passivos contingentes (provisões para litígios trabalhistas, passivos ambientais, etc.). Assim sendo, a auditoria externa sofre restrições para avaliar as estimativas contábeis, uma vez que não pode assegurar de modo absoluto a superveniência desses eventos previstos pela administração da entidade auditada, nem os corretos valores utilizados. ${ }^{271}$

Por este motivo, alguns doutrinadores italianos entendem mais correto dizer que o auditor somente oferece um juizo sobre os critérios e circunstâncias das contas revisadas que apresentem caráter subjetivo (estimativas), e não propriamente uma certificação de veracidade absoluta. Veja-se a lição de Maria Vittoria Cozzi:

P. E. Cassandro, o.c., p. 11, observou que a certificação no sentido de atestação de fatos objetivos... pode existir apenas em relação àqueles valores objetivos do balanço... mas quando se passa a considerar valores do caráter subjetivo (porque são fruto de estimativas e previsões) a certificação do balanço não pode mais ser entendida como atestação de veracidade, uma vez que, em tal caso trata-se de expressar um julgamento

${ }^{271}$ Entenda-se, porém, que a atividade de auditoria atua na verificação das estimativas contábeis, até para analisar os pressupostos e a razoabilidade dos critérios utilizados para sua elaboração. Sobre o tema, aliás, o CFC editou a Resolução n. 1.223/09, que trata de auditoria de estimativas contábeis, inclusive do valor justo, e divulgações relacionadas. O que ocorre é que o auditor, no exame das estimativas, realiza uma revisão naturalmente limitada em termos de oferecimento de segurança quanto à inexistência de distorções, dadas as imprecisões e incertezas que o assunto envolve. O exame regular dos critérios utilizados para estimativas contábeis (p.ex.: a taxa utilizada para depreciação de bens) deve ser objeto de exame do auditor, podendo sua omissão, inclusive, sujeitá-lo a penalidades administrativas. Neste sentido a decisão do CRSFN ACÓRDÃO/CRSFN 4619/03. Recurso 4170. Processo CVM 32/99: "EMENTA: RECURSOS VOLUNTÁRIOS E DE OFÍCIO - Mercado de valores mobiliários - Auditoria independente - Insuficiência relevante em parecer referentemente à taxa linear de depreciação - Irregularidade caracterizada - Razões de defesa acolhidas em parte - Apelo interposto pela responsável técnica acolhido parcialmente. PENALIDADE: Multa Pecuniária. BASE LEGAL: Decreto 23.258/33, art. $6^{\circ}$ ". 
sobre as valorações realizadas pelos administradores. Consequentemente, o juízo de auditoria não pode ter o caráter da certificação, mas de uma declaração do atendimento do balanço em relação às circunstâncias concretas em que foi formulado. Cfr. também S. Fortunato, $\mathrm{La}$ certificazione dei bilancio: i profili giuridici, cit., p. 283; M. Bussoletti, o.c., p. 61; M. Caratozzolo, $N$ atura ed effetti delia certificazione dei bilancio neWordinamento italiano, in Riv.dott.comm., 1986, p. $491 .^{272}$

Por fim, também limita a atividade de auditoria a existência de normas contábeis que permitem a aplicação de princípios e postulados alternativos (alternative accounting principles) em determinadas situações, o que prejudica a comparabilidade e a padronização entre as demonstrações contábeis das entidades, restringindo a possibilidade de o auditor apontar equívoco ou desconformidade.

\subsection{Expectativas sociais em face dos serviços de auditoria externa}

Não obstante as limitações já mencionadas, cada vez mais a sociedade exige resultados de maior efetividade e segurança dos trabalhos de auditoria externa.

Vários fatores contribuem para o aumento da expectativa social em relação à atividade de auditoria, dentre os quais a globalização da economia, o aumento das negociações em mercados de capitais e financeiros e os recentes escândalos contábeis.

A globalização da economia trouxe consigo a internacionalização dos negócios entre os agentes econômicos situados em diversos países, o que resultou na necessidade de maior grau de segurança para as partes interessadas e eventuais financiadores das atividades econômicas. Outrossim, a abertura das fronteiras fez com que houvesse um

${ }^{272}$ Op. cit. p. 22. O texto é tradução livre de: "P.E. Cassandro, o.c., p. 11, aveva osservato che la certificazione nel senso di attestazione di fatti obbiettivi...può aversi solo in rapporto a quei valori di bilancio obbiettivi...ma quando si passa a considerare valori di carattere soggettivo (perche sono frutto di apprezzamenti e previsioni) la certificazione dei bilancio non può piú essere intesa come attestazione di veridicità poiché in tal caso si tratta di esprimere un giudizio sulle valutazioni effettuate dagli amministratori. Di conseguenza il giudizio di revisione non può avere il carattere di certificazione ma quello di una dichiarazione di attendlbilltà di bilancio in rapporto alle circostanze concrete in cui esso è stato formato. Cfr. anche S. Fortunato, La certificazione dei bilancio: i profili giuridici, cit., p. 283; M. Bussoletti, o.c., p. 61; M. 
incremento no rigor da regulação, ou seja, acarretou a transposição de requisitos regulatórios de países em que a expectativa sobre os serviços de auditoria era substancialmente maior para outros em que estas eram diminutas, dada a necessidade de harmonização da regulação dos mercados.

$\mathrm{O}$ aumento dos investimentos em mercados de capitais e financeiros traz como consequência lógica a necessidade de maiores cobranças da atividade de auditoria. Com efeito, quanto maior o volume de transações e do montante aplicado nesses mercados, maiores serão as exigências dos investidores em relação às informações a serem prestadas e à garantia de que sejam críveis e correspondam à realidade, sem conter distorções relevantes.

Por seu turno, os recentes escândalos contábeis influenciaram sobremaneira a expectativa em relação à atividade de auditoria externa, na medida em que expuseram boa parte das fragilidades das bases em que atuavam os profissionais desta área. Conforme visto, para evitar novos acontecimentos deste gênero, o endurecimento da regulação acabou por aumentar as exigências que a sociedade impõe aos profissionais de auditoria e, consequentemente, as expectativas depositadas sobre estes.

O incremento das expectativas do público em relação aos auditores tem sido acompanhado de uma tendência no sentido de que este profissional assuma também maior grau de responsabilidade por suas falhas e omissões, ao mesmo tempo em que existe uma pressão pela realização do trabalho de auditoria a custos razoáveis.

Bem representa esta tendência a lição de Rittenberg et al::

O público, especialmente na forma expressada pelo Congresso, espera que os auditores (a) encontrem fraudes, (b) apliquem princípios de contabilidade que melhor retratem o espírito dos conceitos adotados pelo FASB ou o IASB e (c) sejam neutros aos usuários. Ao mesmo tempo, a administração e o comitê de auditoria esperam auditorias econômicas. Assim, a profissão enfrenta pressão dupla - uma para manter baixos honorários e a outra para reconhecer maiores responsabilidades para um conjunto cada vez mais complexo de clientes de auditoria. ${ }^{273}$

Caratozzolo, $\mathrm{N}$ atura ed effetti delia certificazione dei bilancio neWordinamento italiano, in Riv.dott.comm., 1986, p. 491".

${ }^{273}$ Op. cit. p. 15. O texto é tradução livre do excerto: "The public, particularly as expressed by Congress, expects auditors to (a) find fraud (b) enforce accounting principles that best portray the spirit of the concepts adopted by the FASB or the IASB, and (c) be neutral to users. At the same time, management and the audit 
É fato que muitas das expectativas sociais depositadas sobre a atividade de auditoria são devidas. Dentre elas, podemos citar as de desempenho adequado do auditor (de atuação proba, diligente, independente e competente) e da melhoria das normas de auditoria, que muitas vezes estão aquém do esperado pela sociedade.

Outras expectativas, porém, são demasiadamente rigorosas, como já mencionamos. Nesta linha, leciona Bruno José Machado de Almeida, com apoio em doutrina:

\begin{abstract}
Existe a opinião generalizada, entre os utilizadores da informação financeira, de que qualquer pessoa que tenha um determinado interesse numa empresa deve ser capaz de confiar nas contas auditadas, como garantia da solvência e viabilidade da empresa. Por esse motivo, ao ser do conhecimento público, sem qualquer aviso prévio, que uma empresa está em sérias dificuldades financeiras, existe a opinião generalizada de que alguém deve ser responsabilizado por essa situação, e esse alguém é o auditor (...). Griffiths (p. 9) também acredita que as pessoas mais diretamente envolvidas no mundo dos negócios têm expectativas pouco razoáveis em relação à capacidade de uma auditoria: "A minha experiência diz-me que a comunidade empresarial tem as mais irreais opiniões em relação ao poder de um auditor na detecção de erros e fraudes, não tendo a mínima noção da natureza do trabalho do auditor... $\mathrm{O}$ auditor, através da magia ou por qualquer outro meio, deve prevenir que qualquer irregularidade ocorra, e caso esta situação aconteça, deve ser responsabilizado. ${ }^{274}$
\end{abstract}

Como veremos melhor a seguir, do auditor externo, muitas vezes, espera-se que seja um verdadeiro "caçador de fraudes", alguém cuja especialidade seja a revelação de toda a verdade por trás das atitudes insidiosas da entidade empresarial objeto de auditoria.

Referida expectativa, entretanto, não é totalmente verdadeira. É bem verdade que o auditor externo deve sempre levar em consideração a possibilidade de fraude e, inclusive, preparar-se para o seu eventual reconhecimento. No entanto, a localização e encontro de fraudes não são seu único e principal objetivo.

committee expect cost-effective audits. Thus, the profession faces dual pressure - one to keep fees down and the other to recognize increased responsibilities for an increasingly complex set of audit clients".

274 ALMEIDA, Bruno José Machado de. "Auditoria e sociedade: o diálogo necessário". Revista Contabilidade \& Finanças - USP, São Paulo, n. 34, p. 80-96, janeiro/abril 2004. 
Outra expectativa que usualmente encontramos no meio social em relação aos auditores é aquela segundo a qual estes profissionais devem revelar em seu parecer um prognóstico quanto ao futuro empresarial da entidade auditada, informando aos usuários suas perspectivas de lucro ou prejuízo. Nada mais equivocado, porém. A atividade de auditoria não busca apresentar prognósticos de resultados econômico-contábeis, mas simplesmente informar aos interessados se as demonstrações contábeis, de formulação e responsabilidade originária da entidade auditada, contêm ou não distorções relevantes, em comparação com os princípios contábeis e com a legislação pertinente.

Finalmente, é comum a crença de que, se houve a falência superveniente de uma entidade auditada sem que isso fosse percebido pelos auditores, certamente ocorreu a emissão de um parecer de auditoria equivocado, ou até mesmo fraudulento. ${ }^{275}$ Como também veremos mais adiante, o auditor deve analisar sempre os riscos de continuidade da entidade auditada. No entanto, a superveniência de uma falência é fato cuja previsibilidade é extremamente difícil ao profissional de auditoria, principalmente por estar sujeito a uma diversidade de causas futuras, de ocorrência eventual e incerta.

Resumindo a questão entre as expectativas razoáveis da sociedade em relação à auditoria externa e aquelas que não se apresentem com a devida razoabilidade, vale transcrever o quadro seguinte, novamente apelando para as lições do trabalho de Bruno José Machado de Almeida:

\footnotetext{
${ }^{275}$ Bruno José Machado de Almeida (op.cit., pg. 96) relata essa expectativa indevida nos seguintes temos: "Há a acrescentar a este aspecto, a errada suposição, por parte do público em geral, de que a emissão de um relatório fraudulento tem lugar sempre que há a falência de uma empresa. Assim, o público pode ter a percepção de que a qualidade da auditoria é inferior à que realmente foi desenvolvida".
} 
Tabela 12: Expectativas e desempenho dos auditores

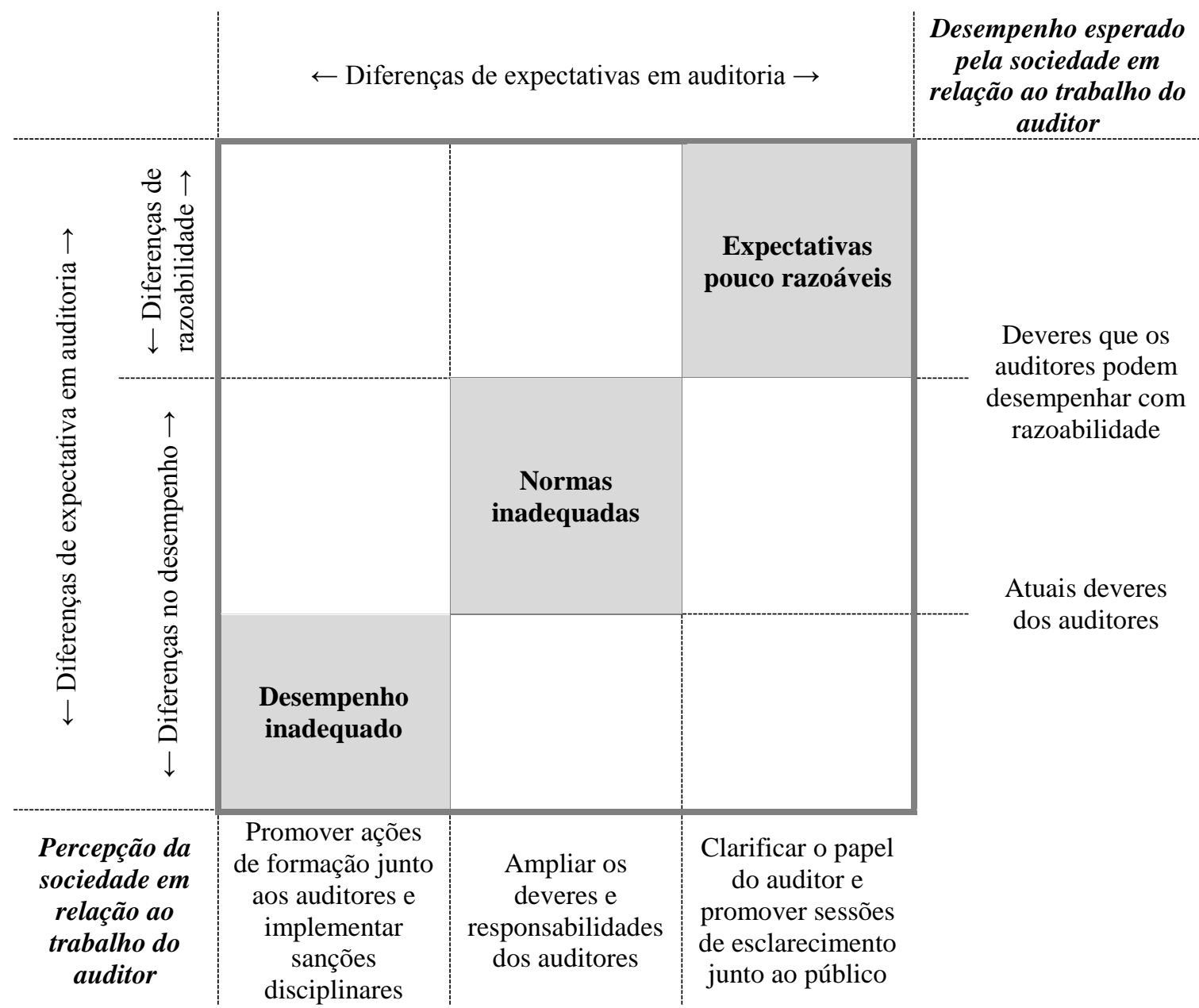

Fonte: Baseado em Almeida, op. cit., p. 90.

Verifica-se, com base no quadro, que as diferenças entre o que é percebido pela sociedade com relação ao trabalho do auditor (canto inferior esquerdo) e o que é por ela esperado deste mesmo trabalho (canto superior direito) são influenciadas pelo desempenho inadequado dos auditores, por normas de auditoria que não atendem aos padrões sociais desejados e por expectativas inadequadas do corpo social. ${ }^{276}$

\footnotetext{
${ }^{276}$ Interessante é verificar que o Poder Judiciário pátrio já se mostrou sensível ao problema, levando em consideração as limitações inatas à atividade de auditoria externa, mesmo diante das expectativas pouco razoáveis em relação a este serviço por parte dos usuários, com o fim de absolver auditor independente em ação civil de reparação de danos. Nesse sentido, vale transcrever o excerto retirado dos autos do processo 99.042.264-0, $11^{a}$ Vara Cível de São Paulo: "É relevante, de início, destacar quais são os objetivos de uma auditoria externa e delimitar a responsabilidade do auditor no exercício de suas atividades profissionais à luz dos termos contratuais e normas vigentes a propósito do tema. Com efeito, infere-se das Normas Internacionais de Auditoria (NIA) emitidas pelo IFAC (International Federarion of Accountants) que o escopo de uma auditoria externa consiste na emissão de parecer sobre a adequação com que as demonstrações contábeis apresentam a posição patrimonial e financeira, o resultado das operações, as variações no patrimônio líquido e as origens e aplicações de recursos em determinado período, de conformidade com os princípios contábeis geralmente aceitos. Em resposta ao quesito 7 formulado pela ré, o
} 
Com relação às expectativas inadequadas, dentre as quais se inserem as limitações da atividade de auditoria vistas no tópico anterior, nada há que se modificar no trabalho dos auditores, devendo ocorrer mera conscientização da sociedade quanto ao dever desses profissionais, uma vez que o atendimento de todas as expectativas sociais, ainda que inadequadas, não seria razoavelmente exigível dos serviços de auditoria.

Em relação às normas que se encontram inadequadas ao que a sociedade espera da atividade e que se situam dentro daquilo que razoavelmente se pode exigir do trabalho do auditor, faz-se mister sua adequação por meio de atividade regulatória, aumentando as obrigações desses profissionais.

Por fim, em relação ao desempenho dos auditores, deve-se atuar na criação de condições para aumento da competência profissional dos atuantes neste ramo, além de implementar controle mais rigoroso, mediante sanções disciplinares.

\subsubsection{Expectativas sociais de detecção de fraudes}

Um dos assuntos mais polêmicos envolvendo a matéria de auditoria externa é a obrigação - e consequente responsabilidade - de detecção de fraudes. ${ }^{277}$

A doutrina costuma separar dois tipos de fraudes relevantes para o trabalho do auditor externo:

- Fraudes que importem elaboração distorcida ou inverídica das demonstrações contábeis: as quais podem envolver manipulação ou

perito judicial esclareceu que as Normas Internacionais de Auditoria (NIA) definem o objeto de uma auditoria das demonstrações financeiras como a ação de habilitar o auditor a expressar uma opinião sobre se as demonstrações financeiras contábeis foram preparadas, em todos os seus atos relevantes, de acordo com uma estrutura conceitual identificada para a elaboração e comunicação de relatórios contáveis. Respondendo a quesito em questão, adverte o perito judicial para a existência de significativa diferença de percepção sobre o papel e responsabilidade do autor entre o que as normas de auditoria definem e a visão dos usuários de demonstrações contábeis, o que o mercado tem denominado de hiato de perspectivas. Nesse sentido, se é certo afirmar que o parecer do auditor aumenta a credibilidade das demonstrações contábeis, não é menos correto concluir que o usuário não pode presumir que aquele seja uma segurança de viabilidade futura da empresa nem da eficiência com a qual a administração conduziu os negócios desta. Portanto, a auditoria externa, em última análise, é planejada para dar uma segurança razoável de que as demonstrações financeiras contábeis estão isentas de distorções relevantes. Não se pode olvidar, porém, que há limitações inerentes a uma auditoria de demonstrações financeiras que afetam a capacidade do auditor de detectar distorções relevantes".

277 Nos termos da Res. n. 1.207/09 do CFC, entende-se por fraude o "ato intencional de um ou mais indivíduos da administração, dos responsáveis pela governança, empregados ou terceiros, que envolva dolo para obtenção de vantagem injusta ou ilegal". 
alteração de lançamentos contábeis, omissão intencional de eventos, valoração dolosamente alterada de elementos patrimoniais (ativos ou passivos), etc.;

- Fraudes que acarretem apropriação indevida de ativos: que frequentemente visam a encobrir desfalques patrimoniais (subtração de ativos, pagamentos indevidos em benefício pessoal, etc.)

Algumas das principais fraudes são relatadas pela doutrina e resumidas na tabela a seguir:

Tabela 13: Alguns tipos de fraude segundo a doutrina especializada

\begin{tabular}{|c|c|}
\hline $\begin{array}{l}\text { Elemento das } \\
\text { demonstrações } \\
\text { a que se refere }\end{array}$ & Descrição \\
\hline \multirow{6}{*}{ Caixa } & Movimentos fraudulentos em dinheiro sem comprovação bancária \\
\hline & $\begin{array}{l}\text { Pagamento de despesas pessoais de sócios com o caixa da sociedade, violando o } \\
\text { princípio da entidade }\end{array}$ \\
\hline & Fraude em vales e retiradas de numerário \\
\hline & Subtrações de numerário com substituição por títulos falsos ou sem valor \\
\hline & $\begin{array}{l}\text { Recebimento de valores no caixa sem contabilização (“caixa dois”) e criação de } \\
\text { passivos fictícios }\end{array}$ \\
\hline & Pagamentos a empregados fantasmas \\
\hline \multirow{4}{*}{ Estoques } & Avaliação fraudulenta de valores de estoque \\
\hline & Estoque sem comprovação por documento idôneo \\
\hline & Desvios em quantidade e qualidade de bens do estoque \\
\hline & Fraudes em sucatas e refugos \\
\hline \multirow{4}{*}{ Contas a receber } & Baixa indevida em títulos a receber \\
\hline & $\begin{array}{l}\text { Recebimentos fraudulentos de clientes em lugar da pessoa jurídica credora, em } \\
\text { concurso com fraude documental }\end{array}$ \\
\hline & Fraude em devolução de bens vinculados a contas a receber \\
\hline & Apropriação fraudulenta de valores de multas por atraso devidas por clientes \\
\hline \multirow{6}{*}{ Ativo permanente } & Investimentos fictícios em imobilizado \\
\hline & Aumento ou diminuição indevida de cotas de depreciação, amortização ou exaustão \\
\hline & Reavaliações fraudulentas \\
\hline & Ativação no imobilizado, em vez de contabilização de despesas \\
\hline & Trocas ruinosas de imobilizado \\
\hline & Contabilização fraudulenta de gastos em pesquisa e desenvolvimento \\
\hline \multirow{4}{*}{ Passivo } & Passivo fictício \\
\hline & Contabilização fraudulenta de datas com o fim de vantagens indevidas \\
\hline & Dupla contabilização de passivos \\
\hline & Contabilização parcial de dívidas \\
\hline \multirow{3}{*}{ Patrimônio líquido } & Integralização com imobilizado obsoleto a valor irreal \\
\hline & Contabilização a maior de valores em conta de capital social \\
\hline & $\begin{array}{c}\text { Criação de falsas reservas por doação de valores fictícios ou reavaliações } \\
\text { fraudulentas }\end{array}$ \\
\hline
\end{tabular}


Como visto, o tema envolve expectativa social dos usuários das informações contábeis auditadas, que vem aumentando incrivelmente nos últimos tempos diante dos escândalos contábeis e crises financeiras que vieram à tona.

A importância e relevância das fraudes, bem como sua repercussão na atividade de auditoria, foram percebidos com riqueza de detalhes por Rittenberg et al.:

Estima-se que a fraude custe aos negócios americanos mais de $6 \%$ de suas receitas. Relatórios financeiros fraudulentos roubaram da comunidade empresarial e da profissão de auditoria grande parte da sua credibilidade. Os usuários esperam mais: eles esperam que os auditores detectem e relatem fraude materiais. Se os auditores falharem em detectar e comunicar fraudes, continuará a existir uma "diferença de expectativas" entre as expectativas dos usuários e o desempenho dos auditores. ${ }^{278}$

Historicamente, porém, os resultados dos trabalhos de auditoria externa na detecção de fraudes apresentam-se muito restritos, pouco eficientes e, aparentemente, aquém do esperado. Este fato é bem demonstrado na pesquisa feita pela consultoria KPMG (divisão KPMG Forensic Services) no ano de 2000, realizada entre mais de mil empresas em território nacional.

\footnotetext{
${ }^{278}$ Op. cit. p. 408 . O texto é tradução livre de "It is estimated that fraud costs American business up to $6 \%$ of revenue. Fraudulent financial reporting has robbed the business community and accounting profession of much of its credibility. Users expect more: they expect auditors to detect and report material fraud. If auditors fail to detect and communicate fraud, there will continue to be an 'expectations gap' between users' expectations and auditors' performance".
} 
Figura 4: Métodos que revelaram fraudes empresariais

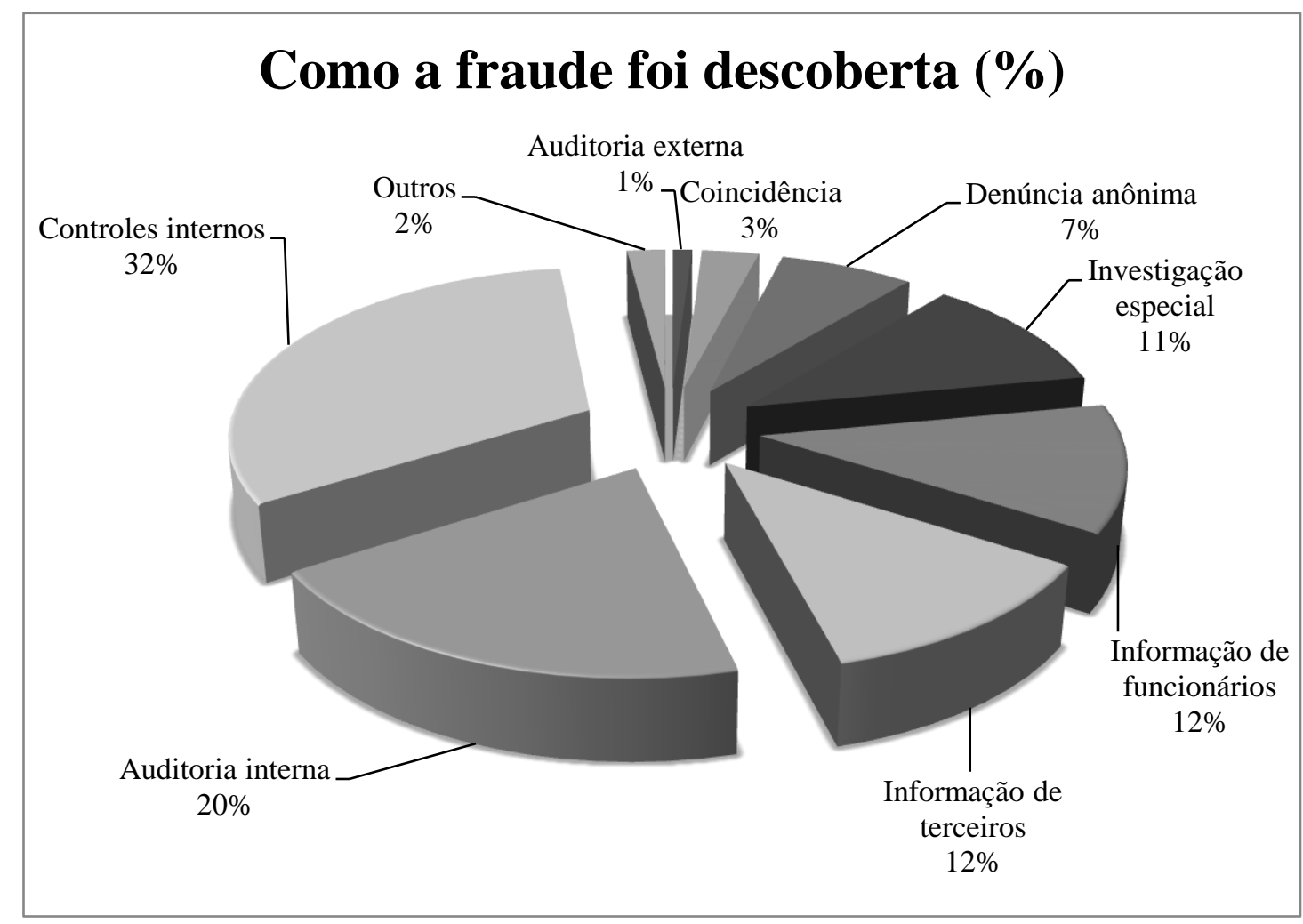

Fonte: KPMG BRASIL, 2000.

Os dados acima entabulados demonstram o pequeno papel da auditoria externa na detecção das fraudes (cerca de $1 \%$ das fraudes descobertas), inferior até mesmo à revelação de fraudes por coincidência, correspondente a 3\% dos casos.

De fato, a própria KPMG, responsável pela pesquisa, conclui o seguinte sobre as os dados coletados:

As empresas foram solicitadas a indicar como as fraudes foram descobertas. Em vários casos, a fraude foi detectada por meio de mais de um método. Os principais métodos para a descoberta de fraudes revelaram-se semelhantes aos identificados em outros países, embora numa outra ordem. Tais métodos são: controles internos (32\%), auditoria interna (20\%), informação de funcionários e de terceiros (ambos com $12 \%)$ e investigação especial (11\%). De modo geral, grande parte da 
detecção ocorreu internamente e tais métodos internos de detecção foram muito mais eficazes do que quaisquer outros mecanismos externos. ${ }^{279}$

Esta pesquisa tem o mérito de demonstrar que a descoberta de grande parte das fraudes depende da delação de pessoas que convivam no ambiente da entidade auditada e que, portanto, tenham conhecimento de seus processos internos, e dos colaboradores que ali prestam seus serviços; ou ainda de controles internamente estabelecidos por referida entidade, derivados do pleno domínio das características de sua atividade e dos meios necessários para sua coibição. Por outro lado, resta também evidenciada a dificuldade e a precariedade da utilização de controles externos na descoberta de fraudes, ao contrário do que usualmente se espera do auditor independente. ${ }^{280}$

As dificuldades da detecção de fraudes e a possibilidade de que estas viessem a ser manipuladas ou ocultadas pela administração das entidades auditadas historicamente levou a doutrina e os órgãos reguladores da profissão a isentarem o auditor independente da obrigação de revelá-las em sua totalidade, embora a opinião pública esperasse que a atuação do auditor prevenisse fraudes. Esta postura esteve particularmente presente nos países de tradição anglo-saxônica, como ressalta Stefano Bartone:

Na experiência anglo-saxônica, a opinião pública desejava que o auditor tivesse um papel mais ativo, mas a tendência jurisprudencial foi no sentido de que o auditor não tivesse a obrigação de assegurar a descoberta de fraudes, subtrações ou outras irregularidades, escondidas frequentemente na contabilidade e nos balanços redigidos pelos administradores e colaboradores da entidade auditada. Para esta jurisprudência, a responsabilidade primária de prevenir erros e subtrações cabe aos administradores, enquanto a tarefa do auditor é conduzir a

\footnotetext{
${ }^{279}$ KPMG BRASIL. A fraude no Brasil - Relatório da Pesquisa 2000. São Paulo: KPMG, 2000.

${ }^{280}$ A dependência da colaboração de pessoas internas aos meandros empresariais para a descoberta de fatos ilícitos não ocorre unicamente nos casos de fraudes objetos de auditoria externa. Como bem doutrina Vasco Rodrigues, uma das áreas mais comuns em que a revelação de ilícitos está a depender de pessoas internas aos quadros das entidades envolvidas é a defesa da concorrência, maculada pela realização de acordos horizontais entre sociedades empresárias. Pondera referido autor que: "Na ausência de provas de comunicação entre as empresas, qualquer acusação de colusão assenta, no entanto, em bases frágeis. A dificuldade reside em que as empresas têm consciência da ilicitude dos acordos colusivos e, portanto, se estiverem envolvidas num acordo, procurarão evitar deixar indícios dessa comunicação. Aliás, procurarão também implementar o acordo de tal forma que o seu comportamento no mercado deixe dúvidas quanto à sua existência. Por exemplo, procurarão que as suas alterações de preços não sejam exatamente iguais nem se produzam exatamente no mesmo momento. Dadas estas dificuldades, uma das principais formas de provar a existência do acordo é obter a confissão dos participantes. Tal como no já citado dilema do prisioneiro, as autoridades pretendem estruturar a sua interação com os envolvidos nos acordos de forma a criar incentivos para a autodenúncia. É por esse motivo que, na generalidade dos países desenvolvidos, a legislação de
} 
revisão de modo a render verossímil a descoberta de distorções materialmente relevantes nos balanços. ${ }^{281}$

Entretanto, os últimos escândalos contábeis, derivados em grande parte de deslizes éticos de auditores, fizeram com que o rigor doutrinário e regulatório se acentuasse marcadamente.

Mais do que isso, acarretaram que a regulação internacional da matéria, como visto anteriormente, saísse, pelo menos em grande parte, das mãos dos órgãos regulamentadores da profissão de auditoria e contabilidade para organismos externos, como se deu com a edição da Lei Sarbanes Oxley e com a criação do PCAOB. Tal fenômeno, porém, ainda não se percebeu na regulação nacional sobre o assunto.

Mais uma vez, é importante tomar em consideração os ensinamentos de Rittenberg et al., que captaram a transformação antes aludida de uma forma assaz interessante, citando a posição histórica do órgão de regulação da profissão nos Estados Unidos da América (AICPA) em confronto com o pronunciamento mais recente de Douglas R. Carmichael (transcrito entre aspas na citação seguinte), na função de Chief Auditor do então criado Public Company Accounting Oversight Board (PCAOB):

As normas de auditoria do AICPA historicamente têm refletido a conviç̧ão de que não é razoável para o auditor detectar todas as fraudes, porque fraudes podem ser manipuladas inteligentemente pela gerência. No entanto, o Conselho de Supervisão de Contabilidade de Companhias Abertas claramente acredita que os auditores têm responsabilidade em detectar todas as fraudes materiais.

“A missão do PCAOB é restaurar a confiança dos investidores, e da sociedade em geral, nos auditores independentes das companhias. Não há dúvida de que repetidas revelações de escândalos de contabilidade e falhas de auditoria prejudicaram seriamente a confiança pública... A detecção de fraudes materiais é uma expectativa razoável de usuários das demonstrações financeiras auditadas. A sociedade precisa e espera

concorrência tem vindo a adotar regras de clemência em relação a quem primeiro confesse a participação num cartel" (RODRIGUES, Vasco. Análise econômica do direito. Coimbra: Almedina, 2007. p.176).

281 BARTONE, Stefano. Società di revisione dei conti. Problematica civile e penale. Sistema angloamericano e italiano. Torino: G. Giappichelli Editore, 2009. p. 59. O texto é tradução livre de: "Nell'esperienza anglosassone, l'opinione pubblica vorrebbe che l'auditor assumesse un ruolo piú attivo, ma la tendenza giurisprudenziale è piuttosto nel senso che l'auditor non debba assicurare la scoperta di frodi, sottrazioni o altre irregolarità, spesso accortamente occultate nella contabilità e nei bilanci redatti dagli amministratori e dai dipendenti della società. Per detta giurisprudenza la responsabilità primaria di prevenire 
a garantia de que informações financeiras não foram materialmente distorcidas devido à fraude. A menos que uma auditoria independente possa fornecer essa garantia, terá pouco ou nenhuma utilidade para a sociedade."

A mensagem aos auditores é clara: eles devem assumir maior responsabilidade pela detecção de fraudes e garantir aos usuários que as demonstrações financeiras estão livres de fraude material. Além disso, a menos que os auditores posam prover essa garantia, haverá pouca ou nenhuma justificativa para os custos dos usuários da atividade de auditoria externa. ${ }^{282}$

A regulação da matéria, embora talvez não tão rigorosa quanto o discurso dos representantes do PCAOB, passou inegavelmente por um incremento no rigor de suas exigências e, portanto, na responsabilização do auditor pela descoberta de fraudes nas demonstrações contábeis.

O entendimento que governava a matéria há algum tempo atribuía a responsabilidade primária pela detecção e repressão de fraudes à administração da entidade auditada, ficando o auditor independente em um papel meramente secundário. Este papel, pela ótica que anteriormente dotava o assunto, em princípio, não incluía no trabalho do auditor a responsabilidade direta pela detecção das fraudes, mas meramente pela preparação e planejamento para o caso de que estas viessem a ser encontradas.

O panorama atual sobre a matéria, embora continue a afirmar a responsabilidade primária da administração da entidade auditada em relação às fraudes, inaugura novo tipo de responsabilidade ao auditor, afirmando que este deve garantir aos

errori e sottrazioni grava sugli amministratori, mentre il compito dei revisore è condurre la revisione in modo da rendere verosimile la scoperta di 'material misstatements' nei bilanci".

${ }_{282}$ Op. cit. p. 410 . O texto é tradução livre de: "The AICPA auditing standards historically have reflected the belief that it is not reasonable for auditor to detect all frauds because frauds can be cleverly manipulated by management. However, the Public Company Oversight Board clearly believes that auditors have a responsibility to detect all material frauds. 'The mission of the PCAOB is to restore the confidence of investors, and society generally, in the independent auditors of public companies. There is no doubt that repeated revelations of accounting scandals and audit failures have seriously damaged public confidence... The detection of material fraud is a reasonable expectation of users of audited financial statements. Society needs and expects assurance that financial information has not been materially misstated because of fraud. Unless an independent audit can provide this assurance, it has little if any usefulness to society.' The message to auditors is clear: They must assume a greater responsibility for detecting fraud and assuring users that the financial statements are free of material fraud. Further, unless auditors can provide that assurance, then there is little justification for the costs to users associated with the external audit function". O pronunciamento citado foi retirado de: CARMICHAEL, Douglas. The PCAOB and the Social Responsibility of the Independent Auditor. Discurso em AAA Auditing Section Midyear Meeting. 16 jan., 2004. 
usuários segurança razoável de que as demonstrações contábeis, como um todo, não contêm distorções relevantes causadas por fraude.

A tabela a seguir demonstra de forma simplificada a mudança de atitude na normatização brasileira da matéria que, de resto, seguiu a tradição mundial.

Tabela 14: Evolução das normas nacionais em matéria de fraude, acompanhando a tendência mundial

\begin{tabular}{|c|c|c|}
\hline & $\begin{array}{c}\text { Res. CFC n. 836/99 } \\
\text { (Revogada pela Resolução CFC no } \\
1.203 / 09)\end{array}$ & $\begin{array}{c}\text { Res. CFC n. 1.207/09 } \\
\text { (equivalente da norma internacional } \\
\text { ISA n. 240) }\end{array}$ \\
\hline $\begin{array}{l}\text { Responsabilidade } \\
\text { da administração }\end{array}$ & $\begin{array}{l}\text { A responsabilidade primeira na } \\
\text { prevenção e identificação de } \\
\text { fraudes elou erros é da } \\
\text { administração da entidade, } \\
\text { mediante a manutenção de } \\
\text { adequado sistema de controle } \\
\text { interno, que, entretanto, não } \\
\text { elimina o risco de sua ocorrência. }\end{array}$ & $\begin{array}{l}\text { A principal responsabilidade pela } \\
\text { prevenção e detecção da fraude é dos } \\
\text { responsáveis pela governança da } \\
\text { entidade e da sua administração. É } \\
\text { importante que a administração, com a } \\
\text { supervisão geral dos responsáveis pela } \\
\text { governança, enfatize a prevenção da } \\
\text { fraude, o que pode reduzir as } \\
\text { oportunidades de sua ocorrência, e a } \\
\text { dissuasão da fraude, o que pode } \\
\text { persuadir os indivíduos a não } \\
\text { perpetrar fraude por causa da } \\
\text { probabilidade de deteç̧ão e punição. }\end{array}$ \\
\hline & & \\
\hline
\end{tabular}




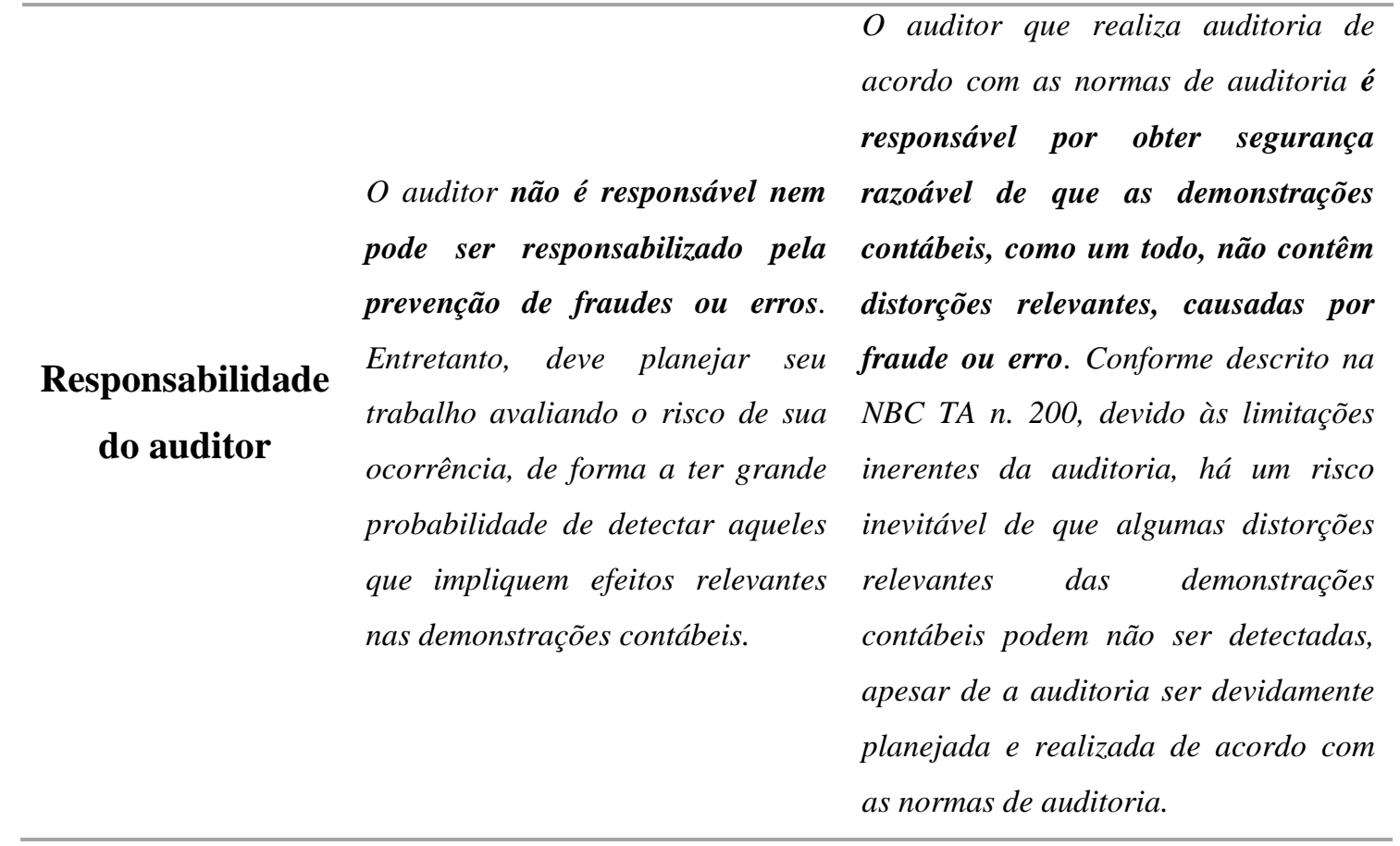

Constata-se, portanto, que a regulamentação nacional, seguindo a tendência das normas ISA da IFAC, veio a atribuir ao auditor um novo papel no que tange à fraude. Este, porém, não é o de ser garantidor da inexistência de qualquer fraude no conteúdo que serviu de base às demonstrações contábeis, como pode parecer inicialmente ser a pretensão do PCAOB no texto que antes transcrevemos, mas sim obter segurança razoável de que não há distorções relevantes causadas por eventuais fraudes.

Em outras palavras, o auditor independente não se encontra na posição de assegurar a inocorrência de qualquer fraude. Sua preocupação é que, se eventual fraude vier a existir dentro das limitações em que se desenvolve o trabalho de auditoria, este fenômeno não deve ter consequências relevantes para as demonstrações contábeis.

A mesma linha de regulação presente na ISA n. 240 (correspondente nacional da Res. CFC n. 1.207/09) foi adotada nos Estados Unidos da América, na norma SAS n. 99 do AICPA, que obriga o auditor externo, em qualquer trabalho, a identificar os fatores de risco de fraude ${ }^{283}$ (fraud risk factors) que, nos termos desta norma, são eventos ou condições que indicam incentivos/pressões para cometer fraudes, oportunidades para realizar a fraude, ou atitudes/racionalizações para justificar uma ação fraudulenta, tais como a ausência de controles, o declínio da atividade empresarial a incentivar a falsa

${ }^{283}$ A Res. CFC n. 1.207/09 define fatores de risco de fraude como "eventos ou condições que indiquem incentivo ou pressão para que a fraude seja perpetrada ou ofereçam oportunidade para que ela ocorra". 
declaração ou avaliação de ativos e passivos, fluxos de caixa negativos recorrentes, pressões excessivas para atingir resultados, etc.

Diante da presença de um fator de risco de fraude, o auditor deve atuar com o devido ceticismo profissional, realizando testes necessários, não podendo assumir que determinados grupos de contas não possuem qualquer risco. Isto deve fundamentar maior procura por parte do auditor de valores distorcidos ou inexistentes, maior evidenciação de auditoria ou mesmo o auxílio de especialistas.

Esta nova postura na regulamentação nacional e internacional, na verdade, inaugura muito mais uma obrigação de postura proativa do auditor externo em relação à detecção de fraudes, em face de uma postura passiva, antes normatizada, do que propriamente uma asseguração por parte do auditor de que as fraudes não existam.

Em princípio, a linha de regulamentação adotada nos parece a mais razoável.

Com efeito, é impossível ao auditor externo a descoberta de todas as fraudes. A prática confirma que a consecução de um objetivo como este seria inexequível, tratando-se muito mais de uma expectativa não razoável que o público mantém a respeito do trabalho de auditoria do que uma possibilidade real e objetivamente viável.

Por outro lado, a postura passiva dada ao auditor externo, conforme se adotou na anterior regulamentação da matéria, igualmente não atendia ao que minimamente poderia ser esperado de um serviço de auditoria: que o profissional empregue a diligência necessária no sentido de buscar eventuais fraudes quando seja razoável que se possa suspeitar desta ocorrência, e não simplesmente que planeje sua eventual e incerta superveniência.

Devemos consignar, porém, que a busca da fraude propriamente dita não exaure o nível de expectativa social em relação à atividade do auditor.

\subsubsection{Fraude e gerenciamento de resultados (contabilidade criativa)}

Além dos procedimentos fraudulentos propriamente ditos, uma das formas mais utilizadas nos dias de hoje, que se situa na maior parte das vezes no limiar da fraude contábil, mas sem caracterizá-la, é o que parte da doutrina denomina gerenciamento de 
resultados (earnings management) e os professores Ariovaldo dos Santos e Ivan Ricardo Guevara Grateron chamam de "contabilidade criativa". 284

Segundo estes autores, o termo "contabilidade criativa" é conceituado como:

O processo mediante o qual os contadores aplicam os conhecimentos da norma contábil para manipular, de acordo com sua conveniência, os valores das demonstrações contábeis (...) GRIFFITHS (1998) citado por LAINEZ (1999, p. 17) apresenta a contabilidade criativa entre o que é legal e o que é ético; entre a criatividade e a fraude contábil. ${ }^{285}$

A possibilidade da utilização de gerenciamento de resultados ou dos processos “criativos" em contabilidade se dá, segundo os autores, por uma série de fatores, entre os quais: 1) a existência de regras e critérios vagos, inexatos, que permitem interpretações divergentes; 2) ausência de normas regulando determinadas matérias; 3) flexibilidade e subjetividade de normas contábeis; 4) dificuldade de percepção por parte de auditores e usuários do sistema de escrituração.

Ainda segundo os professores, a utilização de práticas de gerenciamento de resultados ou "criativas" em matéria escritural tem causado sérios prejuízos, entre eles os recentes escândalos contábeis envolvendo sociedades empresárias internacionais, além de alguns outros efeitos normalmente pretendidos pelos elaboradores: 1) benefícios indevidos na margem de vendas; 2) incentivos fiscais; 3) controle de dividendos; 4) melhoria na imagem institucional, etc.

O gerenciamento de resultados, portanto, ao contrário do que ocorre com a fraude, situa-se no campo legalmente possível de atuação dos profissionais da contabilidade, embora não reflita com propriedade ao usuário externo a real situação econômica da entidade.

Por se tratar de conduta que não resvala propriamente na ilegalidade, permanecendo dentro das alternativas possíveis no campo não regulamentado pelas

\footnotetext{
${ }^{284}$ Tais processos têm chamado a atenção da doutrina contábil em diversos países, como denunciam Rashad e Khalik (Op. cit. p. 205): "Gerenciamento de lucros contábeis - managing accounting earnings (...) refere-se à manipulação proposital que resulta na alteração de números contábeis relatados. Essa definição inclui a noção de suavizar o resultado em torno de algum nível 'normal', bem como as escolhas contábeis dos gestores que beneficiam eles próprios ou acionistas às custas de outros reivindicantes. Entretanto, exclui o relatório 'fraudulento' e está restrito à amplitude fornecida pelos Princípios de Contabilidade Geralmente Aceitos (PCGA)".

285 SANTOS, Ariovaldo dos; GRATERON, Ivan Ricardo Guevara. "Contabilidade Criativa e responsabilidade dos auditores”. Revista Contabilidade \& Finanças - USP, São Paulo, n. 32, p. 7-22, maio/agosto 2003.
} 
diretrizes contábeis, ainda não há, em normas, obrigação específica de o auditor ressalvar seu parecer diante da constatação de práticas criativas de contabilidade, o que seria de todo recomendável.

Por esses motivos, no sentido da melhoria da situação atual, recomendam os autores que: 1) seja incrementada a responsabilidade da auditoria, que deverá se manifestar especificamente sobre a existência ou não de gerenciamento de resultados ou "contabilidade criativa"; 2) haja melhoria na normatização e harmonização contábil, reduzindo alternativas de escolha entre princípios e práticas. ${ }^{286}$

\subsubsection{Expectativas sociais de garantia de solidez econômico-financeira}

Verificamos anteriormente que boa parte dos usuários das demonstrações contábeis pretende encontrar nas conclusões da auditoria externa um atestado de solidez financeira da entidade empresarial auditada, que lhes assegure que esta não virá a falir e que, portanto, o parecer do auditor possa ser utilizado como base para a segurança de decisões de investimento.

Obviamente, esta expectativa é desarrazoada. Bem o demonstra Boyton et al.:

Alguns usuários de demonstrações contábeis consideram que o parecerpadrão de auditoria representa um "atestado" da boa saúde financeira da companhia - que a auditoria endossa as decisões tomadas pela entidade ou garante que os controles internos são adequados. Esse não é o objetivo de uma auditoria de demonstrações contábeis. $O$ parecer do auditor não se refere a essas questões. Outros usuários consideram que a auditoria fornece segurança de que o negócio representa um investimento seguro e não irá à falência. Conforme discutimos anteriormente, contudo, a ausência de referência à dúvida substancial no parecer do auditor não deve ser vista como segurança a respeito da capacidade da entidade de continuar como negócio lucrativo. ${ }^{287}$

\footnotetext{
${ }^{286}$ No Direito Comparado, já houve discussão da matéria relativa à fraude bancária efetivada através de gerenciamento de resultados pelo Poder Judiciário norte-americano no caso United States vs. Harris, no qual o acusado, "criativamente", teria sobrevalorizado o montante dos ativos da companhia da qual exercia a diretoria executiva, visando a ocultar perdas e dificuldades financeiras do exame de auditoria realizada pelo conjunto de bancos credores dos quais havia obtido empréstimo.

${ }^{287}$ Op. cit. p. 82.
} 
A auditoria externa, portanto, em princípio nada atesta a respeito da rentabilidade da entidade auditada, não relata sua capacidade de solver compromissos de curto prazo com os credores (liquidez), ${ }^{288}$ muito menos assegura que a entidade está isenta de falir em determinado período de tempo futuro.

Estes aspectos, portanto, estão fora dos propósitos da atividade de auditoria externa, ao contrário do que muitos acreditam. ${ }^{289}$

No entanto, embora não realize previsões de lucros ou prejuízos, nem apresente aos usuários qualquer análise econômico-financeira sobre os dados contábeis da entidade auditada, o auditor deve levar em consideração no seu trabalho eventuais riscos ou dúvidas concernentes à continuidade empresarial (going concern doubt).

A principal razão para o auditor avaliar eventuais riscos à continuidade empresarial é que a própria contabilização que compõe o conteúdo das demonstrações contábeis atua com o pressuposto de que a entidade continuará por tempo indeterminado com suas atividades empresariais normais. ${ }^{290}$

Em virtude deste pressuposto, resta influenciado o valor econômico dos ativos e, em muitos casos, o valor ou o vencimento dos passivos, especialmente quando a extinção da entidade tem prazo determinado, previsto ou previsível.

\footnotetext{
${ }^{288}$ Entenda-se bem: não é função da auditoria dizer se a liquidez é suficiente, insuficiente, boa ou má. No entanto, se por algum motivo inerente à falta de liquidez o auditor verificar que houve distorções relevantes ou generalizadas nas demonstrações, ou constatar que essa circunstância lança dúvidas sobre a continuidade operacional da entidade auditada, poderá, conforme o caso, lançar mão de parecer com ressalvas, adverso ou mesmo parágrafo de ênfase. A omissão do auditor, em casos como esses, pode gerar consequências legais, como a punição administrativa. Nesta linha a decisão do CRSFN no Processo BCB 0001046032: "EMENTA: RECURSO VOLUNTÁRIO - Auditoria independente - Situação de iliquidez de créditos constantes de demonstrações financeiras - Emissão de parecer sem ressalvas - Irregularidade caracterizada - Apelo a que se nega provimento. PENALIDADE: Multa Pecuniária.BASE LEGAL: Lei n. 6.385/76, art. 11, inciso II".

${ }^{289}$ Ao contrário do que parece ocorrer com a pressão social para que o auditor externo detecte fraudes nas demonstrações, para a qual existe grande expectativa popular derivada em grande parte dos últimos escândalos contábeis, a visão leiga segundo a qual se deve encontrar no parecer de auditoria um atestado de saúde financeira da entidade auditada não parece gozar da mesma força no meio social, nem exerce tamanha pressão sobre os profissionais de auditoria, talvez por se reconhecer de plano sua falta de razoabilidade ou pelo fato de que a previsão de uma falência seja algo que depende em boa parte de fatores aleatórios.

${ }^{290}$ A continuidade é um princípio basilar da contabilidade. A Res. CFC n. 750/93 assim a define em seu art. 5: "A CONTINUIDADE ou não da ENTIDADE, bem como sua vida definida ou provável, devem ser consideradas quando da classificação e avaliação das mutações patrimoniais, quantitativas e qualitativas. $\S 1^{\circ}$ A CONTINUIDADE influencia o valor econômico dos ativos e, em muitos casos, o valor ou o vencimento dos passivos, especialmente quando a extinção da ENTIDADE tem prazo determinado, previsto ou previsível. $\S 2^{\underline{0}}$ A observância do Princípio da CONTINUIDADE é indispensável à correta aplicação do Princípio da COMPETÊNCIA, por efeito de se relacionar diretamente à quantificação dos componentes patrimoniais e à formação do resultado, e de constituir dado importante para aferir a capacidade futura de geração de resultado". Deve-se mencionar que o conceito de entidade está presente em diversas outras normas que definiram estruturas conceituais básicas de contabilidade, como na Deliberação CVM no 29 , de 05 de fevereiro de 1986 (revogada posteriormente pela Deliberação CVM nº 539, de 14 de março de 2008) e na estrutura conceitual do IASB.
} 
Por pressupor a continuidade, muitos dos ativos são avaliados por seu valor histórico de custo, e não pelo valor que realmente atingiriam se fossem postos à venda no mercado. Outrossim, os valores de passivo que constam nas demonstrações refletem, muitas vezes, valores futuros a ser pagos, muito diferentes daquilo que seria devido caso a atividade viesse a se encerrar no momento presente.

Bem explicam as influências da continuidade Iudícibus et al.:

Este princípio, que tem grande validade do ponto de vista prático, apresenta importantes consequências para a Contabilidade. De fato, se aceitarmos a hipótese de que a duração da empresa é indeterminada, a filosofia de avaliação a ser adotada deverá ser oposta àquela que adotaríamos no caso de liquidação da empresa, quando interessam os valores de liquidação do passivo e de realização do ativo. Trata-se de princípio muito explorado pelos defensores dos custos históricos sob a alegação de que, se os valores de realização não interessam, então devemos ater-nos ao custo. ${ }^{291}$

Desta forma, se o auditor tem fundadas dúvidas sobre a possibilidade de continuidade do negócio, grande parte do trabalho de contabilização será posta em risco. De fato, se a continuidade dos negócios é ameaçada, muitos dos ativos e passivos inseridos nas demonstrações já não evidenciarão corretamente seu valor para o usuário. Passivos de longo prazo podem passar a ser exigíveis desde logo, e receitas a prazo podem não vir a ser recebidas. Isto, sem dúvida, modifica completamente os pressupostos sobre os quais o auditor desenvolve seu trabalho.

Assim, deverá o auditor verificar se esta ameaça ocorre na prática, ${ }^{292}$ se é significativa e, se constatados esses pressupostos, analisar se a administração da entidade

${ }^{291}$ IUDÍCIBUS, Sérgio de, et al. Contabilidade introdutória. São Paulo: Atlas, 1990. p. 266.

${ }^{292}$ De acordo com a Res. CFC n. 1.226/07, correspondente à norma internacional ISA n. 570: "A responsabilidade do auditor é obter evidência de auditoria suficiente sobre a adequação do uso, pela administração, do pressuposto de continuidade operacional na elaboração e apresentação das demonstrações contábeis e expressar uma conclusão sobre se existe incerteza significativa sobre a capacidade de continuidade operacional. Essa responsabilidade existe mesmo se a estrutura de relatório financeiro usada na elaboração das demonstrações contábeis não incluir uma exigência explícita para que a administração faça uma avaliação específica da capacidade de continuidade operacional". Esta obrigação é passível de sanção em caso de descumprimento por parte do auditor. Neste sentido, o acórdão CRSFN 2192/97, Recurso 2270, Processo origem CVM 01/93, assim ementado: "RECURSOS VOLUNTÁRIOS. Comissão de Valores Mobiliários - CVM - Auditor independente - Laudo inepto, desobediência aos procedimentos básicos de auditoria, dentre os quais não apresentação de relatório circunstanciado sobre os registros contábeis e deficiência de controle interno, bem como ausência de ressalva acerca da continuidade operacional da companhia - Apelos a que se nega provimento. PENALIDADE: Suspensão de registro. BASE LEGAL: Lei n. 6.385/76, Art. $2^{\circ}$, item V". 
tem capacidade de resolver ou mitigar satisfatoriamente o problema. Caso o risco mencionado esteja presente, sem qualquer capacidade de solução ou mitigação, o auditor deve informar devidamente esta circunstância aos usuários das informações contábeis auditadas. $^{293}$

Na prática, porém, há em algumas vezes certa relutância na revelação de problemas de continuidade por parte do auditor, além de resistências da administração da entidade auditada.

Isto porque a publicidade derivada deste tipo de informação pode acabar agravando os problemas enfrentados pela entidade auditada, revelando-se como uma verdadeira profecia autorrealizadora (self-fulfilling prophecy), na medida em que possa causar aos diversos interessados (investidores, credores, clientes, etc.) perda de credibilidade no futuro da entidade, ocasionando sua definitiva derrocada.

Diante disto, é necessário que o auditor tenha redobrada cautela ao indicar em seu parecer qualquer dúvida sobre a continuidade de um determinado negócio, devendo para tanto basear-se em fundamentos concretos e suficiente evidência de auditoria.

O critério a ser utilizado pelo auditor para concluir a respeito dos riscos à continuidade do negócio pode ser variado. A Res. CFC n. 1.226/07 indica os seguintes pontos cuja observação individual ou conjunta pode revelar ameaça significativa à continuidade.

\footnotetext{
${ }^{293}$ A informação do auditor, neste caso, poderá se dar por meio de um parágrafo de ênfase em parecer sem ressalvas, caso haja a devida evidenciação nas demonstrações das circunstâncias e repercussões à continuidade ou, ainda, a emissão de parecer com opinião adversa ou com ressalvas.
} 


\section{Tabela 15: Eventos ou condições que podem levantar dúvida com relação à continuidade}

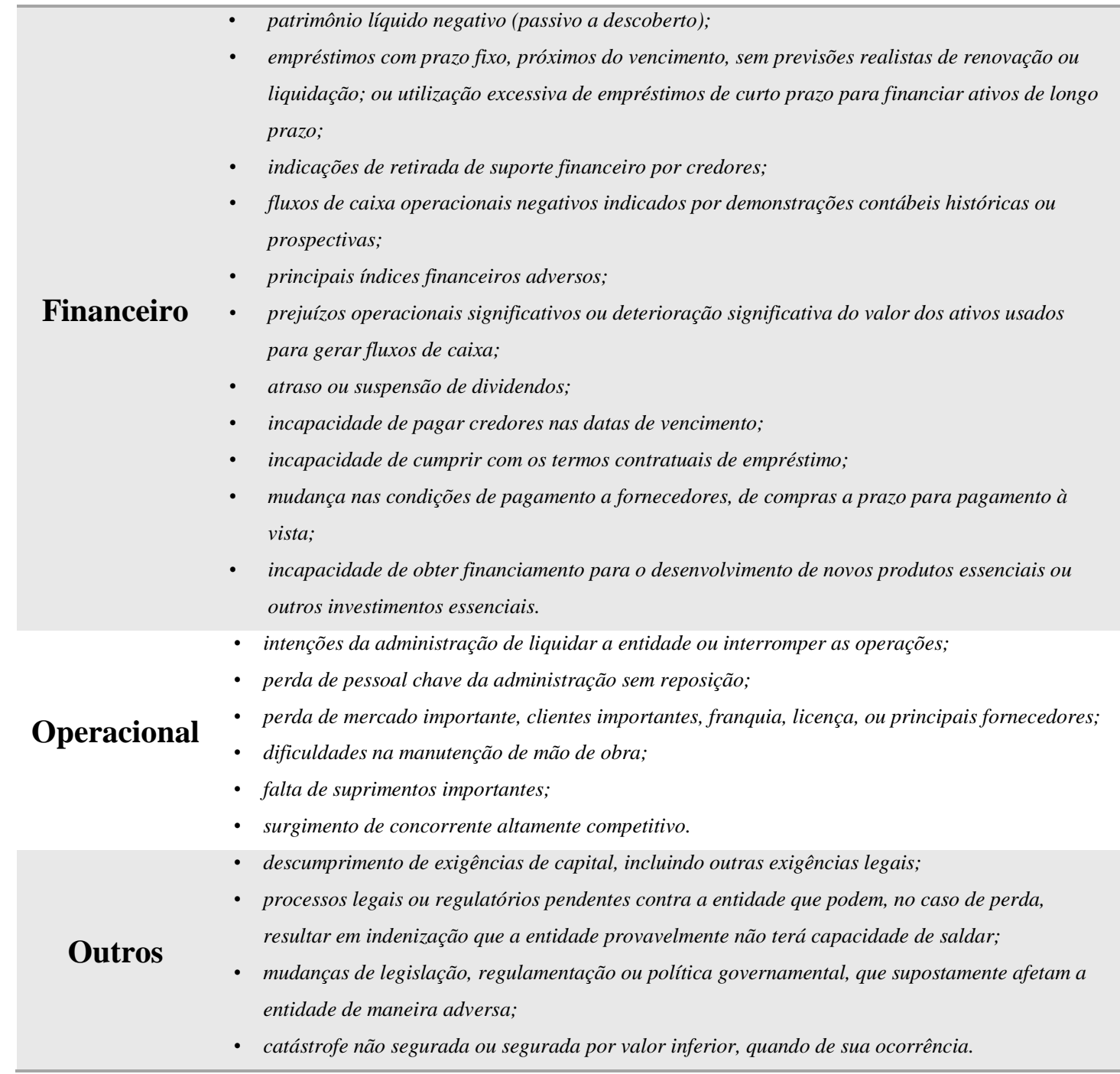

Além dos fatores mencionados na tabela, há ainda uma série de modelos estatísticos que podem ser utilizados pelo auditor, os quais buscam predizer a possibilidade da ocorrência de falência empresarial e, portanto, ensejar dúvidas sobre a continuidade empresarial. Entre eles, o citado por Rashad e Khalik ${ }^{294}$ e Brigham et al., ${ }^{295}$ ambos baseados no modelo de Edward Altman de análise discriminante múltipla, tem conseguido certa primazia na doutrina.

O modelo destina-se à predição de falência para período futuro aproximado de dois anos através de uma função (Z-Score), com as seguintes características:

${ }^{294}$ RASHAD, A.; KHALIK, Abdel. Dicionário enciclopédico de contabilidade. São Paulo: Atlas, 2004. 


$$
Z=0,012 X_{1}+0,014 X_{2}+0,033 X_{3}+0,006 X_{4}+0,999 X_{5}
$$

Na qual:

$$
\begin{aligned}
& \mathrm{X}_{1} \text { - capital circulante/total de ativos; } \\
& \mathrm{X}_{2} \text { - lucros acumulados/total de ativos; } \\
& \mathrm{X}_{3} \text { - lucro antes de juros e imposto sobre a renda/ativo total; } \\
& \mathrm{X}_{4}-\text { valor de mercado do patrimônio/endividamento total no } \\
& \quad \text { balanço; } \\
& \mathrm{X}_{5}-\text { Vendas/ativo total. }
\end{aligned}
$$

Os resultados do teste serão interpretados nos termos do quadro abaixo.

\begin{tabular}{cc}
\hline Resultado do Z-Score & Interpretação \\
\hline $\mathrm{Z}<1,81$ & Grande probabilidade de falência \\
$1,81<\mathrm{Z}<2,99$ & Zona de incerteza \\
$\mathrm{Z}>2,99$ & Reduzidas probabilidades de falência \\
\hline
\end{tabular}

Outro modelo muito utilizado na predição de falências é aquele preconizado por Stephen Kanitz, ${ }^{296}$ que guarda muita semelhança com o anterior.

O modelo de Kanitz parte de cinco índices oriundos das demonstrações contábeis, base em que foi elaborada uma equação matemática através de técnicas estatísticas de regressão múltipla e análise discriminante.

O escopo do estudo de Kanitz foi mensurar o risco de insolvência, por meio do que chamou de fator de insolvência. Cuidava-se de um indicador que apontava a possível insolvência em futuro próximo, na eventualidade de a empresa não corrigir os rumos que estava trilhando.

Assim se compõe a equação de Kanitz para o cálculo do fator de insolvência (FI):

$$
\mathrm{FI}=0,05 \mathrm{X} 1+1,65 \mathrm{X} 2+3,55 \mathrm{X3}-1,06 \mathrm{X} 4-0,33 \mathrm{X5}
$$

Em que:

\footnotetext{
${ }^{295}$ BRIGHAM, Eugene F. et al. Administração financeira: teoria e prática. São Paulo: Atlas, 2001.

${ }^{296}$ KANITZ, Stephen Charles. Como Prever Falências. São Paulo: McGraw do Brasil, 1978.
} 


$$
\begin{aligned}
& \text { X1 = lucro líquido/patrimônio líquido } \\
& \text { X2 = (ativo circulante }+ \text { realizável a longo prazo)/exigível total } \\
& \text { X3 = (ativo circulante }- \text { estoques }) / \text { passivo circulante } \\
& \text { X4 = ativo circulante/passivo circulante } \\
& \text { X5 = exigível total/patrimônio líquido }
\end{aligned}
$$

\begin{tabular}{cc}
\hline Resultado do FI & Interpretação \\
\hline FI $<-3$ & Insolvente \\
$-3<$ FI $<0$ & Zona de penumbra \\
FI $>0$ & Solvente \\
\hline
\end{tabular}

Por fim, podemos citar os modelos de Elizabestsky, ${ }^{297}$ com base teórica e metodologia muito semelhantes aos anteriores.

Para Elizabestsky, temos:

$$
\mathrm{Z}=1,93 \times 32-0,20 \times 33+1,02 \times 35+1,33 \times 36-1,12 \times 37
$$

Sendo:

$$
\begin{aligned}
& \text { X32 = lucro líquido/vendas } \\
& \text { X33 = disponível/ativo permanente } \\
& \text { X35 = contas a receber/ativo total } \\
& \text { X36 = estoque/ativo total } \\
& \text { X37 = passivo circulante/ativo total }
\end{aligned}
$$

A interpretação é dada por:

\begin{tabular}{cc}
\hline Valor de $\mathbf{Z}$ & Interpretação \\
\hline $\mathrm{Z}$ inferior a 0,5 & Empresa insolvente \\
$\mathrm{Z}$ superior a 0,5 & Empresa solvente \\
\hline
\end{tabular}

Saliente-se que o propósito das conclusões derivadas da utilização de modelos de predição de falência não é fornecer verdades absolutas quanto ao futuro econômico de uma entidade em dificuldades econômico-financeiras, mas meramente dar uma base ao

297 ELIZABETSKY, Roberto. Um modelo matemático para a decisão no banco comercial. Trabalho apresentado ao Depto. de Engenharia de Produção da Escola Politécnica da USP, 1976. 
analista (no caso, ao auditor) dos riscos futuros de uma insolvência. Cumpre ao profissional de auditoria ponderar os diversos aspectos envolvidos com o discernimento necessário decorrente de seu experiente julgamento profissional, cotejando as causas e os fatores implicados, e não tomar atitudes precipitadas com base em meros números obtidos da aplicação matemática dos modelos preditivos. 


\section{MÉTODOS E PROCEDIMENTOS NA ATIVIDADE DE AUDITORIA EXTERNA}

Cumpre agora ingressar no estudo da metodologia e procedimentos da atividade de auditoria externa, analisando os aspectos que envolvem a realização efetiva desta tarefa e o substrato que lhe serve de base.

Deve-se consignar que a metodologia e os procedimentos de auditoria variam conforme a regulação a ser aplicada e, dentro de uma mesma normatização, apresentam diferenciações conforme o objeto a ser examinado e as decisões peculiares do auditor.

Em termos gerais, o processo de auditoria tem início normalmente com a atividade do auditor em obter conhecimento suficiente do negócio objeto de seus serviços e de seu cliente.

O auditor, para desempenhar bem seu papel, necessita conhecer o mercado no qual está inserida a entidade auditada, os clientes desta, seus fornecedores, suas obrigações legais, além das próprias características do negócio em si. Isto exerce papel fundamental no bom exercício de uma auditoria, pois possibilita ao profissional entender os motivos que fundamentam as decisões econômicas da entidade. Mais do que isto, porém, o conhecimento do negócio permite ao auditor mensurar o risco do negócio e, consequentemente, gerenciar o risco de auditoria.

A cognição mencionada possibilita ao auditor tomar as devidas decisões de aceitação, continuidade ou rejeição do cliente ${ }^{298}$ (acceptance and retention decisions), planejar os serviços de auditoria de modo pertinente, bem como tornar claros à administração da entidade auditada os deveres e responsabilidades das partes, equalizando

\footnotetext{
${ }^{298}$ Rittenberg et al. (Op. cit. p. 124) assim se expressam a respeito do tema: "Perhaps the most important audit decision made on every audit engagement is determining whether a client will be accepted or retained. Most audit firms have developed detailed checklists and review procedures that help them decide whether to add a potential client to their existing portfolio of clients (i.e., the client acceptance decision) and decide whether to continue their relationship with existing clients (the client retention decision, which is sometimes called the client continuance decision). There are a number of factors that affect the auditor's decision to accept or retain an audit client: • Management integrity, $\bullet$ Independence and competence of management and the board of directors, - The quality of managements risk management process and controls, $\bullet$ Reporting requirements, including regulatory requirements. • Participation of key stakeholders, • Existence of relatedparty transactions, and - The financial health of the organization".
} 
expectativas das partes e prevenindo riscos de litígios entre estas que possam, inclusive, afetar a independência do auditor. ${ }^{299}$

Após tomar pleno conhecimento do negócio desenvolvido pela entidade auditada, o profissional de auditoria deve entrar em contato com os relatórios financeiros por ela produzidos, realizando um reconhecimento dos aspectos relevantes ali constantes. Isto envolve a descoberta das razões econômicas que levaram a administração da entidade auditada incluir vários dos lançamentos efetuados, particularmente as estimativas contábeis (valores de depreciação, provisões, passivos contingentes, etc.).

O bom reconhecimento de aspectos relevantes nas demonstrações permite ao auditor tomar decisões sobre materialidade e relevância que influenciarão seu trabalho.

Como ressaltamos anteriormente, ao auditor independente cabe assegurar que as demonstrações contábeis estejam livres de distorções relevantes. O conceito de relevância, conferido pelas normas internacionais, está relacionado à magnitude de uma omissão ou escrituração indevidas nas demonstrações, que torne provável que o julgamento dos usuários das demonstrações possa ser alterado em virtude dessas circunstâncias.

Desta forma, uma distorção nas demonstrações contábeis é materialmente relevante se tiver o condão de influenciar o comportamento do usuário, possibilitando uma mudança potencial em seu julgamento. Ou, como diz o item 6 da Res. CFC n.1.203/09:

Em geral, as distorções, inclusive as omissões, são consideradas relevantes se for razoável esperar que, individual ou conjuntamente, elas influenciem as decisões econômicas dos usuários tomadas com base nas demonstrações contábeis.

A materialidade ou relevância serve como um guia para o trabalho do auditor, uma vez que nela consiste a essência preventiva de seu trabalho. Este conceito também ajuda o auditor a delimitar o risco de auditoria, definido como a probabilidade de o auditor não ressalvar seu parecer mesmo diante de erros ou omissões indevidas ou, inversamente, ressalvá-lo diante de situações que não se configurem como erros ou omissões.

\footnotetext{
${ }^{299}$ Esta tarefa deve ser consubstanciada em carta de contratação (engagement letter), a que aludimos anteriormente, regulamentada no Brasil pela Res. n. CFC 1.204/09, equivalente à norma internacional de auditoria ISA n. 210.
} 
Englobando os conceitos supracitados, o auditor deve realizar o planejamento da auditoria, definindo quais serão as prioridades de análise e investigação levadas a efeito em seu trabalho.

Em seguida, o auditor deve colher as devidas evidências de auditoria, realizando testes, examinando lançamentos e documentos, efetivando procedimentos de revisão analítica, entre outros atos. É importante salientar que os testes do auditor independente devem abranger os controles internos da entidade auditada (testes de controle ou de observância), para verificar o ambiente em que os lançamentos representados nas demonstrações são efetivados, bem como os fatos materiais que originaram os lançamentos (testes substantivos).

Finalmente, o auditor deve examinar e realizar a comunicação de seu trabalho, através da emissão de um relatório, parecer ou outra forma eventualmente possível.

Passaremos, agora, a examinar os principais aspectos da metodologia e dos procedimentos a serem utilizados pelo auditor independente.

\subsection{Providências preliminares e planejamento de auditoria}

A atividade de auditoria externa não pode ser realizada por meio de simples atuação material do auditor no campo prático. É necessário que ele planeje as diversas etapas nas quais se dará o trabalho.

O planejamento da auditoria, entretanto, não serve meramente para os fins de orientação interna desta tarefa. Por conferir maior eficácia ao trabalho do auditor, o cumprimento desta etapa também é do interesse da entidade auditada e dos terceiros usuários da informação contábil. Por isto, o planejamento não se configura meramente numa alternativa de gestão posta à disposição do auditor unicamente para seus fins, mas num requisito normativo de toda auditoria externa, cuja ausência ou deficiência é passível de imposição de sanções. ${ }^{300}$

300 Veja-se a decisão do Conselho de Recursos do Sistema Financeiro Nacional no Processo CVM RJ2002/5101: "EMENTA: RECURSO VOLUNTÁRIO - Mercado de valores mobiliários - Auditoria 
O planejamento de auditoria vem regulado no Brasil pela Resolução CFC n. 1.211/09, correspondente da norma internacional ISA n. 300.

Preliminarmente ao estabelecimento do plano de auditoria, porém, a norma supracitada, em seu item 6 , exige que o auditor realize as seguintes atividades preliminares ao início do trabalho de auditoria: (a) elabore procedimentos exigidos pela norma NBC TA 220, referente ao Controle de Qualidade da Auditoria de Demonstrações Contábeis; (b) avalie a conformidade com os requisitos éticos, inclusive independência, conforme exigido pela NBC TA 220, itens 9 a 11; e (c) estabeleça entendimento dos termos do trabalho, conforme exigido pela NBC TA 210 - Concordância com os Termos do Trabalho de Auditoria, itens 9 a 13.

Realizadas as atividades preliminares, o planejamento da auditoria externa deve envolver dois pontos: 1) definição de estratégia global para o trabalho; 2) desenvolvimento de plano de auditoria. A diferença entre essas duas fases está basicamente no nível de concreção com que cada uma atua, sendo a definição da estratégia global um nível geral de ação, ${ }^{301}$ e o plano de auditoria uma especificação concreta $^{302}$ dos procedimentos a serem adotados pelo auditor.

independente - Realização dos trabalhos sem consonância com os padrões e normas que regulam a atividade - Falta de planejamento e de adequada estrutura para desenvolver processo de auditoria externa Irregularidades caracterizadas - Apelos a que se nega provimento. PENALIDADE: Suspensão e Inabilitação Temporária. BASE LEGAL: Lei n. 6.385/76, art. 11, incisos III e IV”. No mesmo sentido a decisão do colegiado no Processo CVM 09/2000: “EMENTA: RECURSOS VOLUNTÁRIOS - Mercado de valores mobiliários - Auditoria independente - Falta de planejamento dos trabalhos conforme as Normas Brasileiras de Contabilidade - NBC - Não realização de questionários de avaliação dos controles internos das companhias - Ausência de registro nos papéis das Cartas de Responsabilidade da Administração - Emissão de parecer sem fundamentação em informações e documentos - Assinatura de contratos de locação de serviços sem menção às qualificações profissionais das equipes e dos respectivos números de horas estimadas - Falta de ressalva, no parecer, sobre existência de ativos avaliados em desacordo com os princípios de contabilidade geralmente aceitos e de elaboração do inventário dos bens do ativo fixo - Irregularidades caracterizadas - Adequação da dosimetria da pena - Apelo a que se dá provimento parcial. PENALIDADE: Multa Pecuniária. BASE LEGAL: Lei n. 6.385/76, art. 11, inciso II”.

${ }^{301} \mathrm{O}$ item 8 da Res. CFC n. 1.211/09 bem revela o caráter geral da definição da estratégia global: "Ao definir a estratégia global, o auditor deve: (a) identificar as características do trabalho para definir o seu alcance; (b) definir os objetivos do relatório do trabalho de forma a planejar a época da auditoria e a natureza das comunicações requeridas; (c) considerar os fatores que no julgamento profissional do auditor são significativos para orientar os esforços da equipe do trabalho; (d) considerar os resultados das atividades preliminares do trabalho de auditoria e, quando aplicável, se é relevante o conhecimento obtido em outros trabalhos realizados pelo sócio do trabalho para a entidade; e (e) determinar a natureza, a época e a extensão dos recursos necessários para realizar o trabalho (ver itens A8 a A11)".

${ }^{302}$ Da mesma forma, o item 9 da Res. CFC n. 1.211/09 revela o caráter específico do plano de auditoria: "O auditor deve desenvolver o plano de auditoria, que deve incluir a descrição de: (a) a natureza, a época e a extensão dos procedimentos planejados de avaliação de risco, conforme estabelecido na NBC TA 315 Identificação e avaliação dos riscos de distorção relevante por meio do entendimento da entidade e de seu Ambiente; (b) a natureza, a época e a extensão dos procedimentos adicionais de auditoria planejados no nível de afirmação, conforme previsto na NBC TA 330 - Resposta do Auditor aos Riscos Avaliados; (c) outros 
Alguns autores, como Araújo et al., utilizando os mesmos critérios mencionados, preferem diferenciar a nomenclatura dada a cada fase e dividir a atividade de planejamento na elaboração do plano de auditoria (genérico) e do programa (concreto) de auditoria:

Em uma auditoria, a fase de planejamento compreende as análises e os estudos preliminares para definir a amplitude do exame a ser realizado, de acordo com os objetivos da auditoria. Nessa fase, o auditor deve elaborar o plano e os programas de auditoria. O plano de auditoria corresponde à documentação do planejamento em nível macro, já os programas de auditoria detalham as ações necessárias ao alcance dos objetivos de auditoria, definindo os procedimentos a serem aplicados, em termos de natureza, oportunidade e extensão. Esses dois instrumentos, articulados entre si, devem estar estruturados de forma a servir como guia e meio de controle dos trabalhos a serem executados. ${ }^{303}$

Qualquer que seja a nomenclatura adotada, o fato é que as fases genéricas e concretas da atividade de planejamento de auditoria devem ser devidamente documentadas pelo auditor, garantindo a prova de sua elaboração. ${ }^{304}$

Embora devam constar de documentos próprios, isto não significa que o planejamento, seja ele consistente na elaboração da estratégia geral ou do plano de auditoria, deva ser imutável. Muitas vezes, o início dos trabalhos práticos de auditoria revela ao auditor a necessidade de mudar a rota de tais planos, incluindo ou excluindo etapas. Assim, o auditor deve, sempre que necessário, fazer alterações no planejamento de auditoria.

A fase de planejamento da auditoria compreende vários dos aspectos a que já aludimos, como o conhecimento do negócio do cliente; as considerações do risco de auditoria e as primeiras análises de relevância ou materialidade; a análise do ambiente regulatório da entidade auditada.

procedimentos de auditoria planejados e necessários para que o trabalho esteja em conformidade com as normas de auditoria (ver item A12)".

${ }^{303}$ Op. cit. p. 140.

304 O item 12 da Res. CFC n. 1.211/09 ressalta que: "O auditor deve documentar (NBC TA 230 Documentação de Auditoria, itens 8 a 11 e A6): (a) a estratégia global de auditoria; (b) o plano de auditoria; e (c) eventuais alterações significativas ocorridas na estratégia global de auditoria ou no plano de auditoria durante o trabalho de auditoria, e as razões dessas alterações (ver itens A16 a A19)". 
Nesta fase, o auditor deve verificar os diversos ciclos presentes no negócio desenvolvido pela empresa auditada (ciclo de receitas, compras, vendas, investimentos, produção, etc.), bem como seu fluxo de caixa normal.

Deve também o auditor na fase de planejamento tomar conhecimento inicial dos controles internos da entidade auditada e considerar, ainda que preliminarmente, o risco de sua auditoria.

Embora possa conhecer o cliente, o auditor deve planejar cada auditoria que for realizar, ainda que para a mesma entidade auditada. Obviamente, o conhecimento técnico prévio do auditor sobre a gestão da entidade auditada poderá poupá-lo de algumas etapas relevantes na tarefa de planejamento, diferente do que ocorre na auditoria inicial. ${ }^{305}$

\subsection{Determinação da relevância e materialidade}

Conforme aludimos, numa auditoria externa não é usualmente possível a verificação da totalidade dos lançamentos que compõem as demonstrações contábeis, dadas as limitações de custo razoável e tempo de trabalho.

Assim, resta o auditor impossibilitado de conferir certificações absolutas de credibilidade, mantendo apenas a obrigatoriedade de assegurar que as demonstrações contábeis analisadas estão livres de distorções materialmente relevantes.

\footnotetext{
${ }^{305}$ A Res. CFC n. 1.211/09, item A20, ressalta que, em caso de auditoria inicial: "A finalidade e o objetivo do planejamento da auditoria não mudam caso a auditoria seja inicial ou em trabalho recorrente. Entretanto, no caso de auditoria inicial, o auditor pode ter a necessidade de estender as atividades de planejamento por falta da experiência anterior que é normalmente utilizada durante o planejamento dos trabalhos. Para a auditoria inicial, o auditor pode considerar os seguintes temas adicionais na definição da estratégia global e do plano de auditoria: $\bullet$ exceto se for proibido por lei ou norma, manter contato com o auditor antecessor, por exemplo, para conduzir a revisão de seus papéis de trabalho; • quaisquer assuntos importantes (inclusive a aplicação de princípios contábeis ou de auditoria e normas de elaboração de relatórios) discutidos com a administração e relacionados à escolha do auditor, a comunicação desses temas aos responsáveis pela governança e como eles afetam a estratégia global de auditoria e o plano de auditoria; • os procedimentos de auditoria necessários para obter evidência de auditoria suficiente e apropriada relativa aos saldos iniciais (ver NBC TA 510 - Trabalhos Iniciais - Saldos Iniciais); • outros procedimentos exigidos pelo sistema de controle de qualidade da firma para trabalhos de auditoria inicial (por exemplo, esse sistema pode exigir o envolvimento de outro sócio ou profissional experiente para a revisão da estratégia global de auditoria antes de iniciar procedimentos de auditoria significativos ou de revisão dos relatórios antes da sua emissão)".
} 
Nesta linha de raciocínio, o auditor deve ter presente sempre o conceito de relevância ou materialidade, o qual, como anteriormente abordado, vincula-se à capacidade de que uma distorção nas demonstrações analisadas pelo auditor influencie as decisões econômicas dos usuários tomadas com base nestes relatórios. Se a distorção encontrada tem o condão de influenciar no julgamento do usuário, conceitua-se como materialmente relevante; caso contrário, pode-se concluir que a distorção é imaterial ou irrelevante para a tomada de decisão do usuário.

Assim, o auditor deve determinar os valores que considera como materialmente relevantes para efeito de seu trabalho, conforme seu julgamento profissional, além dos aspectos qualitativos que influenciaram sua decisão. Os valores que estiverem abaixo dos patamares de materialidade serão, em princípio, considerados como representativos de quantias não suficientes para causar influência nas decisões de terceiros usuários da informação contábil. ${ }^{306}$

Do conceito ora mencionado, deduz-se claramente que a materialidade ou relevância não são idênticas a cada caso concreto. Vários fatores podem alterá-la conforme a hipótese: o tamanho e porte da entidade auditada, o tipo de usuário considerado, ${ }^{307}$ a relevância de cada uma das informações econômicas contidas nas demonstrações, entre outros fatores.

O conceito de materialidade é, pois, um verdadeiro guia para o trabalho do auditor, principalmente no que concerne à sua extensão, e pode ter influência decisiva na

\footnotetext{
${ }^{306}$ Deve-se se lembrar que o conceito de materialidade não concerne unicamente a um determinado valor, abaixo do qual eventuais distorções possam ser consideradas irrelevantes. Além disso, mesmo o limite de materialidade fixado pelo auditor não é absoluto. Com efeito, poderá haver casos em que alguns valores, mesmo abaixo do patamar estabelecido, possam ter importância fundamental para as decisões econômicas do usuário das demonstrações. Neste sentido, o item 6 da Res. CFC n. 1.213/09 dispõe que: "A materialidade determinada no planejamento da auditoria não estabelece necessariamente um valor abaixo do qual as distorções não corrigidas, individualmente ou em conjunto, serão sempre avaliadas como não relevantes. As circunstâncias relacionadas a algumas distorções podem levar o auditor a avaliá-las como relevantes mesmo que estejam abaixo do limite de materialidade. Apesar de não ser praticável definir procedimentos de auditoria para detectar distorções que poderiam ser relevantes somente por sua natureza, ao avaliar seu efeito sobre as demonstrações contábeis o auditor considera não apenas a magnitude, mas, também, a natureza de distorções não corrigidas, e as circunstâncias específicas de sua ocorrência (NBC TA 450, item A16)".

${ }^{307}$ Não se presume, para este efeito, que o usuário seja leigo. Ao contrário, o item 4 da Res. CFC n. 1.213/09 dispõe que: "A determinação de materialidade pelo auditor é uma questão de julgamento profissional e é afetada pela percepção do auditor das necessidades de informações financeiras dos usuários das demonstrações contábeis. Neste contexto, é razoável que o auditor assuma que os usuários: (a) possuem conhecimento razoável de negócios, atividades econômicas, de contabilidade e a disposição de estudar as informações das demonstrações contábeis com razoável diligência; (b) entendem que as demonstrações contábeis são elaboradas, apresentadas e auditadas considerando níveis de materialidade; (c) reconhecem as incertezas inerentes à mensuração de valores baseados no uso de estimativas, julgamento e a consideração sobre eventos futuros; e (d) tomam decisões econômicas razoáveis com base nas informações das demonstrações contábeis".
} 
determinação do nexo de causalidade para a responsabilidade civil deste profissional, como veremos com mais detalhes posteriormente.

O julgamento profissional para a determinação da materialidade, entretanto, não é simples. Além de envolver aspectos quantitativos e qualitativos, o julgamento do auditor envolve grande dose de subjetividade, razão pela qual as normas nacionais e internacionais de auditoria exigem que o procedimento de fixação da materialidade seja documentado, possibilitando às autoridades responsáveis a devida fiscalização de sua correção. $^{308}$

Agrava ainda a dificuldade de estabelecimento da materialidade pelo auditor o fato de que as normas de auditoria não fixam diretrizes concretas para esta tarefa. Frequentemente a regulação da matéria traz recomendações genéricas sobre o uso de referenciais (benchmarks) na determinação dos valores inerentes à materialidade. ${ }^{309}$

Todas essas circunstâncias geram grande variabilidade na definição de materialidade, o que traz consequências práticas relevantes, pois, se esta for definida em patamares muito altos, o auditor poderá não realizar um número de verificações suficientes nos lançamentos contábeis de forma a excluir a possibilidade de que as demonstrações contenham distorções relevantes; ao contrário, se a materialidade é estabelecida em patamares muito baixos, o custo da auditoria pode ser substancialmente elevado, pois serão necessários muito mais testes para a formação da opinião do auditor.

Na doutrina, alguns autores fazem alusão a alguns critérios quantitativos mais usados para a determinação da materialidade. Boyton et al., por exemplo, assim se manifestam a respeito da materialidade para a totalidade das demonstrações contábeis:

\footnotetext{
${ }^{308}$ Item 14 da Res. CFC n. 1.213/09: "O auditor deve incluir na documentação de auditoria os seguintes valores e fatores considerados em sua determinação (NBC TA 230 - Documentação de Auditoria. itens 8 a 11 e A6): (a) materialidade para as demonstrações contábeis como um todo (item 10); (b) se aplicável, o nível ou níveis de materialidade para classes específicas de transações, saldos contábeis ou divulgação (item 10); (c) materialidade para execução da auditoria (item 11); e (d) qualquer revisão de (a) a (c) com o andamento da auditoria (itens 12 e13)".

${ }^{309}$ Item A3 da Res. CFC n. 1.213/09: "A determinação da materialidade para o planejamento envolve o exercício de julgamento profissional. Aplica-se frequentemente uma porcentagem a um referencial selecionado como ponto de partida para determinar a materialidade para as demonstrações contábeis como um todo. Os fatores que podem afetar a identificação de referencial apropriado incluem: (a) os elementos das demonstrações contábeis (por exemplo, ativo, passivo, patrimônio líquido, receita, despesa); (b) se há itens que tendem a atrair a atenção dos usuários das demonstrações contábeis da entidade específica (por exemplo, com o objetivo de avaliar o desempenho das operações, os usuários tendem a focar sua atenção em lucro, receita ou patrimônio líquido); (c) a natureza da entidade, a fase do seu ciclo de vida, o seu setor e o ambiente econômico em que atua; (d) a estrutura societária da entidade e como ela é financiada (por exemplo, se a entidade é financiada somente por dívida em vez de capital próprio, os usuários dão mais importância a informações sobre os ativos, e processos que os envolvam, do que nos resultados da entidade); e (e) a volatilidade relativa do referencial".
} 
Atualmente, não existem diretrizes oficiais sobre medidas quantitativas de relevância, nas normas de contabilidade ou nas de auditoria. O que se segue é ilustrativo do que é utilizado na prática:

- 5 a $10 \%$ do lucro antes do imposto de renda (10\% para os lucros menores, $5 \%$ para os maiores);

- 0,5 a $1 \%$ do ativo total;

- $1 \%$ do patrimônio líquido;

- $0,5 \%$ da receita bruta;

- Um percentual variável sobre o ativo total ou a receita, o que for maior. $^{310}$

Rittenberg et al., ${ }^{311}$ por seu turno, estabelecem os seguintes critérios práticos e limites típicos para os julgamentos de materialidade:

Tabela 16: Limites típicos para julgamento de materialidade

\begin{tabular}{cccc}
\hline Referenciais comuns & Não material & Provavelmente material & Sempre material \\
\hline Lucro líquido & $<5 \%$ & $5 \%$ a $10 \%$ & $>10 \%$ \\
Total do ativo & $<1 \%$ & $1 \%$ a $1,5 \%$ & $>1,5 \%$ \\
Receita líquida & $<1 \%$ & $1 \%$ a $1,5 \%$ & $>1,5 \%$ \\
\hline
\end{tabular}

Fonte: Adaptado de Rittenberg et al.

A utilização dos critérios mencionados dependerá do tipo de entidade auditada, dos valores das demonstrações contábeis, da volatilidade do referencial utilizado e de outros fatores a serem analisados pelo auditor. Os critérios podem também variar conforme o caso, ser aplicados distintamente para cada tipo de conta presente nas demonstrações, bem como sofrer modificações no curso da auditoria.

Fixada a materialidade para a totalidade das demonstrações, o auditor deve também considerar o nível ou níveis de materialidade para classes específicas de transações, saldos contábeis ou divulgação, ou seja, deve o profissional estabelecer,

\footnotetext{
${ }^{310}$ Op. cit. p. 287.

${ }^{311}$ Op. cit. p. 567.
} 
conforme o caso, níveis máximos de materialidade para as contas específicas que constam nas demonstrações. ${ }^{312}$

Isto pode ser feito conforme o percentual que cada conta representa em relação à totalidade do ativo, ou atendendo a especificidades derivadas do julgamento profissional do auditor.

Um exemplo simplificado tornará mais claro o conceito exposto até aqui.

Imaginemos uma determinada entidade auditada cujo balanço apresente os seguintes valores em contas de ativo no exercício de X10, representando-se na coluna da direita os valores de análise vertical (AV), representativos do percentual que cada conta possui no total do ativo:

\begin{tabular}{lrr}
\hline & \multicolumn{1}{c}{ X10 } & AV (\%) \\
\hline Ativo & & \\
& & \\
Ativo Circulante & & \\
Disponível (Caixa e Bancos) & $90.000,00$ & $16,36 \%$ \\
Clientes & $110.000,00$ & $20,00 \%$ \\
Estoques & $50.000,00$ & $9,09 \%$ \\
& & \\
Ativo Permanente & & \\
Investimentos & $100.000,00$ & $18,18 \%$ \\
Imobilizado líquido & $200.000,00$ & $36,36 \%$ \\
\hline Total & $\mathbf{5 5 0 . 0 0 0 , 0 0}$ & $\mathbf{1 0 0 , 0 0 \%}$ \\
\hline
\end{tabular}

Suponhamos ainda que o lucro antes do imposto de renda (LAIR) dessa entidade no exercício de X10 tenha sido de R \$500.000,00, e que o auditor, no caso concreto, decidiu utilizar como critério mais adequado para a determinação da materialidade o valor de $5 \%$ do LAIR.

Diante disso, a materialidade geral para as demonstrações contábeis será de R \$ $500.000,00 \times 5 \%$, totalizando R\$25.000,00.

\footnotetext{
312 Item A10 da Res. CFC n. 1.213/09: "Fatores que podem indicar a existência de uma ou mais de uma classe de transações, saldos contábeis ou divulgação para os quais se poderia razoavelmente esperar que distorção, de valores menores que a materialidade para demonstrações contábeis como um todo, influenciem as decisões econômicas dos usuários tomadas com base nas demonstrações contábeis incluem: (a) se leis, regulamentos ou a estrutura de relatório financeiro aplicável afetam as expectativas dos usuários em relação à mensuração ou divulgação de certos itens (por exemplo, transações com partes relacionadas, e a remuneração da administração e dos responsáveis pela governança); (b) as principais divulgações referentes ao setor em que a entidade atua (por exemplo, custos de pesquisa e desenvolvimento para empresa farmacêutica); (c) se a atenção está focada em aspecto específico do negócio da entidade que é divulgado separadamente nas demonstrações contábeis (por exemplo, negócio recém-adquirido)".
} 
Como ressaltamos, o valor de materialidade para as demonstrações deve ser considerado pelo auditor, conforme o caso, para classes específicas de transações, saldos contábeis ou divulgação. Supondo que o auditor não tenha outro critério específico derivado de seu julgamento profissional no caso concreto e apenas distribua proporcionalmente o valor total de materialidade pelas contas do ativo, teremos para cada conta os seguintes valores de materialidade:

\begin{tabular}{lrr}
\hline & X10 & AV (\%) \\
\hline Ativo & & \\
& & \\
Ativo Circulante & & \\
Disponível (Caixa e Bancos) & $4.090,91$ & $16,36 \%$ \\
Clientes & $5.000,00$ & $20,00 \%$ \\
Estoques & $2.272,73$ & $9,09 \%$ \\
\hline Ativo Permanente & & \\
Investimentos & & \\
Imobilizado líquido & $4.545,45$ & $18,18 \%$ \\
\hline Total & $9.090,91$ & $36,36 \%$ \\
\hline
\end{tabular}

Obviamente, o exemplo aqui mencionado é somente ilustrativo e pode ser entendido a outros tipos de contas (p.ex.: contas de passivo, patrimônio líquido e resultado).

É importante, como antes mencionado, que o auditor não se baseie excessivamente em aspectos quantitativos ao estabelecer os patamares de materialidade. Faz-se mister que se leve em conta outros aspectos importantes de natureza qualitativa, conforme o caso concreto, para o estabelecimento de tais critérios.

\subsection{Risco de auditoria e controles internos}

Relacionada ao conceito de materialidade encontra-se a definição de risco de auditoria.

Conforme mencionado anteriormente, quanto menores forem os patamares de materialidade definidos pelo auditor, maiores serão os testes a ser realizados e, consequentemente, menores os riscos de auditoria. Inversamente, à medida que aumentam 
os limites de materialidade, menor será a extensão do trabalho do auditor e maiores os riscos a serem enfrentados.

Genericamente, os riscos a que a auditoria externa se submete podem ser divididos em dois tipos: 1) risco do negócio (business risk); 2) risco nas demonstrações contábeis (financial reporting risk).

O primeiro, na definição constante da Res. CFC n. 1.212/09, consiste no "risco que resulta de condições, eventos, circunstâncias, ações ou falta de ações significativas que possam afetar adversamente a capacidade da entidade de alcançar seus objetivos $e$ executar suas estratégias, ou do estabelecimento de objetivos ou estratégias inadequadas", 313314

313 Para minimizar a influência do risco do negócio, a Res. CFC n. 1.212/09 determina que o auditor desenvolva o conhecimento devido da entidade. Item A24 da Res. CFC n. 1.212/09: "Exemplos de assuntos que o auditor pode considerar na obtenção de entendimento da natureza da entidade incluem: • operações do negócio - tais como: ○ natureza das fontes de receita, produtos ou serviços e mercados, inclusive envolvimento em comércio eletrônico, como vendas pela internet, e atividades de marketing; • condução das operações (por exemplo, etapas e métodos de produção ou atividades expostas a riscos ambientais); • alianças, empreendimentos com controle compartilhado (joint venture) e atividades de terceirização; • dispersão geográfica e segmentação do setor de atividade; • local de instalações de produção, armazéns e escritórios, e local e quantidades dos estoques; - clientes-chave e fornecedores importantes de bens e serviços, acordos trabalhistas (inclusive a existência de acordos sindicais, de pensão e outros benefícios pósemprego, tais como pagamentos baseados em ações ou bônus, e regulamentação governamental relacionada com aspectos trabalhistas); • atividades e gastos de pesquisa e desenvolvimento; • transações com partes relacionadas; • investimentos e atividades de investimento - tais como: • aquisições ou desinvestimentos planejados ou executados recentemente; • investimentos e vendas de títulos mobiliários e empréstimos; • atividades de investimento de capital; • investimentos em entidades não consolidadas, inclusive sociedades, empreendimentos com controle compartilhado (joint venture) e entidades para fins específicos; • financiamento e atividades de financiamento - tais como: - principais subsidiárias e entidades associadas, inclusive estruturas consolidadas e não consolidadas; • estrutura de dívidas e acordos relacionados, inclusive contratos de financiamento e contratos de arrendamento não registrados no balanço; • usufrutuários (domiciliados no país ou no exterior, sua reputação de negócios e experiência) e partes relacionadas; • uso de instrumentos financeiros derivativos; • informações financeiras - tais como: • princípios e práticas contábeis específicas do setor de atividade, inclusive suas características específicas e significativas (por exemplo, no caso de bancos, empréstimos e investimentos, e, no caso da indústria farmacêutica, pesquisa e desenvolvimento); • práticas de reconhecimento de receita; • contabilização a valor justo; • ativos, passivos e transações em moeda estrangeira; - contabilização para transações não usuais ou complexas, inclusive aquelas em áreas controversas ou emergentes (por exemplo, contabilização de pagamentos baseados em ações)".

314 Também para minimizar a influência do risco do negócio, a Res. CFC n. 1.212/09 determina que o auditor desenvolva o conhecimento devido dos fatores do setor de atividade, regulatórios e outros externos. Vejam-se os itens A17 a A19 desta Resolução: "Fatores do setor de atividade. A17. Os fatores relevantes do setor de atividade incluem condições próprias da indústria como o ambiente competitivo, relações entre fornecedor e cliente, e desenvolvimentos tecnológicos. Exemplos de assuntos que os auditores podem considerar incluem: - o mercado e a concorrência, incluindo a demanda, capacidade e concorrência de preços; • atividade cíclica ou sazonal; - tecnologia de produtos relacionada com os produtos da entidade; • fornecimento e custo de energia. A18. O setor de atividade no qual a entidade opera pode dar origem a riscos específicos de distorção relevante com origem na natureza do negócio ou no grau de regulamentação. Por exemplo, contratos de longo prazo podem envolver estimativas significativas de receitas e despesas que dão origem a riscos de distorção relevante. Em tais casos, é importante que a equipe encarregada do trabalho inclua membros com conhecimento e experiência relevante suficientes, como exigido pela NBC TA 220 - Controle de Qualidade da Auditoria de Demonstrações Contábeis, item 14. Fatores regulatórios. A19. Os fatores regulatórios 
Já o segundo, é definido como o risco de que tais relatórios apresentem distorções materialmente relevantes, derivados de problemas inerentes à gestão da entidade auditada, da complexidade das transações envolvidas e da falha nos controles internos.

Essas duas modalidades de risco (do negócio e de auditoria propriamente dito) são cumulativas e compõem o que se chama de risco de aceitação do contrato (engagement risk), ou risco de auditoria (audit risk).

Os riscos de auditoria não são passíveis de completa eliminação, mas apenas de redução a patamares razoáveis dentro das limitações de tempo e custo inerentes ao trabalho do auditor.

A cada caso concreto, o auditor deve ponderar os riscos de aceitação do contrato, devendo recusar comprometer-se em caso de risco por demais elevado. Sempre se deve ter presente que a redução do risco de auditoria importa em quantidade maior de trabalho e, por consequência, no aumento da contraprestação devida ao auditor, o que, em certo ponto, pode tornar a tarefa de auditoria inviável economicamente.

Para quantificar os riscos, boa parte da doutrina contábil emprega modelos matemáticos. Um dos mais usados é o chamado modelo de risco de auditoria (audit risk model), que conceitua o risco de auditoria em função de outros três tipos de risco: 1) inerente (inherent risk): conceituado como a possibilidade de que uma afirmação ou lançamento materialmente relevante contenha erro, ou seja omitido, na falta de controles; 2) de controle (control risk): que contém a probabilidade de que os controles internos da entidade auditada não detectem erros, omissões ou outras falhas de lançamentos ou afirmações nas demonstrações contábeis; 3) de detecção: (detection risk) que se refere à possibilidade de que o auditor, em seu trabalho, não perceba ou detecte um erro ou falha material nas demonstrações contábeis.

Se pudéssemos representar o processo de produção das demonstrações contábeis, conforme a atuação dos riscos supracitados, teríamos o seguinte:

relevantes incluem o ambiente regulatório. $\mathrm{O}$ ambiente regulatório abrange, entre outros assuntos, a estrutura de relatório financeiro aplicável e o ambiente político e jurídico. Exemplos de assuntos que o auditor pode considerar incluem: • princípios e práticas contábeis específicas do setor de atividade; • estrutura regulatória para uma indústria ou setor de atividade regulamentados; • legislação e regulamentação que afetem significativamente as operações da entidade, inclusive atividades de supervisão direta; • tributação (corporativa e outras); • políticas governamentais que afetem no presente a condução do negócio da entidade, como políticas monetárias, inclusive controles de câmbio, fiscais, de incentivos financeiros (por exemplo, 


\section{Figura 5: Fluxograma de processamento e riscos}

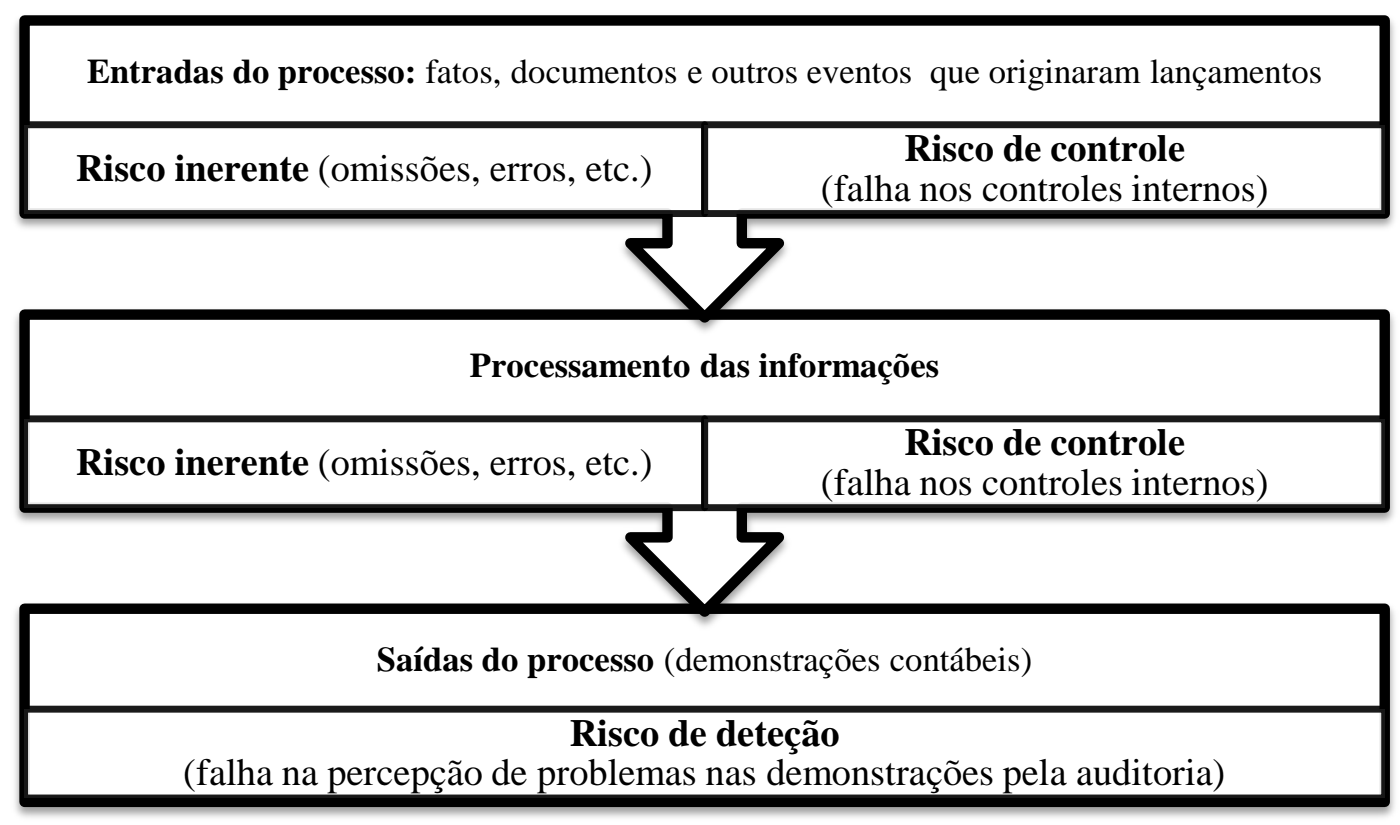

Como se vê na representação supracitada, os riscos inerente e de controle encontram-se presentes nas fases de entrada e processamento das informações contábeis. Já o risco de detecção incide somente perante as saídas do processamento, com a sobrevinda das demonstrações contábeis.

De fato, ao realizar lançamentos contábeis, julgar a valoração que fatos econômicos devem receber na escrituração, entre outras operações, existe sempre o risco de que haja erro ou omissão (p.ex.: lançamento envolvendo contas erradas, subavaliação, etc.), riscos estes que podem não ser percebidos pelos controles da entidade. Do mesmo modo, o processamento das informações pode também conter erros e omissões (p.ex.: erros de sistemas informatizados, perda de informações, etc.), que também podem escapar aos controles internos. Quando das saídas desse processamento de dados e informações, haverá sempre o risco de que o auditor não constate qualquer problema, deixando de evidenciá-lo em seu parecer ou relatório.

O modelo de risco de auditoria, ao considerar os três tipos antes mencionados, conceitua o de auditoria (RA) de forma a combinar em seu conceito o risco inerente (RI), o risco de controle $(\mathrm{RC})$ e o risco de detecção $(\mathrm{RD})$, segundo a seguinte fórmula matemática: 


\section{$R A=R I x R C x R D$}

É dizer: o risco (total) de auditoria corresponde a um produto dos riscos inerentes, de controle e de detecção. ${ }^{315}$

Deve ser sempre do interesse do auditor minimizar o risco de auditoria (RA).

No entanto, bem se pode verificar que o auditor não pode atuar na diminuição dos riscos inerentes, pois estes dependem da atuação da administração da entidade auditada. Da mesma forma, não pode atuar diretamente sobre os controles internos da entidade, pois são de exclusiva responsabilidade desta, cabendo ao auditor apenas reportar irregularidades ou falhas de controle aos responsáveis pela sua governança.

A única espécie de risco sobre a qual o auditor pode intervir é o risco de detecção; este sim diretamente sob sua responsabilidade. O risco de detecção é minimizado pela realização de maior número de testes pelo auditor, de forma a reduzir a probabilidade de eventuais erros ou omissões não serem detectadas na auditoria.

Pelas características do modelo antes citado é simples constatar que quanto maiores os riscos inerentes e de controle detectados pelo auditor, maior deverá ser o número de testes praticados por este, de forma a minimizar o risco de detecção e, com isso, o risco total de auditoria. Inversamente, quando os riscos inerentes e de controle forem mínimos, o auditor poderá realizar menos exames sobre o conteúdo das demonstrações contábeis para manter um baixo nível de risco total de auditoria.

Muito embora o auditor não atue sobre os controles internos da entidade auditada, as normas nacionais e internacionais de auditoria têm aumentado as exigências de relatórios que o auditor tenha de pesquisar e que este reporte falhas nos controles internos da entidade, bem como de que sejam apresentados relatórios da administração da entidade consignando sua expressa ciência sobre tal assunto.

Perante a União Europeia, o art. 41, 4, da Diretiva n. 2006/43/CE, exige que: "O revisor oficial de contas ou a sociedade de revisores oficiais de contas deve informar o comitê de auditoria sobre as questões fundamentais resultantes da revisão legal de contas,

ambientais que afetem o setor de atividade e o negócio da entidade".

315 Obviamente, não se deseja aqui defender que o modelo matemático citado no texto contenha todas as variáveis de risco presentes na realidade. Ao contrário, asseveramos que há muitas críticas ao modelo de risco de auditoria, dentre as quais se encontram a dificuldade e a subjetividade de mensuração concreta dos riscos; e o tratamento separado de cada um dos componentes, quando deveriam receber tratamento interligado, etc. 
nomeadamente sobre insuficiências materiais de controle interno do processo de informação financeira".

A Seção 404 da Lei Sarbanes-Oxley, por exemplo, obriga que a administração das entidades objeto de sua regulação apresentem relatórios gerenciais sobre os controles internos da entidade. ${ }^{316}$ Nesta linha, o auditor independente passa a deter pessoal responsabilidade pela avaliação e emissão de opinião quanto aos controles internos da entidade auditada, informando suas conclusões, por escrito, aos responsáveis pela governança da entidade.

No Brasil, a Res. n. 1.212/09 do CFC obriga que o auditor realize avaliação dos riscos e dos controles internos da entidade, documentando sua análise. ${ }^{317}$

\section{O Committee of Sponsoring Organizations of the Treadway Commission}

(COSO), órgão norte-americano que trata da matéria, subdividiu o conceito de controles internos nas seguintes áreas:

- Ambiente de controle: compreende o conjunto de valores que compõem a filosofia e as políticas adotadas pela entidade auditada no sentido de garantir integridade, ética e comprometimento aos colaboradores. Para criar um ambiente propício ao controle interno, a gestão deve agir e comunicar seus subalternos os princípios sob os quais se desenvolverá a atividade econômica, fornecendo orientação e reduzindo quaisquer

\footnotetext{
316 “SEC. 404. MANAGEMENT ASSESSMENT OF INTERNAL CONTROLS. (a) RULES REQUIRED.The Commission shall prescribe rules requiring each annual report required by section $13(\mathrm{a})$ or $15(\mathrm{~d})$ of the Securities Exchange Act of 1934 (15 U.S.C. $78 \mathrm{~m}$ or $78 \mathrm{o}(\mathrm{d})$ ) to contain an internal control report, which shall- (1) state the responsibility of management for establishing and maintaining an adequate internal control structure and procedures for financial reporting; and (2) contain an assessment, as of the end of the most recent fiscal year of the issuer, of the effectiveness of the internal control structure and procedures of the issuer for financial reporting. (b) INTERNAL CONTROL EVALUATION AND REPORTING.-With respect to the internal control assessment required by subsection (a), each registered public accounting firm that prepares or issues the audit report for the issuer shall attest to, and report on, the assessment made by the management of the issuer. An attestation made under this subsection shall be made in accordance with standards for attestation engagements issued or adopted by the Board. Any such attestation shall not be the subject of a separate engagement."

${ }^{317}$ Item 32 da Res. n. 1.212/09 do CFC: "O auditor deve incluir na documentação de auditoria (NBC TA 230 - Documentação de Auditoria, itens 8 a 11 e A6): (a) a discussão entre a equipe encarregada do trabalho quando requerido pelo item 10, e as decisões significativas alcançadas; (b) elementos-chave do entendimento obtido referentes a cada um dos aspectos da entidade e do seu ambiente especificados no item 11 e de cada um dos componentes do controle interno especificados nos itens 14 a 24; as fontes de informações a partir das quais foi obtido o entendimento; e procedimentos de avaliação de riscos executados; (c) os riscos identificados e avaliados de distorção relevante nas demonstrações contábeis como exigido pelo item 25; e (d) os riscos identificados e controles relacionados a respeito dos quais o auditor tenha obtido entendimento, como resultado dos requerimentos dos itens 27 a 30 (ver itens A131 a A134)".
} 
incentivos que possam levar à prática de atos ilegais, desonestos ou que fraudem os controles instituídos;

- Avaliação e gerenciamento dos riscos: a administração da entidade auditada deve avaliar os riscos de que possa haver erros, omissões ou fraudes em seu ambiente e, em particular, nas informações constantes das demonstrações contábeis;

- Informação e comunicação: concerne à forma e aos métodos de arquivamento e registro da informação referente aos controles internos com relação aos fatos econômicos em que a entidade seja parte. Engloba fixação de responsabilidades aos incumbidos do controle e a ciência destes, de modo claro, a respeito de suas tarefas;

- Atividade de controle: trata-se da materialização das atividades destinadas a controlar os riscos de não conformidades com os objetivos institucionais. Envolve a prática de: 1) segregação de funções (principalmente entre atividades de tesouraria e escrituração); 2) controles físicos e de tecnologia de informação; 3) análise e revisão de desempenho;

- Monitoramento: é a tarefa de realimentação do sistema, na qual se verifica a qualidade da atividade dos responsáveis pelo controle, fazendo, se necessário, os devidos ajustes.

A conceituação do COSO, na forma antes aludida, está contida na maior parte das normas nacionais (no Brasil, a Res. n. 1.212/09 do CFC) e internacionais de auditoria, tornando-se referência para a matéria.

Deve-se ter em consideração, porém, que a existência de controles internos não confere segurança absoluta às demonstrações contábeis, apenas minimizando, como ressaltado anteriormente, um dos riscos que compõem o risco total de auditoria.

Com efeito, haverá sempre a possibilidade de que os controles internos venham a falhar em determinados momentos, como no caso de erros humanos, conluio entre responsáveis para alcançar fins ilícitos, ignorância deliberada dos controles pelos responsáveis da alta administração, etc. Também é necessário lembrar que a presença de controles internos está limitada pelos custos inerentes. Muitas vezes, um nível de controle maior tornará a atividade economicamente inviável ou sem os devidos incentivos. 


\subsection{Testes de controle, revisão analítica e testes substantivos}

Como visto no tópico anterior, o auditor deve se certificar de que a entidade auditada possui os devidos controles internos.

Além de atestar sua existência, o auditor deve realizar testes nos controles internos da entidade, para verificar se funcionam a contento e se são suficientemente eficazes aos fins a que se propõem.

Várias são as técnicas para a realização de testes em controles internos, dentre as quais algumas podem ser citadas: 1) realização de simulações de inserção de dados no sistema contábil da entidade auditada, observando se há processamento de acordo com os padrões exigidos; 2) verificação da eficácia prática da segregação de funções entre os colaboradores que realizam pagamentos ou são responsáveis pelo caixa da entidade e aqueles responsáveis pela escrituração; 3) análise da existência de autorização expressa para que colaboradores responsáveis insiram dados nos sistemas de contabilidade ou outras transações com acessibilidade restrita; 4) conferência da adequação dos sistemas de hardware e software da entidade; 5) exame de documentos dos controles internos; 6) indagações de colaboradores que trabalhem em funções inerentes a controles internos, etc.

Além dos testes dos controles internos, o auditor poderá também realizar o que se chama de revisão analítica, ou procedimentos analíticos de auditoria.

A revisão analítica consiste basicamente na análise de dados retirados diretamente das demonstrações contábeis (análise de índices, comparações de séries temporais, análise vertical e horizontal de demonstrações, cotejo de dados das demonstrações da entidade auditada com o setor em que está inserida, uso de instrumentos estatísticos de regressão e correlação, etc.). ${ }^{318}$

\footnotetext{
${ }^{318} \mathrm{O}$ item A1 da Res. CFC n. 1.221/09, exemplifica os seguintes procedimentos analíticos a serem utilizados pelo auditor: "Os procedimentos analíticos incluem, por exemplo, levar em consideração comparações de informações contábeis e financeiras da entidade: • informações comparáveis de períodos anteriores; • resultados previstos pela entidade, tais como orçamentos ou previsões, ou expectativas do auditor, como uma estimativa de depreciação; • informações de entidades do mesmo setor de atividade, como a comparação entre índices de vendas e contas a receber com as médias do setor ou com outras entidades de porte comparável do mesmo setor".
} 
O uso de procedimentos analíticos baseia-se na existência de padrões de comportamento dos dados contábeis que sejam, ao menos, razoáveis de se esperar das demonstrações verificadas. Como lecionam Rittenberg et al.:

Uma premissa básica subjacente à aplicação dos procedimentos analíticos é a de que se pode esperar a existência e continuidade de plausíveis relacionamentos entre dados, na ausência de condições conhecidas em contrário. Exemplos típicos de técnicas de análise, incluindo relações e fontes de dados, incluem as seguintes:

- Informações financeiras dos períodos anteriores equivalentes, como comparar a tendência das vendas do quarto trimestre para os últimos três anos e analisando as alterações de dólar e mudanças percentuais no exercício anterior;

- Os resultados esperados ou planejados desenvolvidos a partir de orçamentos ou outras previsões, como comparar o desempenho de real com o orçado;

- $\quad$ Comparação dos relacionamentos de contas vinculadas, tais como despesas de juros e de capacidade de endividamento;

- Índices financeiros, tais como a relação entre vendas e custo das mercadorias vendidas ou desenvolver e analisar as demonstrações financeiras de porte comum;

- Tendências da empresa e indústria, tais como comparar percentagens de margem bruta de linhas de produtos ou o giro de estoque com médias de indústria;

- Análise das informações não financeiras relevantes, tais como analisar a relação entre o número de itens enviados e gasto de royalties ou o número de funcionários e despesas de folha de pagamento. ${ }^{319}$

\footnotetext{
319 Op. cit. p. 383. O texto é tradução livre de: "A basic premise underlying the application of analytical procedures is that plausible relationships among data may reasonably be expected to exist and continue in the absence of known conditions to the contrary. Typical examples of analytical techniques, including relationships and sources of data, include the following: - Financial Information for equivalent prior periods, such as comparing the trend of fourth-quarter sales for the past three years and analyzing dollar and percent changes from the prior year; - Expected or planned results developed from budgets or other forecasts, such as comparing actual division performance with budgeted performance; - Comparison of linked account relationships, such as interest expense and interest-bearing debt; - Ratios of financial information, such as examining the relationship between sales and cost of goods sold or developing and analyzing common-sized financial statements; - Company and industry trends, such as comparing gross margin percentages of product lines or inventory turnover with industry averages; - Analysis of relevant nonfinancial Information, such as analyzing the relationship between the numbers of items shipped and royalty expense or the number of employees and payroll expense".
} 
Por meio da revisão analítica, o auditor tem a possibilidade de verificar aspectos que chamam a atenção nas demonstrações contábeis, ou que não correspondam às expectativas razoavelmente admitidas de continuidade. Isto possibilita que o auditor direcione melhor seu trabalho e planeje com mais precisão a extensão dos testes substantivos a serem realizados.

Um exemplo facilitará o entendimento.

Imaginemos que uma determinada entidade auditada apresente as seguintes demonstrações financeiras nos exercícios de X1 e X2:

\begin{tabular}{|c|c|c|c|c|c|}
\hline \multicolumn{6}{|c|}{ BALANÇO PATRIMONIAL - Em R\$ } \\
\hline ATIVO & $\mathbf{X 1}$ & X2 & PASSIVO & $\mathbf{X 1}$ & $\mathbf{X} 2$ \\
\hline $\begin{array}{l}\text { Ativo Circulante } \\
\text { (AC) }\end{array}$ & & & $\begin{array}{l}\text { Passivo Circulante } \\
\text { (PC) }\end{array}$ & & \\
\hline Caixa & $710.000,00$ & $559.600,00$ & $\begin{array}{l}\text { Provisão para salários e } \\
\text { encargos }\end{array}$ & $20.000,00$ & $10.000,00$ \\
\hline Clientes & - & $60.000,00$ & Empréstimos & - & $50.000,00$ \\
\hline Estoques & $7.500,00$ & - & Impostos a pagar & $5.400,00$ & $21.600,00$ \\
\hline $\begin{array}{l}\text { Total do ativo } \\
\text { circulante }\end{array}$ & $717.500,00$ & $619.600,00$ & $\begin{array}{l}\text { Total do passivo } \\
\text { circulante }\end{array}$ & $25.400,00$ & $81.600,00$ \\
\hline $\begin{array}{l}\text { Ativo Permanente } \\
\text { (AP) }\end{array}$ & & & $\begin{array}{l}\text { PATRIMÔNIO } \\
\text { LÍQUIDO (PL) }\end{array}$ & & \\
\hline Veículos & $100.000,00$ & $100.000,00$ & Capital & $1.000 .000,00$ & $1.100 .000,00$ \\
\hline Imóveis & $200.000,00$ & $200.000,00$ & $\begin{array}{l}\text { Lucros e prejuízos } \\
\text { acumulados }\end{array}$ & $(7.900,00)$ & $(277.000,00)$ \\
\hline $\begin{array}{l}\text { Depreciação } \\
\text { acumulada }\end{array}$ & - & $(15.000,00)$ & Total do PL & $992.100,00$ & $823.000,00$ \\
\hline $\begin{array}{l}\text { Total do ativo } \\
\text { permanente }\end{array}$ & $300.000,00$ & $285.000,00$ & & & \\
\hline Total do ativo & 1.017.500,00 & $904.600,00$ & $\begin{array}{l}\text { Total do passivo e } \\
\text { patrimônio líquido }\end{array}$ & $1.017 .500,00$ & $904.600,00$ \\
\hline
\end{tabular}

\begin{tabular}{|c|c|c|}
\hline $\begin{array}{l}\text { DEMONSTRAÇÃO DE RESULTADO DE } \\
\text { EXERCÍCIO - Em R\$ }\end{array}$ & $\mathbf{X 1}$ & $\mathbf{X 2}$ \\
\hline Receita operacional bruta & $30.000,00$ & $120.000,00$ \\
\hline (-) Impostos sobre vendas & $(5.400,00)$ & $(21.600,00)$ \\
\hline (=) Receita operacional líquida & $24.600,00$ & $98.400,00$ \\
\hline (-) Custo das mercadorias vendidas & $(7.500,00)$ & $(52.500,00)$ \\
\hline (=) Lucro Bruto & $17.100,00$ & $45.900,00$ \\
\hline (-) Despesas operacionais & $(25.000,00)$ & $(315.000,00)$ \\
\hline Depreciação & \multicolumn{2}{|c|}{$15.000,00$} \\
\hline Salários e encargos & \multicolumn{2}{|c|}{$250.000,00$} \\
\hline Outras despesas operacionais & \multicolumn{2}{|c|}{$50.000,00$} \\
\hline (=) Prejuízo do exercício & $(7.900,00)$ & $(269.100,00)$ \\
\hline
\end{tabular}


Aplicando procedimentos analíticos, o auditor pode chegar às relações entre os diversos índices oriundos dos relatórios contábeis. Para o caso concreto, utilizaremos como exemplo os índices baseados nas lições de Dante C. Matarazzo, ${ }^{320}$ que poderão ser acrescidos de outros índices em análises concretas.

\begin{tabular}{|c|c|c|c|}
\hline $\mathbf{A N}$ & LISE DE ÍNDICES & $\mathbf{X 1}$ & $\mathbf{X} 2$ \\
\hline \multicolumn{4}{|c|}{ ESTRUTURA DE CAPITAL } \\
\hline (1) & Endividamento & $3 \%$ & $10 \%$ \\
\hline (1) & Composição do Endividamento & $100 \%$ & $100 \%$ \\
\hline (1) & Imobilização do Patrimônio Líquido & $30 \%$ & $35 \%$ \\
\hline (1) & $\begin{array}{l}\text { Imobilização dos Recursos Não } \\
\text { Correntes }\end{array}$ & $30 \%$ & $35 \%$ \\
\hline \multicolumn{4}{|c|}{ LIQUIDEZ } \\
\hline (2) & Geral & 28,25 & 7,59 \\
\hline (2) & Corrente & 28,25 & 7,59 \\
\hline (2) & Seca & 27,95 & 7,59 \\
\hline \multicolumn{4}{|c|}{ RENTABILIDADE } \\
\hline (2) & Giro do Ativo & $\mathbf{0 , 0 2}$ & $\mathbf{0 , 1 1}$ \\
\hline (2) & Margem Líquida & $-32 \%$ & $-273 \%$ \\
\hline (2) & Rentabilidade do Ativo & $-1 \%$ & $-30 \%$ \\
\hline (2) & Rentabilidade do PL & $-2 \%$ & $-30 \%$ \\
\hline \multicolumn{4}{|c|}{ INTERPRETAÇÃO } \\
\hline \multicolumn{4}{|c|}{ (1): Quanto menor, melhor } \\
\hline \multicolumn{4}{|c|}{ (2): Quanto maior, melhor } \\
\hline
\end{tabular}

Da utilização dos índices supracitados, podemos verificar que o endividamento subiu de $3 \%$, em X1, para $10 \%$ em X2, o que enseja ao auditor a possibilidade de focar seus testes nas razões de tal aumento. Ele poderá, por exemplo, verificar quais foram os passivos acrescidos, sua causa, a documentação que lhes deu origem, etc.

Vê-se também que a margem líquida, que já era negativa no exercício de X1 ($32 \%)$, caiu vertiginosamente em X2 (-273\%), o que novamente poderá contribuir para o trabalho investigativo do auditor.

Outros pontos elencados na análise de índices antes demonstrada poderão, conforme o caso, receber menos atenção do auditor, como os aspectos de liquidez, imobilização, etc., que não tiveram grandes alterações imprevisíveis no correr dos períodos analisados.

${ }^{320}$ MATARAZZO, Dante Carmine. Análise Financeira de Balanços. São Paulo: Atlas, 2003. 
Para aprofundar sua investigação com o uso de procedimentos analíticos, o auditor poderá comparar os índices mencionados com aqueles apresentados por outras entidades do setor, obtendo maior nível de informações e melhor direcionamento de seu trabalho.

Poderá também fazer uso de técnicas de análise horizontal e vertical de demonstrações, para verificar qual o percentual de cada conta no total da receita ou do ativo/passivo e sua variação percentual com o passar dos exercícios. ${ }^{321}$ Podemos exemplificar esta conduta com a demonstração de resultado do exercício antes transcrita.

\begin{tabular}{|lrrrrrrr|}
\hline \multicolumn{1}{|c}{ ANÁLISE VERTICAL E HORIZONTAL DA DEMONSTRAÇÃO DE RESULTADO } \\
\hline & & & & & & \\
& X1 & AV(\%) & AH(\%) & X2 & AV(\%) & AH(\%) \\
\hline & & & & & & \\
& & & & & & \\
\hline RECEITA LÍQUIDA & $\mathbf{2 4 . 6 0 0}$ & 100 & 100 & $\mathbf{9 8 . 4 0 0}$ & 100 & 400 \\
\hline Custo dos Produtos Vendidos & $\mathbf{7 . 5 0 0}$ & 30 & 100 & $\mathbf{5 2 . 5 0 0}$ & 53 & 700 \\
\hline LUCRO BRUTO & $\mathbf{1 7 . 1 0 0}$ & 70 & 100 & $\mathbf{4 5 . 9 0 0}$ & 47 & 268 \\
\hline Despesas Operacionais & $\mathbf{2 5 . 0 0 0}$ & 102 & 100 & $\mathbf{3 1 5 . 0 0 0}$ & 320 & 1260 \\
\hline Outras Rec. Desp. Oper. & $\mathbf{0}$ & 0 & 100 & $\mathbf{0}$ & 0 & 0 \\
\hline LUCRO OPER. (sem Res. Fin.) & $\mathbf{- 7 . 9 0 0}$ & -32 & 100 & $\mathbf{- 2 6 9 . 1 0 0}$ & -273 & 3406 \\
\hline Receitas Financeiras & $\mathbf{0}$ & 0 & 100 & $\mathbf{0}$ & 0 & 0 \\
\hline Despesas Financeiras & $\mathbf{0}$ & 0 & 100 & $\mathbf{0}$ & 0 & 0 \\
\hline LUCRO OPERACIONAL & $\mathbf{- 7 . 9 0 0}$ & -32 & 100 & $\mathbf{- 2 6 9 . 1 0 0}$ & -273 & 3406 \\
\hline Resultado Não Operacional & $\mathbf{0}$ & 0 & 100 & $\mathbf{0}$ & 0 & 0 \\
\hline LUCRO ANTES DO I.R. & $\mathbf{- 7 . 9 0 0}$ & -32 & 100 & $\mathbf{- 2 6 9 . 1 0 0}$ & -273 & 3406 \\
\hline LUCRO LÍQUIDO & $\mathbf{- 7 . 9 0 0}$ & -32 & 100 & $\mathbf{- 2 6 9 . 1 0 0}$ & -273 & 3406 \\
\hline
\end{tabular}

Na compreensão da análise horizontal acima, o auditor poderá verificar um importante aumento de receita líquida (400\% maior em X2 que em X1), mas que não foi suficiente para cobrir as despesas operacionais, que subiram na proporção de $1.260 \%$, resultando num lucro operacional e líquido $3.406 \%$ inferior em X2, comparativamente a

\footnotetext{
321 O objetivo deste tipo de análise é, como se disse, demonstrar a participação de cada conta das demonstrações no total (análise vertical - AV) ou sua evolução no tempo (análise horizontal - AH). Com este fim, assume-se na análise vertical (AV) que o total da receita, do ativo e do passivo assume valor 100 (ou 100\%). Cada conta terá o valor percentual indicado por sua divisão pelo total (se uma conta possuir valor 50 , significa dizer que corresponde a $50 \%$ do total considerado). Já na análise horizontal, aos valores das contas do primeiro exercício analisado é atribuído valor 100 (ou 100\%), recebendo os montantes dos exercícios posteriores o percentual respectivo em relação aos do primeiro exercício (p.ex., se uma conta do segundo exercício tiver valor 50, significa dizer que corresponde a 50\% dos valores do primeiro exercício).
} 
X1. Não há despesas e receitas financeiras (p.ex.: juros recebidos ou incorridos) influenciando o resultado final (prejuízo).

De posse dessas informações, o auditor poderá melhor direcionar seu trabalho para verificar as causas do súbito aumento das despesas operacionais, em proporção maior que a receita, podendo ainda melhor concluir sobre eventuais problemas de continuidade operacional.

Além dos testes de controles internos e dos procedimentos de revisão analítica, o auditor deve também realizar testes substantivos (também chamados testes de detalhes), ${ }^{322}$ que podem ser conceituados como o tipo de verificação que incide diretamente sobre os saldos e valores de transações representadas nas demonstrações contábeis.

Alguns dos principais testes substantivos que o auditor pode realizar são:

- Testes de saldos e de detalhes de transações: conferência dos saldos presentes nas demonstrações contábeis e da correção das transações inerentes. Isto pode ser feito por conferência direta (inspeção), verificação de conciliações, documentos, etc.;

- Testes de corte: cuida-se de selecionar determinado interregno temporal das transações presentes nas demonstrações contábeis para verificar a correção quanto ao período dos lançamentos efetivados (p.ex.: seleção dos últimos e dos primeiros meses de dois exercícios consecutivos, analisando se as receitas e os custos das mercadorias e dos serviços foram tempestivamente inseridos); ${ }^{323}$

\footnotetext{
${ }^{322}$ Devemos salientar que, em muitos casos, testes substantivos podem servir também como testes de controle. Podemos citar, como exemplo, a informação dada por "voucherização", consistente em selecionar uma série de transações registradas em livro e seguir sua trilha até sua fonte documental. Isto pode informar ao auditor um eventual problema na transação em si (p.ex., um erro ou fraude), bem como evidenciar uma possível falha de controle interno. Portanto, a divisão doutrinária entre os testes de controle e os testes subjetivos, embora seja clara em alguns casos, pode se tornar duvidosa em algumas hipóteses.

${ }^{323}$ É muito comum a existência de erros ou até mesmo de fraudes em demonstrações contábeis no período que compreende o final de um exercício e início de outro. Isto porque, neste interregno, estão localizadas as últimas receitas e despesas do período, que podem ter influência decisiva no lucro apresentado aos investidores. Muitas vezes, a gestão pode pretender antecipar receitas futuras e/ou postergar despesas (jogando-as para o exercício seguinte), para inflar artificialmente os lucros, ou mesmo diminuí-los, fazendo a operação inversa (postergando receitas do período e/ou antecipando despesas que deveriam ser reconhecidas posteriormente).
} 
- Confirmações ou circularizações (confirmation with outside parties): ${ }^{324}$ trata-se de teste substantivo consistente em solicitação direta pelo auditor a um terceiro (usualmente um credor ou devedor da entidade auditada) que confirme os valores consubstanciados em transações representadas nas demonstrações contábeis. A confirmação, que se faz por comunicação direta entre auditor e terceiro, sem a interveniência da entidade auditada, pode ser: 1) positiva: quando o auditor informa determinado saldo e pede ao terceiro que confirme sua veracidade ou não ${ }^{325}$ 2) negativa: se o auditor solicita apenas que se informe caso os dados enviados não estejam corretos;

- “Voucherização": forma de teste substantivo segundo o qual o auditor parte dos dados constantes nos registros contábeis (livros, fichas, sistemas informatizados, etc.), seguindo seu trâmite até sua fonte (documento, contrato, etc.);

- Rastreamento (Tracking): ao contrário do anterior, consiste em partir da fonte (documento, contrato, etc.), seguindo o trâmite da transação até o pertinente registro contábil;

- Exame físico e inspeção: teste utilizado frequentemente na verificação de ativos tangíveis (inventário de estoque, contagem de caixa, etc.), para constatação de sua existência física;

- Exame de documentos: consiste em analisar a veracidade e qualidade das fontes documentais que basearam os lançamentos contábeis;

- Indagações de colaboradores: este teste pode ser usado pelo auditor para descobrir eventuais falhas ou para esclarecimento de dúvidas quanto às transações.

Deve-se consignar que os testes de controle, os procedimentos analíticos e os testes substantivos estão diretamente relacionados.

Em princípio, poder-se-ia imaginar que uma auditoria externa pudesse ser realizada somente com testes substantivos, uma vez que bastaria verificar diretamente as

\footnotetext{
${ }^{324}$ As confirmações são regidas no Brasil pela Res. CFC n. 1.219/09. Um dos grandes problemas com as confirmações é que estas não costumam ter um percentual muito elevado de respostas. Ao contrário, é comum que os terceiros não se deem ao trabalho de responder ao auditor. Também é comum que as respostas possam não ser confiáveis. Nestes casos, o auditor deve realizar procedimentos alternativos de auditoria.

${ }^{325}$ A confirmação positiva pode ser feita através de carta em branco, na qual o auditor solicita ao terceiro que confirme qual o valor correto de determinada transação, sem informar qualquer saldo previamente.
} 
transações constantes das demonstrações contábeis. Isto não deixaria de ser verdade, caso o número dessas operações fosse diminuto. No entanto, nos dias de hoje, a dimensão das transações de grande parte das entidades auditadas não permite que sejam realizados testes substantivos para a integralidade dos lançamentos contabilizados, dadas as limitações de auditoria a que anteriormente aludimos.

Assim, o auditor deve basear seu trabalho ponderando, conforme seu julgamento profissional, a quantidade de testes de controle, de procedimentos analíticos e de testes substantivos a serem realizados em cada caso.

Em regra, quanto mais confiável sejam os controles internos de uma determinada entidade, menor será a necessidade do auditor realizar testes substantivos. Do mesmo modo, caso o auditor verifique, em procedimentos analíticos, que os dados contábeis se encontram dentro de padrões razoáveis e esperados, poderá diminuir (embora em reduzida proporção) o número de testes substantivos a ser realizados para obter suficiente evidência de auditoria quanto à inexistência de distorções relevantes nas demonstrações contábeis. No entanto, caso os controles internos testados não sejam confiáveis, ou os procedimentos de revisão analítica indicarem dados que extrapolem os padrões esperados, o auditor deverá aumentar o número de testes substantivos a ser realizados.

Segundo o que preceituam Boyton et al., preliminarmente, o auditor pode planejar sua auditoria, dentre outras possibilidades, das seguintes formas: 1) com ênfase em testes substantivos, reduzindo os testes de controle e revisão analítica; 2) dando ênfase a testes de controle, com reduzidos testes substantivos e revisão analítica; 3) com ênfase em revisão analítica, caso em que poderá reduzir os testes de controle, devendo ainda manter níveis elevados de testes substantivos, mesmo que em menor número. ${ }^{326}$

Obviamente, o planejamento da auditoria quanto ao número e a natureza dos testes a serem realizados pode não prevalecer na prática. Com efeito, v. g., se o auditor constatar a ineficiência dos controles internos em seus testes, deverá ampliar o número de testes substantivos para coletar suficientes evidências de auditoria que fundamentem seu parecer.

\footnotetext{
${ }^{326}$ Op. cit. p. 305. Boyton et al. ainda enfatizam uma quarta forma de planejamento, que entendemos menos importante para ser incluída aqui.
} 
O gráfico seguinte, baseado nas lições dos autores supracitados, demonstra algumas das formas prováveis de planejamento de auditoria, entre as opções que enfatizam testes de controle, substantivos ou revisão analítica.

\section{Figura 6: Planejamento da auditoria conforme a ênfase dada pelo auditor}

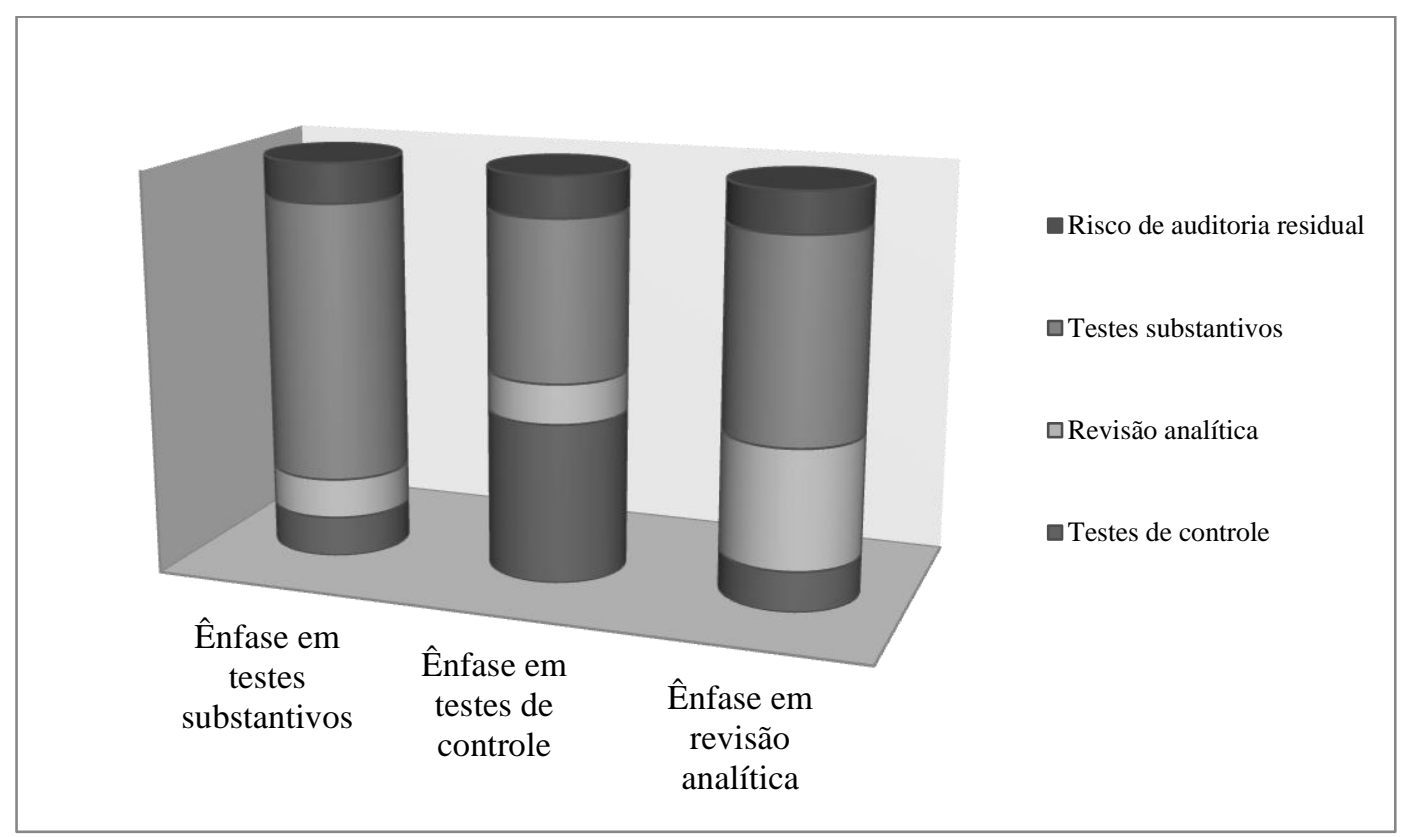

Fonte: Boyton et al. (cit. p. 305)

Pode-se verificar que a parte superior das barras do gráfico transcrito se refere ao risco residual de auditoria, que sempre permanece no mesmo nível, mesmo com a relação de todos os testes possíveis.

Mantendo-se o mesmo nível residual de risco para a auditoria, o auditor pode optar por enfatizar testes substantivos (barra da esquerda), diminuindo os testes de controle e os procedimentos analíticos. Este tipo de auditoria, embora frequentemente seja dotado de evidências mais seguras, costuma ser mais custoso e demorado.

Pode ainda o auditor, com o mesmo risco residual, optar por mais testes de controle, diminuindo o número de testes substantivos e reduzindo da mesma forma os procedimentos analíticos de auditoria. Para a obtenção de suficientes evidências nesse tipo de abordagem, o auditor deve atingir razoável grau de certeza a respeito dos controles internos; caso contrário, deverá incrementar a quantidade de testes substantivos.

Finalmente, ainda com o mesmo grau de risco residual, o auditor pode enfatizar o uso de procedimentos analíticos reduzindo os testes de controle. Veja-se que, neste caso, a redução de testes substantivos não pode ser demasiada, uma vez que os procedimentos 
analíticos não garantem níveis suficientes de evidências para fundamentar o parecer do auditor, razão pela qual este profissional ainda deve realizar razoável número de testes substantivos.

\subsection{Procedimentos de amostragem}

Considerando as limitações de custos e tempo inerentes à atividade de auditoria externa, resta claro que na maior parte das vezes o auditor não pode exercer seu trabalho examinando todas as transações econômicas da entidade auditada, nem mesmo todos os seus controles internos.

Assim, deverá este profissional analisar apenas uma parte de todos os lançamentos contábeis representados nas demonstrações. Em outras palavras, em termos estatísticos, caberá ao auditor retirar conclusões sobre uma determinada população de transações econômicas, não pelo exame direto da totalidade desta, mas sim por meio de inferência proveniente dos dados colhidos de uma parcela do todo (amostra). ${ }^{327}$

Trata-se, portanto, de um raciocínio realizado por indução, ${ }^{328}$ partindo do particular para o geral, ou seja, extrapolando para a totalidade do objeto considerado,

\footnotetext{
${ }^{327}$ A Res. n. 1.222/09 do CFC define os termos citados: "População é o conjunto completo de dados sobre o qual a amostra é selecionada e sobre o qual o auditor deseja concluir".

${ }^{328} \mathrm{Em}$ termos de lógica, o raciocínio por indução é o mecanismo utilizado pela estatística inferencial para operar conclusões. Na definição de Larson e Farber, estatística inferencial "é o ramo que trata de tirar conclusões sobre uma população a partir de uma amostra. A ferramenta básica no estudo da estatística inferencial é a probabilidade" (LARSON, Ron; FARBER, Betsy. Estatística aplicada. São Paulo: Prentice Hall, 2004. p. 5). Por sua vez, Alaôr Café Alves relata: "Indução é a operação do espírito de concluir do particular para o geral, ou seja, de generalizar (em termos do racionalismo, o mais correto seria 'universalizar') uma relação de causalidade entre dois fenômenos, ainda que se tenha verificado apenas um número de vezes relativamente restrito. Através da indução, parte-se de fatos observados ou experimentados para concluir-se a respeito da relação causal que os rege, buscando-lhes a 'lei', isto é, a relação regular (universal) e necessária entre os fatos. A argumentação indutiva é uma inferência mediata, porque é aquela cuja conclusão é alcançada por meio das partes inferiores (ou subjetivas) de um dos dois termos, unidos na conclusão. A indução é um raciocínio pelo qual o espírito, de dados singulares ou parciais suficientemente enumerados, infere uma verdade universal. O raciocínio indutivo é, portanto, o que passa do particular ao universal. Exemplo: 'esta porção de água ferve a $100^{\circ}$, esta outra e esta outra mais também fervem a $100^{\circ}$, logo, a água ferve a $100^{\circ}$ '; 'o cobre, o ferro, a prata, o zinco (e outros) são bons condutores de eletricidade; ora, o cobre, o ferro, a prata, o zinco (e outros) são metais (ou seja, representam suficientemente o metal); logo, o metal é bom condutor de eletricidade" (ALVES, Alaôr Café. Lógica - Pensamento formal e argumentação - Elementos para o discurso jurídico. São Paulo: Edipro, 2000. p. 5).
} 
segundo regras estatísticas ou de julgamento profissional, uma conclusão inicialmente válida apenas para uma parcela do todo.

Conceitua-se, portanto, amostragem de auditoria, nos termos da Res. n. 1.222/09 do CFC, como:

A aplicação de procedimentos de auditoria em menos de $100 \%$ dos itens de população relevante para fins de auditoria, de maneira que todas as unidades de amostragem tenham a mesma chance de serem selecionadas para proporcionar uma base razoável que possibilite o auditor concluir sobre toda a população.

Como visto, mesmo sem realizar amostragens o auditor está sujeito a uma série de possíveis enganos em seu trabalho. ${ }^{329}$

Entretanto, ao partir de uma amostra para concluir sobre a população, acrescenta-se a estes possíveis equívocos uma série de outros erros e distorções. Com efeito, pode ser que o auditor não escolha corretamente a amostra, ou que a amostra seja insuficiente ou não representativa do todo, o que pode levar a conclusões errôneas.

Desse modo, pode ser que o auditor venha a superestimar a qualidade dos controles internos, concluindo que são confiáveis (na amostra), quando não o são efetivamente (na população); ou mesmo venha a subavaliar tais controles por não se terem mostrado confiáveis (na amostra), quando o são (na população). Pode ser também que o auditor venha a concluir, na realização de testes substantivos (ou de detalhes), que os dados das demonstrações contenham distorções materiais (na amostra), quando efetivamente isto não ocorre (na população), rejeitando incorretamente o conteúdo das demonstrações; ou mesmo que conclua que tais dados não contenham referidas distorções materiais (na amostra), quando estas distorções estejam presentes (na população), aceitando incorretamente o conteúdo das demonstrações. ${ }^{330}$

\footnotetext{
${ }^{329}$ A isto se pode dar o nome de risco não resultante da amostragem, que é definido na Res. n. 1.222/09 do CFC como "o risco de que o auditor chegue a uma conclusão errônea por qualquer outra razão que não seja relacionada ao risco de amostragem".

${ }^{330}$ A Res. n. 1.222/09 do CFC define este fenômeno como risco de amostragem, assim conceituando: "Risco de amostragem é o risco de que a conclusão do auditor, com base em amostra, pudesse ser diferente se toda a população fosse sujeita ao mesmo procedimento de auditoria. O risco de amostragem pode levar a dois tipos de conclusões errôneas: (a) no caso de teste de controles, em que os controles são considerados mais eficazes do que realmente são ou no caso de teste de detalhes, em que não seja identificada distorção relevante, quando, na verdade, ela existe. $\mathrm{O}$ auditor está preocupado com esse tipo de conclusão errônea porque ela afeta a eficácia da auditoria e é provável que leve a uma opinião de auditoria não apropriada. (b) no caso de teste de controles, em que os controles são considerados menos eficazes do que realmente são ou no caso de teste de detalhes, em que seja identificada distorção relevante, quando, na verdade, ela não existe. Esse tipo
} 
Assim, cabe ao auditor exercer com propriedade a amostragem, com o fim de não tornar seu trabalho imprestável ou passível de erros e impugnações.

Duas metodologias básicas são preconizadas para a realização de amostragens: 1) amostragem estatística; 2) amostragem não estatística.

A amostragem estatística é realizada com base em postulados desta ciência, conforme padrões de inferência e probabilidade. Tem o benefício de lastrear as conclusões do auditor de forma científica, objetiva, mensurável e demonstrável a qualquer interessado. Por outro lado, exige conhecimentos específicos do auditor e pode ser mais cara, por exigir treinamento e aquisição de programas de computador próprios.

A amostragem não estatística baseia-se na formação de uma amostra decorrente do julgamento profissional do auditor. Não requer treinamentos estatísticos do profissional, nem mesmo qualquer tipo de cálculo, podendo ser mais barata e fácil de planejar. No entanto, é dotada de maior subjetividade e não proporciona um meio de controle objetivo da mensuração da amostra realizada pelo auditor.

Não há na literatura ou nas normas nacionais e internacionais de auditoria uma preferência por um dos tipos de amostragem. ${ }^{331}$ Trata-se, portanto, de uma decisão do auditor a cada caso concreto. Entretanto, utilizando ou não ferramentas estatísticas, o auditor deve sempre considerar, ao selecionar o tamanho da amostra, o nível de risco tolerado, os desvios possíveis da população e o grau de segurança desejado no caso.

A seleção da composição da amostra pode ser feita pelo auditor de forma aleatória (com igual chance de escolha dos elementos que irão compô-la), usando estratificação ${ }^{332}$ da população (separação dos elementos em subclasses com características semelhantes), por blocos (selecionando elementos consecutivos de um determinado bloco

de conclusão errônea afeta a eficiência da auditoria porque ela normalmente levaria a um trabalho adicional para estabelecer que as conclusões iniciais estavam incorretas".

${ }^{331}$ No item A11 da Res. CFC n. 1.222/09 define-se que "O tamanho da amostra pode ser determinado mediante aplicação de fórmula com base em estatística ou por meio do exercício do julgamento profissional". ${ }^{332}$ É muito comum a divisão da população pelo auditor em estratos que correspondam a maior ou menor valor monetário (o auditor separa os lançamentos entre aqueles de maior valor e aqueles de valor menor ou insignificante). Isto atende igualmente ao conceito de materialidade da auditoria, pois eventuais erros em lançamentos de valor diminuto podem, conforme o caso concreto, não ser significativos para influenciar no julgamento do usuário da informação contábil. Também é comum a estratificação por grau de risco. $\mathrm{O}$ Apêndice 1, item 2, da Res. CFC n. 1.222/09 ressalta: "Na execução dos testes de detalhes, a população é geralmente estratificada por valor monetário. Isso permite que o trabalho maior de auditoria possa ser direcionado para os itens de valor maior, uma vez que esses itens podem conter maior potencial de distorção em termos de superavaliação. Da mesma forma, a população pode ser estratificada de acordo com uma característica específica que indica maior risco de distorção como, por exemplo, no teste da provisão para créditos de liquidação duvidosa na avaliação de contas a receber, os saldos podem ser estratificados por idade". 
de itens que se deseja analisar) ou de forma sistemática (seleção de um primeiro item aleatoriamente e os demais por um intervalo constante).

No caso de o auditor utilizar amostragem não estatística, resta imprevisível, como dissemos, o tamanho da amostra, uma vez que dependerá de circunstâncias subjetivas derivadas do julgamento deste profissional.

No entanto, para a amostragem estatística, há algumas recomendações na doutrina, tornando mais previsível o tamanho da amostra a ser selecionada. Boyton et al., ${ }^{333}$ baseando-se nas recomendações do AICPA, ${ }^{334}$ trazem algumas tabelas (17 e 18) que indicam ao auditor o tamanho da amostra a ser considerada para os testes de controles internos, conforme transcrevemos a seguir.

Tabela 17: Tamanho de amostras estatísticas para testes de controles, para populações com mais de $\mathbf{5 . 0 0 0}$ unidades (risco de amostragem de 5\%)

\begin{tabular}{|c|c|c|c|c|c|c|c|c|c|}
\hline \multirow{2}{*}{$\begin{array}{c}\text { Taxa Esperada de } \\
\text { desvios da população } \\
(\%)\end{array}$} & \multicolumn{9}{|c|}{ Taxa aceitável de desvios } \\
\hline & $2 \%$ & $3 \%$ & $4 \%$ & $5 \%$ & $6 \%$ & $7 \%$ & $8 \%$ & $9 \%$ & $10 \%$ \\
\hline 0,00 & 149 & 99 & 74 & 59 & 49 & 42 & 36 & 32 & 29 \\
\hline 0,50 & * & 157 & 117 & 93 & 78 & 66 & 58 & 51 & 46 \\
\hline 1,00 & $*$ & * & 156 & 93 & 78 & 66 & 58 & 51 & 46 \\
\hline 150 & $*$ & $*$ & 192 & 124 & 103 & 66 & 58 & 51 & 46 \\
\hline 2,00 & $*$ & $*$ & * & 181 & 127 & 88 & 77 & 68 & 46 \\
\hline 2,50 & $*$ & $*$ & $*$ & * & 150 & 109 & 77 & 68 & 61 \\
\hline 3,00 & $*$ & $*$ & $*$ & * & 195 & 129 & 95 & 84 & 61 \\
\hline 4,00 & $*$ & $*$ & $*$ & $*$ & * & * & 146 & 100 & 89 \\
\hline 5,00 & $*$ & $*$ & $*$ & * & $*$ & $*$ & $*$ & 158 & 116 \\
\hline 6,00 & $*$ & $*$ & $*$ & $*$ & $*$ & $*$ & $*$ & $*$ & 179 \\
\hline
\end{tabular}

* Tamanho da amostra é muito grande para ser eficiente em termos de custo para aplicações em auditoria

Fonte: Boyton et al. (cit. p. 469)

\footnotetext{
${ }^{333}$ Op. cit. p. 469.

${ }^{334}$ AMERICAN INSTITUTE OF CERTIFIED PUBLIC ACCOUNTANTS. Audit Sampling - AICPA Audit Guide. Nova York: AICPA, 1999.
} 
Tabela 18: Tamanho de amostras estatísticas para testes de controles, para populações com mais de 5.000 unidades (risco de amostragem de $\mathbf{1 0 \%}$ )

\begin{tabular}{|c|c|c|c|c|c|c|c|c|c|}
\hline \multirow{2}{*}{$\begin{array}{c}\text { Taxa Esperada de } \\
\text { desvios da } \\
\text { população }(\%)\end{array}$} & \multicolumn{9}{|c|}{ Taxa aceitável de desvios } \\
\hline & $2 \%$ & $3 \%$ & $4 \%$ & $5 \%$ & $6 \%$ & $7 \%$ & $8 \%$ & $9 \%$ & $10 \%$ \\
\hline 0,00 & 114 & 76 & 57 & 45 & 38 & 32 & 28 & 25 & 22 \\
\hline 0,50 & 194 & 129 & 96 & 77 & 64 & 55 & 48 & 42 & 38 \\
\hline 1,00 & $*$ & 176 & 96 & 77 & 64 & 55 & 48 & 42 & 38 \\
\hline 1,50 & $*$ & $*$ & 132 & 105 & 64 & 55 & 48 & 42 & 38 \\
\hline 2,00 & $*$ & $*$ & 198 & 132 & 88 & 75 & 48 & 42 & 38 \\
\hline 2,50 & $*$ & $*$ & $*$ & 158 & 110 & 75 & 65 & 58 & 38 \\
\hline 3,00 & $*$ & $*$ & $*$ & $*$ & 132 & 94 & 65 & 58 & 52 \\
\hline 4,00 & * & $*$ & $*$ & $*$ & * & 149 & 98 & 73 & 65 \\
\hline 5,00 & $*$ & $*$ & $*$ & $*$ & $*$ & * & 160 & 115 & 78 \\
\hline 6,00 & $*$ & $*$ & $*$ & $*$ & * & * & * & 182 & 116 \\
\hline
\end{tabular}

* Tamanho da amostra é muito grande para ser eficiente em termos de custo para aplicações em auditoria

Fonte: Boyton et al. (cit. p. 469)

Para utilizar estas tabelas, o auditor deve definir preliminarmente o risco de amostragem ( $5 \%$ ou 10\%), determinando ainda qual a taxa máxima de desvios que seria admissível encontrar, conforme o nível de risco de controle definido, em termos de materialidade. Em seguida, deve (com base em amostras anteriores, em sua experiência ou em amostras preliminares de tamanho reduzido) determinar qual o percentual de erro que espera encontrar na população (coluna da esquerda). A partir daí, deve fazer a intersecção dos dados, resultando no tamanho da amostra desejada para cada caso.

Araújo et al., ${ }^{335}$ citando lições da literatura estatística, recomendam a utilização das seguintes fórmulas matemáticas, sequencialmente:

Tabela 19: Definição do tamanho da amostra

\begin{tabular}{ll}
\hline \multicolumn{1}{c}{$\begin{array}{c}\text { Definição da primeira aproximação do } \\
\text { tamanho da amostra }\end{array}$} & \multicolumn{1}{c}{ Definição do tamanho da amostra } \\
\hline \multicolumn{1}{c|}{$\boldsymbol{n}_{\boldsymbol{o}}=\mathbf{1} / \boldsymbol{E}_{\boldsymbol{o}}^{2}$} & \multicolumn{1}{c}{$\boldsymbol{n}=\frac{\boldsymbol{N} \times \boldsymbol{n}_{\boldsymbol{o}}}{\boldsymbol{N}+\boldsymbol{n}_{\boldsymbol{o}}}$} \\
Sendo: & Sendo: \\
$\mathbf{n}_{\mathbf{0}}=$ primeira aproximação do tamanho da amostra & $\mathbf{N}=$ tamanho da população \\
$\boldsymbol{E}^{2}=$ erro amostral tolerável & $\boldsymbol{n}=$ tamanho da amostra \\
\hline
\end{tabular}

Fonte: Araújo et al. (cit. p. 195). 
Ao verificar distorções importantes na amostra, o auditor deve investigar se derivam de anomalias (exceções que podem ser excluídas) ou se estarão presentes em proporções razoáveis na população considerada.

Se constatar que há repetição de distorções, de forma que seja possível concluir que possam ter sido realizadas em série, o auditor poderá decidir examinar toda a população.

Principalmente quando se trate de testes substantivos (testes de detalhes), o auditor deve projetar as distorções encontradas na amostra para a população, verificando se estão compreendidas na definição de materialidade fixada pelo profissional.

\footnotetext{
${ }^{335}$ Op. cit. p. 195 . Os autores dão o seguinte exemplo de cálculo: numa população com 1.000 notas fiscais, em que os erros toleráveis não ultrapassem $5 \%$, tem-se $n_{0}=1 / 0,05^{2}=400$. Portanto $n=(1.000 \times 400) /(1.000$ $+400)=286$ (tamanho da amostra).
} 


\section{O OBJETO DA AUDITORIA EXTERNA: DEMONSTRAÇÕES CONTÁBEIS E A ESCRITURAÇÃO QUE AS FUNDAMENTA}

Se bem verificarmos, a escrituração contábil (consistente na materialização, por meio de lançamentos, dos fatos econômicos de uma entidade), pouco ou nada revela, por si só, aos destinatários.

Com efeito, ao se escriturar, ocorre mera inserção de dados em um substrato, seja este um livro tradicional ou sistema informatizado. No entanto, tais dados lançados na contabilidade normalmente não se prestam a informar, basicamente pelos seguintes motivos: 1) estão submetidos a regime de sigilo e, portanto, não são acessíveis por terceiros externos à entidade; 2) os dados escriturados só fazem algum sentido para aqueles que os efetivaram ou que possuem razoável conhecimento contábil; 3) não possuem organização própria ou objetivo informativo (mas meramente escritural), sendo usualmente inservíveis, em termos de fornecer conhecimento aplicado, aos usuários internos e externos da entidade considerada.

É necessário, portanto, que os dados constantes da escrituração sejam resumidos, organizados e aglutinados de modo a prover uma informação útil aos destinatários sobre a situação econômica da entidade a que se referem.

Assim, justifica-se a necessidade da existência das demonstrações contábeis, consistentes em relatórios cujo papel principal é transformar os dados lançados na escrituração em informações úteis aos destinatários, através da simplificação, organização e sistematização, possibilitando uma futura tomada de decisão.

Nesta linha leciona José Carlos Marion:

Os dados coletados pela Contabilidade são apresentados periodicamente aos interessados de maneira resumida e ordenada, formando, assim, os relatórios contábeis. Os relatórios são elaborados de acordo com as necessidades dos usuários. Evidentemente, um relatório sobre o resultado anual de uma farmácia destacará muito menos pormenores que o de uma siderúrgica, que, normalmente, tem um número elevado de proprietários, grande volume de negócios, diversos tipos de impostos a recolher, operações em muitas agências bancárias. Dos inúmeros relatórios que há 
em Contabilidade, destacam-se aqueles que são obrigatórios de acordo com a legislação brasileira. Esses relatórios são conhecidos como demonstrações financeiras ou, ainda, como demonstrações contábeis. ${ }^{336}$

Cada uma das demonstrações apresenta determinadas tendências, enfoques ou objetivos. Para melhor exemplificar o que veremos a seguir, consignamos o escopo de cada demonstração na tabela seguinte:

Tabela 20: Escopo das demonstrações contábeis

\begin{tabular}{|c|c|}
\hline Demonstração & Escopo \\
\hline Balanço patrimonial (BP) & $\begin{array}{l}\text { Evidencia a situação patrimonial da entidade em } \\
\text { determinada data. Revela os valores dos bens e } \\
\text { direitos (ativo), das dívidas (passivo) e do patrimônio } \\
\text { líquido (ativo - passivo). }\end{array}$ \\
\hline $\begin{array}{l}\text { Demonstração de resultado do exercício } \\
\text { (DRE) }\end{array}$ & $\begin{array}{l}\text { Traz de forma organizada as contas referentes ao } \\
\text { resultado da atividade econômica da entidade } \\
\text { (representativas de receitas e despesas), revelando, } \\
\text { ao final, o acréscimo (lucro) ou decréscimo } \\
\text { (prejuízo) ao patrimônio dos titulares da entidade } \\
\text { pelo exercício da atividade. }\end{array}$ \\
\hline Demonstração de fluxo de caixa (DFC) & $\begin{array}{l}\text { Visa a explicar as razões que levaram o caixa e os } \\
\text { equivalentes de caixa a variarem de um exercício } \\
\text { para outro. }\end{array}$ \\
\hline Demonstração de valor adicionado (DVA) & $\begin{array}{l}\text { Revela os valores que a entidade recebeu e quanto } \\
\text { agregou e devolveu de valor ao montante inicial com } \\
\text { sua atividade. }\end{array}$ \\
\hline $\begin{array}{l}\text { Demonstração de lucros e prejuízos } \\
\text { acumulados (DLPA) }\end{array}$ & $\begin{array}{l}\text { Evidencia como variou a conta de lucros e prejuízos } \\
\text { acumulados entre dois exercícios }\end{array}$ \\
\hline $\begin{array}{l}\text { Demonstração de mutações do patrimônio } \\
\text { líquido (DMPL) }\end{array}$ & $\begin{array}{l}\text { Evidencia como se modificou o patrimônio líquido } \\
\text { entre dois exercícios }\end{array}$ \\
\hline
\end{tabular}

Nas demonstrações contábeis, na verdade, várias declarações são efetivadas pela entidade auditada responsável por sua emissão. Assim, se em um balanço patrimonial há uma afirmação de um valor de $\mathrm{R} \$ 10.000,00$ (dez mil reais) de ativo imobilizado, na verdade, a entidade emissora desta demonstração declara que: 1) o ativo imobilizado existe

${ }^{336}$ MARION, José Carlos. Contabilidade básica. São Paulo: Atlas, 2004. p. 43. 
fisicamente (declaração de existência); 2) o ativo imobilizado é de propriedade ${ }^{337}$ da entidade (declaração de direitos ou obrigações); 3) o ativo imobilizado foi objeto de regular transação que conferiu direitos à entidade sobre o ativo (declaração de integridade); 4) o ativo imobilizado está corretamente avaliado, de acordo com os princípios de contabilidade geralmente aceitos (PGCA) e as leis respectivas; 5) o ativo imobilizado está corretamente classificado na categoria em que foi inserido e recebeu a devida divulgação (declaração de apresentação e divulgação).

Todas essas declarações devem ser objeto de verificação pelo auditor, como veremos nos tópicos seguintes.

\subsection{A escrituração que fundamenta as demonstrações}

Obviamente, o trabalho do auditor não se resume a verificar isoladamente os dados constantes das demonstrações contábeis. Cabe a este profissional analisar a escrituração contábil que deu base à formulação das demonstrações.

Dessa forma, deve-se apresentar aqui um panorama geral de como se desenvolve a escrituração empresarial que dá base às demonstrações contábeis, verificando qual o interesse do auditor em sua análise.

Como já sustentamos, ${ }^{338}$ a escrituração empresarial não pode ser aleatória. Embora nos primórdios das atividades humanas de natureza econômica referido processo pudesse ter natureza simplificada, acessível a qualquer um que não dominasse técnica

\footnotetext{
337 A escrituração de um determinado bem no imobilizado deve ser feita quando a entidade detém a propriedade, e não somente a posse do bem. Desta forma, um imóvel alugado não deve aparecer escriturado no imobilizado da entidade locatária, devendo ser escriturados meramente os passivos referentes às dívidas locatícias, seu reconhecimento respectivo como despesa e as saídas de caixa para os pagamentos necessários. Casos há, entretanto, que podem subverter esta regra. Exemplo disto se deu quando o Conselho Federal de Contabilidade aprovou a Resolução n. 1.141/08, na qual estipula que no caso de arrendamento financeiro o bem arrendado deve ser incluído no ativo imobilizado da entidade arrendatária (item 20). Nesta mesma linha, a alteração da legislação do anonimato com o advento da Lei n. 11.638/07, que passou a incluir nesta classe de ativo aqueles decorrentes de operações que transfiram à companhia os benefícios, riscos e controle desses bens, sem que necessariamente haja a propriedade destes, incluindo claramente no imobilizado a hipótese do leasing financeiro.

${ }^{338}$ PEREIRA, Alexandre Demetrius. Regime jurídico da escrituração empresarial nas sociedades limitadas e anônimas. Dissertação de Mestrado. São Paulo: Universidade de São Paulo, 2008.
} 
alguma, hoje a atividade escritural exige cada vez mais a especialização de quem a pratica ou de quem a observa com as mais diversas finalidades.

Assim, há necessidade de que a escrituração se desenvolva tendo como base um processo científico que lhe dê validade e confiança, de modo que ela possa servir à sua finalidade precípua de se constituir em um sistema de informações sobre a atividade econômica da empresa para fins internos e externos.

Por tal motivo, desenvolveu-se durante séculos a metodologia científica contábil que, como vimos, teve grande incremento com a obra de Pacioli.

Obviamente, não serão tratados no presente trabalho todos os princípios e processos contábeis existentes, bastando por ora um breve panorama de sua existência.

De forma resumida, podemos dizer que a contabilidade separa os diversos aspectos da atividade empresarial em quatro grupos básicos de contas, inter-relacionados:

1) Ativo: que consubstancia os bens, créditos e demais direitos da empresa;

2) Passivo: que abrange as obrigações e dívidas da empresa;

3) Patrimônio líquido: resultante da diferença entre ativo e passivo;

4) Resultado: compreende as contas concernentes às receitas e despesas oriundas do exercício da atividade empresarial.

As contas de cada grupo acima têm, por convenção, uma forma específica de aumento e diminuição de seu montante, que apresentamos no quadro a seguir:

Tabela 21: Formas de aumento e diminuição entre as contas dos diversos grupos

\begin{tabular}{cl}
\hline Ativo & Aumenta a débito \\
\hline \multirow{2}{*}{ Passivo } & Reduz-se a crédito \\
\hline \multirow{2}{*}{ Patrimônio Líquido } & Aumenta a crédito \\
\hline \multirow{2}{*}{ Resultado } & Reduz-se a débito \\
\hline & Aumenta a crédito \\
\hline & Reduz-se a débito \\
\hline
\end{tabular}

A principal técnica revelada por Pacioli, chamada método das partidas dobradas, consiste no fato de que para qualquer operação econômica deverá haver, no 
mínimo, um lançamento contábil a débito e um congênere a crédito, em ao menos duas contas distintas, de modo que a soma do débito seja igual à do crédito.

\section{Exemplifiquemos:}

Suponhamos que uma sociedade decida adquirir à vista um novo imóvel para sua sede, pagando por ele $\mathrm{R} \$ 100.000,00$ (cem mil reais). Referido valor, se bem verificarmos, saiu do ativo da sociedade (caixa ou disponibilidades) e ingressou também no seu ativo, agora como ativo imobilizado (a sociedade "trocou" dinheiro por imóvel). Assim, deverá lançar o valor mencionado a crédito de caixa ou disponibilidades (contas de ativo diminuem seu valor a crédito), e o mesmo valor a débito na conta de imóveis (que aumentará pelo lançamento a débito).

O método das partidas dobradas trouxe inegável vantagem para as técnicas de escrituração empresarial, uma vez que permitiu ao empresário a visualização dos efeitos de cada lançamento na totalidade do patrimônio da empresa. Desta forma, muito embora sua descoberta já conte mais de quinhentos anos, ainda não foi substituído por outra técnica mais aperfeiçoada.

O contraposto do método das partidas dobradas é o método de partidas simples, no qual é utilizada uma única conta para que se lancem débitos e créditos sem correspondência ou igualdade entre ambos. É o caso do empresário que concentra em uma única conta os lançamentos referentes à movimentação de sua conta bancária ou as compras e pagamentos feitos por determinado cliente.

Apesar de o método de partida simples conter várias falhas por não demonstrar uma visão completa do patrimônio da empresa e de seus resultados, ele é utilizado em diversos tipos de escrituração, como é o caso do Livro Caixa, que veremos mais adiante.

Além de obedecer a certas técnicas ou métodos, a escrituração empresarial segue também diversos princípios contábeis. ${ }^{339}$

De acordo com a Resolução CFC n. 750/93, que dispõe sobre os Princípios Fundamentais (ou Gerais) de Contabilidade (PFC), estes são:

\footnotetext{
${ }^{339}$ Há certa divergência na doutrina contábil sobre o que se deve considerar como princípio, convenção ou postulado. Não entraremos nesta divergência, uma vez que entendemos não caber aqui o aprofundamento da questão.
} 
Tabela 22: Princípios gerais de contabilidade nos termos da Resolução CFC n. $\mathbf{7 5 0} / 93^{340}$

\begin{tabular}{|c|c|}
\hline Princípio & Descrição \\
\hline I) da ENTIDADE; & $\begin{array}{l}\text { O Princípio da ENTIDADE reconhece o Patrimônio como objeto da } \\
\text { Contabilidade e afirma a autonomia patrimonial, a necessidade da } \\
\text { diferenciação de um Patrimônio particular no universo dos } \\
\text { patrimônios existentes, independentemente de pertencer a uma pessoa, } \\
\text { um conjunto de pessoas, uma sociedade ou instituição de qualquer } \\
\text { natureza ou finalidade, com ou sem fins lucrativos. Por consequência, } \\
\text { nesta acepção, o Patrimônio não se confunde com aqueles dos seus } \\
\text { sócios ou proprietários, no caso de sociedade ou instituição. }\end{array}$ \\
\hline II) da CONTINUIDADE; ${ }^{341}$ & $\begin{array}{l}\text { A CONTINUIDADE ou não da ENTIDADE, bem como sua vida } \\
\text { definida ou provável, devem ser consideradas quando da classificação } \\
\text { e avaliação das mutaçães patrimoniais, quantitativas e qualitativas. A } \\
\text { CONTINUIDADE influencia o valor econômico dos ativos e, em muitos } \\
\text { casos, o valor ou o vencimento dos passivos, especialmente quando a } \\
\text { extinção da ENTIDADE tem prazo determinado, previsto ou previsível. } \\
\text { A observância do Princípio da CONTINUIDADE é indispensável à } \\
\text { correta aplicação do Princípio da COMPETÊNCIA, por efeito de se } \\
\text { relacionar diretamente à quantificação dos componentes patrimoniais } \\
\text { e à formação do resultado, e de constituir dado importante para aferir } \\
\text { a capacidade futura de geração de resultado. }\end{array}$ \\
\hline III) da OPORTUNIDADE; & $\begin{array}{l}\text { O Princípio da OPORTUNIDADE refere-se, simultaneamente, à } \\
\text { tempestividade e à integridade do registro do patrimônio e das suas } \\
\text { mutações, determinando que este seja feito de imediato e com a } \\
\text { extensão correta, independentemente das causas que as originaram. } \\
\text { Como resultado da observância do Princípio da OPORTUNIDADE: I- } \\
\text { desde que tecnicamente estimável, o registro das variaçôes } \\
\text { patrimoniais deve ser feito mesmo na hipótese de somente existir } \\
\text { razoável certeza de sua ocorrência; II - o registro compreende os } \\
\text { elementos quantitativos e qualitativos, contemplando os aspectos } \\
\text { físicos e monetários;III - o registro deve ensejar o reconhecimento } \\
\text { universal das variaçôes ocorridas no patrimônio da ENTIDADE, em } \\
\text { um perído de tempo determinado, base necessária para gerar } \\
\text { informações úteis ao processo decisório da gestão. }\end{array}$ \\
\hline $\begin{array}{l}\text { IV) do REGISTRO PELO VALOR } \\
\text { ORIGINAL; }\end{array}$ & 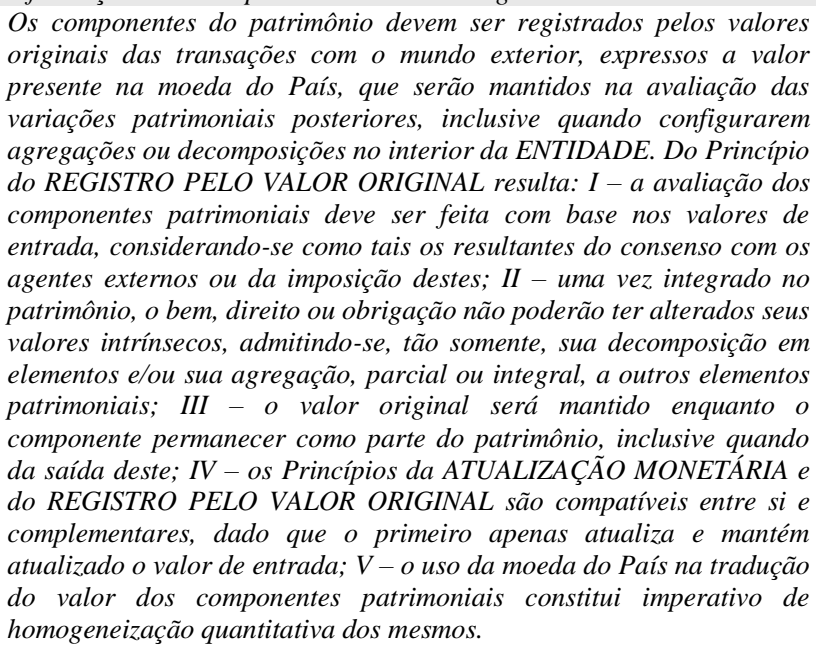 \\
\hline
\end{tabular}

\footnotetext{
${ }^{340}$ Referidos princípios também fazem parte de outras normas que definiram estruturas conceituais básicas de contabilidade, como na Deliberação CVM n 29, de 05 de fevereiro de 1986 (revogada posteriormente pela Deliberação CVM no 539, de 14 de março de 2008) e na estrutura conceitual do IASB.

${ }^{341} \mathrm{O}$ princípio da continuidade, juntamente com o princípio da prudência, é também adotado no art. 2.423 do Código Civil Italiano: "la valutazione delle voci deve essere fatta secondo prudenza e nella prospettiva della continuazione dell'attività".
} 


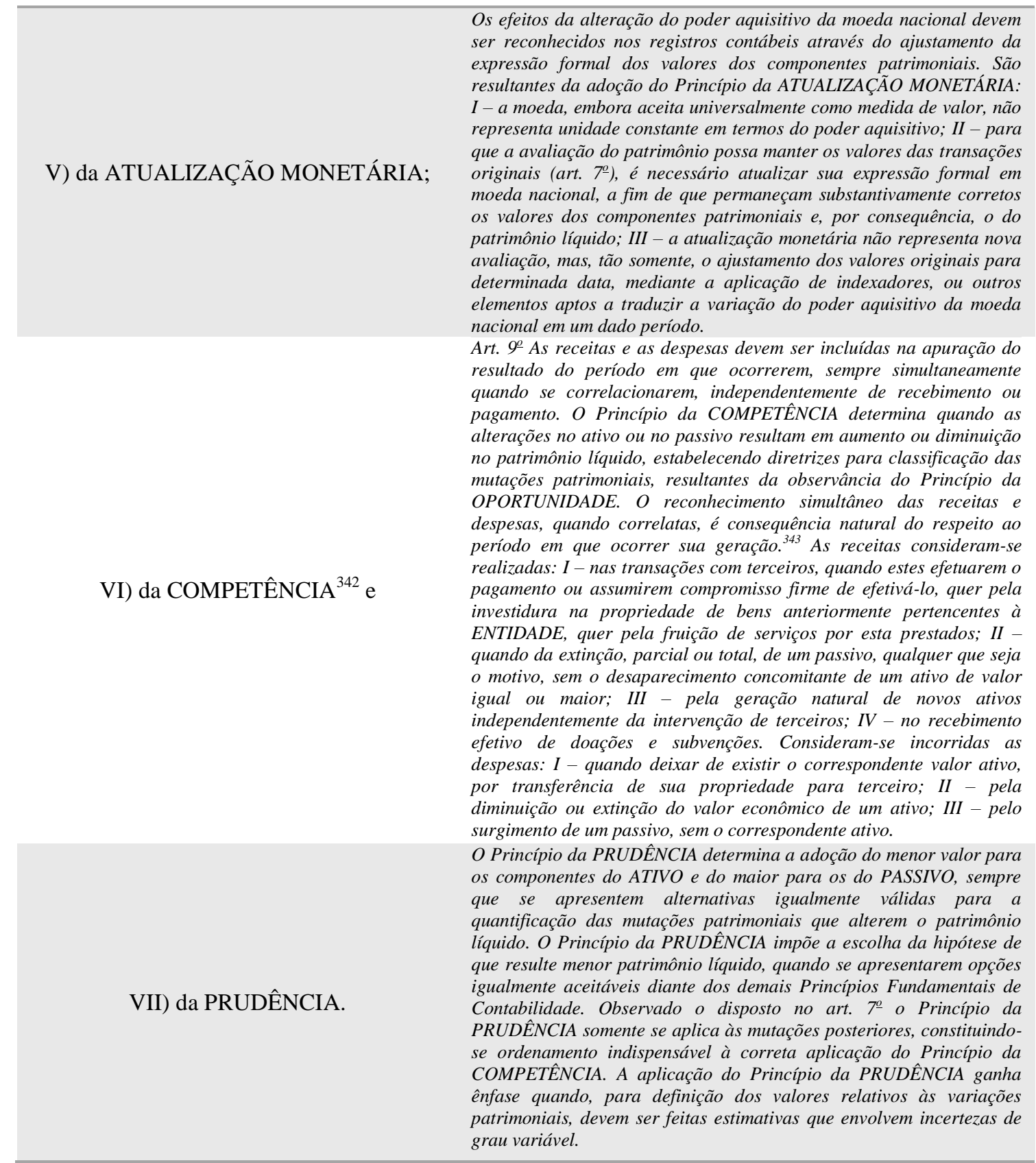

O auditor deve buscar os fundamentos das declarações existentes nas demonstrações contábeis junto à escrituração da qual foram originadas. Usualmente, a escrituração encontra-se presente em livros, fichas ou arquivos informatizados da entidade auditada. Independente da forma utilizada (meio físico ou magnético), as mais frequentes formas de escrituração são exemplificadas a seguir:

\footnotetext{
${ }^{342}$ Também o art. 2.423 do Código Civil italiano adota o princípio da competência: "si deve tener conto dei proventi e degli oneri di competenza dell'esercizio, indipendentemente dalla data dell'incasso o del pagamento".

${ }^{43}$ Há casos especiais referidos nas normas internacionais de contabilidade (IFRS) que não correspondem estritamente ao princípio da correlação entre receitas e despesas. Exemplo disso são os contratos de construção de longo prazo em que usualmente a receita é reconhecida em termos percentuais à conclusão de obra ou aos custos incorridos.
} 
Tabela 23: Meios utilizados para a escrituração

\begin{tabular}{|c|c|}
\hline Meio de escrituração & Conteúdo e forma \\
\hline Livro Diário & $\begin{array}{l}\text { Único livro obrigatório para todos os empresários (com a exceção do } \\
\text { pequeno empresário individual), consubstancia lançamentos, dia a } \\
\text { dia, }{ }^{344} \text { dos atos ou operações da atividade realizada pela entidade, bem } \\
\text { como daqueles fatos que modifiquem ou possam vir a modificar a } \\
\text { situação patrimonial do empresário. Excepcionalmente, os lançamentos } \\
\text { no Diário podem ser somente dos saldos mensais (no caso de contas } \\
\text { cujas operações sejam numerosas ou realizadas fora da sede do } \\
\text { estabelecimento). Neste caso, entretanto, deverão ser escriturados } \\
\text { livros auxiliares destinados à escrita das transações correspondentes } \\
\text { efetuadas no mês. }\end{array}$ \\
\hline Livro Razão (Razão Analítico) & $\begin{array}{l}\text { Retrata os lançamentos contábeis organizando-os não mais pela ordem } \\
\text { cronológica dos lançamentos (como ocorre no Livro Diário), mas tendo } \\
\text { por base as contas que foram utilizadas para consubstanciá-los. É uma } \\
\text { das ferramentas mais importantes ao auditor para a verificação da } \\
\text { correção da escrituração das operações econômicas, possibilitando } \\
\text { vários dos testes substantivos ou de detalhes. }\end{array}$ \\
\hline Livro Caixa & $\begin{array}{l}\text { O Livro Caixa é, na verdade, uma especialização do Razão, que } \\
\text { registra o que se denomina contabilmente disponível ou } \\
\text { disponibilidades, que consiste nos ativos de liquidez imediata, ou seja, } \\
\text { quantias em dinheiro de posse do empresário ou aplicações financeiras } \\
\text { com tais características. Para os fins da escrituração mercantil, trata- } \\
\text { se de mero livro auxiliar, ao qual não está obrigado o empresário. No } \\
\text { entanto, sua utilização se difundiu diante da possibilidade, advinda com } \\
\text { a legislação que regula o imposto de renda, de alguns empresários } \\
\text { substituírem a escrituração completa pela escrituração do livro Caixa. }\end{array}$ \\
\hline Livro Registro de Inventário & $\begin{array}{l}\text { O objetivo de referido livro é arrolar os diversos bens em estoque } \\
\text { (mercadorias, matérias-primas, produtos intermediários, materiais de } \\
\text { embalagem, produtos manufaturados ou em fabricação, etc.) existentes } \\
\text { em data determinada (via de regra, a data de fechamento do balanço), } \\
\text { com determinação de seus valores e identificação especificada de seu } \\
\text { conteúdo. }{ }^{345}\end{array}$ \\
\hline
\end{tabular}

(continua)

\footnotetext{
${ }^{344}$ A exigência de lançamentos dia a dia também consta do art. 2.216 do Código Civil italiano, segundo o qual "Il libro giornale deve indicare giorno per giorno le operazioni relative all'esercizio dell'impresa".

${ }^{345}$ No direito italiano, o livro de inventários tem propósito maior, uma vez que não cuida somente do estoque de bens, mas de todos os ativos e passivos do empresário. Abrangendo todo o patrimônio da empresa, serve referido livro como fundamento para a elaboração do balanço e da conta de lucros e perdas. Isso é o que consta do art. 2.217 do Código Civil Italiano: "Redazione dell'inventario. L'inventario deve redigersi all'inizio dell'esercizio dell'impresa e successivamente ogni anno, e deve contenere l'indicazione e la valutazione delle attività e delle passività relative all'impresa, nonché delle attività e delle passività dell'imprenditore estranee alla medesima. L'inventario si chiude con il bilancio e con il conto dei profitti e delle perdite, il quale deve dimostrare con evidenza e verità gli utili conseguiti o le perdite subite. Nelle valutazioni di bilancio l'imprenditore deve attenersi ai criteri stabiliti per i bilanci delle società per azioni, in quanto applicabili (2425). L'inventario deve essere sottoscritto dall'imprenditore entro tre mesi dal termine per la presentazione della dichiarazione dei redditi ai fini delle imposte dirette".
} 


\begin{tabular}{cl}
\hline Livro de Apuração do Lucro Real & $\begin{array}{l}\text { Cuida-se de um livro fiscal, obrigatório para as entidades que apuram } \\
\text { o imposto sobre a renda sob o regime de lucro real. Contém as } \\
\text { particularidades referentes a lançamentos dessa modalidade tributária. }\end{array}$ \\
Livrigatório para as entidades que emitem duplicatas. Como o Livro \\
Caixa, é uma especialização do Livro Razão, escriturado mediante \\
partidas simples. \\
Outros livros fiscais, como os de registros de entrada e saída de \\
impostos de circulação de mercadorias e serviços, podem ter relevância \\
no trabalho de auditoria.
\end{tabular}

\subsection{Natureza jurídica das demonstrações contábeis}

Diverge-se, sob o ponto de vista jurídico, quanto à natureza jurídica das demonstrações contábeis. O ponto principal de divergência encontra-se em saber se consubstanciam uma declaração de mera ciência (mero ato material) ou se encerram uma declaração de vontade (ato ou negócio jurídico declaratório).

Tullio Ascarelli entende tratar-se de negócio jurídico declaratório, assim opinando:

Juridicamente, constitui, o balanço (ou, melhor, a deliberação assemblear que o aprova) um negócio declaratório, que visa simultaneamente a determinados fatos e às consequências que deles decorrem à vista das regras jurídicas aplicáveis: visa, com efeito, o balanço, a verificar o ativo e o passivo da sociedade, à vista da gestão do exercício; os lucros (ou as perdas) realizadas; os lucros distribuíveis. ${ }^{346}$

\footnotetext{
${ }^{346}$ ASCARELLI, Tullio. Problemas das sociedades anônimas e direito comparado. São Paulo: Quorum, 2008. p. 604. Sustentando esta posição, o renomado autor ainda ressalta não se tratar de mero ato material de ciência: "E não apenas uma declaração de ciência. Cf. sobre o negócio declaratório, em geral, o que escrevi em Teoria Geral dos Títulos de Crédito, São Paulo, 1943, pp. 163 ss.; sobre o balanço, o que escrevi em Appunti di Diritto Commerciale, vol. II, p. 261, 3. ed., Roma, 1936 (análoga parece a orientação de Messineo, Foro Italiano, 1938; I, 1.427, que, entretanto, não pude consultar, e de De Gregorio, n. 411). A aprovação do balanço é, de um lado, o pressuposto para que se aperfeiçoe o direito do acionista à distribuição do lucro do exercício; de outro lado, enquanto não seja anulado, deverá, o balanço, ser atendido na disciplina jurídica das relações sociais que respeitam ao exercício ao qual se refere (disto ressaltando o caráter negocial da deliberação que o aprova, apesar da declaratoriedade da sua função); não representa, entretanto, diretamente, o fato constitutivo dos direitos e das obrigações respectivas e não pode prevalecer sobre as relações jurídicas que lhe cabe declarar. Com efeito, é indubitável o direito, quer do acionista de impugnar o balanço irregular impugnando a respectiva deliberação assemblear e pedindo, então, à autoridade judiciária a verificação dos lucros e do ativo e passivo social, quer da assembleia de retificar o balanço anteriormente aprovado, quando inexato (cf. De Gregorio, op. cit., n. 411-bis)".
} 
Segundo a magistral lição do Prof. Fábio Konder Comparato, cuida-se de um ato jurídico, e não de um ato meramente material:

O balanço é um ato jurídico e não simples ato material. De balanço, a rigor, só se pode falar depois que o titular do patrimônio balanceado pessoa física ou jurídica - o aprova, obedecidas as formalidades legais. Antes disso, o que há é um projeto ou uma minuta de balanço, sem valor contábil ou existência jurídica. Em se tratando de sociedade anônima, balanço haverá tão só depois que a assembleia geral de acionistas regularmente convocada e instalada - delibera sua aprovação. Trata-se, aliás, no Direito brasileiro, de um dos atos de competência privativa daquele órgão societário. ${ }^{347}$

Traz ainda a lume a divergência doutrinária supracitada, com a propriedade que lhe é peculiar, Marcelo Vieira Von Adamek:

Ainda hoje se discute se a aprovação do balanço (e demais demonstrações financeiras) seria mera declaração de ciência (ou conhecimento) ou, então, se seria ato dispositivo (com função constitutiva e conteúdo negocial) (...). Na Itália, a questão vem sendo exaustivamente estudada pelos juristas peninsulares, mas até hoje grassa profunda dissidência. $\mathrm{O}$ Código Comercial de 1882, em seu art. 154, previa expressamente que a assembleia geral tinha poderes para "discutir, aprovar ou modificar o balanço". O Código Civil de 1942, porém, silencia a propósito do poder de introduzir modificações - refere-se no art. 2.364 à possibilidade de aprovar (ou não) o balanço - e, à vista disso, os estudiosos dividem-se entre os que entendem que a assembleia geral poderia aprovar ou recusar o balanço, sem nele introduzir modificações, e outros sustentam que, mesmo à falta de expressa menção na lei, a assembleia geral continuaria habilitada a modificar o balanço (neste último sentido, vide, por todos: GiovanNNI E. COLOMBO, Il bilancio di esercizio delle società per azioni, cit., n. 90, pp. 329-330). Assim, para os partidários da primeira visão, a aprovação do balanço seria ato de ciência e, para os da segunda, ato de cunho dispositivo. FRANCESCO GALGANO, por exemplo, entende que a assembleia poderia aprovar ou rejeitar o balanço, sem lhe ser permitido adotar uma diversa política de balanço. E, de forma coerente com essa visão, sustenta que a correlata deliberação compreenderia declaração de 
conhecimento (La società per azioni. In: Trattato di diritto commerciale e di diritto pubblico dell'economia - diretto da FRANCESCO GALGANO, 2. ed., Padova: CEDAM, 1988, v. 7, n. 5, p. 338, e II nuovo diritto societário. In: Trattato di diritto commerciale e di diritto pubblico dell'economia - diretto da FRANCESCO GALGANO, Padova: CEDAM, 2003 , v. 29, n. 5, p. 332) e alude à posição ainda mais extremada de LIBONATI, autor da tese "segundo a qual o balanço permanece ato dos administradores e não se torna o conteúdo da deliberação assemblear de aprovação, a qual opera somente como uma condição de eficácia". Semelhantes concepções são expressamente repelidas por GASTONE CotTino, que, invocando argumento válido perante a nossa lei acionária (LSA, art. 134, § $4^{\circ}$ ), aponta motivo ponderoso para se reconhecer à deliberação de aprovação caráter dispositivo, "quando a assembleia estabeleça introduzir no projeto variantes, como considera possível a doutrina dominante (COlOMbo, Rossi, Pettiti, De Gregorio, Frè, FERRARA-CORSI, GRECO, GRAZIANI, Di SABATO, FortunAto; mas v. Ferri, Galgano, Libonati, CAVAllo Borgia)" (Diritto commerciale, cit., v. 1, t. 2: Lê società, n. 140, p. 501). Igual posição foi defendida por DE GREGORIO (I bilanci delle società anonime, Milano, 1908, p. 69). ${ }^{348}$

Embora as opiniões doutrinárias supracitadas somente se refiram a uma das demonstrações contábeis, qual seja, o balanço patrimonial, entendemos que seu conteúdo é aplicável à natureza jurídica das demais demonstrações.

Sobre isto, parece-nos que a razão está com a maioria que sustenta que as demonstrações são atos negociais de natureza declaratória, e não mera manifestação de ciência pelos acionistas do conteúdo econômico dos atos praticados pela administração.

É certo que os efeitos jurídicos derivados da aprovação das demonstrações, como a fixação dos lucros ou dividendos devidos aos sócios ou acionistas, bem como a capacidade de a assembleia modificar os termos em que as demonstrações foram apresentadas pela gestão, conferem claro caráter declaratório negocial ao ato praticado, e não mero assentimento assemblear. ${ }^{349}$

${ }^{347}$ COMPARATO, Fábio Konder. Natureza jurídica do balanço. Ensaios e pareceres de direito empresarial. Rio de Janeiro: Forense, 1978. p. 29.

348 ADAMEK, Marcelo Vieira Von. Responsabilidade civil dos administradores de S/A e ações correlatas. São Paulo: Saraiva, 2009. p. 258.

${ }^{349}$ A CVM parece também adotar esta mesma orientação, quando, no Parecer de Orientação n. 16, de 17 de novembro de 1988, ressaltou: “a deliberação da assembleia geral ordinária de aprovar o balanço apresentado 


\subsection{Balanço patrimonial (BP)}

De acordo com a Resolução CFC n. 847/99, que aprovou a Norma Brasileira de Contabilidade NBC-T3, balanço patrimonial é a demonstração contábil destinada a evidenciar, qualitativa e quantitativamente, numa determinada data, o patrimônio e o patrimônio líquido da entidade.

Desta forma, o balanço traz em seu conteúdo os valores correspondentes ao saldo dos lançamentos efetuados a título de ativo, passivo e patrimônio líquido (este último definido pela diferença dos dois primeiros). Ademais, o balanço reflete, no patrimônio líquido, a conta de lucros e prejuízos acumulados ${ }^{350}$ que, consubstanciando o valor final das contas de resultado (receitas e despesas), constitui-se numa espécie de "ponte" ou "ligação" entre o balanço patrimonial (BP) e a demonstração de resultado do exercício (DRE).

Por praticidade e tradição, o balanço é muitas vezes apresentado graficamente com as contas do ativo à esquerda do relatório, enquanto as representativas do passivo remanescem na parte superior direita e as de patrimônio líquido na parte inferior direita, na forma ilustrada a seguir.

pelos administradores constitui-se em autêntica declaração de vontade, e não simples declaração de ciência. Seus efeitos operam ex tunc, a partir do momento em que se deu o ato ao qual se vincula a declaração de vontade".

${ }^{350}$ A chamada conta de "lucros e prejuízos acumulados", após a superveniência da Lei n. 11.638/07, passou a ser denominada, na contabilidade das sociedades anônimas, somente de "prejuízos acumulados", uma vez que o lucro deve ter outra destinação (p.ex.: composição de reservas, distribuição, capitalização, etc.) ao invés de sua manutenção de forma retida nesta conta. Como este trabalho não abrange somente as companhias, mantivemos no texto a denominação original. 
Figura 7: Forma gráfica usual de representação do balanço patrimonial

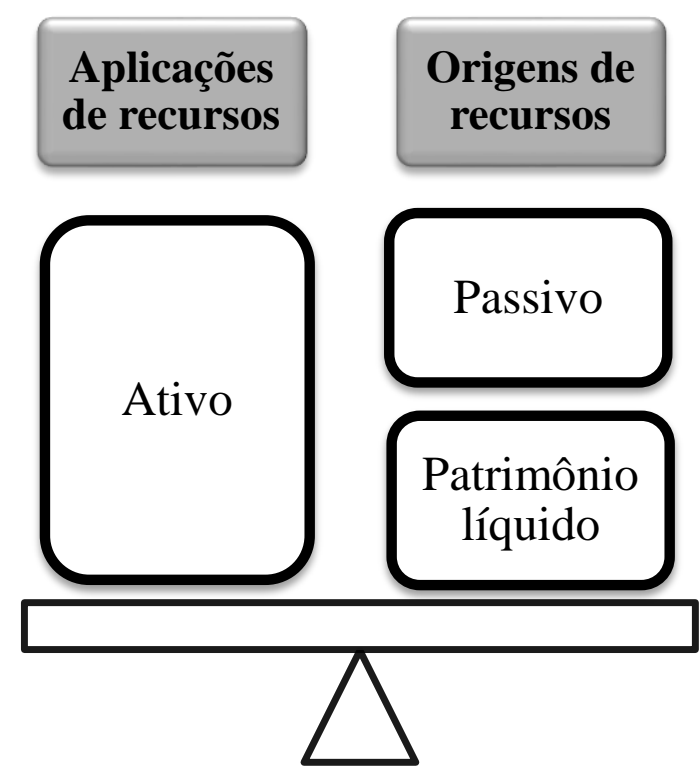

Esta forma gráfica traz o benefício de permitir a melhor visualização do patrimônio líquido, uma vez que este se constitui da diferença ou subtração entre o ativo e o passivo. Não se trata, porém, de forma obrigatória, sendo comuns as publicações que trazem tais agrupamentos em forma vertical, ou mesmo aquelas que unificam passivo e patrimônio líquido.

A forma aludida também traz a vantagem de facilitar a compreensão de que o lado direito do balanço, formado pelo passivo e o patrimônio líquido, consubstancia origens de recursos (de terceiros ou próprias), e o lado esquerdo, representado pelo ativo, encerra as aplicações de recursos, oriundas do passivo e do patrimônio líquido.

Além do saldo dos lançamentos em cada rubrica, o balanço traz em si uma organização interna, consistente na classificação das contas em determinados subgrupos, seguindo alguns critérios, como se verifica na figura seguinte. 
Figura 8: Critérios de organização interna das contas do balanço patrimonial ${ }^{351}$

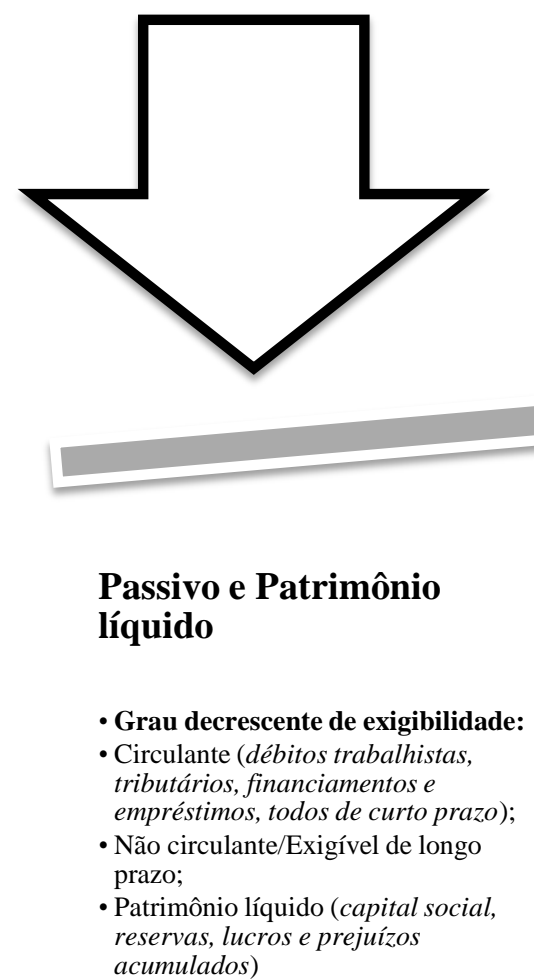

\section{Ativo}

- Grau decrescente de liquidez:

- Circulante (caixa, aplicações

financeiras, estoques, etc.).

- Não circulante

- realizável a longo prazo;

- permanente (investimentos,

intangível, imobilizado)

\section{Passivo e Patrimônio líquido \\ - Grau decrescente de exigibilidade: \\ - Circulante (débitos trabalhistas. \\ Patrimônio líquido (capital social acumulados)}

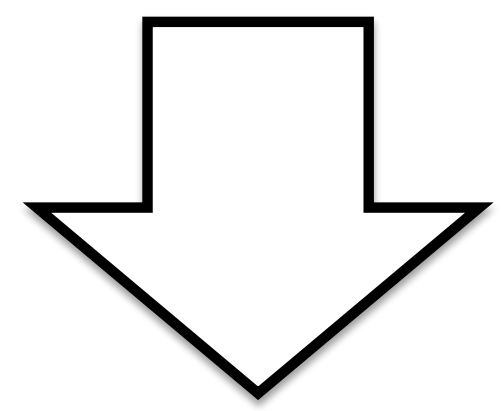

Passaremos a verificar como o auditor deve realizar suas tarefas em relação aos elementos do balanço patrimonial.

\subsubsection{Auditoria de ativo}

Entende-se por ativo, em contabilidade, o feixe de bens, créditos e outros direitos de que a entidade é titular ou, como visto anteriormente, o ativo pode ser compreendido como as aplicações conferidas ao montante de financiamento obtido pela entidade.

\footnotetext{
${ }^{351}$ Este critério não é unânime no Direito Comparado. O Código Civil italiano, por exemplo, classifica o ativo iniciando com os créditos dos sócios e o imobilizado (immobilizzazioni), terminando com as disponibilidades líquidas (disponibilità liquide) no ativo circulante.
} 
Duas são as características de um ativo: 1) deve ser controlado pela entidade; 2) deve gerar a expectativa de recebimento de benefícios futuros ao titular.

Conforme lecionam Neves e Viceconti, os bens e direitos representados pelo ativo compreendem: ${ }^{352}$

- Bens Numerários: são os bens de liquidez imediata, constituindo o disponivel da empresa: dinheiro em espécie, depósitos bancários e aplicações financeiras de liquidez imediata (Fundo de Investimento Financeiro, por exemplo);

- Bens de Venda: são aqueles destinados à venda pela sociedade e que constituem o objeto de seu negócio. No caso de empresas industriais, são constituídos pelos estoques de produtos em elaboração e pelo de produtos acabados. Segundo Hilário Franco, alguns autores consideram os estoques de matérias-primas (ou de material direto ou indireto) como bens de venda pois, embora sua finalidade não seja a de ser vendidos, integram direta ou indiretamente o produto a ser vendido. Outros autores preferem classificá-los como bens circulantes, por não serem fixos (renovam-se constantemente);

- Bens Fixos: são aqueles de caráter permanente ou quase permanente, que constituem os meios de produção da empresa, servindo a vários ciclos produtivos. Também são conhecidos como bens de uso. Estão neste grupo: Imóveis destinados às instalações do estabelecimento industrial (terrenos e edifícios). Máquinas e Equipamentos; Instalações, ferramentas e aparelhos. Veículos, Móveis e Utensílios. São geralmente classificados no Ativo Imobilizado;

- Bens de Renda: são aqueles adquiridos com a finalidade de produzir renda para a sociedade e que não estão diretamente ligados a sua atividade. Exemplos: participações societárias de caráter permanente ou temporário, aplicações financeiras de liquidez não imediata, tais como CDBs, fundos de renda fixa, ouro, debêntures, etc., imóveis para alugar;

- Créditos de Funcionamento: valores a receber decorrentes da própria atividade da empresa. Exemplo: contas a receber, duplicatas a receber, etc.;

\footnotetext{
${ }^{352}$ NEVES, Silvério das; VICECONTI, Paulo Eduardo Vilchez. Contabilidade de custos: um enfoque direto
} e objetivo. São Paulo: Frase, 2000. p. 1. 
- Créditos de Financiamento: valores a receber de prazo mais longo decorrentes de financiamentos a terceiros e que não são relacionados com o objeto da atividade da empresa. Exemplo: Empréstimos Compulsórios à União;

- Valores Imateriais: bens não tangíveis que figuram no ativo, tais como marcas e patentes, despesas pré-operacionais, gastos com reorganização administrativa, etc.

Como salientamos, costuma-se classificar os componentes do ativo em ordem decrescente de liquidez. Este critério de classificação é adotado na Lei n. 6.404/76, em seu art. $179,{ }^{353}$ com redação das Lei ns. 11.638/07 e 11.941/09. ${ }^{354}$

Passaremos a verificar a atuação do auditor com relação a cada espécie de classificação de ativo.

\subsubsection{Ativo circulante}

Denominam-se circulantes os componentes do ativo de uma entidade que servem prioritariamente a seu giro econômico ou ciclo de vendas, como se representa na figura seguinte.

\footnotetext{
353 “Art. 179. As contas serão classificadas do seguinte modo: I - no ativo circulante: as disponibilidades, os direitos realizáveis no curso do exercício social subsequente e as aplicações de recursos em despesas do exercício seguinte; II - no ativo realizável a longo prazo: os direitos realizáveis após o término do exercício seguinte, assim como os derivados de vendas, adiantamentos ou empréstimos a sociedades coligadas ou controladas (artigo 243), diretores, acionistas ou participantes no lucro da companhia, que não constituírem negócios usuais na exploração do objeto da companhia; III - em investimentos: as participações permanentes em outras sociedades e os direitos de qualquer natureza, não classificáveis no ativo circulante, e que não se destinem à manutenção da atividade da companhia ou da empresa; IV - no ativo imobilizado: os direitos que tenham por objeto bens corpóreos destinados à manutenção das atividades da companhia ou da empresa ou exercidos com essa finalidade, inclusive os decorrentes de operações que transfiram à companhia os benefícios, riscos e controle desses bens; (Redação dada pela Lei n. 11.638, de 2007); VI - no intangível: os direitos que tenham por objeto bens incorpóreos destinados à manutenção da companhia ou exercidos com essa finalidade, inclusive o fundo de comércio adquirido. (Incluído pela Lei n. 11.638, de 2007)."

${ }^{354}$ A redação da Lei n. 11.638/07 acompanhou o que já preconizava a deliberação da CVM n. 488, de 3 de outubro de 2005, que classificava o ativo tão somente em circulante e não circulante, sendo que este último deveria ser desdobrado em ativo realizável a longo prazo, investimentos, ativo imobilizado, ativo intangível e ativo diferido (este último já banido da classificação contábil das companhias, por efeito da Lei $\mathrm{n}$. 11.941/09). A mesma classificação é dada para o passivo.
} 
Figura 9: Giro econômico usual e contas utilizadas para registro

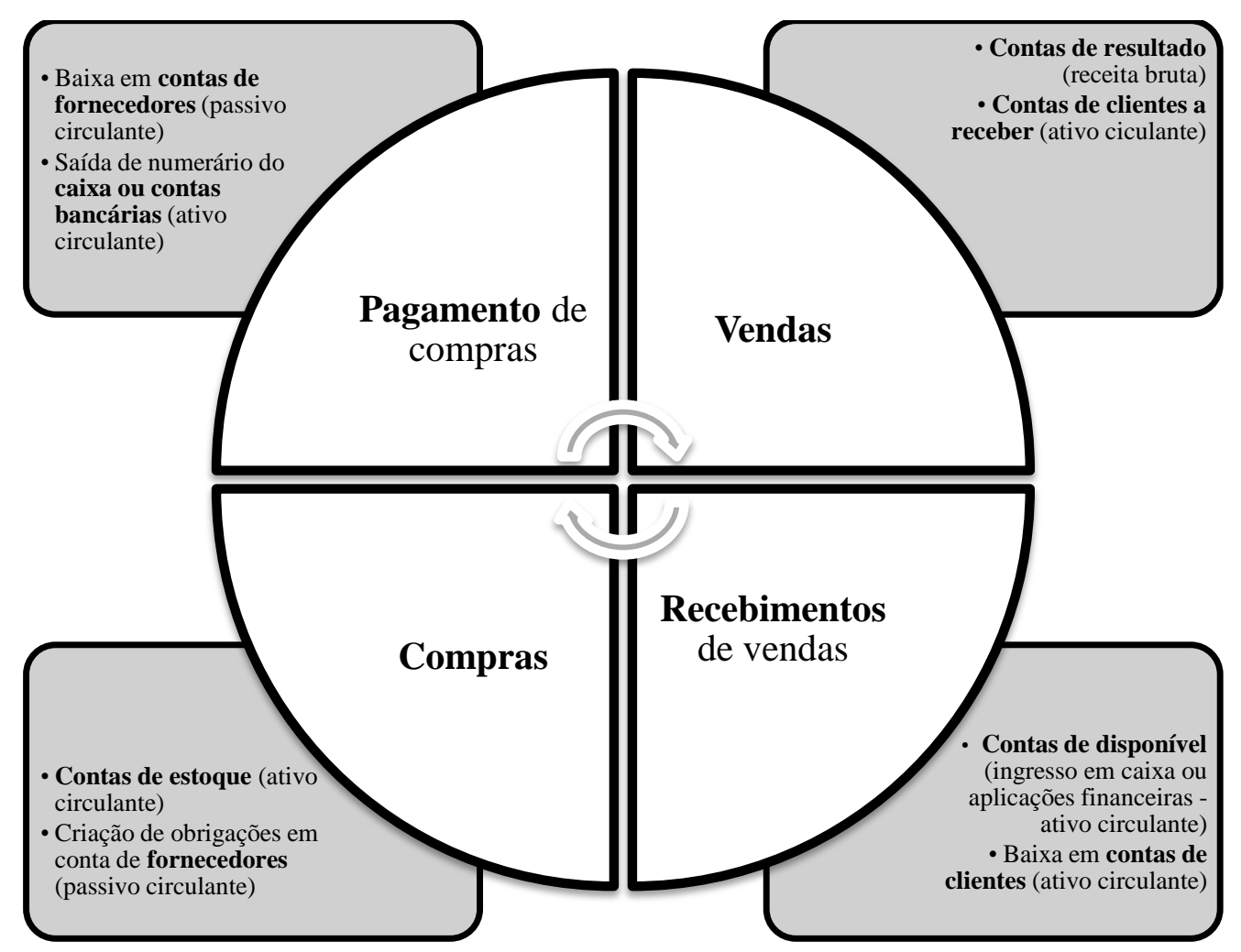

Ao auditor cabe uma série de providências em relação ao ativo circulante.

No que diz respeito às contas que representam maior liquidez, tais como as contas de caixa e aplicações financeiras (o chamado disponível ou disponibilidades), deve o auditor inicialmente verificar se os valores existem fisicamente e se estão corretamente avaliados. Assim, poderá proceder a contagem do caixa, em companhia de um representante da entidade, restituindo seu valor e documentando todo o procedimento, com a devida subscrição do representante no documento, por medida de segurança. Poderá ainda confirmar, mediante documentação bancária, os saldos existentes nas respectivas instituições financeiras.

Não há maiores problemas de avaliação quanto ao caixa, uma vez que este consiste em valores em moeda. No entanto, pode haver nuances no tocante às aplicações financeiras, uma vez que as cifras presentes nas demonstrações contábeis podem não coincidir com os valores dos extratos (p.ex.: pode haver juros, despesas e outros lançamentos presentes nos extratos, mas não efetuados na escrituração). Para tanto, o 
auditor pode realizar as devidas conciliações bancárias para sua verificação ou pode, ainda, lançar mão de circularizações ou confirmações diretamente às instituições financeiras responsáveis.

Deve também o auditor preocupar-se com a correta classificação do disponível. É fato corriqueiro entidades manterem títulos de crédito de recebimento em curto prazo como se disponível fosse. Outrossim, pode haver valores de aplicações financeiras que não possam ser classificados no ativo circulante, uma vez que seu recebimento somente se dará em longo prazo.

Em relação à integridade do disponível, o auditor deve verificar, se possível e desejável, sua origem, ou seja, qual a fonte do caixa ou das aplicações financeiras existentes (empréstimos, lucro da entidade, financiamento por aumento de capital, etc.).

Com relação às contas a receber (clientes, duplicatas a receber, etc.), há também vários aspectos importantes que devem ser observados. Primeiramente o auditor deve confirmar sua existência e integridade pelo exame de documentos idôneos ou, se necessário, por meio de circularizações ou confirmações diretamente com os devedores. Deve ainda verificar sua avaliação, principalmente em relação à apropriação de juros e demais encargos, que pode ter sido majorada ou minorada conforme a hipótese.

O auditor deve verificar se as contas a receber estão devidamente classificadas e apresentadas no ativo circulante, analisando a existência de créditos que possam vencer em prazo posterior ao ano seguinte do fechamento do exercício ao qual o balanço se refere (exame de data de vencimento), ou que possam ser classificados como incobráveis, devendo ser baixados como despesas.

Frequentemente as contas a receber possuem atreladas a si uma ou algumas contas retificadoras, consistentes em provisões para inadimplência (créditos de liquidação duvidosa). Cuida-se de estimativa contábil, para a qual o auditor deverá verificar os critérios utilizados pela administração, seus valores, os riscos de distorções existentes, entre outros procedimentos. ${ }^{355}$

Outro ponto que merece atenção do auditor em relação ao ativo refere-se aos estoques de mercadorias, que também fazem parte do ativo circulante.

O auditor deve se certificar de que os estoques existem, através de inspeção ou contagem física (inventário), o que pode ser feito por amostragem se o estoque contar com 
número muito grande de itens. Deve também verificar se este é de propriedade da empresa (integridade) através da inspeção dos documentos respectivos, ${ }^{356}$ com atenção para a possibilidade de haver estoque de terceiros em posse da entidade auditada.

Do mesmo modo, deve inspecionar se o estoque se encontra corretamente avaliado, verificando os valores de custo, de mercado e de liquidação, aplicando-os conforme o caso. Deve ainda verificar se os critérios de baixa do estoque ${ }^{357}$ pelas vendas foram aplicados uniforme e corretamente.

É importante também que o auditor verifique se os bens apresentados como estoque estão corretamente classificados, pois não é incomum encontrar-se sob esta rubrica itens que não se destinam à venda imediata, mas sim a permanecer à disposição da entidade no curso de sua atividade econômica, os quais deveriam ser classificados no ativo permanente.

Podem estar inseridas dentro do ativo circulante contas de despesas antecipadas (p.ex.: aluguéis e seguros pagos antecipadamente cujo prazo de fruição se dará posteriormente). ${ }^{358}$ Neste caso, deve o auditor verificar a existência e integridade dessas despesas através de exame dos documentos que lhes deram origem (apólices, contratos de aluguel, etc.), e, principalmente, a correta classificação e apresentação, uma vez que não é incomum a utilização deste tipo de conta para manter no ativo despesas que deveriam ser transferidas a contas de resultado, afetando negativamente o lucro do período. Além disso,

\footnotetext{
${ }^{355}$ A auditoria de estimativas contábeis é regulada pela Res. CFC 1.223/09.

${ }^{356}$ É importante também que o auditor verifique nos documentos referentes aos estoques de matérias primas e demais produtos, se for o caso, os respectivos valores de creditamento tributário (p.ex., de ICMS e IPI), bem como a idoneidade do fornecedor da mercadoria (decorrente principalmente da inscrição deste perante os órgãos fazendários). $\mathrm{O}$ creditamento indevido ou de valores maiores que o permitido, como se sabe, pode gerar importantes distorções nas demonstrações contábeis. Caso isso seja percebido pelo auditor, deverá este avaliar os reflexos dessa prática em termos de relevância da distorção e, se for o caso, ressalvar seu parecer.

${ }^{357}$ Para a baixa de estoques, foram criados alguns critérios contábeis, sendo os principais: 1) PEPS ou FIFO (primeiro que entra é o primeiro que sai ou first in first out): a entidade dará baixa em seu estoque pelas vendas utilizando o custo de aquisição dos primeiros lotes adquiridos em estoque; 2) UEPS ou LIFO (último que entra é o primeiro que sai ou last in first out): a entidade dará baixa em seu estoque pelas vendas utilizando o custo de aquisição dos últimos lotes adquiridos em estoque (este critério usualmente não é aceito pelas normas nacionais atinentes à matéria); 3) Média ponderada móvel: a entidade dará baixa em seu estoque pela venda utilizando o preço médio ponderado, calculado pela razão entre o custo total dos estoques e seu número de unidades.

358 Exemplifique-se: suponhamos um caso concreto em que a entidade venha a contratar um seguro de automóvel no início do exercício, pelo prazo de um ano, adiantando à seguradora todo o pagamento do período. Na verdade, nesta hipótese a empresa adquiriu um direito de usufruir o seguro contratado pelo pagamento antecipado. Por outro lado, não seria próprio reconhecer no resultado uma despesa pelo pagamento, uma vez que não houve a contrapartida de receita (a empresa não usou totalmente o direito consistente no seguro contratado). Deve-se, assim, manter o valor retirado das disponibilidades da empresa (caixa, aplicações, etc.) em conta de ativo (p.ex.: "despesas antecipadas"), para que, com o passar do tempo e consequente utilização do objeto do contrato de seguro, sejam as despesas paulatinamente transferidas para o resultado.
} 
deverá verificar a compatibilidade dos valores apontados com aqueles praticados no mercado.

\subsubsection{Ativo não circulante}

O ativo não circulante é composto pelo ativo realizável a longo prazo, investimentos, imobilizado e intangível. ${ }^{359}$

O ativo realizável de longo prazo não guarda qualquer distinção de essência com o ativo circulante. Possui a mesma estrutura de contas. A distinção entre ambos operase tão somente em relação ao prazo de realização do bem ou direito respectivo. ${ }^{360}$

Assim, poderão constar do ativo realizável a longo prazo aplicações financeiras com resgate a longo prazo ou vinculadas a pagamentos de empréstimos de longo prazo. Do mesmo modo, contas a receber no longo prazo, incluindo suas provisões para devedores duvidosos, podem constar neste tópico.

Desta forma, o mesmo tipo de atuação do auditor, conforme anteriormente aludida, é esperada em relação a esta espécie de ativo, com a distinção de que deverá ter atenção à devida classificação dos bens e direitos que compõem o ativo de longo prazo. Além disso, deverá o auditor verificar, conforme a hipótese, se na avaliação do ativo de longo prazo a entidade aplicou critérios de redução a valor presente (art. 183, VIII, da Lei n. 6.404/76).

\footnotetext{
359 Antigamente, classificava-se dentro do não circulante o ativo diferido, que se compunha em sua maioria de gastos pré-operacionais, gastos com projetos de pesquisa e desenvolvimento que ainda não tinham resultado em receitas, entre outros. A partir da vigência da Lei n. 11.941/09, entretanto, tal classificação foi banida do balanço das companhias. Um grande problema que a rubrica gerava era a abertura para fraudes, uma vez que permitia que se mantivessem despesas no ativo, sem transferi-las ao resultado e, portanto, sem impactar os lucros do exercício. Isto acarretava distorções na interpretação das demonstrações, já que companhias aparentemente muito lucrativas escondiam enormes problemas de rentabilidade por não reconhecerem suas despesas, as quais eram dispostas artificialmente no ativo diferido.

${ }^{360}$ Dando um critério mais objetivo, a Lei n. 6.404/76, em seu art. 179, I, ressalta que essa classificação de ativo abrange os direitos realizáveis após o término do exercício seguinte, assim como os derivados de vendas, adiantamentos ou empréstimos a sociedades coligadas ou controladas (art. 243), diretores, acionistas ou participantes no lucro da companhia, que não constituírem negócios usuais na exploração do objeto da companhia. Neste último caso, a classificação independe do prazo. Como bem ensina Modesto Carvalhosa (Op. cit. p. 589): "Para a classificação de créditos dessa espécie, é irrelevante o prazo de realização. Assim, uma companhia com objetivos industriais ou comerciais, que conceder um empréstimo ou adiantamento a diretor, acionista, sociedades coligadas ou controladas, considerará o empréstimo no realizável a longo prazo, ainda que o termo contratual do empréstimo seja fixado, por exemplo, para o sexto mês subsequente à data do balanço".
} 
Em relação aos investimentos, que se consubstanciam em sua maioria em participações societárias, ${ }^{361}$ sua existência e integridade devem ser verificadas pelo auditor através de documentos idôneos (contratos, cópia de registros de livros ou extratos de ações, etc.). Sua avaliação deve ser constatada principalmente no que tange ao critério utilizado (método de custo ou equivalência patrimonial). ${ }^{362}$ Além disso, sua classificação deve ser objeto de especial atenção, uma vez que são comuns investimentos destinados à venda imediata, que deveriam ser classificados no circulante, ${ }^{363}$ constarem como investimentos no balanço.

No que concerne ao intangível, composto pelos direitos que tenham por objeto bens incorpóreos destinados à manutenção da companhia ou exercidos com esta finalidade (inclusive o fundo de comércio adquirido), deverá o auditor verificar a existência e propriedade dos bens (por meio de contratos, registro de marcas, patentes, etc.).

Especial atenção deve ser dada à avaliação do intangível (em regra, avaliado pelo custo incorrido na aquisição), uma vez que há hipóteses em que os valores atribuídos não são de fácil observação. Deve ainda o auditor atentar para o valor das amortizações do intangível (p.ex., referentes a ágio no fundo de comércio adquirido por expectativa de lucro ou preço superior ao que constava do ativo da entidade adquirida). Como essas amortizações são reconhecidas como despesas, podendo afetar os resultados da entidade, não é incomum que se inflem artificialmente seus valores para reduzir a lucratividade e distribuir menor quantia aos sócios ou acionistas.

A classificação do intangível também gera problemas práticos de monta. Como regra, não se classificam nesta rubrica valores internos ou de criação própria (marcas próprias, valores de aviamento ou clientela do estabelecimento, etc.), mas somente os adquiridos de terceiros. Assim, o auditor deverá verificar se a classificação dada pela entidade auditada foi realizada com propriedade, pois pode haver valores indevidamente

\footnotetext{
361 Mas não só. Além das participações societárias, outros direitos de qualquer natureza podem ser classificados no subgrupo investimentos. Um imóvel, v. g., não destinado à venda, nem utilizado nas atividades, mas mantido para futura expansão, deve ter a rubrica de investimento.

${ }^{362}$ De acordo com o método de custo, a participação permanente em outra sociedade (investimento) será consignada na escrituração da investidora pelo custo de aquisição, corrigido pela provisão para adequação dos valores escriturados. Já pelo método da equivalência patrimonial, a escrituração na investidora deve refletir, a cada exercício, o valor correspondente de participação patrimonial na investida, através da aplicação do percentual correspondente. Desta forma, se a investida aumentar seu patrimônio líquido, a escrituração na investidora deverá acompanhar tal aumento, consignando suas posições exatas.

${ }^{363}$ Imagine-se um lote de ações em bolsa de valores destinado à venda diária (operação conhecida como day trade) ou mesmo mensal. Tais valores devem constar do circulante, e não da rubrica de investimentos.
} 
classificados como intangíveis, aumentando artificialmente o ativo e, por consequência, o resultado da entidade.

No que toca ao imobilizado, usualmente sua existência e integridade são constadas tanto pela verificação de documentos quanto pela inspeção física direta (inventário). Importante averiguar sua classificação; bens destinados ao giro econômico, ou mantidos como investimentos, não devem figurar como imobilizado. Quanto à avaliação, em regra o auditor deve checar se os bens foram contabilizados pelo seu custo de aquisição (art. 183, V, da Lei n. 6.404/76), não sendo mais permitido às companhias realizar reavaliações, nos termos do que estipulou a Lei n. 11.638/07.

Deve o auditor estar atento para as provisões de depreciação, amortização e exaustão, conferindo seus valores e critérios.

\subsubsection{Auditoria de passivo}

Entende-se por passivo toda e qualquer obrigação ou débito futuro da entidade em face de terceiros financiadores de sua atividade.

Neves e Viceconti ${ }^{364}$ apresentam interessante e simples classificação do passivo (capital de terceiros), que englobaria:

- Débitos de funcionamento: são recursos obtidos para o funcionamento normal da empresa, por exemplo: fornecedores, salários a pagar, impostos a pagar;

- Débitos de financiamento: recursos obtidos para a ampliação e desenvolvimento da empresa, tais como os decorrentes de debêntures e empréstimos a longo prazo;

A classificação supracitada aplica-se diretamente à composição do passivo circulante ${ }^{365}$ que frequentemente se constitui de um conjunto de dívidas derivado das operações normais da entidade (passivo trabalhista, tributário, etc.), parcela chamada de passivo operacional, podendo também conter dívidas de curto prazo (passivo financeiro).

\footnotetext{
${ }^{364}$ Op. cit. p. 3.

${ }^{365}$ A classificação em passivo em circulante e não circulante (longo prazo) se dá na forma do art. 180 da Lei n. 6.404/76: "As obrigações da companhia, inclusive financiamentos para aquisição de direitos do ativo não circulante, serão classificadas no passivo circulante, quando se vencerem no exercício seguinte, e no passivo
} 
Já no passivo exigível não circulante (de longo prazo) são mais comuns apenas as dívidas de financiamento, uma vez que as obrigações de funcionamento costumam ter vencimento em curto prazo.

Como ocorre com o ativo, não há diferença ontológica entre as duas categorias, tratando-se apenas de uma questão de classificação temporal. O auditor, obviamente, sempre deve examinar os itens componentes de cada um para se assegurar de que foram corretamente classificados.

Ao contrário da auditoria de ativo, que tende a ser superavaliado pela gestão da entidade, a auditoria de passivo preocupa-se muito mais com a subavaliação de seus itens, uma vez que a tendência da administração, quando não deseje agir de forma transparente, é a de apresentar passivos de dimensão reduzida ou mesmo de escondê-los, demonstrando baixo endividamento. ${ }^{366}$

Em relação aos débitos operacionais, o auditor deve ter especial atenção para as questões trabalhistas e tributárias. Poderá para tanto realizar inspeções e, junto a colaboradores, examinar documentos e verificar o cumprimento das obrigações legais da entidade. Deverá constatar ainda se a avaliação dos débitos desta natureza foi corretamente efetuada e se foram computados todos os seus aspectos.

Especial atenção deve ser dada aos eventuais litígios tributários e trabalhistas que a entidade possua. Nestes casos, o auditor deverá analisar cada situação e, se for necessário, buscar parecer de profissional da área jurídica (interno ou externo à entidade) quanto à probabilidade da existência de um passivo e sua quantificação. Conforme a hipótese, o auditor deve instar a entidade auditada a realizar a necessária provisão ou, se já efetivada, verificar a suficiência dos valores provisionados. Caso entenda desnecessário ou impossível o provisionamento, deverá o auditor analisar se é necessária a divulgação do fato em nota explicativa.

não circulante, se tiverem vencimento em prazo maior, observado o disposto no parágrafo único do art. 179 desta Lei”. (Redação dada pela Lei n. 11.941, de 2009).

${ }^{366}$ Não se quer com isso dizer que as contas de ativo não devam ser investigadas e testadas quanto à superavaliação. Cuida-se apenas de uma prioridade ou ênfase de testes. Neste sentido, ressalta Marcelo Cavalcanti de Almeida que "O saldo de uma conta do balanço patrimonial ou da demonstração do resultado do exercício pode estar errado para mais (superavaliado) ou para menos (subavaliado). Devido a esse risco, todas as contas da contabilidade devem ser testadas para superavaliação e subavaliação. A experiência tem demonstrado mais prático dirigir os testes principais de superavaliação para as contas devedoras (normalmente, as contas do ativo e despesas) e os de subavaliação para as contas credoras (geralmente, contas de passivo e receitas)" (ALMEIDA, Marcelo Cavalcanti de. Auditoria: um curso moderno e completo. São Paulo: Atlas, 2007. p. 45). 
No que toca ao passivo financeiro (de curto ou de longo prazo), o auditor deve verificar os contratos que originaram as obrigações existentes, examinar os valores e a contabilização dos juros devidos, bem como pagamentos realizados (e os documentos que os comprovam). Poderá, se for o caso, lançar mão de procedimentos de circularização ou confirmação diretamente junto aos credores da entidade.

Outro ponto de especial atenção do auditor devem ser as garantias (reais, fidejussórias, etc.) dadas pela entidade a terceiros. Tais obrigações, por serem de exigibilidade apenas eventual e sob certas condições, frequentemente não constam dos valores divulgados como passivos no balanço, mas meramente em notas explicativas (por esta razão são chamadas por alguns autores de atividades fora do balanço, ou off-balance sheet). No entanto, podem comprometer seriamente a solvência da entidade se forem efetivadas.

Sobre tais obrigações, ensina Anthony Saunders, analisando este fenômeno no mercado bancário:

Uma das escolhas mais importantes para o administrador de uma IF é a escala relativa das atividades incluídas no balanço, em contraposição a atividades fora do balanço. As atividades incluídas no balanço são aquelas das quais quase todos nós estamos cientes, pois aparecem nas contas publicadas de ativo e passivo das instituições financeiras. Por exemplo, os depósitos e os investimentos em títulos e empréstimos de um banco são atividades incluídas no balanço. Em comparação, as atividades fora do balanço são menos evidentes, e são muitas vezes invisíveis para muitas pessoas, exceto o investidor muito bem informado, ou para as autoridades reguladoras. Em termos contábeis, os itens fora do balanço, em geral, aparecem abaixo da última linha, frequentemente apenas sob a forma de notas explicativas às contas patrimoniais e de resultado. Em termos econômicos, porém, os itens fora do balanço são ativos e passivos condicionais que afetam a estrutura futura, e não a estrutura corrente do balanço de um IF. Consequentemente, a gestão eficiente desses itens fora do balanço é essencial ao controle da exposição geral a risco de um IF moderno. $^{367}$

367 Op. cit. p. 240. As atividades fora do balanço, entretanto, não se compõem somente de passivos. Há também ativos fora do balanço. $\mathrm{O}$ autor citado dá como exemplos de atividades extrabalanço: compromissos de empréstimos, linhas de crédito e cartas de fiança, contratos futuros, contratos a termo, swaps e opções, compromissos de compra e venda de títulos e vendas de empréstimos. 
Desta forma, o auditor deverá ter cuidado em verificar o cumprimento da obrigação de divulgação das atividades fora do balanço pela entidade auditada, bem como analisar se referidas atividades poderão repercutir na solvência e, por conseguinte, na continuidade operacional da entidade.

\subsubsection{Auditoria de patrimônio líquido}

O patrimônio líquido, como ressaltamos, é o resultado da diferença entre o ativo e o passivo. ${ }^{368}$

Compõem ordinariamente o patrimônio líquido as contas referentes ao capital social, aos lucros e prejuízos acumulados e às reservas.

Em relação ao capital social, o auditor deve verificar sua realidade (existência) por meio dos comprovantes documentais de integralização (atas de assembleia, depósitos bancários, etc.). Quando haja integralização em bens ou créditos, o auditor deve verificar os instrumentos de avaliação, bem como eventual solvência dos devedores, juntamente com seu impacto no patrimônio da entidade.

Em regra, não há exigência de capitalização mínima de entidades societárias perante o ordenamento nacional. ${ }^{369}$ No entanto, a capitalização insuficiente pode ser considerada pelo auditor no que toca à análise da continuidade operacional. Deve também o auditor verificar se houve qualquer falha quanto à intangibilidade do capital social, principalmente mediante distribuição disfarçada de lucros ou dividendos.

No que concerne às reservas, o auditor deve conferir se existem, se foram corretamente lançadas e se seus valores estão de acordo com o que dispõem as leis de regência e os atos societários.

\footnotetext{
${ }^{368}$ Não obstante a distinção entre patrimônio líquido e passivo, verifica-se que há autores que classificam o patrimônio líquido juntamente com o passivo, por verem um grande número de semelhanças entre estes. É o caso de José Carlos Marion (Op. cit. p. 337), nos seguintes termos: "Na verdade, pela Lei das Sociedades Anônimas, entende-se como passivo todo o lado direito do balanço patrimonial, incluindo resultados de exercícios futuros e patrimônio líquido. Portanto, o lado direito do balanço que reflete todas as fontes de recursos é constituído de passivo exigível, resultados de exercícios futuros e patrimônio líquido".

${ }^{369}$ Exceção a esta regra é representada pelas instituições financeiras, as quais, nos termos dos acordos de Basileia I e II (International Convergence of Capital Measurement and Capital Standards), necessitam ter valores mínimos de capital social (minimum capital requirements) como forma de proteção aos riscos da atividade.
} 
Finalmente, com relação aos lucros e prejuízos acumulados, o auditor deve averiguar se correspondem aos montantes de resultados devidamente apurados, bem como se eventuais valores distribuídos a título de lucros ou dividendos tiveram origem nesta conta. É recomendável que recalcule os lucros e dividendos distribuídos ou a realizar, verificando sua correta avaliação e constituição de eventuais reservas de lucros a realizar.

\subsection{Demonstração do Resultado do Exercício (DRE)}

A Demonstração de Resultados do Exercício (DRE) visa a demonstrar aos usuários quanto houve de acréscimo ou decréscimo no patrimônio líquido da entidade por efeito da atividade econômica realizada por esta.

Além disso, fornece ao usuário uma tendência para os resultados futuros, possibilitando análises e previsões. ${ }^{370}$

A estrutura básica desta demonstração contábil, nos termos do art. 187 da Lei n. 6.404/76, é trazida a seguir:

\footnotetext{
${ }^{370}$ Justamente por possuir esta característica de predição dos resultados futuros, as normas internacionais de contabilidade (IFRS) exigem que a companhia indique em sua DRE se algum setor ou atividade relevante foi paralisado (descontinuado), apresentando seu resultado separadamente. Isto porque, a apresentação conjunta de resultados de operações descontinuadas pode induzir o usuário da demonstração que referida atividade permanecerá em continuidade nos exercícios seguintes, gerando, pois, expectativas de receitas (que, na verdade, já se encerraram). Isto não consta na Lei n. 6.404/76, muito embora esteja presente no Ofício Circular/CVM/SNC/SEP N. 01/2005. Também pelo mesmo motivo, as normas internacionais determinam a separação da demonstração por segmentos.
} 


\section{Figura 10: Composição geral da Demonstração de Resultado do Exercício (DRE)}

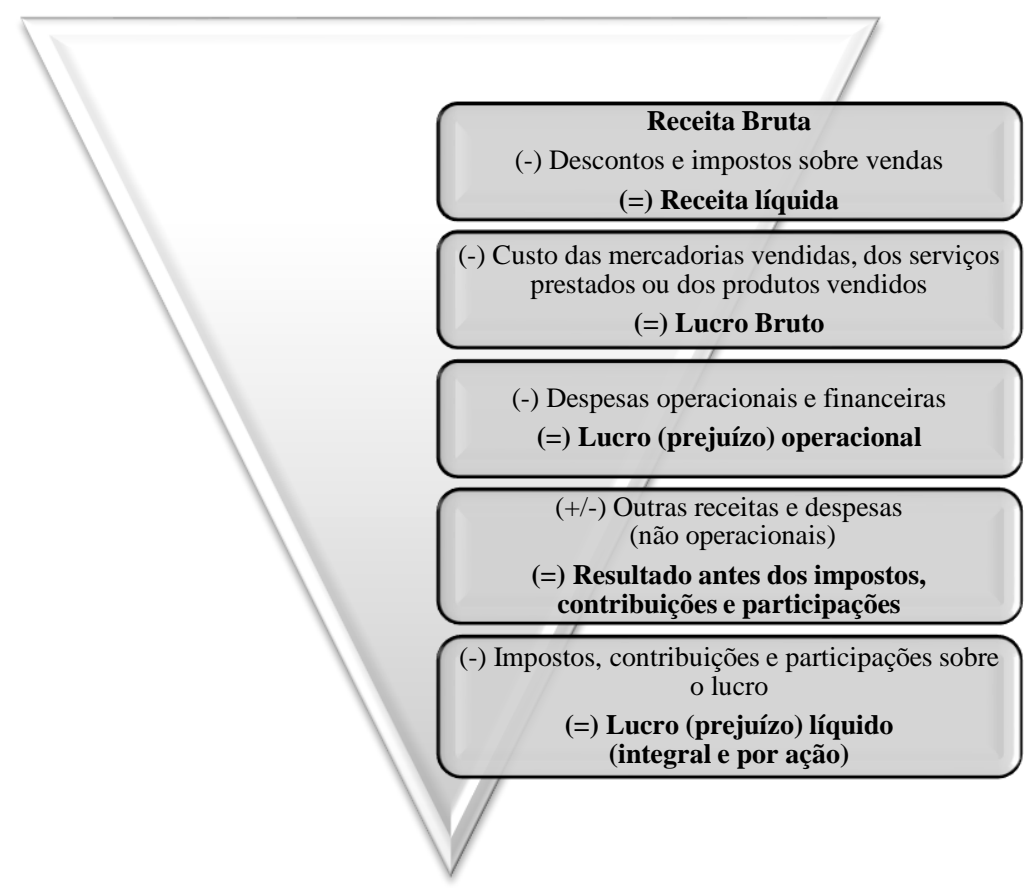

O trabalho de auditoria das contas de resultado (receitas e despesas) que compõem a DRE possui alguns aspectos importantes.

$\mathrm{O}$ primeiro ponto a ser verificado pelo auditor diz respeito à propriedade do reconhecimento de receitas e despesas.

Isto porque tais valores devem obedecer, como vimos, ao princípio da competência. Nos termos deste princípio, as receitas e despesas devem ser reconhecidas quando da ocorrência do fato gerador respectivo, e não quando de seu pagamento ou recebimento em dinheiro (princípio de caixa). Uma receita deve ser reconhecida, em princípio, quando a entidade tenha o direito de receber determinado montante, e não quando o numerário ingresse em seu patrimônio. Do mesmo modo, uma despesa deve ser reconhecida, em princípio, no momento em que se admita que a entidade tenha uma obrigação (de dar, fazer, etc.), e não quando desembolse as quantias necessárias para tanto.

Assim, em uma venda a prazo, para recebimento, e. $g$., depois de três meses da contratação, a entidade deverá reconhecer, desde a formalização do contrato, a receita respectiva. Do mesmo modo, após ter se utilizado da força de trabalho de um empregado durante um mês, deverá provisionar em seu passivo os montantes de encargos devidos (férias, décimo terceiro salário, etc.), com o reconhecimento da despesa respectiva, e não deixar para fazê-lo somente quando do pagamento de referidas verbas. 
Deste modo, a obrigação primeira do auditor, com relação às contas de resultado que compõem a DRE, é verificar se o princípio da competência foi devidamente observado, uma vez que não é rara a contabilização de receitas ou despesas em desacordo com este mandamento, até mesmo com intuito fraudulento.

Deve também o auditor verificar se as despesas e as receitas estão correlacionadas, ou seja, se os sacrifícios incorridos pela entidade ocorreram com o fim de geração de receitas. Caso contrário, o reconhecimento de despesas e receitas pode se dar de modo equivocado, nos termos dos princípios gerais de contabilidade.

Outro ponto importante de verificação do auditor, como ressaltamos anteriormente, é a constatação do período em que as receitas e despesas foram reconhecidas, principalmente no intervalo entre dois exercícios. Isto porque não é incomum a modificação fraudulenta de datas de receitas e despesas (p.ex.: antecipação de receitas do exercício seguinte e postergação de despesas do exercício atual) para modificar artificialmente o lucro.

O auditor deve ter especial atenção às estimativas contábeis constantes do ativo (depreciação, provisão para créditos de liquidação duvidosa, etc.) ou do passivo (provisão para contingências, litígios futuros, etc.), já que a contrapartida dessas estimativas afeta o resultado negativamente, diminuindo os lucros e os eventuais dividendos obrigatórios a serem distribuídos. Esse exame deve ser feito em conjunto com as contas de ativo e passivo que geraram as contrapartidas no resultado.

Também deve o auditor estar atento a eventuais variações bruscas em despesas (p.ex.: aumento demasiado de despesas financeiras ou operacionais entre exercícios) e receitas (principalmente as financeiras, relativas a juros e demais encargos a receber). Para tanto, é recomendável a realização de procedimentos analíticos, além dos testes de controle e substantivos.

A classificação das receitas e despesas em cada uma de suas categorias (operacionais, financeiras, não operacionais) deve ser examinada pelo auditor, pois o erro ou fraude que importe em classificação indevida pode gerar sério prejuízo ao usuário da informação contábil. ${ }^{371}$

\footnotetext{
${ }^{371}$ Um exemplo talvez facilite a compreensão. Imaginemos duas situações: na primeira, uma determinada entidade apresenta uma despesa operacional de $\mathrm{R} \$ 100.000,00$ e um prejuízo líquido de $\mathrm{R} \$ 50.000,00$; na segunda, uma despesa não operacional do mesmo valor, $\mathrm{R} \$ 100.000,00$, e o mesmo prejuízo líquido, $\mathrm{R} \$$ 50.000,00. Suponhamos a inexistência de receitas e despesas financeiras. Podemos concluir, da leitura da
} 
As despesas tributárias incidentes diretamente sobre a receita bruta ou sobre o lucro devem merecer consideração do auditor, uma vez que podem gerar sérios prejuízos à entidade, no tocante ao pagamento de juros e multa, além de afetarem o lucro líquido final.

\subsection{Demonstração do Fluxo de Caixa (DFC)}

A avaliação do caixa é de suma importância na gestão empresarial, porque tem, muitas vezes, valor informativo até mesmo superior à avaliação da lucratividade. Isso por vários motivos, dentre os quais podemos citar: 1) o caixa da empresa, muitas vezes, não é imediatamente afetado por valores contábeis que podem distorcer o montante do lucro (p.ex., depreciações, receitas a prazo, ganhos de equivalência patrimonial ainda não realizados, etc.); ${ }^{372}$ 2) o caixa reflete imediatamente a capacidade de a entidade honrar seus pagamentos, portanto, o melhor sinal de sua liquidez imediata; 3) a avaliação dos montantes inseridos em contas de caixa ou disponibilidades é de maior objetividade e não sujeita a critérios contábeis subjetivos.

A existência de lucros, portanto, sob o ponto de vista econômico, não garante, por si só, que a entidade em análise tenha obtido sucesso ou fracasso em sua atividade empresarial.

De fato, o princípio da competência faz que se lancem como receitas alguns fatos econômicos que ainda não repercutiram no caixa da entidade, bem como exige o

DRE, que em ambos os casos o prejuízo líquido é o mesmo, mas suas causas podem completamente diferentes. No primeiro exemplo, a entidade possivelmente se defronta com um problema de excesso de despesas em cotejo com sua receita líquida, ou seja, as receitas de sua atividade não são suficientes para cobrir as despesas de suas operações; ou as receitas se apresentam insuficientes, ou as despesas, demasiadas. De qualquer forma, considerando que o problema se encontra na atividade econômica, ele tende a se perpetuar, salvo se a entidade modificar suas operações para aumentar as receitas ou diminuir suas despesas. No segundo exemplo, podemos desconfiar que a possível causa da despesa encontra-se fora das atividades normais da entidade (p.ex.: um prejuízo na venda de um item do imobilizado) e que, possivelmente, isto possa não se perpetuar nos exercícios seguintes, mas constituir-se em fato isolado.

372 Entenda-se bem a afirmação: muitas vezes os valores citados não repercutem no caixa no momento de seu lançamento ou evidenciação nas demonstrações contábeis, mas poderão ter relevante efeito no futuro. $\mathrm{O}$ lançamento da depreciação do imobilizado, por exemplo, embora não exija um imediato desembolso de caixa, certamente terá impacto neste quando houver a necessidade de renovação do ativo depreciado, uma vez que eventual venda deste ativo não reporá os valores pelos quais foi adquirido. 
lançamento, como despesa, de operações que não exigiram qualquer desembolso monetário.

Além disso, há fatos que são considerados como componentes do resultado contábil e não operam efeito imediato nas disponibilidades financeiras líquidas da entidade (embora venham a fazê-lo no futuro), mas que podem ter intenso reflexo no resultado empresarial. Alguns exemplos são a depreciação (contabilizada como redução de ativo em contrapartida de despesa, diminuindo o lucro) e as provisões (assim também inseridas).

Alexandre Povoa, em excelente obra sobre avaliação de empreendimentos e precificação de ações, ressalta que:

A primeira pergunta lógica que vem à cabeça de qualquer um é acerca do porquê da projeção de fluxo de caixa de uma empresa. Por que não utilizarmos os lucros diretamente? Normalmente, o cidadão comum associa imediatamente o lucro ao sucesso ou fracasso de uma companhia. Se a empresa "deu prejuízo" normalmente é sinal de fracasso. Conforme já observamos, a contabilidade é recheada de regras que acabam, muitas vezes, distorcendo a verdadeira realidade de uma empresa. Não estamos nem considerando fatos excepcionais como as fraudes contábeis que eclodiram em 2002 e 2003 em grandes empresas mundiais, como a WorldCom, Enron, Vivendi e Parmalat. Neste caso, os executivos destas empresas esconderam passivos e inflaram propositadamente ativos. Estamos alertando para o fato de que princípios contábeis mundialmente aceitos podem não ajudar a refletir o que foi realmente o desempenho de uma empresa em determinado período (...). Portanto, o que mais importa no processo de precificação é mensurar a capacidade de geração de caixa de uma empresa. O que a empresa vai fazer com o caixa gerado é uma questão mais subjetiva, que dependerá de boa ou má administração. ${ }^{373}$

Dessa forma, a principal questão envolvendo a elaboração do relatório de fluxo de caixa é a avaliação do valor de mercado da entidade. Com efeito, a metodologia mais aceita sob o ponto de vista da ciência das finanças para avaliação de empresas é o denominado fluxo de caixa descontado (discounted cash flow-DCF).

Referida metodologia consiste na projeção do fluxo de caixa futuro do empreendimento, trazendo-o a valor presente através do desconto operacionalizado por uma taxa respectiva, usualmente correspondente ao custo médio ponderado de capital - 
CMPC ou WACC (wheighted average cost of capital), que considera, conforme a proporção das fontes de financiamento, o custo do capital próprio ${ }^{374}$ e o custo do capital de terceiros.

\author{
Expressando esta metodologia de forma simplificada, gráfica e
} matematicamente, teríamos o seguinte:

\footnotetext{
${ }^{373}$ POVOA, Alexandre. Valuation. Como precificar ações. São Paulo: Globo, 2004. p. 114.

${ }^{374}$ Pode parecer estranho dizer que o capital próprio, identificado como aquele que o próprio sócio investe na sociedade, através do aporte de recursos em seu capital, tenha custo. No entanto, como já sustentamos na obra Curso de Direito Comercial, em coautoria com o Prof. Haroldo Malheiros Duclerc Verçosa, um ente empresarial "pode se financiar, grosso modo, por dois tipos de fontes: (i) capital de terceiros; (ii) capital próprio. No primeiro caso temos a constituição de um passivo (obrigações a pagar a credores), pelo qual a companhia se obrigará, usualmente, ao pagamento de juros. No segundo o financiamento se dará basicamente pelo aporte de recursos dos acionistas (capital), ou mesmo pelos recursos obtidos do exercício da atividade econômica (lucros). Resta medianamente claro que, ao se financiar mediante o uso de capital de terceiros, a companhia terá um custo sobre tal financiamento, consistente nos juros que terá de pagar pelos recursos disponibilizados pelos credores, uma vez que estes exigirão esta contraprestação por permanecerem, durante o tempo do empréstimo, privados do uso de seus recursos. Em relação ao capital próprio, entretanto, resta mais difícil verificar a existência de um custo, pois normalmente costumamos pensar que o acionista somente deseja auferir parcela dos lucros sociais (se e quando estes existirem), bem como eventuais ganhos de capital pela valorização das ações adquiridas. Ocorre que, analisando sobre o ponto de vista financeiro, o capital próprio demanda efetivamente um custo da companhia, que, aliás, tende a ser maior que o custo de capital de terceiros. Vejamos mais atentamente. Quando um credor faz empréstimo a uma companhia (pressupondo condições de solvência), terá garantido o pagamento de sua remuneração (juros), preferencialmente ao pagamento de qualquer remuneração aos acionistas. Já, o acionista, ao investir seus recursos na companhia, somente receberá algum retorno pelo seu aporte se e quando a sociedade apresentar resultados positivos (lucro), depois de pagas todas as dívidas e despesas. O credor, ao emprestar para a companhia, normalmente pode antever com razoável grau de segurança qual será sua remuneração (juros), seja ela pactuada em termos fixos ou percentuais em relação ao empréstimo. $\mathrm{O}$ acionista, ao contrário, não pode prever com segurança qual será o montante que obterá de retorno ao aplicar recursos em uma companhia. Sua remuneração poderá ser maior ou menor, dependendo de várias circunstâncias e eventos. Ao pagar juros ao credor, a companhia poderá normalmente deduzi-los (como despesas que são) do lucro líquido que servirá de base de cálculo para o imposto sobre a renda. Sendo menor o lucro líquido, a companhia terá um benefício fiscal, pagando menor imposto. No pagamento de dividendos ao acionista, porém, não há incidência de imposto sobre a renda, por força de isenção legal, razão pela qual a companhia não auferirá qualquer benefício fiscal. Após essas explanações, podemos indagar: quem exigirá maior remuneração pelo seu investimento: o credor ou o acionista? Em outras palavras, qual será usualmente mais caro à companhia, o financiamento por recursos de terceiros ou por recursos próprios? (...) A esta altura, podemos afirmar claramente que o capital próprio tende a ser mais caro para a companhia, pois o acionista se vê em condições de maior risco, e, portanto, incrementa sua expectativa (e consequente exigência) de retorno em seu investimento. Além disso, pagar juros ao credor é normalmente mais barato à sociedade anônima (dado o benefício fiscal de dedução de imposto de renda) que pagar dividendos ao acionista" (VERÇOSA, Haroldo Malheiros Duclerc; PEREIRA, Alexandre Demetrius. Curso de Direito Comercial. São Paulo: Malheiros, 2008. v. 3. p. 613).
} 
Figura 11: Expressão gráfica simplificada da conversão dos valores de fluxo de caixa futuros (FC) a valor presente (VP).

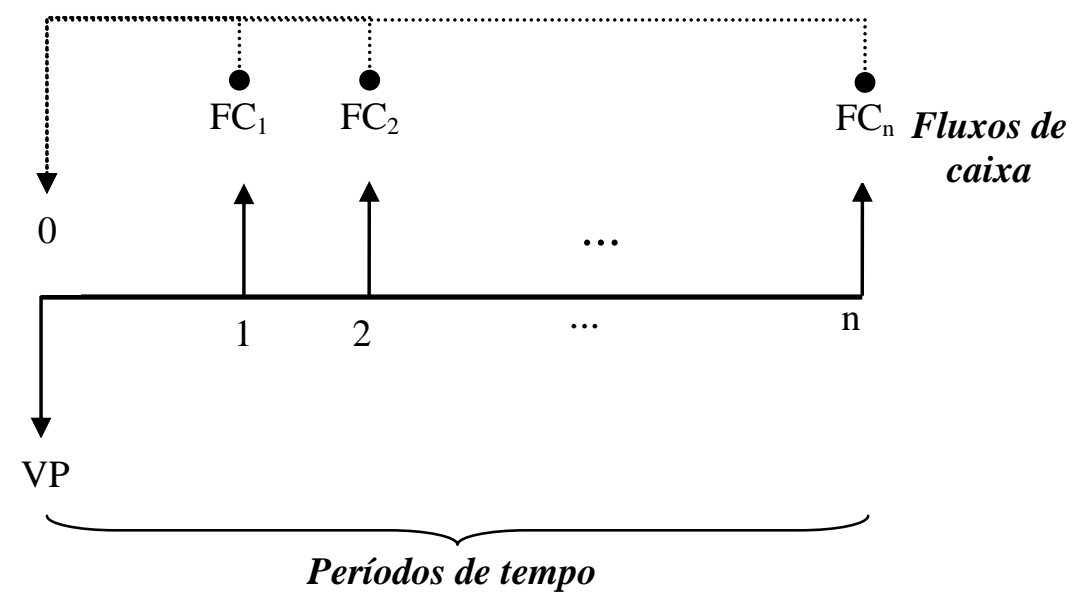

Convertem-se os montantes de fluxo de caixa dos diversos momentos $(1,2, \ldots$ n) ao momento atual (0), para apuração do valor do ente empresarial.

Figura 12: Expressão matemática da conversão dos valores de fluxo de caixa futuros (FC) a valor presente (VP)

$$
V P=\frac{F C_{1}}{(1+i)^{1}}+\frac{F C_{2}}{(1+i)^{2}}+\cdots+\frac{F C_{n}}{(1+i)^{n}}
$$

Considera-se uma taxa de desconto (i) e o tempo de cada fluxo de caixa $(1,2, \ldots n)$.

O fluxo de caixa descontado, como já se mencionou, é a metodologia mais aceita para a avaliação de empresas (valuation). Neste sentido, a lição sempre abalizada de Alexandre Assaf Neto:

Na avaliação econômica de investimentos, o método do Fluxo de Caixa Descontado (FCD) é o que representa o maior rigor técnico e conceitual para expressar o valor econômico (...). Em verdade, uma empresa é avaliada por sua riqueza econômica expressa a valor presente, dimensionada pelos benefícios de caixa esperados no futuro e 
descontados por uma taxa de atratividade que reflete o custo de oportunidade dos vários provedores de capital. ${ }^{375}$

Atento à necessidade de informação dos usuários das demonstrações contábeis quanto à capacidade das entidades em gerar caixa e a respeito da qualidade da administração deste item, o legislador passou a exigir a apresentação da demonstração de fluxo de caixa para as sociedades anônimas com o advento da Lei n. 11.638/07, que, ao dar nova redação ao art. 176, IV, veio substituir a antiga demonstração de origens e aplicações de recursos (DOAR).

A Lei n. 11.638/07, ao conferir nova redação a dispositivos da Lei n. 6.404/76 referentes à DFC, não especificou a metodologia para realização de tal demonstração, preceituando apenas, na redação do art. 188, que esta deve conter, no mínimo: as alterações ocorridas, durante o exercício, no saldo de caixa e equivalentes de caixa, segregando-se essas alterações em, no mínimo, 3 (três) fluxos: a) das operações; b) dos financiamentos; e c) dos investimentos.

$\mathrm{Na}$ doutrina contábil e respectivas normas internacionais, preceituam-se dois métodos para a elaboração da DFC: o direto e o indireto, como veremos a seguir. A base principal para tanto são normas internacionais editadas pelo FASB (Financial Accounting Standards Board) e do IASB (International Accounting Standards Board). ${ }^{376}$

Para fins da DFC, entende-se como caixa não só as quantias disponíveis em dinheiro em posse da entidade, mas também aqueles recursos de liquidez imediata, como as aplicações financeiras que possuam tal característica (equivalentes de caixa). Trata-se, pois, de uma demonstração das disponibilidades, e não somente do caixa propriamente dito.

\footnotetext{
375 ASSAF NETO, Alexandre. Finanças Corporativas e Valor. São Paulo: Atlas, 2007. p. 657.

${ }^{376}$ A Secretaria da Receita Federal tem se utilizado do documento em estudo para a imposição de tributos. Verifique-se a seguinte decisão: "ACÓRDÃO N. 2808 de 20 de fevereiro de 2003. ASSUNTO: Imposto sobre a Renda de Pessoa Jurídica - IRPJ. EMENTA: OMISSÃO DE RECEITAS - Excesso de dispêndios em relação aos recursos, apurado através de elaboração da 'Demonstração de Fluxo de Caixa', é passível de lançamento como omissão de receitas. Sendo apresentados na impugnação novos elementos provando que não houve a ocorrência do fluxo negativo, cabe a exoneração do lançamento. AUTOS REFLEXOS - PIS COFINS - IRRF-CSLL - O decidido no mérito do IRPJ, em decorrência de omissão de receitas, repercute na tributação reflexa, exonerando-se os lançamentos".
} 
Figura 13: DFC e suas metodologias

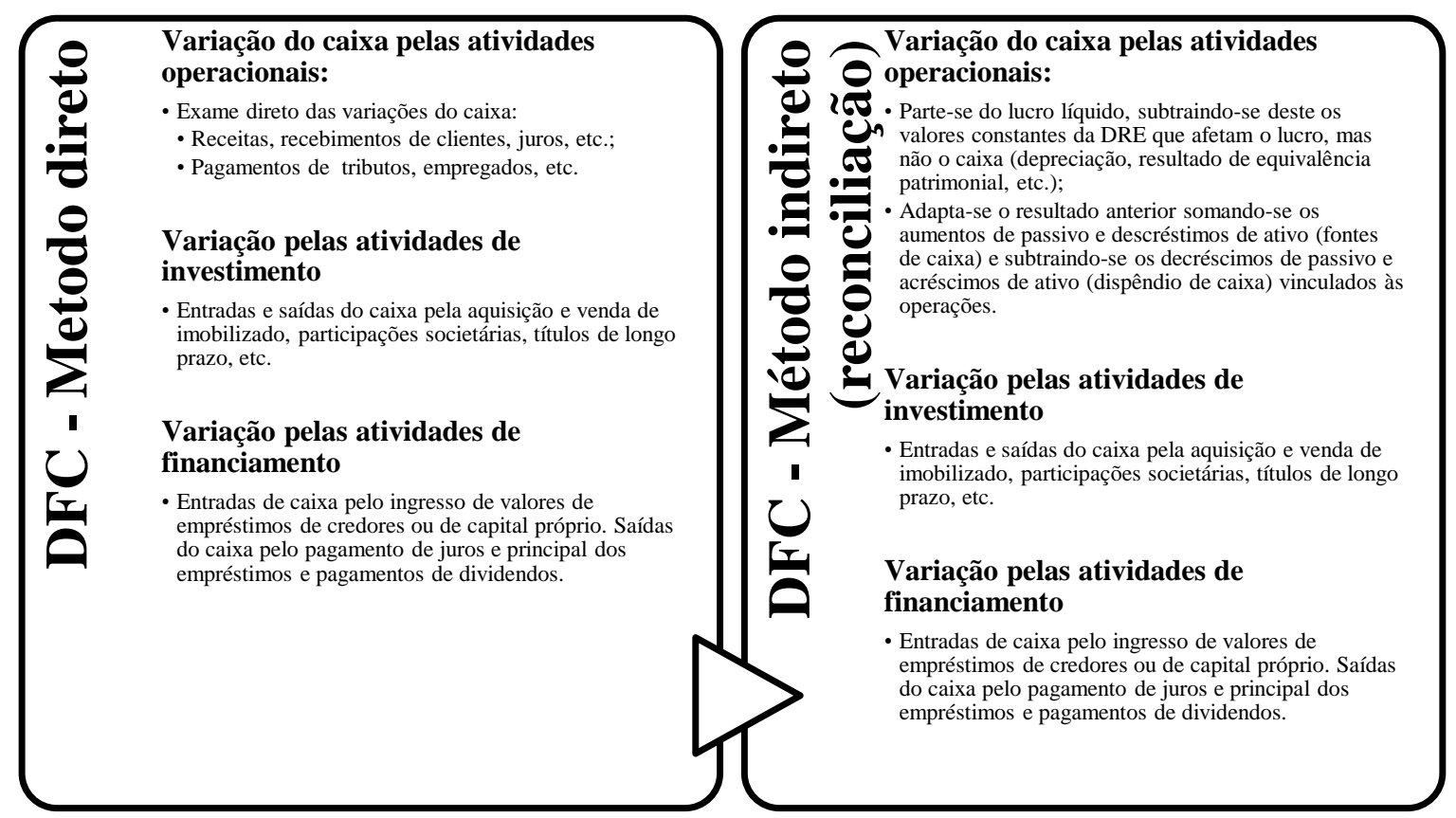

Estas metodologias diferenciam-se apenas no modo de demonstrar o caixa oriundo da atividade operacional. Enquanto no método direto há um exame imediato das entradas e saídas de caixa vinculadas às operações, no indireto parte-se do lucro para chegar ao caixa da entidade. Em relação às atividades de financiamento e investimento, o fluxo de caixa é evidenciado da mesma forma em ambos os métodos.

Para fins de auditoria, pode-se dizer que grande parte - se não a totalidade das contas presentes na DFC constam também do balanço patrimonial e da DRE, por se tratar de contas patrimoniais ou de resultado. Assim, seu exame segue as mesmas regras já tratadas anteriormente.

É importante, porém, que o auditor verifique corretamente a classificação dada a cada um dos valores presentes na DFC, já que um erro ou fraude na classificação pode dar ao usuário da demonstração uma informação absolutamente inverídica sobre a situação da entidade. ${ }^{377}$

\footnotetext{
${ }^{377}$ Como fizemos ao comentar a classificação da DRE, forneceremos um exemplo para esclarecer a questão: imaginemos que a variação total de caixa de uma determinada entidade entre dois exercícios componha-se, numa primeira hipótese, de um total de $\mathrm{R} \$ 100.000,00$ : $\mathrm{R} \$ 50.000,00$ oriundos das operações e $\mathrm{R} \$ 50.000,00$ oriundos de financiamentos (aumento de capital). Ora, o usuário será instado a concluir que metade do aumento de caixa é devido à atividade operacional da entidade, sendo a outra metade originada da vontade de seus sócios ou acionistas de lhe proverem um aumento no financiamento. Vamos supor uma segunda hipótese, em que o aumento de $\mathrm{R} \$ 100.000,00$ seja integralmente oriundo das atividades operacionais.
} 
Outra questão importante que deve ser objeto de consideração do auditor na DFC é a concernente a eventuais problemas de continuidade operacional. Como já ressaltamos, a DFC traz, entre outras informações, a capacidade de a entidade gerar caixa e, portanto, manter-se cumpridora de seus compromissos de curto prazo. Assim, o auditor pode utilizar a DFC, juntamente com outros dados, para fundamentar suas conclusões sobre a liquidez imediata da entidade analisada e eventuais problemas daí derivados.

\subsection{Demonstração de Lucros e Prejuízos Acumulados (DLPA) e Demonstração de Mutações no Patrimônio Líquido (DMPL)}

As demonstrações de lucros e prejuízos acumulados e das mutações no patrimônio líquido são complementares entre si. Na verdade, a DLPA está contida na DMPL, da mesma forma que a conta de lucros e prejuízos acumulados está contida no patrimônio líquido.

Deste modo, a publicação da DMPL, por ser mais completa, torna desnecessária a publicação da DLPA.

$\mathrm{Na}$ verdade, essas duas demonstrações visam a evidenciar como se comportaram no exercício a conta de lucros e prejuízos acumulados (no caso da DLPA) ou a totalidade das contas que compõem o patrimônio líquido (capital, reservas, lucros e prejuízos acumulados, no caso da DMPL).

Um esquema gráfico dessas demonstrações (com a DLPA incluída na DMPL na coluna "lucros acumulados"), baseado na Instrução CVM n. 59/86, sem as reservas de reavaliação (por força da Lei n. 11.638/07), pode ser visto a seguir:

Obviamente, neste caso, o usuário se sentirá mais seguro quanto à capacidade desta entidade em gerar caixa de suas atividades, uma vez que ela possivelmente não dependerá da vontade de seus proprietários para lhe proporcionar recursos. Assim, podemos verificar como a mera classificação da origem do caixa gera importantes distorções nas demonstrações contábeis. 
Tabela 24: Modelo de DMPL (com DLPA inclusa)

\begin{tabular}{|c|c|c|c|c|c|c|c|c|}
\hline & \multicolumn{2}{|c|}{$\begin{array}{c}\text { Capital realizado } \\
\text { atualizado }\end{array}$} & \multicolumn{3}{|c|}{ Reservas de capital } & \multirow[t]{2}{*}{$\begin{array}{l}\text { Reservas } \\
\text { de lucros }\end{array}$} & \multirow{2}{*}{$\begin{array}{c}\text { Lucros } \\
\text { acumulados } \\
\text { (DLPA) }\end{array}$} & \multirow[t]{2}{*}{ Total } \\
\hline & $\begin{array}{c}\text { Capital } \\
\text { subscrito }\end{array}$ & $\begin{array}{c}\text { A } \\
\text { realizar }\end{array}$ & $\begin{array}{c}\text { Correção } \\
\text { monetária }\end{array}$ & $\begin{array}{c}\text { Ágio na } \\
\text { subscrição }\end{array}$ & $\begin{array}{c}\text { Ações em } \\
\text { tesouraria }\end{array}$ & & & \\
\hline \multicolumn{9}{|l|}{ Saldos em / / } \\
\hline \multicolumn{9}{|l|}{$\begin{array}{c}\text { Ajuste de } \\
\text { exercícios } \\
\text { anteriores/ } \\
\text { mudança de } \\
\text { critério } \\
\text { contábil (N.E.) }\end{array}$} \\
\hline \multicolumn{9}{|l|}{$\begin{array}{c}\text { Aumento de } \\
\text { capital AGE / / }\end{array}$} \\
\hline \multicolumn{9}{|l|}{$\begin{array}{l}\text { Aquisição ações } \\
\text { próprias com } \\
\text { reserva de ágio } \\
\text { na subscrição }\end{array}$} \\
\hline \multicolumn{9}{|l|}{$\begin{array}{l}\text { Subvenções - } \\
\text { incentivo fiscal } \\
\text { IR }\end{array}$} \\
\hline \multicolumn{9}{|l|}{$\begin{array}{c}\text { Reversão e } \\
\text { transferência } \\
\text { de reservas }\end{array}$} \\
\hline \multicolumn{9}{|l|}{$\begin{array}{c}\text { Atualização } \\
\text { monetária }\end{array}$} \\
\hline \multicolumn{9}{|l|}{$\begin{array}{l}\text { Lucro líquido } \\
\text { de exercício }\end{array}$} \\
\hline \multicolumn{9}{|l|}{$\begin{array}{l}\text { Destinação do } \\
\text { lucro líquido: } \\
\text { reservas } \\
\text { dividendos }\end{array}$} \\
\hline Saldos em / / & & & & & & & & \\
\hline
\end{tabular}

Como se verifica, a DLPA é uma demonstração que ocupa uma das colunas da DMPL, incluindo-se nesta última, portanto.

Ao auditor é importante a verificação correta da movimentação das contas de patrimônio líquido entre dois exercícios, devendo este profissional constatar se os saldos existentes no exercício anterior (primeira linha da demonstração) foram devidamente mantidos ou, se distribuídos, de que forma o foram para as demais contas de patrimônio líquido.

A DMPL permite ao auditor a verificação de várias operações, como capitalização de lucros e reservas, pagamentos de dividendos, constituição de reservas, etc., permitindo-lhe cotejar os dados que constam da DMPL com os registros do livro razão e diário, refazer as contas, verificar os saldos, entre outras providências.

Relacionada com a DMPL e a DLPA, torna-se importante nos dias de hoje a denominada demonstração de resultado abrangente, que deriva da necessidade de evidenciação de valores que modificam o patrimônio líquido da entidade, sem implicar no 
resultado. ${ }^{378}$ Referida demonstração, de acordo com o Pronunciamento n ${ }^{\text {o }} 26$ do Comitê de Pronunciamentos Contábeis (CPC), pode ser apresentada em quadro demonstrativo próprio ou dentro das mutações do patrimônio líquido (DMPL) e deve, no mínimo, incluir as seguintes rubricas: (a) resultado líquido do período; (b) cada item dos outros resultados abrangentes classificados conforme sua natureza (exceto montantes relativos ao item "c"); (c) parcela dos outros resultados abrangentes de empresas investidas reconhecida por meio do método de equivalência patrimonial; e (d) resultado abrangente do período.

Ao auditor, a demonstração de resultados abrangentes será de importante valia, principalmente para a constatação da correção da classificação dos valores que transitaram ou não pelo resultado do período, os quais podem gerar distorções na informação ao usuário.

\subsection{Demonstração de valor adicionado (DVA)}

Esta demonstração é fruto da inovação da legislação de sociedades anônimas ocorrida com o advento Lei n. 11.638/07. Referido diploma, ao dar nova redação ao art. 176, V, da Lei n. 6.404/76, exigiu das companhias abertas que evidenciassem o valor da riqueza gerada pela atividade e a sua distribuição entre os elementos que contribuíram para esta geração, tais como empregados, financiadores, acionistas, governo e outros, bem como a parcela da riqueza não distribuída. ${ }^{379}$

\footnotetext{
${ }^{378}$ Nos termos do Pronunciamento ${ }^{\circ} 26$ do Comitê de Pronunciamentos Contábeis (CPC), resultado abrangente (comprehensive income) é a mutação que ocorre no patrimônio líquido durante um período que resulta de transações e outros eventos não derivados de transações com os sócios na sua qualidade de proprietários. Ainda nos termos da norma mencionada, outros resultados abrangentes compreendem itens de receita e despesa (incluindo ajustes de reclassificação) que não são reconhecidos na demonstração do resultado. Os componentes dos outros resultados abrangentes incluem: (a) variações na reserva de reavaliação quando permitidas legalmente; (b) ganhos e perdas atuariais em planos de pensão com benefício definido, reconhecidos conforme item 93A do Pronunciamento Técnico CPC 33 - Benefícios a Empregados; (c) ganhos e perdas derivados de conversão de demonstrações contábeis de operações no exterior; (d) ajuste de avaliação patrimonial relativo aos ganhos e perdas na remensuração de ativos financeiros disponíveis para venda; (e) ajuste de avaliação patrimonial relativo à efetiva parcela de ganhos ou perdas de instrumentos de hedge em hedge de fluxo de caixa.

${ }^{379}$ Um breve estudo sobre as demonstrações de valor adicionado no Brasil mostra a importância inegável deste relatório em evidenciar informações sobre o valor agregado que é distribuído aos diversos interessados (stakeholders). Reportagem do jornal Valor Econômico evidencia que, de acordo com os dados divulgados pelas DVAs das 100 maiores companhias abertas por valor de mercado, em média, distribui-se $12,1 \%$ do
} 
Rompendo com o caráter individualista das outras demonstrações contábeis (tais como o balanço e a DRE, que somente focam os interesses dos proprietários da entidade ao evidenciarem tão somente o patrimônio e o lucro), a Demonstração do Valor Adicionado surge como uma forma de a ciência contábil demonstrar a riqueza gerada e distribuída de uma determinada entidade, promovendo uma espécie de "contabilidade social".

Várias são as repercussões práticas da DVA no cenário atual. A doutrina aponta a Demonstração de Valor Adicionado como instrumento relevante na análise governamental destinada à concessão de empréstimos ou incentivos fiscais, e até mesmo para cálculo do Produto Interno Bruto.

Ariovaldo dos Santos ressalta a importância da Demonstração do Valor Adicionado, em confronto com a Demonstração de Resultado do Exercício:

Como se percebe, na demonstração de resultados o enfoque está dirigido para a linha do lucro líquido e, dessa forma, seu interesse é muito maior para proprietários sócios ou acionistas. Os demais componentes da demonstração de resultados são apresentados de acordo com sua natureza e não segundo seus beneficiários. Por exemplo, na demonstração de resultados, as remunerações pagas aos empregados podem ser expostas como componentes do custo e/ou das despesas operacionais; os diversos impostos e taxas incidentes sobre as vendas, resultado, operações financeiras, etc., podem ser apresentados em linhas totalmente diversas na demonstração de resultados (...) Já para a DVA, a distribuição da riqueza gerada pela empresa obedecerá ao critério do beneficiário da renda. Assim, a distribuição será apresentada entre os detentores de capitais, acionistas e financiadores externos, os trabalhadores, destacando-se os salários e encargos e, finalmente, a parte destinada ao governo na forma de impostos, que podem ser municipais, estaduais ou federais. Quanto à importância da DVA, parece que é inquestionável seu

valor agregado aos credores (capital de terceiros), 20\% ao pessoal (empregados, prestadores de serviço, etc.), $23,1 \%$ aos sócios e acionistas (capital próprio) e incríveis $44,8 \%$ aos governos, por força de tributação. Ainda segundo a reportagem mencionada, há setores em que a distribuição do valor agregado ao governo chega a $63,8 \%$, como no caso das telecomunicações. Também é relevante a participação no governo no valor adicionado nos setores de bebidas e fumo $(56,9 \%)$, petróleo e gás $(56,1 \%)$, energia $(51,5 \%)$ e bens de consumo $(42,7 \%)$. Outros setores, entretanto, sofrem bem menos com a participação governamental no valor adicionado, tais como aqueles que exportam grande parte de sua produção, exemplo da siderurgia (29\% do valor adicionado destinado ao governo). ("Sócio Preferencial”. Valor Econômico. 31.05.2010, Caderno EU\&Investimentos, p. D1). 
auxílio no cálculo do PIB e de indicadores sociais extremamente importantes. As decisões de investimentos por áreas, regiões, Estados, etc., terão nessa demonstração excelente instrumental para auxiliar na solução de conflitos. ${ }^{380}$

Um modelo gráfico de DVA preconizado pela literatura contábil é fornecido a seguir:

Figura 14: Modelo de DVA apresentado por Neves e Viceconti

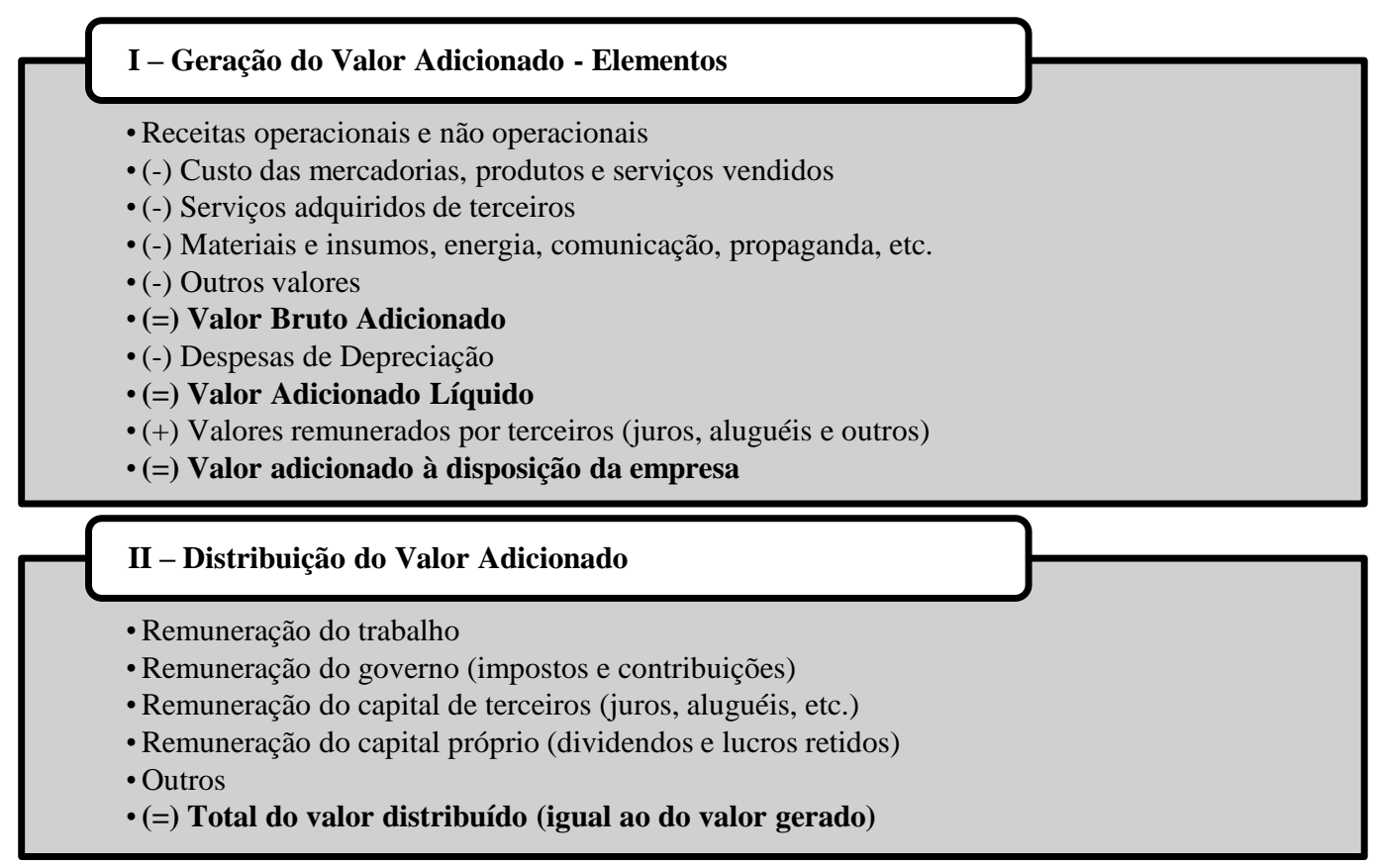

Fonte: NEVES, Silvério das; VICECONTI, Paulo Eduardo Vilchez. Contabilidade avançada e análise das demonstrações financeiras. São Paulo: Frase, 1999. p. 263.

Para o auditor, como ocorre com a DFC e a DMPL, as principais contas a serem auditadas já estão presentes na avaliação do balanço e da DRE, razão pela qual poderá este profissional aproveitar as verificações das contas destas demonstrações ao auditar os itens que compõem a DVA.

${ }^{380}$ SANTOS, Ariovaldo dos. Demonstração do Valor Adicionado: como elaborar e analisar a DVA. São Paulo: Atlas, 2003. p. 36. 
No entanto, a DVA apresenta alguns itens que englobam várias contas específicas, que são apresentadas somente de forma genérica na DRE e no balanço. É o caso, por exemplo, das despesas com propaganda, energia, insumos, etc., bem como da remuneração do trabalho (muitas vezes tratada de forma conjunta com outras despesas de pessoal).

Caberá ao auditor, portanto, verificar se a separação entre contas apresentadas de forma conjunta foi adequada, bem como averiguar a correta avaliação dos itens constantes da DVA, estimando eventuais distorções relevantes que possam existir. De fato, pode ocorrer de a entidade desejar demonstrar maior distribuição de riquezas para a sociedade, distorcendo os valores da riqueza gerada e distribuída.

É importante também que o auditor verifique eventuais erros ou fraudes na classificação dos itens, dada a possibilidade de a entidade desejar desvirtuá-los em alguns pontos (p.ex.: menor distribuição de riqueza aos titulares do capital próprio na forma de dividendos, supostamente por ter de atender à distribuição ao governo ou ao trabalho). 


\section{AUDITORIA EXTERNA E GOVERNANÇA CORPORATIVA}

A auditoria externa é um dos elementos básicos da definição de governança corporativa.

Com efeito, na definição do Instituto Brasileiro de Governança Corporativa (IBGC):

Governança corporativa é o sistema pelo qual as sociedades são dirigidas e monitoradas, envolvendo os relacionamentos entre acionistas, conselho de administração, diretoria, auditoria independente e conselho fiscal. O objetivo das práticas de governança corporativa é a criação e operacionalização de um conjunto de mecanismos que visam a fazer com que as decisões sejam tomadas de forma a otimizar o desempenho de longo prazo das empresas. ${ }^{381}$

Entre outros pilares, a governança corporativa baseia-se na transparência da gestão e na prestação de contas (accountability), envolvendo a prestação completa e constante de informações aos destinatários, a vinculação da gestão aos resultados da entidade e a responsabilidade pelas contas apresentadas. Nestes termos, a auditoria externa é essencial a estes objetivos, ao adicionar credibilidade às demonstrações contábeis elaboradas pela gestão.

Com o fim de obter maior grau de boas práticas em governança corporativa, a auditoria externa pode ser adotada por entidades que não se configurem como companhias $\operatorname{abertas}^{382}$ e que, portanto, não tenham obrigação de contratar tais serviços. Neste caso, o intuito será meramente o de incrementar a transparência da gestão no interesse dos sócios ou acionistas. Bem ressalta Haroldo Malheiros Duclerc Verçosa que:

Nada impede dentro de um projeto de instauração de um sistema adequado de governança corporativa que a companhia fechada adote como um dos instrumentos correspondentes à auditoria independente, a

381 INSTITUTO BRASILEIRO DE GOVERNANÇA CORPORATIVA. Governança corporativa em empresas de controle familiar: casos de destaque no Brasil. São Paulo: Saint Paul Editora, 2007. p. 23.

${ }^{382}$ É interessante verificar, porém, que para o ingresso de companhias abertas nacionais em segmentos de mercado que têm como base maiores níveis de governança corporativa, como forma de proteger o acionista minoritário (p.ex.: o novo mercado da BM\&F-Bovespa e seus diversos níveis correlatos), não se encontram quaisquer dos requisitos mencionados pelo IBGC, como boas práticas de governança corporativa relacionadas à auditoria externa, a criação de comitês de auditoria, o rodízio de auditores, entre outros. 
qual exercerá as mesmas funções estabelecidas para as companhias abertas. Trata-se, no caso, tão somente do interesse dos acionistas em utilizar tal mecanismo e da aceitação dos custos financeiros que ele acarretará à companhia, a serem suportados a partir do reconhecimento no sentido de que os benefícios resultantes serão importantes para aqueles. ${ }^{383}$

Cumpre, desta forma, analisar nos tópicos seguintes as relações dos auditores externos independentes com os demais órgãos societários, nos termos preconizados pela doutrina para as boas práticas de governança corporativa.

\subsection{Auditoria externa e Assembleia}

Em vários países, a assembleia de acionistas tem como função decidir sobre a contratação ou a resilição do contrato (nas hipóteses em que isto for permitido) de auditoria externa.

Tal medida visa a proteger a independência do auditor em relação à gestão da entidade auditada, evitando eventual conflito de interesses, uma vez que o profissional de auditoria não pode ficar subordinado aos administradores, cujo trabalho deve fiscalizar.

Seguindo esta linha de raciocínio, perante os países que compõem a União Europeia, a Diretiva n. 2006/43/CE ressalta, ainda em suas considerações iniciais, que:

O revisor oficial de contas ou a sociedade de revisores oficiais de contas deverão ser nomeados pela assembleia geral de acionistas ou membros da entidade examinada. A fim de proteger a independência do revisor oficial de contas, é relevante que a destituição seja apenas possível quando houver justificação válida para tal e se esta for comunicada à autoridade ou autoridades responsáveis pela supervisão pública.

A mesma Diretiva, em seu art. 37, novamente volta a salientar a mesma regra, possibilitando eventuais sistemas distintos de escolha, desde que não haja subordinação do auditor à administração:

${ }^{383}$ Curso de Direito Comercial, cit. p. 510. 
1. O revisor oficial de contas ou a sociedade de revisores oficiais de contas são designados pela assembleia geral de acionistas ou membros da entidade examinada.

2. Os Estados-Membros podem autorizar sistemas ou modalidades alternativos de designação do revisor oficial de contas ou da sociedade de revisores oficiais de contas, desde que esses sistemas ou modalidades sejam concebidos de modo a assegurar a independência do revisor oficial de contas ou da sociedade de revisores oficiais de contas relativamente aos membros executivos do órgão de administração ou ao órgão de direção da entidade examinada.

Na Itália, mais especificamente, o art. 159, 1, do Decreto Legislativo de 24 de fevereiro de 1998, n. 58, dispõe cumprir à assembleia a conferência e a revogação do encargo do auditor, como vimos anteriormente.

No Brasil, entretanto, a escolha e destituição dos auditores independentes cabe ao Conselho de Administração, e não diretamente à assembleia (art. 142, IX, da Lei n. 6.404/76), como veremos com mais detalhes no tópico seguinte.

Sem prejuízo das atribuições do Conselho de Administração na contratação e destituição dos auditores, preconiza-se doutrinariamente dois casos de participação da assembleia de acionistas em relação aos serviços de auditoria externa: 1) quando da recontratação dos auditores; 2) na ocorrência de destituição motivada do auditor de suas funções.

O primeiro é defendido como boa prática de governança corporativa pelo IBGC, nos seguintes termos:

Recomenda-se que a eventual renovação com a firma de auditoria, após prazo máximo de 5 (cinco) anos, seja submetida a aprovação da maioria dos sócios presentes em Assembleia Geral. A votação deve incluir todas as classes de ações. ${ }^{384}$

O segundo é defendido por Modesto Carvalhosa. Muito embora não o diga o autor, entendemos que a medida preconizada, que não se encontra entre as hipóteses de competência privativa da assembleia (art. 122 da Lei n. 6.404/76), também se enquadra numa recomendação de boa prática de governança, pois visa justamente a evitar conflitos de interesse e manter a independência do auditor: 
No pressuposto de que existe um conflito formal entre os auditores que examinam e certificam as contas de quem os contrata, o órgão de administração competente - o Conselho -, se vier a destituir profissionais encarregados de tais serviços, deverá ato contínuo convocar e apresentar à assembleia geral (e, nos casos de companhias abertas, informar também à Comissão de Valores Mobiliários) os fundamentos dessa deliberação. Trata-se de medida de interesse inquestionável dos acionistas e do próprio mercado em que a empresa atua. Muito embora a assembleia geral não possa deliberar a respeito, poderá questionar a medida e dela inferir conclusões sobre a administração da companhia, ensejando outras medidas correlatas e até a destituição dos administradores. ${ }^{385}$

Em ambas as hipóteses, o intuito é tornar a assembleia mais próxima das principais decisões administrativas dos gestores e do próprio Conselho de Administração, uma vez que estas podem ser contrárias aos interesses dos acionistas ou de outros interessados.

Por outras palavras, as medidas preconizadas visam a não deixar que o auditor se perpetue em sua função sem nenhum controle dos acionistas, nem que seja destituído sem o expresso conhecimento (e eventuais providências) destes. Isto evita, ainda, que o Conselho de Administração aja sem qualquer controle no tocante à matéria de auditoria externa.

No entanto, há de se convir que, se para a renovação e resilição (ainda que motivada) do contrato com o auditor, a intervenção da assembleia deve ocorrer como princípio de boa prática de governança (seja aprovando a renovação nos moldes apontados pelo Conselho de Administração, ou tomando ciência para eventuais providências no concernente a destituições), é forçoso concluir que, em se adotando os princípios aludidos, a única hipótese em que não haverá intervenção dos acionistas reunidos em assembleia será na contratação inicial do auditor, cuja competência recairá integralmente sobre o Conselho, sem necessidade de qualquer convocação ou manifestação do órgão máximo da sociedade.

Ora, se assim pudermos concluir, melhor seria, a nosso ver, que o princípio adotado em nossa legislação, acolhendo as práticas de boa governança, fosse aquele

\footnotetext{
${ }^{384}$ INSTITUTO BRASILEIRO DE GOVERNANÇA CORPORATIVA. Código das melhores práticas de governança corporativa. São Paulo: IBGC, 2009. p. 60.
} 
segundo o qual a escolha e a destituição do auditor independente passassem diretamente para a competência da assembleia geral, como preconizado na regulamentação italiana e europeia em geral sobre a matéria.

Embora possa vir a ser mais custosa, é fato que a mudança de competência reduziria muito a possibilidade de conflito de interesses entre a posição do auditor e a dos conselheiros que, embora obrigatoriamente sejam acionistas e, portanto, representem esta categoria (art. 146 da Lei n. 6.404/76), também podem ser diretores e participar diretamente da administração (art. 143, § 1ํㅡㄹ da Lei n. 6.404/76).

\subsection{Auditoria externa e Conselho de Administração}

Como vimos no tópico antecedente, a legislação nacional incumbe ao Conselho de Administração escolher e destituir os auditores externos independentes (art. 142, IX, da Lei n. 6.404/76).

Esta norma visou a evitar conflitos de interesses entre auditores e a administração da entidade, representada pela diretoria. Tendo os auditores de fiscalizar os negócios elaborados pela gestão, não poderiam, pelo evidente conflito, ficar subordinados à diretoria, uma vez que isto implicaria a perda de sua independência.

Neste sentido é o ensinamento de Haroldo Malheiros Duclerc Verçosa:

A competência do conselho para esta matéria é natural, pois caberá aos auditores independentes, dentro de sua função, examinar os negócios da companhia, praticados pelos diretores, a fim de dar seu parecer. Diante do evidente conflito de interesses, não se poderia incumbir a própria diretoria desta atribuição. ${ }^{386}$

Embora o intuito da legislação pátria em atribuir tal competência ao Conselho de Administração seja evitar os conflitos de interesse (conflitos de agência) e preservar a independência do auditor, como já salientamos, poderia haver ainda maior redução desses

\footnotetext{
385 CARVAlHOSA, Modesto; LATORRACA, Nilton. Comentários à lei de sociedades anônimas. São Paulo: Saraiva, 1998, v. 3. p. 126.

${ }^{386}$ Curso de Direito Comercial. cit. p. 424.
} 
conflitos se o modelo adotado seguisse os padrões europeus, em geral, e italianos, especificamente, segundo os quais a contratação e destituição do auditor são feitas diretamente pela própria assembleia de acionistas. ${ }^{387}$

Conquanto a lei atribua ao Conselho de Administração a prerrogativa de escolher e destituir os auditores, as boas práticas de governança corporativa requerem um maior número de cuidados de referido órgão.

Primeiramente, não basta o Conselho de Administração limitar-se à escolha ou destituição dos auditores. É necessário, nos termos do que preconiza o IBGC, que o Conselho atue no tocante à auditoria externa no sentido de:

Aprovar os respectivos honorários e ratificar um plano de trabalho, bem como avaliar seu desempenho (...). O Conselho também deve aprovar o planejamento anual, analisar os resultados e monitorar a implementação das recomendações apresentadas pela Auditoria Interna. Em caso de terceirização desta atividade, os serviços de auditoria interna não devem ser exercidos pelos auditores independentes. ${ }^{388}$

Em suma, é necessária uma atuação participativa e proativa ${ }^{389}$ deste órgão societário no que diz respeito à auditoria, que não se limite à formalização da escolha ou destituição do auditor, mas que efetivamente se mantenha inteirada do desenvolvimento dos trabalhos, sempre cuidando da manutenção da independência do auditor.

\footnotetext{
${ }^{387}$ Dentre os conflitos que podem surgir no modelo nacional de escolha e destituição dos auditores pelo Conselho de Administração encontram-se: 1) o conselheiro pode ser diretor e, portanto, pode revelar uma escolha de auditor tendenciosa, uma vez que terá seu trabalho fiscalizado por este, além de proporcionar outras restrições e eventualmente não ter interesse na transparência da gestão; 2) o conselheiro, apesar de ser acionista, muitas vezes não representa propriamente o interesse de sua classe, havendo casos em que tal função é exercida por indivíduos que possuem uma única ação, apenas para legitimar sua atuação; 3) o conselheiro é demissível ad nutum pelo controlador, que poderá usar seu poder para escolher, de forma indireta, auditor que esteja alinhado a seus interesses, e não aos do restante dos acionistas ou investidores.

${ }^{388}$ Governança corporativa em empresas..., cit., p. 49. Segundo pesquisa do IBGC, realizada com quinze companhias abertas de controle familiar, que adotam níveis elevados de governança corporativa (níveis 1, 2 e novo mercado da Bovespa), a contratação de auditores por período predefinido e recontratação apenas após avaliação formal e documentada, efetuada pelo Comitê de Auditoria elou Conselho de Administração foi constatada em 73,3\% dos casos (idem, ibidem).

${ }^{389}$ A crise econômica ocorrida em 2008 mostrou uma série de ineficiências do trabalho de Conselhos de Administração de companhias nacionais no acompanhamento e fiscalização dos aspectos financeiros da gestão. Exemplo disto ocorreu com a aplicação de recursos em vendas de opções e contratos futuros de dólar norte-americano, com o intuito de proteger a empresa contra variações desta moeda (hedge) nas exportações de suas mercadorias. No entanto, as operações mencionadas, em muitas companhias, foram excessivamente arriscadas e muito além da necessidade de proteção requerida, encerrando verdadeiras apostas na queda da moeda norte-americana. Com a crise, e o consequente aumento do valor do dólar, esta operação acabou por expor enormes passivos e prejuízos relevantes, em detrimento dos investidores. Os administradores das companhias brasileiras que assim operaram, incluindo membros de Conselhos de Administração, agora têm sua conduta sob apreciação da CVM e do Poder Judiciário.
} 
Outra recomendação inerente às boas práticas de governança formuladas pelo IBGC é que o Conselho de Administração somente contrate e recontrate o auditor externo por período definido, e que tais atos sejam efetivados mediante prévia avaliação formal e documentada, de forma a garantir a idoneidade moral e técnica do profissional ou da sociedade contratada. A recontratação (se legalmente permitida) deve necessariamente ser precedida de rotação dos componentes da equipe de auditoria. ${ }^{390}$

Cabe ainda, nos termos das recomendações supracitadas de boas práticas de governança, que o Conselho não permita ao auditor a realização de serviços outros que não os de auditoria externa, ${ }^{391}$ bem como que divulgue a quantia e proporcionalidade de honorários pagos ao auditor e se assegure de que o auditor ou sociedade de auditoria não dependam econômica ou financeiramente da entidade auditada, dado seu pequeno número de outros clientes.

O Conselho de Administração deve discutir com o auditor todo e qualquer caso envolvendo falhas em critérios contábeis, critérios dúbios ou alternativos de contabilização, entre outros problemas encontrados. Igualmente, na forma das normas brasileiras do setor financeiro, securitário e de previdência, já citadas neste trabalho, deve ser, na ausência de Comitê de Auditoria, o órgão próprio para receber comunicações do auditor independente em relação a fraudes e desvios encontrados nas demonstrações contábeis.

No caso de entidades que não possuam Conselho de Administração, o auditor deve se reportar diretamente aos sócios ou acionistas, ficando aos órgãos deliberativos representativos destes últimos (assembleia, reunião de sócios, etc.) as prerrogativas de contratação e destituição dos auditores, bem como de acompanhamento de seu trabalho, uma vez que não se pode atribuir tal prerrogativa, pelo evidente conflito de interesses, à diretoria. $^{392}$

\footnotetext{
${ }^{390}$ Código das melhores práticas. cit. p. 60.

${ }^{391}$ Novamente é importante citar a pesquisa do IBGC referida em nota anterior. Segundo o apurado, a não prestação de outros serviços pelo auditor independente além dos de auditoria foi constatada em $66,7 \%$ dos casos (in Governança corporativa em empresas de controle familiar: casos de destaque no Brasil, cit., p. 49).

${ }^{392}$ Esta também é uma recomendação do IBGC (Código das melhores práticas. cit. p. 59).
} 


\subsection{Auditoria externa e Diretoria}

Conforme já salientado, a diretoria ocupa uma posição peculiar em face dos auditores independentes, uma vez que o trabalho daquela é o principal alvo do exame da auditoria.

Muito embora se tenha como regra a impossibilidade de subordinação do auditor externo aos administradores, impondo certo distanciamento entre ambos, é fato que as boas práticas de governança corporativa determinam que o relacionamento entre auditores e gestores deva se dar em um clima de seriedade, marcado pelo profissionalismo e transparência.

A primeira regra geral que a diretoria deve ter em mente é sempre permitir o livre acesso dos auditores às instalações, documentos, arquivos e informações necessárias ao seu trabalho. ${ }^{393} \mathrm{O}$ acesso às informações e documentos deve incluir também a forma de remuneração variável dos diretores (bônus, recebimento de valores mobiliários, etc.), de modo a possibilitar ao auditor a verificação do conflito de agência e do alinhamento de interesses proporcionado pela remuneração mencionada.

Os diretores, igualmente, devem se dispor a atender ao auditor e debater com este as eventuais dúvidas, conflitos e divergências, adequando seu procedimento, quando for o caso.

Outro ponto de contato entre o trabalho dos auditores externos e dos membros da diretoria é relativo aos controles internos. Com efeito, a legislação internacional, marcadamente com o advento da Lei Sarbanes-Oxley (seção 404), passou a exigir dos diretores a elaboração de relatórios gerenciais sobre os controles internos da entidade, ao mesmo tempo em que exigiu que os auditores externos apresentassem avaliação sobre a eficácia desses controles.

\footnotetext{
${ }^{393}$ Sem o qual, como comentamos no curso deste trabalho: 1) em princípio, o auditor deve comunicar o fato à administração da entidade auditada; 2) caso não sejam tomadas providências, deverá fazer a mesma comunicação ao Conselho de Administração, Comitê de Auditoria, ou outro órgão de representação dos acionistas; 3 ) poderá, se isto for possível, resilir o contrato com justa causa (audit withdraw) ou, não havendo esta possibilidade, apresentar parecer com ressalva ou abstenção de opinião.
} 
Esta imposição acarretou um aumento do nível de exigências recíprocas entre auditores e diretores, dada a maior possibilidade de responsabilização desses profissionais pelas irregularidades nos controles internos.

Como ensina Marcos Peters:

Em relação ao controle interno e à responsabilidade pela qualidade de informações públicas, a SOX exige que os principais executivos da empresa confiram os relatórios periódicos entregues à SEC, garantindo assim que esses não contenham informações falsas ou omissões, representando a real situação financeira da companhia; no caso de divulgação de informações errôneas ou inexatas, são impostas penalidades. Especificamente, os diretores presidente (Chief Executive Officer - CEO) e financeiro (Chief Financial Officer - CFO) têm de apresentar à SEC, além dos relatórios já correntemente previstos, declaração certificando que tanto o relatório da administração quanto as demonstrações financeiras indicam a real situação financeira e de resultado operacional da empresa e estão em conformidade com as normas da SEC; a quem não atender a esses requisitos há sanções pecuniárias de U\$ 1 milhão a U\$ 5 milhões e/ou penais de dez a vinte anos de reclusão. Em outras palavras, os referidos administradores não poderão alegar ignorância a respeito de erros e fraudes em relatórios financeiros de sua responsabilidade. ${ }^{394}$

Devem, portanto, os administradores e auditores ensejar esforços para a atuação comum no sentido de proporcionar melhores controles das operações econômicas da entidade auditada.

A necessidade de evitar um conflito de interesses por meio da ausência de subordinação dos auditores aos gestores, na forma das normas que regulamentam a matéria e das boas práticas de governança, gera, porém, uma questão jurídica: em caso de eventual prejuízo causado pela ação dos auditores externos independentes à entidade auditada, os diretores deteriam legitimação para responsabilizar os auditores em juízo, ou seria necessária autorização (ou mesmo a atuação direta) de outros órgãos sociais, como a Assembleia ou o Conselho de Administração?

\footnotetext{
394 PETERS, Marcos R. S. Controladoria internacional: incluindo Sarbanes Oxley Act e USGAAP. São Paulo: DVS Editora, 2004. p.39.
} 
Em princípio, não se encontra nas regras do direito societário nacional uma disciplina legal expressa desta matéria.

Seria possível argumentar que, não havendo norma expressa prevendo competência privativa da Assembleia ou do Conselho para autorizar o ajuizamento de ação em face dos auditores, a atribuição de fazê-lo ficaria unicamente com a diretoria, que teria a incumbência de representar a entidade em juízo e decidir, por si só, as hipóteses em que deve fazê-lo. Esta atribuição, inclusive, não poderia se delegada a outros órgãos (art. 139 da Lei n. 6.404/76).

Igualmente favorece a atribuição da diretoria o fato de que a decisão assemblear ou do Conselho poderia ser demasiado lenta e custosa, contrariamente ao que ocorreria com uma decisão dos diretores.

No entanto, há de se considerar que os diretores podem estar em conflito de interesses com o auditor e, portanto, usar da faculdade de acioná-lo em juízo como mecanismo de coerção, submissão aos interesses próprios ou vingança. Indiretamente, o processo judicial poderia se transformar em uma ameaça ou mecanismo de pressão da diretoria sobre o trabalho do auditor, ou até mesmo num modo de afastá-lo por via oblíqua, burlando a atribuição privativa do Conselho de Administração. Outrossim, poderiam os diretores, agindo em conluio com o auditor, evitar o ingresso de um processo judicial contra este. Assim, a necessidade de atuação direta ou autorização do Conselho de Administração (ou assemblear) tornar-se-ia necessária.

Também conspira favoravelmente à necessidade de autorização do Conselho de Administração o fato de que este órgão detém competência para escolher e destituir o auditor, dentro da qual estaria a prerrogativa de decidir sobre o processo judicial que responsabilizasse civilmente este profissional.

Outro argumento favorável à necessidade de atuação ou autorização assemblear para responsabilizar o auditor em juízo estaria no fato de que este exerce função auxiliar dos administradores da sociedade, principalmente no tocante às atribuições do Conselho Fiscal. Ora, se é necessário que a assembleia autorize o ajuizamento de ação em face de seus administradores pelos prejuízos causados por estes (art. 159 da Lei n. 6.404/76), também haveria necessidade desta autorização para processar o auditor em juízo. 
Neste sentido, no ordenamento italiano, em que a Assembleia (e não o Conselho de Administração) possui competência na escolha e destituição do auditor, o art. 164 do Decreto Legislativo de 24 de fevereiro de 1998, n. 58, ${ }^{395}$ ressalta que se aplica às sociedades de auditoria o disposto no art. 2.407 do Código Civil italiano, ${ }^{396}$ que diz respeito à responsabilização do membro do Conselho Fiscal (Collegio Sindacale). A ação de responsabilidade contra citados membros, nos termos do art. 2.393 do Código Civil italiano, ${ }^{397}$ somente pode ser proposta após autorização assemblear.

Parte da doutrina italiana, entretanto, não dá interpretação literal ao reenvio existente entre as normas supracitadas, argumentando que, na verdade, a exigência de autorização assemblear não está contida na remessa feita pelo art. 164 do Decreto Legislativo de 24 de fevereiro de 1998, n. 58, ao art. 2.407 do Código Civil italiano.

Posicionando-se sobre o tema, Daniela Casadei ensina:

Foi enfrentada muito raramente na doutrina a questão do órgão competente para promover a ação de responsabilidade contratual em face da sociedade de auditoria (...). A competência assemblear pode ser sustentada considerando que, sendo atribuição da assembleia conferir e revogar o encargo do auditor, só esta tem o poder de deliberar sobre a ação de responsabilidade. A solução encontra também justificações práticas, porquanto seria incoerente atribuir a ação ao próprio artífice dos atos que são objeto do controle da sociedade de auditoria. Se fosse admitida esta solução, a competência teria que ser da assembleia em sede ordinária (...). É claro que, uma vez deliberado, a ação virá proposta pelo representante legal da sociedade examinada, segundo os princípios gerais

\footnotetext{
395 “Art. 164 (Responsabilità). Alla società di revisione si applicano le disposizioni dell'articolo 2407 del codice civile."

396 “Art. 2.407. Responsabilità. I sindaci devono adempiere i loro doveri con la diligenza del mandatario (1710), sono responsabili della verità delle loro attestazioni e devono conservare il segreto sui fatti e sui documenti di cui hanno conoscenza per ragione del loro ufficio (2622; Cod. Pen. 622). Essi sono responsabili solidalmente con gli amministratori (1292 e seguenti, 2392) per i fatti o le omissioni di questi, quando il danno non si sarebbe prodotto se essi avessero vigilato in conformità degli obblighi della loro carica (2.621). L'azione di responsabilità contro i sindaci è regolata dalle disposizioni degli artt. 2.393 e 2.394 (att. 209)."

397 “Art. 2.393. Azione sociale di responsabilità. L'azione di responsabilità contro gli amministratori è promossa in seguito a deliberazione dell'assemblea, anche se la società è in liquidazione. La deliberazione concernente la responsabilità degli amministratori può essere presa in occasione della discussione del bilancio (2.364), anche se non è indicata nell'elenco delle materie da trattare (2.373). La deliberazione dell'azione di responsabilità importa la revoca dall'ufficio degli amministratori contro cui è proposta, purché sia presa col voto favorevole di almeno un quinto del capitale sociale. In questo caso l'assemblea stessa provvede alla loro sostituzione (2.386; att. 209). La società può rinunziare all'esercizio dell'azione di responsabilità e può transigere, purché la rinunzia e la transazione siano approvate con espressa deliberazione dell'assemblea, e purché non vi sia il voto contrario di una minoranza di soci che rappresenti almeno il quinto del capitale sociale (2.407)."
} 
de legitimação processual. Mas também a legitimação do órgão administrativo é justificável. Pode-se sustentar que a competência assemblear se limita à conferência e revogação do encargo, enquanto a execução do relacionamento constituído em consequência, tocando à diretoria, é de competência do órgão administrativo (...). Por fim, na ausência de disposições normativas e ou de argumentos sistemáticos decisivos, pode-se pensar que não há razões para derrogar a regra de competência do órgão administrativo para os aspectos gerenciais do relacionamento. A legitimação é do órgão administrativo quando os administradores não são os artífices do comportamento ilegítimo. Isto pode acontecer na ação envolvendo a responsabilidade contratual, quando os administradores da sociedade auditada tenham sido substituídos. Por outro lado, a legitimação será da assembleia quando o órgão administrativo estiver em situação do conflito de interesse. ${ }^{398}$

$\mathrm{O}$ argumento alternativo desenvolvido por esta autora, segundo o qual a legitimidade poderia caber tanto à diretoria quanto à Assembleia, conforme a presença ou não de um conflito de interesses, inicialmente parece ser dotado de razoabilidade.

No entanto, a existência do conflito de interesses pode ser matéria extremamente controvertida e difícil de se determinar em um processo judicial, ensejando, por vezes, longas discussões processuais necessárias somente à definição da legitimidade processual para a ação.

Isto pode gerar toda sorte de protelações processuais, insegurança jurídica e levantamento de óbices formais preliminares ao conhecimento da matéria de mérito no

\footnotetext{
398 Op. cit. p. 171. O texto é tradução livre de: "È stata raramente affrontata in dottrina la questione dell'organo competente a promuovere l'azione di responsabilità contrattuale nei confronti della società di revisione (...). La competenza assembleare può essere sostenuta considerando che, essendo l'assemblea l'organo competente a conferire e a revocare l'incarico di revisione, solo essa abbia il potere di deliberare sull'azione di responsabilità. La soluzione trova anche giustificazioni pratiche, in quanto sarebbe incoerente attribuire l'azione próprio all'artefice dell'operato che è oggetto di controllo da parte delia società di revisione. Se si accede a questa soluzione, la competenza dovrebbe essere dell'assemblea in sede ordinária (...). È chiaro che, una volta deliberata, l'azione verrà proposta dal legale rappresentante della società revisionata, secondo i principi generali di legittimazione processuale. Ma anche la legittimazione dell'organo amministrativo è giustificabile. Può sostenersi che la competenza assembleare si fermi alla nomina e alla revoca dell'incarico mentre l'esecuzione dei rapporto cosi costituito, attenendo alia gestione, sia di competenza dell'organo amministrativo (...). Alla fine, in assenza di disposizioni normative e di decisivi argomenti sistematici, può ritenersi che non ci sono motivi per derogare alla regola della competenza dell'organo amministrativo per gli aspetti gestionali dei rapporti. La legittimazione è dell'organo amministrativo quando gli amministratori non siano gli artefici dei comportamento illegittimo. Cio può accadere, nell'azione contrattuale, quando gli amministratori delia società revisionata siano stati sostituiti. Viceversa, la legittimazione sara dell'assemblea quando l'organo amministrativo versi in situazione di conflitto di interessi”.
} 
processo, sem falar em extinções desnecessárias ou desarrazoadas de feitos sem julgamento da lide, somente em virtude de incertezas quanto à legitimidade da parte autora e até mesmo o reconhecimento de eventual prescrição do direito à responsabilização civil.

Tal situação, obviamente, não atende aos fins de realização de justiça e pacificação social buscados pelo ordenamento jurídico.

Desta forma, entendemos que, podendo haver conflito de interesses entre a diretoria e os auditores externos, o melhor seria que, de lege ferenda, nosso ordenamento previsse regra específica disciplinando a matéria e atribuindo, de forma preventiva e pacificadora, a necessidade de autorização da Assembleia, ou ao menos do Conselho de Administração, para o ingresso da entidade auditada em juízo destinado a responsabilizar civilmente $\mathrm{o}$ auditor.

$\mathrm{Na}$ ausência de regra a respeito, preferimos entender que para a entidade auditada processar o auditor, é necessário, ao menos, a autorização do Conselho de Administração, dadas as prerrogativas que este órgão detém no que tange à escolha e destituição dos auditores, que incluiria também a prerrogativa de autorizar um processo civil contra estes. Em outras palavras, entendemos que a prerrogativa de escolha e destituição, constante do art. 142, IX, da Lei n. 6.404/76, engloba o poder de autorizar o ingresso em juízo contra o auditor para responsabilizá-lo civilmente.

Obviamente, em havendo autorização assemblear, com mais razão a entidade estará legitimada a ingressar em juízo em face dos auditores, dado que se trata da expressão da vontade do órgão máximo da entidade. Nas companhias em que o Conselho de Administração não for obrigatório (art. 138, § 2º , da Lei n. 6.404/76), entendemos indispensável a autorização assemblear para que se intente tal processo judicial.

De qualquer forma, diante da lacuna legal e dada a possibilidade de discussão da matéria em juízo, gerando incertezas e confusões, entendemos recomendável, como boa prática de governança corporativa, que os contratos societários ou estatutos da entidade prevejam norma expressa quanto à necessidade de deliberação assemblear ou do Conselho de Administração para processar o auditor em juízo. 


\subsection{Auditoria externa e Conselho Fiscal}

Muitas vezes, a prestação de serviços de auditoria externa, consubstanciando um trabalho de revisão de contas, é confundida com a atribuição fiscalizadora do Conselho Fiscal sobre a administração da entidade. ${ }^{399}$

$\mathrm{Na}$ verdade, porém, embora existam pontos de contato entre as atribuições do Conselho Fiscal e do auditor independente, há elementos que diferenciam os campos de atuação de cada qual.

Primeiramente, devemos dizer que as atribuições do Conselho Fiscal não se limitam ao exame de contas ou das demonstrações contábeis. Uma breve visualização do art. 163 da Lei n. 6.404/76 dá noção da maior abrangência da competência de tal órgão, que inclui uma fiscalização geral sobre a administração, incluindo aspectos não necessariamente vinculados à escrituração da entidade, mas à adequação de condutas dos administradores aos termos legais e estatutários.

Ademais, quando o Conselho Fiscal realiza um controle sobre as contas dos gestores, fá-lo principalmente com vistas a determinar não somente uma adequação formal, mas também de mérito nos resultados apresentados.

O auditor independente, por sua vez, limita-se a verificar o conteúdo das demonstrações contábeis - e o substrato escritural que lhe deu base -, com o fim precípuo de evidenciar eventual existência de distorções relevantes. Cuida-se de controle apenas formal, limitado e especializado sobre uma parcela da atuação dos gestores da entidade.

Neste sentido, interessante a lição de Maria Vittoria Cozzi:

A distinção entre a competência do conselho fiscal e aquela da sociedade de auditoria vinha, assim, individualizada na diversidade de funções que

\footnotetext{
${ }^{399}$ Aliás, não faltaram vozes a preconizar, com grande razoabilidade, a ineficiência do controle exercido pelo Conselho Fiscal, dada sua falta de independência em relação ao controlador ou mesmo à administração (em razão de sua eleição por aqueles que representam a maioria acionária), além do desconhecimento econômico contábil dos componentes, tudo a limitar um controle efetivo sobre os atos de gestão. Obviamente, muitas dessas ineficiências também se aplicam ao controle de contas feito pela auditoria independente. Vale lembrar a lição de Haroldo Malheiros Duclerc Verçosa (Curso de Direito Comercial. cit. p. 491): "Tanto a obrigatoriedade da atuação do conselho fiscal nas companhias abertas quanto a institucionalização do mecanismo de auditoria independente revelaram-se solução abaixo das expectativas da reforma legislativa, tendo ocorrido a quebra de grandes empresas como resultado, em parte, da falha dos dois órgãos, encontrando-se o direito societário na busca de soluções mais eficazes a partir da adoção de princípios de governança corporativa, a exemplo do que é feito no Direito Norte-Americano, aqui inicialmente adotados voluntariamente por companhias abertas que aceitam participar do sistema do Novo Mercado, implantado pela Bolsa de Valores de São Paulo".
} 
o exame da contabilidade dizia respeito às características do controle contábil: os conselheiros examinavam a contabilidade a fim verificar a correção da administração, enquanto a sociedade de auditoria verificava que os fatos da gerência fossem transcritos corretamente na contabilidade e no balanço. ${ }^{400}$

\section{Desta lição não discrepa o magistério de Daniela Casadei:}

Em conclusão, não há uma superposição de competências porque diversas são as finalidades do controle da contabilidade desenvolvido pelo auditor e aquele de competência do conselho fiscal: a vigilância dos conselheiros é um controle de legalidade através do exame do mérito da gestão, que compreende também, como instrumento de auxílio, o controle contábil; a vigilância do auditor, inversamente, é um controle de legalidade formal e substancial sobre os dados da contabilidade. A função do auditor vem a ser, de uma parte, mais limitada que a dos conselheiros, porque, não sendo órgão social, o auditor não participa da sociedade e das decisões da gerência; de outra parte, é mais incisiva a função de controle que a sociedade de auditoria deve realizar, porquanto a estrutura, a dimensão organizacional e o elevado profissionalismo permitem e impõem um controle muito mais penetrante e eficaz do que aquele que o conselho fiscal pode desenvolver. ${ }^{401}$

Vistas as distinções entre as competências do Conselho Fiscal e dos auditores externos, é necessário passar em revista às boas práticas de governança que devem reger o relacionamento entre ambos.

A primeira questão inerente ao relacionamento entre competências do Conselho Fiscal e dos auditores externos é relativa ao correto acompanhamento dos

\footnotetext{
${ }^{400}$ Op. cit. p. 14. O texto é tradução livre de: "La distinzione tra competenza del collegio sindacale e quella della società di revisione veniva cosi individuata nella diversa funzione che l'esame della contabilità aveva rispetto a quella caratterizzante il controle contabile: i sindaci esaminavano la contabilità per accertare la correta amministrazione, mentre la società di revisione verificava che i fatti di gestione fossero corretamente transcritti nella contabilità e nel bilancio".

${ }^{401}$ Op. cit. p. 13. O texto é tradução livre de: "In conclusione, non vi è sovrapposizione di competenze perche diverse sono le finalità dei controllo contabile svolto dal revisore e di quello di cui è competente il collegio sindacale: la vigilanza dei sindaci è un controllo di legalità attraverso l'esame dei mérito della gestione che comprende anche, come strumento di ausilio, il controllo contabile; la vigilanza dei revisore, invece, è un controllo di legalità formale e sostanziale sui dati contabili. La funzione dei revisore viene ad essere, da una parte, piú limitata di quella dei sindaci perche, non essendo organo sociale, il revisore non partecipa alla gestione ed alle decisioni della società; dall'altra parte è piú incisiva la funzione di controllo che la società di revisione deve svolgere in quanto la struttura, la dimensione organizzativa e l'alta professionalità permettono e impongono un controllo molto piú penetrante ed efficace di quello che il collegio sindacale può svolgere".
} 
trabalhos, devendo os conselheiros estar em permanente contato com os auditores, levando em consideração as conclusões destes para basear seu trabalho fiscalizatório.

Isto, segundo o IBGC, pode ser feito por meio da busca de uma agenda de trabalho produtiva e mutuamente benéfica. ${ }^{402}$

Outra questão importante diz respeito à não interferência ou oposição de qualquer óbice ao relacionamento entre auditores e conselheiros fiscais, principalmente em relação à comunicação de informações, relatórios ou outros documentos necessários à fiscalização da gestão.

Como os auditores realizam tarefa auxiliar às atribuições do Conselho Fiscal, por dever legal (art. 163, $\S 4^{\circ}$, da Lei n. 6.404/76) e também no cumprimento de boas práticas de governança, devem os auditores prestar toda sorte de assessoramento aos conselheiros, inclusive através do comparecimento às reuniões do órgão.

Para a melhoria do relacionamento entre auditores e conselheiros fiscais, possibilitando assim maior amplitude no acompanhamento dos trabalhos e trocas de informações, é recomendável, como boa prática de governança, um maior grau de independência dos conselheiros e de especialização destes em matéria contábil.

\subsection{Auditoria externa e Comitê de Auditoria}

A criação de Comitês de Auditoria tem sido objeto de intensa regulamentação internacional e nacional sobre a matéria, com o fim de dar maior transparência às informações financeiras prestadas pelas companhias.

A Lei Sarbanes-Oxley, como vimos, obrigou a criação de Comitê de Auditoria $^{403}$ nas companhias cujos valores mobiliários sejam listados em bolsa. Este órgão,

\footnotetext{
${ }^{402}$ Governança corporativa em empresas... cit. p. 64. Segundo a pesquisa do IBGC, mencionada em nota anterior, houve a constatação de que o conselho fiscal se comunica com representantes da auditoria independente e membros da auditoria interna em 78\% dos casos (idem, p. 50).

${ }^{403}$ Assim é definido na SOX o Comitê de Auditoria: “AUDIT COMMITTEE.- The term 'audit committee' means- (A) a committee (or equivalent body) established by and amongst the board of directors of an issuer for the purpose of overseeing the accounting and financial reporting processes of the issuer and audits of the
} 
que é competente para aprovar e acompanhar todo o processo de elaboração das demonstrações financeiras e respectiva auditoria, deve: 1) ser composto por membros do Conselho de Administração, que devem ser independentes, não podendo aceitar qualquer outro tipo de remuneração por serviços que não aquela inerente ao cargo ocupado no Conselho, nem ser vinculados ao instituidor; ${ }^{404}$ 2) dispor de um especialista financeiro (financial expert), como visto previamente; 3) receber denúncias relativas a irregularidades na contabilidade ou auditoria; ${ }^{405} 4$ ) dispor de recursos próprios, inclusive para contratar especialistas necessários a seu assessoramento. ${ }^{406}$

Perante a União Europeia, a Diretiva n. 2006/43/CE estabelece em seu art. 41 o seguinte:

\section{Comitê de auditoria}

1. Cada entidade de interesse público deve ter um comitê de auditoria. Os Estados-Membros devem determinar se os comitês de auditoria são compostos por membros não executivos do órgão de administração e/ou por membros dos órgãos de fiscalização da entidade examinada e/ou por membros designados pela assembleia geral de acionistas dessa entidade. Pelo menos, um membro do comitê de auditoria deve ser independente e ter competência nos domínios da contabilidade e/ou da revisão ou auditoria.

Os Estados-Membros podem permitir que, nas entidades de interesse público que satisfaçam os critérios da alínea f) do $\mathrm{n}$. 1 do artigo $2^{\underline{o}}$ da Diretiva 2003/71/CE, as funções atribuídas ao comitê de auditoria possam ser desempenhadas pelo órgão de administração ou de fiscalização no seu conjunto, desde que, pelo menos, se o presidente

financial statements of the issuer; and (B) if no such committee exists with respect to an issuer, the entire board of directors of the issuer".

404 Seção 301 da SOX: “(B) CRITERIA.- In order to be considered to be independent for purposes of this paragraph, a member of an audit committee of an issuer may not, other than in his or her capacity as a member of the audit committee, the board of directors, or any other board committee- (i) accept any consulting, advisory, or other compensatory fee from the issuer; or (ii) be an affiliated person of the issuer or any subsidiary thereof'.

${ }^{405}$ Seção 301 da SOX: "COMPLAINTS.-Each audit committee shall establish procedures for- (A) the receipt, retention, and treatment of complaints received by the issuer regarding accounting, internal accounting controls, or auditing matters; and '(B) the confidential, anonymous submission by employees of the issuer of concerns regarding questionable accounting or auditing matters".

${ }^{406}$ Seção 301 da SOX: “(6) FUNDING.-Each issuer shall provide for appropriate funding, as determined by the audit committee, in its capacity as a committee of the board of directors, for payment of compensation (A) to the registered public accounting firm employed by the issuer for the purpose of rendering or issuing an audit report; and (B) to any advisers employed by the audit committee under paragraph (5)". 
desse órgão for um membro executivo, não seja o presidente do comitê de auditoria.

2. Sem prejuízo da responsabilidade dos membros dos órgãos de administração, de direção ou de fiscalização, ou de outros membros designados pela assembleia geral de acionistas da entidade examinada, o comitê de auditoria procede nomeadamente:

a) Ao acompanhamento do processo de informação financeira;

b) Ao controle da eficácia dos sistemas de controle interno, da auditoria interna, sempre que aplicável, e da gestão de risco da empresa;

c) Ao acompanhamento da revisão legal das contas anuais e consolidadas;

d) À análise e ao controle da independência do revisor oficial de contas ou da sociedade de revisores oficiais de contas e, em especial, da prestação de serviços adicionais à entidade examinada.

No Brasil, a adoção do Comitê de Auditoria só é obrigatória a algumas instituições financeiras (Res. n. 3.198/04 do Banco Central, arts. 10 e seguintes) ${ }^{407}$ e a certas sociedades seguradoras, de capitalização e de previdência complementar (Res. CNSP n. 118, de 2004, arts. 12 e seguintes), ${ }^{408}$ ambas contendo extensa regulamentação da matéria.

Para as companhias abertas em geral, ainda não é obrigatória a existência de Comitê de Auditoria. No entanto, a cartilha da CVM sobre boas práticas de governança corporativa recomenda sua adoção nos seguintes termos:

Um comitê de auditoria, composto por membros do conselho de administração com experiência em finanças e incluindo pelo menos um conselheiro que represente os minoritários, deve supervisionar o relacionamento com o auditor. Como parte da análise das demonstrações

\footnotetext{
${ }^{407}$ Nos termos da norma supracitada: "Art. 10. Devem constituir órgão estatutário denominado comitê de auditoria as instituições referidas no art. $1^{\circ}$, inciso I, alínea "a", que tenham apresentado no encerramento dos dois últimos exercícios sociais: I - Patrimônio de Referência (PR) igual ou superior a $\mathrm{R} \$ 1.000 .000 .000,00$ (um bilhão de reais); ou II - administração de recursos de terceiros em montante igual ou superior a R \$1.000.000.000,00 (um bilhão de reais); ou III - somatório das captações de depósitos e de administração de recursos de terceiros em montante igual ou superior a $\mathrm{R} \$ 5.000 .000 .000,00$ (cinco bilhões de reais)".

${ }^{408}$ Também nos termos da norma supracitada: "Art. 12. Devem constituir órgão estatutário denominado Comitê de Auditoria as sociedades supervisionadas referidas no art. $1^{\circ}$, que tenham apresentado no encerramento dos dois últimos exercícios sociais, no mínimo, uma das condições abaixo: I - Patrimônio Líquido Ajustado (PLA) igual ou superior a R \$ 500.000.000,00 (quinhentos milhões de reais); ou II Provisões Técnicas em montante igual ou superior a R \$ 700.000.000,00 (setecentos milhões de reais)".
} 
da companhia, o conselho fiscal e o comitê de auditoria devem se reunir regular e separadamente com os auditores sem a presença da diretoria.

Esta recomendação tem por finalidade a disseminação e discussão detalhada das demonstrações financeiras da companhia por agentes capazes de analisá-las e propor ao conselho de administração as alterações que se façam necessárias para que reflitam mais adequadamente a situação financeira, econômica e patrimonial da companhia. Naturalmente, caso um executivo da companhia seja membro do conselho de administração, este não deve ser membro do comitê de auditoria. Qualquer membro do comitê de auditoria pode solicitar reunião individual com diretor ou auditor, quando achar necessário. ${ }^{409}$

Também o IBGC recomenda como boa prática de governança a instalação do Comitê de Auditoria:

Recomenda-se a instituição do Comitê de Auditoria para analisar as demonstrações financeiras, promover a supervisão e a responsabilização da área Financeira, garantir que a Diretoria desenvolva controles internos confiáveis (que o comitê deve entender e monitorar adequadamente), que a Auditoria Interna desempenhe a contento o seu papel e que os auditores independentes avaliem, por meio de sua própria revisão, as práticas da Diretoria e da Auditoria Interna. O comitê deve ainda zelar pelo cumprimento do Código de Conduta da organização (...), quando não houver Comitê de Conduta (ou de Ética) designado pelo Conselho de Administração para essa finalidade. No caso do Comitê de Auditoria, pelo menos um integrante deverá ter experiência comprovada na área Contábil ou de Auditoria. A existência do Comitê de Auditoria não exclui a possibilidade da instalação do Conselho Fiscal (...). O Conselho de Administração e o Comitê de Auditoria devem, permanentemente, monitorar as avaliações e recomendações dos auditores independentes e internos sobre o ambiente de controles e os riscos. Cabe também a ambos garantir que os diretores prestem contas das ações tomadas em relação a essas recomendações. ${ }^{410}$

Como visto, ao Comitê de Auditoria - seja ele adotado nos moldes de subcomitê do Conselho de Administração, ou mesmo de modo a não integrar este órgão -

409 BRASIL. COMISSÃO DE VALORES MOBILIÁRIOS. Recomendações da CVM sobre governança corporativa. Disponível em <http://www.cvm.gov.br/port/public/index.asp>. Acesso em 21 fev. 2010.

${ }^{410}$ Código das melhores práticas. cit. p. 45. 
caberá a difícil tarefa de dar maior transparência e confiabilidade às informações financeiras da entidade, através da supervisão de todo o processo de elaboração e revisão das demonstrações contábeis, além de outros aspectos práticos.

Faz-se necessário, portanto, que a regulação nacional da matéria passe a exigir a instituição do Comitê de Auditoria pelas companhias abertas, de forma a dar maior credibilidade às demonstrações contábeis e outras informações financeiras prestadas.

No entanto, a mera instituição formal do comitê não basta. É importante que as condições principais de atuação do órgão, no tocante à independência financeira, hierárquica e moral, sejam estabelecidas como obrigatórias, de forma a tornar efetivas suas incumbências práticas.

Tais incumbências, a serem adotadas pela legislação brasileira (hoje ainda na forma de recomendações de boas práticas de governança), podem ser aquelas preconizadas pelo IBGC, que incluem, no que toca à auditoria externa, o seguinte:

O Comitê de Auditoria deve tratar com os auditores independentes: (i) mudança ou manutenção de princípios e critérios contábeis; (ii) uso de reservas e provisões; (iii) estimativas e julgamentos relevantes utilizados na elaboração das demonstrações financeiras; (iv) métodos de avaliação de risco e resultados dessas avaliações; (v) principais riscos; (vi) mudanças do escopo da auditoria independente; (vii) deficiências relevantes e falhas significativas nos controles internos; (viii) conhecimento de atos ilegais; e (ix) efeitos de fatores externos (econômicos, normativos, setoriais, sociais e ambientais) nos relatórios financeiros e no processo de auditoria. A discussão deve incluir questões como a clareza das divulgações financeiras e o grau de agressividade ou conservadorismo dos princípios e critérios contábeis e premissas adotadas. $^{411}$

É necessário lembrar, entretanto, que a instituição de Comitês de Auditoria, embora recomendável de lege ferenda, não é solução definitiva para todos os problemas de divulgação transparente de informações, constituindo-se apenas um aprimoramento necessário para se atingir grau mais elevado de evidenciação aos usuários e redução das assimetrias informacionais. $^{412}$

${ }^{411}$ Código das melhores práticas. cit. p. 46.

${ }^{412}$ Há estudos que questionam a eficácia de Comitês de Auditoria. Nesse sentido, o estudo de Aldomar Guimarães dos Santos, em dissertação de mestrado perante a FEA-USP, reflete: "Como se percebeu durante 
$\mathrm{O}$ incremento nas atividades dos mercados de capitais e financeiros, incluindo ampla gama de investidores, tem indubitavelmente aumentado a importância da atividade de auditoria externa.

Este fato, em conjunto com os problemas derivados de escândalos contábeis envolvendo a participação de sociedades de auditoria, levou a uma profunda discussão, no âmbito internacional, sobre o grau de responsabilidade civil a que o auditor estaria submetido.

As tendências neste debate são as mais variadas.

Há, naturalmente, aqueles que defendem um maior nível de responsabilização do auditor, como forma de incentivo à adoção de maiores cautelas por estes profissionais.

Em contrapartida, argumenta-se que essa majoração de rigor aumentaria os riscos do negócio, tendo inúmeras consequências sobre o mercado de auditoria, tais como: 1) o aumento dos custos e dos preços dos serviços; $;^{413}$ 2) a concentração de mercado entre as sociedades de maior porte que pudessem enfrentar os riscos inerentes ao ramo e a consequente criação de barreiras à entrada de novos competidores; 3 ) a rejeição de clientes de alto risco por parte das auditorias, o que privaria a sociedade de um serviço relevante.

Estes últimos argumentos são defendidos por aqueles que sustentam, ao contrário da majoração da responsabilidade civil do auditor, a limitação ou restrição desta

o texto, o problema do conflito de interesses e o próprio Comitê de Auditoria não são novidades para a sociedade moderna e nem assunto criado nesse século. O problema da eficácia do Comitê de Auditoria não é uma questão nova e a maioria das empresas abertas envolvidas em casos de relatórios financeiros fraudulentos levantados pela SEC entre 1981 e 1986, tinham comitê de auditoria" (SANTOS, Aldomar Guimarães dos. Comitê de auditoria: uma análise baseada na divulgação das informações de empresas brasileiras. Dissertação de Mestrado. São Paulo: Universidade de São Paulo, 2009. p. 111).

${ }^{413}$ Qualquer que seja a abordagem da matéria ou a forma preferida de responsabilização do auditor, os custos de indenizações contra auditores externos independentes não devem ser desconsiderados em qualquer estudo. Pesquisa feita na Inglaterra, em 2006, dá uma noção do montante de indenizações cobradas em processos judiciais (contra as quatro ou cinco maiores sociedades de auditoria, as chamadas big five ou big four). Segundo o divulgado, em valores de moeda constante (de 2005), os valores demandados judicialmente dessas sociedades na União Europeia (Costs of claims against Big-5/4 firms in the EU by policy year) foi de US\$ 15,2 milhões em 1975, passando a US\$224,1 milhões em 2003, um aumento de impressionantes $1.374 \%$ dos valores cobrados. Houve exercícios, particularmente em 1991, em que os valores cobrados chegaram à cifra de US\$ 581,3 milhões. (LONDON ECONOMICS, Study on the Economic Impact of Auditors' Liability Regimes. Disponível em <http://ec.europa.eu/internal_market/auditing/docs/liability/auditors-finalreport_en.pdf $>$. Acesso em 23 fev. 2010). 
responsabilidade, seja através de responsabilização proporcional, imposição de limites legais ou contratuais.

A abordagem desses temas é feita de modo muito diferente nos diversos países. Independente do maior rigor concernente à responsabilidade civil do auditor na legislação de regência, em alguns Estados existe uma tradição de maior responsabilização do auditor, bem como de maior litigiosidade judicial em assuntos inerentes à auditoria independente. $^{414}$

Obviamente, isto cria diversos desafios à regulação da matéria, nacional e internacionalmente.

O primeiro desafio é encontrar um razoável ponto de equilíbrio entre a necessidade de responsabilizar o auditor independente, no interesse dos terceiros e dos contratantes dos serviços de auditoria, e os problemas derivados da responsabilização civil deste profissional.

Outro desafio às autoridades regulatórias é tentar uniformizar a legislação que rege a responsabilidade civil do auditor.

De fato, a atividade de auditoria externa, em consequência da globalização econômica, torna-se cada vez mais internacionalizada, o que traz a necessidade de uma regulamentação unificada em termos de responsabilidade civil, do mesmo modo como se tem realizado no tocante às normas profissionais que regem a profissão contábil e de auditoria.

Esta necessidade de uniformização internacional põe-se de modo mais evidente ainda quando se verifica que a distinção dos regimes de responsabilidade civil dos auditores em diversos países, em conjunto com as tradições da jurisprudência e os padrões de litigiosidade de cada sociedade, pode levar a uma futura mudança de local em que os serviços de auditoria tenderão a ser prestados majoritariamente, com a consequente redução desses serviços em outros locais.

\footnotetext{
${ }^{414}$ Nos Estados Unidos da América, popularizou-se a convicção de que, em muitos casos, os auditores externos independentes eram tidos como deep pocket defendants (ou "réus de bolsos profundos", na tradução literal). Isto derivava do fato de que, em falências e liquidações judiciais, havia uma tendência segundo a qual os interessados em receber seus créditos usualmente direcionavam os processos de indenização contra os auditores, uma vez que eram os únicos com condições de ressarcir os danos, já que a sociedade falida não tinha patrimônio suficiente para tanto, nem tampouco os sócios (pessoas físicas ou jurídicas), que ainda gozavam de limitação de responsabilidade subsidiária pelas dívidas sociais.
} 
No Brasil o tema ainda não teve a devida repercussão na doutrina e na jurisprudência. ${ }^{415}$

Isto pode derivar de inúmeros fatores, tais como o pequeno desenvolvimento, até pouco tempo, de nosso mercado de capitais, bem como a falta de entendimento do papel do auditor independente pelo público investidor. A esses aspectos ainda pode ser acrescentada a pequena tradição brasileira de levar questões concernentes a falhas de auditoria ao Poder Judiciário.

No entanto, cremos que a situação atual deva passar por sensíveis modificações em futuro próximo. O crescimento do mercado de capitais brasileiro, as pressões internacionais de regulação da matéria e da tendência de judicialização dos conflitos conspiram para tanto.

\subsection{Evolução do tema e primeiros casos surgidos envolvendo a responsabilidade civil do auditor. Distinções nos países de tradição anglo- saxônica e romano-germânica}

A evolução dos casos a respeito da responsabilidade civil do auditor ocorridos nos diversos países aponta grande diversidade na abordagem do problema, além de importantes evoluções históricas.

Decisão judicial emblemática na questão da responsabilidade do auditor em face de terceiros, ocorrida nos Estados Unidos da América, deu-se com o caso Ultramares Corporation vs. Touche, decidido em 1931.

O caso envolveu a realização de empréstimo pela Ultramares Corporation à companhia Fred Stern \& Co, que exercia atividade de venda e importação de borracha,

\footnotetext{
${ }^{415}$ Grandes doutrinadores nacionais em tema de responsabilidade civil ainda não abordam em suas obras a matéria concernente à responsabilidade civil do auditor. Quando muito, passam ao largo da responsabilidade civil do profissional de contabilidade, este no papel de preposto do titular do estabelecimento, figura que, evidentemente, difere em muito da posição e das responsabilidades do auditor externo. Também não há monografias a respeito do assunto. $\mathrm{Na}$ jurisprudência pátria, incrivelmente, apesar de inúmeras pesquisas, muito raras e esparsas são as decisões que enfrentaram o tema da responsabilidade civil do auditor.
} 
ramo no qual se fazia necessário grande financiamento para a manutenção e operação do negócio.

A Ultramares, sociedade cuja atividade principal era referente à aquisição de recebíveis (factoring recivables), condicionou a realização do empréstimo solicitado pela Fred Stern \& Co à realização de uma auditoria externa em suas demonstrações contábeis, o que deu ensejo à contratação da sociedade de auditoria Touche, Niven \& Company para a realização desta tarefa.

Depois de realizados os exames necessários, a Touche emitiu parecer sem ressalvas (unqualified opinion), afirmando que os ativos da Fred Stern \& Co somavam cerca de US\$ 2,5 milhões, e seu patrimônio líquido, a quantia aproximada US\$ 1 milhão.

Diante dessas constatações, a Ultramares concedeu um primeiro empréstimo à Fred Stern \& Co, no valor de US\$100.000,00, além de mais dois outros, posteriormente, no valor total de US\$ 65.000,00.

No entanto, a Fred Stern \& Co acabou falindo em 1925, descobrindo-se que houve sonegação de informações à auditoria externa, em valores aproximados de US\$ 700.000,00 em dívidas.

Após referida falência, a Ultramares veio a processar a Touche, alegando fraude, conivência e negligência nos trabalhos de auditoria e buscando receber desta os valores emprestados, além dos danos respectivos.

Após julgamentos em primeira e segunda instâncias, o caso foi examinado pela Corte de Apelações de Nova York, sob os cuidados do juiz Benjamin Cardozo. ${ }^{416}$ A decisão deste órgão, tomada por unanimidade, revelou que o auditor não deveria ser responsável por negligência normal (mas somente por fraude ou grave negligência) em relação a terceiros que não o contrataram (liability to third parties), principalmente quando não haja prévio conhecimento por parte do auditor a respeito da identidade daqueles que possam fazer uso de seu trabalho.

Em outras palavras, a decisão seguiu a regra de que o auditor não seria responsável com relação a terceiros, uma vez que não haveria uma reserva, privacidade ou

${ }^{416}$ Posteriormente juiz da Corte Suprema dos Estados Unidos da América. 
privilégio de contrato (privity of contract) ${ }^{417}$ entre o terceiro e o auditor, mas apenas entre este e seu contratante.

Neste julgamento, o juiz Cardozo assentou:

Se existir a responsabilidade por negligência, uma desatenção ou erro impensado, uma falha para detectar um furto ou falsificação sob a cobertura de entradas enganosas, podem expor contabilistas a um passivo de montante indeterminado, por um tempo indeterminado, a uma classe indeterminada. Os perigos de uma atividade exercida sobre esses termos são tão extremos que ensejam dúvida se há uma falha na conclusão de que um dever exponha a essas consequências. ${ }^{418}$

Restou fixado também no caso que responsabilidade incondicional em face de qualquer terceiro acabaria por desestimular a profissão, dado o nível de risco existente.

Apesar das posteriores evoluções da matéria, o caso Ultramares Corporation vs. Touche inaugurou o que se chama de "doutrina Ultramares" (Ultramares doctrine), e ainda permanece como precedente válido, servindo de base, posteriormente, a outros julgamentos. $^{419}$

As regras estabelecidas na denominada Ultramares doctrine, entretanto, logo se tornaram insuficientes para todos os casos, principalmente pelos estreitos limites de responsabilização do auditor perante terceiros.

\footnotetext{
${ }^{417}$ Beatty e Samuelson (Op. cit. p. 926) ressaltam, nos termos do direito norte-americano, que entre duas partes ocorre a situação de privacidade de contrato (privity of contract) se entre ambas existe uma relação contratual: "Two parties are in 'privity of contract' if they have entered into a contract with each other. If two parties enter into a contract that affects a third party, that third party is not in privity". Como se verifica, não há esta relação entre terceiro e auditor externo.

${ }^{418}$ Ultramares Corp. vs. Touche, 255 N.Y. 170, 174 N.E., 441, 1931. O texto é tradução livre de "If liability for negligence exists, a thoughtless slip or blunder, the failure to detect a theft or forgery beneath the cover of deceptive entries, may expose accountants to a liability in an indeterminate amount for an indeterminate time to an indeterminate class. The hazards of a business conducted on these terms are so extreme as to enkindle doubt whether a flaw may not exist in the implication of a duty that exposes to these consequences".

${ }^{419}$ Mais recentemente, em 1992, no caso Robert R. Bily v. Arthur Young \& Co., 834 P. 2d 745, 767 (Cal.1992), a Suprema Corte da Califórnia se utilizou, com algumas peculiaridades, do precedente existente no caso Ultramares Corp. vs. Touche, para afirmar que a responsabilidade do auditor independente é restrita ao cliente que o contratou, não se estendendo a terceiros (third parties). O caso envolvia a sociedade Osborne Computer Corporation, cujo crescimento acelerado na década de 1980 gerou interesse de expansão de capital mediante oferta de ações, financiando-se, até a final abertura de capital, por meio de apelo à poupança de inúmeros investidores. Isso acarretou a contratação da Arthur Young \& Co. (hoje Ernst \& Young) para auditar as demonstrações da companhia, emitindo esta pareceres sem ressalvas a respeito. No entanto, o lucro e a expansão de projetos que se esperava não aconteceram, possivelmente devido à forte competição de grandes empresas (notadamente a IBM) e problemas internos de produção da Osborne, havendo finalmente um pedido de concordada em 1983 e a perda dos investimentos realizados, acarretando que alguns dos investidores viessem a processar a Arthur Young \& Co., alegando que suas decisões foram baseadas nos pareceres sem ressalvas emitidos pela auditoria, supostamente de forma negligente.
} 
As decisões, portanto, começaram a evoluir no sentido de permitir a responsabilidade do auditor em face de terceiros, inicialmente exigindo que este terceiro fosse um usuário do trabalho do auditor, previsto, identificado ou conhecido por este (foreseen user doctrine).

São representativas deste entendimento as decisões nos casos Credit Alliance Corp. vs. Arthur Andersen ${ }^{420}$ e Rush Factors Inc. vs. Levin. ${ }^{421}$

No primeiro, os fatos discutidos muito se assemelham ao caso Ultramares. A Credit Alliance Corp., companhia que se destinava à atividade de concessão de empréstimos, veio a processar a Arthur Andersen, alegando que havia se baseado em seus pareceres, os quais não revelavam com fidelidade a situação econômico-financeira do tomador do empréstimo. A decisão, dada pela Corte de Apelações de Nova York, foi a improcedência do pedido da Credit Alliance Corp., fixando, todavia, que o auditor pode ser responsabilizado por terceiros, desde que estes sejam conhecidos pelo auditor e que este saiba que seu trabalho será utilizado por aqueles.

No segundo caso, que também se baseou na alegação de concessão de empréstimo com base em auditoria supostamente negligente, acabou pela definição de que o auditor deve ser responsabilizado perante terceiros se souber que seu trabalho será utilizado por usuários identificados (p.ex., um concedente de empréstimo).

As decisões que se baseavam na foreseen user doctrine também se mostraram, de certa forma, insatisfatórias. Como vimos, uma das características da atividade de auditoria é que, em grande parte das vezes, ela se destina a usuários indeterminados ou indetermináveis. Diante da necessidade de determinação dos terceiros, a foreseen user doctrine deixava os usuários potenciais, mas não conhecidos, sem proteção.

Assim, algumas decisões passaram a admitir a responsabilidade do auditor perante terceiros previsíveis, o que se constituiu na chamada foreseeable user doctrine. Duas são as principais decisões que representam a adoção desta teoria: Citizens State Bank vs. Tim, Schimdt \& Co. ${ }^{422}$ e Rosemblum vs. Adler. ${ }^{423}$

Na primeira, a Suprema Corte de Wisconsin entendeu que a responsabilidade do auditor perante terceiros se estendia a todos aqueles usuários que previsivelmente

\footnotetext{
${ }^{420}$ Credit Alliance Corp. vs. Arthur Andersen \& Co. 483 N.E. 2d 110 (N.Y. 1985).

${ }^{421}$ Rush factors Inc. vs. Levin, 284 F. Supp. 85 (D.C.R.I. 1968).

${ }^{422}$ Citizens State Bank vs. Tim, Schimdt \& Co., 335, N.W. 2d 361 (Wis. Sup. Ct. 1983).

${ }^{423}$ Rosemblum, Inc. vs. Adler, 461 A. 2d 138 (N. J. 1983).
} 
pudessem usar a informação contábil auditada. Na segunda decisão, a Suprema Corte de New Jersey reconheceu as mudanças econômicas ocorridas desde a decisão no caso Ultramares, admitindo a possibilidade de responsabilização do auditor em face de usuários previsíveis do trabalho de auditoria, mas inadmitindo que o profissional se escude na alegação de privacidade de contrato.

Embora estes julgados mencionados possam representar uma evolução histórica na admissão da responsabilidade do auditor em face de terceiros, a adoção de teorias mais liberais em julgamentos não representou o abandono das doutrinas restritivas. Assim, conforme o Estado norte-americano e o tipo de caso submetido a julgamento, as doutrinas de irresponsabilidade do auditor em face de terceiros (Ultramares doctrine) ainda continuam aplicáveis.

As decisões citadas envolvem, em regra, a responsabilidade em face de terceiros específicos ou de uma classe limitada de pessoas, usualmente conhecida como responsabilidade do auditor em face do direito comum (comon law auditor's liability).

No entanto, a responsabilidade do auditor em face de terceiros investidores de mercado de capitais, no ordenamento norte-americano, veio a ser incrementada pelo Securities Act de 1933 e pelo Securities Exchange Act de 1934 (statutory law auditor's liability). O reforço na responsabilização do auditor em face de terceiros inclui a legitimação de qualquer adquirente de títulos para demandar o auditor em juízo, sob a alegação de falhas na auditoria.

Um resumo das posições modernamente acolhidas nos Estados Unidos da América em termos de responsabilidade do auditor nos é dado por Rittenberg et al. ${ }^{424}$ na tabela seguinte:

${ }^{424}$ Op. cit. p. 832. 
Tabela 25: Resumo das posições assumidas no ordenamento norte-americano em relação à responsabilidade do auditor

\begin{tabular}{|c|c|c|c|c|c|}
\hline \multicolumn{6}{|c|}{ Responsabilidade do auditor ( $\mathrm{S}=\operatorname{sim}, \mathrm{N}=$ não, $\mathrm{NA}=$ não aplicável) } \\
\hline \multirow{3}{*}{$\begin{array}{l}\text { Quem pode processar? } \\
\text { Sob qual legislação? }\end{array}$} & \multicolumn{2}{|c|}{ Cliente } & \multicolumn{3}{|c|}{ Terceiros } \\
\hline & \multirow[b]{2}{*}{ Direito contratual } & \multirow[b]{2}{*}{ Direito comum } & \multirow[b]{2}{*}{ Direito comum } & \multicolumn{2}{|c|}{ Direito estatutário } \\
\hline & & & & Lei de 1933 & Lei de 1934 \\
\hline \multicolumn{6}{|l|}{ Por que motivo? } \\
\hline Quebra de contrato & $\mathrm{S}$ & NA & NA & NA & NA \\
\hline Negligência & $\mathrm{S}$ & $\mathrm{S}$ & $?^{*}$ & $\mathrm{~S}$ & $\mathrm{~N}$ \\
\hline Negligência grave & $\mathrm{S}$ & $\mathrm{S}$ & $\mathrm{S}$ & $S$ & Incerto \\
\hline \multirow[t]{2}{*}{ Fraude } & $\mathrm{S}$ & $\mathrm{S}$ & $\mathrm{S}$ & $\mathrm{S}$ & $\mathrm{S}$ \\
\hline & & $\bullet$ & rio identificado; $l$ & \multicolumn{2}{|c|}{ ?* Depende do teste utilizado: } \\
\hline
\end{tabular}

Fonte: Rittenberg et al. (cit. p. 832)

Em suma, temos que o cliente sempre pode processar o auditor, com base na legislação contratual ou no direito comum (salvo quando se basear em quebra de contrato, em que estas últimas normas não serão aplicáveis).

Em relação aos terceiros, estes sempre podem processar o auditor por negligência grave e fraude com base no direito comum. No que toca à negligência comum, a possibilidade de imputar ao auditor a responsabilidade dependerá da doutrina adotada, ou seja, se o auditor somente é responsabilizado em face do cliente (usuário identificado), ou se há responsabilidade em face de usuário previsto ou previsível.

Com base na legislação do mercado de capitais de 1933 e 1934, o terceiro sempre pode processar o auditor por fraude. No que toca à negligência, conforme o tipo de legislação, verifica-se que a legislação de 1933 é mais restritiva e clara quanto à possibilidade de um terceiro responsabilizar o auditor por seus atos.

Enquanto nos países de tradição normativa anglo-saxônica (common law) houve historicamente um movimento da jurisprudência no sentido de restringir a possibilidade de responsabilização do auditor perante terceiros, naqueles cujo ordenamento segue a base romano-germânica (civil law) a responsabilidade do auditor em face de terceiros teve maior receptividade.

Estudo da União Europeia sobre o tema bem reflete esta questão: 
Uma diferença importante diz respeito à permissão de terceiros a intentar ações de responsabilidade civil contra auditor externo independente. $\mathrm{Na}$ maioria dos Estados-Membros (Bélgica, Dinamarca, Finlândia, França, Grécia, Itália, Luxemburgo, Portugal e Suécia), a atividade do auditor é considerada não só no interesse da companhia, mas também no interesse público. Como resultado, quaisquer terceiros podem recuperar danos causados pelo auditor após provar os elementos necessários à responsabilidade civil, geralmente falhas, danos e nexo de causalidade. No entanto, em países de common law (Irlanda e o Reino Unido) bem como na Espanha, o terceiro deverá provar que o revisor oficial de contas lhe deve um dever de diligência (duty of care). $\mathrm{O}$ auditor externo tem um dever de diligência para uma pessoa que não seja a entidade auditada somente se ele assume a responsabilidade para com tal pessoa no sentido de garantir a precisão substancial das contas perante os fatos de um caso concreto. Isto implica que o auditor soubesse ou devesse saber que requerente iria confiar a seu trabalho e/ou seu relatório para uma finalidade específica. Um raciocínio semelhante se aplica na Áustria e na Alemanha com o conceito de contratos implícitos e de contratos tendo efeitos protetivos de terceiros. Na Holanda, o assunto não está resolvido, mas uma parte da literatura jurídica desenvolve estes critérios de proximidade. ${ }^{425}$

Exemplo da receptividade da responsabilidade do auditor em face de terceiros encontra-se na jurisprudência italiana, que é repleta de casos versando este tema. Neste sentido, Stefano Bartone doutrina:

A orientação consolidada na jurisprudência sobre a responsabilidade do auditor no confronto com terceiros nos é oferecido de maneira clara na

\footnotetext{
${ }^{425}$ EUROPEAN COMISSION. A study on systems of civil liability of statutory auditors in the context of a single Market for auditing services in the European Union. Disponível em <http://ec.europa.eu/internal_market/auditing/liability/index_en.htm\#study>. Acesso em 27 dez. 2009. O texto é tradução livre de: "An important difference concerns the standing of third parties to bring liability actions against the statutory auditor. In a majority of Member States (Belgium, Denmark, Finland, France, Greece, Italy, Luxembourg, Portugal and Sweden), the statutory audit is considered to be not only in the interest of the company, but also in that of the public. As a result, any third party may recover damages from the statutory auditor upon proving the elements of the liability claim, usually fault, damages and causation. However, in Common Law countries (Ireland and the United Kingdom) as well as Spain, the third party must prove that the statutory auditor owes him a duty of care. The statutory auditor will owe a duty of care to a person other than the audited company only if he assumes responsibility to that person for ensuring the substantial accuracy of the accounts with regard to the facts of the particular case. This entails that the auditor knew or should have known that claimant would rely upon his work and/or his report for a particular purpose. A similar reasoning applies in Austria and Germany with the concept of implied contracts and of
} 
decisão da Corte de Cassação Civil, seção III, 18 julho 2002, N. 10403, na causa "Arthur Andersen S.P.A. c. Carraro S.P.A.”, fazendo exame da configuração "da responsabilidade extracontratual da sociedade de auditoria”, e consequentemente a referência ao art. 2.043, 2.407 Códice civil e ao art. 2 e 12, D.P.R. 31 março 1975, n. 136. Foi afirmada a responsabilidade extracontratual da sociedade de auditoria no confronto com adquirentes de quotas de uma holding de um grupo do societário, quando estes, se soubessem o valor real do patrimonial líquido agregado, erroneamente certificado, não teriam firmado o contrato definitivo. ${ }^{426}$

No Brasil, como veremos melhor a seguir, a tendência legislativa seguiu notadamente a abordagem dos países de tradição romano-germânica.

\subsection{Fontes normativas e sistemas de responsabilidade. Normas que regulam a responsabilidade do auditor no Brasil}

A questão a ser discutida neste tópico é a de se saber se a responsabilidade do auditor é fruto de um sistema próprio e peculiar de normas, ou se está submetida ao regime geral de responsabilidade civil, para, em seguida, verificar quais as normas incidem $a$ priori sobre tal espécie de responsabilidade em nosso ordenamento jurídico.

Estudo perante a União Europeia ressalta a importância do tema, principalmente dada a necessidade de harmonização da matéria na legislação dos EstadosMembros:

Dada a natureza fundamental das regras de responsabilidade civil, é importante, como uma questão preliminar, verificar se existe um regime especial no local para a responsabilidade dos auditores externos independentes ou, ao contrário, se auditores estão sujeitos às mesmas

contracts having protecting effects to third parties. In the Netherlands, the matter is not settled, but one part of the legal literature develops this proximity criteria".

${ }^{426}$ Op. cit. p. 10. O texto é tradução livre de: "L'orientamento giurisprudenziale consolidato sulla responsabilità nei confronti dei terzi delle società di revisione ci è offerto in maniera chiara dalla Cassazione Civile, Sezione III, 18 luglio 2002, n. 10403 6, nella causa 'Arthur Andersen s.p.a. c. Carraro s.p.a.', prendendo in esame la configurabilità e le condizioni di configurabilità della "responsabilità extracontrattuale della società di revisione", e quindi il riferimento agli artt. 2043, 2407 Códice Civile e agli artt. 2 e 12, D.P.R. 31 marzo 1975, n. 136. Ė affermata la responsabilità extracontrattuale della società di revisione nei confronti degli acquirenti delle quote della holding di un gruppo societário, in quanto costoro, se avessero conosciuto il reale valore dei relativo stato patrimoniale netto aggregato, erroneamente certificato, non avrebbero stipulato 
regras de responsabilidade civil, como outros profissionais ou o público em geral. Esta questão é de particular importância para a considerada harmonização das legislações nacionais. Com efeito, se forem aplicadas as regras gerais de responsabilidade civil aos auditores, então, a aplicação das regras uniformes exigiria uma mudança fundamental nos regimes de responsabilidade civil dos Estados-Membros em geral, ou a criação de corpos de regras específicas relativas aos auditores externos independentes. Ao contrário, um regime de regras legais específicas para a responsabilidade de auditores tenderia a tornar a harmonização menos onerosa. $^{427}$

O mesmo estudo relata a situação de cada Estado-Membro:

Tabela 26: Sistemas legais de responsabilidade na União Europeia

\begin{tabular}{|ccc|}
\hline País & $\begin{array}{c}\text { Regras gerais de } \\
\text { responsabilidade }\end{array}$ & $\begin{array}{c}\text { Regras especiais de } \\
\text { responsabilidade }\end{array}$ \\
\hline Áustria & Sim & Sim \\
\hline Bélgica & Sim & Sim \\
\hline Dinamarca & Sim & Não \\
\hline Finlândia & Sim & Sim \\
\hline França & Sim & Sim \\
\hline Alemanha & Sim & Sim \\
\hline Grécia & Sim & Sim \\
\hline Irlanda & Sim & Não \\
Itália & Não & Sim \\
\hline Luxemburgo & Sim & Não \\
Holanda & Sim & Não (continua) \\
\hline
\end{tabular}

il contratto definitivo. La natura extracontrattuale della responsabilità della società di revisione deriva dagli effetti verso i terzi dell'illegittimo comportamento di quest'ultima".

${ }^{427}$ EUROPEAN COMISSION. A study on systems of civil liability of statutory auditors in the context of a single Market for auditing services in the European Union. Disponível em <http://ec.europa.eu/internal_market/auditing/liability/index_en.htm\#study>. Acesso em 27 dez. 2009. O texto é tradução livre de: "Given the fundamental nature of civil liability rules, it is important, as a preliminary issue, to ascertain whether there is a special regime in place for the liability of statutory auditors or, on the contrary, if statutory auditors are subjected to the same rules of civil liability as other professionals or the public in general. This question is of particular importance to the considered harmonisation of national laws. Indeed, if general rules of civil liability are applied to statutory auditors, then the implementation of uniform rules would require either a fundamental change to the Member States' civil liability regimes in general, or the creation of bodies of specific rules concerning statutory auditors. On the contrary, a regime of specific statutory rules for statutory auditor liability would tend to make harmonisation a less burdensome undertaking". 


\begin{tabular}{ccc}
\hline Portugal & Sim & Sim \\
\hline Espanha & Sim & Sim \\
\hline Suíça & Sim & Sim \\
Reino Unido & Sim & Não \\
\hline
\end{tabular}

Fonte: EUROPEAN COMISSION. A study on systems of civil liability of statutory auditors in the context of a single Market for auditing services in the European Union

O estudo conclui que somente em cinco países da União Europeia (Dinamarca, Irlanda, Luxemburgo, Holanda e Reino Unido) não há dispositivos especiais regendo a responsabilidade civil do auditor, aplicando-se a este as regras gerais de responsabilidade civil.

Em outros nove países (Áustria, Bélgica, Finlândia, França, Alemanha, Grécia, Portugal, Espanha e Suíça) as regras gerais de responsabilidade são complementadas por dispositivos especiais relacionados ao auditor independente. $\mathrm{Na}$ Itália, a responsabilidade é baseada em regras específicas, com remissão ao artigo referente à responsabilidade dos administradores (art. 2.407 do Código Civil Italiano).

Além da melhoria na harmonização da legislação internacional, a adoção de um sistema de regras próprias para a responsabilidade civil do auditor torna mais simples ao aplicador das normas entender as peculiaridades da atividade de auditoria, facilitando também o afastamento de outras regras de responsabilidade que não se adaptam perfeitamente à atividade desenvolvida pelos profissionais deste ramo, sob o argumento de especialidade (lex specialis derogat generalis).

Confirma ainda a necessidade de um regime especial de responsabilidade do auditor, o fato de que algumas normas gerais de responsabilidade civil concernentes aos contadores em geral - categoria que compreende a profissão de auditor independente - não sejam aplicáveis aos serviços de auditoria externa.

No ordenamento nacional, exemplo disto consta da norma insculpida no art. 1.177, parágrafo único, do Código Civil, segundo a qual o contabilista e outros auxiliares, na qualidade de prepostos do titular do estabelecimento comercial, são pessoalmente responsáveis, perante os preponentes, pelos atos culposos; e, perante terceiros, solidariamente com o preponente, pelos atos dolosos.

A aplicação desta norma aos auditores independentes é absolutamente impossível, só se podendo concluir pela sua não incidência na hipótese. 
Primeiramente, porque a norma pressupõe uma relação de preposição comercial, ${ }^{428}$ o que não existe entre auditor independente e entidade auditada, uma vez que não há qualquer ingerência ou hierarquia estabelecida entre estes, nem mesmo representação de uma parte por outra.

Além disso, a aplicação desta norma levaria ao contrassenso de que o auditor independente, ao omitir-se culposamente, não respondesse perante terceiros, mas tão somente em regresso pelo que terceiros cobrassem do preponente em virtude de prejuízos derivados da conduta do auditor. Ora, como vimos, isto equivaleria a adotar as regras da Ultramares doctrine, perante a qual terceiros não podem processar o auditor por negligência, teoria de certo modo ultrapassada em sua origem, e que nos países de tradição romano-germânica não foi absolutamente acolhida pela legislação de regência, justamente por abrir um flanco enorme à irresponsabilidade do auditor.

Parece inegável, portanto, que existe clara necessidade da adoção de regras próprias de responsabilidade civil à atividade de auditoria externa.

No Brasil, pelo menos no que tange à responsabilidade extracontratual, entendemos que vige sistema especial de responsabilidade do auditor, derivado da regra do art. $26, \S 2^{\underline{o}}$, da Lei n. $6.385 / 76,{ }^{429}$ razão pela qual a responsabilidade deste profissional deve ser buscada nas normas próprias que incidem sobre tal atividade, e não naquelas comuns que regem a responsabilidade civil extracontratual em geral, as quais restam afastadas pela especialidade da primeira. ${ }^{430}$

\footnotetext{
${ }^{428}$ Carvalho de Mendonça assim define a preposição comercial: "O contrato por meio do qual se estabelece a relação de dependência entre o comerciante e o empregado, denomina-se preposição comercial, ou também contrato de emprego no comércio" (MENDONÇA, José Xavier Carvalho de. Tratado de direito comercial brasileiro. Rio de Janeiro: Freitas Bastos, 1957. 2.v. p. 435).

429 "As empresas de auditoria contábil ou auditores contábeis independentes responderão, civilmente, pelos prejuízos que causarem a terceiros em virtude de culpa ou dolo no exercício das funções previstas neste artigo."

${ }^{430} \mathrm{O}$ fenômeno da especialidade ou generalidade das normas sobre responsabilidade civil aquiliana do auditor no Brasil é discutido por Erasmo Valladão Azevedo e Novaes França, que entende que a responsabilidade civil do auditor existiria de qualquer forma, ainda que não houvesse regras especiais regendo a matéria: "Por fim, além de poderem ter sua responsabilidade administrativa debatida na CVM, os auditores independentes respondem civilmente, à evidência, pela reparação de danos causados à sociedade de grande porte, sócios ou terceiros, no desempenho de suas atividades profissionais. A responsabilidade dos auditores independentes é mesmo inegável. Conquanto o $§ 2^{2}$ do art. 26 da Lei 6.385/1976 afirme que 'as empresas de auditoria contábil ou auditores independentes responderão, civilmente, pelos prejuízos que causarem a terceiros em virtude de culpa ou dolo no exercício das funções previstas neste artigo', e muito embora no artigo em questão trate apenas da atuação desses profissionais com relação a 'companhias abertas e instituições, sociedades ou empresas que integram o sistema de distribuição e intermediação de valores mobiliários', não se há de olvidar que a responsabilidade civil desses profissionais deriva do próprio sistema geral de responsabilidade civil e existe independentemente da enunciação do princípio na Lei 6.385/1976". Prossegue o renomado autor em nota de rodapé ao texto citado: "Por essa linha, é bastante discutível se o art.
} 
Muito embora a norma constante do art. $26, \S 2^{\underline{o}}$, da Lei $n$. 6.385/76 diga respeito, em princípio, somente ao auditor independente ou sociedade de auditoria registrados na CVM, que prestem serviços a entidades que negociem valores mobiliários, entendemos que a regra deve ser aplicada a todos os tipos de auditores ou sociedades de auditoria.

Isto, porque não há sentido em aplicar regras do regime geral de responsabilidade, de natureza mais gravosa (p.ex.: responsabilidade civil objetiva baseada no risco profissional), a auditores (pessoas físicas) ou a sociedades de auditoria de menor porte, quando os auditores e sociedades de maior porte econômico (qualificados para a revisão de demonstrações de grandes sociedades anônimas) estariam sujeitos a regime menos severo.

Assim, como não há normas próprias que adotem regime especial menos severo aos auditores e sociedades de menor porte, a regra de responsabilidade civil aquiliana constante do art. $26, \S 2^{\circ}$, da Lei n. 6.385/76 deve ser estendida a estes, afastando normas mais gravosas de responsabilidade civil constantes do regime comum.

É bem verdade que o regime especial de responsabilidade do auditor em nosso ordenamento é imperfeito e pouco detalhista, merecendo maior número de disposições normativas que abranjam as peculiaridades da atividade de auditoria.

Diante desta omissão, podemos cogitar da incidência subsidiária de outras normas, presentes do regime geral de responsabilidade civil, à atividade do auditor, naquilo que não contrariem a regra geral do sistema de responsabilidade civil próprio dos profissionais de auditoria. É o que ocorre, por exemplo, com as normas constantes dos arts. 389 (norma geral de responsabilidade contratual) e 942, parágrafo único (regra de solidariedade), ambos do Código Civil.

$26, \S 2^{\circ}$, da Lei $6.385 / 1976$, ao enunciar a responsabilidade civil subjetiva dos auditores independentes, teria pretendido criar ou destacar a existência de responsabilidade desses profissionais ou, pelo contrário, teria pretendido restringi-la. É que, com ou sem a citada regra, a responsabilidade civil profissional dos auditores independentes existiria e seria dedutível das regras gerais de responsabilidade civil. Seria ingênuo, por isso mesmo, crer que o intento da regra foi o de tornar expresso o que antes já existia. O que não havia - isto, sim - era uma regra claramente dispondo que a responsabilidade civil destes profissionais é subjetiva, afastando construções que pretendessem submetê-la a regime objetivo, como as que podem ser elaboradas em relação aos trabalhos prestados para sociedades de grande porte que não integrem o mercado de valores mobiliários e dos quais resultem prejuízos a terceiros (em especial os by standers)”. 


\subsection{Responsabilidade solidária ou proporcional}

Cumpre discutir aqui o tipo de responsabilidade do auditor em concurso com terceiros, definindo a incidência da regra de responsabilidade solidária ou proporcional.

A questão inclui, dentre outros, os casos em que o auditor venha a ser responsabilizado em concurso com a entidade auditada por danos realizados a terceiros, bem como aquelas hipóteses em que duas ou mais sociedades de auditoria venham a ser demandadas em conjunto - ao, p.ex., prestarem serviços simultaneamente ao mesmo cliente -, ou nas quais uma sociedade de auditoria seja demandada juntamente com seus membros ${ }^{431}$ (auditores pessoas físicas).

Os sistemas utilizados para solucionar a questão são de dois tipos: 1) responsabilidade solidária (joint and several liability); e 2) responsabilidade proporcional (proportional liability).

No primeiro, como se sabe, os responsáveis podem ser cobrados, individual ou coletivamente, pela totalidade da dívida, conforme a escolha do credor. No segundo, a responsabilidade pela dívida é cindida proporcionalmente a cada devedor, conforme critérios estabelecidos.

Na legislação norte-americana, como ensinam Beatty e Samuelson, ${ }^{432}$ desde o Securities Exchange Act de 1934, o sistema de responsabilidade do auditor era tradicionalmente baseado na solidariedade. No entanto, reforma legislativa ocorrida em 1995 passou a adotar a regra da responsabilidade proporcional do auditor.

Perante a União Europeia, estudo específico ${ }^{433}$ demonstra a diversidade dos regimes adotados em cada Estado-Membro:

\footnotetext{
${ }^{431} \mathrm{Na}$ Itália, o art. 164, 2, do Decreto Legislativo de 24 de fevereiro de 1998 n. 58, permite expressamente que a sociedade de auditoria e seus membros (seus dependentes) sejam demandados pelos danos causados, verbis: "I responsabili della revisione e i dipendenti che hanno effettuato l'attività di revisione contabile sono responsabili, in solido con la società di revisione, per i danni conseguenti da propri inadempimenti o da fatti illeciti nei confronti della società che ha conferito l'incarico e nei confronti dei terzi danneggiati". Perante a legislação brasileira, a possibilidade de demandar a sociedade de auditoria e seus prepostos, solidariamente, pelos danos causados, parece expressamente admitida pelo art. 932, III, c.c. art. 942, parágrafo único, ambos do Código Civil.

432 Op. cit. p. 932.

${ }^{433}$ EUROPEAN COMISSION. A study on systems of civil liability of statutory auditors in the context of a single Market for auditing services in the European Union. Disponível em <http://ec.europa.eu/internal_market/auditing/liability/index_en.htm\#study>. Acesso em 27 dez. 2009.
} 
Tabela 27: Alocação de responsabilidade nos Estados-Membros da União Europeia

\begin{tabular}{|cc|}
\hline País & $\begin{array}{c}\text { Regra de alocação de } \\
\text { responsabilidade }\end{array}$ \\
\hline Áustria & Solidária \\
\hline Bélgica & Solidária \\
\hline Dinamarca & Solidária/Proporcional \\
\hline Finlândia & Solidária \\
\hline França & Solidária/Proporcional \\
\hline Alemanha & Solidária \\
\hline Grécia & Solidária \\
\hline Irlanda & Solidária/Proporcional \\
\hline Itália & Solidária \\
\hline Luxemburgo & Solidária \\
\hline Holanda & Incerto \\
\hline Portugal & Solidária \\
\hline Espanha & Solidária \\
\hline Suíça & Solidária/Proporcional \\
\hline Reino Unido & Solidária \\
\hline
\end{tabular}

Fonte: EUROPEAN COMISSION. A study on systems of civil liability of statutory auditors in the context of a single Market for auditing services in the European Union

Constata-se, portanto, que a maioria dos países componentes da União Europeia adota um regime de responsabilização solidária, com algumas concessões ao sistema proporcional.

No Brasil, duas regras determinam a responsabilidade solidária: 1) o art. $4^{\circ}$, III, da Instrução CVM n. 308/99, quanto às sociedades ali registradas; 2) o art. 942, parágrafo único, do Código Civil. Porém, como salientamos anteriormente, entendemos que tais regras não abrangem a responsabilidade contratual subsidiária dos sócios por dívidas não referentes à atividade profissional de auditoria, para as quais poderá ser determinada contratualmente a regra proporcional, nos termos do art. 1.023 do CC.

Pondere-se, porém, que do ponto de vista econômico não existe a prevalência de um dos regimes sobre o outro. Ambos apresentam vantagens e desvantagens, e sua adoção dependerá da prudente opção política do legislador de cada país. 
Com efeito, o sistema de responsabilidade proporcional, em cotejo com o sistema de responsabilidade solidária, tem a vantagem de diminuir a exposição ao risco do auditor, gerando, em consequência, menores custos de auditoria e menor incentivo ao ajuizamento de demandas em face deste profissional, o que possibilita maior concorrência de mercado, uma vez que auditores individuais (pessoas físicas) e pequenas sociedades de auditoria poderão fazer frente às indenizações eventualmente pleiteadas. Acarreta também, ante a diminuição dos riscos, maior possibilidade de cobertura de seguro de responsabilidade civil.

No entanto, o sistema proporcional também apresenta desvantagens em relação ao regime de solidariedade.

Isto porque, em casos de ilícitos cometidos em conjunto com a gestão da entidade auditada, caso a responsabilidade do auditor em face de terceiros seja proporcionalmente maior que a dos gestores, estes poderão se sentir incentivados a não revelar ou distorcer informações constantes das demonstrações contábeis, uma vez que sua responsabilidade por eventuais danos causados a terceiros será diminuta em face do montante a cargo do auditor.

O sistema de proporcionalidade também pode gerar sérios danos a terceiros quando da existência de falência de um dos responsáveis, uma vez que reduzirá, proporcionalmente, a parcela de indenização que o prejudicado poderá exigir do corresponsável.

Por fim, é necessário dizer que haverá sempre certa dificuldade de determinar a proporcionalidade entre os coautores do dano, por não se saber exatamente qual o grau de participação de cada corresponsável no ilícito cometido.

\subsection{Responsabilidade contratual e extracontratual do auditor}

$\mathrm{O}$ auditor independente pode prejudicar terceiros em sua atividade em virtude de descumprimento de uma avença anterior (p.ex., inadimplemento do contrato de prestação de serviços de auditoria) ou simplesmente por descumprir um dever legal previamente estabelecido na legislação que rege sua atividade. 
A estas duas formas de ilicitude civil geradoras de danos a terceiros, como se sabe, ligam-se duas formas de responsabilidade: 1) a responsabilidade contratual ou por ilícito relativo; 2) a responsabilidade extracontratual, aquiliana, ou por ilícito absoluto.

Como explica Carlos Roberto Gonçalves:

Uma pessoa pode causar prejuízo a outrem por descumprir uma obrigação contratual. Por exemplo: quem toma um ônibus tacitamente celebra um contrato, chamado contrato de adesão, com a empresa de transporte. Esta, implicitamente, assume a obrigação de conduzir o passageiro ao seu destino, são e salvo. Se, no trajeto, ocorre um acidente e o passageiro fica ferido, dá-se o inadimplemento contratual, que acarreta a responsabilidade de indenizar as perdas e danos, nos termos do art. 389 do Código Civil. Acontece o mesmo quando o comodatário não devolve a coisa emprestada porque, por sua culpa, ela pereceu; com o ator, que não comparece para dar o espetáculo contratado. Enfim, com todas as espécies de contratos não adimplidos. Quando a responsabilidade não deriva de contrato, diz-se que ela é extracontratual. Neste caso, aplica-se o disposto no art. 186 do Código Civil. Todo aquele que causa dano a outrem, por culpa em sentido estrito ou dolo, fica obrigado a repará-lo. É a responsabilidade derivada de ilícito extracontratual, também chamada aquiliana. $\mathrm{Na}$ responsabilidade extracontratual, o agente infringe um dever legal e, na extracontratual, descumpre o avençado, tornando-se inadimplente. Nesta, existe uma convenção prévia entre as partes, que não é cumprida. Na responsabilidade extracontratual, nenhum vínculo jurídico existe entre a vítima e o causador do dano, quando este pratica o ato ilícito. ${ }^{434}$

Conforme anteriormente salientado, o auditor independente, para realizar seu trabalho, deve formular um contrato especial de prestação de serviços com a entidade auditada. Ao mesmo tempo, o auditor age, em regra, no interesse de terceiros interessados na tomada de decisões que terão por base as demonstrações contábeis auditadas.

Desta forma, o auditor estará sujeito simultaneamente aos dois tipos de responsabilidade: em face da entidade auditada, terá o dever de cumprir o pactuado; em face dos usuários das demonstrações, terá o dever de realizar sua tarefa de modo

${ }^{434}$ GONÇALVES, Carlos Roberto. Responsabilidade civil. São Paulo: Saraiva, 2003. p. 26. 
compatível com o determinado na legislação de regência e nas normas que regulam sua atividade.

É necessário frisar, porém, que, embora a natureza da responsabilidade do auditor independente perante terceiros seja extracontratual - já que inexistirá, em regra, qualquer avença entre terceiros e auditor -, nem sempre a natureza da responsabilidade entre auditor e entidade auditada será contratual.

De fato, pode ocorrer que o dano realizado pelo auditor à entidade auditada não esteja consubstanciado num dever contratual, mas sim no descumprimento de deveres legais.

A distinção entre a responsabilidade civil contratual e extracontratual tem relevâncias práticas, sendo a principal delas relativa ao ônus da prova da culpa.

$\mathrm{Na}$ responsabilidade contratual, basta ao credor provar o inadimplemento do contrato e o dano daí derivado, presumindo-se a culpa do devedor e transferindo a este último o dever de provar que não concorreu culposamente para o descumprimento do contrato.

Na responsabilidade aquiliana, porém, o ônus da prova da culpa, em regra, recai sobre o credor, que deverá provar, além do dano e do nexo de causalidade, a ação ou omissão culposa do devedor.

No caso da responsabilidade extracontratual do auditor independente, entretanto, entendemos que a distinção das duas espécies de responsabilidade, no tocante ao ônus da prova, não terá a repercussão prática mencionada; por duas razões: 1) a obrigação do auditor é de resultado, e não de meio; 2) na responsabilidade extracontratual do auditor em face de terceiros haverá a incidência da legislação do consumidor, que permite ao juiz inverter o ônus da prova no caso concreto.

Como já salientamos, a obrigação do auditor é de resultado, ou seja, referido profissional obriga-se a atingir determinado efeito ao prestar seus serviços, qual seja, externar uma opinião no sentido de dizer se as demonstrações contábeis apresentam ou não distorções relevantes.

Se assim ocorre, basta que o terceiro prejudicado demonstre em juízo que sofreu um dano e que o auditor não atingiu o resultado esperado em prestar uma informação sobre a presença ou não de distorções materialmente relevantes nas 
demonstrações, ficando ao profissional de auditoria o ônus de provar que não agiu ou se omitiu culposamente.

Deste modo, a distinção inerente ao ônus da prova, usualmente presente entre os institutos de responsabilidade contratual e aquiliana, não apresenta utilidade quando a obrigação do devedor seja de resultado, uma vez que, nesta última hipótese, o ônus de provar que sua conduta não foi culposa sempre recairá sobre o devedor, cuide-se de responsabilidade contratual ou extracontratual.

Esta, aliás, é a posição da mais moderna doutrina norte-americana sobre ônus da prova em demandas envolvendo responsabilidade extracontratual do auditor independente, com fundamento no Securities Act de1933.

Nas palavras de Michael C. Knapp:

Ao abrigo da lei de 1933, demandantes não têm de provar a fraude, negligência grave, ou mesmo negligência por parte dos auditores. Essencialmente, os demandantes devem só estabelecer que sofreram perdas de investimento e que as demonstrações contábeis relevantes contêm erros ou omissões materiais. Se um queixoso estabelece esses elementos de prova, a sociedade de auditoria demandada assume o ônus de demonstrar que seus funcionários foram "devidamente diligentes" na realização da auditoria. ${ }^{435}$

Ainda que assim não fosse, incidindo na hipótese da demanda entre auditor e terceiro a legislação de defesa do consumidor - uma vez que o terceiro equipara-se ao consumidor por ser vítima do denominado acidente de consumo -, permite-se ao juiz que inverta o ônus da prova (CDC, art. $\left.6^{-}, \mathrm{VIII}\right)$, medida que, como veremos mais adiante, é sempre recomendável.

Considerando que os danos praticados pelo auditor podem ser coletivos, é necessário analisar, dentro do tema da responsabilidade contratual e extracontratual do auditor, os seguintes temas: 1) a responsabilidade do auditor com relação a uma coletividade de prejudicados, em demanda por meio de ações coletivas (collective and class actions); e 2) a responsabilidade do auditor em face de acionista individual que atue

\footnotetext{
${ }^{435}$ KNAPP, Michael C. Contemporary auditing - Real issues and cases. Ohio: South-Western Cengage Learning, 2010. p. 376. O texto é tradução livre de: "Under the 1933 Act, plaintiffs do not have to prove fraud, gross negligence, or even negligence on the part of auditors. Essentially, plaintiffs must only establish that they suffered investment losses and that the relevant financial statements contain material errors or omissions. If a plaintiff establishes those elements of proof, the defendant accounting firm assumes the burden of proving that its employees were 'duly diligent' in performing the audit".
} 
no interesse da companhia como seu substituto processual (ações ut singuli / derivative actions).

As ações coletivas de reparação de dano surgem como uma forma de possibilitar, através da reunião de pretensões em um único processo, a demanda judicial envolvendo partes cujo dano individual não seria de monta a compensar os custos de um litígio judicial. Usualmente envolvem a constituição de associações ou organizações de prejudicados para o fim de tutelar coletivamente os interesses comuns.

No ordenamento norte-americano, no qual teve origem o mecanismo processual das class actions suits (forma que permite a alguns prejudicados litigar em nome de todo o grupo com interesse comum), estas têm sido amplamente utilizadas para a reparação de danos em face de auditores, por iniciativa de acionistas e credores prejudicados pela conduta dos primeiros. ${ }^{436}$

Perante os países da União Europeia, entretanto, estudo específico relata que na maior parte dos Estados-Membros não são admitidas ações coletivas ajuizadas por organizações de acionistas, nem tampouco mecanismos semelhantes às class actions, com algumas ressalvas específicas, a saber: na legislação francesa admite-se a propositura de ação por organizações de acionistas ${ }^{437}$ e, em Portugal, admite-se a propositura de ação no modelo de class action (ação popular) para a defesa dos interesses dos consumidores lesados. ${ }^{438}$

\footnotetext{
${ }^{436}$ Revela Michael C. Knapp (Op. cit. p. 20) a ampla utilização das class actions em face da Arthur Andersen, no famoso episódio envolvendo a companhia Enron: "During the early months of 2002, Andersen faced scathing criticism from Congressional investigators, enormous class-action lawsuits filed by angry Enron stockholders and creditors, and a federal criminal indictment stemming from the shredding of Enronrelated documents".

${ }^{437}$ Assim se manifesta o estudo: "France is the only Member State which grants standing to sue to shareholder's organizations. French decisions support the position that an association of shareholders may maintain an action to recover the damages sustained by each of its members individually. Moreover, the law of 5 January 1988, as modified by the laws of 23 June 1989 and 8 August 1994, grants associations certain powers to defend the rights of persons in the areas of investment in securities and in other financial products. Certified associations have the right to represent all investors". EUROPEAN COMISSION. A study on systems of civil liability of statutory auditors in the context of a single Market for auditing services in the European Union. Disponível em <http://ec.europa.eu/internal_market/auditing/liability/index_en.htm\#study>. Acesso em 27 dez. 2009.

${ }^{438}$ Assim se manifesta o estudo: "Portugal is the only Member State which allows class actions. Law n. 83/95 dated 31 August 1995 establishes the circumstances and terms under which a class action (Ação Popular) can be brought. It provides among others, for "the protection of consumers of goods and services" (Article 1 paragraph 2, of let n. 83/95). However, such a situation has never come before the Courts in the field of statutory auditing. The Securities Exchange Act, which was approved by Decree-Law n. 486-99 of 13 November 1999, deals with the rights of investors and completes Law n. 83/9542. Every individual with a legitimate interest has standing to sue. Associations defending the interests protected by the class action law and whose articles of incorporation expressly provide for the defence of their members' rights, also have standing to sue. In the class action, the plaintiff represents all the potential injured parties, without their
} 
No que toca às ações ut singuli ou derivative actions, nas quais acionista(s) individualmente considerado(s) atua(m) judicialmente em nome e no interesse da companhia que sofreu prejuízo, seu ajuizamento em face dos auditores é admitido em cinco dos Estados-Membros da União Europeia: Itália, Luxemburgo, Portugal, Espanha e Reino Unido; não sendo admitido nos demais. ${ }^{439}$ Para o ajuizamento, entretanto, normalmente são exigidas condições relativas à propriedade de percentual mínimo das ações e/ou inércia dos órgãos societários competentes.

No Brasil, os mecanismos de organização de prejudicados em associações, ajuizamento de ações coletivas e ações uti singuli, são expressamente previstos em nosso ordenamento, embora não se tenha notícia da utilização em face de auditores externos independentes.

O direito de associação é assegurado constitucionalmente (CF, art. 5ํ, XVII), vedada a interferência estatal (CF, art. 5º XVIII) e garantida a legitimação para representar interesses de seus membros judicial e extrajudicialmente (CF, art. $\left.5^{\mathrm{o}}, \mathrm{XXI}\right)$.

Por seu turno, a defesa dos terceiros prejudicados, considerados consumidores por serem vítimas de eventual serviço defeituoso prestado pelo auditor, pode ser efetivada através de ação civil pública em juízo, ${ }^{440}$ desde que presentes as condições de legitimação

formal permission or a power of attorney. When the Court receives the class action petition, it notifies the injured parties who must take a formal position in the action, and state whether they accept or refuse to be represented in the case. Silence is deemed acceptance. If a potential plaintiff expressly refuses to be part of the group, he is said to be exercising his right to "self-exclusion" (direito de autoexclusão). EUROPEAN COMISSION. A study on systems of civil liability of statutory auditors in the context of a single Market for auditing services in the European Union. Disponível $\mathrm{em}$ <http://ec.europa.eu/internal_market/auditing/liability/index_en.htm\#study>. Acesso em 27 dez. 2009.

439 Assim se manifesta estudo da matéria nos países da União Europeia: "In Portugal, collective actions, as defined by articles 77 par. 1 in fine and 4 of the CSC, require the company to be judicially called to the action. In Spain, holders of 5\% or more of the capital of the audited company (as a group or individually) are entitled to require the company's directors to convene a shareholders' meeting in order to decide whether or not to bring an action against the company's auditors. If the meeting is not convened, the shareholders decide not to bring the action or the claim is not filed within one month, then the minority shareholders may bring the action on behalf of the company. In the United Kingdom, minority shareholders who could not show that the auditor owed them a duty of care as individuals and who could not persuade a majority of shareholders to compel the company to take action may attempt to persuade the Court that action should be taken in the company's name despite the refusal of the majority of shareholders to do so". EUROPEAN COMISSION. A study on systems of civil liability of statutory auditors in the context of a single Market for auditing services in the European Union. Disponível em <http://ec.europa.eu/internal_market/auditing/liability/index_en.htm\#study>. Acesso em 27 dez. 2009. Cumpre salientar que a restrição de alguns países às ações $u$ t singuli se deve à sua possível utilização como instrumento de vingança, pressões e ganhos extraordinários em honorários advocatícios ou acordos judiciais. São os chamados strike suits ou strike litigations, muitas vezes promovidos por iniciativa de advogados empresariais que se utilizam de acionistas minoritários para a obtenção de referidas vantagens.

440 Sem querer aprofundar o tema, devemos salientar que a ação civil pública e demais ações coletivas são baseadas nas class actions norte-americanas, com algumas particularidades quanto à legitimação ativa. Neste sentido, a lição sempre pertinente de Rodolfo de Camargo Mancuso: "No sistema norte-americano das class 
necessárias (CDC, art. 82). Em se tratando de investidores do mercado de capitais, a defesa do interesse dos prejudicados poderá ainda ser feita pelo próprio Ministério Público (Lei n. $7.913 / 89){ }^{441}$

As ações ut singuli também têm expressa previsão na legislação nacional (arts. 159, $\S 4^{\mathrm{o}}$ e $5^{\mathrm{o}}$, da Lei n. 6.404/76), embora se tenham os administradores (e não os auditores, isoladamente), em princípio, como legitimados passivos.

\subsection{Pressupostos da responsabilidade}

Para a responsabilização civil do auditor independente devem existir os mesmos pressupostos da responsabilidade civil em geral, quais sejam, ação ou omissão do auditor, culpa ou dolo, nexo de causalidade e dano.

No entanto, algumas particularidades da atividade de auditoria podem ensejar dúvidas quanto à aplicabilidade desses pressupostos. Exemplos podem ser citados quanto à necessidade ou não de se provar a culpa do auditor para sua responsabilização (responsabilidade objetiva ou subjetiva), a extensão dos danos ressarcíveis e mesmo a relação de causalidade da atividade do auditor com o dano finalmente experimentado.

Assim sendo, preferimos desmembrar nos tópicos seguintes o estudo dos pressupostos de responsabilidade, analisando-os em face das peculiaridades dos serviços de auditoria.

actions, onde se inspirou o legislador brasileiro para criar o modo de liquidação das indenizações por danos pessoalmente sofridos pelos consumidores (=condenação genérica, seguida pelas habilitações dos interessados - CDC, arts. 95 a 100), o juiz aparece dotado de poder para, em cada caso concreto, definir, v. g., se efetivamente se trata de uma ação coletiva e se o expoente do grupo (ideological plaintiff) é realmente seu representante adequado (adequacy of representation), poder esse que se denomina defining function. Essa técnica, conquanto de início cogitada pelo legislador brasileiro, não chegou a ser implementada em sua pureza original, visto que no texto final se optou por indicar na própria lei, de um lado, os representantes cuja idoneidade vem presumida" (MANCUSO, Rodolfo de Camargo. Manual do consumidor em juízo. São Paulo: Saraiva, 1994. p. 8).

${ }^{441}$ Veja-se que o art. $1^{\underline{0}}$, III, da Lei n. $7.913 / 89$ contém hipótese que bem se adapta à prestação de serviços inadequados pelo auditor, a saber: "omissão de informação relevante por parte de quem estava obrigado a divulgá-la, bem como sua prestação de forma incompleta, falsa ou tendenciosa”. 


\subsubsection{Ação ou omissão. Fatos que ensejam a responsabilização: casuística}

O auditor independente pode ser responsabilizado por ação ou omissão (inação), sendo esta última hipótese de maior ocorrência prática (omissão culposa ou por negligência).

É necessário frisar, porém, na esteira do magistério de Heleno Cláudio Fragoso, que (mesmo doutrinando matéria penal) nos dá importante lição sobre a distinção de condutas comissivas e omissivas para fins jurídicos:

É equívoco supor que naturalisticamente poderíamos reconhecer omissão pela simples observação do comportamento humano. Esta somente nos pode revelar uma atividade ou inatividade corpórea. A omissão, porém, envolve sempre a necessidade de um termo de relação, um dever jurídico de ativar-se (...). O conceito de omissão é necessariamente normativo. No plano ontológico, existem apenas ações. A omissão pressupõe a existência de norma que imponha a ação omitida; refere-se à ação ordenada e se situa em plano distinto ao desta. A omissão não consiste na conduta diversa que o agente realiza enquanto omite. A omissão consiste na abstenção da atividade devida, ou seja, na não realização da conduta positiva que o agente tinha o dever jurídico e a possibilidade de realizar. A possibilidade de agir é pressuposto indispensável do dever jurídico de agir. $^{442}$ (grifo do original)

A conduta omissiva do auditor, portanto, só se revela juridicamente relevante quando entre a omissão e a consequência desta conduta se interponha um dever jurídico de agir, usualmente definido nas normas regulatórias da profissão e tenha o auditor tido condições efetivas de agir no caso concreto.

Pode ser elencado um número infinito de condutas comissivas e omissivas do auditor que, tomadas sem a devida cautela ou contrariando a definição das normas que regulam a atividade, poderão gerar responsabilidade, se causadoras de danos.

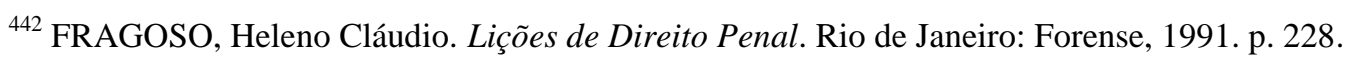


$\mathrm{Na}$ doutrina e na jurisprudência brasileiras não encontramos exemplos de condutas de auditores externos independentes em que a responsabilidade civil deste profissional tenha sido admitida ou proclamada.

Na doutrina italiana, porém, Daniela Casadei elenca uma série de condutas do auditor independente que podem levá-lo a responder civilmente por seus atos, dentre elas: 1) emissão de ações, pela entidade auditada, em valor superior ou inferior ao devido, com base em parecer de auditoria, causando prejuízo aos acionistas ingressantes ou existentes; 2) impedimento de aumento de capital, uma vez que o parecer de auditoria reputa incongruente, de modo indevido, o valor estipulado para emissão das ações; 3) omissão de comunicação, pelo auditor, de que a entidade auditada tenha perdido valores inerentes ao capital social, acarretando a falta de providências da gestão a respeito do fato e sua ulterior falência; 4) omissão na divulgação de reservas ocultas criadas pela gestão da entidade auditada, gerando prejuízo aos acionistas no preço de venda de suas ações; 5) omissão na divulgação de disponibilidades ocultas, levando a procedimentos penais e despesas judiciais; 6) omissão em evidenciar operações contábeis fictícias, gerando prejuízos aos acionistas e a terceiros (credores, devedores, etc.); 7) ausência de evidenciação de passivos ou de garantias de passivos, sofrendo a entidade auditada cobrança de credores ou execução sobre bens dados em garantia, em prejuízo dos acionistas; 8) juízos negativos errôneos, como ressalvas indevidas em pareceres, ênfase errônea sobre risco de continuidade operacional, causando descrédito da entidade auditada perante seus financiadores (acionistas, credores, etc.) e no mercado em geral. ${ }^{443}$

A casuística feita pela autora supracitada tem o mérito de esclarecer algumas das hipóteses em que o auditor pode ser responsabilizado por sua conduta, obviamente sem esgotá-las.

Outras circunstâncias não apontadas por esta doutrinadora podem levar claramente o auditor a responder pelos seus atos. Entre elas, incluem-se a quebra de deveres contratuais gerais (qualificação, entrega tempestiva da prestação, etc.), a revelação de fatos confidenciais cujo conhecimento foi obtido na atividade de auditoria; a ausência de revelação à entidade auditada de fatos que comprometam a independência do auditor ou de recusa de contratação nessas condições; bem como a utilização de informações privilegiadas em proveito próprio e em detrimento do cliente.

${ }^{443}$ Op. cit. p. 63-70. 
Alguns dos exemplos citados pela autora, particularmente aqueles em que o auditor independente se omite na realização de seus deveres, podem ser resumidos em um único caso, referente à omissão do auditor em revelar distorções materialmente relevantes nas demonstrações contábeis que venham causar prejuízos ao cliente ou a terceiros.

É de se ressaltar, embora não mencione a autora, que a relevância da omissão do auditor deve ter influência definitiva na possibilidade de responsabilização deste profissional. Com efeito, sendo a auditoria externa uma atividade que envolve inerentes limitações, não se afigura acertado responsabilizar o auditor por qualquer omissão em sua atividade, ainda que prejudicial ao cliente ou aos interessados.

Além da omissão propriamente dita, pode haver também divulgação tardia de fatos relevantes em prejuízo dos interessados, o que também pode levar à responsabilidade civil do auditor.

Divergimos de Daniela Casadei no que concerne à responsabilidade do auditor independente por não comunicar à entidade auditada que esta, por efeito de suas atividades não lucrativas, tenha perdido valores inerentes ao capital social, acarretando a falta de providências da gestão a respeito do fato e a superveniente falência.

Porque isto equivaleria a equiparar a atividade de auditoria externa a uma prestação de serviços de consultoria da entidade auditada, o que não é correto, a nosso ver. Considerando que o montante de capital social necessário a fazer frente a uma determinada atividade é, em última análise, uma decisão de financiamento da própria entidade, cabe a esta - e somente a esta - através de seus gestores, tomar as decisões de funding que entendam adequadas à natureza e porte da atividade exercida, não competindo ao auditor externo informar à gestão que o nível de financiamento da atividade, pelos prejuízos supervenientes, não se encontra adequado.

Saliente-se que o auditor independente poderá responder perante terceiros isto sim - pela ausência de ênfase ou ressalva em seu parecer, informando aos interessados eventual dúvida sobre a possibilidade de continuidade operacional da entidade auditada, diante da precariedade dos valores adotados para seu financiamento com capital próprio, em face dos prejuízos operacionais existentes. 


\subsubsection{Culpa (responsabilidade subjetiva) ou risco (responsabilidade objetiva)}

Uma das maiores controvérsias envolvendo a responsabilidade civil dos profissionais de auditoria é a exigência ou não do requisito culpa para configuração da responsabilidade.

A doutrina majoritária costuma basear a ideia de responsabilidade subjetiva no descumprimento de um dever de cuidado, enquanto a responsabilidade objetiva encontraria fundamento no risco, principalmente na compensação dada pelo criador e beneficiário econômico da situação risco àqueles que a ele se expõem, podendo sofrer um prejuízo (ubi emolumentum ibi onus).

Alguma doutrina chega a divergir desta postura tradicional. Ressalta Fábio Ulhoa Coelho que o fundamento primeiro da existência da responsabilização sem culpa (objetiva) não é a presença de uma tarefa de risco, mas a possibilidade de que os custos inerentes à atividade empresarial sejam repassados à sociedade como um todo através de sua inclusão nos preços praticados no mercado.

Segundo este autor:

A doutrina costuma apontar o risco, inerente ao exercício de determinada atividade, como o fundamento da responsabilidade objetiva (Savatier, 1945; Lima, 1960; Dias, 1979: passim). O fabricante de fármacos assume forçosamente um risco, inerente à exploração de qualquer atividade econômica, que é o de produzir e comercializar algumas unidades com defeitos. Pois bem, seria tal risco o fundamento valorativo para as normas jurídicas estabelecedoras da responsabilidade objetiva: da opção de o assumir decorreria, segundo tal formulação, a justeza da imputação do dever de indenizar. No final, não se livram os partidários dessa doutrina de algum apego à noção clássica da vontade do devedor como fonte da obrigação. De fato, ao se tomar o risco de determinada atividade por fundamento da responsabilidade objetiva, considera-se o demandado responsável pelo dano, em última análise, em razão de ter ele querido dedicar-se à atividade (...). Não é esse, contudo, o melhor enfoque a ser emprestado à matéria. Na verdade, o fundamento axiológico e racional para a responsabilidade objetiva não são propriamente os riscos da 
atividade, mas a possibilidade de se absorverem as repercussões econômicas ligadas ao evento danoso, por meio da distribuição do correspondente custo entre as pessoas expostas ao mesmo dano ou, de algum modo, beneficiárias do evento. É o mecanismo da socialização das repercussões econômicas do dano, que torna justa a imputação da responsabilidade aos agentes em condições de o acionar. Note-se que o Estado pode responder objetivamente pelos danos causados por seus funcionários, porque tem meios para distribuir entre os contribuintes mediante criação e cobrança de tributos - os encargos derivados de sua responsabilização. Por outro lado, o fornecedor pode ter responsabilidade objetiva por acidentes de consumo, na medida em que consegue incluir na composição de seus preços um elemento de custo correspondente às indenizações por aqueles acidentes. ${ }^{444}$

A opinião deste autor, embora razoável, não está imune a questionamentos.

Com efeito, fazer depender o regime de responsabilidade civil (subjetiva ou objetiva) da possibilidade de repasse de custos indenizatórios ao mercado por meio do sistema de preços, é por demais incerto e casuístico, uma vez que o aumento de preços na forma mencionada só será efetivamente possível se assim permitirem as condições de elasticidade da demanda. Num setor altamente competitivo, é bem possível que tais repasses sejam impossíveis do ponto de vista econômico, sob pena de perda de receitas e, consequentemente, de competitividade empresarial.

Qualquer que seja o fundamento adotado para legitimar os sistemas mencionados, é fato que o regime de responsabilidade subjetiva (negligence liability), baseando sua incidência na consideração de culpa ou negligência, tem como elemento fulcral a ineficiência da conduta em comparação com padrões exigidos; enquanto o regime de responsabilidade objetiva (chamado por alguns de regime de responsabilidade incondicional ou strict liability) preconiza a responsabilidade do causador do dano independentemente de qualquer consideração sobre a natureza ou forma de sua atuação externa.

Obviamente, entre os extremos da responsabilidade objetiva e subjetiva existe um grande número de hipóteses intermediárias, várias delas marcadas por inversões do

${ }^{444}$ COELHO, Fábio Ulhoa. Curso de Direito Comercial. São Paulo: Saraiva, 2003, v.2. p. 256. 
ônus de prova de culpa, ${ }^{445}$ ou mesmo pela possibilidade de atenuações ao rigor da responsabilização do causador diante de causas específicas que contribuíram para o evento (causas de exclusão de responsabilidade).

Deste modo, os temas a serem tratados neste tópico envolvem basicamente as seguintes questões: 1) qual regime de responsabilidade do auditor afigura-se mais justo e adequado à natureza de sua atividade? 2) sob o ponto de vista legal, adota-se, no Brasil, o sistema mais adequado de responsabilidade?

Para tratar melhor dessas questões, abriremos para cada uma subtópicos respectivos.

\subsubsection{Análise das vantagens e desvantagens dos regimes de responsabilidade}

Para verificar as vantagens e desvantagens dos sistemas de responsabilidade, usaremos os critérios preconizados pela Análise Econômica do Direito (Law and Economics). Dentre eles, analisaremos: 1) natureza do evento danoso (infortúnios unilaterais ou bilaterais) e sua causa (determinada pelo nível de cuidado ou pelo nível de atividade); 2) repercussões no sistema de incentivos à melhoria nos cuidados inerentes à tarefa do auditor; 3) vantagens e desvantagens quanto à justiça das decisões e erros judiciais; 4) ganhos ou perdas em relação à litigiosidade da matéria.

O primeiro ponto a ser abordado concerne à natureza e à causa dos infortúnios envolvendo a atividade de auditoria.

Devemos saber inicialmente se os danos causados pela atividade do auditor são influenciados pela conduta de ambas as partes envolvidas no evento (auditor e vítima), recebendo então a denominação de acidentes ou infortúnios bilaterais, ou se são resultado apenas da atuação do causador do dano (em nosso caso, o auditor independente), quando serão conhecidos por acidentes ou infortúnios unilaterais.

\footnotetext{
${ }^{445}$ Neste sentido, a opinião sempre abalizada de Waldírio Bulgarelli, ainda que trate de assunto análogo, referente à responsabilidade civil do conselheiro fiscal: "Não iremos, a propósito, nos afadigar com a questão da natureza ou do tipo dessa responsabilidade, se objetiva ou subjetiva, que ainda preocupa uma certa doutrina nacional pois que, a toda evidência, conforme já demonstramos em obra específica existem graus intermediários entre uma e outra, voltados para a inversão do ônus da prova e das presunções legais, relativas ou absolutas, concepção que conta hoje com declarado apoio da doutrina nacional" (BULGARELLI, Waldírio. Regime jurídico do Conselho Fiscal das S/A. Rio de Janeiro: Renovar, 1998. p. 228).
} 
Logo em seguida, deveremos investigar se os danos causados pelo auditor externo são determinados apenas pelo nível de cuidado profissional ou se também têm causa na quantidade ou nível de atividade empreendida pelo auditor.

Considerando a responsabilidade extracontratual em relação a terceiros, ou mesmo a responsabilidade contratual por dano ao cliente, os eventos causados a estes pela atividade de auditoria podem ser considerados como infortúnios bilaterais, já que pode existir (mesmo que de modo reduzido) a contribuição da conduta da vítima para o desfecho danoso.

Suponhamos, por exemplo, o caso de uma entidade auditada que não forneça elementos suficientes para o auditor verificar a existência de um determinado passivo, ou mesmo que dolosamente o esconda (deixando o profissional, por isso, de ressalvar seu parecer), daí decorrendo danos à entidade, derivados de processos judiciais de indenização por iniciativa de terceiros.

Do mesmo modo, além de uma falha do auditor, pode ter contribuído para o evento danoso a negligência de terceiro que, $v . g$., ao adquirir valores mobiliários da entidade auditada, não se tenha informado corretamente das circunstâncias de risco e rentabilidade de seu investimento, ou ainda que, mesmo conhecendo os problemas do parecer de auditoria, tenha realizado tal aquisição.

Em suma, temos que tanto pode concorrer com a conduta do auditor para o evento danoso a negligência da parte contratante (entidade auditada) quanto a do terceiro usuário da informação contábil auditada.

Esta negligência contributiva da vítima do dano da atividade de auditoria externa é definida e explicada por Boyton et al., com base na legislação norte-americana, nos seguintes termos:

Em sua seção 465, de 1965, o Restatement (Second) of Torts define negligência contributiva como conduta do queixoso abaixo do padrão compatível com sua própria proteção, e que coopera com a negligência do acusado para causar dano ao queixoso. Assim, se a negligência de um queixoso contribuir para um dano a si próprio, a lei considera que ele é tão responsável pelo dano quanto o acusado. Nesse caso, não existe base legal para que ele seja indenizado, porque sua negligência elimina a negligência da outra parte. Durante uma auditoria ou preparação de 
declaração de Imposto de Renda, por exemplo, o queixoso pode ter deixado de apresentar informação vital ao CPA. ${ }^{446}$

Visto que os eventos danosos decorrentes da atividade de auditoria externa são de natureza bilateral, devemos verificar se o fator decisivo que contribui para esses eventos é somente o nível de precaução das partes ou se, juntamente com este, também contribui para o dano o nível de atividade econômica de seu autor.

Em princípio, tem-se que, em se tratando de atividades naturalmente arriscadas ou sobre as quais não se tenha o devido controle no sentido de evitar prejuízos, ao lado da falta de precaução, o maior nível de atividade econômica acarreta certamente maior número de danos, uma vez que, probabilisticamente, o dano estará necessariamente vinculado à atividade, mesmo que sejam tomados todos os cuidados devidos.

No que tange à atividade de auditoria, porém, não vislumbramos o nível de atividade do auditor como um fator decisivo para o incremento na elevação do número de infortúnios, uma vez que não se pode associar, a priori, o grau de atividade tomada pelo auditor com o aumento proporcional dos danos causados, do mesmo modo que ocorre com atividades de alto risco ( $v . g$., atividades insalubres, perigosas, penosas, etc.).

Desta forma, podemos concluir que os eventos danosos derivados da atividade de auditoria conceituam-se como infortúnios bilaterais (uma vez que podem ser influenciados pelo comportamento de ambas as partes envolvidas) e determinados fundamentalmente pelo nível de precaução adotado na atividade.

Posto isto, devemos verificar o segundo ponto citado, qual seja, como o sistema de responsabilidade subjetiva ou objetiva repercute nos incentivos à melhoria da qualidade do trabalho do auditor, uma vez que estamos diante de infortúnios influenciados pela conduta de ambas as partes envolvidas no evento, conforme o grau de precaução empregado.

Sob o ponto de vista da Análise Econômica do Direito, podemos verificar certo consenso na doutrina quanto às vantagens do sistema de responsabilidade subjetiva sobre o de responsabilidade objetiva (incondicional) para proporcionar melhores incentivos às partes em evitar os eventos danosos.

Neste sentido, a lição de Vasco Rodrigues:

${ }^{446}$ Op. cit. p. 142. 
Já num acidente bilateral determinado apenas pelo nível de precaução, a responsabilidade incondicional não é eficiente porque cria incentivos para que apenas uma das partes tome precauções. A responsabilidade por negligência continua a ser eficiente porque cria uma dupla responsabilidade na margem. ${ }^{447}$

Nesta linha também opina um estudo da London Economics:

Em primeiro lugar, a respeito dos incentivos para aumentar os esforços de auditoria, a análise teórica mostra que um sistema baseado em responsabilidade por negligência tem uma série de vantagens em relação a um sistema de responsabilidade estrita. Em um sistema baseado em negligência, um auditor é suscetível de ser responsabilizado apenas se existem erros no sistema financeiro e este não conseguiu apresentar certo nível de cuidado devido, enquanto sob responsabilidade objetiva (incondicional), um auditor é sempre responsável se existem erros nas demonstrações financeiras. Sob um sistema baseado em negligência, um auditor tem maior incentivo para aumentar o esforço de auditoria (...) o que leva a uma redução dos pagamentos de danos esperados e diminui a probabilidade de que o esforço de auditoria seja visto como negligente num julgamento. ${ }^{448}$

Parece, portanto, induvidoso que o sistema de responsabilidade subjetiva ou por negligência traz maiores incentivos ao auditor e à parte eventualmente prejudicada para que tomem as devidas precauções em evitar o dano, o que não ocorre sob um sistema de responsabilidade objetiva ou incondicional.

Além da questão dos incentivos, cumpre delimitar as vantagens e desvantagens dos sistemas de responsabilidade subjetiva ou objetiva no que toca à possibilidade de erro nas decisões judiciais.

Com relação a este critério, podemos dizer que não há, a priori, vantagens de um sistema sobre outro. Isto porque, se um sistema baseado na responsabilidade objetiva

\footnotetext{
${ }^{447}$ Op. cit. p. 119.

$448 \mathrm{O}$ texto é tradução livre de: "First, with respect to the incentives to increase audit efforts, the theoretical analysis shows that a negligence-based liability system has a number of advantages relative to a strict liability system. Under a negligence-based system, an auditor is liable only if there are errors in the financial system and he/she has failed to deliver a certain level of due care while under strict liability, an auditor is always liable if there are errors in the financial statements. Under a negligence-based system, an auditor has greater incentive to increase the audit effort (...) which leads to a reduction of the expected damage payments and it decreases the probability that the audit effort is viewed as negligent in a trial." (LONDON ECONOMICS, Study on the Economic Impact of Auditors' Liability Regimes. Disponível em
} 
pode ser menos sujeito a erros no que tange aos casos em que a negligência não consegue ser evidenciada judicialmente (deixando o ofensor impune), também pode sancionar o responsável ainda que sua conduta seja eficiente, dentro do que dela se espera, além de devidamente cautelosa, o que não ocorre num sistema de responsabilidade subjetiva. ${ }^{449}$

Por fim, há a questão de saber qual sistema é mais favorável à diminuição ou aumento da litigiosidade da matéria, facilitando a pacificação social.

Apesar das divergências doutrinárias, entendemos que o regime de responsabilidade objetiva, por tornar mais fácil a responsabilização do suposto autor do dano, aumenta a expectativa de ressarcimento de prejuízos e, com isto, acaba por dar mais estímulos ao ingresso das vítimas em juízo para obter a reparação dos danos causados, até mesmo, em alguns casos, de forma temerária.

É verdade que, prescindindo da prova de culpa, o processo judicial em regime de responsabilidade objetiva tende a ser menos custoso, pois não será necessária a produção de prova de negligência.

Mais uma vez, é importante verificar a lição de Vasco Rodrigues:

No entanto, faria sentido considerar ainda os custos inerentes à litigação dos processos decorrentes dos acidentes. Anteriormente, notamos de passagem que uma regra de negligência tende a gerar maiores custos do que uma regra de responsabilidade incondicional, no caso de um processo chegar a ser litigado. Isto, por si só, é insuficiente para permitir comparar os dois tipos de regras: dado que é mais difícil ganhar um processo sob uma regra de negligência, esta tenderá a resultar na apresentação de um menor número de processos. ${ }^{450}$

Em suma, podemos fixar preliminarmente que: 1) o sistema de responsabilidade subjetiva, em se tratando de infortúnios cuja causa possa residir na conduta de ambas as partes, tende a gerar melhores incentivos para que ambas tomem as devidas precauções, ao contrário da regra de responsabilidade objetiva incondicional de

<http://ec.europa.eu/internal_market/auditing/docs/liability/auditors-final-report_en.pdf >. Acesso em 23 fev. 2010).

${ }^{449}$ Esta também é a opinião de Richard Posner (POSNER, Richard A. Economic Analysis of law. Nova York: Aspen Publishers, 2007. p. 181). Este autor ainda observa que a responsabilidade objetiva incondicional promove verdadeiro seguro de danos às vítimas através do sistema legal de responsabilidade. Isto, em suma, só seria uma vantagem se for menos custoso segurar as vítimas através da imposição legislativa de responsabilidade do que através do sistema de mercado, por meio da celebração de contratos de seguro de responsabilidade.

${ }^{450}$ Op. cit. p. 116. 
uma das partes, que não incentiva a vítima a também atuar com o devido cuidado em evitar o dano; 2) no que concerne à possibilidade de erro nas decisões, não há uma preferência clara por um dos sistemas; isto porque cada qual apresenta pontos em que o erro judicial se apresenta mais ou menos provável. A responsabilidade subjetiva pode favorecer a impunidade do autor do dano, enquanto a responsabilidade objetiva pode levar à punição do autor do dano que tenha tomado todos os cuidados devidos e esperados; 3 ) o sistema de responsabilidade subjetiva, embora proporcione maiores custos probatórios, tende a diminuir a litigiosidade da matéria.

Dentre os dois sistemas, em cotejo com a hipótese concreta de responsabilidade civil do auditor, entendemos que a melhor solução é a adoção de sistema intermediário, qual seja, responsabilidade civil subjetiva, com presunção de culpa do auditor, diante da existência de dano derivado da conduta deste.

A vantagem da adoção de regra de presunção de culpa parece-nos evidente.

Primeiramente, mantém o sistema de incentivo à realização dos esforços de ambas as partes envolvidas: auditor e vítima do dano, na vigência desta regra, continuam a ter incentivos para não ser negligentes.

A presunção de culpa, por outro lado, evita um dos maiores problemas do sistema de responsabilidade subjetiva, em que o ônus da prova fica a cargo da vítima, qual seja, o de dificultar em demasia a prova, correndo o risco de deixar impune o autor do dano.

Como se sabe, a atividade de auditoria envolve ampla gama de trabalhos, de natureza técnica, frequentemente realizados por diversas pessoas de modo difuso e complementar. Isto dificulta em demasia a tarefa da vítima do dano em provar a culpa do auditor, uma vez que, para desincumbir-se de seu ônus, necessitará ter conhecimento minucioso dos trabalhos realizados, além de conhecer os aspectos técnicos envolvidos. Deixando-se a cargo do auditor a prova de que sua conduta foi adequada, este tem todas as condições técnicas de fazê-lo com muito menor esforço, proporcionando situação superior em termos de equilíbrio na distribuição do ônus probatório.

A presunção de culpa evita igualmente o problema antes mencionado no sistema de responsabilidade objetiva incondicional, qual seja, o de responsabilizar o suposto autor do dano, mesmo que sua conduta seja eficiente e cautelosa, dentro do devido 
e esperado. Podendo provar, com efeitos positivos, que sua conduta não foi culpável, o auditor tem condições de evitar eventual erro judicial ou decisão injusta.

Por fim, num sistema com culpa presumida, há o efeito de menor litigiosidade judicial, evitando estímulos ao ingresso de processos por causas temerárias, diante da maior dificuldade de se obter a responsabilização do auditor, ao contrário do que ocorre num sistema de responsabilidade objetiva incondicional.

O sistema também traz vantagens em relação aos custos de demonstração de culpa (ou de sua ausência). Efetivamente, é de se considerar que a atribuição do ônus da prova ao auditor é menos custosa do que deixar esta tarefa à vítima do dano, já que o auditor dispõe de conhecimento e provas técnicas que podem ser produzidas e/ou apresentadas em juízo com menores custos.

Concluímos, portanto, que um sistema de responsabilidade subjetiva com presunção de culpa do auditor, sob o ponto de vista da Análise Econômica do Direito, apresenta maiores vantagens em comparação com as outras hipóteses ora analisadas (responsabilidade subjetiva em que a prova da culpa está a cargo da vítima ou responsabilidade objetiva incondicional).

\subsubsection{Regime adotado na legislação brasileira}

Cabe agora verificar qual regime foi adotado na legislação brasileira.

Para o caso de responsabilidade contratual do auditor, a regra primordial a incidir sobre a matéria é a existente no art. 389 do Código Civil, segundo a qual não cumprida a obrigação, responde o devedor por perdas e danos, mais juros e atualização monetária segundo índices oficiais regularmente estabelecidos, e honorários de advogado.

Como já salientamos, no caso de responsabilidade contratual, provado o inadimplemento da obrigação, a doutrina é pacífica em admitir que a culpa do devedor será presumida, bastando ao contratante que sofreu o prejuízo provar o inadimplemento e o dano derivados da conduta do devedor.

Em termos de responsabilidade extracontratual, entretanto, podem surgir dúvidas sobre o regime adotado. 
A regra do art. $26, \S 2^{\circ}$, da Lei n. 6.385/76 estabelece que as empresas de auditoria contábil ou auditores contábeis independentes responderão, civilmente, pelos prejuízos que causarem a terceiros em virtude de culpa ou dolo, adotando claramente uma regra de responsabilidade civil subjetiva.

No entanto, na forma antes sustentada neste trabalho, a relação que se estabelece entre terceiro e auditor tem natureza de consumo, uma vez que o terceiro prejudicado pela atividade do auditor se equipararia ao consumidor, em razão de ser vítima de acidente de consumo.

O Código de Defesa do Consumidor, entretanto, estabelece em seu art. 14 uma regra de responsabilidade objetiva, estatuindo que o fornecedor de serviços responde, independentemente da existência de culpa, pela reparação dos danos causados aos consumidores por defeitos relativos à prestação dos serviços, bem como por informações insuficientes ou inadequadas sobre sua fruição e riscos. Esta regra poderia ser excepcionada apenas no caso de auditor pessoa física, uma vez que no art. $14, \S 4^{\underline{o}}$, do CDC, ressalta-se que a responsabilidade pessoal dos profissionais liberais será apurada mediante a verificação de culpa.

Este conflito de normas pode gerar várias interpretações, dentre as quais citamos: 1) a regra do art. 26, $\S 2^{\underline{o}}$, da Lei n. 6.385/76 está revogada pelas normas do CDC, dado que este é legislação posterior; 2) o sistema de responsabilidade subjetiva aplica-se somente aos auditores que não atuem no mercado financeiro ou de capitais e aos auditores pessoas físicas, uma vez que o art. $26, \S 2^{\underline{o}}$, da Lei n. 6.385/76 só incide sobre a atividade dos auditores registrados na CVM que atuem nesses mercados, e o próprio CDC determina a aplicação das regras de responsabilidade subjetiva aos profissionais liberais. Aos demais auditores aplicar-se-ia a regra de responsabilidade objetiva; 3) por se tratar de lei especial, o art. 26, $\S 2^{\underline{o}}$, da Lei n. 6.385/76 afasta a aplicação dos dispositivos do CDC em relação ao regime de responsabilidade do auditor independente.

Destas interpretações citadas, preferimos claramente a terceira.

Isto, porque a primeira não pode ser aceita em virtude de que, sendo legislação especial que regula a responsabilidade do auditor, o art. $26, \S 2^{\circ}$, da Lei n. 6.385/76 não pode ter sido revogado pelo CDC, ainda que este seja posterior. Prevalece aqui o princípio da especialidade sobre o da anterioridade no conflito de normas. 
A segunda interpretação também nos parece inviável, dado que, como já sustentamos, aplicaria regra mais severa de responsabilidade justamente aos profissionais de auditoria que teriam menor porte econômico para fazer frente às vultosas indenizações a que estariam sujeitos (auditores não registrados na CVM), deixando regra mais favorável aos de maior porte econômico (auditores registrados na CVM).

Assim, a única interpretação viável nos parece aquela segundo a qual a regra do art. 26, $\S 2^{\underline{0}}$, da Lei n. 6.385/76 afasta a aplicação do CDC, por se tratar de norma especial que regula a responsabilidade do auditor.

É bem verdade que este art. $26, \S 2^{\circ}$, não faz menção ao ônus da prova, que, como regra, permaneceria a cargo da vítima.

No entanto, entendemos que, na forma antes sustentada, cuidando-se de obrigação de resultado, à vítima ficará apenas a incumbência de provar o dano e o nexo de causalidade com a ação ou omissão do auditor, cabendo a este provar que não agiu de forma culpável.

Concluímos, portanto, que a legislação brasileira adota sistema de presunção de culpa em tema da responsabilidade civil do auditor. ${ }^{451}$

\subsubsection{Nexo de causalidade}

Questão de difícil resolução é o estabelecimento do nexo de causalidade para a responsabilização do auditor independente.

\footnotetext{
${ }^{451}$ Muito embora não trate do tema relativo ao ônus da prova da culpa, o extinto Primeiro Tribunal de Alçada Civil de São Paulo, nos autos da apelação n. 1218741-6, bem retratou que a responsabilidade do auditor externo, em nossa legislação, é subjetiva, não havendo o que se falar em responsabilidade objetiva na hipótese. Provam isso os excertos retirados do inteiro teor do acórdão mencionado: "Como se percebe, não se pode falar, ao menos pelo que consta dos autos, em inadimplemento ou em conduta culposa dos auditores da ré. Culpa, em sentido amplo, é a inobservância de um dever de cuidado, de uma atenção, a que o agente estava obrigado na situação concreta. E isso não ocorreu. Pelo menos não há nos autos prova nesse sentido. Em realidade, a culpa pelo desvio deve ser atribuída aos administradores do banco, à sua auditoria interna. Destaque-se a percuciente observação do ilustre magistrado, Dr. Alexandre Batista Alves, em sua magnífica decisão, no sentido de que é difícil supor que um banqueiro experiente "deixaria passar despercebida a existência desses saldos, sem remuneração, na conta de disponibilidades da instituição financeira" (fls. 2635). Não se nega que a legislação vigente prevê a responsabilidade indenizatória nos trabalhos de auditorias. Mas não se trata, em absoluto, de responsabilidade objetiva. Está ela condicionada à presença do dolo ou da culpa. O que não ocorreu, repita-se, no caso dos autos".
} 
Não há dúvidas em se estabelecer o liame causal quando o dano acarretado pela conduta do auditor seja resultado de uma ação positiva (comissiva) ou dolosa (comissiva ou omissiva) deste profissional.

Estará indubitavelmente presente o nexo de causalidade, por exemplo, na conduta do auditor que frauda demonstrações contábeis ou, ciente da existência de fraude, dolosamente omite-se em revelá-la, causando dano a terceiros. Haverá nexo, sem qualquer dúvida, na conduta positiva do auditor ao ressalvar culposamente seu parecer, informando ao público fatos que não ocorreram, causando dano à imagem do cliente.

O problema se põe principalmente quando se tenha de estabelecer o nexo entre o dano suportado pela vítima (terceiro usuário da informação contábil) e a conduta omissiva culposa (negligente) do auditor. Esta hipótese, que é a mais frequente na prática, gera sérios problemas para o estabelecimento da relação de causalidade, uma vez que a conduta omissiva do auditor apenas permite (ou não impede) que a informação contábil inidônea, de responsabilidade da gestão da entidade auditada, influencie a decisão de terceiros usuários das demonstrações contábeis.

Nas palavras de Maria Vittoria Cozzi:

O problema nasce do fato de que os atos da sociedade de auditoria não são normalmente, em si, causa do dano imediato da sociedade revisionada ou dos terceiros que com esta se relacionam; a causa imediata dos danos é, de fato, a má gestão dos administradores. ${ }^{452}$

Aplicável aqui a lição de Paulo José da Costa Júnior a respeito da causalidade omissiva:

Indubitavelmente, a causa da queda do vaso que estava na janela não foi o deixar de fechá-la, mas o vento que a impulsionou contra aquele, fazendo-o precipitar-se na calçada graças à ação da gravidade. Como a causa do incêndio não será a falta de para-raios, mas a queda do próprio raio. Logo, com relação à realidade material e tangível, do nada, nada pode nascer. $^{453}$

O problema, portanto, é estabelecer até que ponto a omissão culposa (negligente) do auditor pode ser considerada como causa do dano suportado pela vítima.

${ }^{452}$ Op. cit. p. 62. O texto é tradução livre de: "Il problema nasce dal fatto che l'operato della società di revisione non è normalmente in sè causa del dano subito dalla società revisionada ou dai terzi che con questa entrano in relazione; causa immediata del danno è, infatti, la mala gestio degli amministratori”.

${ }^{453}$ COSTA JÚNIOR, Paulo José da. Nexo causal. São Paulo: Malheiros, 1996. p. 121. 
Observe-se que, nos eventuais litígios judiciais envolvendo vítima e auditor, aquela tenderá a afirmar que baseou inteiramente suas decisões na credibilidade que o parecer de auditoria conferia às demonstrações financeiras, mesmo que isto não corresponda à verdade absoluta. Por outro lado, o auditor tenderá a refutar o nexo causal, seja pela alegação de que não deu causa ao dano, seja por invocar que a vítima se baseou em outras fontes para sua decisão de investimento.

É preciso, portanto, fixar um parâmetro dentro do qual deve a conduta omissiva do auditor ser admitida como causa do evento.

Para tanto, necessitamos observar os seguintes pontos: 1) se a omissão do auditor se configura como causa ou condição; 2) quais os requisitos para que a omissão seja considerada como relevante no processo causal.

Na definição de Régis Jolivet, causa é aquilo de que uma coisa depende quanto à existência, enquanto condição é o que permite à causa produzir seu efeito, seja positivamente a título de instrumento ou meio, seja negativamente, afastando os obstáculos. $^{454}$

Conforme visto, a omissão negligente do auditor não é, em princípio, causa do dano suportado por terceiros que tomaram decisões com base nas demonstrações contábeis, uma vez que não dá existência ou faz surgir a informação contábil distorcida, a qual foi originada pela atuação dos gestores da entidade auditada. ${ }^{455}$

Desta forma, a omissão do auditor, a priori, configura-se como condição que permite (ou não impede) que à causa original - distorção das demonstrações contábeis -, de responsabilidade dos gestores, venha a atuar no caso concreto, proporcionando danos aos terceiros.

Ao não realizar corretamente o dever jurídico de que era incumbido, a conduta omissiva do auditor deixa de remover os obstáculos à credibilidade das demonstrações, que

\footnotetext{
${ }^{454}$ JOLIVET, Regis. Curso de filosofia. Rio de Janeiro: Agir, 1961. p. 295.

${ }^{455}$ Pelo que até aqui afirmamos, discordamos do ponto de vista de Daniela Casadei (Op.cit. p. 157), segundo a qual o parecer de auditoria é sempre causa principal e exclusiva do dano produzido à vítima, verbis: "A rigori, 1'intervento istituzionale delia società di revisione nell'iter di diffusione delle informazioni su una determinata realtà aziendale dovrebbe relegare il comportamento colposo o doloso della società revisionata $\mathrm{a}$ 'occasione' dei danno e quindi rappresentare causa esclusiva di produzione dei danno. Con cio non si vuole assolutamente sostenere che il bilancio diventi, in qualche modo, 'atto' dei revisore, ma solo osservare che la causalità esclusiva dei fatto dei revisore andrebbe affermata perche il fatto causativo dei danno non è il bilancio falso, ma l'informazione inesatta immessa sul mercato dalla società di revisione: l'informazione dei revisore, insomma, è diversa dali'informazione che qualunque bilancio societário può offrire ai mercato".
} 
existiriam se houvesse evidenciado as distorções ali presentes. Esta conduta permite à causa original atuar plenamente no mundo fenomênico.

A condição, entretanto, pode ser elevada à estatura de causa do evento, sempre que assim seja normativamente determinado.

Mais uma vez é importante chamar à colação as lições de Paulo José da Costa Júnior:

Consequentemente, se não é exato falar numa causalidade omissiva, parece possível mencionar a condicionalidade omissiva sempre que uma norma imponha o dever de movimentar-se ou de impedir o evento. A falta de alimentação da criança não é causa de sua morte, mas constitui condição da menor resistência orgânica à ação das bactérias que causam a morte. Aquele que se abstiver de alimentá-la, desde que tenha obrigação de fazê-lo, movimenta a condição necessária para que a causa opere. Pelo que seria legítima a conclusão de que a lei declara punível a omissão sempre que e somente quando "a condição seja elevada à causa, sem que com esta se confunda nem se identifique". ${ }^{456}$

Cumpre, deste modo, saber quando teremos a omissão negligente do auditor elevada à categoria de causa, para fim de se determinar a responsabilidade deste profissional pelo evento danoso. Para tanto, é necessário saber se a conduta comissiva do auditor, se existente, teria influenciado o resultado danoso.

Nessa linha, entendemos que se for possível presumir que, no processo causal, a hipotética ação positiva ou comissiva do auditor, em lugar de sua omissão negligente no caso concreto, aumentaria a probabilidade de que o dano não ocorresse, estaremos diante de um evento em que a omissão do auditor, naturalmente considerada como condição, poderá ser tomada como causa principal.

No entanto, se no caso concreto a conduta comissiva do auditor não poderia aumentar a probabilidade da superveniência do dano, deveremos excluir a participação da conduta do auditor do processo causal.

Poder-se-ia argumentar que o aumento de probabilidade de um evento não se constitui em sua causa, mas meramente no incremento das chances de que venha a ocorrer. Isto, no entanto, não seria correto.

${ }^{456}$ Op. cit. p. 124. 
Primeiramente, a causalidade omissiva atua sempre com base no raciocínio probabilístico de que a ação (ao invés da omissão) aumentaria as chances de o dano não acontecer (p.ex.: a alimentação da criança, em lugar da omissão materna, no exemplo antes citado, aumentaria as chances de que o óbito daquela não ocorresse, mas não garantiria que este não pudesse sobrevir).

Além disso, há processos causais em que vários fatores etiológicos atuam simultaneamente, sem que se possa estabelecer um único deles como decisivo, ${ }^{457}$ mas apenas determinar o aumento da frequência de um evento quando um determinado fator esteja presente. É exatamente o que ocorre no caso da atividade de auditoria: em grande parte das vezes, não se sabe ao certo se a vítima do dano, em seu processo decisório, levou em consideração única e exclusivamente o parecer do auditor como fator decisivo, ou se atuou com base em ampla gama de outras informações.

Veja-se a lição de Túlio Aguiar:

Outra noção que oferece uma rica variedade de recursos para se tratar da causação é a de probabilidade. Muitas são as motivações para se construir uma teoria probabilística da causação. Talvez a principal delas venha da possibilidade de lidar com as relações causais em contextos indeterministas. Nestes, a presença da causa pode levar apenas à probabilidade da ocorrência do efeito. Mesmo em contextos deterministas, probabilidades podem ser usadas para medir o impacto de um certo fator causal sobre um efeito de certo tipo, na suposição de que

\footnotetext{
${ }^{457}$ Interessante verificar excerto da decisão do extinto Primeiro Tribunal de Alçada Civil de São Paulo, nos autos da apelação n. 1218741-6, o qual, ainda que de forma perfunctória, também pareceu ter percebido o problema da causalidade na omissão do auditor, bem como o problema da multiplicidade de causas (atuação indevida da gestão e omissão do auditor) agindo sob um mesmo evento, verbis: "Requisito essencial da obrigação de reparar é a existência de uma relação de causalidade entre a ação ou omissão (na responsabilidade aquiliana), ou o descumprimento de obrigação contratual (na responsabilidade contratual), e o dano experimentado pela vitima. Sem essa relação causal não se há falar em dever indenizatório. De fato, sem esse liame causal a ligar a conduta ao dano não surge a responsabilidade civil indenizatória. A determinação desse nexo causal é situação de fato a ser analisada em cada caso concreto, sendo certo que a grande questão, nesse tema, diz com a correta identificação do fato que constitui a verdadeira causa do dano, em especial quando este decorre de causas múltiplas (...). Porém, ainda que assim não fora, o exame do segundo aspecto, nexo causal entre a conduta dos auditores da ré e o dano experimentado pelos autores, também leva à improcedência da pretensão ajuizada. É que o dano que dizem ter experimentado os autores decorreu de ação direta e fraudulenta dos prepostos do próprio Banco. Foram eles que, com aquele procedimento bem detalhado na inicial, fraudaram o Banco, desviando aquelas altas somas para contas no exterior. E não de conduta dos auditores. A concessão de amplos poderes ao Diretor de Área Internacional, (...), que os exerceu de forma verdadeiramente ditatorial, chegando mesmo a limitar os trabalhos da auditoria interna, impedindo o acesso à movimentação da Agência Cayman no sistema SWIFT, por simples anotação à mão e sem qualquer justificativa (fls. 1551), aliada à não observação feita pelas auditorias interna e externa, ao não fiscalizar e supervisionar as operações nessa Agência Cayman, é que acabaram por permitir os
} 
ignoramos exatamente quais fatores estão operando em um caso de causação singular. O que se percebe, entretanto, como uma motivação mais geral, dentro da literatura contemporânea, é que o cálculo de probabilidades fornece um rico aparato formal, com o qual muitas distinções causais podem ser feitas, pelo menos de maneira aproximada. Assim, as relações entre causação e probabilidade são exploradas tanto por autores engajados em um projeto reducionista quanto por aqueles que abandonaram tal projeto. ${ }^{458}$

Faz-se necessário ainda responder à indagação: quando a ação omitida do auditor independente aumentaria a probabilidade do evento danoso, podendo ser considerado como causa deste mesmo evento?

Entendemos que a resposta está ligada à possibilidade de que a ação omitida do auditor influenciasse, efetiva e objetivamente, o comportamento da vítima do evento danoso.

Em outras palavras, o conceito de aumento de probabilidade, nos termos do ora tratado, relaciona-se com o conceito de materialidade ou relevância de auditoria e, em última análise, com o dever fundamental do auditor independente em informar se existem distorções materialmente relevantes nas demonstrações contábeis, uma vez que se presume que, em havendo distorções relevantes nessas demonstrações, a vítima do evento danoso poderia alterar seu comportamento e evitar a superveniência do resultado.

Obviamente, num processo judicial, o juiz não fica adstrito ao conceito de materialidade conferido pelo auditor para limitar sua atuação no caso concreto, até mesmo porque o auditor pode tê-lo fixado equivocadamente. Poderá, entretanto, o magistrado, com base neste conceito, afastar a relação de causalidade no caso concreto, sempre que entender que, pela ausência de materialidade da omissão do auditor, a conduta da vítima do evento danoso provavelmente não seria alterada ou influenciada.

desfalques. Realmente, tão elevada a culpa dos administradores do Banco que acabaria mesmo por absorver qualquer eventual conduta culposa dos auditores da ré".

${ }^{458}$ AGUIAR, Túlio. Causalidade e direção do tempo: Hume e o debate contemporâneo. Belo Horizonte: Humanitas, 2008. p. 101. 


\subsubsection{Dano}

No estudo do dano indenizável em virtude da responsabilização civil do auditor é de se perquirir quais verbas o compõem.

Como é sabido, a doutrina e a jurisprudência têm pugnado pela inclusão de inúmeras verbas na composição dos danos (danos materiais, morais, à imagem, etc.), de modo a tornar a compensação da vítima a mais perfeita possível, além de admitirem, embora com certa relutância, a fixação de valores não só para compensar a vítima, mas também para desestimular o autor do dano da prática de novas violações no futuro.

No que tange diretamente à responsabilidade do auditor, é indiscutível o cabimento de algumas verbas indenizatórias, como os danos materiais (incluindo os danos emergentes e lucros cessantes) e morais ( $v . g$. , pela mácula à imagem do cliente derivada de um parecer equivocado de auditoria). Outras verbas, entretanto, são de discutível cabimento, tais como a mera deterioração no valor de mercado de valores mobiliários objeto de investimento por parte da vítima.

Para basear a discussão sobre a matéria, levaremos em consideração estudo feito no âmbito da União Europeia ${ }^{459}$ sobre quais verbas indenizáveis podem ser incluídas na indenização a ser paga pelo auditor independente se eventualmente condenado na esfera judicial.

A tabela seguinte representa as conclusões do estudo:

Tabela 28: Verbas que compõem a indenização nos países da União Europeia

\begin{tabular}{cccccc}
\hline País & $\begin{array}{c}\text { Danos } \\
\text { morais } \\
\text { (imateriais) }\end{array}$ & $\begin{array}{c}\text { Queda de } \\
\text { preço de } \\
\text { ações }\end{array}$ & $\begin{array}{c}\text { Danos } \\
\text { futuros }\end{array}$ & $\begin{array}{c}\text { Custas } \\
\text { judiciais }\end{array}$ & $\begin{array}{c}\text { Honorários } \\
\text { de } \\
\text { advogado }\end{array}$ \\
\hline Áustria & Não & Não & Sim & Sim & Sim \\
\hline Bélgica & Sim & Sim & Sim & Sim & Não \\
Dinamarca & Não & Sim & Sim & Sim & Sim \\
Finlândia & Sim & Sim & Não & Sim & $\begin{array}{c}\text { Sim } \\
\text { (continua) }\end{array}$ \\
\hline
\end{tabular}

${ }^{459}$ EUROPEAN COMISSION. A study on systems of civil liability of statutory auditors in the context of a single Market for auditing services in the European Union. Disponível em <http://ec.europa.eu/internal_market/auditing/liability/index_en.htm\#study>. Acesso em 27 dez. 2009. 


\begin{tabular}{|c|c|c|c|c|c|}
\hline França & Sim & Não & Sim & Sim & Sim \\
\hline Alemanha & Não & Não & Sim & Sim & Sim \\
\hline Grécia & Sim & Sim & Não & Sim & Sim \\
\hline Irlanda & Sim & Sim & Sim & Sim & Sim \\
\hline Itália & Não & Não & Não & Sim & Sim \\
\hline Luxemburgo & Sim & Sim & Sim & Sim & Não \\
\hline Holanda & Sim & Sim & Sim & Sim & Sim \\
\hline Portugal & Sim & Sim & $\operatorname{Sim}$ & Sim & Sim \\
\hline Espanha & Sim & Sim & Não & Sim & Sim \\
\hline Suíça & Não & Não & Sim & Sim & Sim \\
\hline Reino Unido & Sim & Sim & Sim & Sim & Sim \\
\hline
\end{tabular}

Com algumas pequenas exceções, os honorários advocatícios são sempre admitidos na indenização. As custas judiciais apresentam unanimidade quanto à sua inclusão nessas mesmas verbas.

Os danos imateriais, entretanto, são recuperáveis na maioria dos ordenamentos dos países citados, mas não em todos, o mesmo ocorrendo com os danos futuros (que não possam ser calculados no momento presente) e o perda no valor de ações.

No Brasil, não há qualquer dúvida quanto ao cabimento de valores imateriais, morais e mesmo lucros cessantes (futuros) nas verbas indenizatórias devidas pelo auditor. O grande problema é saber se é cabível, também perante o ordenamento nacional, a indenização pela perda no preço de mercado de ações (ou até mesmo no valor de outros valores mobiliários).

Alguns dos maiores problemas ao reconhecimento da indenizabilidade referente à perda de valor de ações consistem em que: 1) os valores de mercado das ações são variáveis, compostos por expectativas nem sempre racionais (portanto, nem sempre atribuíveis em sua totalidade à conduta do auditor) e fazem parte do risco assumido pelo investidor; 2) muitas vezes, não há como conhecer quais foram os danos efetivos do investidor, uma vez que este, ao não vender o valor mobiliário, ainda não realizou a perda respectiva. Caso tenha vendido, porém, ainda resta a questão de se saber se a alienação não 
foi decorrente da precipitação do investidor, principalmente quando tenha havido posterior valorização.

As objeções levantadas efetivamente dificultam a apreciação da indenização, no entanto, dizem respeito apenas à quantificação do prejuízo, e não à sua existência propriamente dita. Entendemos, portanto, que nada obsta que o juiz, no caso concreto, verificando uma perda perene e duradoura no preço de mercado da ação, derivada da conduta do auditor, determine a indenização com base em patamar estabelecido por estudos de mercado que delimitem uma faixa de valor dentro do que se esperaria razoavelmente ocorrer com o preço de mercado da ação aludida.

Aplicando-se por analogia a lição de Modesto Carvalhosa a respeito da responsabilidade dos administradores das sociedades anônimas, deve-se entender que não obsta a ação de responsabilidade o mero fato de o prejuízo não ser quantificável ou ser meramente simbólico:

Deve, portanto, ser acolhido o pedido de processamento de ação de responsabilidade, nos casos acima, e reconhecida a legitimidade ativa da companhia e de seus acionistas, em hipótese em que o dano material é meramente simbólico ou não quantificável. Nesses casos, o autor deve dar à ação um valor igualmente simbólico, para o efeito de caracterizar o aspecto não propriamente material da lesão ou ofensa aos direitos atingidos. $^{460}$

Reforça ainda a possibilidade de indenização referente à perda de valor de mercado de ações, a recente evolução jurisprudencial que admite ser indenizável a perda de uma chance, oportunidade ou expectativa. Aplicando-se este entendimento ao tema em estudo, deve-se entender viável ao magistrado fixar indenização com base no montante de valorização da ação que seria objetivamente razoável esperar que ocorresse, caso inexistisse a ação ou omissão danosa do auditor. ${ }^{461}$

\footnotetext{
${ }^{460}$ Comentários. cit., p. 341.

${ }^{461}$ Embora não seja referente ao trabalho de auditoria externa, é ilustrativo da hipótese o seguinte acórdão do STJ, que aplicou a teoria da perda de uma chance em questão referente à responsabilidade civil do advogado, verbis: "Processo REsp 1079185 / MG. RECURSO ESPECIAL 2008/0168439-5. Relator(a): Ministra NANCY ANDRIGHI (1118). Órgão Julgador: T3 - TERCEIRA TURMA. Data do Julgamento: 11/11/2008. Data da Publicação/Fonte: DJe 04/08/2009. Ementa: PROCESSUAL CIVIL E DIREITO CIVIL. RESPONSABILIDADE DE ADVOGADO PELA PERDA DO PRAZO DE APELAÇÃO. TEORIA DA PERDA DA CHANCE. APLICAÇÃO. RECURSO ESPECIAL. ADMISSIBILIDADE. DEFICIÊNCIA NA FUNDAMENTAÇÃO. NECESSIDADE DE REVISÃO DO CONTEXTO FÁTICO-PROBATÓRIO. SÚMULA 7, STJ. APLICAÇÃO. - A responsabilidade do advogado na condução da defesa processual de seu cliente é de ordem contratual. Embora não responda pelo resultado, o advogado é obrigado a aplicar toda a
} 
Concluímos, portanto, que o preço de mercado de ações, embora sejam encontradas dificuldades na quantificação da indenização, pode ser incluído nas verbas indenizatórias devidas pelo auditor independente.

\subsection{Limitações de responsabilidade e defesas do auditor}

As matérias de limitação de responsabilidade e defesa do auditor em ação de indenização podem ser de vários tipos. Para o efeito do presente estudo, verificaremos: 1) alegação de conduta devida (não culposa ou dolosa); 2) a influência da culpa da vítima ou de terceiros como fator de exclusão ou diminuição da indenização devida; 3) as limitações contratuais e legais de responsabilidade; e 4) a matéria prescricional.

\subsubsection{Cuidado devido}

A defesa do auditor baseada no zelo de sua conduta é sempre admitida nos sistemas que fundam a responsabilidade deste profissional na culpa, como ocorre, a nosso ver, no ordenamento jurídico nacional.

Explicando este tipo de defesa no ordenamento norte-americano, Boyton et al., ressaltam:

sua diligência habitual no exercício do mandato. - Ao perder, de forma negligente, o prazo para a interposição de apelação, recurso cabível na hipótese e desejado pelo mandante, o advogado frustra as chances de êxito de seu cliente. Responde, portanto, pela perda da probabilidade de sucesso no recurso, desde que tal chance seja séria e real. Não se trata, portanto, de reparar a perda de 'uma simples esperança subjetiva', nem tampouco de conferir ao lesado a integralidade do que esperava ter caso obtivesse êxito ao usufruir plenamente de sua chance. - A perda da chance se aplica tanto aos danos materiais quanto aos danos morais. - A hipótese revela, no entanto, que os danos materiais ora pleiteados já tinham sido objeto de ações autônomas e que o dano moral não pode ser majorado por deficiência na fundamentação do recurso especial. - A pretensão de simples reexame de prova não enseja recurso especial. Aplicação da Súmula 7, STJ. - Não se conhece do Especial quando a decisão recorrida assenta em mais de um fundamento suficiente e o recurso não abrange todos eles. Súmula 283, STF. Recurso Especial não conhecido”. 
Ao utilizar a defesa de cuidado devido em uma ação relacionada com um contrato de auditoria, o auditor tenta mostrar que a auditoria foi realizada de acordo com as normas de auditoria geralmente aceitas (NAGA). Seus papéis de trabalho desempenham papel crucial nessa defesa. Além disso, o auditor espera convencer o tribunal de que o processo de auditoria contém limitações que lhe são inerentes. A auditoria envolve testes seletivos, por exemplo, o que implica risco de que eventuais erros ou irregularidades materiais possam não ser detectados. $^{462}$

Perante a União Europeia, estudo demonstra que a totalidade dos países que a compõem admite a defesa baseada no cuidado devido ou ausência de culpa:

A culpa é um dos elementos da causa da ação contra o auditor. Como resultado, o auditor pode se defender mostrando a ausência de culpa, que geralmente requer que demonstre que agiu em conformidade com normas de auditoria ou alguma forma de teste de conformidade com seu dever de cuidados. Estas questões têm sido objeto de decisões do Tribunal na Dinamarca e França: tribunais dinamarqueses têm estipulado em favor de auditores externos independentes em pelo menos duas ocasiões com base na ausência de falhas; na França, isto aparece em numerosas decisões de tribunais segundo as quais a culpa do auditor externo independente é necessária, podendo ser deduzida a partir de indícios. A ausência de tais falhas pode ser deduzida de uma comparação entre o padrão do "normalmente prudente e diligente auditor" e seu comportamento real. ${ }^{463}$

Para a alegação de que a auditoria foi feita com a cautela exigida e obedeceu às normas profissionais, é necessário, entretanto, que o auditor desenvolva todo um trabalho preventivo de minimização de exposição à responsabilidade. Rittenberg et al. recomendam que isto inclua: 1) supervisão contínua de condições de independência (rotação, proibição

\footnotetext{
${ }^{462}$ Op. cit. p. 142.

${ }^{463}$ EUROPEAN COMISSION. A study on systems of civil liability of statutory auditors in the context of a single Market for auditing services in the European Union. Disponível em <http://ec.europa.eu/internal_market/auditing/liability/index_en.htm\#study>. Acesso em 27 dez. 2009. O texto é tradução livre de: "Fault is one of the elements of the cause of action against the auditor. As a result, the auditor may defend by showing the absence of fault, which usually requires showing that he acted in accordance with auditing standards or meeting some form of objective test of compliance with his duty of care. These issues have been the subject of Court decisions in Denmark and France: Danish Courts have ruled in favour statutory auditors on at least two occasions based on an absence of fault; in France, it appears from numerous Court decisions that the statutory auditor's fault is required to be inferred from circumstantial evidence. The absence of such fault may be deducted from a comparison between the standard of the "normally prudent and diligent auditor" and his actual behavior".
} 
de outros serviços, etc.); 2) programas de controle de qualidade; 3) programas de revisão pelos pares; 4) perenes e contínuos programas de educação continuada; 5) inclusão em contrato de circunstâncias que esclareçam os limites de responsabilidade do auditor; 6) exame minucioso dos riscos dos clientes; 7) manutenção completa de documentação de auditoria. $^{464}$

\subsubsection{Culpa da vítima e fato de terceiro}

As defesas referentes à culpa da vítima e à existência de fato de terceiro têm por consequência, se acolhidas em sua integralidade, a exclusão do nexo causal entre a conduta do auditor e o dano experimentado pelo prejudicado.

Se exclusiva, a culpa da vítima exclui a relação de causalidade; se concorrente, mantém vivo este nexo, atenuando, porém, o rigor da responsabilidade.

O mesmo ocorre, em regra, com o fato de terceiro: se causar por si só o dano, equiparando-se ao que ocorre com o caso fortuito ou força maior, exclui o liame causal; caso concorra para o desfecho danoso, permitirá a responsabilização dos participantes do evento conforme o grau de culpa.

Diz Silvio Rodrigues:

Com efeito, no caso de culpa exclusiva da vítima, o agente que causa diretamente o dano é apenas um instrumento do acidente, não se podendo, realmente, falar em liame de causalidade entre seu ato e o prejuízo por aquela experimentado (...). Casos há, entretanto, em que existe culpa da vítima, paralelamente à culpa concorrente do agente causador do dano. Nessas hipóteses o evento danoso decorreu tanto do comportamento culposo daquela quanto do comportamento culposo deste. Por conseguinte, se houver algo a indenizar, a indenização será repartida entre os dois responsáveis, na proporção que for justa.

\section{(...)}

Portanto, concluindo quanto a essa parte, poder-se-ia dizer que o fato de terceiro, para excluir integralmente a responsabilidade do agente causador direto do dano, há que se vestir de características semelhantes às do caso

${ }^{464}$ Op. cit., p. 843-6. 
fortuito, sendo imprevisível e irresistível. Nessa hipótese, não havendo relação de causalidade, não há responsabilidade pela reparação. Os escritores apontam a possibilidade de o fato de terceiro ser causa parcial do evento danoso, para o qual, entretanto, o agente direto do dano concorre com uma parcela de culpa. Aliás, Aguiar Dias aventa mesmo a hipótese de o desastre resultar da conjunção de três atividades, a saber, a da vítima, a do indigitado, responsável e a de terceiro. Em casos como este, a responsabilidade se subdivide de acordo com o grau de culpa, que é o grau de causalidade de cada qual. ${ }^{465}$

No que toca à possibilidade de alegação de culpa exclusiva ou concorrente da vítima em relação à responsabilidade do auditor, na forma que vimos anteriormente, este argumento é sempre possível, uma vez que se trata de danos cuja ocorrência pode ser influenciada tanto pelo comportamento do auditor quanto da vítima.

Perante a União Europeia, a defesa do auditor baseada na culpa da vítima é plenamente aceita, havendo decisões a respeito. Estudo específico ressalta:

Em todos os Estados-Membros, com exceção da Áustria, o auditor externo independente pode alegar a culpa do queixoso como defesa. $\mathrm{Na}$ Áustria, tal defesa só é possível contra o queixoso que seja um terceiro, e não a empresa auditada. Esta regra está bem desenvolvida na França e é objeto de inúmeras decisões de tribunais, já que é um princípio estabelecido de responsabilidade civil que a negligência da vítima alivia o recorrido de responsabilidade. Esta franquia pode ser total ou parcial. Na Finlândia, um tribunal decidiu a favor de um auditor externo independente com base na negligência do autor, o que não removeu a negligência do auditor em relação ao relatório de auditoria falso, mas quebrou o nexo de causalidade entre a negligência do auditor e o dano sofrido pelo terceiro. Finalmente, na Irlanda e Reino Unido, atos errôneos ou omissões da parte dos agentes ou empregados do queixoso poderiam justificar uma redução de qualquer concessão de indenização com base em negligência contributiva da parte do queixoso, seus agentes ou empregados. Por exemplo, no Reino Unido, se a negligência do auditor e

${ }^{465}$ RODRIGUES, Silvio. Direito Civil - Responsabilidade civil. São Paulo: Saraiva, 2002, 4.v. p. 166 e 173. 
do queixoso contribuir para o dano, responsabilidade é repartida entre eles. $^{466}$

Perante o ordenamento nacional, a solução não há de ser diferente.

De fato, ao auditor independente deve ser permitido alegar, com sucesso, as falhas contributivas da vítima para seu próprio prejuízo. Exemplos seriam a utilização de fontes diversas e inidôneas por parte da vítima para basear um investimento, ou o prévio conhecimento, por outros meios, da irregularidade omitida pelo auditor nas demonstrações contábeis.

Já o fato de terceiro deve possuir maiores restrições quanto à sua admissibilidade em tema de auditoria. Embora seja uma alegação defensiva possível e viável de ocorrer na prática (p.ex., quando o auditor, processado por terceiro, alega a impossibilidade de evidenciar um passivo por não ter sido informado pela entidade auditada), esta linha de defesa somente deve ter sucesso quando não houver um dever do auditor de considerar, investigar ou descobrir os fatos por si só, independente da atuação ou omissão do terceiro, ou se restar provado que era impossível ao auditor descobrir ou desvendar um fato de responsabilidade do terceiro sem a iniciativa deste.

Bem ressalta o estudo antes citado, no âmbito da União Europeia:

A culpa de terceiros pode ser considerada na determinação se houve uma falha própria do auditor externo independente: como um princípio comum, o auditor externo independente não deve negligentemente confiar nas informações que pode receber de terceiros, por exemplo, auditores de subsidiárias, peritos contadores, etc. ${ }^{467}$

\footnotetext{
${ }^{466}$ EUROPEAN COMISSION. A study on systems of civil liability of statutory auditors in the context of a single Market for auditing services in the European Union. Disponível em <http://ec.europa.eu/internal_market/auditing/liability/index_en.htm\#study>. Acesso em 27 dez. 2009. O texto é tradução livre de: "In all the Member States, except Austria, the statutory auditor may raise the plaintiff's own fault as a defence. In Austria, such a defence is only possible against the plaintiff who is a third party and not the audited company. This rule is well developed in France and the subject of numerous Court decisions, as it is an established principle of civil liability that the victim's negligence relieves the defendant of liability. This relief can be total or partial. In Finland, a Court ruled in favour of a statutory auditor, based on the negligence of the plaintiff, which did not remove the negligence of the auditor with regard to the false auditing report, but broke the causal link between the negligence of the auditor and the damage suffered by the third party. Finally, in Ireland and the United Kingdom, wrongful acts or omissions on the part of the officers or employees of the plaintiff could justify a reduction in any award of damages on the basis of contributory negligence on the part of the plaintiff or its officers or employees. For example, in the United Kingdom, if the negligence of the auditor and the plaintiff both contribute to the damage, liability is apportioned between them".

${ }^{467}$ EUROPEAN COMISSION. A study on systems of civil liability of statutory auditors in the context of a single Market for auditing services in the European Union. Disponível em <http://ec.europa.eu/internal_market/auditing/liability/index_en.htm\#study>. Acesso em 27 dez. 2009. O
} 
Obviamente, não será admissível a alegação de fato de terceiro quando o auditor aduzir que obedeceu a ordem ilegal de quem o contratava, mesmo que sob pena de perder seus honorários contratuais, até mesmo porque o auditor tem o dever de se opor a atos ilegais do seu cliente.

\subsubsection{Limitação contratual de responsabilidade}

Outra questão importante diz respeito à possibilidade de as partes fixarem limitações de responsabilidade contratualmente. Essas limitações podem ser: 1) fixação de menores prazos prescricionais; 2) criação de valores máximos (tetos) de responsabilidade civil; 3) exclusão total ou parcial de responsabilidade civil decorrente de algumas obrigações específicas.

Em nosso ordenamento, a limitação contratual de responsabilidade não pode atingir o terceiro usuário da informação contábil auditada. Primeiramente, porque não é parte na avença entre auditor e entidade auditada. Ao depois, em virtude de que, em se tratando de relação de consumo (entre terceiro e auditor/entidade auditada), a limitação de responsabilidade é expressamente vedada (CDC, art. 51, I).

Cabe, portanto, indagar se as limitações supracitadas poderiam ser inseridas no contrato entre auditor e entidade auditada.

Perante a União Europeia, admitem a redução do prazo prescricional Dinamarca, Holanda e Espanha. A fixação de tetos de responsabilidade é admitida na Dinamarca, Luxemburgo, Holanda e Espanha. Já a supressão de responsabilidade por determinadas obrigações somente o é na Dinamarca e Holanda. Nos demais países, tais hipóteses são vedadas. ${ }^{468}$

No Brasil, a prescrição não pode ser alterada por acordo entre as partes $(\mathrm{CC}$, art. 192).

texto é tradução livre de: "The fault of a third party may be considered in determining whether there was a fault of the statutory auditor himself: as a common principle, the statutory auditor should not negligently rely on information he may receive from third parties, e.g. subsidiaries' auditors, chartered accountants, etc.". ${ }^{468}$ EUROPEAN COMISSION. A study on systems of civil liability of statutory auditors in the context of a single Market for auditing services in the European Union. Disponível em <http://ec.europa.eu/internal_market/auditing/liability/index_en.htm\#study>. Acesso em 27 dez. 2009. 
Também entendemos que a cláusula limitativa de responsabilidade, de qualquer gênero, não tem validade em contratos de prestação de serviços de auditoria externa.

Neste sentido, o argumento de Daniela Casadei parece irrebatível:

Poder-se-ia objetar que as finalidades da lei seriam ressalvadas se, reconhecendo a validez do pacto entre as partes, a inoponibilidade fosse mantida em relação ao terceiro. Mas, seguindo este ponto de vista, o objetivo da norma seria frustrado igualmente, porque a proteção pública tem como pressuposto principal que a atividade de auditoria seja realizada com o máximo de severidade e responsabilização do auditor, pelo que toda a perspectiva de limitação resulta improponível. Em segundo lugar, a inderrogabilidade ex lege decorre da incompatibilidade do pacto de limitação de responsabilidade com o conteúdo do contrato de auditoria: é, de fato, contrário à obrigação principal do auditor (de garantir um controle preciso da gerência da sociedade revisionada objetivando reconstruir e difundir a informação sobre a realidade societária) a eventual exoneração de responsabilidade por haver seguido um controle "menos preciso" do que aquele exigido na lei. ${ }^{469}$

$\mathrm{O}$ argumento da autora chama a atenção para um aspecto importante, segundo o qual a limitação ou exoneração da responsabilidade do auditor, mesmo que limitada ao contrato com a entidade auditada, pode estimular este profissional a empregar diligência menor que a exigida, uma vez que não temeria ser responsabilizado por eventual negligência. Isto viria claramente em prejuízo dos terceiros que tomam suas decisões em confiança no parecer de auditoria.

Desta forma, havendo questões de ordem pública a serem protegidas, não se deve admitir qualquer exoneração de responsabilidade do auditor, ainda que limitadas ao contrato estabelecido entre este e a entidade auditada.

\footnotetext{
${ }^{469}$ Op. cit. p. 120-1. O texto é tradução livre de: "Potrebbe obiettarsi che le finalità della legge sarebbero fatte salve se, pur riconoscendo la validità dei patto tra le parti, se ne mantenesse ferma l'inopponibilità ai terzi. Ma, seguendo questo punto di vista, lo scopo della normativa verrebbe ugualmente frustrato perche la tutela pubblica ha come primo presupposto un'attività di revisione svolta con il massimo della severità $\mathrm{e}$ responsabilizzazione dei revisore, per cui qualunque prospettiva di limitazione risulta improponibile. In secondo luogo, l'inderogabilità ex lege si ricava dall'incompatibilità dei patto di limitazione di responsabilità con il contenuto dei contralto di revisione: è infatti contrario all'obbligo principale dei revisore (di garantire un controllo accurato della gestione della società revisionata finalizzato a ricostruire e diffondere informazioni sulla realtà sociale) l'eventuale esonero da responsabilità per aver eseguito un controllo « meno accurato » di quello richiesto dalla legge".
} 


\subsubsection{Limitação legal de responsabilidade}

No Brasil, não há limitações legais de valores inerentes às responsabilidades dos auditores externos independentes. Ao contrário, a ideia de limitar legalmente a responsabilidade profissional não é bem-aceita entre nós, uma vez que faz surgir o pensamento segundo o qual as vítimas de um determinado evento danoso, mesmo que causado por culpa de outrem, poderiam ficar desprotegidas juridicamente.

No entanto, a questão foi objeto de recente estudo perante a União Europeia, no qual concluiu-se que:

Os riscos de responsabilidade são significativos para as sociedades de revisores oficiais de contas e que, hoje em dia, não existe capacidade seguradora disponível para lhes fazer face. A avaliação de impacto conclui que, à luz da atual estrutura do mercado da auditoria, estes riscos de responsabilidade, aliados a uma insuficiente cobertura de seguro, podem dissuadir os revisores oficiais de contas de prestar serviços de auditoria a empresas cotadas. Os serviços da Comissão concluem que se os entraves estruturais (riscos de responsabilidade/falta de seguros) não forem ultrapassados, será pouco provável que as sociedades de revisores oficiais de contas de dimensão média possam constituir uma alternativa importante às quatro grandes redes de auditoria (big four) nos mercados europeus de capitais. ${ }^{470}$

O estudo traz uma série de opções a serem adotadas para a resolução do problema, conforme a tabela seguinte:

\footnotetext{
${ }^{470}$ EUROPEAN COMISSION. Recomendação da comissão relativa à limitação da responsabilidade civil dos revisores oficiais de contas e das sociedades de revisores oficiais de contas. Disponível em <http://ec.europa.eu/internal_market/auditing/docs/liability/summary_pt.pdf>. Acesso em 27 dez. 2009.
} 
Tabela 29: Opções de limitação de risco aos auditores no âmbito da União Europeia

\begin{tabular}{|c|c|}
\hline Opções & Definição \\
\hline Opção 1 & Inação no nível da UE. \\
\hline Opção 2 & $\begin{array}{l}\text { Exigir que os investidores ou as empresas paguem por segurar } \\
\text { os riscos de responsabilidade dos revisores de contas. } \\
\text { Contudo, a volatilidade dos riscos de responsabilidade } \\
\text { dificultaria a aplicação desta opção. Os investidores ou as } \\
\text { empresas teriam de pagar custos de seguro muito elevados. } \\
\text { Além disso, esta opção também implicaria riscos morais na } \\
\text { profissão, na medida em que os revisores de contas não teriam } \\
\text { de pagar os riscos de responsabilidade. }\end{array}$ \\
\hline Opção 3 & $\begin{array}{l}\text { Limitar a exposição dos revisores de contas aos riscos, } \\
\text { excluindo certas tarefas arriscadas da atividade de auditoria ao } \\
\text { abrigo de normas internacionais ("zona de segurança"). Esta } \\
\text { opção implica as mesmas dificuldades que a opção 2, na } \\
\text { medida em que os revisores de contas se esforçariam por } \\
\text { desempenhar as suas tarefas nos limites dessa "zona de } \\
\text { segurança". }\end{array}$ \\
\hline Opção 4a & $\begin{array}{l}\text { Harmonizar os regimes de responsabilidade com base num } \\
\text { limite máximo fixado no nível dos Estados-Membros. O } \\
\text { instrumento mais eficaz para o efeito seria uma diretiva. }\end{array}$ \\
\hline Opção 4b & $\begin{array}{l}\text { Harmonizar os regimes de responsabilidade com base na } \\
\text { responsabilidade proporcional. Neste regime, as sociedades de } \\
\text { revisores oficiais de contas só seriam responsáveis em função } \\
\text { da sua contribuição para os danos provocados. O instrumento } \\
\text { mais eficaz para o efeito seria também uma diretiva. }\end{array}$ \\
\hline Opção 4c & $\begin{array}{l}\text { Fixar o objetivo de uma limitação da responsabilidade, sem } \\
\text { definir o método para alcançá-la. Incumbiria aos Estados- } \\
\text { Membros definir as modalidades de aplicação, permitindo } \\
\text { assim uma convergência progressiva. Tanto uma diretiva } \\
\text { como uma recomendação poderiam ser adequadas para esta } \\
\text { opção. }\end{array}$ \\
\hline
\end{tabular}

Fonte: EUROPEAN COMISSION. Recomendação da comissão relativa à limitação da responsabilidade civil dos revisores oficiais de contas e das sociedades de revisores oficiais de contas

As conclusões do estudo, embora não definitivas, denotam certa preferência pelas opções 4a, 4b e 4c, e dentre elas, pela última.

A importância do estudo, como já dissemos neste trabalho, é adotar alguma limitação de risco ao auditor, de forma que possa haver maior concorrência de mercado pela presença de um maior número de auditores de pequeno porte econômico. 


\subsubsection{Prescrição}

Outra matéria de defesa a ser alegada pelo auditor independente é a prescrição da pretensão do demandante à indenização civil.

Os maiores problemas envolvendo a matéria prescricional dizem respeito à diversidade das legislações internacionais no que toca aos prazos de prescrição e quando estes iniciam sua contagem. ${ }^{471}$

Perante o ordenamento nacional, o prazo da responsabilidade civil (contratual ou extracontratual) de dá, em regra, em três anos (CC, art. 206, § $\left.3^{\circ}, \mathrm{V}\right)$, iniciando-se a partir do momento da violação do direito (CC, art. 189).

No entanto, por entendermos que a relação entre o terceiro e o auditor é abrangida pelo Código de Defesa do Consumidor, inferimos que a prescrição se dá, nestes casos, nos termos do art. 27 do CDC, que estipula que referido prazo se dá em cinco anos, iniciando-se a contagem do prazo a partir do conhecimento do dano e de sua autoria.

\footnotetext{
${ }^{471}$ Perante a União Europeia, são diversos os prazos das legislações dos Estados-Membros, distinguindo-se também em função da natureza contratual ou extracontratual da responsabilidade do auditor (EUROPEAN COMISSION. Recomendação da comissão relativa à limitação da responsabilidade civil dos revisores oficiais de contas e das sociedades de revisores oficiais de contas. Disponível em <http://ec.europa.eu/internal_market/auditing/docs/liability/summary_pt.pdf〉. Acesso em 272009).
} 


\section{CONCLUSÕES}

A atividade empresarial, ao contrário do que ocorre na intervenção estatal na economia, está sujeita a eventualidades diversas, em grande parte imprevisíveis ao longo do tempo, submetendo-se a riscos de insucesso em seu resultado.

Para que a atividade privada cumpra seu papel no desenvolvimento da economia, é necessário que haja disponibilidade de fontes de financiamento, que podem ser obtidas das mais diversas formas junto ao mercado.

Diante disto, faz-se necessária a disponibilização ao investidor, por parte dos titulares de um empreendimento privado que se financia através de recursos externos, de uma série de informações econômicas, consubstanciadas nas demonstrações contábeis.

Entretanto, por serem referidas demonstrações verdadeiras declarações unilaterais de vontade, nada impede, em princípio, que sejam alteradas (ainda que dentro dos "limites" legalmente permitidos, por meio dos chamados "procedimentos criativos de contabilidade"), ou mesmo falsificadas, por seus emissores.

Diante de tal quadro, surge a necessidade básica da auditoria externa, realizada por profissional individual ou sociedade independente.

Ao contrário da atividade contábil propriamente dita, da qual os serviços de auditoria são derivados, em relação a estes não há maiores dados ou informações precisas quanto ao seu início histórico ou mesmo sobre seus precursores. Vários autores identificam os primórdios da atividade de auditoria na ação de órgãos estatais que, visando à arrecadação de tributos, faziam verificações nos papéis e registros contábeis dos cidadãos. $\mathrm{Na}$ forma como é conhecida hoje, porém, a atividade de auditoria ter-se-ia iniciado no período de expansão ultramarina (séculos XV e XVI) e durante a Revolução Industrial na Inglaterra.

A auditoria externa tem como funções primordiais a redução das assimetrias de informação, de custos de transação e dos custos derivados do conflito de agência.

A atividade de auditoria, entretanto, passou por severa crise nos últimos tempos, na maior parte derivada de escândalos contábeis nos quais auditores foram coniventes com irregularidades presentes nas demonstrações financeiras. 
Vários casos abalaram a credibilidade da auditoria independente junto ao público, tanto os ocorridos no exterior (p. ex., Enron, WorldCom, Parmalat, etc.) como no Brasil (p. ex., Banco Nacional, Banco Econômico, Panair, Banco Noroeste, etc.).

Entendemos que o contrato envolvendo auditor e entidade auditada tem natureza jurídica de prestação de serviço sui generis, por não se adaptar às figuras do mandato, empreitada, obra intelectual, nem mesmo a um contrato atípico e inominado.

O contrato de auditoria também não se adapta à figura da estipulação em favor de terceiro, dado que este último não detém prerrogativas ou deveres na relação estabelecida entre auditor e entidade auditada.

Da mesma forma, a natureza do pacto estabelecido entre auditor e entidade auditada continua a ser contratual, mesmo nos casos de auditoria externa obrigatória, uma vez que a determinação legal de contratação, com vistas ao interesse público, não supre a vontade das partes. Consequência imediata disto é o fato de que a responsabilidade derivada do descumprimento desta avença também deve ser conceituada como contratual.

Nos contratos de auditoria, vige liberdade limitada de contratar e de estabelecer o conteúdo de contrato. No entanto, não se pode conceituar esta avença como contrato de adesão; faltam-lhe requisitos essenciais para tanto, como a existência de cláusulas padronizadas, a prática da contratação de massa e a generalidade dos contratos para várias relações.

Não conceituamos a relação estabelecida entre auditor e entidade auditada como sendo regida pela legislação consumerista, porque lhe faltam características de vulnerabilidade ou hipossuficiência, além da utilização do serviço pelo destinatário como usuário final. Entretanto, a relação estabelecida entre auditor e terceiro deve sofrer a incidência dos preceitos protetivos do CDC, uma vez que o terceiro se enquadra no conceito de consumidor por equiparação.

A regulação concernente ao contrato de auditoria externa deve ocorrer ex ante; basear-se no princípio da prevenção, e não no da dissuasão pela aplicação de sanções; deve ser permanentemente revisada, principalmente quando editada em momentos de crise econômica; não deve ignorar os custos regulatórios; deve ser proveniente de único órgão ou precedida de mecanismos de alinhamento e unidade de atuação dos órgãos reguladores, ou incidir sobre campos específicos e claramente delimitados. 
Entendemos que a obrigação do auditor independente é de resultado, e não de meio. Isto, porque o resultado buscado por este profissional não é a certeza da inexistência de erros ou omissões nas demonstrações contábeis, mas a segurança razoável de que não existem distorções materialmente relevantes nestas. Este resultado pode ser atingido com razoável grau de empenho por parte do auditor, situando-se, portanto, dentro de suas possibilidades. A conceituação traz importante consequência no tocante ao ônus da prova da culpa.

O auditor está obrigado a manter confidencialidade ou sigilo em face de terceiros. Esta obrigação é forma oblíqua de proteger o sigilo dos dados contábeis e, portanto, estende-se ao acionista, nos termos do art. 105 da Lei n. 6.404/76. A obrigação de sigilo não se estende aos órgãos de fiscalização de profissão e às autoridades reguladoras do mercado de capitais, financeiro e de seguros.

O auditor não pode ser compelido pelo fisco a fornecer dados que comprometam seus clientes, salvo nas hipóteses legais em que também estará obrigado a denunciar os fatos às autoridades regulatórias do mercado de capitais, financeiro e de seguros privados. Por outro lado, deve-se admitir que o auditor seja obrigado a romper o sigilo a que está obrigado diante de ordem judicial, ainda que não seja parte na causa.

Um dos requisitos essenciais do contrato de auditoria é a obrigação de independência do auditor. Trata-se de uma questão que envolve a própria legitimação para contratar e a possibilidade de continuar prestando o serviço.

No Brasil, há duplo registro do auditor independente: junto ao CFC, para o exercício profissional, e perante à CVM, para o exercício profissional em mercado de capitais, financeiro e de seguros privados. O registro não tem natureza de proposta contratual, mas de mero requisito para o exercício profissional do auditor.

Além dos registros, conta-se com a obrigação de qualificação técnica do auditor, educação continuada e controle de qualidade.

Em princípio, a natureza da atividade do auditor não é empresária. No entanto, é de se assim admitir quando, conforme o entendimento do que seja elemento de empresa, a atividade de auditoria for prestada em caráter organizado, ou como parte de um todo maior.

Para a obtenção de registro na CVM, somente se admite a inscrição de sociedades de auditoria na forma de sociedades simples (antiga sociedade civil) com sócios 
contadores ou auditores, o que não ocorre com as sociedades de auditoria com mero registro no $\mathrm{CFC}$, às quais são permitidos outros tipos societários e sócios não contadores. A tendência mundial, entretanto, parece caminhar no sentido de se admitir limitações de responsabilidade pela adoção de tipos societários que as permitam, bem como sócios não auditores que possibilitem maiores condições de financiamento da sociedade.

Além das companhias abertas, por efeito da Lei n. 11.638/07, tornou-se obrigatória a auditoria em sociedades de grande porte, qualquer que seja o tipo societário. Vários problemas ainda existem, entretanto. Dentre eles analisamos os critérios divergentes utilizados para contabilização e os problemas de padronização derivados de critérios distintos.

Entendemos que no atual estágio da regulação nacional, o contrato de prestação de serviços de auditoria está limitado temporalmente por cinco exercícios (sistema de rodízio de auditor) no caso de entidades auditadas que se constituam como instituições financeiras, seguradoras, companhias abertas ou suas assemelhadas, nas quais incidam as normas regulatórias específicas da CVM, BACEN ou CNSP. Para os demais casos de auditoria, caberá apenas o rodízio da equipe de auditores, não havendo limitação de contrato por prazo indeterminado.

O contrato de auditoria deve ser formalizado por escrito, devendo o auditor manter guardados pelo prazo legal os documentos e papéis de trabalho concernentes à execução dos serviços de auditoria.

Há uma tendência mundial, seguida no Brasil, de não admitir a resilição unilateral desmotivada do contrato de auditoria por parte da entidade auditada, dado que isto poderia ser uma forma de punição indireta ao auditor que contrariasse o interesse de seu contratante.

A auditoria externa é atividade inerentemente limitada. Tempo, custo razoável, estimativas contábeis e outros fatores limitam a precisão do trabalho do auditor.

No entanto, as expectativas sobre a tarefa de auditoria existem, sendo algumas relevantes e outras desarrazoadas. As expectativas sociais de detecção de fraudes cresceram inegavelmente nos últimos anos após os comentados escândalos contábeis. Há também expectativas sociais de garantia de solidez econômico-financeira, sobre as quais não há, em regra, responsabilidade do auditor, que somente deve se pronunciar sobre eventuais dúvidas em relação à continuidade operacional da entidade. 
É de extrema importância a determinação da relevância e materialidade pelo auditor. Isto demonstra claramente como o auditor enfrentará os riscos e pode ter reflexos na determinação de sua responsabilidade civil.

Na realização de testes de controle, revisão analítica e testes substantivos o auditor deve utilizar, de forma criteriosa, os procedimentos de amostragem, justificando-os e mantendo a guarda da documentação respectiva.

A auditoria externa tem por objeto principal as demonstrações contábeis e a escrituração que as fundamenta, as quais se conceituam juridicamente como negócios jurídicos unilaterais, e não como mera declaração de ciência.

As principais demonstrações a serem analisadas pelo auditor são o Balanço Patrimonial (BP), a Demonstração do Resultado do Exercício (DRE), a Demonstração do Fluxo de Caixa (DFC), a Demonstração de Lucros e Prejuízos Acumulados (DLPA), a Demonstração de Mutações no Patrimônio Líquido (DMPL) e a Demonstração de Valor Adicionado (DVA).

A auditoria externa está intimamente ligada aos processos de governança corporativa.

Em vários países, a contratação de auditoria externa está a cargo da assembleia. No Brasil, entretanto, a escolha e destituição dos auditores independentes cabe ao Conselho de Administração, e não diretamente à assembleia (art. 142, IX, da Lei n. 6.404/76). Não obstante, preconizam-se doutrinariamente dois casos de participação da assembleia de acionistas em relação aos serviços de auditoria externa: 1) quando da recontratação dos auditores; 2) na ocorrência de destituição motivada do auditor de suas funções.

Ao Conselho de Administração cabe uma postura proativa em relação à auditoria externa. Cumpre a este órgão escolher e supervisionar o auditor, garantindo suas condições de independência, proibindo a realização de outros serviços que não sejam de auditoria, entre outras providências. Onde não haja Conselho, os auditores devem se reportar diretamente aos acionistas.

Cabe ao auditor independente fiscalizar o trabalho da diretoria, devendo-se entender que há a necessidade de autorização assemblear ou do Conselho de Administração para que os diretores possam processar judicialmente o auditor. 
As atribuições do auditor independente não se confundem com as do conselho fiscal. Devem os auditores prestar toda sorte de assessoramento aos conselheiros, inclusive através do comparecimento às reuniões do órgão.

O Comitê de Auditoria é uma preocupação da legislação internacional, constando da Lei Sarbanes-Oxley e da regulação da União Europeia. No Brasil, entretanto, este só é obrigatório para algumas instituições financeiras e certas sociedades de seguro, previdência privada e complementar. Sua instituição, porém, é recomendada como boa prática de governança corporativa pela CVM e pelo IBGC.

A responsabilidade civil do auditor independente é assunto pouco tratado na literatura nacional, não havendo disponíveis julgados a respeito.

A evolução do tema teve início com a apresentação dos primeiros casos nos Estados Unidos da América, firmando-se inicialmente a doutrina segundo a qual o auditor externo não seria responsável perante terceiros por negligência normal, mas apenas por negligência grave e por dolo.

Esta linha de pensamento ficou conhecida como Ultramares doctrine, em vista do nome de uma das partes envolvidas na questão. Embora a linha da Ultramares doctrine não tenha sido completamente abandonada, a jurisprudência norte-americana consagrou em outros casos que o auditor poderia ser responsabilizado perante terceiros se conhecesse quem faria uso de seu trabalho ou, até mesmo, se o usuário fosse meramente previsível.

Nos países de tradição romano-germânica, entretanto, prevaleceu a possibilidade de que o auditor fosse plenamente responsável em face de terceiros.

Há vantagens em que o sistema de responsabilidade do auditor seja separado do regime geral de responsabilidade civil. No Brasil, entendemos que, no que tange à responsabilidade extracontratual, há regime próprio de responsabilidade do auditor, que afasta a incidência de outras normas gerais no que não sejam compatíveis com o regime especial. Dada a incompletude deste regime especial, porém, deve-se admitir a incidência de normas gerais subsidiárias.

No que toca aos regimes de responsabilidade solidária ou proporcional, no Brasil, duas regras determinam a responsabilidade solidária do auditor: 1) o art. $4^{\circ}$, III, da Instrução CVM n. 308/99, quanto às sociedades ali registradas; 2) o art. 942, parágrafo único, do Código Civil. Porém, entendemos que tais regras não abrangem a responsabilidade contratual subsidiária dos sócios por dívidas não referentes à atividade 
profissional de auditoria, para as quais poderá ser determinada contratualmente a regra proporcional, nos termos do art. 1.023 do CC. É necessário ponderar, porém, que não existe a prevalência de um dos regimes sobre o outro. Ambos apresentam vantagens e desvantagens, e sua adoção dependerá da prudente opção política do legislador.

O auditor está sujeito à responsabilidade contratual e extracontratual, tendo como pressupostos a ação ou omissão culposa, o nexo de causalidade e o dano.

Após analisar as vantagens e desvantagens dos regimes de responsabilidade, concluímos que a responsabilidade em regime de culpa presumida apresenta vantagens sobre os demais no caso particular da auditoria externa. Concluímos ainda que este regime é o adotado na legislação brasileira.

O nexo de causalidade em relação à conduta do auditor apresenta sérios problemas diante dos casos de omissão culposa. Referida omissão, que, em regra, deve-se conceituar como mera condição para a atuação da causa principal, pode ser elevada à categoria de causa se a hipotética ação positiva ou comissiva do auditor, em lugar de sua omissão negligente no caso concreto, fosse capaz de aumentar a probabilidade de que o dano não ocorresse, o que, por sua vez, está ligado ao conceito de materialidade ou relevância de auditoria.

No dano indenizável, além das verbas consagradas pela doutrina e pela jurisprudência, são exigíveis os decréscimos nos preços de mercado de ações.

Uma vez que em nosso ordenamento está consagrada uma regra de responsabilidade subjetiva com presunção de culpa, será sempre admissível ao auditor alegar em sua defesa que operou com o cuidado devido, em respeito às normas de auditoria.

Poderá também alegar com sucesso a culpa (exclusiva ou concorrente) da vítima e o fato de terceiro, sendo este último admissível somente quando o auditor não tiver o dever de, por si, investigar e descobrir os fatos e circunstâncias derivados da conduta do terceiro.

Entendemos inadmissível a limitação contratual de responsabilidade do auditor, mesmo que restrita ao contrato entre as partes.

A regulação internacional sobre a matéria, entretanto, vem admitindo a adoção de limitações legais de responsabilidade, principalmente com o fim de proporcionar melhor limitação de risco e maiores condições de concorrência no setor. 


\section{REFERÊNCIAS BIBLIOGRÁFICAS}

ADAMEK, Marcelo Vieira Von. Responsabilidade civil dos administradores de S/A e ações correlatas. São Paulo: Saraiva, 2009.

AGUIAR, Túlio. Causalidade e direção do tempo: Hume e o debate contemporâneo. Belo Horizonte: Humanitas, 2008.

AKERLOF, George. “The Market for 'Lemons': Quality Uncertainty and the Market Mechanism Quarterly", Journal of Economics, 84: 488- 500. 1970.

ALMEIDA, Bruno José Machado de. “Auditoria e sociedade: o diálogo necessário". Revista Contabilidade \& Finanças - USP, São Paulo, n. 34, p. 80-96, janeiro/abril 2004.

ALMEIDA, Marcelo Cavalcanti de. Auditoria: um curso moderno e completo. São Paulo: Atlas, 2007.

ALVES, Alaôr Café. Lógica - Pensamento formal e argumentação - Elementos para o discurso jurídico. São Paulo: Edipro, 2000.

AMERICAN ACCOUNTING ASSOCIATION. "A statement on basic auditing concepts". Accounting Review, vol. 47, 1972.

AMERICAN INSTITUTE OF CERTIFIED PUBLIC ACCOUNTANTS. Audit Sampling AICPA Audit Guide. Nova York: AICPA, 1999.

ARAÚJO, Inaldo da Paixão Santos; ARRUDA, Daniel Gomes; BARRETO, Pedro Humberto Teixeira. Auditoria Contábil - Enfoque teórico, normativo e prático. São Paulo: Saraiva, 2008.

ARNOLDI, Paulo Roberto Colombo. Teoria Geral do Direito Comercial. São Paulo: Saraiva, 1998.

ASCARELLI, Tullio. Corso de Diritto Commerciale. Introduzione e teoria dell'impresa. Milão: Giuffrè, 1962.

Quorum, 2008

ASSAF NETO, Alexandre. Finanças corporativas e valor. São Paulo: Atlas, 2007. 
ASSUNÇÃO, Juliano; CARRASCO, Vinicius. Avaliação da Rotatividade dos Auditores Independentes. Rio de Janeiro: Pontifícia Universidade Católica, 2008.

BARTONE, Stefano. Società di revisione dei conti. Problematica civile e penale. Sistema angloamericano e italiano. Torino: G. Giappichelli Editore, 2009.

BEATTY, Jeffrey F.; SAMUELSON, Susan S. Business Law and the legal environment. Ohio: South-Western Cengage Learning, 2010.

BELOCH, Henrique Vargas; ALVES, Rafael de Carvalho Ramos. A auditoria das sociedades de grande porte. Disponível em <http://www.valoronline.com.br>. Acesso em 9 jan. 2010.

BERLE, Adolf Augustus; MEANS, Gardiner C. A moderna sociedade anônima e a propriedade privada. São Paulo: Nova Cultural, 1988.

BESANKO, David, et al. A economia da estratégia. Porto Alegre: Bookman, 2006.

BOBBIO, Norberto. Teoria do Ordenamento Jurídico. Brasília: Polis, 1989.

BOTTON, Alain. Os prazeres e desprazeres do trabalho. Rio de Janeiro: Rocco, 2009.

BOYNTON, Willian C. et al. Auditoria. São Paulo: Atlas, 2002.

BRASIL. COMISSÃO DE VALORES MOBILIÁRIOS. Recomendações da CVM sobre governança corporativa. Disponível em <http://www.cvm.gov.br/port/public/index.asp>. Acesso em 21 fev. 2010.

BRIGHAM, Eugene F. et al. Administração financeira: teoria e prática. São Paulo: Atlas, 2001.

BULGARELLI, Waldirio. Direito Comercial. São Paulo: Atlas, 1991. Regime jurídico do Conselho Fiscal das S/A. Rio de Janeiro:

Renovar, 1998.

CARVAlHO, L. Nelson. O Brasil e a adoção do padrão contábil internacional. Revista Brasileira de Contabilidade, v. 167, p. 7-19, 2007.

Uma só norma contábil - entidades internacionais trabalham pela harmonização das demonstrações contábeis das empresas em todo o mundo. Mercado de Capitais, São Paulo - SP, v. 95, p. 26-28, 2004. 
Momento de transição - A agenda de regulamentação da Lei 11.638 avança conforme o planejado. O desafio, agora, é acelerar a adaptação dos balanços às normas internacionais. Razão Contábil, São Paulo, p. 40 - 44, 01 set. 2008.

A nova lei das S/As e o processo de implementação das normais contábeis internacionais no Brasil - como funcionam as mudanças da Lei 11.638 na prática. Revista ANEFAC, São Paulo - SP, p. 16 - 26, 01 nov. 2008.

CARVAlHOSA, Modesto. A nova legislação contábil e as limitadas. Disponível em <http://www.valoronline.com.br>. Acesso em 9.01.2010.

; LATORRACA, Nilton. Comentários à lei de sociedades anônimas. São Paulo: Saraiva, 1998, v. 2 e 3.

CASADEI, Daniela. La responsabilità della società di revisione. Milão: Giuffrè, 2000.

COASE, Ronald. The nature of the firm, In The Firm, the Market, and the Law. University of Chicago Press, 1988.

COELHO, Fábio Ulhoa. Código Comercial e Legislação Complementar anotados. São Paulo: Saraiva, 2003. . Curso de Direito Comercial. São Paulo: Saraiva, 2003. v. 1, 2 e 3. . Manual de Direito Comercial. São Paulo: Saraiva, 2003. . Comentários à Lei de Falências e Recuperação de empresas. São Paulo: Saraiva, 2005.

COMPARATO, Fábio Konder. Natureza jurídica do balanço. Ensaios e pareceres de direito empresarial. Rio de Janeiro: Forense, 1978.

COSTA JÚNIOR, Paulo José da. Nexo causal. São Paulo: Malheiros, 1996.

COTTINO, Gastone. Diritto Commerciale. Padova: Cedam, 1994.

COZZI, Maria Vitória. Tutela dei mercati finanziari e responsabilità della società di revisione.Napoli: Edizione Scientifiche Italiane, 2001.

DELOITTE. Normas internacionais de contabilidade. São Paulo: Atlas, 2006. 
ELIZABETSKY, Roberto. Um modelo matemático para a decisão no banco comercial. Trabalho apresentado ao Depto. de Engenharia de Produção da Escola Politécnica da USP, 1976.

EU Project N. MARKT/2007/15/F LOT 2. Evaluation of the differences between International Standards on Auditing (ISA) and the standards of the US Public Company Accounting Oversight Board (PCAOB). Maastricht Accounting, Auditing and Information Management Research Center (MARC) - Executive Summary. 20 July 2009.

EUROPEAN COMISSION. A study on systems of civil liability of statutory auditors in the context of a single Market for auditing services in the European Union. Disponível em $<$ http://ec.europa.eu/internal_market/auditing/liability/index_en.htm\#study>. Acesso em 27 dez. 2009.

- Recomendação da comissão relativa à limitação da responsabilidade civil dos revisores oficiais de contas e das sociedades de revisores oficiais de contas. Disponível em $<$ http://ec.europa.eu/internal_market/auditing/docs/liability/summary_pt.pdf >. Acesso em 27 dez. 2009.

- Green Paper on the role, the position and the liability of the statutory auditor within the European Union. European Commission, 1996.

FABRETTI, Láudio Camargo. Contabilidade tributária. São Paulo: Atlas, 2005.

FERREIRA, Waldemar Martins. Instituições de direito comercial. São Paulo: Max Limonad, 1954.

FIALE, Aldo. Diritto Commerciale. Napoli: Simone, 2008

FILOMENO, José Geraldo Brito. Código brasileiro de defesa do consumidor. Rio de Janeiro: Forense, 1993.

FRAGOSO, Heleno Cláudio. Lições de Direito Penal. Rio de Janeiro: Forense, 1991.

FRANÇA, Erasmo Valladão Azevedo e Novaes. Direito societário, falimentar e teoria da empresa. São Paulo: Malheiros, 2009.

FUNDAÇÃO INSTITUTO DE PESQUISAS CONTÁBEIS, ATUARIAIS E FINANCEIRAS. Aprendendo contabilidade em moeda constante. São Paulo: Atlas, 2004. 
GITMAN, Lawrence J. Princípios de administração financeira. São Paulo: Harbra, 1997.

GOMES, Orlando. Introdução ao Direito Civil. Rio de Janeiro: Forense, 1990. . Obrigações. Rio de Janeiro: Forense, 2001. . Contratos. Rio de Janeiro: Forense, 2008.

GONÇALVES, Carlos Roberto. Responsabilidade civil. São Paulo: Saraiva, 2003.

GREENSPAN, Alan. A era da turbulência - Aventuras em um novo mundo. Rio de Janeiro: Elsevier, 2008.

HEILBRONER, Robert L.; THUROW, Lester C. Introdução à microeconomia. Rio de Janeiro: Guanabara, 1988.

INSTITUTO BRASILEIRO DE GOVERNANÇA CORPORATIVA. Governança corporativa em empresas de controle familiar: casos de destaque no Brasil. São Paulo: Saint Paul Editora, 2007.

. Código das melhores práticas de governança corporativa. São Paulo: IBGC, 2009. p. 60.

INSTITUTO DOS AUDITORES INDEPENDENTES DO BRASIL. Auditoria: Registros de uma profissão. São Paulo: IBRACON, 2007.

INTERNATIONAL FEDERATION OF ACCOUNTANTS. Handbook of international standards on auditing and quality control. Disponível em: 〈http//www.ifac.org >. Acesso em 3.01.2010

. Code of ethics for professional

accountants. Disponível em: <http//www.ifac.org>. Acesso em 3.01.2010

IUDÍCIBUS, Sérgio de, Teoria da Contabilidade. São Paulo: Atlas, 2000. , et al. Contabilidade introdutória. São Paulo: Atlas, 1990.

; MARTINS, Eliseu; GELBCKE, Ernesto Rubens. Manual de contabilidade das sociedades por ações. São Paulo: Atlas, 2003.

JOLIVET, Regis. Curso de filosofia. Rio de Janeiro: Agir, 1961. 
JUND, Sérgio. Auditoria - Conceitos, normas, técnicas e procedimentos. Rio de Janeiro: Elsevier, 2007.

KANITZ, Stephen Charles. Como Prever Falências. São Paulo: McGraw do Brasil, 1978.

KNAPP, Michael C. Contemporary auditing - Real issues and cases. Ohio: South-Western Cengage Learning, 2010.

KOTLER, Philip. Administração de marketing. São Paulo: Atlas, 1998.

KPMG BRASIL. A fraude no Brasil - Relatório da Pesquisa 2000. São Paulo: KPMG, 2000.

LACERDA, J. C. Sampaio de. Manual de Direito Falimentar. Rio de Janeiro: Freitas Bastos, 1978.

LARSON, Ron; FARBER, Betsy. Estatística aplicada. São Paulo: Prentice Hall, 2004.

LAZZARESCHI NETO, Alfredo Sérgio. Lei das sociedades por ações anotada. São Paulo: Atlas, 2006.

LIMA, Iran Siqueira; LIMA, Gerlando Augusto Sampaio Franco de; PIMENTEL, Renê Coppe. Curso de mercado financeiro. São Paulo: Atlas, 2006.

LONDON ECONOMICS, Study on the Economic Impact of Auditors' Liability Regimes. Disponível em <http://ec.europa.eu/internal_market/auditing/docs/liability/auditors-finalreport_en.pdf>. Acesso em 23 fev. 2010.

LOPES, Alexsandro Broedel. A informação contábil e o mercado de capitais. São Paulo: Thomson, 2002.

; MARTINS, Eliseu. Teoria da Contabilidade: uma nova abordagem. São Paulo: Atlas, 2005.

MANCUSO, Rodolfo de Camargo. Manual do consumidor em juízo. São Paulo: Saraiva, 1994.

MARION, José Carlos. Contabilidade empresarial. São Paulo: Atlas, 1997. . Contabilidade básica. São Paulo: Atlas, 2004. 
MARQUES, Claudia Lima. Contratos no Código de Defesa do Consumidor. São Paulo: RT, 2002.

MARTINS, Eliseu. “Atrocidades contábeis no novo Código Civil”. Boletim IOB-Thomson, São Paulo, n. 41, ano 2002, partes 1 e 2.

MARTINS, Fran. Comentários à lei das sociedades anônimas. Rio de Janeiro: Forense, 1984.

Curso de Direito Comercial. Rio de Janeiro: Forense, 1990.

MATARAZZO, Dante Carmine. Analise Financeira de Balanços. São Paulo: Atlas, 2003.

MAXIMILIANO, Carlos. Hermenêutica e aplicação do direito. Rio de Janeiro: Forense, 2001 .

MECKLING, William H.; JENSEN, Michael C. "Theory of the Firm: Managerial Behavior". Agency Costs and Ownership Structure. Julho, 1976.

MELLO, Marcos Bernardes de. Teoria do fato jurídico: plano da existência. São Paulo: Saraiva, 1995.

Teoria do fato jurídico: plano de validade. São Paulo: Saraiva, 1995.

MENDONÇA, José Xavier Carvalho de. Dos livros dos comerciantes. São Paulo: Rothschild, 1906.

.Tratado de Direito Comercial Brasileiro. São Paulo: Freitas Bastos, 1957. 2.v.

MIRANDA, Pontes de. Tratado de Direito Privado. São Paulo: Revista dos Tribunais, 1983.

t. III, XXXVIII, L.

MONTEIRO, Washington de Barros. Curso de Direito Civil - Direito das obrigações, $2^{\text {a }}$ parte. São Paulo: Saraiva, 1994. 5. v.

NEVES, Silvério das; VICECONTI, Paulo Eduardo Vilchez. Contabilidade avançada e análise das demonstrações financeiras. São Paulo: Frase, 1999.

. Contabilidade de custos: um enfoque direto e objetivo. São Paulo: Frase, 2000. . Contabilidade básica. São Paulo: Frase, 2000. 
OXERA CONSULTING LTD. Ownership rules of audit firms and their consequences for audit market concentration. Disponível em $<$ http://ec.europa.eu/internal_market/auditing/docs/market/oxera_report_en.pdf>. Acesso em 27 dez. 2009.

PACCIOLI, Luca. Summa de arithmetica, geometria, proportioni et proportionalità, Veneza, 1494.

PENTEADO, Mauro Rodrigues. Dissolução e liquidação de sociedades. São Paulo: Saraiva, 2000.

PEREIRA, Alexandre Demetrius. Regime jurídico da escrituração empresarial nas sociedades limitadas e anônimas. Dissertação de Mestrado. São Paulo: Universidade de São Paulo, 2008.

PETERS, Marcos R. S. Controladoria internacional: incluindo Sarbanes Oxley Act e USGAAP. São Paulo: DVS Editora, 2004.

POSNER, Richard A. Economic Analysis of law. Nova York: Aspen Publishers, 2007. A failure of capitalism. Cambridge, Massachussetts: Harvard University Press, 2009.

POVOA, Alexandre. Valuation. Como precificar ações. São Paulo: Globo, 2004.

RASHAD, A.; KHALIK, Abdel. Dicionário enciclopédico de contabilidade. São Paulo: Atlas, 2004.

REQUIÃO, Rubens. Curso de Direito Comercial. São Paulo: Saraiva, 1991. . Curso de Direito Falimentar. São Paulo: Saraiva, 1992.

RIBEIRO, Osni Moura. Contabilidade avançada. São Paulo: Saraiva, 2005. Contabilidade intermediária. São Paulo: Saraiva, 2005.

RITTENBERG, Larry E. et al. Auditing - A business risk approach. Ohio: South-Western Cengage Learning, 2010.

RODRIGUES, Silvio. Direito Civil-Responsabilidade civil. São Paulo: Saraiva, 2002, 4. v. Direito Civil - Dos contratos e das declarações unilaterais de vontade. São Paulo: Saraiva, 2003. 3. v. 
RODRIGUES, Vasco. Análise econômica do direito. Coimbra: Almedina, 2007.

SÁ, Antônio Lopes de. Planos de Contas. São Paulo: Atlas, 1998.

; HOOG, Wilson Alberto Zappa. Corrupção, fraude e contabilidade. Curitiba: Juruá, 2005.

SANGIOVANNI, Valerio. "La responsabilità extracontrattuale della società di revisione nel caso parmalat". Corriere giuridico, 4/2009, p. 531-542.

SANTOS, Ariovaldo dos. Demonstração do Valor Adicionado: como elaborar e analisar a DVA. São Paulo: Atlas, 2003.

; GRATERON, Ivan Ricardo Guevara. "Contabilidade Criativa e responsabilidade dos auditores". Revista Contabilidade \& Finanças - USP, São Paulo, n. 32, p. 7-22, maio/ago. 2003.

SANTOS, José Luiz dos; SCHIMIT, Paulo. Fundamentos de Contabilidade Societária. São Paulo: Atlas, 2005.

SAUNDERS, Anthony. Administração de instituições financeiras. São Paulo: Atlas, 2007.

SEVERINO, Antônio Joaquim. Metodologia do trabalho científico. São Paulo: Cortez, 2002.

SILVA, Edson Cordeiro da. Governança corporativa nas empresas. São Paulo: Atlas, 2006.

SOUZA JÚNIOR, Francisco Satiro de e PITOMBO, Antônio Sérgio A. de Moraes (coords.). Comentários à Lei de recuperação de empresas e falência: Lei 11.101/2005. São Paulo: Editora Revista dos Tribunais, 2005.

SROUR, Robert Henry. Ética empresarial - A gestão da reputação. Rio de Janeiro: Campus, 2003.

STASSANO, Giuseppe; STASSANO, Matteo. Il Falso in bilancio. Milão: Giuffrè, 1996.

STOCO, Rui. Tratado de Responsabilidade Civil. São Paulo: RT, 2004.

SZTAJN, Raquel. Contrato de sociedade e formas societárias. São Paulo: Saraiva, 1989. . Teoria jurídica da empresa - Atividade empresária e mercados. São Paulo: Atlas, 2004. 
UNIVERSITY OF DUISBURG-ESSEN. Evaluation of the Possible Adoption of International Standards on Auditing (ISAs) in the EU. Disponível em <http://ec.europa.eu/internal_market/auditing/docs/ias/study2009/summary_en.pdf>. Acesso em 16.12.2009

VALVERDE, Trajano de Miranda. Comentários à lei de falências. Rio de Janeiro: Forense, 1962.

VARELA, João de Matos Antunes. Das obrigações em geral. Coimbra: Almedina, 1994.

VENOSA, Sílvio de Salvo. Direito Civil - Teoria geral das obrigações e teoria geral dos contratos. São Paulo: Atlas, 2003, 2 v.

VERÇOSA, Haroldo Malheiros Duclerc. Curso de Direito Comercial. São Paulo: Malheiros, 2004, v. 1 e 2.

; PEREIRA, Alexandre Demetrius. Curso de Direito Comercial. São Paulo:

Malheiros, 2008. v. 3 